LUCIANA DINIZ BORGES

\title{
Desenvolvimento de Catalisadores Nano e Microestruturados para Produção de Bio-olefinas
}

Orientador: Prof. Dr. Julio Lemos de Macedo

BRASÍLIA - DF 


\section{UnB - Universidade de Brasília}

\section{Desenvolvimento de Catalisadores Nano e Microestruturados para Produção de Bio-olefinas}

\section{Luciana Diniz Borges}

Tese apresentada ao Instituto de Química da Universidade de Brasília como parte do requisito para obtenção do título de Doutor em Química.

Orientador: Prof. Dr. Julio Lemos de Macedo

Brasília - DF 
"A percepção do desconhecido é a mais fascinante das experiências. $O$ homem que não tem os olhos abertos para o misterioso passará pela vida sem ver nada."

Albert Einstein 


\section{Agradecimentos}

Após quase dez anos nessa jornada acadêmica, não são poucos aqueles a quem devo meu profundo e sincero agradecimento. Em primeiro lugar, agradeço a Deus, por me inspirar, iluminar meus caminhos e me guiar, permitindo a finalização de mais essa etapa em minha vida.

Agradeço especialmente ao meu orientador, professor Julio Lemos de Macedo, por todo o conhecimento a mim passado e a todas as tarefas a mim confiadas ao longo desses anos. É certo que esse trabalho não seria o mesmo sem suas valiosas contribuições e incansável dedicação. Obrigada pelo dia a dia de frutíferas discussões e orientações, fazendo com que a realização dessa pesquisa fosse mais que agradável, com direito a várias comemorações a cada descoberta.

Aos professores Sílvia Dias e José Dias, grandes incentivadores, agradeço por terem sido o começo de toda minha história na pesquisa em Catálise, por terem sempre um tempo dedicado a me orientar, aconselhar e ensinar. Agradeço também às professoras Grace Ghesti, Andréia Alves e Maria José Sales por terem contribuído enormemente para que esse trabalho se tornasse melhor.

Um super obrigada aos amigos do Laboratório de Catálise, em especial à Júlia, ao Elon, à Ana Elisa e à Liana pelos conhecimentos preciosos compartilhados, pelos constantes favores prestados e por tornarem os momentos de trabalho mais felizes e descontraídos. Agradeço ao Noberto e à Natália por terem sido personagens centrais na etapa final desse trabalho e meu braço direito (e esquerdo) na realização das sínteses e caracterizações dos materiais de HPW. Agradeço ao CDT/UnB e, em especial, ao Ernani, pelas contribuições e auxílios prestados ao longo do desenvolvimento da patente gerada a partir desse trabalho.

Ao meu marido Luiz, meu cúmplice, obrigada, por todo o carinho, pela paciência nas intermináveis horas que precisei me ausentar para concretizar esse sonho, por sonhar comigo, por estar sempre ao meu lado, ansiando, mais do que eu mesma, para que esse trabalho terminasse brilhantemente. Obrigada não só por me apoiar emocionalmente, mas pelas excelentes 
contribuições proporcionadas, com sua lógica de engenheiro, fazendo-me refletir e melhorar minhas análises.

Agradeço à minha família por me amparar, por ser meu pilar de sustentação, pois, mesmo distante fisicamente, sei que estão sempre orando e torcendo por mim. Devo a vocês o que hoje sou e agradeço por terem possibilitado meu acesso ao conhecimento.

À minha mãe, obrigada por ser meu exemplo de mulher, por seu amor incondicional, um amor maior que minha gratidão. Obrigada por ter moldado meu caráter, que hoje permitiu que eu chegasse até aqui. Minhas vitórias são seus frutos.

Aos amigos, obrigada pelo carinho e por saber que sempre posso contar com vocês.

Agradeço a todos aqueles que, podendo eu não ter citado, também tenham contribuído para que esse trabalho pudesse ser realizado.

Agradeço ao Instituto de Biologia pela cessão dos microscópios eletrônicos de varredura e de transmissão. Esse trabalho recebeu auxílio financeiro da Petrobras, CAPES, CNPq, UnB/IQ, Finatec, Finep-CTPetro, Finep-CTInfra e FAPDF/SDCT/CNPq.

Luciana, novembro 2014. 


\section{Resumo}

A produção seletiva de olefinas a partir da desidratação de alcoóis foi alcançada utilizando uma zeólita $Y$ desaluminizada no estado sólido, $Y(80) 5 \mathrm{C}$. Resultados experimentais obtidos por CG-FID mostraram que uma quantidade reduzida $(0,1 \mathrm{~g})$ desse sólido foi capaz de gerar valores de seletividades superiores a $96 \%$ para produção de etileno com conversão média de $90 \%$ durante 5 dias de reação, mesmo mediante uma alta velocidade espacial de etanol de $14,2 \mathrm{~h}^{-1}$. A recuperação e a reativação da zeólita modificada reduziu o número de sítios ácidos do material de 1,1088 para $0,4850 \mathrm{mmol} \mathrm{g}^{-1} \mathrm{e}$, apesar da menor acidez, a $\mathrm{Y}(80) 5 \mathrm{C}$ manteve os valores de conversão do etanol PA acima de $86 \% \mathrm{e}$ os de seletividade para etileno acima de $90 \%$, convertendo quase $20 \%$ a mais que a zeólita HY no mesmo período. Estudos com soluções aquosas de etanol em distintas concentrações mostraram que a presença de água no álcool de partida não se comportou como um veneno para o catalisador desaluminizado durante $o$ período reacional investigado. Ao contrário, elevou a $100 \%$ os valores de seletividade para a formação da olefina devido à menor proporção de álcool etílico que passava por minuto pela zeólita sem prejuízo nas taxas de conversão. $O$ bioetanol, com $93 \%$ de pureza, também foi testado nesse trabalho, evidenciando um ligeiro decréscimo de seletividade por parte da zeólita $Y(80) 5 \mathrm{C}$ em relação à seletividade apresentada pela $Y$ comercial, $Y($ pura $) C$, quando um curto tempo reacional, de até $25 \mathrm{~h}$, é considerado. No entanto, a resistência do material desaluminizado foi consideravelmente superior à da $Y($ pura $) C$, conservando sua eficiência catalítica durante um longo tempo de reação. Novos materiais também foram investigados a partir da síntese dupla via molde biológico com o ácido 12tungstofosfórico (HPW). Nesse caso, três diferentes cátions $\left(\mathrm{Zr}^{4+}, \mathrm{Zn}^{2+}\right.$ e $\left.\mathrm{Ag}^{+}\right)$ foram utilizados como substituintes dos prótons do heteropoliácido HPW, gerando tanto sólidos micrométricos como materiais nanoestruturados. Dessa forma, nanofibras foram obtidas por meio da modelagem dos sais de HPW com papel filtro ou celulose em pó, tendo sido detectadas por MEV e MET. Análises termogravimétricas evidenciaram uma alta estabilidade térmica e baixos valores de perda de água para esses sólidos. Os materiais com zircônia (ZrHPW) foram aqueles que apresentaram os maiores valores de conversão/seletividade para aplicação em catálise ácida, devido à facilidade dos íons zircônio de se hidrolisarem em meio aquoso, formando desde espécies monoméricas até polímeros e gerando sítios $\mathrm{H}^{+}$. $\mathrm{Na}$ esterificação do álcool benzílico com ácido acético, a molécula volumosa do álcool teve forte influência nas conversões alcançados, uma vez que efeitos estéricos podem ocorrer, sendo determinante a quantidade de sítios ácidos por unidade de área superficial do catalisador. Assim, os heteropolissais com maior quantidade de sítios ácidos fortes não foram aqueles que apresentaram as maiores conversões. Os catalisadores de ZrHPW também exibiram boas conversões na catálise oxidativa do álcool benzílico. Porém, os materiais de prata foram aqueles que apresentaram os melhores dados de seletividade para formação do benzaldeído (98\%) em $2 \mathrm{~h}$ de reação. Nesse caso, a capacidade REDOX do centro metálico, em conjunto com ligações $\mathrm{W}-\mathrm{O}$, foi o fator determinante na reação de oxidação. 


\begin{abstract}
The selective production of olefins from the dehydration of alcohols was achieved using the $Y$ zeolite dealuminated in the solid-state, $Y(80) 5 C$. Experimental results obtained by GC-FID have shown that a reduced amount $(0.1 \mathrm{~g})$ of this solid was capable to generate selectivity values greater than $96 \%$ for ethylene with average conversion of $90 \%$ during 5 days reaction, even with a high ethanol space velocity of $14.2 \mathrm{~h}^{-1}$. The recovery and the reactivation of the modified zeolite reduced the number of acid sites of the material from 1.1088 to $0.4850 \mathrm{mmol} \mathrm{g}^{-1}$ and, despite the lower acidity, the $\mathrm{Y}(80) 5 \mathrm{C}$ kept the values of ethanol conversion over $86 \%$ and the selectivity to ethylene above $90 \%$, converting almost $20 \%$ more than HY zeolite in the same period. Studies with aqueous ethanol solutions in different concentrations showed that the water in the reactant did not act as a poison in $Y(80) 5 \mathrm{C}$ catalyst during the investigated period of reaction. Instead, the presence of water elevated to $100 \%$ the selectivity values to olefin formation due to the smaller proportion of ethyl alcohol that passed through the zeolite per minute without decreasing the conversion rates. A sample of bioethanol, $93 \%$ purity, was also tested in this work, showing a slight decrease in selectivity for $Y(80) 5 \mathrm{C}$ compared with the selectivity presented by the commercial $Y$ zeolite, $Y($ pure $) C$, when a short period of $25 \mathrm{~h}$ is considered. However, the resistance of the dealuminated material was considerably higher than the one showed by $\mathrm{Y}$ (pure)C, keeping its catalytic efficiency for a long reaction time. New materials were also investigated by the dual synthesis via biological template with the 12tungstophosphoric acid (HPW). In this case, three different cations $\left(\mathrm{Zr}^{4+}, \mathrm{Zn}^{2+} \mathrm{e}\right.$ $\mathrm{Ag}^{+}$) were used as proton substituents of the HPW heteropolyacid, resulting in either micrometric and nanometric materials. Therefore, nanofibers were obtained modeling the HPW salts with filter paper or powdered cellulose and they were detected by SEM and TEM. Thermogravimetric analysis showed a high thermal stability and low values of water loss for these solids. The zirconia materials (ZrHPW) presented the greater conversions/selectivity values for application in acid catalysis, since zirconium ions can be easily hydrolyzed in aqueous media, forming monomers and polymers and generating $\mathrm{H}^{+}$sites. In the esterification of benzyl alcohol with acetic acid, the bulky alcohol molecule had a strong influence on the achieved yields, since steric effects may occur, and the amount of acid sites per unit of catalyst surface area seems to be also decisive. Therefore, the solid heteropolyacids with higher amount of strong acid sites were not the ones that showed the highest conversions. ZrHPW catalysts also exhibited good yields in the oxidative catalysis of benzyl alcohol. However, the best selectivity data for benzaldehyde formation in $2 \mathrm{~h}$ of reaction was found employing silver materials. In this case, the REDOX capacity of the metal center, together with $\mathrm{W}-\mathrm{O}$ bonds, was the key factor in the oxidation reaction.
\end{abstract}




\section{Sumário}

Introdução, Revisão Bibliográfica \& Objetivos............................................ 15

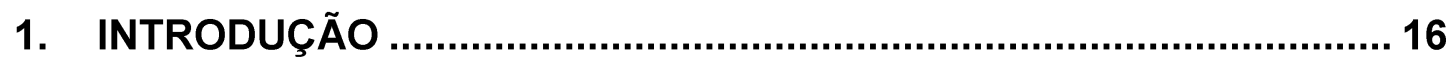

2. REVISÃO BIBLIOGRÁFICA …................................................... 18

2.1. Catalisadores para Aplicação na Produção de Bio-olefinas: Zeólitas

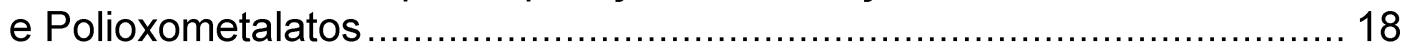

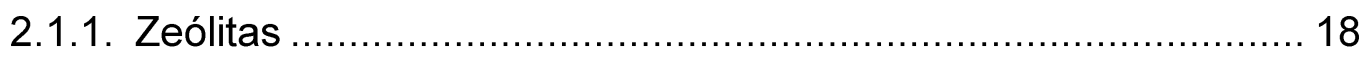

2.1.1.1. Modificação de Zeólitas: processo de desaluminização ...... 22

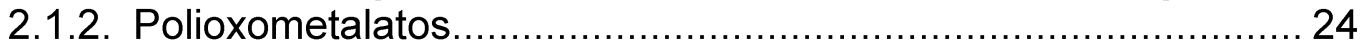

2.1.2.1. Modificação de Heteropoliácidos: formação de

heteropolissais

2.2. Desidratação de Alcoóis C2-C4 para Produção de Bio-olefinas

Leves 35

2.2.1. Síntese de Bioetileno via Desidratação do Bioetanol

2.3. Reatores para Simulação e Aperfeiçoamento de Reações em

Catálise Heterogênea.................................................................... 47

2.3.1. Reatores de Leito Fixo ........................................................ 47

2.3.2. Reatores de Leito Fluidizado ............................................. 50

2.3.3. Microrreatores de Pulso ........................................................ 51

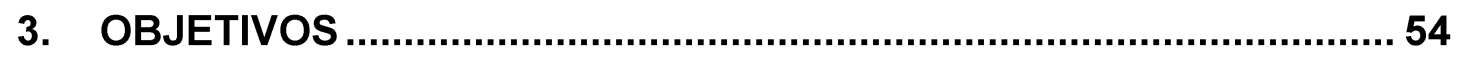

3.1. Objetivos Gerais ............................................................. 54

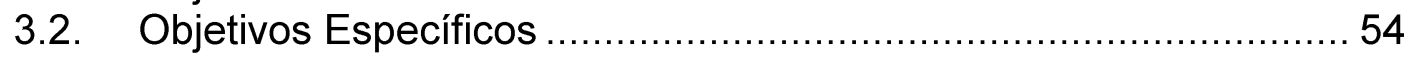

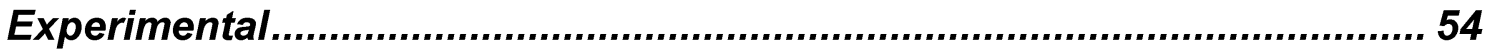

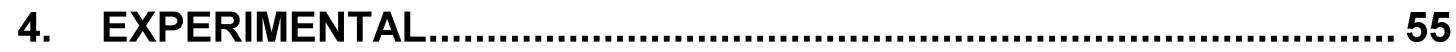

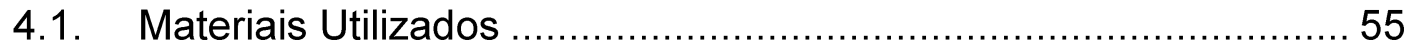

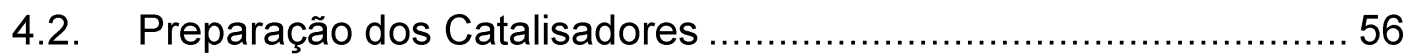

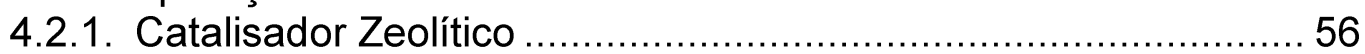

4.2.2. Catalisadores de Heteropoliácidos ....................................... 56

4.2.2.1. Síntese Dupla via Molde Biológico ................................. 57

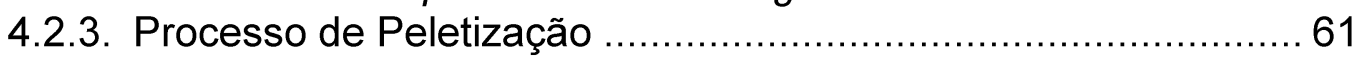

4.3. Técnicas de Caracterização ....................................................... 63

4.3.1. Determinação de Acidez: adsorção de piridina gasosa ...............63

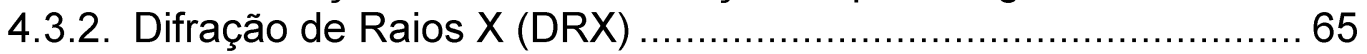

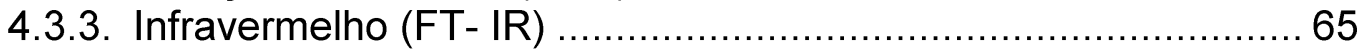

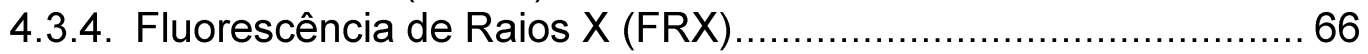

4.3.5. Análise Elementar de Carbono, Hidrogênio e Nitrogênio ( $\mathrm{CHN}$ ). 67

4.3.6. Análise Térmica (TG/DTG/DTA) ............................................... 67

4.3.7. Análise Textural: área superficial e porosimetria $\left(\operatorname{ASAP}^{\circledR}\right)$.........6 69

4.3.8. Técnicas de Microscopia Eletrônica......................................... 70

4.3.8.1. Microscopia Eletrônica de Varredura (MEV)..................... 71

4.3.8.2. Microscopia Eletrônica de Transmissão (MET) .................. 72

4.4. Análises de Atividade Catalítica ................................................ 73

4.4.1. Desidratação de Alcoóis C2-C4 …..................................... 73

4.4.1.1. Reator Tubular de Leito Fixo com Fluxo Contínuo .............. 73

4.4.1.2. Microrreator de Pulso .................................................... 77 
4.4.2. Esterificação do Álcool Benzílico .............................................. 77

4.4.3. Oxidação do Álcool Benzílico.................................................. 79

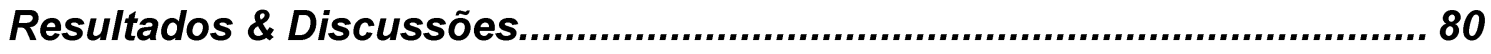

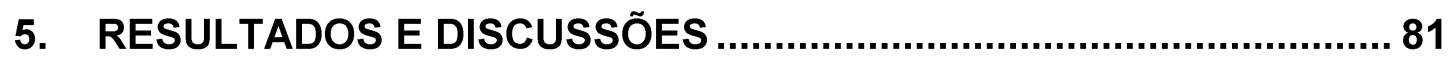

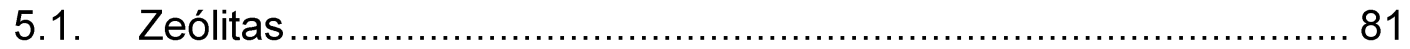

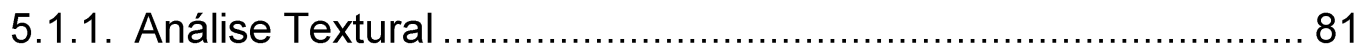

5.1.2. Desidratação do Etanol Pró-Análise e do Bioetanol via Reator

Tubular de Leito Fixo com Fluxo Contínuo ......................................... 85

5.1.2.1. Desidratação do Etanol Pró-Análise ................................. 86

5.1.2.2. Desidratação do Bioetanol............................................ 97

5.1.3. Desidratação de Alcoóis via Microrreator de Pulso.................. 104

5.1.3.1. Desenvolvimento e Montagem do Microrreator de Pulso .. 104

5.1.3.2. Desidratação do Etanol em Diferentes Concentrações ..... 110

5.1.3.3. Desidratação do 1-Propanol, do Isopropanol e do

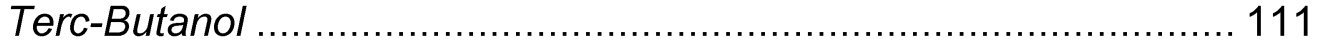

5.1.4. Análise de Propostas de Mecanismos .................................. 113

5.2. Heteropoliácidos............................................................. 118

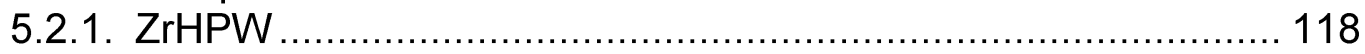

5.2.1.1. Caracterizações Estruturais - ZrHPW (papel filtro) ........... 118

5.2.1.2. Caracterizações Estruturais - ZrHPW (celulose em pó).... 134

5.2.1.3. Caracterizações de Acidez ........................................... 138

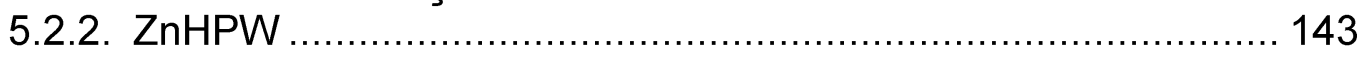

5.2.2.1. Caracterizações Estruturais - ZnHPW (papel filtro) .......... 143

5.2.2.2. Caracterizações Estruturais - ZnHPW(acetato) ................ 154

5.2.2.3. Caracterizações de Acidez .......................................... 161

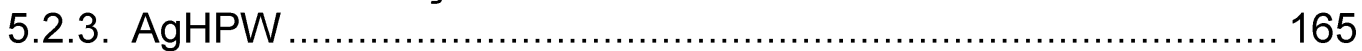

5.2.3.1. Caracterizações Estruturais - AgHPW (papel filtro) .......... 165

5.2.3.2. Caracterizações de Acidez ............................................ 173

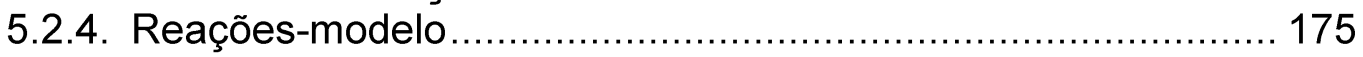

5.2.4.1. Desidratação do Etanol PA .......................................... 175

5.2.4.2. Esterificação do Álcool Benzílico ..................................... 177

5.2.4.3. Oxidação do Álcool Benzílico ............................................. 182

Conclusões e Perspectivas........................................................................ 187

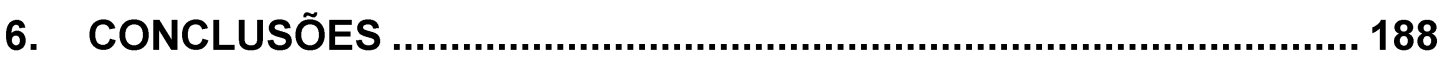

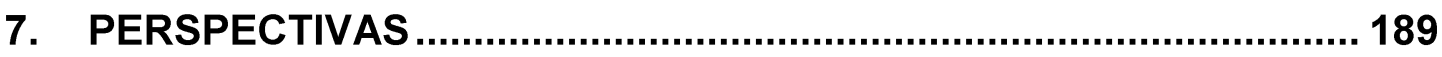

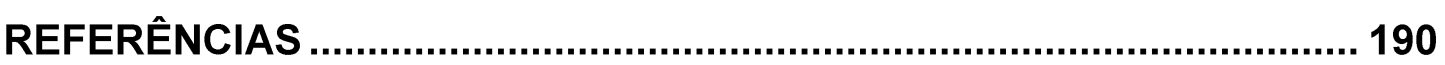

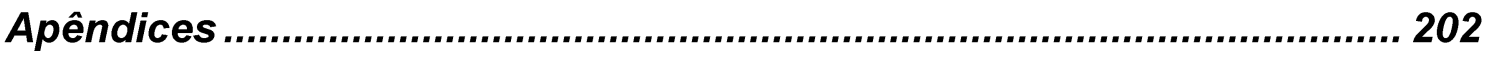

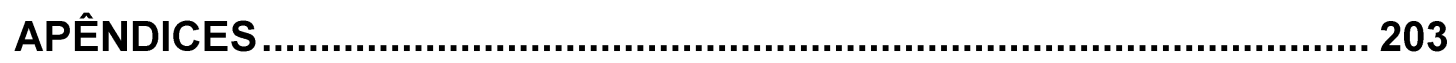




\section{Lista de Abreviaturas e Acrônimos}

\section{(ordem alfabética)}

ANP - Agência Nacional do Petróleo, Gás Natural e Biocombustíveis API - American Petroleum Institute (Instituto Americano de Petróleo) ASAP - Accelerated Surface Area and Porosimetry (Analisador de Área Superficial e Porosimetria)

BEA - Zeólita do tipo Beta

BzAc - Acetato de Benzila

BzH - Benzaldeído

BzOH - Álcool Benzílico

CG - Cromatografia Gasosa ou Cromatógrafo Gasoso

D6R - Anel de seis membros

DTA - Differential Thermal Analysis (Análise Térmica Diferencial)

DTG - Differential Termogravimetry (Termogravimetria Derivada)

EFAI - Extraframework Aluminium (alumínio fora da rede zeolítica)

EFSi - Extraframework Silicon (silício fora da rede zeolítica)

$\mathrm{EtOH}-$ Etanol

FAU - Faujasita

FCC - Fluid Catalytic Cracking (Craqueamento Catalítico em Leito Fluidizado)

FID - Flame Ionization Detector (Detector por lonização de Chama)

FRX/EDX - Energy-dispersive X-ray Fluroescence (Fluorescência de Raios X por Energia Dispersiva)

FT-IR - Fourier Transform Infrared Spectroscopy (Espectroscopia na região do infravermelho com transformada de Fourier)

HAc - Ácido Acético

HY - Zeólita Y protônica

HPA - Heteropoliácido

$\mathrm{HPW}$ - Ácido 12-tungstofosfórico: $\mathrm{H}_{3}\left[\mathrm{PW}_{12} \mathrm{O}_{40}\right]$

IBGE - Instituto Brasileiro de Geografia e Estatística

LTA - Linde Type A (Zeólita do tipo A)

MCM-41 - Mobil Composition of Matter - Sólido amorfo mesoporoso composto de sílica 
MEV - Microscopia Eletrônica de Varredura ou Microscópio Eletrônico de Varredura

MFI - Zeólita do tipo ZSM-5

$\mathrm{NH}_{4} \mathrm{Y}$ - Zeólita $\mathrm{Y}$ amoniacal

OPEP - Organização dos Países Exportadores de Petróleo

PA - Pró-Análise

PE - Polietileno

POM - Polioxometalato

PS - Poliestireno

PVC - Policloreto de vinila

REDOX - processo químico de Redução e Oxidação

RMN - Ressonância Magnética Nuclear

RMN-RAM ${ }^{27} \mathrm{Al}$ - Ressonância Magnética Nuclear de Alumínio com Rotação no Ângulo Mágico

RMN-RAM ${ }^{1} \mathrm{H}$ - Ressonância Magnética Nuclear de Hidrogênio com Rotação no Ângulo Mágico

RMN-RAM ${ }^{29} \mathrm{Si}$ - Ressonância Magnética Nuclear de Silício com Rotação no Ângulo Mágico

SAPO - Silicoaluminofosfatos

SBA-15 - Santa Barbara Amorphous - Sólido amorfo mesoporoso composto de sílica

SBU - Secondary Building Units (Unidades Secundárias de Construção)

SOD - Sodalita

TG - Termogravimetria

TOF - Turnover Frequency (frequência de rotação do catalisador)

UNICA - União da Indústria da Cana-de-Açúcar

USY - Ultrastable Y (zeólita Y ultraestável)

WHSV - Weight Hourly Space Velocity (Velocidade Mássica Espacial Horária)

$\mathrm{Y}(80) 5$ - Zeólita Y desaluminizada a $80^{\circ} \mathrm{C}$, em $5 \%$

ZSM - Zeolite Socony Mobil (Zeólita da produtora Socony Mobil Oil Company) 


\section{Lista de Tabelas}

Tabela 1: Principais estruturas de heteropoliânions. ...................................... 26

Tabela 2: Propriedades físico-químicas de sais de HPAs............................ 31

Tabela 3: Algumas dimensões médias aproximadas importantes em análise microestrutural........................................................................... 70

Tabela 4: Dados obtidos por adsorção de nitrogênio (BET, BJH e método t-

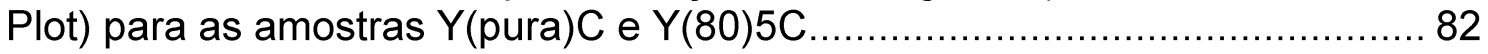

Tabela 5: Dados de conversão média, seletividade média e eficiência catalítica para $42 \mathrm{~h}$ de reação de desidratação de etanol PA, utilizando a zeólita $\mathrm{Y}$ padrão e a zeólita desaluminizada como catalisadores. 91

Tabela 6: Dados de conversão média, seletividade média e eficiência catalítica para $25 \mathrm{~h}$ do segundo ciclo catalítico da reação de desidratação de etanol PA, com reutilização dos catalisadores zeólita Y padrão e zeólita desaluminizada.95 Tabela 7: Dados obtidos de conversão, seletividade e WHSV para a variação do fluxo de etanol PA, a cada hora de reação, sobre $0,1 \mathrm{~g}$ da zeólita $\mathrm{Y}(80) 5 \mathrm{C}$.

Tabela 8: Dados de conversão, seletividade para etileno e eficiência catalítica para $42 \mathrm{~h}$ de reação de desidratação do etanol PA e do bioetanol, utilizando a zeólita Y padrão e a zeólita desaluminizada como catalisadores.................... 99

Tabela 9: Dados de conversão e seletividade para etileno, obtidos na desidratação de $80,0 \mathrm{~mL}$ de bioetanol em alta pressão e em pressão atmosférica................................................................................ 104

Tabela 10: Dados de intensidade, conversão e seletividade médios obtidos na produção de etileno a partir de diferentes concentrações de etanol. ............. 111

Tabela 11: Dados conversão e seletividade médios obtidos na produção das bio-olefinas propileno e isobutileno. ..................................................... 112 Tabela 12: Valores de número de onda encontrados para as amostras de ZrHPW-micro e HPW padrão nos espectros de FT-IR .............................. 127 Tabela 13: Dados obtidos por CHN para as amostras sintetizadas de ZrHPW. 128

Tabela 14: Análise Elementar das amostras ZrHPW-micro e ZrHPW-nano por FRX/EDX e TG/DTG/DTA. 131

Tabela 15: Resultados da análise textural para o ZrHPW-micro e ZrHPW-nano. 134

Tabela 16: Dados obtidos por CHN para as amostras sintetizadas de ZrHPW. 137

Tabela 17: Número de sítios ácidos calculados via TG a partir da adsorção gasosa de piridina para o HPW e para as amostras sintetizadas com zircônia. 142

Tabela 18: Dados obtidos por CHN para as amostras sintetizadas ZnHPW. 144 Tabela 19: Análise Elementar da amostra ZnHPW-micro-2,66 por FRX/EDX e TG/DTG/DTA 153

Tabela 20: Dados obtidos por CHN para as amostras sintetizadas ZnHPWacetato. 156

Tabela 21: Número de sítios ácidos calculados via TG a partir da adsorção gasosa de piridina para o HPW e para as amostras sintetizadas com zinco. 165 Tabela 22: Dados obtidos por CHN para as amostras sintetizadas AgHPW. 166 
Tabela 23: Análise Elementar das amostras AgHPW-micro e AgHPW-nano por FRX/EDX e TG/DTG/DTA.

Tabela 24: Número de sítios ácidos calculados via TG a partir da adsorção gasosa de piridina para o HPW e para as amostras sintetizadas com prata. 175 Tabela 25: Conversão média de etanol em etileno e Turnover Number (TON) calculados para os catalisadores HPW e ZrHPW.

Tabela 26: Conversão do álcool benzílico em acetato de benzila, Turnover Number (TON) e Turnover Frequency (TOF) calculados para os catalisadores de HPW. 179

Tabela 27: Conversão e seletividade obtidos na oxidação do álcool benzílico em benzaldeído calculada para os catalisadores de HPW após $2 \mathrm{~h}$ de reação a $60{ }^{\circ} \mathrm{C}$ 183 


\section{Lista de Figuras}

Figura 1: Representação da estrutura tridimensional da zeólita natural clinoptilolita gerada pelo programa ArgusLab. .......................................................... 19 Figura 2: Formação da estrutura final das zeólitas $Y$ e ZSM-5, com poros e cavidades específicos, gerada pelo agrupamento de tetraedros de alumínio ou silício. 20

Figura 3: Em (a), uma molécula linear tem acesso aos poros da zeólita LTA. Em (b), a ramificação da molécula impede esse acesso. 21

Figura 4: Estrutura da zeólita Beta. No detalhe, a representação dos sítios ácidos de Brønsted existentes nas zeólitas em geral, em que a carga negativa das espécies $\mathrm{AlO}_{4}{ }^{-}$é contrabalanceada pelo íon hidrogênio.....................................21 Figura 5: Modelos de clusters de POMs. Em (a), a representação da estrutura hexacoordenada do cluster $\left[\mathrm{W}_{24} \mathrm{O}_{84}\right]^{24-}$, em que a cor cinza claro representa átomos de tungstênio e, a cinza escuro, átomos de oxigênio; em (b), a representação do cluster do ânion tungstofosfato $\left(\left[\mathrm{PW}_{12} \mathrm{O}_{40}\right]^{3-}\right)$, em que a cor rosa (heteroátomo central) representa o átomo de fósforo, a cor azul, os átomos de tungstênio e, a cor vermelha, átomos de oxigênio............................................ 25

Figura 6: (a) Representação do ânion de Keggin. (b) Grupo $\mathrm{M}_{3} \mathrm{O}_{13}$. (c) Representação do cluster formado pela união das quatro tríades $\mathrm{M}_{3} \mathrm{O}_{13}$, com o detalhe em rosa representando o heteroânion. ............................................... 27

Figura 7: Diagrama esquemático ilustrando a estrutura secundária do HPA hidratado $\mathrm{H}_{3}\left[\mathrm{PW}_{12} \mathrm{O}_{40}\right] \cdot \mathrm{nH}_{2} \mathrm{O}$. (a) Espécies do tipo $\mathrm{H}_{5} \mathrm{O}_{2}{ }^{+}(\mathrm{H}=$ cor azul, $\mathrm{O}=$ cor vermelha), com prótons duplamente hidratados, conectam 4 ânions de Keggin por meio de ligações hidrogênio, formando uma estrutura hexahidratada $\left(\mathrm{H}_{3}\left[\mathrm{PW}_{12} \mathrm{O}_{40}\right] \cdot 6 \mathrm{H}_{2} \mathrm{O}\right)$. (b) Espécies do tipo $\mathrm{H}_{9} \mathrm{O}_{4}{ }^{+}$geram a estrutura dodecahidratada $\left(\mathrm{H}_{3}\left[\mathrm{PW}_{12} \mathrm{O}_{40}\right] \cdot 12 \mathrm{H}_{2} \mathrm{O}\right)$.................................................... 28 Figura 8: Imagens obtidas por MEV para as amostras $\mathrm{Cs}_{2} \mathrm{HPW}$ preparadas com

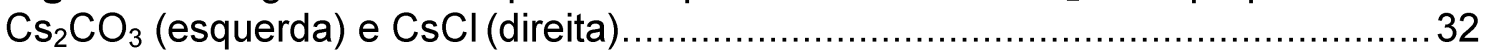

Figura 9: Esquema simplificado da cadeia petroquímica.................................. 36 Figura 10: Etapas do mecanismo de desidratação intramolecular do etanol com

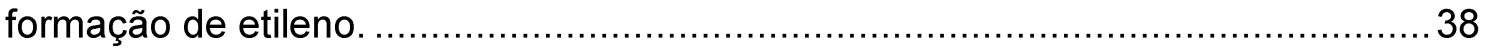
Figura 11: Etapas do mecanismo de desidratação intermolecular do etanol com

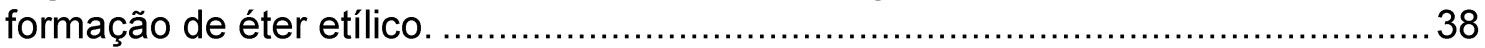
Figura 12: Coprocessamento de gasóleo e etanol com alimentação segregada. . 43 Figura 13: Ilustração de um reator catalítico de leito fixo. Em (a), um reator de leito fixo multitubular; em (b), um tubo do reator empacotado com catalisador formando o leito fixo; e, em (c), um exemplo de trocador de calor tubular...........................48 Figura 14: Em (a), um reator de leito fixo; em (b), um reator de leito fluidizado com fluidização mínima ideal; e, em (c), uma fluidização borbulhante, provocada pelo aumento da vazão do gás. 50 Figura 15: Esquema simplificado de um microrreator de pulso acoplado externamente a um cromatógrafo gasoso (CG). "F" é o forno, aquecido na temperatura reacional desejada e "T" é um termostato. O frasco de segurança impede que possíveis partículas sólidas do leito de catalisador contaminem e danifiquem o CG. 52 Figura 16: Representação estrutural da celulose (a), formada a partir de monômeros de glicose, em que "n" é, no mínimo, igual a 200 repetições. A micrografia (b) mostra as fibras de celulose e o diagrama (c) ilustra internamente uma dessas fibras, composta por conjuntos de microfibrilas de cadeias poliméricas da celulose que interagem entre si por meio de ligações hidrogênio. 
Figura 17: Resumo do procedimento experimental adotado para a síntese dupla dos sais ácidos de HPW utilizando como molde um papel filtro. .........................59 Figura 18: Resumo do procedimento experimental adotado para a síntese dupla dos sais ácidos de HPW utilizando celulose em pó

Figura 19: Peneiras granulométricas em aço inoxidável com diferentes tamanhos de abertura. À direita, o encaixe de diferentes peneiras formando o sistema para peletização utilizado no presente trabalho

Figura 20: Representação esquemática para o sistema de adsorção gasosa simultânea desenvolvido no Laboratório de Catálise. (a) representa o tubo de vidro envolto em manta de aquecimento onde estão as amostras; (b) representa o controlador de temperatura ligado a um gerador do tipo Variac; (c) ilustra a torneira que direciona a passagem de $\mathrm{N}_{2}$ ou diretamente pela amostra ou para 0 reservatório de piridina; (d) mostra o reservatório de piridina líquida levemente aquecido $\left(\sim 50{ }^{\circ} \mathrm{C}\right)$; e (e) ilustra a armadilha de $\mathrm{HCl} 0,1 \mathrm{~mol} \mathrm{~L}^{-1} \ldots \ldots \ldots \ldots \ldots \ldots \ldots \ldots . . . . . . . . . . .64$ Figura 21: Imagem das celas de cobre (presas a uma fita de carbono) utilizadas nas análises de MET.

Figura 22: Montagem do leito fixo no tubo de quartzo (i) do reator Parr antes (a) e depois (b) da reação: porção de lã de vidro (ii), zeólita (iii), segunda porção de lã de vidro (iv) e manta (v) para evitar o escape do sólido. Após a reação, verifica-se a formação de coque devido à mudança de coloração do catalisador sólido. .......74 Figura 23: Equipamentos utilizados na produção de bioetileno, compreendendo: fluxo de gases (a); reator de leito fixo (b) acoplado a uma bomba peristáltica com injeção de álcool (c); e cromatógrafo gasoso (d) conectado ao reator por uma linha

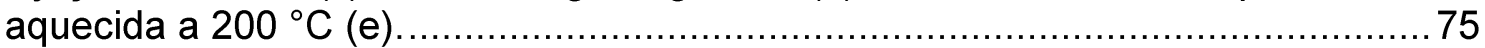

Figura 24: Micrografias das zeólitas $Y$ (pura)C aproximada $2.500 \times$ (a) e $5.000 \times$ (b) e da zeólita desaluminizada Y(80)5C também aproximada $2.500 \times$ (c) e $5.000 \times$ (d).

Figura 25: Micrografias da zeólita desaluminizada $Y(80) 5 \mathrm{C}$. A aproximação de $1.000 \times(a)$ exibe grandes aglomerados que, ao serem analisados com aproximações de 2.500 x (b) e 5.000 x (c), revelam uma superfície com cristalitos menores e coesos.

Figura 26: Micrografias da zeólita desaluminizada $Y(80) 5 \mathrm{C}$ na forma de pellets. $A$ imagem (a), aproximada $170 \mathrm{x}$, exibe um pellet de tamanho igual a $0,7 \mathrm{~mm}(661$ $\mu \mathrm{m})$ e, a micrografia (b), aproximada $200 \mathrm{x}$, mostra um pellet menor, de $0,3 \mathrm{~mm}$ $(333 \mu \mathrm{m})$. As imagens (c), aproximada $500 \mathrm{x}$, e (d), aproximada $4.000 \mathrm{x}$, ampliam o pellet exibido em (b), mostrando a manutenção dos pequenos cristalitos, da ordem de $0,5 \mu \mathrm{m}$.

Figura 27: Gráfico de conversão em função do tempo para a reação de desidratação do etanol PA, utilizando como catalisador $0,1 \mathrm{~g}$ da zeólita Y(pura)C.

Figura 28: Gráfico de seletividade em função do tempo para a reação de desidratação do etanol PA, utilizando como catalisador $0,1 \mathrm{~g}$ da zeólita Y(pura)C.

Figura 29: Gráfico de conversão em função do tempo para a reação de desidratação do etanol PA, utilizando como catalisador $0,1 \mathrm{~g}$ da zeólita $Y(80) 5 \mathrm{C} .87$ Figura 30: Gráfico de seletividade em função do tempo para a reação de desidratação do etanol PA, utilizando como catalisador $0,1 \mathrm{~g}$ da zeólita Y(80)5C. 88 Figura 31: Picos obtidos por CG (ponto 100) mostrando o excesso de etanol não reagido (em 1,87 $\mathrm{min}$ ) e do produto etileno (em $1,38 \mathrm{~min}$ ) para a reação de desidratação do etanol PA, utilizando como catalisador $0,1 \mathrm{~g}$ da zeólita $\mathrm{Y}(80) 5 \mathrm{C} .88$ Figura 32: Picos obtidos por CG (ponto 520) mostrando o excesso de etanol não reagido (em 1,87 $\mathrm{min}$ ) e do produto etileno (em 1,38 $\mathrm{min}$ ) para a reação de 
desidratação do etanol PA, utilizando como catalisador $0,1 \mathrm{~g}$ da zeólita Y(80)5C. Traços do subproduto dietil éter começaram a ser observados.

Figura 33: Picos obtidos por CG (ponto 1487) mostrando o excesso de etanol não reagido (em 1,87 $\mathrm{min}$ ), do produto etileno (em 1,38 $\mathrm{min}$ ) e do subproduto dietil éter (em 1,41 min) para a reação de desidratação do etanol PA, utilizando como catalisador $0,1 \mathrm{~g}$ da zeólita $\mathrm{Y}(80) 5 \mathrm{C}$.

Figura 34: Picos obtidos por CG (ponto 100) do excesso de etanol não reagido (em 1,87 $\mathrm{min}$ ), do produto etileno (em 1,38 $\mathrm{min}$ ) e do subproduto dietil éter (em 1,41 min) para a reação de desidratação do etanol PA, utilizando como catalisador $0,1 \mathrm{~g}$ da $\mathrm{Y}$ (pura)C.

Figura 35: Gráfico de conversão em função do tempo para o segundo ciclo catalítico da reação de desidratação do etanol PA, reutilizando $0,09 \mathrm{~g}$ da zeólita Y(pura)C

Figura 36: Gráfico de seletividade em função do tempo para o segundo ciclo catalítico da reação de desidratação do etanol PA, reutilizando $0,09 \mathrm{~g}$ da zeólita Y(pura)C.

Figura 37: Gráfico de conversão em função do tempo para o segundo ciclo catalítico da reação de desidratação do etanol PA, reutilizando $0,09 \mathrm{~g}$ da zeólita Y(80)5C.

Figura 38: Gráfico de seletividade em função do tempo para o segundo ciclo catalítico da reação de desidratação do etanol PA, reutilizando $0,09 \mathrm{~g}$ da zeólita $\mathrm{Y}(80) 5 \mathrm{C}$.

Figura 39: Difratograma da amostra $Y(80) 5 C$ (preto), antes da reação de desidratação de etanol PA e com padrão interno de Si elementar, e da mesma amostra após reação e calcinação (azul). .94

Figura 40: Curvas TG/DTG obtidas para a zeólita padrão $\mathrm{Y}$ (pura)C recuperada após reação de desidratação do etanol PA e adsorvida com Py..........................99 Figura 41: Curvas TG/DTG obtidas para a zeólita $\mathrm{Y}(80) 5 \mathrm{C}$ recuperada após reação de desidratação do etanol PA e adsorvida com Py..... .95

Figura 42: Gráfico de conversão em função do tempo obtido no teste de fluxo de etanol PA sobre o catalisador $\mathrm{Y}(80) 5 \mathrm{C}$. Os marcadores em preto representam um fluxo de 0,03 e $0,05 \mathrm{~mL} \mathrm{~min}^{-1}$; os vermelhos de $0,10 \mathrm{~mL} \mathrm{~min}^{-1}$; os azuis de $0,15 \mathrm{~mL}$ $\mathrm{min}^{-1}$; os amarelos de $0,18 \mathrm{~mL} \mathrm{~min}^{-1}$; os verdes de $0,20 \mathrm{~mL} \mathrm{~min}^{-1}$; e, os roxos de $0,22 \mathrm{~mL} \mathrm{~min}^{-1}$.

Figura 43: Gráfico de seletividade para etileno em função do tempo obtido no teste de fluxo de etanol PA sobre o catalisador $\mathrm{Y}(80) 5 \mathrm{C}$. Os marcadores em preto representam um fluxo de 0,03 e $0,05 \mathrm{~mL} \mathrm{~min}^{-1}$; os vermelhos de $0,10 \mathrm{~mL} \mathrm{~min}^{-1}$; os azuis de $0,15 \mathrm{~mL} \mathrm{~min}^{-1}$; os amarelos de $0,18 \mathrm{~mL} \mathrm{~min}^{-1}$; os verdes de $0,20 \mathrm{~mL} \mathrm{~min}^{-1}$;

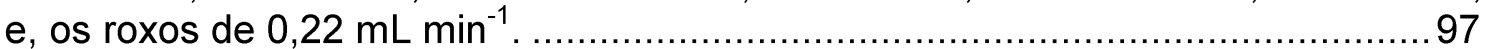

Figura 44: Gráfico de conversão em função do tempo para a reação de desidratação do bioetanol hidratado, utilizando como catalisador $0,1 \mathrm{~g}$ da zeólita

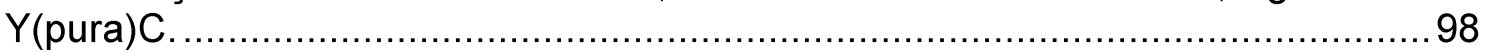

Figura 45: Gráfico de seletividade em função do tempo para a reação de desidratação do bioetanol hidratado, utilizando como catalisador $0,1 \mathrm{~g}$ da zeólita

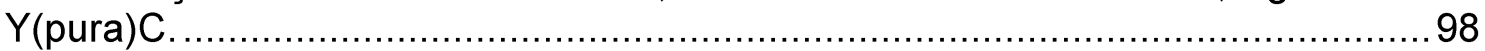

Figura 46: Gráfico de conversão em função do tempo para a reação de desidratação do bioetanol hidratado, utilizando como catalisador $0,1 \mathrm{~g}$ da zeólita

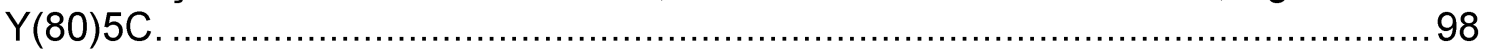

Figura 47: Gráfico de seletividade em função do tempo para a reação de desidratação do bioetanol hidratado, utilizando como catalisador $0,1 \mathrm{~g}$ da zeólita $\mathrm{Y}(80) 5 \mathrm{C}$. 
Figura 48: Catalisadores $\mathrm{Y}(80) 5 \mathrm{C}$ (a) e $\mathrm{Y}($ pura)C (b) submetidos à desidratação de bioetanol com posterior recuperação por calcinação a $550{ }^{\circ} \mathrm{C}$ durante $8 \mathrm{~h}$......... 100 Figura 49: Difratograma da amostra $Y($ pura)C (preto), antes da reação de desidratação do bioetanol e com padrão interno de Si elementar, e da mesma amostra após reação e calcinação (azul). 101

Figura 50: Difratograma da amostra $Y(80) 5 \mathrm{C}$ (preto), antes da reação de desidratação do bioetanol e com padrão interno de Si elementar, e da mesma amostra após reação e calcinação (azul).

Figura 51: Curvas TG/DTG da amostra $Y($ pura)C recuperada e calcinada após reação de desidratação com bioetanol hidratado com posterior adsorção de Py

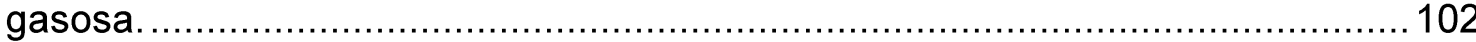

Figura 52: Curvas TG/DTG da amostra $Y(80) 5 \mathrm{C}$ recuperada e calcinada após reação de desidratação com bioetanol hidratado com posterior adsorção de Py

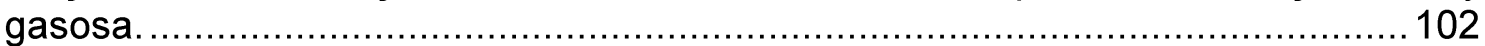

Figura 53: Gráfico de conversão em função do tempo para a reação de desidratação do bioetanol hidratado à pressão de 7,0 atm (azul), em comparação com a desidratação feita à pressão atmosférica (vermelho), utilizando como

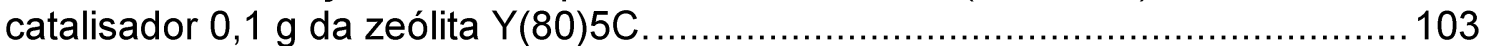

Figura 54: Gráfico de seletividade em função do tempo para a reação de desidratação do bioetanol hidratado à pressão de 7,0 atm (azul), em comparação com a desidratação feita à pressão atmosférica (vermelho), utilizando como

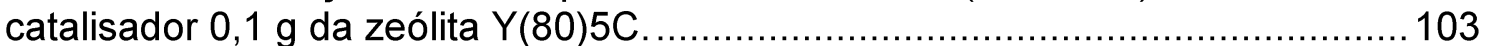

Figura 55: Em (a), a parte externa da câmara de injeção. Em (b), o tubo de borossilicato localizado dentro da câmara por onde passa a amostra injetada para a coluna cromatográfica. Em (c), a parte interna da câmara de injeção contendo o

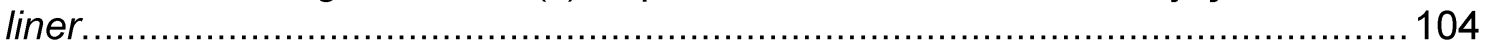

Figura 56: llustração da montagem interna da câmara de injeção de um cromatógrafo gasoso................................................................................... 105

Figura 57: Esquema simplificado do funcionamento do sistema split, em que somente uma parte do analito é injetada na coluna cromatográfica. ...................105

Figura 58: Esquema ilustrando o empacotamento do leito fixo no liner utilizado

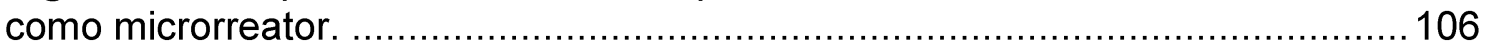

Figura 59: Diagrama esquemático do microrreator desenvolvido por Choudhary combinado com a cromatografia gasosa. Nesse caso, dois injetores (A e B) estão

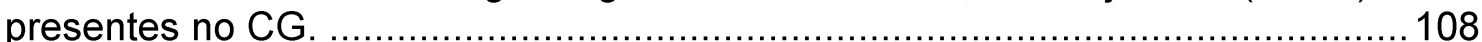

Figura 60: Detalhes do microrreator desenvolvido por Choudhary. .................. 109 Figura 61: Mecanismo proposto, adaptado da referência [149], para a desidratação de alcoóis sobre alumina ativa via reação direta pelo sítio de Lewis (Al). O símbolo $\left({ }^{*}\right)$ mostra o oxigênio marcado................................................ 114 Figura 62: Mecanismo proposto, adaptado da referência [149], para a desidratação de alcoóis sobre alumina ativa via reação direta do álcool com um sítio básico do tipo $\mathrm{Al}-\mathrm{O}^{-}$. O símbolo $\left(^{*}\right)$ mostra o oxigênio marcado. ...................114 Figura 63: Mecanismo proposto, adaptado da referência [149], para a desidratação de alcoóis sobre alumina ativa a partir da utilização de um sítio de Lewis (1), um sítio de Brønsted (2) e um sítio básico (3) ................................... 115 Figura 64: Mecanismo proposto, adaptado da referência [149], para a produção de olefinas a partir da desidratação de alcoóis................................................... 115 Figura 65: Etapas elementares propostas para a dimerização do etanol com formação do dietil éter, favorecido pela acessibilidade do álcool aos maiores canais do catalisador. 116 
Figura 66: Etapas elementares propostas para a produção de etileno a partir da desidratação do etanol dentro dos poros da zeólita, que não permitem a formação de grandes estruturas diméricas.

Figura 67: Em (a), imagem digital do molde papel filtro embebido com a mistura de ZrHPW e, em (b), o sólido nanoestruturado de ZrHPW no formato do papel após calcinação e eliminação da celulose.

Figura 68: Em (a), imagem digital obtida para os cristais microestruturados de ZrHPW sendo formados após um dia de secagem ao ar e, em (b), o mesmo sólido já totalmente seco após 3 dias.

Figura 69: Em (a), imagem digital obtida para o pó ZrHPW-nano de coloração esbranquiçada e, em (b), o pó ZrHPW-micro de coloração levemente amarelada mais finamente disperso.

Figura 70: Micrografias do reagente $\mathrm{ZrOCl}_{2}$ com aproximações de $100 \times$ (a) e $300 \times(b)$. 119

Figura 71: Micrografias do reagente HPW não calcinado com aproximações de $600 \times(a), 1.600 \times$ (b), $2.500 \times$ (c) e $6.000 \times$ (d) ............................................ 120 Figura 72: Micrografias do sólido sintetizado ZrHPW-micro com aproximações de $600 \times(a), 2.000 \times$ (b), $800 \times$ (c) e $4.500 \times$ (d) ............................................ 121 Figura 73: Análise de FRX/EDX pelo equipamento de MEV da amostra ZrHPW-micro em sua totalidade (a) e do ponto 1, em azul, em (b). ...................121 Figura 74: Microscopias do sólido ZrHPW moldado com papel filtro em aproximações de $160 \times(\mathrm{a}), 800 \times$ (b), $2.500 \times$ (c) e $4.500 \times$ (d), na região de fibras entrelaçadas, e $1.000 \times$ (e), $4.300 \times$ (f) e $10.000 \times$ (g), na região com fibras soltas.

Figura 75: Imagens obtidas por MET para o sólido ZrHPW moldado com papel filtro. Em (a), a estrutura obtida de tamanho nanométrico e, em (b), os aglomerados depositados no material fibroso. ................................................ 123

Figura 76: Micrografia (a) e mapas de distribuição dos elementos oxigênio (b), zircônio (c) e tungstênio (d) na superfície das nanofibras de ZrHPW. ..................124 Figura 77: Difratogramas do HPW e da celulose em comparação com aqueles obtidos para as amostras ZrHPW-micro e ZrHPW-nano. ................................. 125 Figura 78: Espectros de FT-IR obtidos para o HPW, para a celulose e para as amostras ZrHPW-micro e ZrHPW-nano....................................................... 126

Figura 79: Curvas TG/DTG/DTA obtidas para o HPW puro............................. 129

Figura 80: Curvas TG/DTG/DTA obtidas para a amostra ZrHPW-micro............129

Figura 81: Curvas TG/DTG/DTA obtidas para a amostra ZrHPW-nano..............130

Figura 82: Esquema ilustrativo do cluster catiônico $\left[\mathrm{Zr}_{4}(\mathrm{OH})_{8}\left(\mathrm{H}_{2} \mathrm{O}\right)_{16}\right]^{+8}$............. 132

Figura 83: Materiais obtidos a partir da oligomerização do $\mathrm{ZrOCl}_{2}$ em água. $\mathrm{A}$ imagem (a) mostra as nanofibras após calcinação, que exibem o mesmo formato do molde papel filtro, e a foto (b) mostra o sólido recuperado após a síntese que não passou pelo molde............................................................................... 132

Figura 84: Microscopias do sólido $\mathrm{ZrOCl}_{2}$ hidrolisado e moldado com papel filtro em aproximações de $120 \times$ (a), $1.000 \times$ (b), $2.000 \times$ (c) e $10.000 \times$ (d) ................ 133 Figura 85: Microscopias da celulose em pó, com aproximações de $300 \times$ (a) e $1.000 \times$ (b); do material ZrHPW-micro-cp, com aproximações de $1.000 \times$ (c) e 6.000 x (d); e da amostra ZrHPW-nano-cp, com aproximações de 450 x (e) e 2.300 x (f).

Figura 86: Difratogramas do HPW e da celulose em pó em comparação com aqueles obtidos para as amostras ZrHPW-micro-cp e ZrHPW-nano-cp. .............. 136 Figura 87: Espectros de FT-IR obtidos para o HPW, para a celulose em pó e para as amostras ZrHPW-micro-cp e ZrHPW-nano-cp. ........................................... 136 Figura 88: Curvas TG/DTG/DTA obtidas para a amostra ZrHPW-micro-cp........ 138 
Figura 89: Curvas TG/DTG/DTA obtidas para a amostra ZrHPW-nano-cp........ 138

Figura 90: Espectros de FT-IR obtidos para as amostras ZrHPW-micro, ZrHPW-micro-cp, ZrHPW-nano e ZrHPW-nano-cp após adsorção de Py. ...........139

Figura 91: Curvas TG/DTG obtidas para o HPW após adsorção de Py.............. 140

Figura 92: Curvas TG/DTG obtidas para a amostra ZrHPW-micro após adsorção

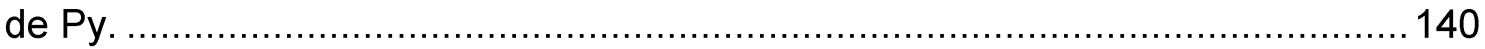

Figura 93: Curvas TG/DTG obtidas para a amostra ZrHPW-micro-cp após adsorção de Py................................................................................. 141

Figura 94: Curvas TG/DTG obtidas para a amostra ZrHPW-nano após adsorção de Py. ........................................................................................... 141

Figura 95: Curvas TG/DTG obtidas para a amostra ZrHPW-nano-cp após adsorção de Py....................................................................................... 141

Figura 96: Imagens digitais dos sólidos Zn-HPW obtidos na síntese dupla com papel filtro. Em (a), o papel filtro mergulhado na solução de ZnHPW; em (b), o sólido branco residual ZnHPW-micro-1,33 após 3 dias de secagem ao ar; em (c), o mesmo sólido da foto (b) após calcinação; em (d), o sólido amarelado ZnHPW-micro-2,66, de mesma aparência do ZnHPW-micro-3,98; e, em (e), o sólido preto obtido para todas as amostras moldadas com o papel filtro após

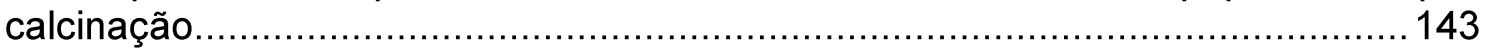

Figura 97: Micrografias dos sólidos sintetizados ZnHPW-micro-1,33, em aproximações de $30 \times$ (a) e $230 \times$ (b); ZnHPW-micro-2,66, em aproximações de 85 x (c) e 700 x (d); e ZnHPW-micro-3,98, em aproximações de 300 x (e) e 700 x (f). 145

Figura 98: Micrografias do sólidos moldado com papel filtro ZnHPW-nano-1,33 em aproximações de $200 \times$ (a), $1.100 \times$ (b), $2.300 \times$ (c) e $10.000 \times$ (d) .................... 146 Figura 99: Micrografias do sólido moldado com papel filtro ZnHPW-nano-2,66 em aproximações de $200 \times$ (a), 2.300 x (b), 4.300 x (c) e $10.000 \times$ (d) ................... 147 Figura 100: Micrografias do sólido moldado com papel filtro ZnHPW-nano-3,98 em aproximações de $300 \times$ (a), $1.000 \times$ (b), $1.500 \times$ (c) e $4.300 \times$ (d) ....................... 147 Figura 101: Espectros de FT-IR obtidos para o HPW e para as amostras ZnHPW-micro-1,33, ZnHPW-nano-1,33, ZnHPW-micro-2,66 e ZnHPW-nano-2,66.

Figura 102: Curvas TG/DTG/DTA obtidas para o reagente $\mathrm{Zn}\left(\mathrm{NO}_{3}\right)_{2}$. A partir de $170{ }^{\circ} \mathrm{C}$, complexos hidroxilados são observados, decompondo-se acima de 250 ${ }^{\circ} \mathrm{C}$.

Figura 103: Curvas TG/DTG/DTA obtidas para a amostra ZnHPW-micro-1,33. 150 Figura 104: Curvas TG/DTG/DTA obtidas para a amostra ZnHPW-micro-2,66 . 150 Figura 105: Difratogramas do HPW em comparação com aqueles obtidos para as amostras ZnHPW-micro-1,33 e ZnHPW-micro-2,66. O símbolo $\left(^{*}\right)$ destaca as reflexões não encontradas nos sólidos sintetizados. 151

Figura 106: Difratogramas do HPW calcinado em diferentes temperaturas: (a) HPW hexahidratado a $170{ }^{\circ} \mathrm{C}$; (b) HPW anidro a $250^{\circ} \mathrm{C}$; (c) HPW anidro a $350{ }^{\circ} \mathrm{C}$; e (d) HPW anidro a $400{ }^{\circ} \mathrm{C}$.

Figura 107: Micrografias obtidas para o reagente $\mathrm{Zn}\left(\mathrm{CH}_{3} \mathrm{COO}\right)_{2}$ em aproximações de $100 \times(a)$ e $3.000 \times(b)$. 154

Figura 108: Micrografias do sólido ZnHPW-micro-acetato em aproximações de $110 \times(a), 370 \times(b), 1.500 \times(c)$ e $3.500 \times(d)$. 155 Figura 109: Micrografias do sólido ZnHPW-nano-acetato em aproximações de 330 $x(a), 1.100 \times(b), 2.300 \times$ (c) e $10.000 \times$ (d). O detalhe em (c) mostra dois padrões de fibras encontrados: um com abertura em sua extremidade e outro totalmente fechado. 155

Figura 110: Curvas TG/DTG/DTA obtidas para o reagente $\mathrm{Zn}\left(\mathrm{CH}_{3} \mathrm{COO}\right)_{2} \ldots \ldots \ldots 157$ 
Figura 111: Espectros de FT-IR obtidos para o HPW e para as amostras ZnHPW-micro-acetato e ZnHPW-nano-acetato.

Figura 112: Difratogramas do HPW em comparação com aqueles obtidos para as amostras $\mathrm{ZnHPW}$-micro-acetato e $\mathrm{ZnHPW}$-nano-acetato. O símbolo $\left(^{*}\right)$ destaca as reflexões não encontradas no sólido ZnHPW-micro-acetato.

Figura 113: Difratogramas do polimorfo $\mathrm{PW}_{8} \mathrm{O}_{26}$ na faixa de temperatura de 650 $1150{ }^{\circ} \mathrm{C}$ : (a) cúbico, $650^{\circ} \mathrm{C}$; (b) monoclínico, $750{ }^{\circ} \mathrm{C}$; (c) ortorrômbico, $1050^{\circ} \mathrm{C}$; e

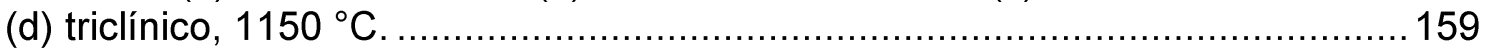

Figura 114: Micrografias dos óxidos de tungstênio e do metal $W$ formado pela redução do $\mathrm{WO}_{3}$ com hidrogênio. De acordo com Weil e Schubert, a razão para a mudança significativa na forma dos padrões das partículas é um transporte químico de vapor (CVT, do inglês Chemical Vapour Transport) de tungstênio via

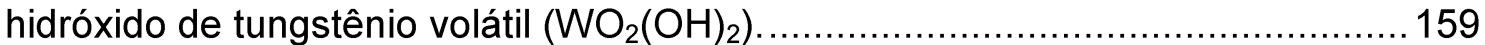

Figura 115: Com a elevação da temperatura, a cor do $\mathrm{WO}_{3}$ muda de amarelo esverdeado para amarelo escuro e, finalmente, laranja. ............................... 160

Figura 116: Curvas TG/DTG/DTA obtidas para o sólido ZnHPW-micro-acetato. 161 Figura 117: Curvas TG/DTG/DTA obtidas para o sólido ZnHPW-nano-acetato.. 161 Figura 118: Espectros de FT-IR obtidos para as amostras ZnHPW, sintetizadas com nitrato e acetato, após adsorção de Py................................................ 162 Figura 119: Curvas TG/DTG obtidas para a amostra ZnHPW-micro-1,33 após adsorção de Py........................................................................................ 162

Figura 120: Curvas TG/DTG obtidas para a amostra ZnHPW-micro-2,66 após adsorção de Py......................................................................................... 163

Figura 121: Curvas TG/DTG obtidas obtida para a amostra ZnHPW-micro-acetato após adsorção de Py.................................................................................. 163

Figura 122: Curvas TG/DTG obtidas para a amostra ZnHPW-nano-acetato após adsorção de Py....................................................................................... 164

Figura 123: Imagens digitais dos sólidos AgHPW obtidos na síntese dupla com papel filtro. Em (a), a solução de AgHPW; em (b), o sólido residual AgHPW-micro após 3 dias de secagem ao ar - no detalhe, o mesmo sólido após calcinação; em (c), o papel filtro após ser embebido na solução de AgHPW; e, em (d), o sólido moldado AgHPW-nano de cor amarelada, após calcinação, com o mesmo formato do papel filtro.

Figura 124: Micrografias do reagente $\mathrm{AgNO}_{3}$ em aproximações de 70 x (a) e

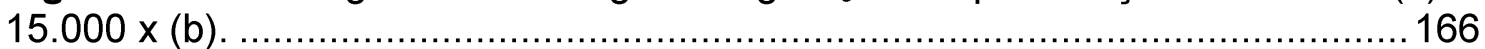

Figura 125: Micrografias da amostra AgHPW-micro em aproximações de $400 \mathrm{x}$ (a), $1.000 \times$ (b), 2.000 x (c) e 6.000 x (d) .................................................... 167

Figura 126: Micrografias da amostra AgHPW-nano em aproximações de $200 \times$ (a e b), 1.100 x (c) e 2.300 x (d) ............................................................... 168

Figura 127: Difratogramas do HPW em comparação com aqueles obtidos para as amostras AgHPW-micro e AgHPW-nano........................................................ 169 Figura 128: Espectros de FT-IR obtidos para o HPW e para as amostras AgHPW-micro e AgHPW-nano. ............................................................ 170 Figura 129: Curvas TG/DTG/DTA obtidas para a amostra AgHPW-micro.......... 171 Figura 130: Curvas TG/DTG/DTA obtidas para a amostra AgHPW-nano...........171 Figura 131: Espectros de FT-IR obtidos para as amostras AgHPW após adsorção

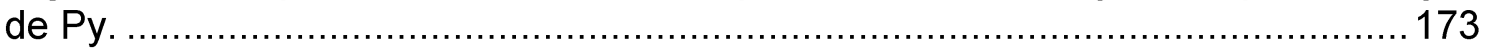
Figura 132: Curvas TG/DTG obtidas para a amostra AgHPW-micro após adsorção de Py. ............................................................................................ 174 Figura 133: Curvas TG/DTG obtidas para a amostra AgHPW-nano após adsorção

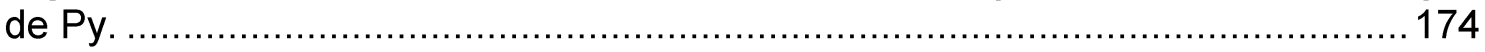


Figura 134: Gráfico da conversão versus o número de injeções para a reação de desidratação do etanol PA utilizando os catalisadores HPW e ZrHPW-micro. ....176 Figura 135: Gráfico de seletividade versus o número de injeções para a reação de desidratação do etanol PA utilizando os catalisadores HPW e ZrHPW-micro. ....176 Figura 136: Ilustração do mecanismo da reação de esterificação do álcool benzílico com ácido acético na presença de um catalisador ácido.

Figura 137: Gráfico de conversão (éster) versus o tempo de reação obtido na reação de esterificação do álcool benzílico sem catalisador (branco) e utilizando o HPW e os materiais de HPAs sintetizados.

Figura 138: Gráfico de conversão (benzaldeído) versus o tempo de reação obtido na reação de oxidação do álcool benzílico sem catalisador (branco) e utilizando o HPW e os materiais de HPAs sintetizados. 184

Figura 139: Gráfico de conversão (benzaldeído) versus o tempo de reação obtido em $2 \mathrm{~h}$ de reação de oxidação do álcool benzílico sem catalisador e utilizando o sólido ZrHPW-nano em dois ciclos reacionais.

Figura 140: Esquema representativo do mecanismo da oxidação do álcool benzílico utilizando um catalisador com grupos metálicos em alto estado de oxidação. ${ }^{193}$ 186

Figura 141: Gráfico de conversão (benzaldeído) versus o tempo de reação obtido nas $6 \mathrm{~h}$ da reação de oxidação do álcool benzílico sem catalisador e utilizando os materiais ZrHPW-micro e ZnHPW-micro-acetato. As barras representam o erro mensurado a partir da duplicata da reação 187

Figura 137: Gráfico de conversão (benzaldeído) versus o tempo de reação obtido nas $2 \mathrm{~h}$ da reação de oxidação do álcool benzílico sem catalisador e utilizando os materiais ZrHPW-micro e ZrHPW-nano na presença e ausência do solvente acetonitrila. 189 


\section{Introdução, Revisão}

\section{Bibliográfica \& Objetivos}




\section{INTRODUÇÃO}

Hoje, a principal forma utilizada para produção de olefinas leves é aquela em que se emprega o petróleo como matéria prima. No entanto, pensando em um país como o Brasil, que possui uma vasta extensão territorial e um clima favorável para o cultivo da cana-de-açúcar, uma rota sintética alternativa, que usa o bioetanol como reagente de partida, oriundo dessa biomassa, também deve ser considerada. O Brasil é destaque na produção mundial do etanol de cana-de-açúcar, sobressaindo-se nos quesitos tecnológicos para produção desse álcool. Assim, os avanços em tecnologias permitem que o país produza etanol de primeira e segunda geração a custos bem inferiores àqueles da concorrência internacional. ${ }^{1,2}$ Além disso, a existência de uma nova aplicação para o bioetanol pode favorecer o equilíbrio comercial desse insumo em nível global, uma vez que a preocupação que vem sendo gerada pela baixa dos preços do álcool, sentida pelos produtores, é diminuída em virtude de um maior escoamento dos estoques de cana-deaçúcar e de etanol.

A produção de olefinas a partir da biomassa, além de industrialmente vantajosa pelos motivos supracitados, torna-se ainda mais interessante quando também são considerados os benefícios ambientais gerados ao se utilizar esse processo. De acordo com dados fornecidos pela empresa Braskem, ${ }^{3}$ pioneira no país na produção de polietileno verde, advindo do bioetanol, 2,10 toneladas de $\mathrm{CO}_{2}$ são lançadas à atmosfera ao se produzir o plástico a partir de fontes de combustíveis fósseis, enquanto a rota sintética que produz o polietileno a partir de fontes renováveis absorve 2,15 toneladas desse gás prejudicial ao meio ambiente. Dessa forma, no total, 4,25 toneladas de $\mathrm{CO}_{2}$ deixam de ser lançadas à atmosfera por tonelada de polietileno produzida, o que implica em um processo mais sustentável.

Justamente por ser uma fonte advinda da biomassa, a produção e, consequentemente, o preço do bioetanol são fortemente influenciados pelas variações sazonais e pelas alterações climáticas, fatores desvantajosos para a indústria. Portanto, a existência de uma planta industrial capaz de processar exclusivamente 0 etanol para produzir etileno nem sempre pode ser interessante em termos financeiros. Uma maneira de contornar esse problema 
é desenvolver, por exemplo, catalisadores resistentes, que permitam o coprocessamento das matérias-primas álcool e petróleo, visando à otimização do processo de produção de olefinas. Os catalisadores zeolíticos surgem, então, como uma boa opção nesse cenário, pois as estruturas cristalinas porosas das zeólitas, além de apresentarem alta acidez, permitem que esses materiais sejam utilizados em um sistema de coprocessamento. ${ }^{4,5}$

O trabalho apresentado nesta tese também envolve 0 estudo morfológico e de acidez de novos materiais baseados em heteropoliácidos, que são sólidos versáteis, com potencial para serem aplicados nas mais variadas áreas da ciência. Heteropolissais, por exemplo, advindos da troca iônica de átomos de hidrogênios dos heteropoliácidos por cátions metálicos, são pesquisados em diferentes setores além da catálise, com aplicações em energia, em eletrônicos, em biomedicina, em óptica e ainda como componentes de semicondutores, de nanofluidos, de nanofios, a depender da geometria e das características químicas apresentadas pelos materiais. ${ }^{6}$

Abordando esses conceitos, o presente trabalho foi subdividido em 4 capítulos principais e um apêndice. O capítulo 1 contextualiza e detalha o tema por meio de uma revisão bibliográfica, mostrando os objetivos que nortearam a pesquisa. O capítulo 2 apresenta as técnicas e as condições experimentais utilizadas na síntese e na modificação dos catalisadores, nas reações em que foram aplicados e em suas caracterizações de estrutura e acidez. O capítulo 3 expõe os resultados das conversões, seletividades e atividades catalíticas gerados pela aplicação dos catalisadores desenvolvidos nas reações de desidratação de alcoóis e, ainda, nas outras reações-modelo (de esterificação e oxidação do álcool benzílico) em que os heteropolissais foram empregados. Nesse mesmo capítulo também são discutidos os mecanismos das reações, bem como sua correlação com os parâmetros de acidez e de estrutura obtidos pelas caracterizações feitas nos materiais. Além disso, o capítulo 3 descreve o microrreator de pulso desenvolvido e utilizado em algumas das reações neste trabalho. O capítulo 4, por fim, resume as conclusões da pesquisa, apresentando algumas perspectivas futuras. 


\section{REVISÃO BIBLIOGRÁFICA}

\subsection{Catalisadores para Aplicação na Produção de Bio-olefinas: Zeólitas e Polioxometalatos}

Materiais com estruturas bem definidas possuem características peculiares e previsíveis, com geometrias diferenciadas. A existência de arranjos cristalinos com canais e cavidades determinados permite o transporte tanto de íons e elétrons como de moléculas, confere uma alta capacidade adsortiva ao material e, não raro, gera uma atividade catalítica ressaltada. Essas propriedades são de grande interesse industrial, pois permitem a aplicação dos materiais em diferentes áreas, como na catálise química.

Dentre uma infinidade de catalisadores existentes, as zeólitas e os polioxometalatos (POMs), estudados nesse trabalho, sobressaem-se por sua grande importância e aplicabilidade no cenário da pesquisa e da indústria. De um lado, as zeólitas se destacam devido a seu atrativo sistema poroso, que permite a seleção de moléculas de determinadas dimensões, e a sua alta acidez, advinda dos fortes sítios de Brønsted. ${ }^{7}$ De outro lado, os polioxometalatos exibem características também únicas, com possibilidade de aplicação tanto em reações ácido-base, pela presença de sítios ácidos de Brønsted, como em reações de oxirredução. ${ }^{8}$ Outras propriedades como fotocromismo, ${ }^{9,10}$ eletrocromismo, ${ }^{9,11}$ magnetismo $^{12}$ e quiralidade ${ }^{13}$ ampliam ainda mais o campo de aplicação desses materiais. ${ }^{14}$

Ambos os materiais, zeólitas e POMs, com suas especificidades, podem ainda ter sua atividade catalítica incrementada, tornando-se bifuncionais com a adição de sítios ácidos de Lewis em sua estrutura, o que gera um sinergismo com sítios de Brønsted pré-existentes.

\subsubsection{Zeólitas}

Zeólitas são sólidos aluminossilicatos microporosos, naturais ou sintéticos, com alta área superficial, formados a partir da união de tetraedros de átomos de alumínio $(\mathrm{Al})$, oxigênio $(\mathrm{O})$ e silício $(\mathrm{Si}) .{ }^{15}$ Os átomos de $\mathrm{Si}$ e $\mathrm{Al}$ estão coordenados por meio do oxigênio (vide Figura 1) de tal maneira que há 
a formação de espécies $\mathrm{SiO}_{4}$, neutras, e espécies com uma densidade de carga negativa $\mathrm{AlO}_{4}^{-}$. Estas são balanceadas por cátions durante o processo de síntese, os quais estão localizados principalmente nos poros zeolíticos e apresentam alta mobilidade, podendo ser trocados por outras espécies catiônicas. $^{7}$

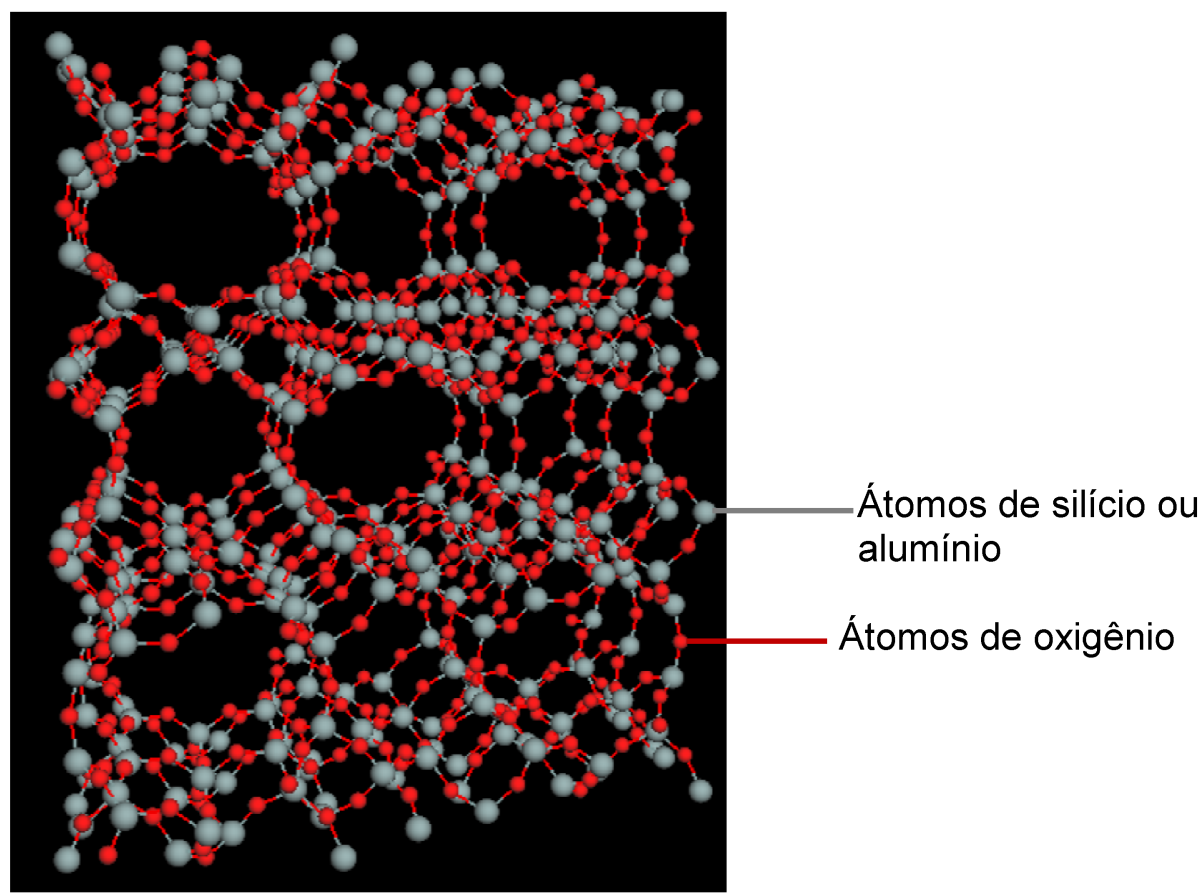

Figura 1: Representação da estrutura tridimensional da zeólita natural clinoptilolita gerada pelo programa ArgusLab. ${ }^{16}$

Assim, a formação da rede cristalina de uma zeólita se dá a partir do agrupamento dos tetraedros, compondo as chamadas unidades secundárias de construção (SBU - Secondary Building Units), as quais, por sua vez, dão origem a diferentes poliedros que se repetem ao longo da estrutura. ${ }^{17} \mathrm{De}$ acordo com as diversas geometrias que podem ser formadas pela união das SBUs, diferentes zeólitas podem ser originadas, gerando, também, desde grandes cavidades internas até uma série de canais que atravessam todo o material, o que leva à formação da extensa rede microporosa. A Figura 2, por exemplo, ilustra a formação da zeólita do tipo Y (FAU - faujasita), a partir da união de unidades sodalita (SOD) com uma unidade secundária que é o anel de seis membros (D6R), e da zeólita do tipo ZSM-5 (MFI - Mobil Five), gerada pelo empilhamento de unidades pentasil. ${ }^{7,15,17,18}$ 


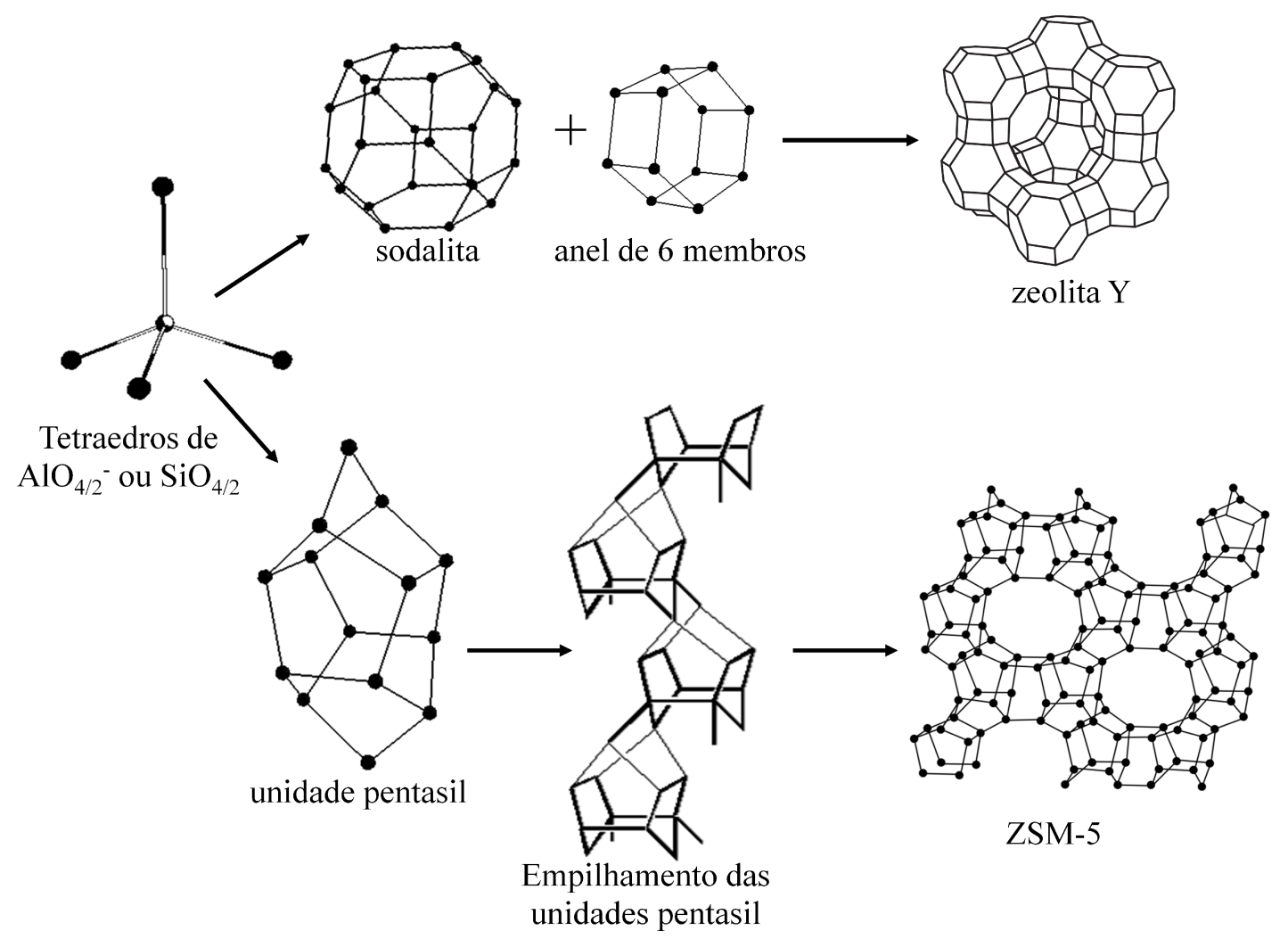

Figura 2: Formação da estrutura final das zeólitas $Y$ e ZSM-5, com poros e cavidades específicos, gerada pelo agrupamento de tetraedros de alumínio ou silício. ${ }^{16}$

Os diferentes tamanhos de poros existentes na armação final das zeólitas conferem a elas uma propriedade muito importante na catálise: a seletividade de forma. As cavidades zeolíticas, por possuírem um diâmetro limitado, permitem apenas a passagem de determinadas moléculas, o que pode originar vários tipos de seletividade (como a de reagente, a de produto e a de estado de transição) e elevar a capacidade adsortiva desses materiais. ${ }^{7} \mathrm{~A}$ Figura 3 mostra uma zeólita do tipo A (LTA - Linde Type A), em que moléculas lineares são capazes de atravessar os canais e serem adsorvidas (Figura 3-a), mas o grande volume de uma molécula ramificada impede que esta adentre ao poro (Figura 3-b). É essa capacidade seletiva de adsorção que faz com que esses sólidos sejam classificados como peneiras moleculares. ${ }^{7,16}$ 
(a)

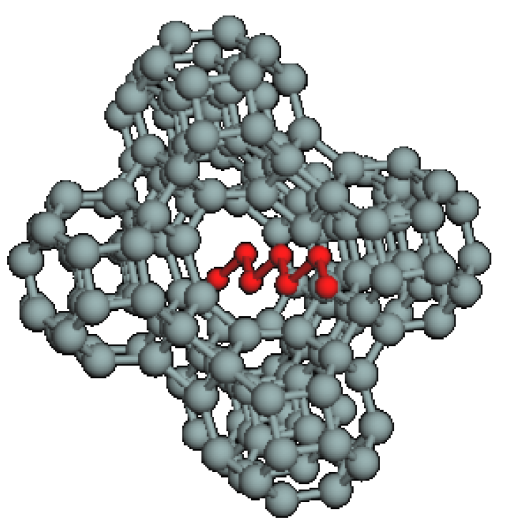

(b)

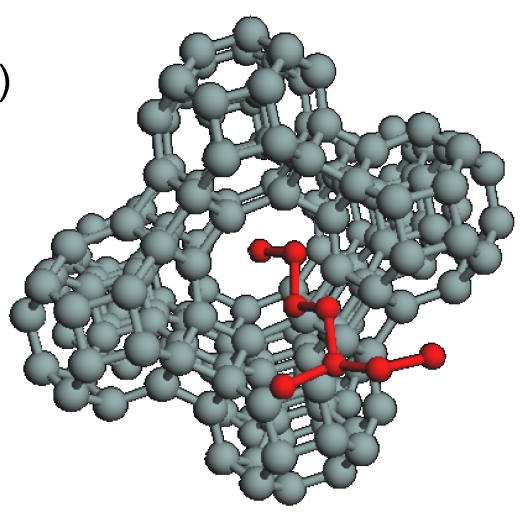

Figura 3: Em (a), uma molécula linear tem acesso aos poros da zeólita LTA. Em (b), a ramificação da molécula impede esse acesso. ${ }^{16}$

A eficiência das zeólitas em catálise também está intimamente relacionada à presença de centros ativos, que podem ser ácidos, básicos ou do tipo REDOX. A existência de sítios de Brønsted, por exemplo, responde pela forte acidez dos materiais que os contêm, sendo formados pela presença do cátion $\mathrm{H}^{+}$como íon compensador da carga negativa das espécies $\mathrm{AlO}_{4}^{-}$.

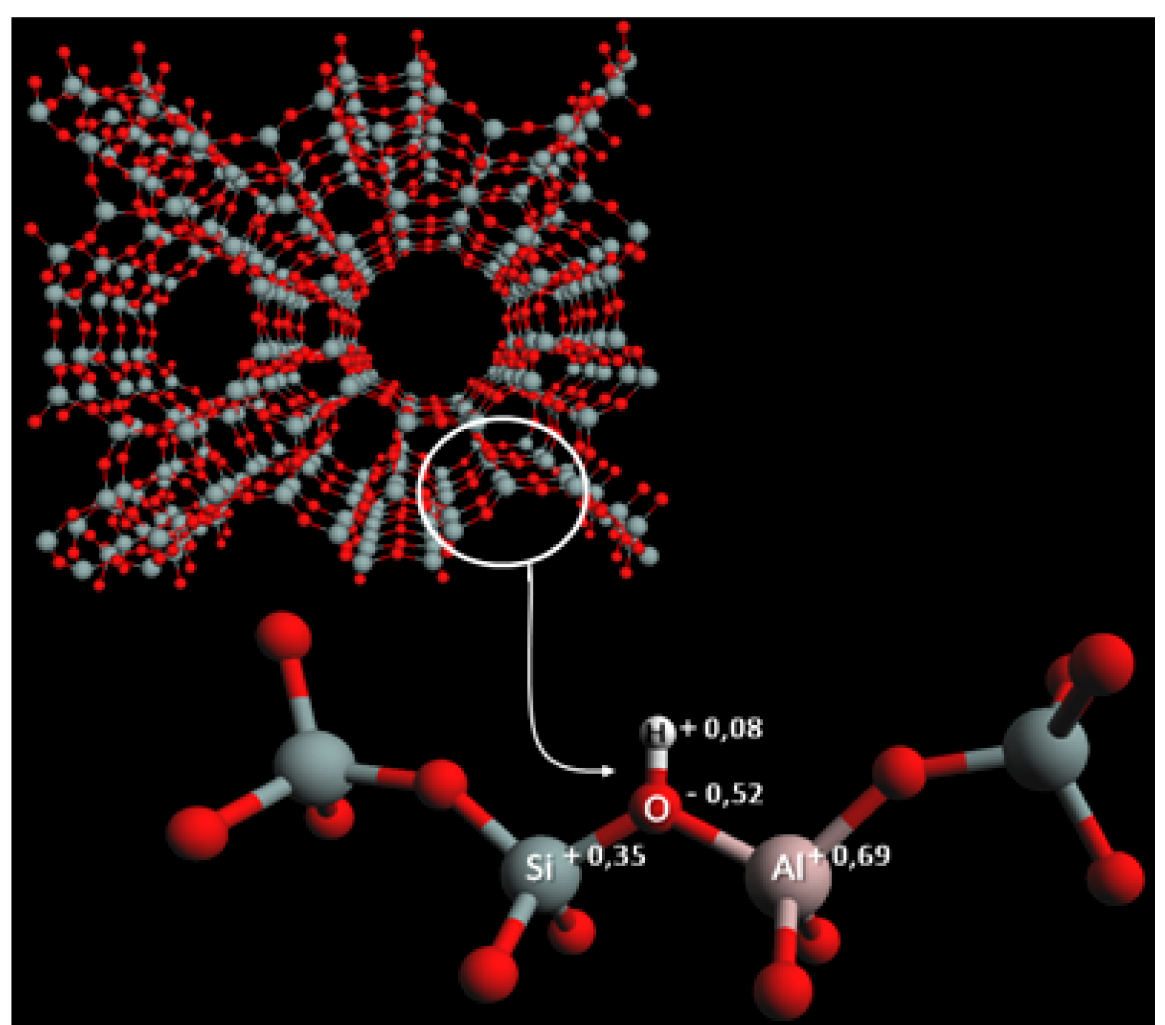

Figura 4: Estrutura da zeólita Beta. No detalhe, a representação dos sítios ácidos de Brønsted existentes nas zeólitas em geral, em que a carga negativa das espécies $\mathrm{AlO}_{4}{ }^{-}$é contrabalanceada pelo íon hidrogênio. 
A Figura 4 destaca a presença do sítio ácido de Brønsted na estrutura da zeólita Beta (BEA) e as cargas parciais dos átomos responsáveis por gerar essa acidez. Como pode ser notado, o número de centros ácidos protônicos (sítios de Brønsted) diz respeito ao número de átomos de alumínios tetraédricos na rede cristalina da zeólita., ${ }^{75-17}$

\subsubsection{Modificação de Zeólitas: processo de desaluminização}

Desde a descoberta das zeólitas, em 1756, pelo mineralogista sueco Axel Fredrik Cronstedt (1722 - 1765), mais de 200 tipos diferentes de zeólitas já foram identificados. ${ }^{16,19,20}$ Como são constituídos basicamente por átomos de silício e alumínio, cada um desses sólidos, com suas diversas geometrias, são caracterizados por uma determinada razão Si/Al. Este importante parâmetro exerce forte influência em diversas propriedades das zeólitas: estabilidade térmica e hidrotérmica, hidrofobicidade, concentração e força de sítios ativos, atividade catalítica e seletividade. ${ }^{18,21,22}$ Todos esses fatores estão diretamente relacionados com sua aplicação em catálise heterogênea, tendo em vista que um catalisador mais hidrofóbico e mais estável será, em tese, mais resistente em reações que geram água como produto (por exemplo, a desidratação de alcoóis, a esterificação de ácidos carboxílicos, etc.) e, dessa forma, deverá permanecer ativo por mais tempo. ${ }^{18}$ Assim, como os átomos de alumínio são aqueles que conferem uma maior hidrofilicidade à zeólita, uma modificação na estrutura zeolítica que vise à remoção total ou parcial de $\mathrm{Al}$, isto é, um processo de desaluminização que aumente a razão Si/Al, deverá conferir maior hidrofobicidade a esses sólidos. ${ }^{18}$

Dentre as diversas formas de desaluminização existentes, três métodos principais podem ser destacados. O primeiro, mais comum e amplamente difundido, é o método hidrotérmico, em que os átomos de alumínio são removidos pelo aquecimento da zeólita na presença de vapor d'água (steaming) sem inserção adicional de silício. McDaniel e Maher, ${ }^{23}$ em 1968 , estudaram o procedimento para tornar as zeólitas ultraestáveis, reportando que as espécies de alumínio removidas da estrutura zeolítica se depositavam na forma de óxido de alumínio nos espaços inter e/ou intracristalinos, enquanto as vacâncias eram, simultaneamente, preenchidas pelo próprio silício reticular. ${ }^{23,24}$ 
O segundo método, ao invés de água, utiliza um agente desaluminizante, como o ácido clorídrico, mas também remove os átomos de alumínio sem adição de silício externo à rede zeolítica para preencher as vacâncias geradas. Já o terceiro método é dito substitutivo, pois um agente desaluminizante já contendo átomos de silício, como 0 tetracloreto de silício $\left(\mathrm{SiCl}_{4}\right)^{25,26}$ e o hexa(fluoro)silicato(IV) de amônio $\left(\mathrm{NH}_{4} \mathrm{SiF}_{6}\right),{ }^{27,28}$ é utilizado para remover o alumínio estrutural da zeólita e preencher as vacâncias formadas pela desaluminização. Para esse último método, por substituição direta, existem diversas derivações metodológicas, já tendo sido reportado na literatura procedimentos experimentais com a zeólita entrando em contato com o agente desaluminizante $\mathrm{SiCl}_{4}$ em fase gasosa, em temperaturas acima de $200{ }^{\circ} \mathrm{C} ;{ }^{29,30}$ com zeólitas amoniacais tratadas em suspensão aquosa com $\mathrm{NH}_{4} \mathrm{SiF}_{6}$, sob controle de temperatura e de $\mathrm{pH} ;{ }^{31}$ e, bem menos comum, com a zeólita sendo desaluminizada no estado sólido, ${ }^{18,24,32}$ via mistura mecânica com $\mathrm{NH}_{4} \mathrm{SiF}_{6}$ com posterior ativação em diferentes temperaturas.

É sabido que drásticas metodologias de desaluminização, como altas temperaturas ${ }^{18}$, utilização de ácidos fortes e de agentes desaluminizantes que agem somente por remoção, isto é, que não substituem o átomo de alumínio removido por um átomo de silício, tendem a deteriorar a cristalinidade das zeólitas mais facilmente e gerar defeitos irreversíveis. ${ }^{22,24}$ Com isso, sítios ácidos de Lewis podem ser formados a partir de átomos de alumínios extraídos da rede zeolítica. Tais espécies são conhecidas como espécies de alumínio fora de rede (EFAl, do inglês, Extraframework Aluminium), geralmente de coordenação octaédrica, ${ }^{33}$ e podem tanto incrementar a força ácida do material, a partir de sua interação com os sítios de Brønsted, como bloquear o acesso de outras moléculas aos poros e cavidades da zeólita. ${ }^{18,22}$

Uma das alterações causada pelo processo desaluminização nas características desses materiais é a variação de seletividade de forma. $O$ caráter microporoso das zeólitas restringe a entrada de certas moléculas em seus poros e canais, reduzindo sua aplicação em determinadas reações e gerando a chamada limitação difusional. ${ }^{27}$ Essa desvantagem vem sendo contornada por meio de modificações em sua morfologia, como pela desaluminização, transformando alguns dos microporos (diâmetro de poro de até $2 \mathrm{~nm}$ ) em mesoporos (diâmetro de poro entre 2 e $50 \mathrm{~nm}$ ). Qin e 
colaboradores, ${ }^{27}$ por exemplo, modificaram a zeólita NaY de forma a obter um material ultraestável e com maior desempenho para o craqueamento catalítico. Para tanto, o processo de desaluminização foi escolhido como estratégia para gerar mesoporos na estrutura, preservando a acidez da zeólita. Segundo os autores, a metodologia de desaluminização utilizada favoreceu, de fato, uma melhora na atividade e na estabilidade do catalisador devido à introdução de vacâncias na estrutura com manutenção da acidez. Esses defeitos levaram à migração de espécies $\mathrm{Si}(\mathrm{OH})_{4}$, constatada pela técnica de RMN-RAM de ${ }^{29} \mathrm{Si}$ e ${ }^{27} \mathrm{Al}$, que preencheram algumas lacunas e reestruturaram a rede zeolítica com a consequente formação dos mesoporos. ${ }^{27}$

Em se tratando especificamente da zeólita $Y$, utilizada no presente trabalho, sua aplicação em diferentes áreas já é conhecida, sendo vastamente empregada como catalisador microporoso ácido, principalmente nas refinarias, como em processos de craqueamento catalítico em leito fluidizado (FCC) e hidrocraqueamento, e na síntese de petroquímicos. A zeólita $Y$ com baixa proporção de alumínio, não raro, apresenta propriedades mais favoráveis para o uso como catalisador do processo $\mathrm{FCC}$. $^{21}$ Entretanto, via rota sintética, ela geralmente não é fabricada com razões Si/Al muito altas $(>2,5)$, pois o longo período de cristalização necessário para esse caso torna sua síntese economicamente inviável, ${ }^{21}$ o que ressalta a importância em se pesquisar e aprimorar métodos de modificações pós-síntese em zeólitas, como o processo de desaluminização.

A desaluminização, assim como quaisquer modificações na morfologia das zeólitas, implica em alterações de suas propriedades e, consequentemente, de sua atividade catalítica. Assim, torna-se possível descobrir novas peneiras moleculares, com combinações de diversas características, gerando catalisadores aprimorados para determinada reação.

\subsubsection{Polioxometalatos}

Os polioxometalatos (POMs) são materiais bastante versáteis em termos de estrutura, química REDOX, fotoquímica e distribuição de carga. ${ }^{34}$ São constituídos, de forma geral, por oxiânions de metais de transição, mais comumente tungstênio $(\mathrm{W})$, vanádio $(\mathrm{V})$, nióbio $(\mathrm{Ni})$ e molibdênio $(\mathrm{Mo})$, ligados 
entre si por átomos de oxigênio compartilhados. ${ }^{35,6}$ Essas ligações dão origem a diversos clusters tridimensionais, como o que pode ser observado na Figura 5. Desse modo, sua estrutura está baseada na combinação de diferentes tipos poliedros formados por unidades de construção $\left\{M O_{x}\right\}$, em que "M" é um elemento do bloco d da tabela periódica em alto estado de oxidação. ${ }^{36}$ Esses óxidos são formados por um processo semelhante a uma automontagem (self-assembly) em meio ácido, ${ }^{36}$ o que significa que o arranjo geométrico de POMs advém de um sistema em que espécies pré-existentes formam uma estrutura ordenada, isto é, um arranjo padrão, em consequência de suas interações específicas, sem a existência de um direcionador externo. O processo de automontagem leva à formação de agregados que podem estar conectados de diversas maneiras, gerando clusters moleculares da ordem de nanômetros até micrômetros. ${ }^{6}$

(a)

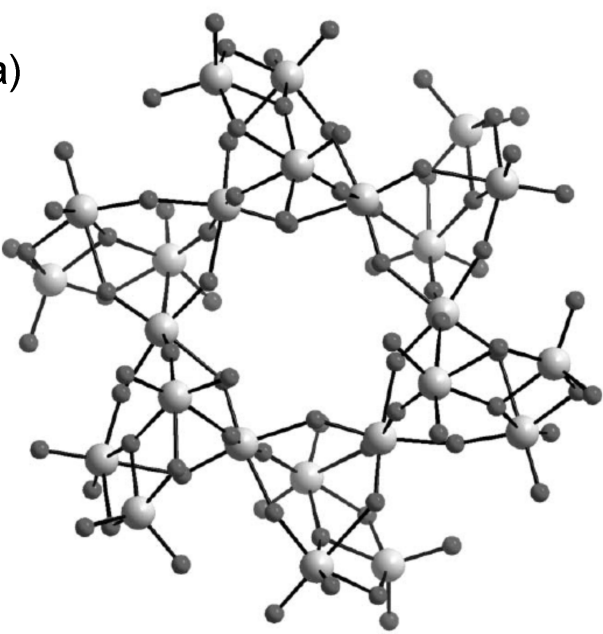

(b)

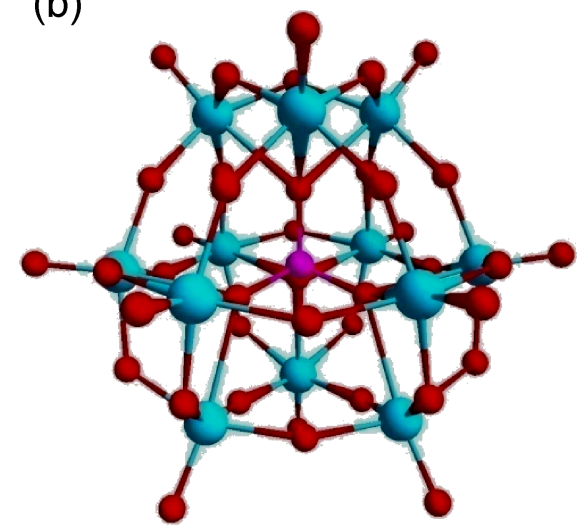

Figura 5: Modelos de clusters de POMs. Em (a), a representação da estrutura hexacoordenada do cluster $\left[\mathrm{W}_{24} \mathrm{O}_{84}\right]^{24-}$, em que a cor cinza claro representa átomos de tungstênio e, a cinza escuro, átomos de oxigênio; em (b), a representação do cluster do ânion tungstofosfato ( $\left[\mathrm{PW}_{12} \mathrm{O}_{40}\right]^{3-}$ ), em que a cor rosa (heteroátomo central) representa o átomo de fósforo, a cor azul, os átomos de tungstênio e, a cor vermelha, átomos de oxigênio. ${ }^{34}$

As metodologias utilizadas para se produzir clusters de POMs são extremamente simples, consistindo na acidificação de uma solução aquosa contendo o oxoânion do metal, como molibdato, tungstato e vanadato. ${ }^{34,37}$ As Equações 1 e 2 ilustram a formação de dois tipos de POMs: ${ }^{37}$ 


$$
\begin{aligned}
& 8 \mathrm{H}^{+}+7 \mathrm{WO}_{4}{ }^{2-} \rightarrow\left[\mathrm{W}_{7} \mathrm{O}_{24}\right]^{6-}+4 \mathrm{H}_{2} \mathrm{O} \\
& 23 \mathrm{H}^{+}+\mathrm{HPO}_{4}{ }^{2-}+12 \mathrm{MoO}_{4}{ }^{2-} \rightarrow\left[\mathrm{PMo}_{12} \mathrm{O}_{40}\right]^{3-}+12 \mathrm{H}_{2} \mathrm{O}
\end{aligned}
$$

De forma geral, a grande variedade de tipos de estruturas na química dos POMs pode ser agrupada em isopoliânions (produto da Equação 1) e heteropoliânions (produto da Equação 2). Há ainda uma terceira classe, mais recentemente investigada, que inclui POMs altamente simétricos e volumosos, como é o caso do azul de molibdênio e dos kepleratos esféricos. ${ }^{6}$ Um isopoliânion, como aquele exemplificado na Figura 5-a, é um polioxometalato formado apenas por um tipo de óxido, representado pela fórmula geral $\left[\mathrm{M}_{\mathrm{m}} \mathrm{O}_{\mathrm{y}}\right]^{\mathrm{p}-}$. No caso de um heteropoliânion, como o da Figura 5-b, dois ou mais tipos de ânions se condensam, apresentando fórmula geral $\left[\mathrm{X}_{x} \mathrm{M}_{\mathrm{m}} \mathrm{O}_{\mathrm{y}}\right]^{q-}$, em que $\mathrm{x} \leq \mathrm{m} \cdot{ }^{37}$ Assim, o heteroátomo " $X$ ", que pode ser um íon metálico ou um heteroânion (fosfatos, boratos, silicatos ou sulfatos), fornece um centro em torno do qual outros óxidos, como $\circ \mathrm{WO}_{6}$, compartilham átomos de oxigênio. ${ }^{6,34,36,38}$ Nesses materiais, a presença do heteroátomo é imprescindível para a manutenção do arranjo cristalino, já que sua remoção implicaria em destruição estrutural. É possível que haja ainda um ou mais heteroátomos secundários, cuja remoção não resulta em perda estrutural, mas faz com que lacunas sejam formadas. ${ }^{39}$

A relação entre o número de unidades de óxidos $\mathrm{MO}_{\mathrm{x}}$ e de heteroátomo "X" é variável e, dentre as principais, destacam-se a 12:1, a 9:1 e a 6:1, em que cada proporção se relaciona a uma estrutura geométrica. ${ }^{38} \mathrm{~A}$ Tabela 1 exemplifica as razões estequiométricas que foram precursoras no desenvolvimento da química dos polioxometalatos, indicando suas estruturas correspondentes.

Tabela 1: Principais estruturas de heteropoliânions. ${ }^{40}$

\begin{tabular}{c|c|c|c|c}
\hline Razão M:X & Estrutura & Átomo (M) & Heteroátomo (X) & Fórmula \\
\hline $12: 1$ & Keggin & $\mathrm{Mo}, \mathrm{W}$ & $\mathrm{P}, \mathrm{As}, \mathrm{Si}, \mathrm{Ge}$ & $\mathrm{XM}_{12} \mathrm{O}_{40}$ \\
\hline $18: 2$ & Wells-Dawson & $\mathrm{Mo}, \mathrm{W}$ & $\mathrm{P}, \mathrm{As}$ & $\mathrm{X}_{2} \mathrm{M}_{18} \mathrm{O}_{62}$ \\
\hline $9: 1$ & Anderson & $\mathrm{Mo}, \mathrm{W}$ & $\mathrm{Te}, \mathrm{I}$ & $\mathrm{XM}_{6} \mathrm{O}_{24}$ \\
\hline $6: 1$ & Waugh & $\mathrm{Mo}$ & $\mathrm{Mn}, \mathrm{Ni}$ & $\mathrm{XM}_{9} \mathrm{O}_{32}$ \\
\hline
\end{tabular}


No caso da proporção 12:1, umas das mais estudadas e utilizada neste trabalho, tem-se o arranjo conhecido como estrutura de Keggin (vide Figura 6), de fórmula $\left[\mathrm{XM}_{12} \mathrm{O}_{40}\right]^{\mathrm{n}-}$, em que $\mathrm{M}$ é um átomo de tungstênio ou de molibdênio e X representa o heteroátomo (Tabela 1). Nesse caso, o cluster é formado pela junção de quatro tríades $\mathrm{M}_{3} \mathrm{O}_{13}$, feita por meio do compartilhamento de oxigênios posicionados nos vértices. ${ }^{38,39,41}$ Cada tríade, por sua vez, possui três grupos $\mathrm{MO}_{6}$, que são conectados pelas arestas a partir do compartilhamento de oito átomos de oxigênio, restando cinco oxigênios terminais. Além disso, um oxigênio de cada uma das quatro tríades se coordena ao heteroátomo central, de maneira que, na estrutura de Keggin, podem ser identificados quatro tipos de oxigênio: os terminais; os conectados ao heteroátomo; os compartilhados via vértice; e os compartilhados via aresta. $^{37,38}$

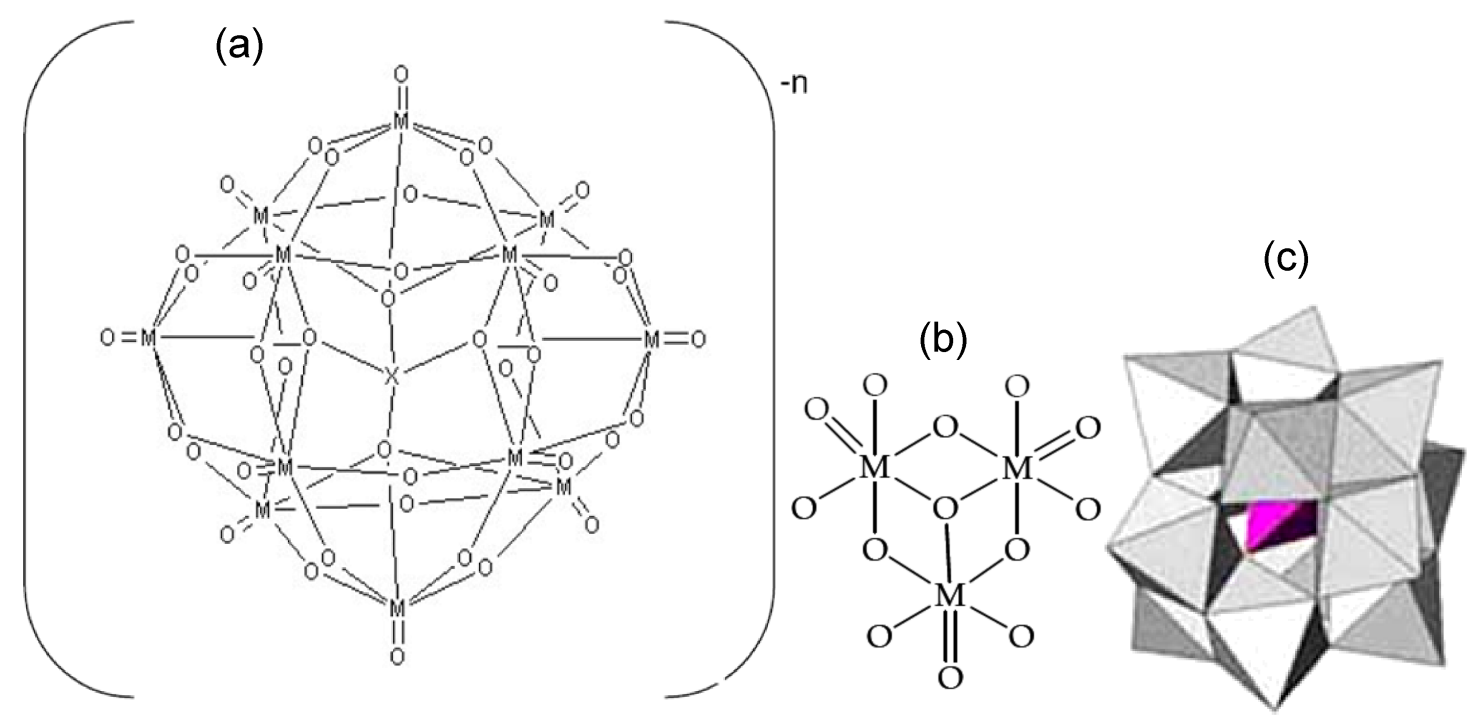

Figura 6: (a) Representação do ânion de Keggin. (b) Grupo $\mathrm{M}_{3} \mathrm{O}_{13}$. (c) Representação do cluster formado pela união das quatro tríades $\mathrm{M}_{3} \mathrm{O}_{13}$, com $\circ$ detalhe em rosa representando o heteroânion. ${ }^{38,39,41}$

\subsubsection{Modificação de Heteropoliácidos: formação de heteropolissais}

Dentre os vários compostos de POMs existentes, os heteropoliácidos (HPAs) possuem grande relevância. Pertencentes à classe de heteropoliânions, são formados a partir da inserção de prótons como 
contraíons em sua estrutura, o que confere a eles sítios ácidos de Brønsted. ${ }^{35,40,42,43}$ Apesar de sua grande força ácida, os HPAs são limitados pela quantidade de sítios disponíveis devido à baixa área superficial que apresentam (em torno de $5 \mathrm{~m}^{2} \mathrm{~g}^{-1}$ ). ${ }^{44}$ No entanto, os prótons possuem extrema mobilidade, principalmente os hidratados. Eles, juntamente com moléculas de solvente, como água e alcoóis, formam a chamada estrutura secundária do HPA (vide Figura 7), a qual varia de acordo com o grau de hidratação do composto e interliga os heteropoliânions por meio de ligações hidrogênio com os oxigênios terminais $W=0 .{ }^{35,40,42,45} A$ estrutura terciária é gerada quando essas estruturas secundárias se agrupam em partículas sólidas, conferindo propriedades intrínsecas ao material, como volume de poro, área superficial, dispersão, tamanho, etc. ${ }^{35,42}$
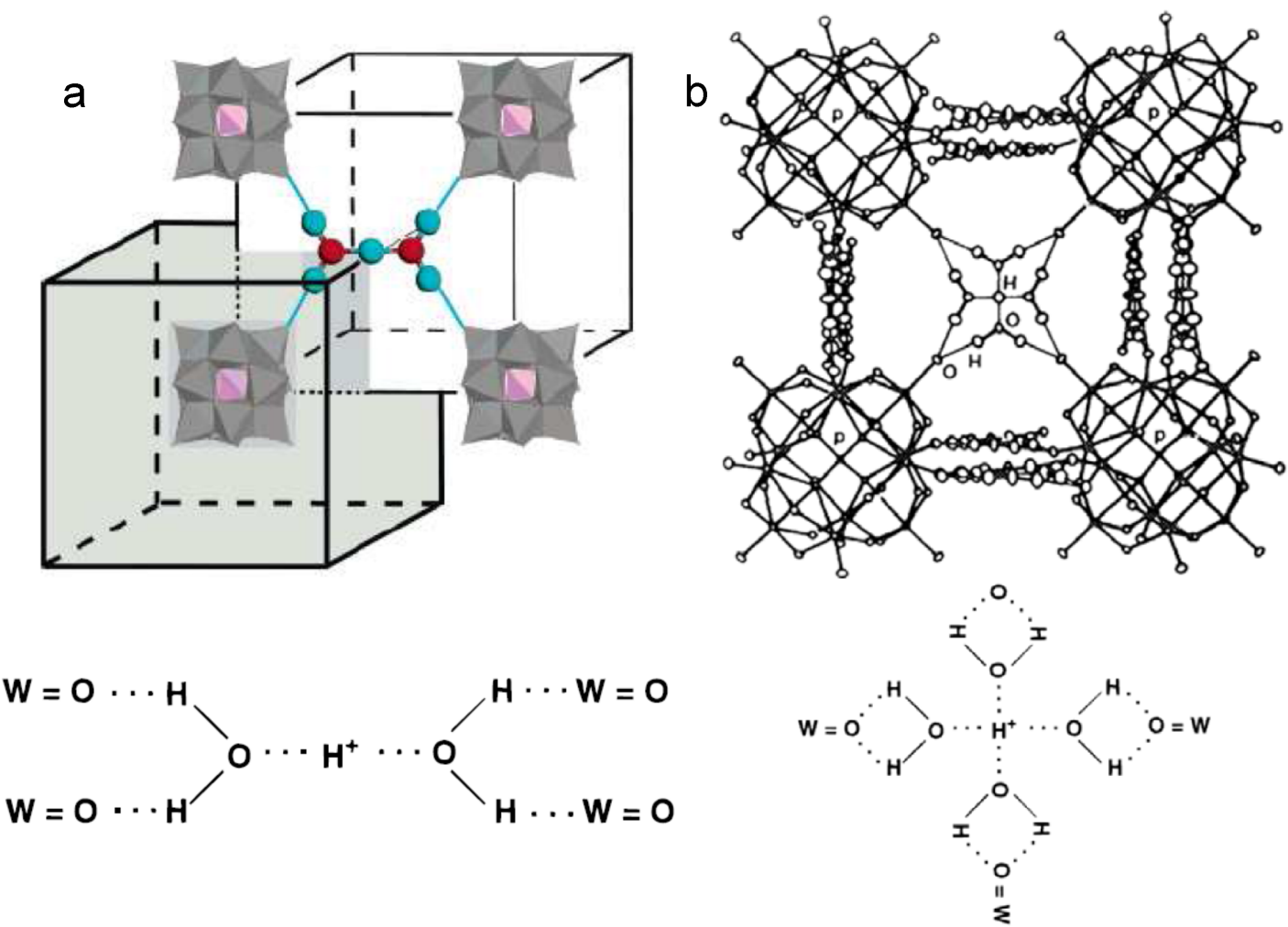

Figura 7: Diagrama esquemático ilustrando a estrutura secundária do HPA hidratado $\mathrm{H}_{3}\left[\mathrm{PW}_{12} \mathrm{O}_{40}\right] \cdot \mathrm{nH}_{2} \mathrm{O}$. (a) Espécies do tipo $\mathrm{H}_{5} \mathrm{O}_{2}{ }^{+}(\mathrm{H}=$ cor azul, $\mathrm{O}=$ cor vermelha), com prótons duplamente hidratados, conectam 4 ânions de Keggin por meio de ligações hidrogênio, formando uma estrutura hexahidratada $\left(\mathrm{H}_{3}\left[\mathrm{PW}_{12} \mathrm{O}_{40}\right] \cdot 6 \mathrm{H}_{2} \mathrm{O}\right)$. (b) Espécies do tipo $\mathrm{H}_{9} \mathrm{O}_{4}{ }^{+}$geram a estrutura dodecahidratada $\left(\mathrm{H}_{3}\left[\mathrm{PW}_{12} \mathrm{O}_{40}\right] \cdot 12 \mathrm{H}_{2} \mathrm{O}\right) \cdot{ }^{29,37,37,45}$

Além disso, HPAs podem apresentar diversos arranjos: de WellsDawson, como o $\mathrm{H}_{7}\left[\mathrm{P}_{2} \mathrm{Mo}_{17} \mathrm{VO}_{62}\right]$; de Pope-Jeannin-Preyssler, por exemplo, o 
$\mathrm{H}_{14}\left[\mathrm{NaP}_{5} \mathrm{~W}_{30} \mathrm{O}_{110}\right]$; de Keggin, como o $\mathrm{H}_{3}\left[\mathrm{PW}_{12} \mathrm{O}_{40}\right]$; etc. ${ }^{35,46}$ Os mais amplamente estudados e aplicados em catálise são aqueles com estrutura de Keggin, devido a sua grande disponibilidade, estabilidade termodinâmica, alta acidez e propriedades oxidantes. ${ }^{37,45,47}$ Por isso, catalisadores, como os conhecidos ácido 12-tungstofosfórico $\left(\mathrm{H}_{3}\left[\mathrm{PW}_{12} \mathrm{O}_{40}\right]\right.$ ou, simplesmente, HPW), ácido 12-molibdofosfórico $\left(\mathrm{H}_{3}\left[\mathrm{PMo}_{12} \mathrm{O}_{40}\right]\right)$, 12-tungstossilicato $\left(\mathrm{H}_{4}\left[\mathrm{SiW}_{12} \mathrm{O}_{40}\right]\right)$ e 12-molibdossilicato $\left(\mathrm{H}_{4}\left[\mathrm{SiMo}_{12} \mathrm{O}_{40}\right]\right)$, são efetivos para diversas reações ácidobase e de oxirredução. ${ }^{43,48}$ Estes, especialmente, apresentam grandes quantidades de água de cristalização e são bastante solúveis em solventes polares, como água, éter, alcoóis, cetonas, aldeídos, etc. ${ }^{43}$ Por isso, são considerados catalisadores homogêneos, sendo utilizados em diversos processos industriais: hidratação de propeno, n-buteno e isobuteno; polimerização do tetrahidrofurano; oxidação da metacroleína a ácido metacrílico; reações de isomerização, alquilação e esterificação de hidrocarbonetos; desidratação de alcoóis, dentre outros. ${ }^{48,49}$

Buscando aprimorar as propriedades desses materiais e aplicá-los também em reações de catálise heterogênea, de forma a reutilizá-los, algumas modificações em HPAs vêm sendo propostas na literatura. Uma delas é sua impregnação em suportes porosos de diferentes óxidos, como $\mathrm{ZrO}_{2}$ e $\mathrm{SiO}_{2},{ }^{45,50,51}$ ou óxidos mistos, como $\mathrm{SiO}_{2}-\mathrm{Al}_{2} \mathrm{O}_{3}$, que dispersam 0 heteropoliácido, tornando-o insolúvel em solventes polares, aumentam sua área superficial e melhoram sua atividade catalítica em relação ao HPA não suportado. ${ }^{42}$ De acordo com dados de dessorção térmica de amônia, a força ácida de espécies HPW suportadas diminui na seguinte ordem: $\mathrm{SiO}_{2}>\alpha-\mathrm{Al}_{2} \mathrm{O}_{3}$ $>$ carvão ativado. ${ }^{45}$ Peneiras moleculares mesoporosas, como a MCM-41 e a SBA-15, ${ }^{47}$ também vêm sendo empregadas como suporte para os HPAs, principalmente para o HPW, o qual se dispersa finamente na superfície e nos poros desses materiais, gerando uma atividade catalítica superior à do $\mathrm{H}_{2} \mathrm{SO}_{4} \mathrm{e}$ alta seletividade para diversas reações. ${ }^{45,47,52}$ Micek-Ilnicka e colaboradores estudaram a atividade catalítica de materiais de HPW suportados em nanotubos de carbono na reação de desidratação de etanol, constatando uma melhora de conversão em relação ao HPW não suportado. ${ }^{53}$

Outra maneira de modificar os HPAs, também bastante explorada pela literatura, é submetê-los à troca iônica, substituindo parcialmente ou totalmente 
os prótons pré-existentes por cátions metálicos. ${ }^{44}$ As características dos sais de heteropoliácidos, originados por troca iônica, foram descobertas por Baxter e Griffin em 1905 quando eles lavaram um precipitado de molibdofosfato de amônio, utilizado na determinação gravimétrica de fósforo, com uma solução salina de potássio. Todavia, suas propriedades somente começaram a ser utilizadas a partir do final da década de 1950 e começo da década de 1960, quando esses sais foram aplicados na concentração e separação de íons de metais alcalinos e na determinação de césio em efluentes, na água do mar e em materiais biológicos. ${ }^{54}$

Sais insolúveis de heteropoliácidos são valiosos trocadores iônicos inorgânicos: são baratos, disponíveis e facilmente preparados em laboratório. Sua síntese é feita por precipitação, a partir de uma solução do heteropoliácido precursor desejado com outra solução do sal, por exemplo, carbonatos, cloretos ou nitratos, contendo o cátion de interesse. Além disso, com a formação desses heteropolissais, outras vantagens são esperadas, como o aumento na estabilidade térmica dos materiais e, ainda, que os catalisadores atuem bifuncionalmente em reações químicas com a presença de sítios ácidos de Lewis. $^{42,55}$

A adição desses diferentes cátions influencia significativamente na estrutura terciária do HPA. Dependendo da metodologia de troca iônica utilizada, bem como do tamanho e da quantidade de matéria do cátion adicionado, podem ser observadas diferentes características no sal formado, como solubilidade, microporosidade, hidrofobicidade, volume de poro e acidez. De forma genérica, sais formados pela troca por cátions muito pequenos apresentam propriedades semelhantes ao HPA de partida: são mais solúveis em água, pouco porosos e possuem área superficial inferior a $10 \mathrm{~m}^{2} \mathrm{~g}^{-1}$ (vide Tabela 2). Já a substituição por cátions grandes, na maioria das vezes monovalentes $\left(\mathrm{NH}_{4}^{+}, \mathrm{K}^{+}, \mathrm{Cs}^{+}\right.$, etc.), forma sais insolúveis em água, de estrutura micro/mesoporosa e com área superficial superior a $100 \mathrm{~m}^{2} \mathrm{~g}^{-1} .44,45$

O mecanismo de catálise envolvido nas reações químicas também é fortemente influenciado pelo heteropolissal formado, variando conforme o tamanho do cátion adicionado. Por exemplo, cátions grandes, que agregam alta área superficial ao HPA, favorecem a catálise de superfície, em que reagentes são adsorvidos e convertidos na superfície sólida do POM. Já os 
heteropolissais com cátions menores permitem que moléculas reagentes polares se difundam pelo sólido, sendo absorvidas nos poros entre os poliânions, reagindo como se estivessem em solução e liberando os produtos, líquidos ou gasosos, para a superfície. Esse tipo de catálise é conhecido como pseudolíquida ou bulk I. Um terceiro tipo de mecanismo pode ocorrer ainda quando a reação catalisada for do tipo REDOX. Nesse caso, conhecido como catálise bulk II, a reação ocorre na superfície do POM, mas o sólido como um todo participa do processo para que haja a transferência de elétrons, pois a grande mobilidade dos íons no heteropolissal permite essa difusão elétrica. ${ }^{42}$

Tabela 2: Propriedades físico-químicas de sais de HPAs. ${ }^{45}$

\begin{tabular}{c|c|c|c}
\hline Cátion & Raio lônico $(\AA)$ & Solubilidade & Área Superficial $\left(\mathbf{m}^{\mathbf{2}} \mathbf{g}^{-1}\right)$ \\
\hline $\mathrm{Li}^{+}$ & 0,68 & $\mathrm{~S}$ & $<10$ \\
\hline $\mathrm{Na}^{+}$ & 0,97 & $\mathrm{~S}$ & $<10$ \\
\hline $\mathrm{Ag}^{+}$ & 1,26 & $\mathrm{~S}$ & $<10$ \\
\hline $\mathrm{Mg}^{2+}$ & 0,66 & $\mathrm{~S}$ & $<10$ \\
\hline $\mathrm{Ca}^{2+}$ & 0,99 & $\mathrm{~S}$ & $<10$ \\
\hline $\mathrm{Cu}^{2+}$ & 0,72 & $\mathrm{~S}$ & $<10$ \\
\hline $\mathrm{Zn}^{2+}$ & 0,74 & $\mathrm{~S}$ & $<10$ \\
\hline $\mathrm{Al}^{3+}$ & 0,51 & $\mathrm{~S}$ & $<10$ \\
\hline $\mathrm{Fe}^{3+}$ & 0,64 & $\mathrm{~S}$ & $<10$ \\
\hline $\mathrm{La}^{3+}$ & 1,02 & $\mathrm{~S}$ & $>10$ \\
\hline $\mathrm{Ce}^{3+}$ & 1,03 & $\mathrm{~S}$ & $>100$ \\
\hline $\mathrm{K}^{+}$ & 1,33 & $\mathrm{~N}$ & $>100$ \\
\hline $\mathrm{Rb}^{+}$ & 1,47 & $\mathrm{~N}$ & $>100$ \\
\hline $\mathrm{Cs}^{+}$ & 1,67 & $\mathrm{~N}$ &
\end{tabular}

*Solubilidade em água: S, solúvel; N, não solúvel.

No caso do HPW hexahidratado, sua estrutura cristalina de arranjo cúbico de corpo centrado é reportada por se manter preservada quando todos os prótons são substituídos por cátions monovalentes, como $\mathrm{Cs}^{+}$. Assim, no lugar dos íons $\mathrm{H}^{+}$, íons $\mathrm{Cs}^{+}$em ponte ligam os quatro ânions de Keggin. ${ }^{42}$ Quando a síntese gera sais neutros, como $\circ \mathrm{Cs}_{3}\left[\mathrm{PW}_{12} \mathrm{O}_{40}\right]$, as propriedades ácidas do catalisador sólido têm origem nos sítios metálicos de Lewis e os sítios de Brønsted apenas são formados quando houver hidrólise do metal em água ${ }^{55}$ como mostra a Equação $3 .^{56}$

$\mathrm{M}^{\mathrm{n+}}+\mathrm{mH}_{2} \mathrm{O} \rightarrow\left[\mathrm{M}\left(\mathrm{H}_{2} \mathrm{O}\right)_{m}\right]^{\mathrm{n}+} \rightarrow\left[\mathrm{M}\left(\mathrm{H}_{2} \mathrm{O}\right)_{\mathrm{m}-1}(\mathrm{OH})\right]^{(\mathrm{n}-1)}+\mathrm{H}^{+}$ 
Essa hidrólise é fortemente influenciada pelo pH da solução preparada na síntese, pois, a depender da acidez e do tipo de cátion metálico envolvido, diferentes espécies, inclusive poliméricas, podem ser formadas. O reagente utilizado como precursor dos cátions metálicos é um dos fatores capaz de interferir no $\mathrm{pH}$ da solução e nas características físico-químicas do heteropolissal sintetizado. Por exemplo, o sal $\mathrm{Cs}_{2} \mathrm{H}\left[\mathrm{PW}_{12} \mathrm{O}_{40}\right]\left(\mathrm{Cs}_{2} \mathrm{HPW}\right)$ já foi citado por apresentar área superficial específica igual a $1 \mathrm{~m}^{2} \mathrm{~g}^{-1}$, quando sintetizado a partir do carbonato de césio $\left(\mathrm{Cs}_{2} \mathrm{CO}_{3}\right)$, e outra bastante discrepante, igual a $78,2 \mathrm{~m}^{2} \mathrm{~g}^{-1}$, ao ser sintetizado com cloreto de césio $(\mathrm{CsCl})$, ambas calculadas por isotermas de adsorção-dessorção de nitrogênio gasoso. ${ }^{57}$ As imagens obtidas por microscopia eletrônica de varredura (MEV) também corroboraram com a variação de área superficial entre os dois catalisadores (vide Figura 8), mostrando uma diferença morfológica nítida entre o sólido sintetizado com carbonato de césio, de superfície mais compacta, e aquele sintetizado com cloreto de césio, de superfície mais rugosa e com partículas agregadas. ${ }^{57} \mathrm{~A}$ explicação fornecida pelos autores reside no fato de que o ânion cloreto, $\mathrm{Cl}^{-}$, é mais difícil de ser removido da solução por ser mais solúvel em água, gerando $\mathrm{HCl}$ como produto da precipitação do heteropolissal e formando, com isso, partículas coloidais de tamanhos maiores ao longo da síntese. Isso ocasiona um aumento nas distâncias entre as partículas, bem como um aumento de microporos. O carbonato, $\mathrm{CO}_{3}{ }^{2-}$, ao contrário, gera $\mathrm{CO}_{2}$ com a precipitação e, portanto, é facilmente eliminado da solução, formando partículas coloidais menores e, consequentemente, menores distâncias entre as partículas, diminuindo a superfície microporosa. ${ }^{57}$
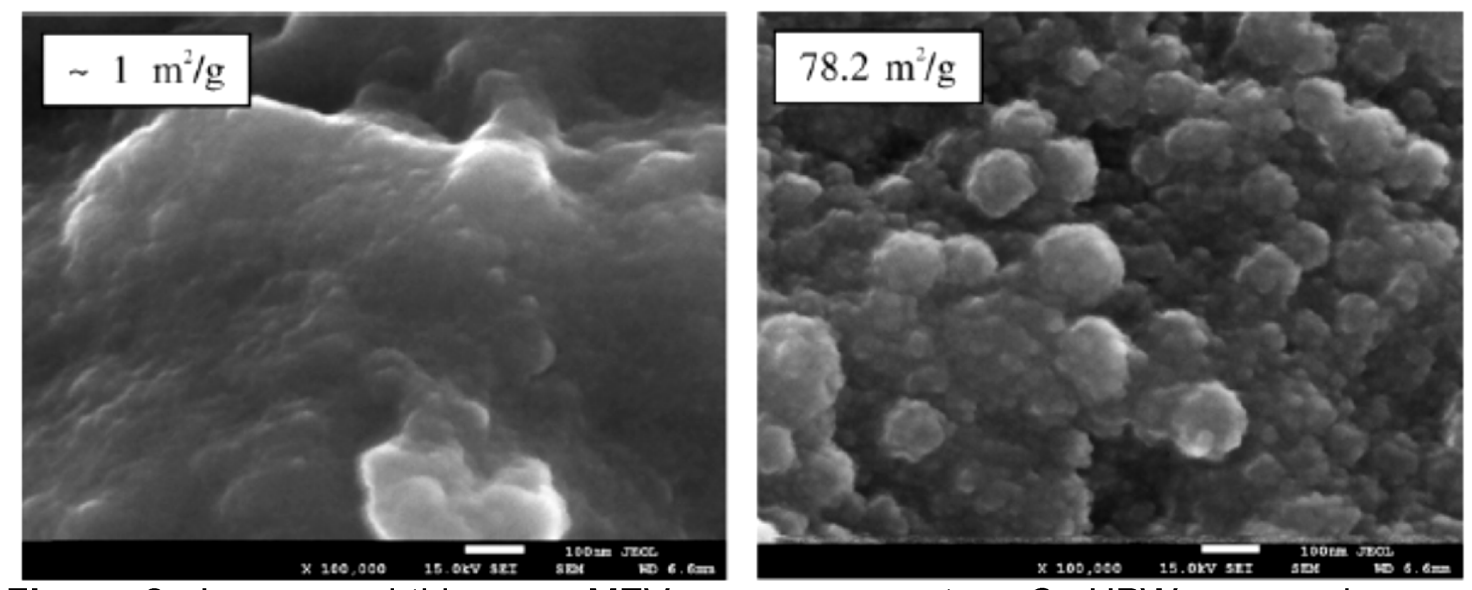

Figura 8: Imagens obtidas por MEV para as amostras $\mathrm{Cs}_{2} \mathrm{HPW}$ preparadas com $\mathrm{Cs}_{2} \mathrm{CO}_{3}$ (esquerda) e $\mathrm{CsCl}$ (direita). ${ }^{57}$ 
Além do césio, muito pesquisado, a literatura reporta diferentes tipos de cátions utilizados na troca iônica para formação dos heteropolissais. Baba e colaboradores, ${ }^{56}$ em 1983, já haviam sintetizado POMs de $\mathrm{Ag}_{3}\left[\mathrm{PW}_{12} \mathrm{O}_{40}\right]$ (AgPW), $\mathrm{Cu}_{3}\left[\mathrm{PW}_{12} \mathrm{O}_{40}\right]_{2}$ (CuPW) e Al[PW $\left.{ }_{12} \mathrm{O}_{40}\right]$ (AIPW), trocando todos os íons $\mathrm{H}^{+}$do HPW. Os catalisadores foram aplicados na isomerização de xileno em um reator de leito fixo contínuo a $300^{\circ} \mathrm{C}$, ficando constatado que apenas o AIPW apresentou atividade catalítica para essa reação. ${ }^{56} \mathrm{AgPW}$ e CuPW, nas proporções estequiométricas estudadas, não apresentaram acidez intrínseca. Esses mesmos materiais foram também aplicados na reação de desidratação do 1-butanol. Como a reação libera água como um dos produtos, os autores constataram que a exposição dos catalisadores a vapores de água incrementava ainda mais a atividade catalítica do AIPW e gerava acidez de Brønsted no AgPW e CuPW, os quais passaram a apresentar conversões de $20 \%{ }^{56}$

Em um trabalho recente de Gurgul e colaboradores, foi estudada a influência de duas diferentes condições de umidade relativa do ar, 2 e 9\%, na atividade catalítica do $\mathrm{AgPW}$ e do $\mathrm{Ag}_{3}\left[\mathrm{PMo}_{12} \mathrm{O}_{40}\right]$ (AgPMo) durante sua aplicação na reação de desidratação de etanol. ${ }^{58}$ De acordo com os autores, a variação da umidade praticamente não influenciou nas conversões obtidas pelo AgPMo (de até $20 \%$ ), em contraste com os resultados obtidos para o sal de AgPW. Com o ânion de tungstênio, maiores porcentagens de umidade relativa do ar provocaram um aumento da conversão de 75 para $100 \%$ em temperaturas reacionais superiores a $220{ }^{\circ} \mathrm{C}$ e aumentaram também a seletividade para etileno. Entretanto, estudos de Varisli e colaboradores mostraram que mais de $10 \%$ de água em etanol geraram uma diminuição da atividade catalítica do $\mathrm{AgPW}$, possivelmente porque a água passou a ser adsorvida mais fortemente em relação ao etanol na superfície do catalisador, causando uma redução na quantidade de sítios ativos disponíveis. ${ }^{59}$

Outra alteração, percebida por Matachowski e colaboradores, diz respeito à influência de moléculas de água na composição e estrutura do AgPW. ${ }^{60}$ Segundo eles, quando a atmosfera possui $10 \%$ de umidade, há a formação de uma estrutura secundária em que uma molécula de água está ligada a cada cátion $\mathrm{Ag}^{+}$. Além disso, dados de termogravimetria (TG) mostraram que temperaturas reacionais acima de $160{ }^{\circ} \mathrm{C}$ provocam a perda 
das moléculas de água coordenadas aos cátions de prata $\mathrm{e}$, consequentemente, a estrutura terciária do AgPW também é afetada, formando poros com diâmetros menores devido à aproximação dos íons de Keggin. Esse fato interfere diretamente na atividade catalítica dos heteropolissais. ${ }^{60}$

À parte de heteropolissais neutros, existem HPAs submetidos apenas à troca parcial de íons $\mathrm{H}^{+}$por cátions metálicos. Nesse caso, o catalisador pode apresentar uma bifuncionalidade intrínseca, gerada a partir de um sinergismo existente entre sítios ácidos de Lewis e de Brønsted, assim como ocorre em zeólitas desaluminizadas contendo espécies EFAl. Certamente, a estequiometria de troca iônica torna-se um fator determinante nas características do sólido, já que materiais com proporções distintas de sítios metálicos de Lewis e de sítios fortes de Brønsted podem ser sintetizados. Haber e colaboradores, por exemplo, sintetizaram e investigaram a estrutura do sal de potássio $\mathrm{K}_{\mathrm{x}} \mathrm{H}_{3-\mathrm{x}}\left[\mathrm{PW}_{12} \mathrm{O}_{40}\right]{ }^{44}$ Os autores constataram uma mistura de espécies, do sal ácido $\mathrm{K}_{2} \mathrm{H}\left[\mathrm{PW}_{12} \mathrm{O}_{40}\right]$ e do sal neutro $\mathrm{K}_{3}\left[\mathrm{PW}_{12} \mathrm{O}_{40}\right]$, gerando, com isso, uma mistura também de fases, onde coexistem ânions de Keggin circundados por diferentes quantidades de íons $\mathrm{K}^{+}$. 44

Heteropolissais ácidos de césio, como $0 \mathrm{Cs}_{\mathrm{x}} \mathrm{H}_{3-\mathrm{x}}\left[\mathrm{PW}_{12} \mathrm{O}_{40}\right]$ e $\circ \mathrm{Cs}_{\mathrm{x}} \mathrm{H}_{6-}$ $x\left[\mathrm{P}_{2} \mathrm{~W}_{18} \mathrm{O}_{62}\right]$, vêm sendo bastante pesquisados. Pozniczek e colaboradores também verificaram uma mistura de espécies ao analisarem os resultados encontrados para heteropolissais preparados a partir da precipitação do HPA com estrutura de Wells-Dawson $\left(\mathrm{H}_{6}\left[\mathrm{P}_{2} \mathrm{~W}_{18} \mathrm{O}_{62}\right]\right)$, o $\mathrm{Cs}_{2} \mathrm{H}_{4}\left[\mathrm{P}_{2} \mathrm{~W}_{18} \mathrm{O}_{62}\right]$ e 0 $\mathrm{Cs}_{5} \mathrm{H}\left[\mathrm{P}_{2} \mathrm{~W}_{18} \mathrm{O}_{62}\right]{ }^{61}$ Segundo os autores, ambos os sólidos apresentaram fases do HPA não substituído depositadas na superfície do heteropolissal, sendo o catalisador $\mathrm{Cs}_{5} \mathrm{H}\left[\mathrm{P}_{2} \mathrm{~W}_{18} \mathrm{O}_{62}\right]$ aquele mais ativo para a produção de etil-terc-butil éter. ${ }^{61}$ Zhao e colaboradores trabalharam com o sal ácido de Keggin $\mathrm{Cs}_{2,5} \mathrm{H}_{0,5}\left[\mathrm{PW}_{12} \mathrm{O}_{40}\right]$, verificando que este apresentava alta área superficial (130 $\mathrm{m}_{2} \mathrm{~g}^{-1}$ ) e forte acidez, além de ser insolúvel em água e solventes orgânicos. ${ }^{49} \mathrm{~A}$ aplicação desse catalisador na reação da desidratação de frutose se mostrou muito efetiva, convertendo mais de $94 \%$ em apenas 120 min de reação. Além de ácido, o material preparado apresentou forte resistência, mantendo a conversão acima de $70 \%$ após 6 ciclos catalíticos. ${ }^{49}$

De forma geral, tanto os compostos com prótons remanescentes, de acidez multifuncional intrínseca, como aqueles totalmente substituídos, ou seja, 
com sais neutros, estão sendo pesquisados e aplicados como bons catalisadores em diversas reações. Em heteropolissais neutros, a ausência de prótons geradores de acidez de Brønsted pode ser contornada por meio de um pré-tratamento do sólido com vapor de água, originando um catalisador também bifuncional quando a reação em questão não fornecer umidade suficiente para formar esses sítios ácidos.

\subsection{Desidratação de Alcoóis $\mathrm{C} 2-\mathrm{C} 4$ para Produção de Bio-olefinas Leves}

Atualmente, grande parte da produção de olefinas leves, como eteno, propeno, isobuteno e butadieno, vem das indústrias petroleiras de primeira geração, isto é, das indústrias de craqueamento térmico (vide Figura 9). ${ }^{62,63} \mathrm{O}$ petróleo, por ser uma mistura de hidrocarbonetos de diferentes tamanhos de cadeias carbônicas, em proporções variáveis, necessita passar por um processo de refino para que hidrocarbonetos com cadeias semelhantes possam ser agrupados e utilizados como insumos. Para tanto, ele é submetido à destilação fracionada, ou seja, é aquecido em uma torre de destilação gerando gases que sobem por colunas de fracionamento, onde cada fase desejada é recuperada por condensação. ${ }^{64}$

A nafta leve*, uma das fases do refino do petróleo, é vastamente utilizada para a produção de olefinas a partir de sua decomposição em temperaturas bastante altas, acima de $850^{\circ} \mathrm{C}$. No Brasil, a Petrobras é a única produtora de nafta petroquímica, atendendo parte da demanda do país com produção própria. ${ }^{62,64}$ Já o gás natural, uma mistura de alcanos (de metanos a pentanos) e gases (como $\mathrm{N}_{2}, \mathrm{CO}_{2}$ e pequenas quantidades de $\mathrm{He}$ ), é também muito usado para produzir alcenos, podendo ser extraído de formações rochosas no subsolo terrestre, da mesma forma como é feito para o petróleo. 0 gás natural ainda é encontrado dissolvido no próprio petróleo, podendo, então, ser obtido a partir deste. ${ }^{64}$

\footnotetext{
“Nafta é o termo genérico adotado na indústria petrolífera para designar frações leves do petróleo. Ao longo do processo de destilação fracionada, entre temperaturas de 20 a $220^{\circ} \mathrm{C}$, três tipos de nafta podem ser recolhidos no alto da torre de destilação: a leve, a intermediária e a pesada. A nafta leve, recuperada entre 30 e $120^{\circ} \mathrm{C}$, possui hidrocarbonetos de cadeias carbônicas menores, entre 5 e 12 carbonos, e é aquela utilizada para a produção das olefinas. Por isso, também é chamada de nafta petroquímica. ${ }^{64}$
} 
As olefinas são petroquímicos básicos, com alto valor de mercado e possuem amplo interesse econômico em diversos setores industriais, principalmente como insumos para produção de outros reagentes e materiais. O eteno, comercialmente conhecido como etileno, e o propeno (ou propileno), por exemplo, são matérias-primas para a produção dos polímeros polietileno e polipropileno, respectivamente, pelos quais existe uma crescente demanda devido às suas vastas aplicações, como pode ser observado na Figura $9 .^{62,63}$

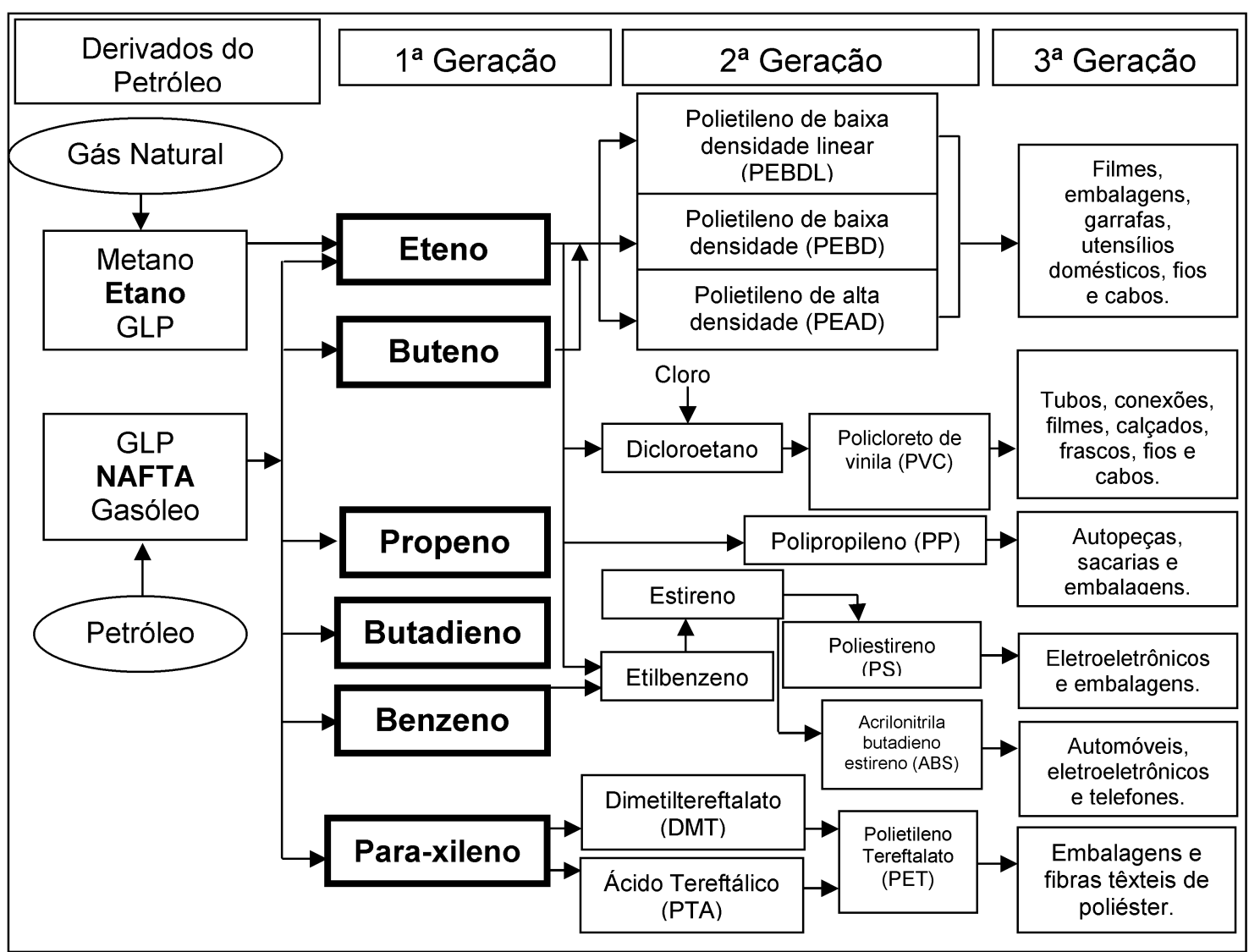

Figura 9: Esquema simplificado da cadeia petroquímica. ${ }^{63,65,66}$

O etileno é um dos produtos químicos mais comercializados no mundo e um dos mais importantes insumos na indústria petroquímica. Aproximadamente $75 \%$ dos produtos petroquímicos são produzidos a partir desse alceno, como acetaldeído, ácido acético, óxido de etileno (epoxietano), etileno glicol, etilbenzeno, acetato de vinila, dentre outros. ${ }^{67}$ Além disso, a partir de sua polimerização, produz-se uma variedade de produtos químicos orgânicos, como o polietileno (PE), o policloreto de vinila (PVC) e o poliestireno (PS). 
Atualmente, mais de 50 milhões de toneladas são produzidos de PE por ano no mundo. Devido a sua vasta aplicação e a sua grande importância, a produção de etileno é considerada um dos indicadores do nível de desenvolvimento petroquímico dos países em todo o mundo, pois $99 \%$ de sua produção vêm do craqueamento de hidrocarbonetos. ${ }^{66,67}$ Além do petróleo, o etileno pode ser obtido diretamente a partir da hulha, um tipo de carvão mineral. A destilação seca desse carvão, isto é, seu aquecimento em temperaturas entre $1000 \mathrm{e}$ $1300{ }^{\circ} \mathrm{C}$, na presença de ar, gera uma fração gasosa de 3 a $5 \%$ de etileno.

As olefinas também podem ser obtidas a partir da reação de desidratação de alcoóis: uma maneira ecologicamente atrativa, pois utiliza fontes alternativas de matéria-prima, como o bioetanol, evitando o uso do petróleo. Dada as limitações causadas pela natureza do óleo brasileiro (pesado, ou seja, com baixo grau $\mathrm{API}^{\dagger}$ e pobre em derivados leves), a nafta petroquímica possui sua disponibilidade reduzida. Nesse sentido, o desenvolvimento de metodologias que explorem diferentes rotas sintéticas, além de serem processos ambientalmente sustentáveis, auxiliam na expansão da indústria brasileira e permitem um melhor aproveitamento do petróleo nacional. $^{62,63}$

Nesses casos em que a desidratação é feita a partir de um reagente que vem da biomassa, os alcenos gerados são chamados bio-olefinas. A desidratação de alcoóis, de forma geral, é bastante conhecida e possui um mecanismo bem elucidado, ${ }^{68,69}$ como ilustram as Figura 10 e 11 . Trata-se de uma reação de eliminação que pode se dar de duas formas concomitantemente: intramolecular e intermolecular, a depender da temperatura utilizada no processo. Na desidratação intramolecular, o processo é endotérmico e ocorre apenas na presença de um catalisador, gerando o alceno (Figura 10). Não raro, a catálise é feita utilizando-se o ácido sulfúrico $\left(\mathrm{H}_{2} \mathrm{SO}_{4}\right)$ concentrado em temperaturas de aproximadamente $180{ }^{\circ} \mathrm{C}$, o que, industrialmente, pode se tornar uma desvantagem do processo, tendo em vista

\footnotetext{
${ }^{\dagger}$ A maior parte do óleo brasileiro apresenta baixo grau API (American Petroleum Institute), que é uma escala utilizada para medir a densidade relativa de líquidos. Como ela é inversamente proporcional à densidade relativa do líquido, quanto maior a densidade relativa do petróleo, menor o grau $\mathrm{API}$. O petróleo do tipo mais leve, com grau API superior a $30^{\circ}$, custa menos para ser refinado, pois produz derivados claros (gasolina, GLP, querosene e diesel) em maior quantidade em etapas preliminares de refino. 63
} 
a difícil manipulação desse ácido. $\mathrm{O} \mathrm{H}_{2} \mathrm{SO}_{4}$ é bastante nocivo por ser um oxidante muito forte, com alto poder de corrosão e que, além disso, exibe todas as dificuldades intrínsecas da catálise homogênea. $\mathrm{Na}$ desidratação intermolecular, a reação se processa em temperaturas mais baixas, em torno de $130{ }^{\circ} \mathrm{C}$ quando o catalisador é $\circ \mathrm{H}_{2} \mathrm{SO}_{4}$, e é energeticamente favorável, formando um éter (Figura 11). Já os mecanismos envolvendo catalisadores heterogêneos baseados em óxidos metálicos são mais complexos e serão abordados posteriormente.

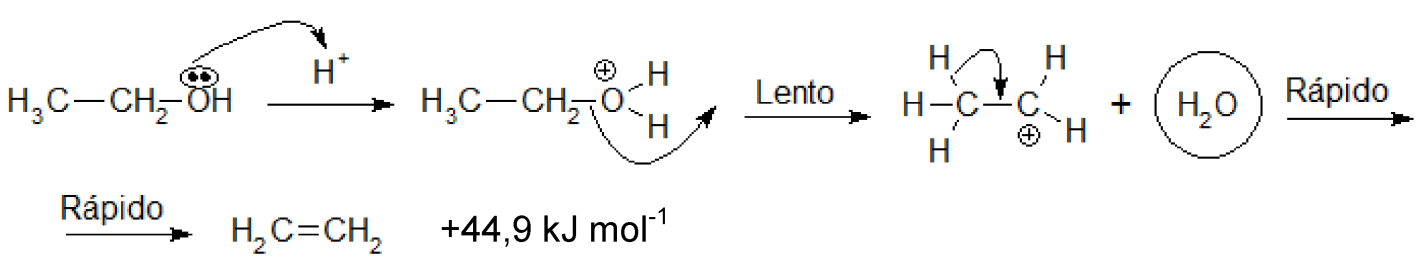

Figura 10: Etapas do mecanismo de desidratação intramolecular do etanol com formação de etileno. ${ }^{68}$

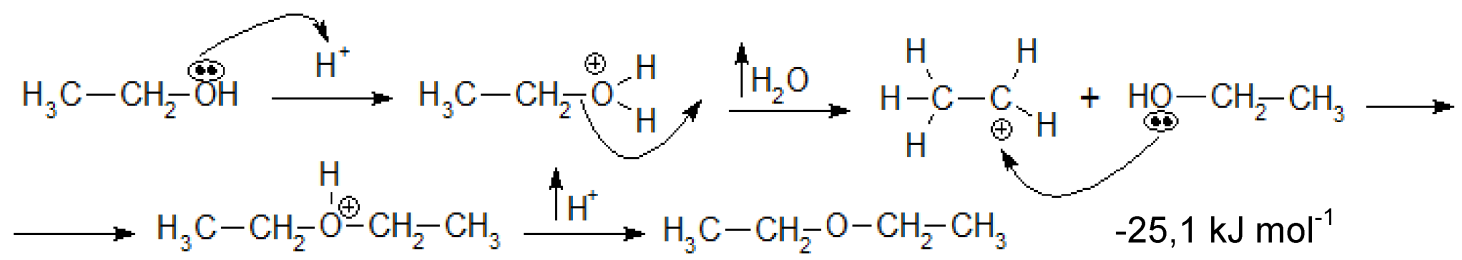

Figura 11: Etapas do mecanismo de desidratação intermolecular do etanol com formação de éter etílico. ${ }^{68}$

A depender das condições reacionais utilizadas, uma pequena quantidade de aldeído pode ser formada a partir da desidrogenação do álcool, com liberação de hidrogênio. ${ }^{69}$ No entanto, a formação do aldeído só é possível no caso de alcoóis primários, pois, em secundários, só há possibilidade de formação de cetonas e, em terciários, os átomos de carbono não fazem ligações diretas com o hidrogênio, não havendo, portanto, a possibilidade de ataque em nenhum ponto da molécula por um oxigênio externo. ${ }^{68}$

A desidratação catalítica do álcool etílico para produção de éter ou etileno é conhecida desde os séculos 13 e 18, respectivamente. ${ }^{70}$ Entretanto, 0 uso desse processo na indústria é relativamente recente. ${ }^{67}$ Para se ter uma 
ideia, estudos de desidratação do etanol sobre catalisadores baseados em aluminossilicatos para produzir o etileno existem há algumas décadas, como pode ser visto em referências que datam de $1967 .^{70-72}$ Foi somente a partir da década de 70 que Paquistão, Brasil (Petrobras) e Peru desenvolveram suas próprias tecnologias de desidratação de etanol, as quais incluem tipicamente duas partes: a reação de desidratação e a purificação do etileno e seus produtos. $^{67,73}$

Dentre os catalisadores heterogêneos investigados, é notadamente conhecida a utilização de $\gamma$-alumina $\left(\gamma-\mathrm{Al}_{2} \mathrm{O}_{3}\right)^{69-75}$ nas reações de desidratação de alcoóis em substituição ao ácido sulfúrico. A desidratação do etanol, particularmente, é uma das mais estudadas nesse tipo de catálise. Todavia, o uso da alumina nessa reação implica no aparecimento tanto da olefina quanto do éter, o que dificulta a separação dos produtos, além de serem usadas temperaturas mais altas $\left(400-450{ }^{\circ} \mathrm{C}\right)$ no processo reacional. ${ }^{76}$

Igualmente à catálise via alumina, a utilização de zeólitas na reação de desidratação de alcoóis vem sendo bastante pesquisada, ${ }^{4,77,78} \mathrm{com}$ destaque para o uso da zeólita ZSM-5. Esta, por conter uma menor quantidade de átomos de alumínio em sua rede cristalina, apresenta-se mais hidrofóbica, com alta razão Si/Al. Dessa forma, como há liberação de água na reação de desidratação, a maior hidrofobicidade do catalisador proporcionará uma resistência superior àquela apresentada por catalisadores mais hidrofílicos.

Por exemplo, a patente europeia EP96996, de $1988,{ }^{79}$ já relatava a produção de olefinas leves a partir do uso de catalisadores zeolíticos da família pentasil, como a ZSM-5, em reações de desidratação de alcoóis em temperaturas entre 315 e $370{ }^{\circ} \mathrm{C}$. Porém, nas condições estudadas, a conversão alcançou valores entre $40 \%$ e não mais que $90 \%$. Já a patente norte-americana US4873392, de $1989,{ }^{80}$ comparou os resultados de conversão da desidratação de soluções aquosas de etanol utilizando como catalisador as zeólitas ZSM-5 e ZSM-11 com diferentes razões Si/AI (5 a 50). A maior seletividade para etileno encontrada (99\%) foi obtida com o catalisador mais hidrofóbico, o qual mostrou ainda maior resistência à desativação, convertendo o etanol durante $100 \mathrm{~h}$ sem grandes variações de conversão. Entretanto, a 
velocidade espacial de álcool (conhecida como WHSV ${ }^{\ddagger}$, Weight Hourly Space Velocity) se restringiu a $3,2 \mathrm{~h}^{-1}$.

Trabalhos recentes, como as patentes internacionais WO162717, ${ }^{81} \mathrm{de}$ 2011, e WO005864 ${ }^{82}$ de 2012, exploraram a vantagem em se empregar uma mistura de dois ou mais alcoóis (metanol e outro álcool escolhido com cadeia C2 a C6) de forma a gerar olefinas leves. No caso da patente WO162717, foram empregados catalisadores zeolíticos modificados com metais em temperaturas na faixa de 350 a $500^{\circ} \mathrm{C}$. O processo, segundo os autores, gera preferencialmente olefinas $\mathrm{C} 3 \mathrm{com}$ alta seletividade, mas com conversões em torno de $50 \%$. Os inventores da patente WO005864 utilizaram uma combinação de peneiras moleculares do tipo MCM-22, ZSM-5 e USY (zeólita Y ultraestável), mostrando obter uma mistura de olefinas com $100 \%$ de conversão dos alcoóis em temperaturas reacionais a partir de $300{ }^{\circ} \mathrm{C}$. Todavia, a velocidade espacial da mistura alcoólica permaneceu na faixa de 0,7 a $5 \mathrm{~h}^{-1}$.

Um grande benefício em se utilizar o catalisador zeolítico nessas reações de desidratação de alcoóis do tipo C2-C4, como a zeólita Y ${ }^{83}$, ZSM-5 e mordenita ${ }^{84}$, é o fato de a conversão e a seletividade para a produção de olefinas serem superiores do que aqueles obtidos com o uso da alumina $e$ outros aluminossilicatos amorfos. A zeólita $\mathrm{Y}$, que possui a vantagem de apresentar menor custo econômico que a ZSM-5, é menos estudada atualmente nessas reações do que os catalisadores da família pentasil por serem, em geral, mais hidrofilicas, apresentando menor resistência e/ou potencial para converter alcoóis em olefinas. O trabalho de Kakodkar e colaboradores $^{83}$ mostrou que, na desidratação do terc-butanol na faixa de 240 a $400{ }^{\circ} \mathrm{C}$, a zeólita $\mathrm{Y}$ modificada com cobre apresentou conversão máxima de $90 \%$ para o isobutileno, enquanto que, na desidratação do etanol a $450{ }^{\circ} \mathrm{C}$, um álcool menos reativo que o terc-butanol, apenas $15 \%$ de eteno foi formado.

\footnotetext{
‡ A velocidade espacial de um reagente, isto é, o parâmetro WHSV, indica a quantidade de massa de reagente que é adicionado ao reator por unidade de massa de catalisador, por hora de reação. Esse quociente é muito utilizado para se comparar a eficiência de diferentes catalisadores para uma mesma reação, pois permite uma correlação entre diversos estudos da literatura mesmo quando as condições de massas de reagente e de catalisador são distintas entre as pesquisas. Um baixo valor de WHSV significará ou que menos massa de reagente passou pelo catalisador por hora de reação, gerando, consequentemente, menores quantidades do produto desejado; ou que uma maior massa de catalisador foi empregada para converter a quantidade de reagente pré-estabelecida em produtos. Ambas as situações são desvantajosas em termos da aplicação industrial do catalisador.
} 


\subsubsection{Síntese de Bioetileno via Desidratação do Bioetanol}

O Bioetanol é o álcool etílico de origem agrícola, isto é, produzido a partir de uma fonte renovável oriunda da biomassa. A maior parte desse bioetanol é produzida por fermentação dos açúcares presentes nas matériasprimas de origem vegetal, como as plantas açucareiras e outras fontes, como madeiras, serragens, cascas, etc. Subsequentemente à fermentação, uma etapa de destilação permite chegar a uma composição azeotrópica do binário álcool/água com apenas $8 \%$ de água. ${ }^{67}$

Por meio do Programa Nacional do Álcool (Proalcool), implantado no Brasil na década de 70 , a produção de cana-de-açúcar cresceu de 79,7 milhões de toneladas em 1970 para 717,1 milhões de toneladas em 2010, segundo dados do Instituto Brasileiro de Geografia e Estatística (IBGE). ${ }^{85}$ Ainda na década de 70 , foram construídas no país unidades de desidratação de etanol em etileno, tendo em vista a crise petrolífera que ocorria num contexto de déficit de oferta do petróleo, com o início do processo de nacionalizações e de uma série de conflitos envolvendo os produtores árabes da Organização dos Países Exportadores de Petróleo (OPEP). Os preços do barril de petróleo atingiram valores altíssimos, chegando a aumentar até $400 \%$ em cinco meses. $^{86}$

Por causa desses e outros fatores, como a existência de condições ambientais e territoriais favoráveis, o Brasil é um dos maiores produtores mundiais e o maior exportador de etanol, com 9,2 milhões de hectares destinados somente para o cultivo da cana-de-açúcar, o que representa 1,4\% das terras aráveis. ${ }^{87}$ Desde o início da safra 2012 de cana-de-açúcar até 31 de dezembro do mesmo ano, o país produziu 21,28 bilhões de litros de etanol nas unidades sucroalcooleiras do Centro-Sul do Brasil, segundo dados divulgados

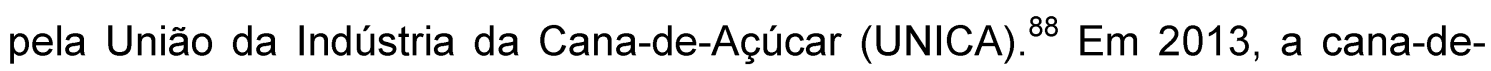
açúcar se destacou dentre os produtos que mais obtiveram incremento de produção: $6,1 \%$ a mais em relação à safra de $2012 .{ }^{89}$ Além disso, em dezembro de 2013, a produção das usinas da região Centro-Sul do país confirmou a expectativa de uma expansão recorde na oferta de etanol durante a safra 2013/2014 de cana-de-açúcar. ${ }^{90}$ Nesse contexto propício, torna-se viável o desenvolvimento e aperfeiçoamento de tecnologias que visam 
aproveitar o bioetanol para uso como reagente na produção de novas substâncias e materiais.

Catalisadores baseados em alumina são usados na maioria dos reatores industriais de produção de etileno. ${ }^{67} \mathrm{O}$ documento "Process Economics Reviews (SRI international)" $\mathrm{n}^{\circ}$. 79-3 de 1979, reportou uma conversão e seletividade de mais de $99 \%$ em etileno a partir de uma mistura de etanol:água $(95: 5, v / v)$. Nesse caso, foi utilizado um catalisador de sílica-alumina em um reator tubular de leito fixo a $400{ }^{\circ} \mathrm{C}$, porém a velocidade espacial de etanol era de apenas $0,7 \mathrm{~h}^{-1}$. Na década de 80, a empresa American Halcon Scientific Design Inc. desenvolveu um novo tipo de catalisador multióxido com composição do tipo $\mathrm{Al}_{2} \mathrm{O}_{3}-\mathrm{MgO} / \mathrm{SiO}_{2}$, chamado de catalisador Syndol, o qual apresentou boa conversão (97-99\%) e boa seletividade para a olefina $(97 \%)$ em temperaturas equivalentes às industriais da época nos reatores de leito fixo. ${ }^{67,91}$ A partir de então, diferentes catalisadores de alumina dopados com metais, principalmente com os de transição, foram e vêm sendo desenvolvidos para aplicação nas reações de desidratação de etanol. ${ }^{92}$ Dessa forma, a catálise poderia ser processada por meio de uma combinação de sítios ácidos de Lewis, advindos dos metais incorporados, e de Brønsted, gerados pela alumina que também serve como suporte. Chen e colaboradores ${ }^{93}$ estudaram a atividade de catalisadores do tipo $\mathrm{TiO}_{2} / \gamma-\mathrm{Al}_{2} \mathrm{O}_{3}$ na desidratação do bioetanol hidratado, mostrando o efeito das temperaturas de calcinação dos mesmos na estabilidade reacional. De acordo com os autores, o catalisador dopado com $10 \%$ de $\mathrm{TiO}_{2}$ e calcinado em temperaturas de 400 a $500{ }^{\circ} \mathrm{C}$ foi aquele com maior conversão de etanol $(99,96 \%)$ e seletividade para a produção de etileno $(99,4 \%)$, superando o poder de conversão do catalisador Syndol para a mesma quantidade de massa de catalisador utilizado por hora de reação. ${ }^{93}$

A catálise baseada em alumina ativa se apresenta como um método apropriado para a desidratação de etanol, com o catalisador possuindo boa estabilidade e alta seletividade para produção de etileno. Entretanto, a concentração de etanol na solução alcoólica não pode ser muito baixa, caso contrário, temperaturas mais altas e menores velocidade espaciais de etanol devem ser utilizadas, levando a um maior consumo de energia. ${ }^{67}$

Dessa maneira, apesar de serem seletivos para a reação de desidratação de etanol, os catalisadores supracitados ainda possuem uma 
desvantagem significativa quando se pensa na produção de etileno em escala industrial: eles são inadequados para o coprocessamento de etanol e hidrocarbonetos pesados do refino de petróleo, importante para atender à demanda do mercado de produção do etileno. ${ }^{5}$ Quando o catalisador permite o coprocessamento, a planta industrial pode conter duas zonas de reação diferentes dentro do reator. A primeira delas é a zona de desidratação, onde o catalisador quente, proveniente de um regenerador em alta temperatura, entra em contato com o álcool. A outra zona é a de craqueamento, onde a carga com subprodutos do petróleo é processada. ${ }^{94}$ A Figura 12 ilustra duas zonas de alimentação segregadas em um reator de coprocessamento de etanol e gasóleo. Com esse tipo de planta, a injeção de etanol pode ser interrompida caso os preços do álcool se tornem pouco atraentes sem interferir na operação da unidade. ${ }^{94}$

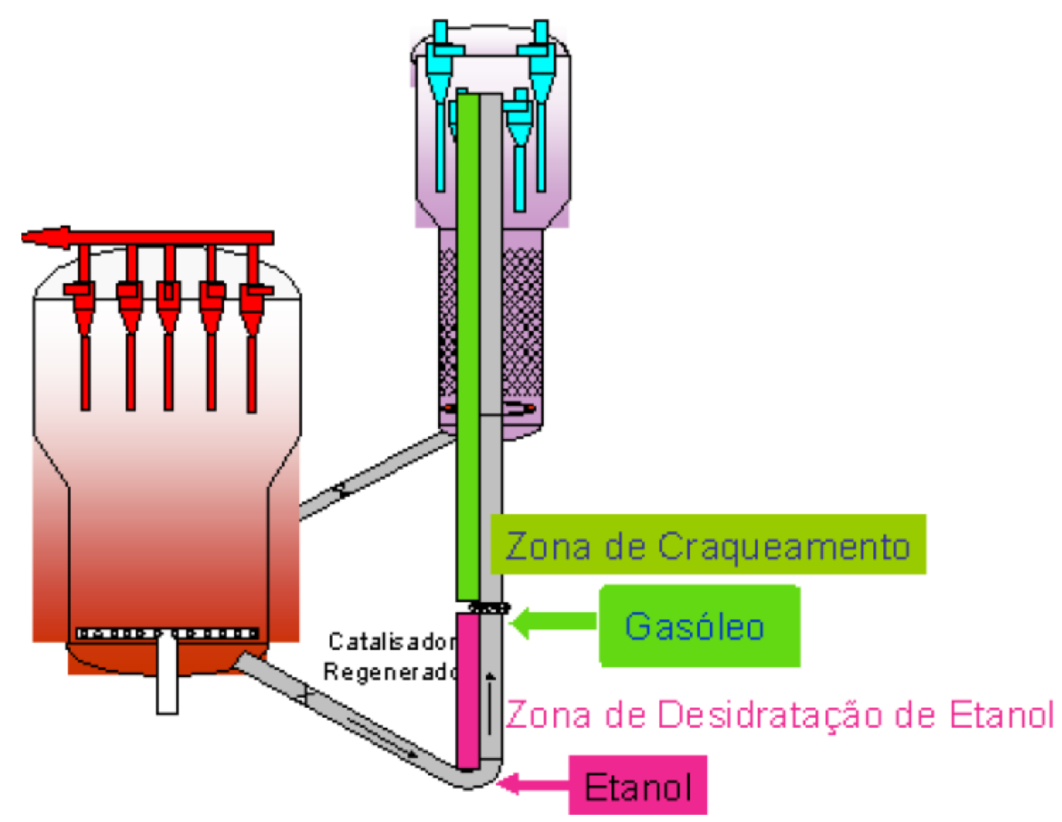

Figura 12: Coprocessamento de gasóleo e etanol com alimentação segregada. ${ }^{94}$

Como o preço e a produção de etanol sofrem grandes variações sazonais, dependentes dos valores econômicos alcançados no mercado internacional do açúcar e do álcool etílico, essa oscilação inviabiliza a construção de plantas industriais dedicadas exclusivamente à geração de etileno via processamento de etanol. Por isso, hoje, apenas algumas poucas unidades de desidratação de etanol de baixa capacidade continuam em operação. $^{5}$ 
Esse motivo corrobora com a grande vantagem em se utilizar zeólitas para desidratar o álcool etílico. Catalisadores de estrutura zeolítica viabilizam esse coprocessamento, podendo garantir o suprimento contínuo de etileno para as indústrias petroquímicas. ${ }^{5}$ Por essa razão, diferentes patentes, exemplificadas a seguir, podem ser encontradas envolvendo a reação de desidratação de etanol via catálise ácida com materiais zeolíticos de distintas estruturas, com destaque para os da família MFI, ${ }^{95}$ como a ZSM-5.

As patentes chinesas $\mathrm{CN} 101138735,{ }^{96} \mathrm{CN} 101139241,{ }^{97} \mathrm{CN} 101244971^{98}$ e CN1974007 ${ }^{99}$ empregaram a zeólita ZSM-5 em diferentes razões Si/Al, modificadas com tratamento ácido e/ou com metais, na desidratação do etanol e relataram conversões e seletividades para etileno acima de $99 \%$ em temperaturas entre 210 e $270{ }^{\circ} \mathrm{C}$. A patente $\mathrm{CN} 1974007^{99}$ descreveu um tratamento hidrotérmico na ZSM-5, seguido de outro com diferentes ácidos para emprego na desidratação do etanol, com diferentes proporções de água, num reator de leito fixo. Entretanto, a WHSV de etanol se limitou a valores entre 1,5 e 4,5 $\mathrm{h}^{-1}$, a depender da porcentagem de etanol na solução de partida. Nesse caso, apesar de haver boa conversão e seletividade para produzir etileno, os pré-tratamentos feitos no catalisador encarecem 0 processo, além de ser necessário o trabalho com metais e ácidos, um inconveniente para a indústria, em termos de manipulação, e para o meio ambiente.

A patente brasileira BRPI0806359 $9^{100}$ reportou um processo que integra a conversão conjunta de alcoóis em etileno e propileno num reator de leito fluidizado utilizando as peneiras moleculares ZSM-5 e/ou SAPO-34. Opcionalmente, são sugeridos outros tipos de catalisadores, dentre eles a titânia, a zircônia e argilas, além de uma mistura de sólidos. Segundo os inventores, as tecnologias existentes para produzir seletivamente etileno a partir do etanol possuem problemas, como escala de produção pequena e baixa economia de processo. De fato, como será apresentado posteriormente, um fluxo alto de etanol causa uma supersaturação dos sítios ácidos do catalisador, o que acaba por gerar mais subprodutos, como o dietil éter, comprometendo as taxas de conversão do processo.

A patente internacional WO2009098268 ${ }^{101}$ relatou um processo de desidratação de etanol com reciclagem opcional do álcool não reagido, usando 
temperaturas de 260 a $500{ }^{\circ} \mathrm{C}$. Nesse caso, a desidratação ocorreu na presença de um componente inerte, que, segundo os autores, pode ser hidrocarbonetos saturados ou uma mistura deles, como naftas e butanos de cadeia linear. Isso substitui o gás de arraste, com a vantagem de o hidrocarboneto poder ser recuperado e reutilizado no final da reação. Entretanto, a tecnologia necessita de um reator adiabático e, na presença de diferentes tipos de catalisadores (silicatos, aluminossilicatos, zeólitas modificadas, etc.), a velocidade espacial de etanol máxima foi $12 \mathrm{~h}^{-1}$. Além disso, o fato de não haver um catalisador específico para a reação nas condições estudadas, apesar de tornar o processo mais abrangente, dificulta a sua otimização.

Assim como o presente trabalho propõe, também existem patentes que descrevem catalisadores mais hidrofóbicos para uso na reação de desidratação do bioetanol. Na patente WO2010066830, ${ }^{102}$ os inventores sugeriram um método para produção de a-olefinas a partir do bioetanol utilizando catalisadores zeolíticos com razão Si/Al igual a, pelo menos, 100, além de outros que passaram por processo de desaluminização e que foram modificados com fósforo. A desvantagem do processo é a utilização de pressões que podem chegar a $30 \mathrm{bar}$, sendo a velocidade espacial de etanol preferencial nos experimentos entre 7 e $12 \mathrm{~h}^{-1}$. Também, o processo de desaluminização utilizado alcança temperaturas superiores (entre 540 e 815 $\left.{ }^{\circ} \mathrm{C}\right)$ à da própria reação de desidratação.

Como visto, há muitas patentes que utilizam a zeólita ZSM-5 como catalisador na reação de desidratação do etanol, mas poucas empregam a zeólita $Y$, que, apesar de possuir um preço mais atrativo, é descrita por não possuir um nível de acidez tão alto como a ZSM-5. Mesmo sendo mais amplamente utilizada, a ZSM-5 gera mais subprodutos que a zeólita $Y$, como o acetaldeído e alguns compostos aromáticos ${ }^{76}$. A patente europeia EP034006 $1^{103}$ relatou a produção de etileno a partir da desidratação de uma mistura etanol:água em um reator de leito fluidizado, a baixas temperaturas, utilizando uma zeólita $Y$ como catalisador. No entanto, uma baixa velocidade espacial de etanol (apenas 1,5 $\mathrm{h}^{-1}$ ) teve que ser utilizada para que a conversão em etileno não ficasse abaixo de $99 \%$.

Outros catalisadores com estrutura cristalina, mas não zeolíticos, 
também vêm sendo pesquisados para desidratar o etanol. Matachowski e colaboradores $^{60}$ desenvolveram um catalisador de um sal neutro de heteropoliácido $\left(\mathrm{Ag}_{3}\left[\mathrm{PW}_{12} \mathrm{O}_{40}\right]\right)$, o qual exibiu uma conversão e seletividade para etileno em torno de $99 \%$ em baixas temperaturas, a partir de $200{ }^{\circ} \mathrm{C}$. Chen e colaboradores ${ }^{104}$ reportaram uma conversão de $99,35 \%$ para a desidratação de etanol e $98,4 \%$ de seletividade para produção de etileno a 340 ${ }^{\circ} \mathrm{C}$ em um reator de leito fixo. Nesse caso, os autores utilizaram peneiras moleculares da família dos silicoaluminofosfatos (SAPO) modificadas com átomos de zinco e manganês. Apesar das boas seletividades e conversões apresentadas em ambos os trabalhos, a quantidade de catalisador utilizada foi superior a $2 \mathrm{~g}$, evidenciando que a atividade dos materiais propostos foi baixa.

No caso das zeólitas e outros aluminossilicatos, a seletividade para produzir etileno irá depender de diversos fatores, como da temperatura reacional, da pressão utilizada, da quantidade de água presente tanto no catalisador como no reagente ${ }^{60,91}$ da velocidade espacial de etanol e da razão Si/Al. Neste último caso, uma quantidade menor de átomos de alumínios na rede zeolítica torna o material mais resistente em reações que geram água como subproduto. Além disso, pesquisas indicam que a extração de alumínios da rede da zeólita ressalta a acidez dos sítios remanescentes, podendo tornála mais seletiva para um determinado produto. ${ }^{18}$

Outra questão a ser levada em consideração é que o etanol obtido da biomassa, além de água, pode conter impurezas, como metanol, hidrocarbonetos, cloretos, sulfatos, ferro, cobre e sódio, ${ }^{105}$ espécies monitoradas pela Agência Nacional do Petróleo, Gás Natural e Biocombustíveis $(A N P)^{\S}$ para controlar a qualidade do etanol anidro e hidratado vendido comercialmente. Essas impurezas podem contaminar o etileno produzido pela reação de desidratação e afetar a atividade do catalisador. Assim, fazer um pré-tratamento do etanol advindo da biomassa pode ser uma solução, mas a utilização de zeólitas mais hidrofóbicas e mais resistentes também auxiliará a economia e eficiência do processo.

\footnotetext{
${ }^{\S}$ Em sua resolução $n^{\circ} 7$, de 21/2/2013, retificada em 15/4/13, a ANP determinou as quantidades máximas que podem estar presente no etanol, anidro ou hidratado, vendido comercialmente: $3 \%$ (volume) de hidrocarbonetos; $1 \mathrm{mg} \mathrm{kg}^{-1}$ de cloretos; $4 \mathrm{mg} \mathrm{kg}^{-1}$ de sulfatos; $5 \mathrm{mg} \mathrm{kg}^{-1}$ de ferro; $2 \mathrm{mg} \mathrm{kg}^{-1}$ de sódio; $\mathrm{e}$ $0,07 \mathrm{mg} \mathrm{kg}^{-1}$ de cobre.
} 


\subsection{Reatores para Simulação e Aperfeiçoamento de Reações em Catálise Heterogênea}

$\mathrm{Na}$ literatura científica e de patentes são encontrados diversos processos catalíticos para a produção de etileno a partir de etanol, tanto em reatores de leito fixo como em leito fluidizado, principalmente em locais como Ásia e América do Sul, onde há agroindústrias para a produção de etanol. ${ }^{67,91}$ Nos tópicos a seguir, serão listados alguns desses reatores.

\subsubsection{Reatores de Leito Fixo}

O leito fixo é uma das principais tecnologias usadas nas produções industriais por se tratar de um reator que pode ser generalizado para diversas reações catalíticas sólido-gás, as quais, por sua vez, são empregadas em muitos campos da indústria química. ${ }^{67}$ Ele pode ser subdividido ainda em dois outros tipos: reatores isotérmicos tubulares e reatores adiabáticos. $O$ isotérmico tubular, utilizado neste trabalho, é adaptado a processos com desativação lenta do catalisador e foi o primeiro tipo de reator de leito fixo desenvolvido e aplicado em processos de desidratação de etanol em etileno, podendo suportar pressões elevadas. ${ }^{67}$ Todavia, existe uma maior complexidade associada à substituição do catalisador e o controle de temperatura é muito sensível a pequenas mudanças das condições reacionais. Assim, variações sutis de temperatura podem levar o reator a um completo descontrole interno. ${ }^{67,106}$ Alguns pesquisadores chamam esse fenômeno de instabilidade térmica dos reatores isotérmicos de "sensibilidade paramétrica", que é a resposta "exagerada" do reator a essas pequenas ou mesmo imperceptíveis variações que podem acontecer nos parâmetros operacionais. ${ }^{106,107}$ Segundo Andrigo e colaboradores, ${ }^{106}$ isso acontece quando pontos de calor (hot spots) no leito fixo excedem determinado valor, devido a perturbações na temperatura de alimentação e quando a capacidade de transferência de calor do sistema não está totalmente adequada à taxa de calor gerado pela reação. Portanto, 0 controle térmico nesse tipo de tecnologia está estritamente relacionado ao formato do reator e, como o objetivo é manter a conversão desejada constante, torna-se crucial controlar fatores como a massa, a estequiometria reacional, a pressão, a temperatura de aquecimento e o calor de transferência médio. 
Já os reatores de leito fixo adiabáticos são a forma mais básica nesse tipo de tecnologia, sendo considerados não exatamente como um tipo de reator, mas como uma condição de operação em que não há trocas de calor com o meio externo. ${ }^{108}$ Devem ser utilizados quando não existem efeitos adversos sobre a seletividade e a conversão reacional ao longo da evolução adiabática da temperatura, necessitando, portanto, de um maior controle desta. Por isso, reatores adiabáticos possuem melhor desempenho nas reações exotérmicas em que o calor reacional é pequeno. ${ }^{43}$

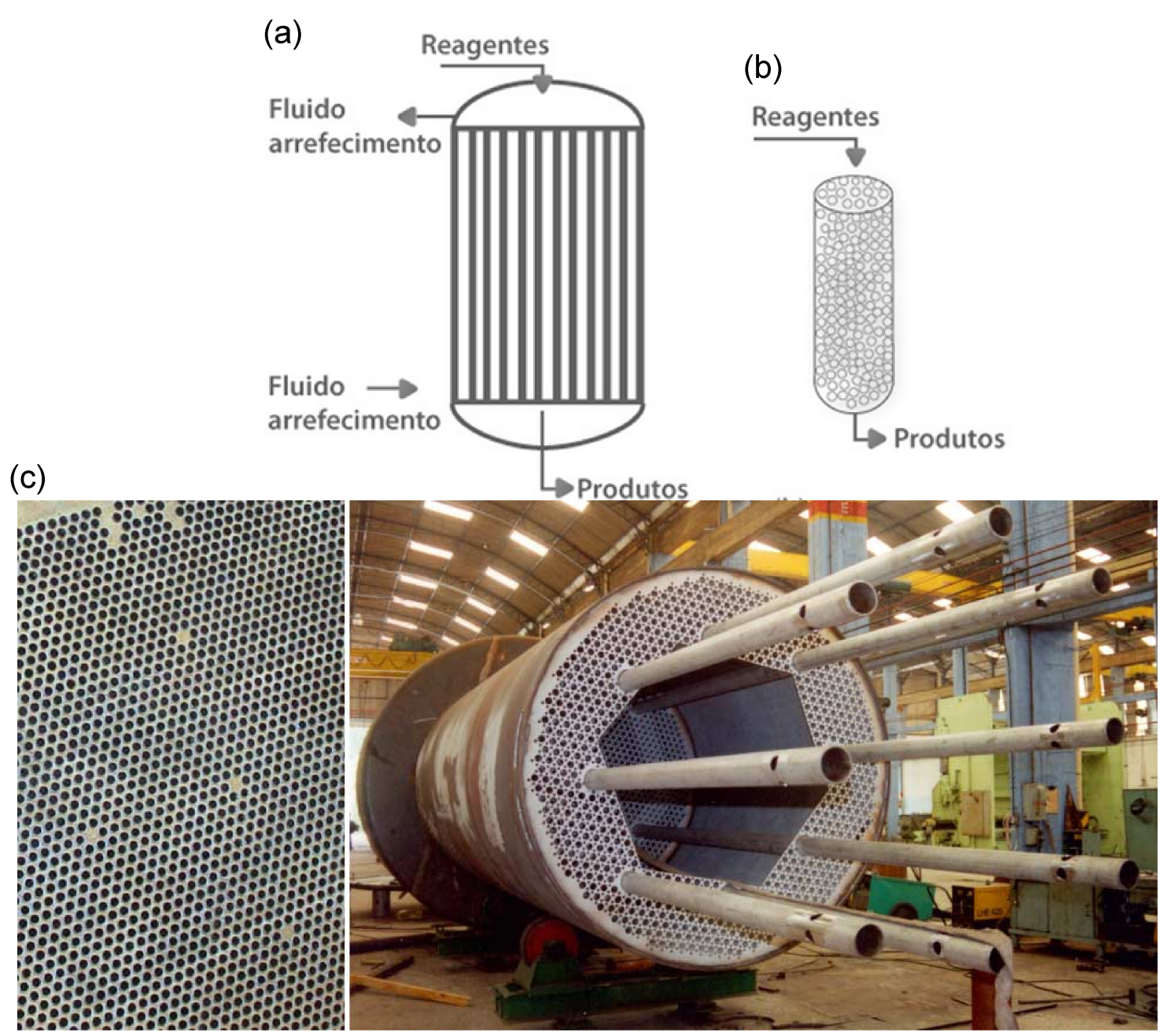

Figura 13: Ilustração de um reator catalítico de leito fixo. Em (a), um reator de leito fixo multitubular; em (b), um tubo do reator empacotado com catalisador formando o leito fixo; e, em (c), um exemplo de trocador de calor tubular. ${ }^{109,110}$

Em reações endotérmicas, como é o caso da síntese de etileno via desidratação do etanol, a temperatura do leito catalítico diminui 
significativamente durante o processo. Assim, é importante que os reagentes adentrem ao reator juntamente com o fluxo de calor e, muitas vezes, torna-se necessário utilizar um reator adiabático multitubular (Figura 13-a), onde os leitos fixos (Figura 13-b) ficam separados por um trocador de calor (Figura 13c) ${ }^{110} \mathrm{Um}$ trocador de calor nada mais é do que um dispositivo, de aço, cuproníquel, latão, cobre, cerâmica, etc., que efetua a transferência de calor entre fluidos por meio, por exemplo, de tubos ou placas dispostos lado a lado, ou formando diferentes geometrias, no interior do reator (Figura 13-a). ${ }^{111}$

Um fluido de arrefecimento, para o caso de reações exotérmicas, percorre os tubos gerando uma maior taxa de transferência $e$, consequentemente, resfriando mais rápido o reator. Além de garantir uma maior e mais eficiente capacidade de produção, esse procedimento evita que as paredes do reator se superaqueçam, impedindo que bruscas variações de temperatura aconteçam no interior dos tubos. No caso de reações endotérmicas, o fluido deve ser de aquecimento para que a temperatura reacional seja mantida. Normalmente são utilizados óleos orgânicos com alto ponto de ebulição $\left(\sim 370{ }^{\circ} \mathrm{C}\right)$ ou sais inorgânicos de baixo ponto de fusão $\left(\sim 550^{\circ} \mathrm{C}\right)$, a depender da temperatura da reação. ${ }^{94}$

A Petrobras, em uma patente depositada nos Estados Unidos (US4232179), ${ }^{112}$ adotou leitos fixos adiabáticos, em paralelo ou em série, para produzir etileno a partir da desidratação catalítica do etanol em altas temperaturas, que variaram de 600 a $800{ }^{\circ} \mathrm{C}$. $\mathrm{O}$ calor requerido pela reação foi provido por um fluxo de vapores de uma mistura de gás inerte, água e etanol adentrando conjuntamente no reator. Os resultados experimentais mostraram que $\circ$ reator $e$ as condições reacionais estabelecidas foram efetivas para aumentar a taxa de conversão do etanol e a seletividade para formação de etileno.

Evidentemente, um processo em meio adiabático consome maior energia e necessita ter suas condições otimizadas de modo a reduzir os custos operacionais. Por isso, estudos para melhorar o desempenho de catalisadores são essenciais, já que a economia do processo depende amplamente das características desses sólidos. 


\subsubsection{Reatores de Leito Fluidizado}

O leito fluidizado é um tipo de tecnologia de reatores que apresentou ao longo da história pequeno desenvolvimento. Entretanto, pode ser usado em uma variedade de reações, inclusive as de fases múltiplas, já sendo bastante empregado em processos químicos industriais como no craqueamento catalítico de hidrocarbonetos. ${ }^{67,113}$ Ao contrário dos reatores de leito fixo (Figura 14-a), onde os gases apenas fluem pelos espaços entre as partículas estacionárias, a vazão do fluido (líquido ou gás) no leito fluidizado é maior, de forma que o catalisador sólido fique suspenso no interior do reator e possua um comportamento semelhante ao do fluido. Dessa forma, obtém-se uma alta taxa de transferência de massa e de calor com uniformidade térmica no leito. ${ }^{67,113,114}$

O problema desse tipo de reator é que, quando se tem um sistema gássólido, caso a vazão fique acima da mínima fluidização (Figura 14-b), haverá uma instabilidade no leito com formação de bolhas (Figura 14-c) que transpassam as partículas fluidizadas, resultando em um contato menos efetivo do gás reagente com o catalisador. ${ }^{113,114}$

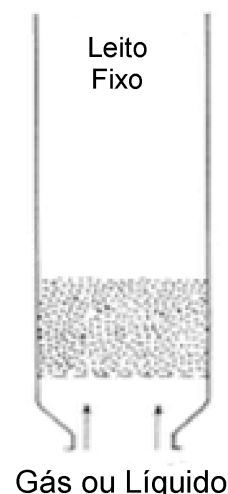

(a)

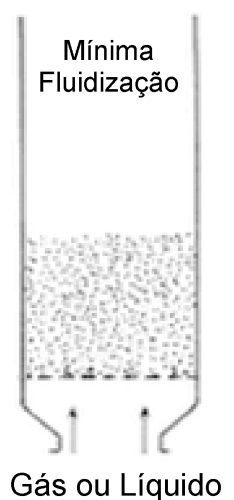

(b)

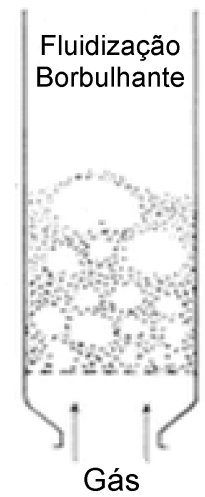

(c)

Figura 14: Em (a), um reator de leito fixo; em (b), um reator de leito fluidizado com fluidização mínima ideal; e, em (c), uma fluidização borbulhante, provocada pelo aumento da vazão do gás. ${ }^{114}$

Também é bem conhecida a dificuldade em se utilizar sólidos muito coesos ou em escala nanométrica em reatores de leito fluidizado, pois, ao invés de apresentarem boa fluidização, esses catalisadores empacotam-se facilmente. Outras desvantagens são o comprometimento da uniformidade do produto gerado e a redução nos valores de conversão, que podem ocorrer caso 
haja uma rápida mistura das partículas sólidas no leito, a qual conduz a tempos de permanência não uniformes do catalisador no reator. ${ }^{113,114}$

São raros os trabalhos que utilizam esse tipo de reator especificamente na desidratação do etanol. A patente norte-americana de Tsao e Zasloff, de $1979,{ }^{115}$ desenvolveu a reação de desidratação do álcool etílico em um reator de leito fluidizado utilizando um catalisador de aluminossilicato. Segundo os inventores, a conversão média do álcool foi de $99,6 \%$ e a seletividade para produção de etileno foi de 99,9\%, gerando apenas quantidades traço de acetaldeído. Entretanto, as temperaturas utilizadas foram entre 700 e $1000{ }^{\circ} \mathrm{C}$. Além disso, problemas típicos de reatores de leitos fluidizados, como a fricção e colisão entre as partículas do sólido e as paredes do reator acabaram por gerar um desgaste do catalisador, diminuindo sua resistência. ${ }^{67,115}$

\subsubsection{Microrreatores de Pulso}

Diversos estudos e caracterizações de catalisadores heterogêneos são conduzidos por meio de reações em reatores de leito fixo com fluxo contínuo de reagentes ou mesmo em reatores de batelada, sendo os produtos coletados em fase líquida ou gasosa para posterior análise por cromatografia gasosa (CG). Muitas vezes, alguns dos produtos formados são voláteis, o que dificulta o estudo de conversão e seletividade do catalisador. Além disso, são necessários tempo e esforço para retirar alíquotas ao longo da reação para proceder com as análises. No caso da catálise heterogênea, não raro, utiliza-se uma quantidade relativamente grande de amostra para gerar bons resultados, passíveis de análise para futuras comparações com outros catalisadores. Em adição, reatores com fluxo contínuo apresentam um alto gasto de reagentes e gases de arraste, além de provocarem uma rápida desativação do catalisador.

Por isso, um microrreator de pulso é um tipo de tecnologia que foi desenvolvida visando à economia do processo nos experimentos de catálise heterogênea. Ele envolve pulsos/injeções de quantidades conhecidas de um fluido ao longo de um microleito de catalisador ativado. Assim, é possível quantificar de forma eficaz a conversão do reagente ou a adsorção do fluido pelo sólido por meio da técnica de cromatografia gasosa. Vários pulsos, da ordem de microlitros $(\mu \mathrm{L})$, podem ser utilizados e a grande vantagem desse 
sistema, além da economia dos materiais, é a rápida comparação da atividade de diferentes catalisadores em diversas reações em um tempo menor de análise.

São poucos os trabalhos que empregam os microrreatores de pulso nos experimentos de catálise heterogênea e, em sua forma mais conhecida, utilizase um microtubo de aço inoxidável contendo uma pequena quantidade do catalisador a ser testado, da ordem de miligramas $(\mathrm{mg})$. Esse microtubo é acoplado à parte externa do CG, de maneira que a injeção (pulso) do reagente no estado gasoso passa primeiramente pelo microrreator e, em seguida, os produtos, também gasosos, são direcionados e analisados pelo equipamento de cromatografia (Figura 15).

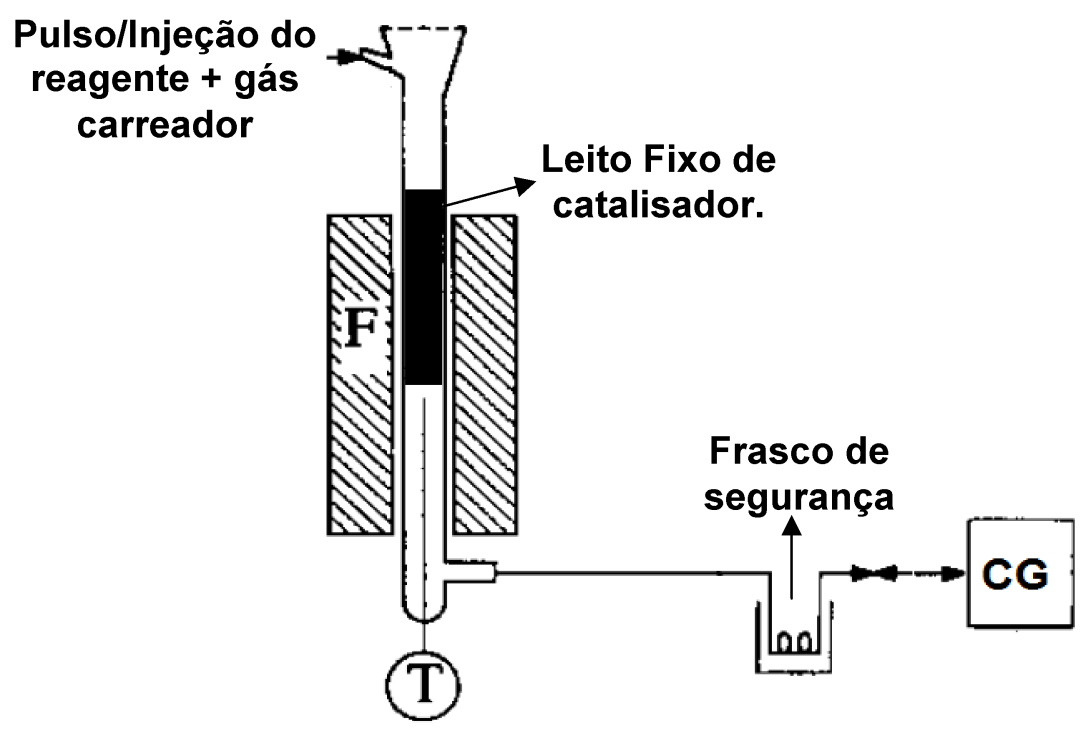

Figura 15: Esquema simplificado de um microrreator de pulso acoplado externamente a um cromatógrafo gasoso (CG). " $F$ " é o forno, aquecido na temperatura reacional desejada e "T" é um termostato. O frasco de segurança impede que possíveis partículas sólidas do leito de catalisador contaminem e danifiquem o CG ${ }^{116}$

Liu e Dadyburjor estudaram a atividade, a seletividade e a desativação de zeólitas $Y$ com alta proporção de contraíons $\mathrm{Na}^{+}$na reação de craqueamento de isopropilbenzeno a $500{ }^{\circ} \mathrm{C} .{ }^{116}$ Para tanto, utilizaram um microrreator de pulso, como ilustrado na Figura 15, com um fluxo de $100 \mathrm{~mL}$ $\min ^{-1}$ de hélio a cada injeção de $5 \mu \mathrm{L}$ dos gases do reagente. Dumitriu e colaboradores ${ }^{117}$ também utilizaram o mesmo sistema de microrreator de pulso externo a um CG para fazer a transalquilação de tolueno e de trimetilbenzeno 
na presença da zeólita Y ultraestável (USY). Nesse caso, $20 \mathrm{mg}$ do catalisador foram empacotados no tubo de aço inox, onde foram injetados $0,2 \mu \mathrm{L}$ dos reagentes por meio de um fluxo de gás nitrogênio $\left(30 \mathrm{~mL} \mathrm{~min}^{-1}\right)$ a $500{ }^{\circ} \mathrm{C}$.

Em um trabalho mais recente, Cobzaru e colaboradores ${ }^{118}$ procederam com a condensação aldólica de aldeídos sobre a zeólita natural clinoptilolita no microrreator de pulso, sendo obtidos bons resultados de conversão e seletividade (acima de 90\%) de uma mistura de acetaldeído e formaldeído em acroleína. Nesse estudo, pulsos de $0,5 \mu \mathrm{L}$ dos reagentes foram injetados por meio de um fluxo de $20 \mathrm{~mL} \mathrm{~min}^{-1}$ do gás carreador $\left(\mathrm{N}_{2}\right)$ em $30 \mathrm{mg}$ da clinoptilolita em uma temperatura de $450^{\circ} \mathrm{C}$. Han e colaboradores, ${ }^{119} \mathrm{em} 2011$, publicaram um artigo sobre a estabilidade hidrotérmica de catalisadores mesomicroporosos, baseados na família MFI, no craqueamento de 1,3,5triisopropilbenzeno. Para tanto, conduziram seus estudos com a utilização de um microrreator de pulso construído no laboratório e com análise direta via CG. Assim, $50 \mathrm{mg}$ do catalisador foram pré-ativados e receberam injeções pulsadas de $0,1 \mu \mathrm{L}$ do reagente, sendo carreado por um fluxo de $20 \mathrm{~mL} \mathrm{~min}{ }^{-1}$ de $\mathrm{N}_{2}$ a $400{ }^{\circ} \mathrm{C}$.

Semelhante ao microrreator descrito anteriormente e ilustrado na Figura 15 , existem alguns raros trabalhos ${ }^{119-121}$ que, ao invés de empregarem um microtubo de aço inox externo ao CG, adaptam o equipamento de cromatografia de forma que a reação se processe in situ, isto é, dentro do cromatógrafo. Essa técnica foi aprimorada nesse trabalho para realização das reações de desidratação de alcoóis. 


\section{OBJETIVOS}

As diferentes estruturas das zeólitas, somadas à alta acidez de seus sítios ativos, possibilitam sua aplicação nos mais variados tipos de reações em catálise ácida. Os heteropolissais, com diferentes cátions de compensação inseridos na estrutura dos HPAs, exibem um abrangente campo de investigação no que concerne ao seu uso em catálise.

\subsection{Objetivos Gerais}

Dando continuidade a pesquisas desenvolvidas anteriormente, ${ }^{18} \circ$ presente trabalho objetivou aplicar a zeólita $\mathrm{Y}$, modificada por meio de um processo de desaluminização, como catalisador nas reações de desidratação de diferentes alcoóis $\mathrm{C} 2-\mathrm{C} 4$ devido à sua forte acidez de Brønsted, em sinergia com possiveis espécies de alumínio fora de rede (EFAl) acrescentadas pela desaluminização. Este trabalho também buscou desenvolver novos materiais baseados em HPAs com características químicas e morfológicas diferenciadas para aplicação em reações de catálise ácida e REDOX.

\subsection{Objetivos Específicos}

Foram objetivos específicos dessa pesquisa:

a) ampliar/complementar as caracterizações do melhor material zeolítico desenvolvido anteriormente, ${ }^{18}$ que foi a zeólita $Y$ desaluminizada no estado sólido a $5 \%(\mathrm{~mol} / \mathrm{mol})$ na temperatura de $80{ }^{\circ} \mathrm{C}$ e calcinada $-\mathrm{Y}(80) 5 \mathrm{C}$, por meio de técnicas de determinação de área superficial específica (ASAP) e microscopia eletrônica de varredura (MEV) e de transmissão (MET).

b) estudar a atividade catalítica da $Y(80) 5 \mathrm{C}$ em reações de desidratação de alcoóis utilizando dois tipos de reatores: um reator tubular de leito fixo de fluxo contínuo e um microrreator de pulso desenvolvido no próprio Laboratório de Catálise, o qual também foi objeto de estudo dessa pesquisa. As taxas de conversão e seletividade foram medidas a partir da técnica de CG. 
c) preparar sais de HPW com diferentes contraíons, como prata, zinco e zircônia, utilizando uma metodologia de síntese dupla, de fácil execução, em que, concomitantemente, são produzidos sólidos de HPAs nanométricos e micrométricos.

d) caracterizar os heteropolissais sintetizados por meio de diferentes técnicas de análise de estrutura e de acidez, como MEV, MET, ASAP, TG, difração de raios $X$ (DRX), infravermelho (FT-IR), adsorção de piridina, etc.

e) estudar a atividade catalítica desses heteropolissais, aplicando-os como catalisadores na desidratação do etanol e, ainda, em reaçõesmodelo, como na esterificação do álcool benzílico com ácido acético e em uma reação REDOX (oxidação do álcool benzílico). 
Experimental 


\section{EXPERIMENTAL}

\subsection{Materiais Utilizados}

- Zeólita Y (CBV 300), na forma amoniacal $\left(\mathrm{NH}_{4}-\mathrm{Y}\right)$, obtida da Zeolyst International com as seguintes características:

○ razão molar $\mathrm{SiO}_{2} / \mathrm{Al}_{2} \mathrm{O}_{3}=5,10$; área superficial $=925 \mathrm{~m}^{2} \mathrm{~g}^{-1}$; parâmetro de cela unitária $=24,68$; e 2,8\% em massa de $\mathrm{Na}_{2} \mathrm{O}$.

- Hexa(fluoro)silicato(IV) de amônio, $\left(\mathrm{NH}_{4}\right)_{2} \mathrm{SiF}_{6}$, pureza $=98 \%$, Aldrich;

- Etanol (EtOH), $\mathrm{CH}_{3} \mathrm{CH}_{2} \mathrm{OH}$, pureza $\geq 99,8 \%$, Vetec;

- Bioetanol $(\mathrm{EtOH})$, massa específica $=809,7 \mathrm{~kg} \mathrm{~m}^{3-}$, teor alcoólico $=$ $93,02 \%(\mathrm{~m} / \mathrm{m}), \mathrm{pH}=6,7$, ANP;

- 1-Propanol, $\mathrm{CH}_{3} \mathrm{CH}_{2} \mathrm{CH}_{2} \mathrm{OH}$, pureza $\geq 99,8 \%$, Aldrich;

- Isopropanol, $\mathrm{CH}_{3} \mathrm{CH}_{2} \mathrm{CH}_{2} \mathrm{OH}$, pureza $\geq 99,5 \%$, Pró-Química;

- Terc-butanol, $\mathrm{CH}_{3} \mathrm{CH}_{2} \mathrm{CH}_{2} \mathrm{CH}_{2} \mathrm{OH}$, pureza $\geq 99,0 \%$, Vetec;

- Hidrogênio, $\mathrm{H}_{2}$, pureza $\geq 99,999 \%$, White Martins;

- Ar sintético, pureza $\geq 99,999 \%$, White Martins;

- Hélio, He, pureza $\geq 99,999 \%$, White Martins;

- Nitrogênio, $\mathrm{N}_{2}$, pureza $\geq 99,999 \%$, White Martins;

- Ácido 12-tungstofosfórico, $\mathrm{H}_{3} \mathrm{PW}_{12} \mathrm{O}_{40} \cdot \mathrm{nH}_{2} \mathrm{O}$, Aldrich;

- Cloreto de zirconila, $\mathrm{ZrOCl}_{2} \cdot 8 \mathrm{H}_{2} \mathrm{O}$, pureza $=98 \%$, Aldrich;

- Nitrato de prata, $\mathrm{AgNO}_{3}$, pureza $=99,99 \%$, Reagentes Analíticos Impex;

- Nitrato de zinco, $\mathrm{Zn}\left(\mathrm{NO}_{3}\right)_{2} \cdot 10 \mathrm{H}_{2} \mathrm{O}$, pureza $=98 \%$, Isofar;

- Acetato de zinco, $\mathrm{Zn}\left(\mathrm{CH}_{3} \mathrm{COO}\right)_{2} \cdot 2 \mathrm{H}_{2} \mathrm{O}$, pureza $\geq 98 \%$, Aldrich;

- Papel filtro faixa preta (JP41), ø $7 \mathrm{~cm}$, porosidade média $28 \mu \mathrm{m}$, QuantyJProlab;

- Celulose em pó, Riedel de Haën;

- Ácido acético glacial, $\mathrm{CH}_{3} \mathrm{COOH}$, pureza $\geq 99.7 \%$, Vetec;

- Álcool benzílico $(\mathrm{BzOH}), \mathrm{C}_{7} \mathrm{H}_{8} \mathrm{O}$, pureza $\geq 99 \%$, Aldrich;

- Acetonitrila, $\mathrm{CH}_{3} \mathrm{CN}$, pureza $\geq 99 \%$, Vetec;

- Piridina anidra (Py), $\mathrm{C}_{5} \mathrm{H}_{5} \mathrm{~N}$, pureza $=99,8 \%$, Aldrich;

- Peneira molecular 3A, Aldrich;

- Peróxido de hidrogênio, $\mathrm{H}_{2} \mathrm{O}_{2}$, pureza $=30 \%$, Vetec;

- Hidreto de cálcio, $\mathrm{CaH}_{2}$, pureza $\geq 98 \%$, Merck;

- Brometo de potássio, $\mathrm{KBr}$, pureza $\geq 99,5 \%$, Merck. 


\subsection{Preparação dos Catalisadores}

O presente trabalho foi baseado em sínteses, caracterizações e testes catalíticos de sólidos micro e nanoestruturados. Em um primeiro momento, um catalisador zeolítico (zeólita $\mathrm{Y}$ ) desenvolvido em trabalhos anteriores foi utilizado na pesquisa. ${ }^{18,122} \mathrm{Na}$ busca por novos materiais, sais de heteropoliácidos foram sintetizados e caracterizados com o objetivo de elucidar sua estrutura e sua acidez. As metodologias de preparação desses dois tipos de catalisadores serão descritas a seguir.

\subsubsection{Catalisador Zeolítico}

A zeólita Y comercial (fabricante Zeolyst, CBV 300) foi modificada por meio de uma reação de desaluminização no estado sólido, utilizando como agente desaluminizante $\circ\left(\mathrm{NH}_{4}\right)_{2} \mathrm{SiF}_{6}$. $\mathrm{O}$ sólido foi submetido a uma mistura mecânica e, em seguida, foi ativado por $2 \mathrm{~h}$ em um forno a vácuo à temperatura de $80{ }^{\circ} \mathrm{C}$. Utilizou-se uma quantidade de $\left(\mathrm{NH}_{4}\right)_{2} \mathrm{SiF}_{6}$ para a substituição de $5 \%(\mathrm{~mol} / \mathrm{mol})$ dos átomos de alumínio da rede zeolítica por átomos de silício advindos do agente desaluminizante. Após a reação, o forno foi resfriado ainda sob vácuo até temperatura ambiente e o material resultante foi lavado com água quente duas vezes em filtro de placa sinterizada para eliminar os subprodutos formados, tais como, $\mathrm{NH}_{4} \mathrm{HF}_{2}, \mathrm{NH}_{4}\left[\mathrm{AlF}_{4}\right]$ e $\mathrm{AlO}_{4}{ }^{-42,61-63}$ Após a lavagem, o material foi seco em estufa a $100^{\circ} \mathrm{C}$.

Antes de ser utilizado em cada uma das reações de desidratação, o catalisador preparado foi calcinado em mufla a $550{ }^{\circ} \mathrm{C}$ durante $8 \mathrm{~h}$. Essa amostra foi nomeada como $\mathrm{Y}(80) 5 \mathrm{C}$.

\subsubsection{Catalisadores de Heteropoliácidos}

Diferentes sais de HPAs foram sintetizados nesse trabalho a partir do $\mathrm{H}_{3}\left[\mathrm{PW}_{12} \mathrm{O}_{40}\right]$ (HPW). Para tanto, uma metodologia de síntese dupla foi desenvolvida, de maneira que, com um único procedimento, fossem gerados dois heteropolissais de mesma composição, mas com estruturas distintas. Assim, em cada síntese, foram gerados tanto sólidos nanoestruturados como microestruturados, como será descrito a seguir. 


\subsubsection{Síntese Dupla via Molde Biológico}

Diversas pesquisas têm mostrado a preparação de polioxometalatos nanoestruturados via síntese com moldes de carbono, ${ }^{123}$ membranas poliméricas, ${ }^{123}$ surfactantes, ${ }^{124}$ etc. Entretanto, poucos são os estudos que utilizam moldes biológicos, como a celulose, para fabricar novos materiais derivados de HPAs. ${ }^{8,125}$

As fibras naturais da celulose são polímeros de cadeia longa compostos de monômeros de glicose (vide Figura 16) que possuem grupos hidroxila (-OH) em sua superfície. Os grupos $-\mathrm{OH}$ podem interagir com os POMs em solução, distribuindo homogeneamente os cátions de compensação e os ânions $\left[\mathrm{PW}_{12} \mathrm{O}_{40}\right]^{3-}$ em escala nanométrica, os quais se solidificam nas duplas superfícies dos poros da celulose por atração eletrostática e ficam expostos para servirem como sítios ativos reativos em catálise heterogênea. ${ }^{8} \mathrm{~A}$ solidificação dos cátions e ânions de Keggin no molde biológico acaba por gerar um material com formato semelhante ao da celulose, apresentando-se com uma estrutura nanotubular, conforme apresentado por Zhang $e$ colaboradores. $^{8}$

(b)

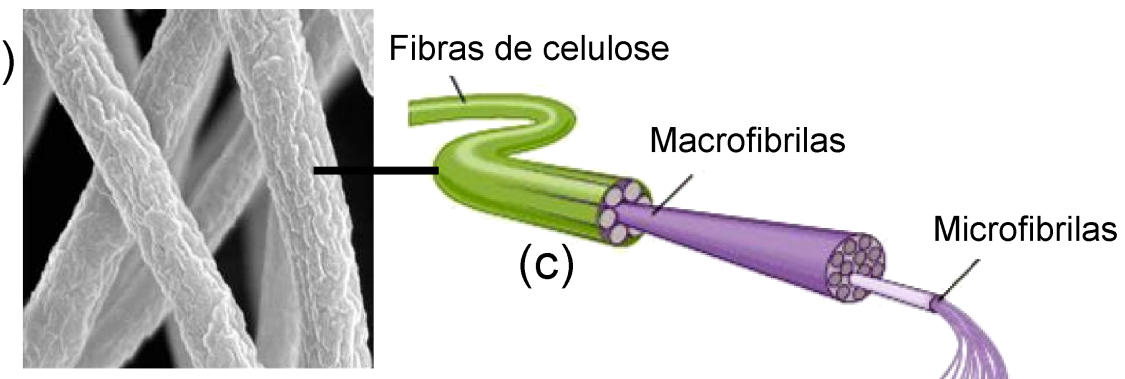

(a)

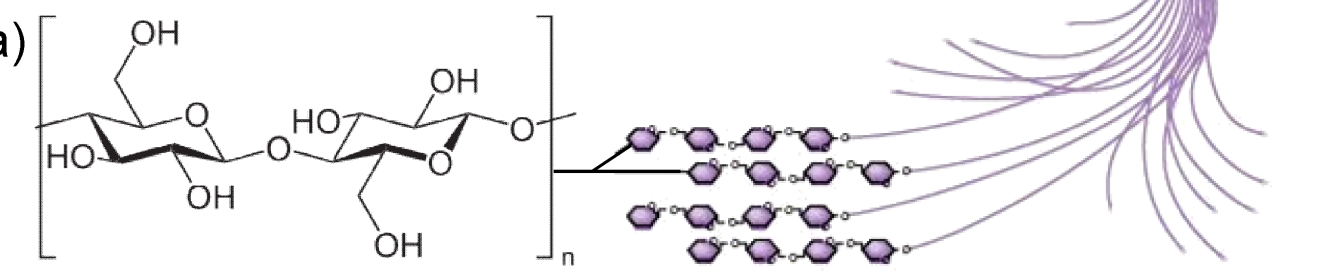

Figura 16: Representação estrutural da celulose (a), formada a partir de monômeros de glicose, em que "n" é, no mínimo, igual a 200 repetições. A micrografia (b) mostra as fibras de celulose e o diagrama (c) ilustra internamente uma dessas fibras, composta por conjuntos de microfibrilas de cadeias poliméricas da celulose que interagem entre si por meio de ligações hidrogênio. ${ }^{126}$

Pensando nisso, no presente trabalho, foi utilizado um molde de celulose em uma das etapas da síntese para a formação de sais de HPW com 
contraíons prata (AgHPW), zinco (ZnHPW) e zircônia (ZrHPW). Buscando estudar a influência da celulose na formação de nanotubos de heteropolissais, esta foi utilizada tanto na forma de pó como de papel filtro. A segunda etapa da síntese consistiu na recuperação da solução residual utilizada para formação dos sólidos nanométricos, a qual gerou os catalisadores micrométricos.

\section{- Síntese do ZrHPW com Papel Filtro}

Para a formação do sal ácido ZrHPW, uma massa de $8,00 \mathrm{~g}$ do ácido $\mathrm{H}_{3}\left[\mathrm{PW}_{12} \mathrm{O}_{40}\right] \cdot 15 \mathrm{H}_{2} \mathrm{O}$ foi dissolvida em $20 \mathrm{~mL}$ de água destilada, resultando em uma solução transparente. Esta, por sua vez, foi adicionada, gota a gota, em $20 \mathrm{~mL}$ de uma solução de etanol contendo $0,54 \mathrm{~g}$ de $\mathrm{ZrOCl}_{2} \cdot 8 \mathrm{H}_{2} \mathrm{O}$ sob agitação lenta em temperatura ambiente. Após $30 \mathrm{~min}$ agitando, a mistura, já visivelmente heterogênea, foi transferida para uma placa de Petri. Um papel filtro (faixa preta, $\varnothing 7 \mathrm{~cm}$ ) foi mergulhado nessa mistura final de ZrHPW durante $15 \mathrm{~min}$. Passado o tempo de repouso, o papel foi lavado com $40 \mathrm{~mL}$ de uma solução etanol:água $(1: 1, \mathrm{v} / \mathrm{v})$ sob filtração a vácuo, a fim de remover o complexo $\mathrm{ZrHPW}$ e $\circ \mathrm{ZrOCl}_{2} \cdot 8 \mathrm{H}_{2} \mathrm{O}$ não retidos pela celulose. Em seguida, secou-se o papel com fluxo de ar (ainda sob vácuo) durante 5 min. Esse procedimento de embeber o papel na mistura de ZrHPW, lavá-lo com etanol:água e secá-lo foi repetido 20 vezes, totalizando um tempo médio de síntese de aproximadamente $8 \mathrm{~h}$. O complexo celulose/ZrHPW foi calcinado na mufla, em ar, a $400{ }^{\circ} \mathrm{C}$ durante $6 \mathrm{~h}$ a $1^{\circ} \mathrm{min}^{-1}$. Assim, pôde-se remover lentamente o papel filtro original utilizado como molde, restando apenas o ZrHPW nanoestruturado, nomeado ZrHPW-nano, de coloração branca. As condições de calcinação foram escolhidas com base na temperatura de decomposição da celulose, que ocorre entre 270 e $370{ }^{\circ} \mathrm{C}$, e de forma a não afetar a estrutura de Keggin dos materiais.

A mistura residual de ZrHPW da placa de Petri foi evaporada em temperatura ambiente naturalmente por 3 dias, até que restasse apenas um precipitado cristalino. Posteriormente, o material foi calcinado sob as mesmas condições anteriores gerando o sólido ZrHPW microestruturado na forma de pó, nomeado ZrHPW-micro, com coloração levemente amarelada. A descrição de todo o procedimento experimental foi resumida na Figura 17. 


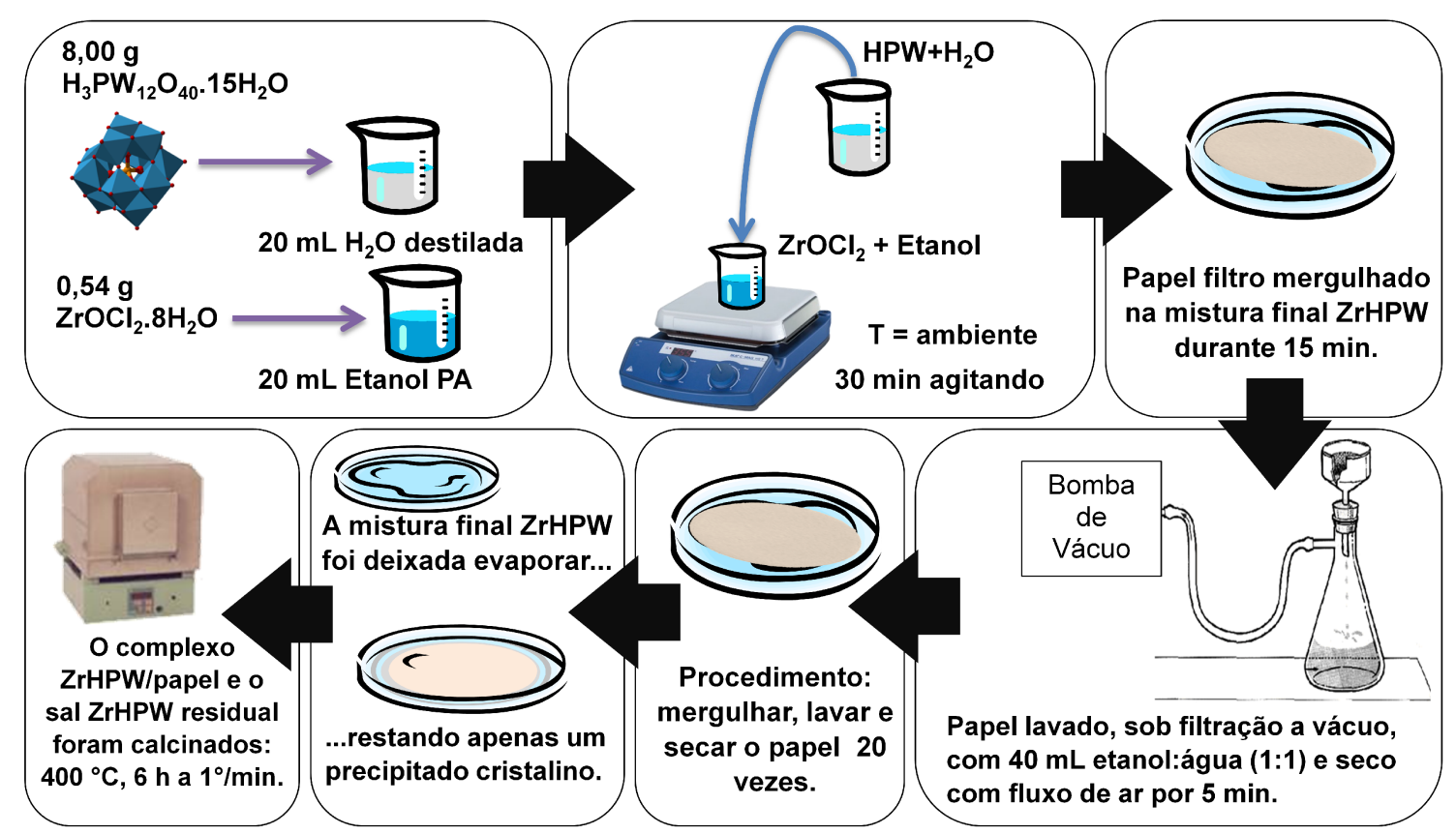

Figura 17: Resumo do procedimento experimental adotado para a síntese dupla dos sais ácidos de HPW utilizando como molde um papel filtro.

\section{- Síntese do ZrHPW com Celulose em Pó}

Na síntese dupla dos sais de HPW com celulose em pó, as mesmas soluções de $\mathrm{HPW}$ e de $\mathrm{ZrOCl}_{2}$ foram preparadas, repetindo-se o mesmo procedimento experimental da síntese com papel filtro. Agora, entretanto, ao invés de se utilizar o papel, foi pesado $0,50 \mathrm{~g}$ de celulose em pó, valor referente à massa do papel filtro de $7 \mathrm{~cm}$ de diâmetro utilizado anteriormente. Essa massa foi transferida para um balão de fundo redondo de $100 \mathrm{~mL}$, adicionando-se, a ela, a solução etanólica de $\mathrm{ZrOCl}_{2} \cdot 8 \mathrm{H}_{2} \mathrm{O}$. A mistura celulose- $\mathrm{ZrOCl}_{2}$ permaneceu sob agitação lenta, em temperatura ambiente, enquanto acrescentava-se, gota a gota, a solução aquosa de HPW. Finalizado o gotejamento, o balão foi fechado com tampa de borracha e a mistura final foi mantida sob a mesma agitação durante $20 \mathrm{~h}$. Passado esse tempo, essa mistura foi filtrada a vácuo, em funil de placa sinterizada, sendo lavada com $50 \mathrm{~mL}$ de uma solução etanol:água $(1: 1, \mathrm{v} / \mathrm{v})$ para remoção das espécies não retidas pela celulose. O líquido residual obtido na filtração foi deixado evaporar em placa de Petri, em temperatura ambiente, até restar apenas o precipitado de ZrHPW. Ambos os materiais, o sal ZrHPW puro (ZrHPW-micro-cp) e o 
sólido celulose-ZrHPW (ZrHPW-nano-cp), foram calcinados a $400{ }^{\circ} \mathrm{C}$, em ar, a $1^{\circ} \mathrm{min}^{-1}$, durante $6 \mathrm{~h}$. A Figura 18 ilustra o procedimento dessa síntese.

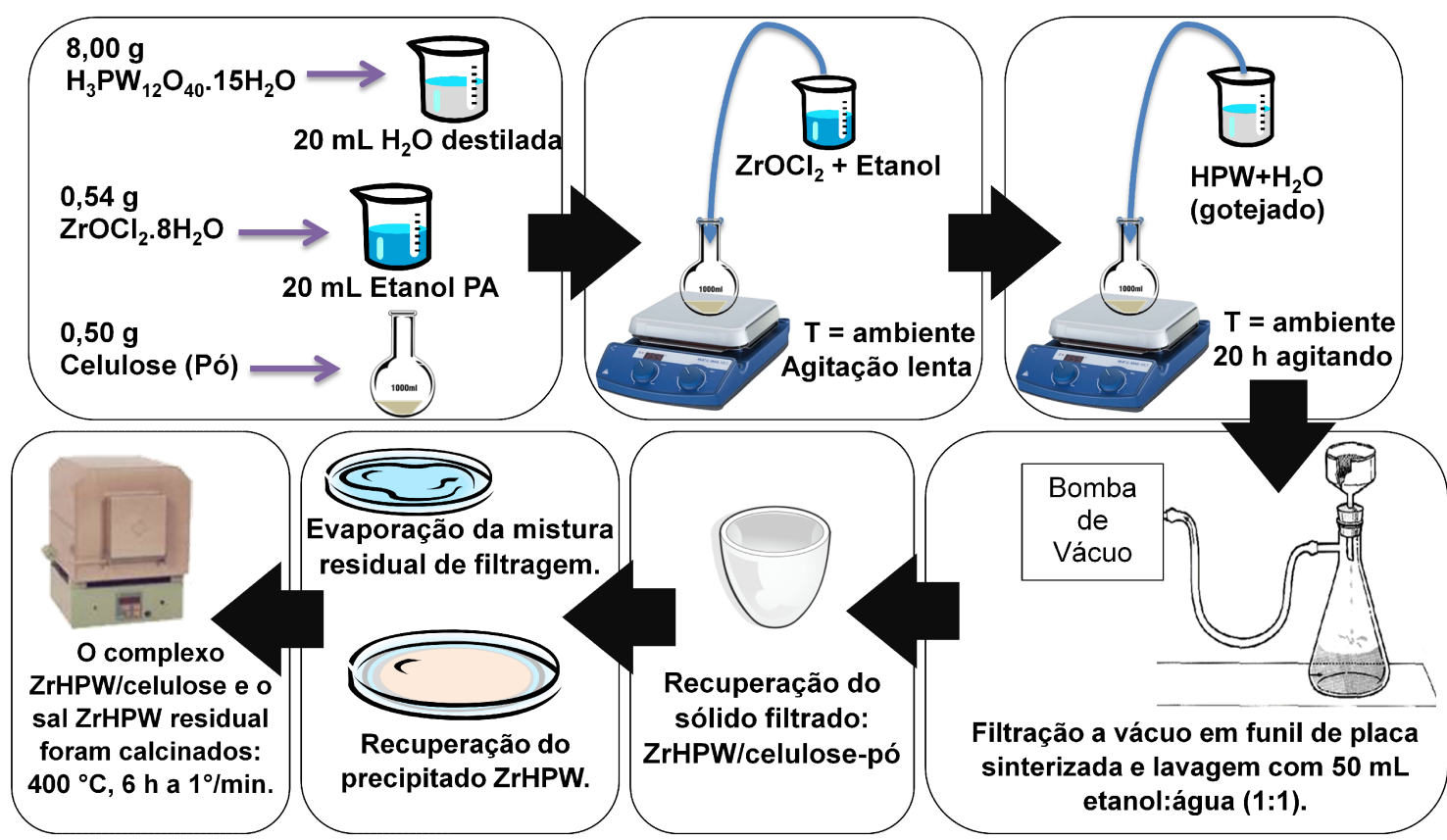

Figura 18: Resumo do procedimento experimental adotado para a síntese dupla dos sais ácidos de HPW utilizando celulose em pó.

\section{- Síntese do ZnHPW}

A síntese e calcinação do ZnHPW foram feitas seguindo o mesmo procedimento desenvolvido para o sal com zircônia, utilizando a celulose sob a forma de papel filtro (Figura 17). Nesse caso, foi pesada a mesma massa $(8,00 \mathrm{~g})$ de HPW $\left(2,4 \times 10^{-3} \mathrm{~mol}\right)$ e foram dissolvidos $2,66 \mathrm{~g}$ de nitrato de zinco $\left(7,2 \times 10^{-3} \mathrm{~mol}\right)$ em $15 \mathrm{~mL}$ de etanol. Essa síntese visou à produção de duas amostras: os sólidos nanométricos de ZnHPW, moldados pela celulose, e o sal micrométrico ZnHPW advindo das espécies não retidas pela celulose.

Buscando investigar as alterações causadas pelo cátion $\mathrm{Zn}^{2+}$, a proporção desse íon em relação ao ânion de Keggin foi variada a partir da pesagem de diferentes massas de $\mathrm{Zn}\left(\mathrm{NO}_{3}\right)_{2}: 1,33 \mathrm{~g}\left(3,6 \times 10^{-3} \mathrm{~mol}\right)$ e $3,98 \mathrm{~g}$ $\left(10,8 \times 10^{-3} \mathrm{~mol}\right)$, ambas utilizadas na síntese com papel filtro e com celulose em pó. Dessa forma, foram preparados outros 4 catalisadores.

$\mathrm{O}$ precursor de íons $\mathrm{Zn}^{2+}$ também foi variado, utilizando-se, além do nitrato, o acetato de zinco, $\mathrm{Zn}\left(\mathrm{CH}_{3} \mathrm{COO}\right)_{2}$. Com isso, esperou-se observar 
alterações na estrutura e, consequentemente, na atividade catalítica dos materiais. Trabalhos prévios, assim como discutido anteriormente, já relataram modificações morfológicas em sais de césio ao se utilizar o $\mathrm{CsCl}$ no lugar de $\mathrm{Cs}_{2} \mathrm{CO}_{3}{ }^{57}$ Portanto, $1,60 \mathrm{~g}\left(7,2 \times 10^{-3} \mathrm{~mol}\right)$ do $\mathrm{Zn}\left(\mathrm{CH}_{3} \mathrm{COO}\right)_{2}$ foram dissolvidos em $15 \mathrm{~mL}$ de etanol, visando à produção de 2 outros catalisadores para análise: um nano estruturado e, outro, na forma do sal simples de ZnHPW.

\section{- Síntese do AgHPW}

Para a síntese dos sais de HPW com o contraíon $\mathrm{Ag}^{+}$, a mesma metodologia anterior foi seguida, com celulose na forma de papel filtro (Figura 17). O sal de prata utilizado foi $\circ \mathrm{AgNO}_{3}$, baseando-se no trabalho de Matachowski e colaboradores. ${ }^{60}$ Entretanto, como esses autores procederam com a substituição total dos íons $\mathrm{H}^{+}$do HPW, optou-se por reduzir à metade o valor de massa utilizado por eles. Com isso, buscou-se manter parte da acidez de Brønsted pré-existente do heteropolissal. Nesse caso, então, para 8,00 g de $\mathrm{HPW}$, foram pesados e dissolvidos $0,12 \mathrm{~g}\left(0,7 \times 10^{-3} \mathrm{~mol}\right)$ de $\mathrm{AgNO}_{3} \mathrm{em} 35 \mathrm{~mL}$ de água.

\subsubsection{Processo de Peletização}

$\mathrm{Na}$ indústria, o uso de catalisadores sólidos em pó é pouco utilizado, pois há inconvenientes relacionados à sua manipulação, como levantamento de poeiras finas facilmente inaláveis que podem gerar problemas de saúde para aqueles que trabalham diretamente com o sólido, perdas de material e, ainda, necessidade de frequente limpeza dos equipamentos para evitar contaminações e interferências a outros dutos da planta industrial. ${ }^{127}$ Sólidos com partículas maiores, no formato de pellets, diminuem esses problemas, facilitam seu manuseio e acabam por minimizar os custos do processo.

A peletização consiste na aglomeração de pós, feita a partir da compressão de um sólido em pequenas partículas de tamanho médio conhecido. ${ }^{128,129}$ Dessa maneira, diz-se que o material está em formato de pellets, com geometria cilíndrica. Os pellets são geralmente traduzidos como grânulos, mas se diferenciam destes por serem produzidos de maneira 
alternativa ao processo de granulação clássico e por apresentarem características físicas específicas. Em um processo industrial padrão de peletização, usada para sólidos em geral, os pós secos são primeiramente umidificados e, em seguida, passam por um equipamento dotado de um molde, onde a massa úmida sofre compactação e é modelada na forma de cilindros de diâmetro e tamanho uniformes. Na indústria, essa fase é conhecida como extrusão, em que equações de fluxo de massa são utilizadas para calcular quanto do sólido umidificado passará pelos orifícios do molde, com raio e comprimento definidos, por unidade de tempo. ${ }^{128,129}$

Entretanto, para esse trabalho, o processo de peletização utilizado foi simplificado, sem umidificação do sólido e mais semelhante a uma granulação, consistindo apenas de duas etapas:

a) prensagem mecânica do catalisador em pó, com formação de uma fina pastilha do material desejado;

b) quebra manual da pastilha dentro de um sistema de duas peneiras de aço inoxidável que se encaixavam, contendo uma malha (mesh) com orifícios de abertura média conhecida. Nesse caso, foram usadas peneiras de tamanhos 42 mesh-tyler $(0,355 \mathrm{~mm})$ e 24 meshtyler $(0,710 \mathrm{~mm})$.

O sistema de peneiras (Figura 19) modela o catalisador em pellets e limita seu tamanho àquele desejado. Assim, dentro da peneira com os maiores orifícios (24 mesh-tyler), a pastilha foi quebrada manualmente em partes cada vez menores, de maneira que o sólido passasse por seus furos e caísse na segunda peneira (42 mesh-tyler), de menor abertura. Os pellets retidos entre ambas as peneiras foram aqueles utilizados em algumas das reações estudadas, possuindo, portanto, granulometria entre 24 e 42 mesh-tyler.

Além dos problemas já supracitadas em se utilizar pós finos em plantas industriais, existem ainda desvantagens associadas à atividade catalítica desses sólidos. Por possuírem uma área superficial mais elevada que a dos pellets, os sólidos em pó, não raro, apresentam maior poder de conversão de reagentes em produtos, mas sua desativação acontece mais rapidamente. Assim, também fica evidente que o tamanho dos pellets terá efeito direto sobre sua área superficial. ${ }^{129}$ 


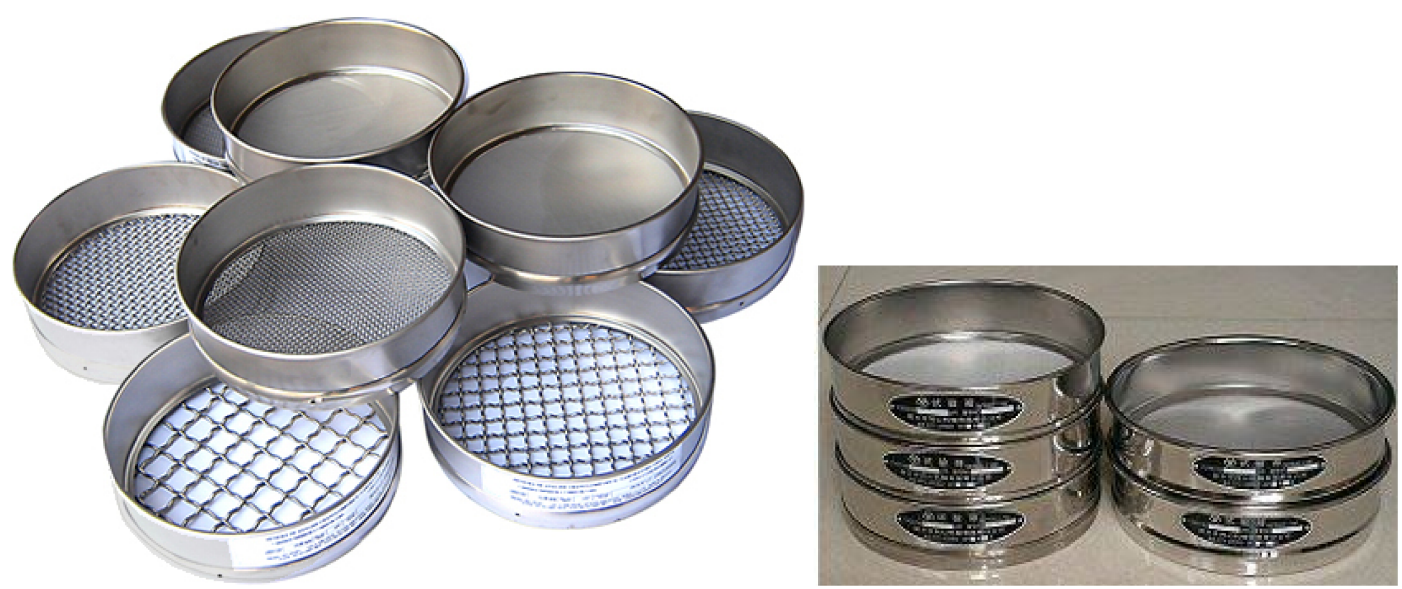

Figura 19: Peneiras granulométricas em aço inoxidável com diferentes tamanhos de abertura. À direita, o encaixe de diferentes peneiras formando o sistema para peletização utilizado no presente trabalho. ${ }^{130}$

A dimensão das partículas de um catalisador pode ainda conferir características únicas ao material. Portanto, diferentes tamanhos e formatos de pellets, por exemplo, implicarão em sólidos com densidade, porosidade, rugosidade, bem como dureza e resistência distintas. ${ }^{129}$ Essas e outras variações podem influenciar no contato dos reagentes com o catalisador e, consequentemente, em sua capacidade de conversão.

\subsection{Técnicas de Caracterização}

\subsubsection{Determinação de Acidez: adsorção de piridina gasosa}

Um sistema de adsorção gasosa de piridina (Py), desenvolvido no Laboratório de Catálise (Figura 20), ${ }^{18,32,37}$ foi utilizado para qualificar e quantificar os sítios ácidos existentes nos HPAs e na zeólita em conjunto com as técnicas de análise elementar de CHN, de FT-IR e de TG. Esse sistema permitiu a adsorção simultânea de Py gasosa em até 10 amostras, as quais foram colocadas separadamente, sem compactação (entre 40 e 50 mg de sólido), em cadinhos de alumínio. Estes, por sua vez, foram enfileirados em cápsulas de porcelana (barquetes típicos de calcinação) para facilitar a manipulação dos materiais.

As cápsulas contendo as amostras foram então inseridas dentro de um forno tubular de vidro envolto em manta de aquecimento (Thermolyne, model F21100) (Figura 20-a), a qual foi ligada a um gerador do tipo Variac conectado 
a um controlador de temperatura (Figura 20-b). Por meio de uma torneira de vidro (Figura 20-c), o $\mathrm{N}_{2}$, com fluxo controlado de $100 \mathrm{~mL} \mathrm{~min}^{-1}$, possui dois caminhos para passagem no sistema: (i) no início do experimento, ele passa por um material dessecante (do tipo drierite) e chega anidro às amostras, sem carregar piridina, a fim de se fazer uma secagem prévia dos materiais; e (ii) no decorrer do experimento, a torneira é girada manualmente de maneira que o nitrogênio anidro passe pelo reservatório de Py líquida (Figura 20-d), carreando-a pelo tubo de vidro onde estão as amostras. À saída do tubo, uma armadilha contendo solução $0,1 \mathrm{~mol} \mathrm{~L}^{-1}$ de $\mathrm{HCl}$ (Figura 20-e) foi conectada para neutralizar o excesso de base.

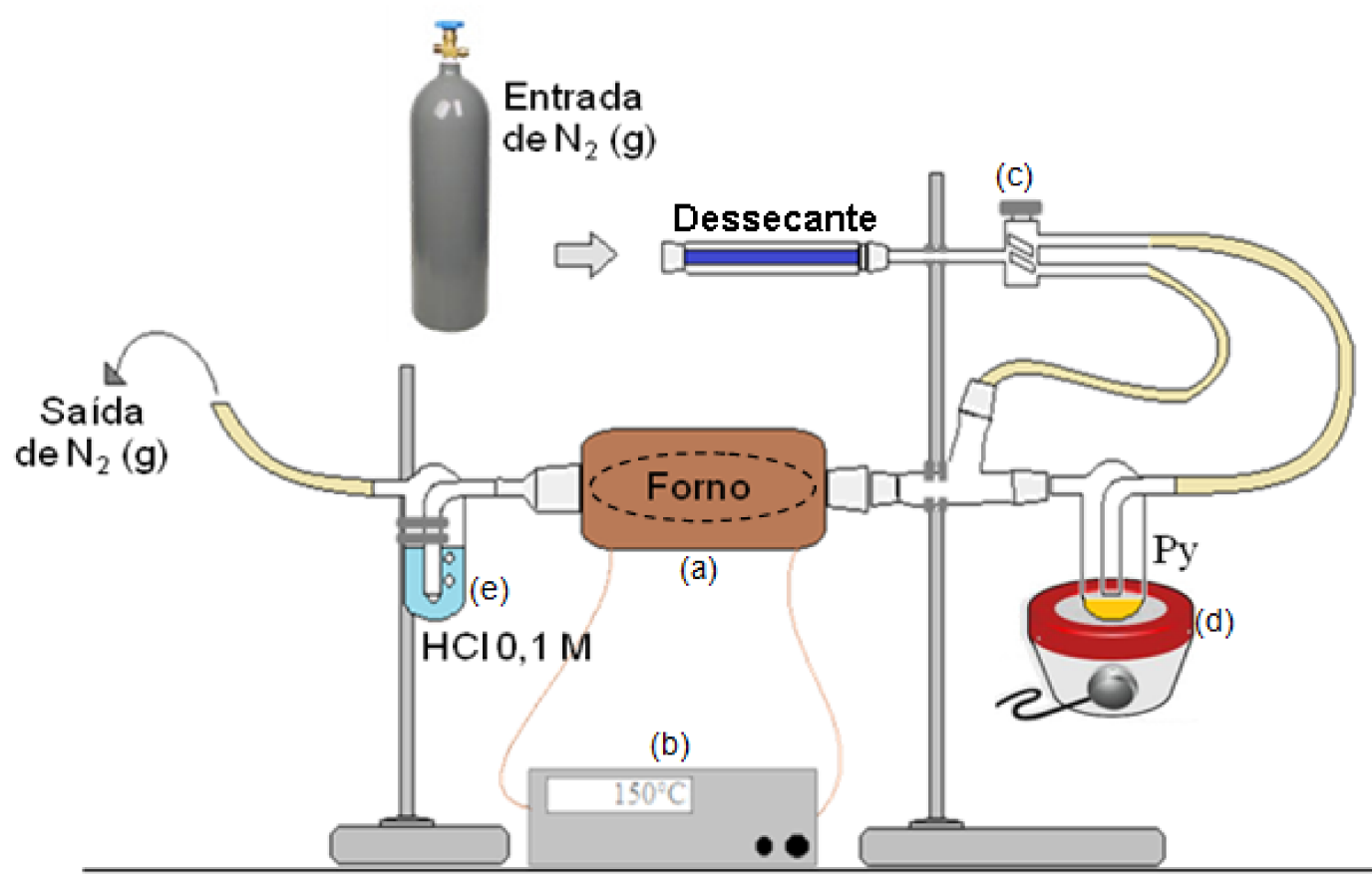

Figura 20: Representação esquemática para o sistema de adsorção gasosa simultânea desenvolvido no Laboratório de Catálise. (a) representa o tubo de vidro envolto em manta de aquecimento onde estão as amostras; (b) representa o controlador de temperatura ligado a um gerador do tipo Variac; (c) ilustra a torneira que direciona a passagem de $\mathrm{N}_{2}$ ou diretamente pela amostra ou para o reservatório de piridina; (d) mostra o reservatório de piridina líquida levemente aquecido $\left(\sim 50{ }^{\circ} \mathrm{C}\right)$; e (e) ilustra a armadilha de $\mathrm{HCl} 0,1 \mathrm{~mol} \mathrm{~L}^{-1} \cdot 18,32,37$

Sucintamente, a metodologia experimental consistiu no seguinte procedimento:

- as amostras foram primeiramente desidratadas a $300{ }^{\circ} \mathrm{C}$ sob fluxo de $\mathrm{N}_{2}$ $\left(100 \mathrm{~mL} \mathrm{~min}^{-1}\right)$ por $1 \mathrm{~h}$; 
- depois, resfriou-se o sistema para $150{ }^{\circ} \mathrm{C}$ com contínua passagem do $\mathrm{N}_{2}$ pelas amostras;

- atingida a temperatura de $150{ }^{\circ} \mathrm{C}$, a torneira de vidro das conexões foi aberta para alterar o caminho do $\mathrm{N}_{2}$ anidro, de forma a fazê-lo passar pelo reservatório de Py líquida por mais $1 \mathrm{~h}$;

- após $1 \mathrm{~h}$ de adsorção, a torneira que direcionou o $\mathrm{N}_{2}$ para o reservatório de Py foi fechada e o fluxo de gás passou outra vez diretamente pelas amostras, na temperatura de $150{ }^{\circ} \mathrm{C}$, durante $1 \mathrm{~h}$, para remoção de piridina fisicamente adsorvida;

- o sistema, ainda com fluxo de $\mathrm{N}_{2}$, foi resfriado até temperatura ambiente;

- fechou-se o cilindro de $\mathrm{N}_{2}$ e as amostras foram retiradas então do forno tubular para serem analisadas por TG, FT-IR e CHN.

\subsubsection{Difração de Raios $X(D R X)$}

Na técnica de DRX, são gerados padrões de difração (difratogramas) únicos para cada tipo de cristal, possibilitando, com isso, descobrir a composição dos materiais. Nesse trabalho, difratogramas foram obtidos para as amostras de HPW, celulose e de heteropolissais calcinados a fim de se verificar a manutenção da cristalinidade dos materiais preparados, bem como identificar picos indicativos de variações estruturais. Para tanto, um difratômetro de pó da Bruker, modelo D8 Focus, com radiação CuKa = 1,5406 Å a $40 \mathrm{kV}$ e $30 \mathrm{~mA}$, foi utilizado. A varredura foi feita a $1^{\circ} \mathrm{min}^{-1}$ e os valores de $2 \theta$ foram analisados na região de 2 a $70^{\circ}$ por meio dos programas Origin $^{\circledR} \mathrm{e}$ MatLab ${ }^{\circledR}$.

\subsubsection{Infravermelho (FT- IR)}

A técnica de espectroscopia no infravermelho com transformada de Fourier (FT-IR) foi utilizada para caracterização dos heteropolissais, do HPW padrão e da celulose, por meio de análises qualitativas que visaram à identificação das bandas referentes ao ânion de Keggin. $\mathrm{Na}$ região de vibrações estruturais $\left(1300-300 \mathrm{~cm}^{-1}\right)$, modificações ligadas à estrutura dos 
sólidos e, portanto, à sua cristalinidade podem ser detectadas, permitindo a identificação e a comparação dos catalisadores desenvolvidos.

Os espectros foram obtidos por meio de um espectrômetro da Thermo Scientific (Modelo Nicolet 6700). Para as análises estruturais, as aquisições foram feitas em temperatura ambiente, com 128 varreduras, numa resolução de $2 \mathrm{~cm}^{-1}$. Já para as análises após adsorção de Py, os espectros foram gerados com resolução de $8 \mathrm{~cm}^{-1}$, também com 128 varreduras e em temperatura ambiente. A modificação de resolução foi feita procurando amenizar os ruídos existentes na banda de interesse, correspondente à vibração do grupo $\mathrm{N}-\mathrm{H}$ do íon piridínio. Todos os materiais preparados foram diluídos em $\mathrm{KBr}$ seco, na proporção de $1 \mathrm{mg}$ do catalisador para $150 \mathrm{mg}$ de $\mathrm{KBr}$ e, em seguida, foram pastilhados para posterior análise no equipamento. Os espectros foram plotados e analisados nos programas OPUS ${ }^{\circledR}$ e Matlab $^{\circledR}$.

\subsubsection{Fluorescência de Raios $X(F R X)$}

A Fluorescência de Raios $X$ por Energia Dispersiva (FRX/EDX) é uma técnica espectroscópica não destrutiva que detecta uma série de elementos químicos por meio dos comprimentos de ondas discretos (linhas espectrais) gerados pelas radiações fluorescentes específicas de cada um desses elementos. O espectrômetro de FRX/EDX utilizado foi o da Shimadzu, modelo EDX-720, que analisa a faixa de elementos que vai do sódio $\left({ }_{11} \mathrm{Na}\right)$ ao urânio $\left({ }_{92} \mathrm{U}\right)$, com tubo de raios $\mathrm{X}$ com alvo de ródio (Rh). Dessa forma, o equipamento detecta linhas de energia $K \alpha, K \beta, L \alpha$ e $L \beta$ de cada elemento presente nas amostras que esteja na faixa Na-U. Essa técnica serviu para determinar, qualitativamente e quantitativamente, os elementos presentes nas amostras dos heteropolissais sintetizados e suas proporções estequiométricas. Para o cálculo estequiométrico, os sais de HPW foram previamente calcinados até $1000{ }^{\circ} \mathrm{C}$, buscando, com isso, transformar todos os metais existentes na estrutura em sua forma de óxido simples. Dessa maneira, foi possível determinar mais precisamente a composição das amostras.

Para gerar os espectros, os catalisadores de HPAs foram colocados em recipientes plásticos cobertos com filme de polipropileno (PP), mas não totalmente lacrados, para que o vácuo pudesse ser feito em seu interior. Além 
disso, foi utilizado um método Quali-Quanti, com tempo de detecção de $100 \mathrm{~s}$. Como a emissão da radiação característica dos elementos da amostra ocorre em todas as direções, torna-se necessário transformá-la em um feixe paralelo, sendo utilizado, para tanto, um colimador de $5 \mathrm{~mm}$, proporcional ao diâmetro do porta-amostra empregado. A análise das linhas de energia foi realizada pelo programa EDX software.

\subsubsection{Análise Elementar de Carbono, Hidrogênio e Nitrogênio (CHN)}

Análises elementares de carbono, hidrogênio e nitrogênio foram feitas por meio do uso de um analisador CHNS da Perkin Elmer (série II, modelo 2400). O equipamento foi ajustado para análise simultânea de carbono, hidrogênio e nitrogênio utilizando acetanilida como padrão. Em cadinhos de estanho maleáveis, aproximadamente $3,0 \mathrm{mg}$ dos sólidos foram pesados.

Essa técnica permitiu determinar a quantidade de carbono total advinda dos resíduos de celulose nas amostras de heteropolissais, bem como da formação de coque nos catalisadores após estes terem sido submetidos aos testes catalíticos. Também foi possível mensurar a quantidade total de Py adsorvida (fisicamente e quimicamente) nos testes de acidez a partir da determinação de nitrogênio nos materiais.

\subsubsection{Análise Térmica (TG/DTG/DTA)}

A técnica de TG mede a perda de massa de uma amostra ao longo de seu aquecimento gradativo até altas temperaturas. $O$ equipamento possui uma balança de alta precisão e um sistema de passagem de gás, conhecido como gás de purga, que pode interagir ou não com a amostra, a depender do que se deseja analisar. Assim, como a temperatura é programada para variar ao longo do tempo, a balança também fornecerá dados de massa ao longo do tempo, tornando possível medir quantitativamente cada decaimento apresentado pelo material. Não raro, essa perda pode ocorrer de maneira bastante sutil, dificultando a análise. Para facilitar, a quantificação das perdas de massa 
registradas foi feita por meio da derivada da curva termogravimétrica (DTG, do inglês Differential Termogravimetry).

Nesse trabalho, curvas termogravimétricas TG/DTG/DTA foram geradas em um 2960 Simultaneous DSC-TGA da TA Instruments. Os experimentos foram realizados aquecendo-se os sólidos até $1000{ }^{\circ} \mathrm{C}\left(10^{\circ} \mathrm{C} \mathrm{min}{ }^{-1}\right) \mathrm{em}$ atmosfera de ar sintético com fluxo de $100 \mathrm{~mL} \mathrm{~min}^{-1}$. Alfa-Alumina $\left(\alpha-\mathrm{Al}_{2} \mathrm{O}_{3}\right)$ foi utilizada como referência para todas as análises. Por meio das curvas TG/DTG/DTA, informações quantitativas sobre as amostras, como perda de água fisicamente e quimicamente adsorvida, desidroxilações e estabilidade térmica puderam ser geradas e analisadas, utilizando-se, para isso, o programa Universal Analysis 2000.

Também foram feitas análises de TG para as amostras adsorvidas com Py, o que possibilitou a determinação da quantidade de base adsorvida e, consequentemente, do número total de sítios ácidos no material em estudo. Nesse caso, entretanto, um ambiente oxidativo pode influenciar nas transições termodinâmicas oriundas da interação da Py com o sólido e, portanto, a atmosfera foi alterada para inerte, com fluxo de $\mathrm{N}_{2}$ também a $100 \mathrm{~mL} \mathrm{~min}^{-1}$. Para o cálculo do número de sítios ácidos, a Equação 4 foi utilizada, a qual emprega uma amostra padrão, que não foi submetida à adsorção de Py, para se calcular a quantidade real de sítios ácidos do material, eliminando, com isso, possiveis interferências que possam existir nessa amostra padrão. A Equação 4 foi deduzida seguindo as quatro etapas detalhadas a seguir:

(i) a partir da massa total de amostra pesada para análise no equipamento de TG ( $\left.m_{\text {total }}\right)$, subtraiu-se a massa correspondente a espécies fisicamente adsorvidas (massa dessorvida até $\left.300{ }^{\circ} \mathrm{C}\right)$, como a água e/ou a própria Py fisicamente ligada $\left(m_{300}\right)$, resultando, então, em apenas massa de catalisador anidro:

$$
\left(m_{\text {anidra }}\right) \rightarrow m_{\text {total }}-m_{300}=m_{\text {anidra }}
$$

(Equação 4a)

(ii) a quantidade de massa perdida entre 300 e $1000{ }^{\circ} \mathrm{C}\left(m_{1000}\right)$ correspondeu, para os sólidos não adsorvidos, à massa de degradação do material e, para as amostras geradas após 
adsorção gasosa de Py, correspondeu também à base quimicamente adsorvida Esses valores foram obtidos pelo software do equipamento e foram normalizados para um grama:

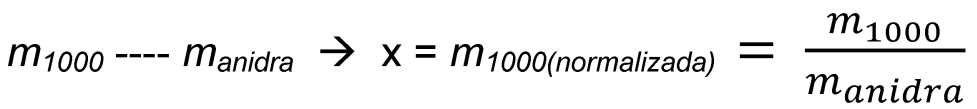

$$
\begin{aligned}
& x \text {---- } 1 \mathrm{~g}
\end{aligned}
$$

Feitos esses cálculos para as amostras antes e depois do experimento de adsorção, seguiu-se para a determinação do número de sítios ácidos no material da seguinte maneira:

(iii) o valor normalizado da amostra com Py adsorvida foi subtraído do valor normalizado da amostra sem Py, obtendo-se, assim, a massa real de base adsorvida no sólido $\left(m_{\text {realPy }}\right)$;

(iv) esse valor foi convertido para número de sítios ácidos, em mmol:

$$
n_{\text {sítios ácidos }}=\frac{m_{\text {real } P y}}{M M_{P y}} \times 1000
$$

(Equação 4b)

Dessa forma, chegou-se à seguinte equação global:

$n_{P y}(m m o l)=\frac{\overbrace{\left(m_{1000} /\left(m_{\text {total }}-m_{300}\right)\right.}^{\text {Amostra_com_ } P_{y}}-\overbrace{\left(m_{1000} /\left(m_{\text {total }}-m_{300}\right)\right)}^{\text {Amostra_sem_Py }}}{M P_{P y}} x 1000$

(Equação 4c)

\subsubsection{Análise Textural: área superficial e porosimetria $\left(A S A P^{\circledR}\right)$}

A análise textural fornece informações importantes sobre a morfologia dos materiais, gerando dados de volume e diâmetro de poro (análise de porosimetria), de área superficial externa e área de micro e mesoporos. Dessa forma, o equipamento ASAP ${ }^{\circledR} 2020$ (Accelerated Surface Area and Porosimetry System) da Micrometrics foi utilizado, o qual se baseia na adsorção física de nitrogênio pela amostra. As medidas são 
realizadas à $77 \mathrm{~K}\left(-196^{\circ} \mathrm{C}\right)$, temperatura do $\mathrm{N}_{2}$ líquido, a fim de se obter valores detectáveis de adsorção. Com isso, isotermas de adsorção, que relacionam o volume de gás adsorvido em função da pressão relativa ( $\left.p_{\text {equilibrio }} / p_{\text {inicial }}\right)$, são geradas de acordo com o grau de interação entre o adsorvente e o adsorbato.

Para proceder com os cálculos de porosimetria e área superficial a partir das isotermas, o aparelho faz uso de equações matemáticas, como aquelas dos métodos BET (ou teoria da adsorção multimolecular, desenvolvido por Brunauer, Emmet e Teller), t-plot, BJH (desenvolvido por Barrett, Joyner e Halenda) e MP-Method. Antes de serem analisados, os sólidos $(\sim 0,5 \mathrm{~g})$ foram pré-tratados a $300{ }^{\circ} \mathrm{C}$ durante $4 \mathrm{~h}$ com vácuo (pressão alvo de $10 \mu \mathrm{mHg}$ ).

\subsubsection{Técnicas de Microscopia Eletrônica}

A microscopia eletrônica é uma importante ferramenta no desenvolvimento de novos materiais, pois permite, a partir das imagens fornecidas pelos equipamentos, entender melhor sua estrutura e, até mesmo, prever propriedades.

Tabela 3: Algumas dimensões médias aproximadas importantes em análise microestrutural. $^{131}$

\begin{tabular}{c|c|c}
\hline Tamanho (A) & Descrição & Microscopia* $^{*}$ \\
\hline $1-5$ & Distâncias interatômicas & MT/MFA/MET \\
\hline $1-5$ & Defeitos puntiformes (lacunas) & MT/MFA/MET \\
\hline $2-10$ & $\begin{array}{c}\text { Espessura de contornos de grão, interfaces } \\
\text { e falhas/defeitos de empilhamento }\end{array}$ & MT/MFA/MET \\
\hline$>5$ & Defeitos cristalinos & MT/MFA/MET/MEV \\
\hline$>10$ & Diâmetro de fases & MET/MEV \\
\hline$>30$ & $\begin{array}{c}\text { Espaçamento entre falhas de empilhamento } \\
\text { (fissuras) e espaçamento de partículas }\end{array}$ & MET/MEV \\
\hline 1000 & $\begin{array}{c}\text { Diâmetro de subgrão e de grão, de } \\
\text { agregados e determinação de morfologia }\end{array}$ & MEV/MO
\end{tabular}

*Técnica com requisitos mínimos para análise nos tamanhos especificados: MT - Microscopia de Tunelamento; MFA - Microscopia de Força Atômica; MET - Microscopia Eletrônica de Transmissão; MEV - Microscopia Eletrônica de Varredura; MO - Microscopia Óptica. 
Uma caracterização microestrutural é capaz de fornecer dados de cristalinidade, como ordenamento estrutural, orientação de fases, interfaces, contornos e tamanho de grãos, quantidade (densidade) e distribuição de defeitos, porosidade, etc., e, ainda, dados de composição, com a utilização conjunta de um acessório de FRX/EDX. ${ }^{131,132}$ Somado a isso, a microscopia eletrônica, de varredura e transmissão, pode ser trabalhada dentro de uma ampla faixa de dimensões, como pode ser visto na Tabela 3.

\subsubsection{Microscopia Eletrônica de Varredura (MEV)}

$\mathrm{Na}$ técnica de MEV, a geração de imagem é feito a partir de modificações que ocorrem nos sinais gerados por um feixe de elétrons primários. Estes, à medida que varrem a amostra, produzem feixes de elétrons secundários e retroespalhados, a depender do grau de interação com os átomos desta. Os elétrons secundários são gerados a partir de interações em regiões de pouca profundidade e são emitidos pelo material com uma energia média inferior a $50 \mathrm{eV}$. Os elétrons retroespalhados, ao contrário, são produzidos em regiões mais profundas da amostra e também têm energia suficiente (superior a $50 \mathrm{eV}$ ) para originar elétrons secundários quando retornam à superfície do material. Assim, utilizando um sistema de lentes magnéticas, os elétrons secundários são capazes de fornecer imagens de topografia da superfície da amostra em alta resolução e, os retroespalhados, imagens características de variação de composição. O aumento máximo conseguido pelo MEV é da ordem 20 a $50 \AA$, existindo equipamentos com alcance de até $5 \AA$, com aproximações médias entre 10 e $50.000 x^{132,133}$

Nesse trabalho, um microscópio eletrônico de varredura da JEOL, modelo JSM-7001F, foi utilizado. Os sólidos foram previamente depositados em fita de carbono e metalizados com ouro ou platina para melhor condução de elétrons pela amostra (equipamento Sputter Coater, modelo Leica - SCD 5500). As análises foram feitas em alto vácuo em diferentes níveis de aproximação. 


\subsubsection{Microscopia Eletrônica de Transmissão (MET)}

Assim como no caso do MEV, a MET também se baseia em um conjunto de lentes eletromagnéticas que trabalham para permitir a deteç̧ão de feixes difratados. Entretanto, a técnica de MET permite aproximações médias entre 1.000 e $300.000 \mathrm{x}$, podendo chegar a aumentos acima de $1.000 .000 \mathrm{x}$, com resolução de $3 \AA$. A imagem observada é a projeção média de determinada espessura do material, ocorrendo projeções de linhas, áreas e volumes de interesse. Portanto, o sólido deve ser fino, da ordem de micrômetros ou menos, e, se ele não estiver suficientemente disperso, poderá ocorrer uma superposição dessas projeções, impossibilitando a obtenção de uma imagem nítida. Dessa forma, ao ser preparada, a amostra necessita ser dispersa em um solvente, o qual deve ser evaporado na cela de análise, restando apenas o material seco com partículas bem separadas. O equipamento também gera padrões de difração que contêm informações da estrutura cristalina, como a repetibilidade das distâncias na rede e sua forma. ${ }^{131}$

Nesse trabalho, utilizou-se um microscópio eletrônico de transmissão da JEOL, modelo 1011, obtendo-se imagens com diferentes aproximações em alto vácuo. Uma massa de $1,5 \mathrm{mg}$ da amostra foi dispersa em $50 \mathrm{~mL}$ de solução etanol:água (1:1), o que possibilitou a secagem rápida do material, e gotas da dispersão foram distribuídas em pequenas telas de cobre (vide Figura 21) para posterior secagem e análise.

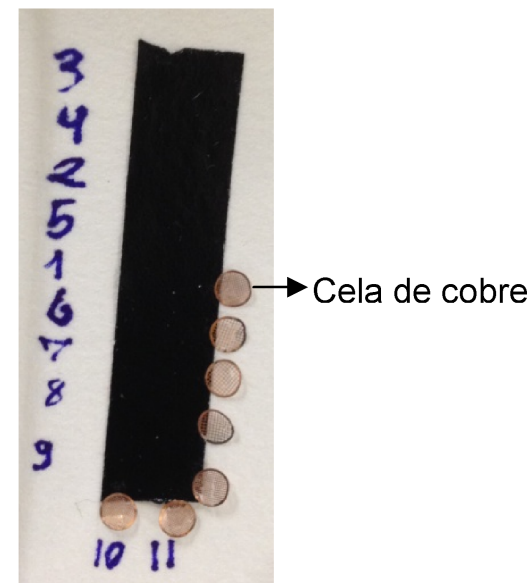

Figura 21: Imagem das celas de cobre (presas a uma fita de carbono) utilizadas nas análises de MET. 


\subsection{Análises de Atividade Catalítica}

Os catalisadores foram submetidos a ensaios catalíticos em reações de desidratação de alcoóis, as quais possibilitaram estimar a atividade catalítica e a resistência à desativação dos sólidos sintetizados. Os sais de HPAs foram ainda empregados na reação de esterificação do álcool benzílico $(\mathrm{BzOH})$ e na oxidação do $\mathrm{BzOH}$ em fase líquida, buscando ampliar as possíveis aplicações desses materiais e estudar seu comportamento (conversão, seletividade, desativação, etc.) frente a diferentes condições reacionais, assim como feito em trabalhos anteriores para os catalisadores zeolíticos desaluminizados. ${ }^{18}$

\subsubsection{Desidratação de Alcoóis C2-C4}

Os testes catalíticos de desidratação dos alcoóis foram feitos de duas maneiras. Em um primeiro momento, estudou-se a atividade e desativação do catalisador zeolítico em um reator tubular de leito fixo com fluxo contínuo frente à desidratação do álcool etílico pró-análise (PA, pureza $\geq 99,8 \%$ ) e de uma amostra de bioetanol comercial (teor alcoólico $=93,02 \%(\mathrm{~m} / \mathrm{m})$ ), vendido em postos de gasolina do Distrito Federal. Posteriormente, foram feitas análises de conversão e seletividade utilizando a zeólita $Y$ desaluminizada na desidratação de diferentes alcoóis, bem como na desidratação de soluções de etanol de diferentes concentrações. Como essas últimas observações foram feitas a título de comparação, as reações foram estudadas em um microrreator de pulso desenvolvido no Laboratório de Catálise da Universidade de Brasília, o que garantiu a obtenção de resultados mais rápidos, mas com grande eficiência e repetibilidade.

\subsubsection{Reator Tubular de Leito Fixo com Fluxo Contínuo}

Reatores tubulares de leito fixo são bastante empregados em diversas reações industriais. Nos experimentos realizados, um modelo do fabricante Parr foi utilizado, o qual contém um tubo de quartzo conectado ao sistema de injeção de reagentes e está inserido em um forno que mantém a temperatura interna constante. Nesse tubo foi montado o leito fixo de catalisador, como será descrito a seguir. 


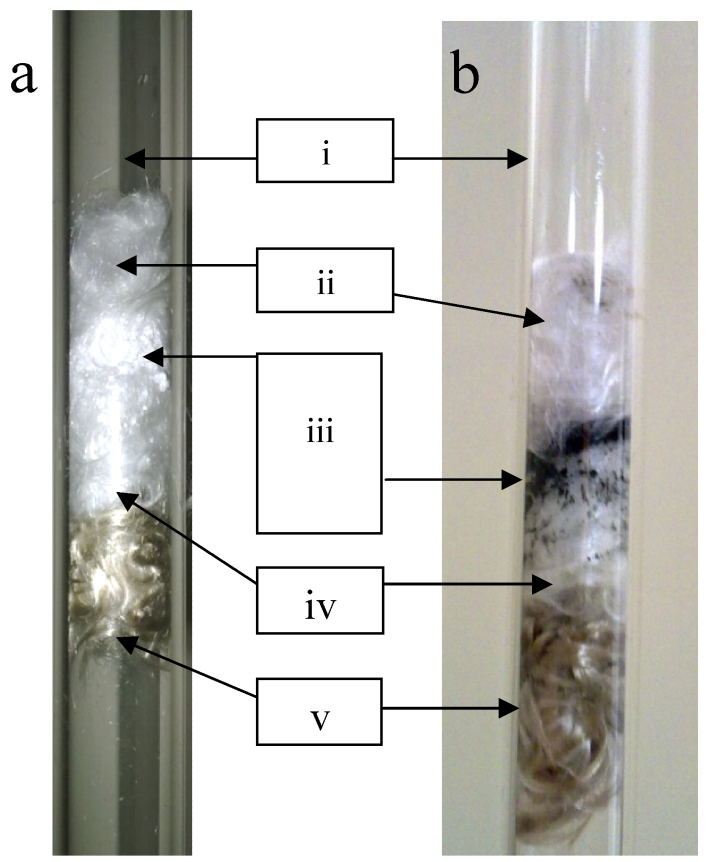

Figura 22: Montagem do leito fixo no tubo de quartzo (i) do reator Parr antes (a) e depois (b) da reação: porção de lã de vidro (ii), zeólita (iii), segunda porção de lã de vidro (iv) e manta (v) para evitar o escape do sólido. Após a reação, verifica-se a formação de coque devido à mudança de coloração do catalisador sólido.

Apenas $0,1 \mathrm{~g}$ do sólido (correspondente a $0,3 \mathrm{~cm}$ de espessura no tubo) foram colocadas em um tubo de quartzo (comprimento $=42 \mathrm{~cm}$ e diâmetro $=$ $0,7 \mathrm{~cm}$ ) entre camadas de lã de vidro inerte e inserido no reator de leito fixo, como mostra a Figura 22. Para que o catalisador não fosse deslocado no tubo de quartzo, uma manta resistente ao aquecimento foi acoplada na saída deste.

- Reação de Desidratação do Etanol PA e do Bioetanol com Análise por Cromatografia Gasosa

Inicialmente, o catalisador foi seco a $300{ }^{\circ} \mathrm{C}$ durante $1 \mathrm{~h}$, utilizando-se um fluxo de gás nitrogênio de $50 \mathrm{~mL} \mathrm{~min}^{-1}$. Em seguida, acoplou-se ao reator uma bomba peristáltica, que funciona como uma bomba hidráulica, utilizando a energia mecânica para mover os fluidos num volume específico desejado. Para os experimentos de atividade catalítica e reuso dos sólidos, o fluxo de 0,03 mL de etanol por minuto foi preferido por fornecer melhores condições de análise. Entretanto, em outros testes, os catalisadores foram submetidos a uma 
variação crescente de fluxo, de 0,03 a $0,22 \mathrm{~mL} \mathrm{~min}^{-1}$, de forma a investigar a faixa, mínima e máxima, de conversão/seletividade para etileno e de WHSV.

Para monitorar a formação dos produtos, um cromatógrafo gasoso (CG-FID, modelo GC-2010 da Shimadzu com uma coluna RTX ${ }^{\circledR}$-WAX da Restek de $30 \mathrm{~m} \times 0,32 \mathrm{~mm} \times 0,50 \mu \mathrm{m}$ ) foi utilizado. A Figura 23 mostra o reator de leito fixo e o cromatógrafo acoplado utilizados na reação. Um método split (taxa $=100)$ foi desenvolvido no cromatógrafo para evitar a coeluição dos picos das substâncias geradas.

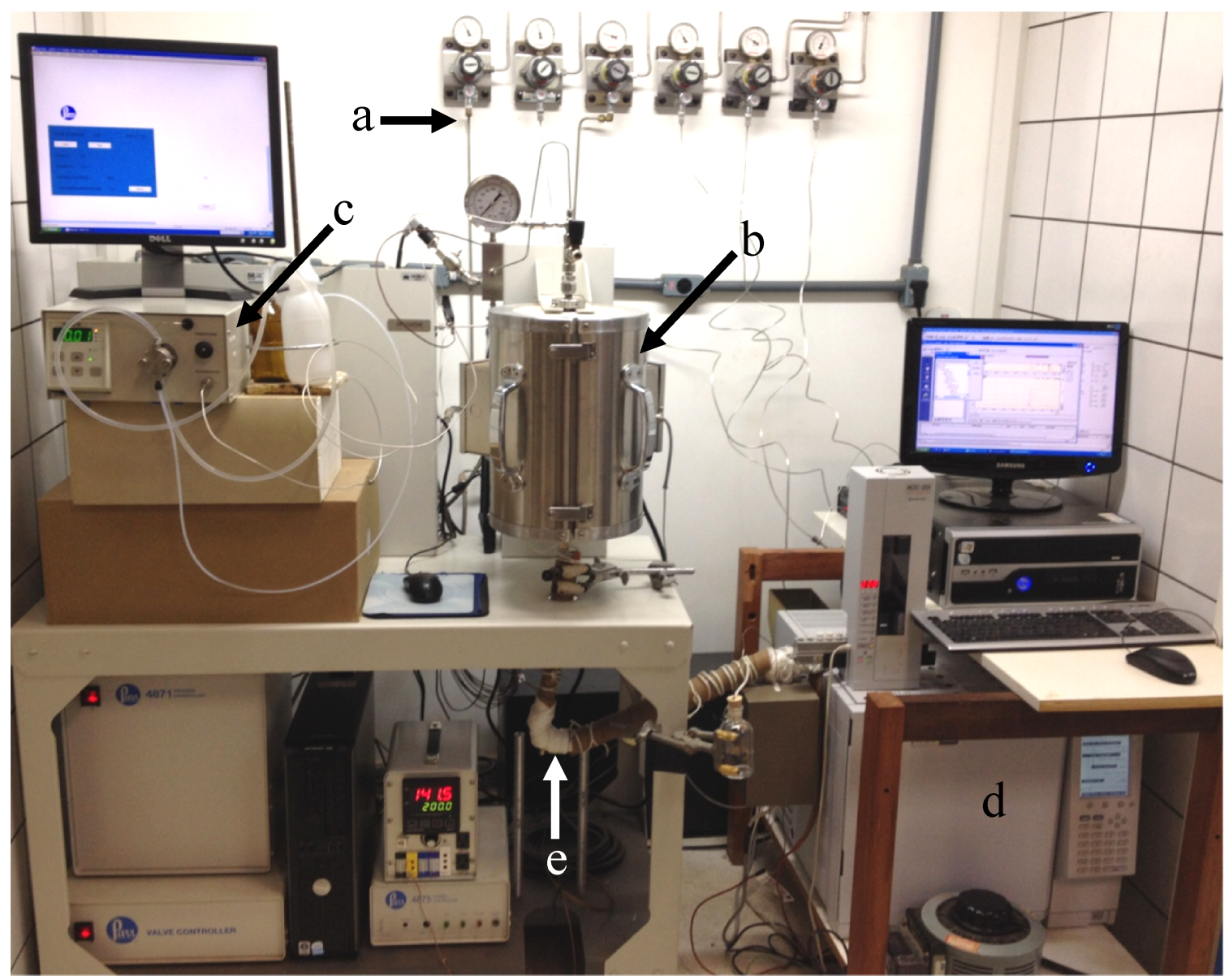

Figura 23: Equipamentos utilizados na produção de bioetileno, compreendendo: fluxo de gases (a); reator de leito fixo (b) acoplado a uma bomba peristáltica com injeção de álcool (c); e cromatógrafo gasoso (d) conectado ao reator por uma linha aquecida a $200^{\circ} \mathrm{C}(\mathrm{e})$.

A cada 5 min de passagem ininterrupta de etanol pelo catalisador, uma alíquota de $0,5 \mu \mathrm{L}$ dos produtos era diretamente injetada no $\mathrm{CG}$, gerando um cromatograma a partir de uma rampa de aquecimento da coluna cromatográfica de 40 até $80^{\circ} \mathrm{C}$. A temperatura do injetor e do detector por 
ionização de chama (FID) utilizada nesse método foi de $250^{\circ} \mathrm{C}$, com pressão do gás carreador Hélio $(\mathrm{He})$ igual a $146,1 \mathrm{kPa}$, fluxo total de $236,1 \mathrm{~mL} \mathrm{~min}^{-1} \mathrm{e}$ fluxo na coluna de $2,24 \mathrm{~mL} \mathrm{~min}^{-1}$. Padrões de etanol, etileno e dietil éter foram injetados para se descobrir os tempos de retenção de cada uma dessas substâncias na coluna cromatográfica, obtendo-se os tempos 1,87, 1,38 e 1,41 min, respectivamente. Outros produtos podem também ser formados, como acetaldeído ou alcanos, porém, nenhum pico adicional foi detectado nos cromatogramas obtidos nesse trabalho.

A desidratação do etanol PA e do bioetanol ocorreu a $300{ }^{\circ} \mathrm{C}$ sob fluxo constante de $\mathrm{N}_{2}$ nas mesmas condições da secagem do catalisador. A pressão do sistema foi a atmosférica, sendo detectada, em alguns casos, uma pressão interna de, no máximo, $172,4 \mathrm{kPa}$ (ou 1,7 atm). Buscando entender as modificações de conversão e seletividade em sistemas pressurizados, um teste de variação de pressão foi feito na desidratação do bioetanol.

Todas as reações foram feitas em duplicata, obtendo-se desempenhos semelhantes em ambos os casos. Os catalisadores testados foram a zeólita $Y$ pura calcinada, $Y$ (pura)C, que serviu como um padrão de comparação, e a zeólita $Y$ desaluminizada também calcinada, $Y(80) 5 \mathrm{C}$. A desativação do catalisador foi avaliada de acordo com a formação de subprodutos, ou seja, até que o catalisador deixasse de ser $100 \%$ seletivo e começasse a apresentar grandes quantidades de produtos indesejáveis, como o dietil éter, ou de excesso de etanol em porcentagens não mais vantajosas, superiores ou iguais a $50 \%$. Assim, a análise dos picos obtidos por CG foi feita pela integração de suas alturas correspondentes, a partir do software OPUS ${ }^{\circledR}$, gerando valores de integração referentes ao etanol (Int.EtOH) e aos produtos etileno (Int.Etileno) e dietil éter (Int.Éter). Desse modo, pôde-se calcular a porcentagem de conversão relativa $(R \%)$ de etanol em produtos a partir da Equação 5 e a seletividade relativa $\left(S_{\text {etileno\%}}\right)$ do catalisador para produzir etileno pela Equação 6.

$$
\begin{aligned}
& R \%=\frac{\text { Int .Éter }+ \text { Int .Etileno }}{\text { Int.Éter }+ \text { Int .Etileno }+ \text { Int .EtOH }} \times 100 \\
& S_{\text {etileno }} \%=\frac{\text { Int .Etileno }}{\text { Int .Éter }+ \text { Int .Etileno }} x 100
\end{aligned}
$$


Os catalisadores recolhidos nas duplicatas da reação serviram para que fossem feitas novas caracterizações de estrutura e de acidez, como DRX, FT-IR, CHN, adsorção de Py e TG, buscando, com isso, analisar as modificações apresentadas pelo material após o teste catalítico.

\section{- Recuperação e Reutilização do Catalisador}

Para que fosse possível reutilizar o catalisador zeolítico, este foi retirado do tubo de quartzo e submetido a uma reativação feita via tratamento térmico a $550{ }^{\circ} \mathrm{C}$ durante $8 \mathrm{~h}$ em mufla. A forma peletizada foi mantida mesmo após a calcinação. O sólido recuperado foi pesado e reutilizado na mesma reação de desidratação de etanol PA a partir de um novo empacotamento do leito fixo. Não foram feitos testes de reuso para os catalisadores testados na reação de desidratação do bioetanol.

\subsubsection{Microrreator de Pulso}

O microrreator de pulso [Borges, L. D.; Müller, J. M.; Macedo, J. L. de Ind. Eng. Chem. Res., a ser submetido, 2014] foi utilizado para testar os materiais de HPW na reação de desidratação do etanol PA e para comparar as atividades da zeólita $Y$ desaluminizada nas reações de desidratação do etanol PA e em soluções aquosas de diferentes concentrações (25, 50 e 75\%, v/v). A amostra $Y(80) 5 C$ também foi testada na desidratação de outros alcoóis próanálise, como o 1-propanol, o isopropanol e o terc-butanol.

A metodologia desenvolvida para o microrreator de pulso foi tema de estudo do presente trabalho e, portanto, faz parte dos resultados obtidos nessa pesquisa. Assim, a construção desse tipo de reator e as condições reacionais empregadas serão descritas no capítulo seguinte, de Resultados e Discussões.

\subsubsection{Esterificação do Álcool Benzílico}

Além da reação de desidratação do etanol, os sais de HPW e o HPW padrão também tiveram sua atividade catalítica mensurada por uma reação em estado líquido: a esterificação do álcool benzílico. Nesse caso, foi simulada 
uma reação em reator em batelada. Dessa maneira, todo o conteúdo do reator é misturado completamente e os constituintes da mistura são expostos a igual tempo de permanência no reator. Para isso, fez-se reagir $4,00 \mathrm{~g}$ de ácido acético ( $\mathrm{HAc})$ com $7,20 \mathrm{~g}$ de álcool benzílico $(\mathrm{BzOH})(1: 1, \mathrm{~mol} / \mathrm{mol})$, utilizando $10 \%$ de massa de catalisador $(\mathrm{m} / \mathrm{m})$, sem ativação prévia, em relação à massa do ácido, isto é, 0,40 g. Essa mistura ficou sob agitação em um balão de duas bocas, a $60{ }^{\circ} \mathrm{C}$, em um sistema de refluxo, durante $120 \mathrm{~min}$. A segunda boca do balão permitiu a retirada de alíquotas de $0,05 \mathrm{~mL}$ a cada $30 \mathrm{~min}$, por meio de uma seringa Hamilton de 1,00 mL, de forma a acompanhar o andamento da reação. As alíquotas foram diluídas em $1,0 \mathrm{~mL}$ de acetona em um vial para, em seguida, serem analisadas por CG.

Como se trata de uma reação reversível e que pode ser catalisada pelo próprio HAc, o mesmo procedimento reacional foi repetido sem utilizar um catalisador sólido. Assim, obteve-se o "branco" da reação. A formação do acetato de benzila foi verificada a partir dos dados de integração obtidos pelo software do próprio equipamento de CG (GC Solution) no tempo de retenção de 5,11 min, de acordo com o padrão injetado previamente no cromatógrafo. Para tanto, um método de análise foi desenvolvido no CG (CG-FID, modelo GC-17A da Shimadzu com uma coluna RTX ${ }^{\circledR}$-WAX da Restek de $30 \mathrm{~m} \times 0,32$ $\mathrm{mm} \times 0,50 \mu \mathrm{m})$, com taxa split igual a 40 , aquecimento da coluna cromatográfica de $50^{\circ} \mathrm{C}$ a $250^{\circ} \mathrm{C}$, utilizando gás de araste $\mathrm{He}(145 \mathrm{kPa})$ com fluxo total igual a $238 \mathrm{~mL} \mathrm{~min}^{-1}$ e fluxo na coluna de $5,69 \mathrm{~mL} \mathrm{~min}{ }^{-1}$. O injetor e o detector permaneceram a $250^{\circ} \mathrm{C}$. Os cálculos de conversão relativa $(R \%)$ para o éster foram feitos de acordo com a Equação 7, a partir da integração da altura dos picos referentes ao éster e da quantidade de $\mathrm{BzOH}$ não reagida, detectada no tempo de 5,69 min.

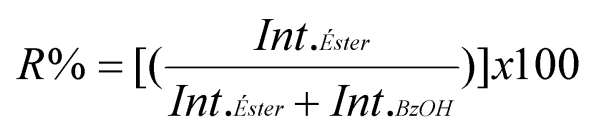

As conversões obtidas foram transformadas em atividade catalítica, usando, para isso, a medida de rotação do catalisador (Turnover Frequency TOF), dada pela quantidade de matéria (mol) formada do produto desejado por hora, por mol de catalisador (moléster $\mathrm{h}^{-1} \mathrm{~mol}^{-1}$ cat). A quantidade de matéria de 
catalisador empregada nas reações $\left(\mathrm{mol}_{\mathrm{cat}}\right)$ foi medida a partir dos valores de número de sítios ácidos $(\mathrm{mmol} / \mathrm{g})$, obtidos pelo TG dos catalisadores adsorvidos com Py, e da massa pesada do material (g) para cada ciclo reacional.

\subsubsection{Oxidação do Álcool Benzílico}

Além de serem reportados como catalisadores ácidos, os materiais de HPW também são conhecidos por suas propriedades oxirredutoras, advindas do alto estado de oxidação do tungstênio, capaz de se reduzir, capturando elétrons em reações REDOX, e de se reoxidar na presença de oxidantes, como $\mathrm{H}_{2} \mathrm{O}_{2}$ e $\mathrm{O}_{2}$, ou mesmo de íons metálicos. ${ }^{8,134-136}$ Por possuírem mobilidade estrutural, essa reversibilidade eletrônica se torna possível e ainda mantém a estrutura do catalisador preservada. ${ }^{135,136}$ Pensando nisso, os sais de HPW sintetizados foram testados na reação de oxidação do álcool benzílico, na presença e ausência do solvente acetonitrila.

Para as reações realizadas sem solvente, $2,00 \mathrm{~g}$ de $\mathrm{BzOH}$ (19 mmol) foi pesado em um balão de 2 bocas, o qual foi imerso em banho de óleo a $60{ }^{\circ} \mathrm{C}$, com agitação moderada. Temperaturas superiores a $60^{\circ} \mathrm{C}$ já foram reportadas por decomporem o peróxido de hidrogênio, inviabilizando a reação de oxidação. ${ }^{137}$ Ao balão, foi adicionada uma massa de catalisador de $0,10 \mathrm{~g}$, sem ativação prévia, correspondente a $5 \%(\mathrm{~m} / \mathrm{m})$ em relação ao álcool. O oxidante utilizado na reação foi o peróxido de hidrogênio $\left(\mathrm{H}_{2} \mathrm{O}_{2}\right)$, na proporção $1: 1$ (mol/mol) também em relação ao álcool. Assim, 2,10 g de $\mathrm{H}_{2} \mathrm{O}_{2}$ foram adicionados à mistura reacional, que permaneceu sob agitação por $2 \mathrm{~h}$. Alíquotas de $0,05 \mathrm{~mL}$ foram coletadas a cada 30 min por meio de uma seringa Hamilton $(1,00 \mathrm{~mL})$ e diluídas em $1,0 \mathrm{~mL}$ de acetona em um vial para, em seguida, serem analisadas por CG. Os dois catalisadores que apresentaram melhor conversão para a produção de benzaldeído $(\mathrm{BzH})$ foram testados na mesma reação por $6 \mathrm{~h}$. Além disso, o "branco" da reação foi feito, repetindo-se a reação na ausência de catalisador.

A oxidação do álcool benzílico também foi feita na presença de solvente, buscando, com isso, otimizar o contato entre os reagentes e, ainda, facilitar a retirada das alíquotas do meio reacional, já que a reação produz uma mistura 
de duas fases: uma fase orgânica, contendo o benzaldeído, e outra mais polar, com água em sua composição. Nesse caso, o mesmo procedimento supracitado foi utilizado, acrescentando-se $10,0 \mathrm{~mL}$ de acetonitrila ao balão. As alíquotas de $0,05 \mathrm{~mL}$ foram diluídas em $1,0 \mathrm{~mL}$ de acetonitrila para análise no cromatógrafo gasoso.

Os cálculos de conversão e de seletividade foram feitos de acordo com as Equações 8 e 9, respectivamente, a partir dos valores de integração obtidos pelo software do próprio equipamento de CG (GC Solution). O tempo de retenção detectado para o $\mathrm{BzH}$ foi 4,2 min e, para $\circ \mathrm{BzOH}$, foi 5,7 min, de acordo com padrões injetados previamente no cromatógrafo. Na literatura, é possível encontrar relatos de formação de subprodutos, como o ácido benzoico. ${ }^{138}$ Entretanto, em nenhum caso foi evidenciado o pico referente a esse produto, que possui tempo de retenção de 1,6 min no método de análise pré-estabelecido (igual àquele utilizado para a reação de esterificação).

$$
\begin{aligned}
& R \%=\left[\left(\frac{\text { Int }_{. B z H}+\text { Int }_{\text {.Subprodutos }}}{\text { Int }_{\text {BzH }}+\text { Int }_{\text {Subprodutos }}+\text { Int }_{\text {BzOH }}}\right)\right] x 100 \\
& S_{B z H} \%=\left[\left(\frac{\text { Int }_{. B z H}}{\text { Int. } . B z H+\text { Int.Subprodutos }}\right)\right] x 100
\end{aligned}
$$


Resultados \& Discussões 


\section{RESULTADOS E DISCUSSÕES}

\subsection{Zeólitas}

O conhecido uso da zeólita $Y$ no craqueamento catalítico do petróleo, especialmente da USY, ${ }^{139}$ amplia a possibilidade de emprego de sua versão desaluminizada na indústria, já que, além de ser economicamente viável, ela pode ser utilizada no coprocessamento de alcoóis e de hidrocarbonetos sem a necessidade de grandes modificações da planta e do processo industrial. Trabalhos prévios ${ }^{18}$ mostraram que a zeólita $Y 5 \%(\mathrm{~mol} / \mathrm{mol})$ desaluminizada com $\left(\mathrm{NH}_{4}\right)_{2} \mathrm{SiF}_{6}$ no estado sólido a $80{ }^{\circ} \mathrm{C}$ durante $2 \mathrm{~h}, \mathrm{Y}(80) 5 \mathrm{C}$, manteve sua integridade estrutural, comprovada por meio das técnicas de DRX, que indicou uma cristalinidade de mais de $98 \%$ em relação à zeólita de partida, e de FT-IR, que evidenciou a conservação da banda entre 570 e $600 \mathrm{~cm}^{-1}$, referente à vibração dos anéis duplos da $\mathrm{Y}$. Um aumento da razão Si/Al da amostra desaluminizada também foi constatado por DRX, sendo igual a 3,8 , enquanto que, para a zeólita Y comercial, o valor calculado foi de 2,7.

Já o espectro de ressonância magnética nuclear (RMN) de ${ }^{27} \mathrm{Al}$ do material $\mathrm{Y}(80) 5 \mathrm{C}$ mostrou, além da banda relacionada aos alumínios tetraédricos da estrutura zeolítica, um segundo ambiente correspondente à existência de espécies octaédricas, fora da rede da zeólita, com $23 \%$ de intensidade relativa. ${ }^{18}$ Esse fato foi relacionado como uma das causas da alta acidez encontrada para o catalisador $\mathrm{Y}(80) 5 \mathrm{C}$. Espécies EFAl, como o cátion $\left[\mathrm{Al}\left(\mathrm{H}_{2} \mathrm{O}\right)_{6}\right]^{3+}$, foram reportadas na literatura por influenciar ambientes de $\mathrm{Al}$ tetraédrico, pois possuem um forte efeito polarizante capaz de desestabilizar grupos hidroxilas, tornando o hidrogênio mais ácido. ${ }^{18,140}$

\subsubsection{Análise Textural}

A zeólita $\mathrm{Y}$ comercial calcinada, $\mathrm{Y}$ (pura)C, e a amostra desaluminizada e calcinada, $Y(80) 5 C$, foram submetidas a análises texturais, feitas via adsorção de nitrogênio e por meio de micrografias obtidas por MEV.

Dados de área superficial, área de microporos e mesoporos, bem como tamanho de poro são mostrados na Tabela 4. Como pode ser observado, o 
processo de desaluminização favoreceu um aumento da área superficial total do sólido quando comparado com a zeólita $Y$ de partida. Esse resultado pode estar relacionado à formação de mesoporos, evidenciado pelo aumento da área superficial externa e pela diminuição da área de microporos. Além disso, a área superficial cumulativa de poros entre 1,7 e 300,0 nm, aferida pelo método $\mathrm{BJH}$, aumentou $43 \mathrm{~m}^{2} \mathrm{~g}^{-1}$ após a desaluminização. O tamanho de poro dos microporos praticamente não variou, sendo obtidos os valores de 1,98 nm para a $\mathrm{Y}$ (pura)C e 2,01 $\mathrm{nm}$ para a $\mathrm{Y}(80) 5 \mathrm{C}$, e seu volume permaneceu inalterado, igual a $0,27 \mathrm{~cm}^{3} \mathrm{~g}^{-1}$.

Tabela 4: Dados obtidos por adsorção de nitrogênio (BET, BJH e método t-Plot) para as amostras $\mathrm{Y}$ (pura) $\mathrm{C}$ e $\mathrm{Y}(80) 5 \mathrm{C}$.

\begin{tabular}{c|c|c|c|c}
\hline Amostra & $\boldsymbol{S}^{a}$ & $S_{\text {micro }}{ }^{b}$ & $S_{\text {ext-meso }}{ }^{c}$ & $S_{\text {poros }}{ }^{d}(\mathbf{1 , 7}$ a 300,0 $\mathbf{~ m m})$ \\
\hline $\mathrm{Y}($ pura $) \mathbf{C}$ & 647 & 591 & 56 & 30 \\
\hline $\mathrm{Y}(\mathbf{8 0}) \mathbf{5 C}$ & 688 & 585 & 103 & 73 \\
\hline
\end{tabular}

Dados em $\mathrm{m}^{2} \mathrm{~g}^{-1}$ de ${ }^{a}$ Área superficial, ${ }^{0}$ Área de microporos, "Área superficial externa e de mesoporos e ${ }^{d}$ Área superficial cumulativa de poros.

As micrografias obtidas para a zeólita Y pura (Figura 24-a e 24-b) e para o material desaluminizado $\mathrm{Y}(80) 5 \mathrm{C}$ (Figura 24-c e 24-d) mostraram que não foram detectadas grandes variações de morfologia entre as amostras. As imagens exibem os mesmos pequenos cristalitos, de tamanho médio entre 0,7 e $1 \mu \mathrm{m}$, na forma de poliedros irregulares. Todavia, pode-se notar na Figura 25-a, aproximada $1.000 \times$, que o sólido desaluminizado se apresenta na forma de grandes aglomerados em diversas regiões. Com aproximações de $2.500 \mathrm{x}$ (Figura 25-b) e $5.000 \times$ (Figura 25-c), esses agregados mostram cristalitos reduzidos, de tamanho médio entre 0,5 e 0,6 $\mu \mathrm{m}$, bastante próximos um do outro. Em outras regiões (Figuras 24-c e 24-d), há apenas pequenos aglomerados e a superfície se mostra semelhante àquela da zeólita $Y$ comercial (Figura 24-a e 24-b). Ligações hidrogênio entre grupos silanóis de superfície $(\mathrm{Si}-\mathrm{OH})$ de cristalitos vizinhos são capazes de formar clusters e originar aglomerados. ${ }^{141}$ Essa formação pode ser facilitada pela temperatura do tratamento térmico na desaluminização e/ou pela presença de um agente químico, como o hexafluorosilicato de amônio. ${ }^{141} \mathrm{~A}$ redução constatada no tamanho médio das partículas por MEV relaciona-se com o aumento da área superficial da zeólita e, consequentemente, com um aumento em sua atividade 
catalítica. Problemas difusionais, que favorecem reações secundárias, também são diminuídos quando os catalisadores possuem partículas reduzidas, pois espécies menores são capazes de se arranjarem formando canais mais estreitos, que diminuem o tempo de permanência dos reagentes nos microporos da zeólita e, por isso, facilitam o contato das moléculas com os sítios ativos do catalisador. Zeólitas nanocristalinas com grandes agregados, por exemplo, já foram reportadas por serem mais mesoporosas e possuírem maior atividade catalítica. ${ }^{142}$

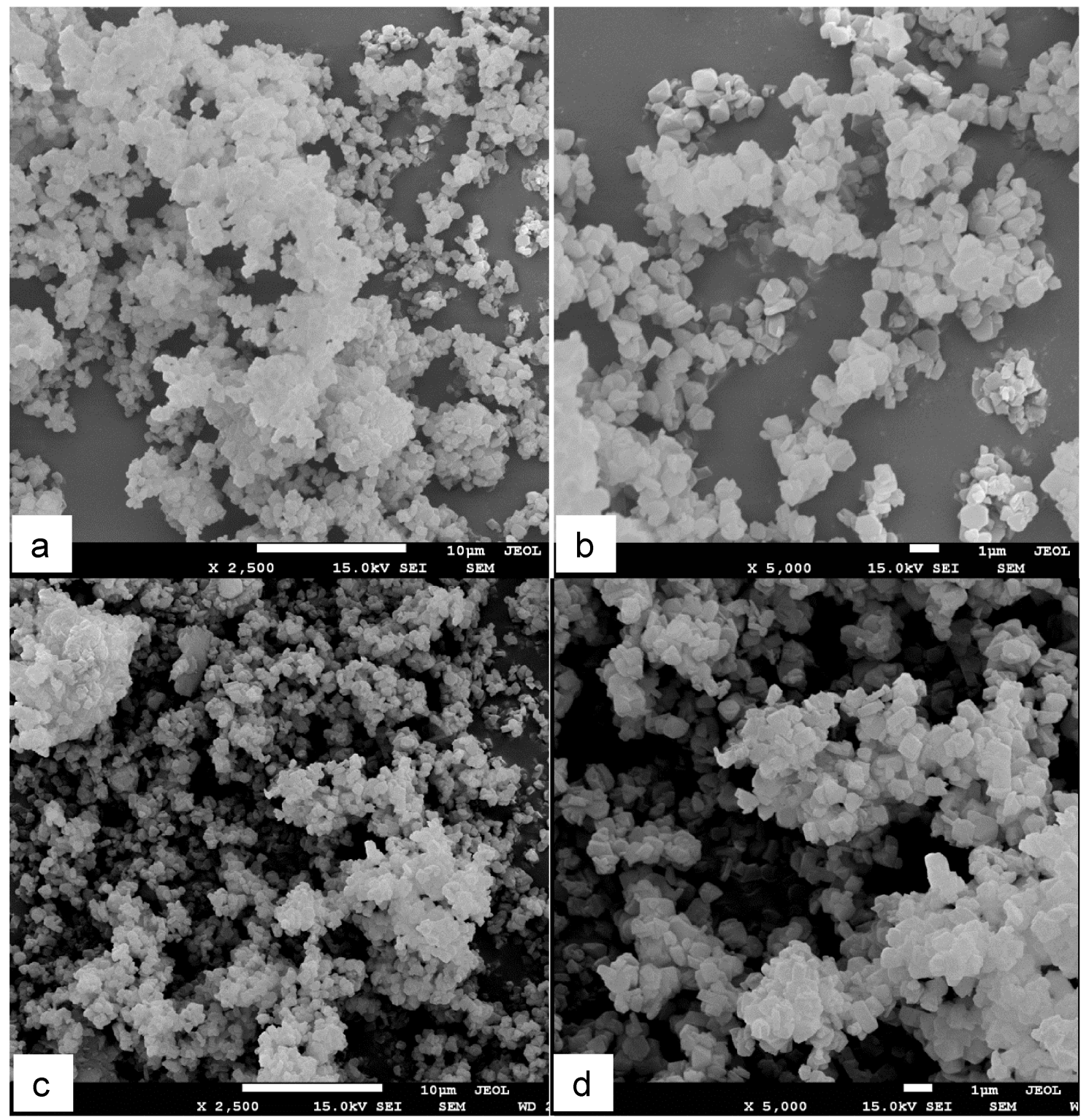

Figura 24: Micrografias das zeólitas $Y($ pura)C aproximada $2.500 \times(a)$ e $5.000 \times$ (b) e da zeólita desaluminizada Y(80)5C também aproximada $2.500 \times$ (c) e $5.000 \times$ (d). 
Outra informação obtida a partir do MEV está relacionada com a forma como a imagem foi obtida pelo equipamento e a hidrofobicidade dos materiais em análise. A forte energia que incide sobre os sólidos ao longo da análise de MEV provoca a evaporação da água presente nesses materiais, com consequentes deslocamentos dos cristalitos na fita de carbono. Por isso, sólidos hidrofílicos fornecem imagens menos definidas do que aqueles mais hidrofóbicos, dificultando a obtenção de micrografias com altas aproximações. Esse fato foi constatado nas análises realizadas, podendo ser observado uma menor resolução e um menor contraste das micrografias a e b da Figura 24, correspondente à $Y$ comercial, em relação às imagens c e d da Figura 24, referentes à zeólita desaluminizada, o que evidencia a maior hidrofobicidade da $\mathrm{Y}(80) 5 \mathrm{C}$.

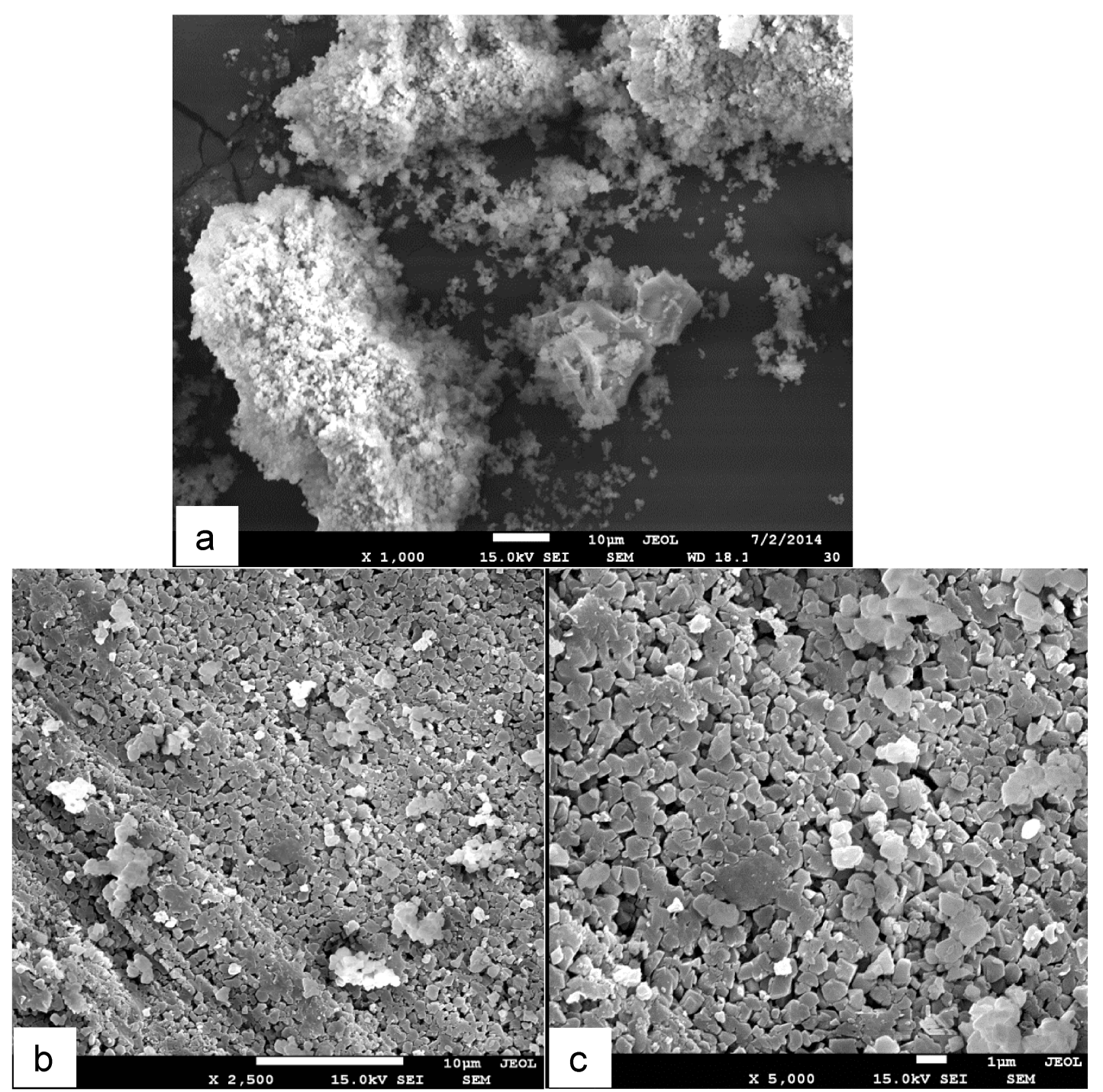

Figura 25: Micrografias da zeólita desaluminizada $Y(80) 5 \mathrm{C}$. A aproximação de $1.000 \times(a)$ exibe grandes aglomerados que, ao serem analisados com aproximações de $2.500 \times$ (b) e $5.000 \times$ (c), revelam uma superfície com cristalitos menores e coesos. 


\subsubsection{Desidratação do Etanol Pró-Análise e do Bioetanol via Reator Tubular de Leito Fixo com Fluxo Contínuo}

No reator tubular de leito fixo com fluxo contínuo, foram feitos testes catalíticos das amostras peletizadas $Y$ (pura)C e $Y(80) 5 C$ na reação de desidratação do etanol PA e do bioetanol. A Figura 25 exibe micrografias da $\mathrm{Y}(80) 5 \mathrm{C}$ na forma de pellets. Na imagem da Figura 26-a, o pellet possui tamanho igual a $0,7 \mathrm{~mm}$, enquanto a Figura 26-b mostra um pellet de comprimento igual a $0,3 \mathrm{~mm}$. Os dois tamanhos encontrados estão de acordo com os valores máximo e mínimo, respectivamente, das peneiras utilizadas no processo de peletização. A dimensão do cristalito permanece mantida na média de $0,5 \mu \mathrm{m}$.

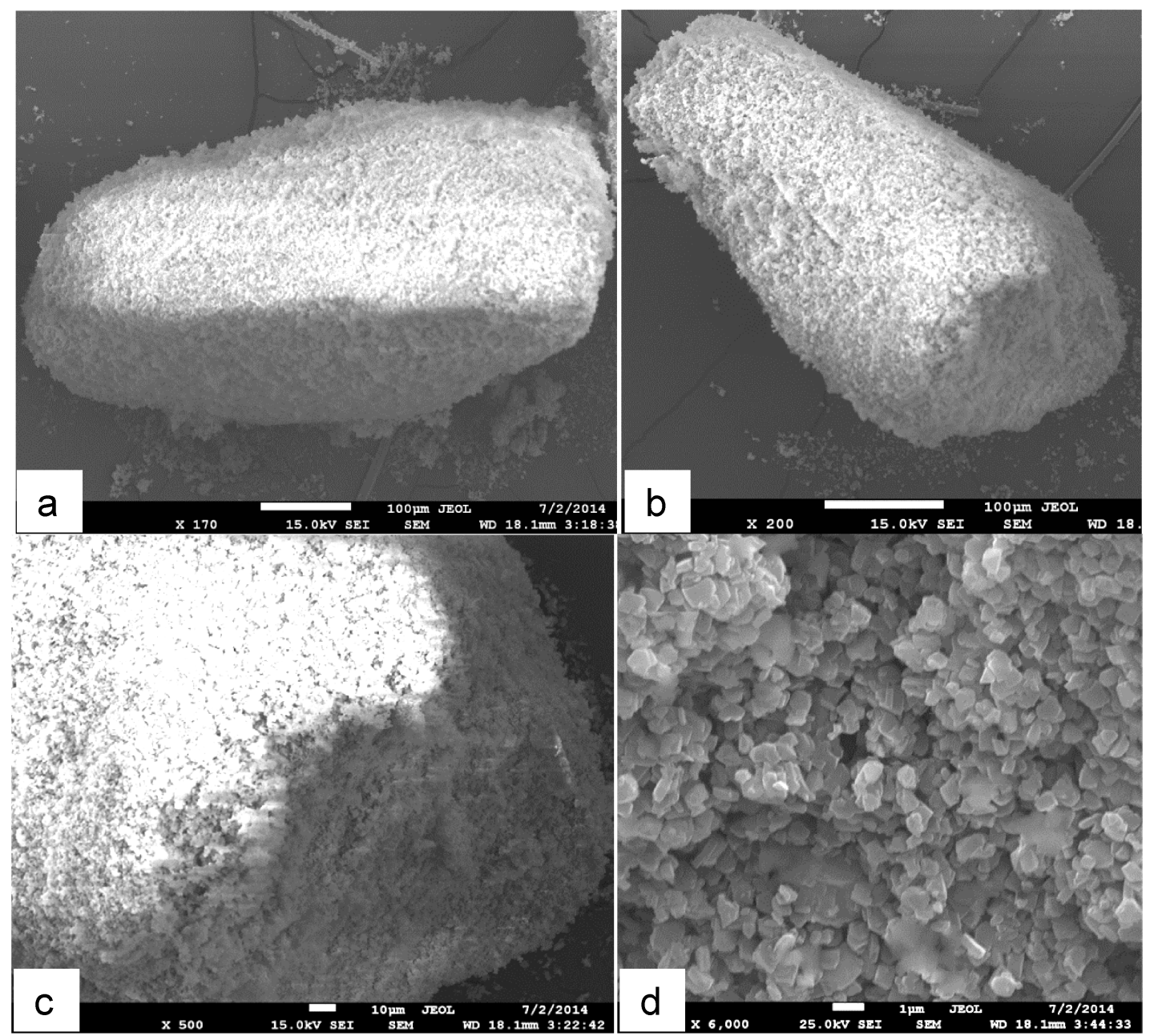

Figura 26: Micrografias da zeólita desaluminizada $Y(80) 5 \mathrm{C}$ na forma de pellets. A imagem (a), aproximada $170 \mathrm{x}$, exibe um pellet de tamanho igual a 0,7 $\mathrm{mm}(661 \mu \mathrm{m}) \mathrm{e}$, a micrografia (b), aproximada $200 \mathrm{x}$, mostra um pellet menor, de 0,3 $\mathrm{mm}(333 \mu \mathrm{m})$. As imagens (c), aproximada $500 \mathrm{x}, \mathrm{e}(\mathrm{d})$, aproximada $4.000 \mathrm{x}$, ampliam o pellet exibido em (b), mostrando a manutenção dos pequenos cristalitos, da ordem de $0,5 \mu \mathrm{m}$. 
A massa de catalisador utilizada na presente pesquisa é pequena, apenas $0,1 \mathrm{~g}$, quando comparada com aquelas empregadas nos artigos e patentes mostrados no capítulo introdutório desse trabalho, bem como em outros não citados, considerando a utilização de condições reacionais semelhantes, como o fluxo de etanol $\left(0,03 \mathrm{~mL} \mathrm{~min}^{-1}\right)$ e a temperatura $\left(300{ }^{\circ} \mathrm{C}\right)$. Isso proporcionou uma melhor visualização da resistência e acidez do catalisador desenvolvido, a zeólita desaluminizada $\mathrm{Y}(80) 5 \mathrm{C}$, frente a diferentes materiais geralmente empregados nessa mesma reação, como os baseados em alumina e em zeólitas da família MFI, por exemplo, a ZSM-5.

Devido à reduzida quantidade utilizada de zeólita, foi encontrado um alto valor para a velocidade espacial de etanol (WHSV), isto é, para a massa que flui de reagente, no caso o etanol, por grama de catalisador a cada hora: $14,2 \mathrm{~h}^{-1}$. Trabalhos recentes, como o de Wang e colaboradores, ${ }^{64}$ mostram o emprego de um catalisador da família MFI em condições racionais semelhantes às utilizadas nesse trabalho, destacando altas conversões do etanol ( 97,9\%) e altas seletividades para etileno $(\sim 99,1 \%)$ geradas pelo sólido durante longos períodos sem desativação. Todavia, o valor de WHSV se restringiu a 1,25 $\mathrm{h}^{-1}, 0$ que, industrialmente, pode não ser vantajoso, pois, em grandes escalas, é preferível um catalisador capaz de converter maiores massas de reagente por hora de reação.

\subsubsection{Desidratação do Etanol Pró-Análise}

Para a zeólita padrão $\mathrm{Y}($ pura)C, observou-se uma conversão média de apenas $65,0 \%$ (Figura 27 ).

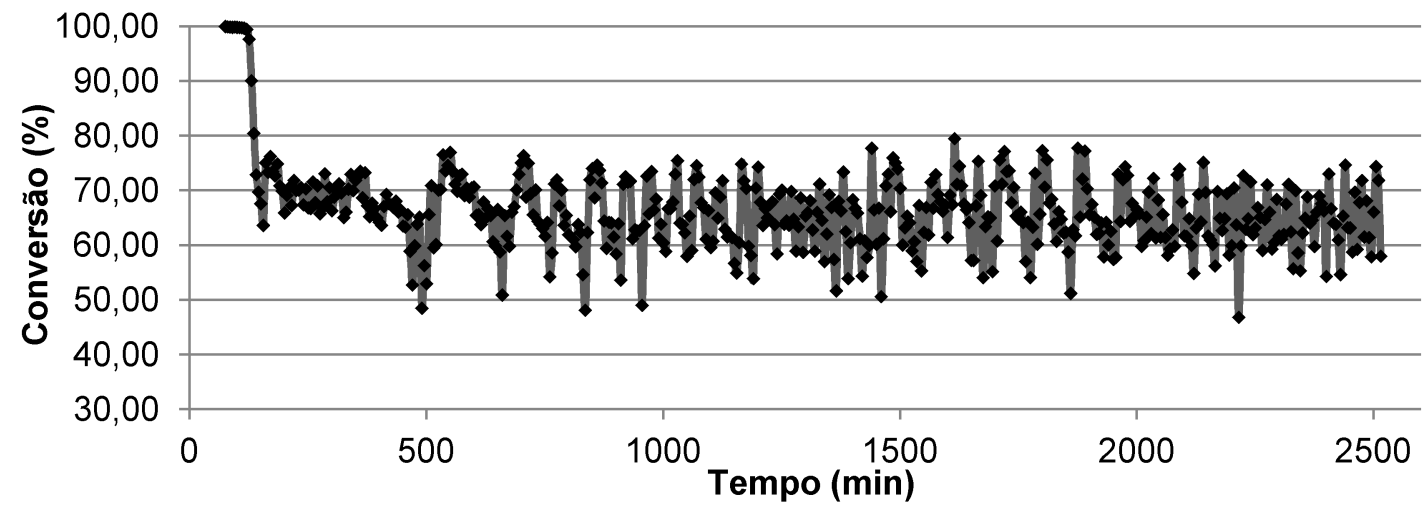

Figura 27: Gráfico de conversão em função do tempo para a reação de desidratação do etanol PA, utilizando como catalisador $0,1 \mathrm{~g}$ da zeólita Y(pura)C. 
O subproduto dietil éter, mesmo que em pequenas quantidades, foi detectado com apenas $2 \mathrm{~h}$ de reação. A seletividade média no tempo estudado foi de $97,2 \%$ (Figura 28).

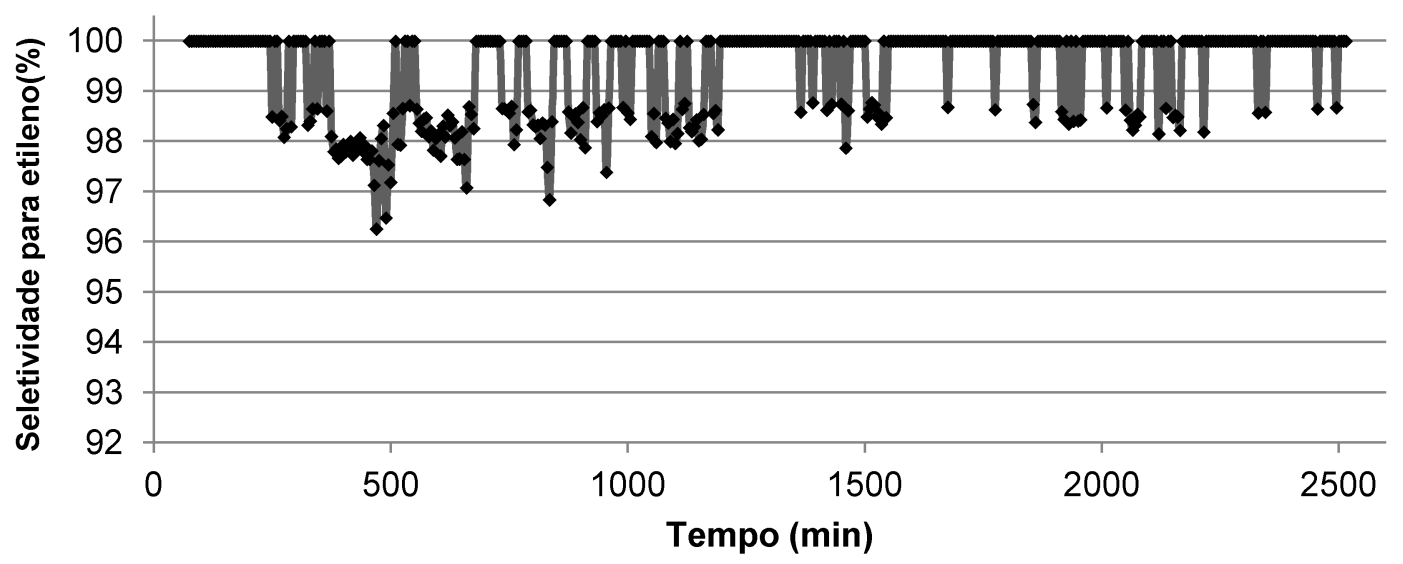

Figura 28: Gráfico de seletividade em função do tempo para a reação de desidratação do etanol PA, utilizando como catalisador $0,1 \mathrm{~g}$ da zeólita Y(pura)C.

Já para a zeólita modificada, a reação durou cinco dias sem o surgimento de subprodutos, como o dietil éter. Somente após 118,6 h (mais de 7000 minutos) de reação é que conversões menores que $80 \%$ foram observadas (Figura 29), porém bastante superiores àquelas verificadas para a zeólita $Y$ padrão. Também, a partir desse tempo reacional, já havia formação de dietil éter, como mostra o gráfico da Figura 30.

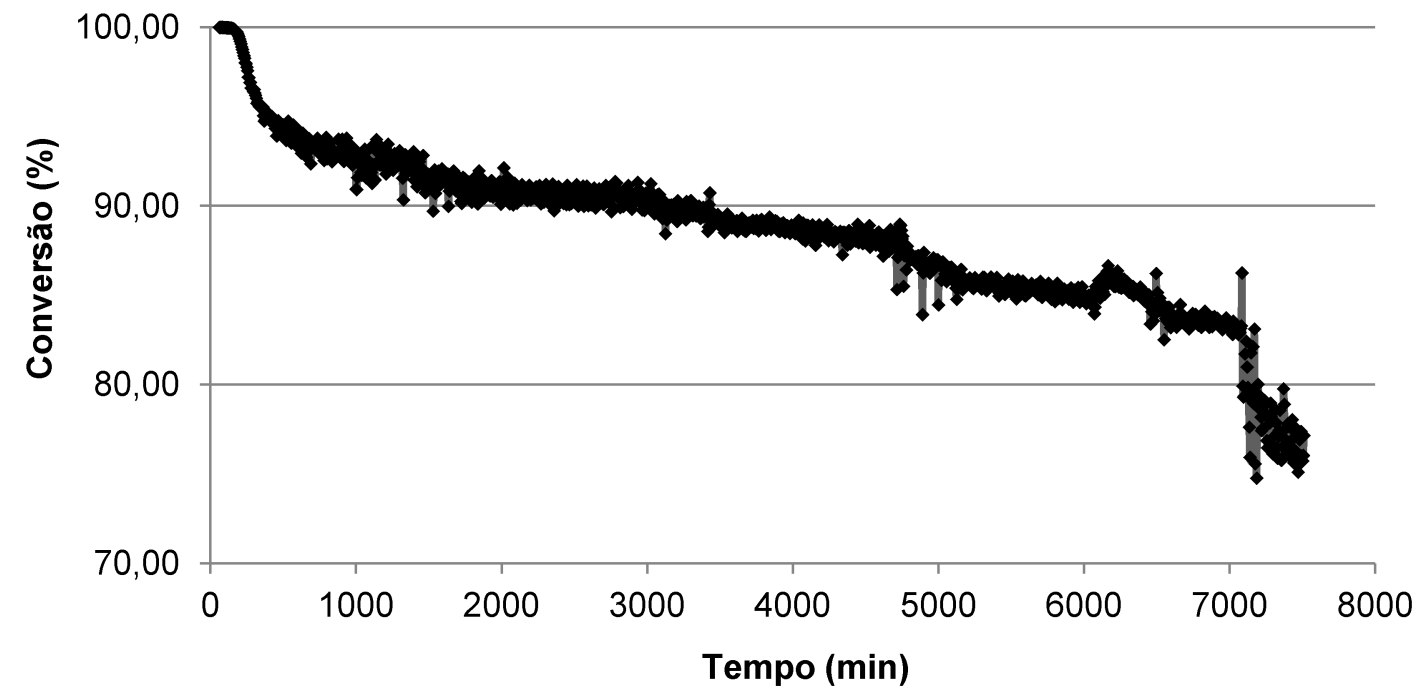

Figura 29: Gráfico de conversão em função do tempo para a reação de desidratação do etanol PA, utilizando como catalisador $0,1 \mathrm{~g}$ da zeólita $\mathrm{Y}(80) 5 \mathrm{C}$. 


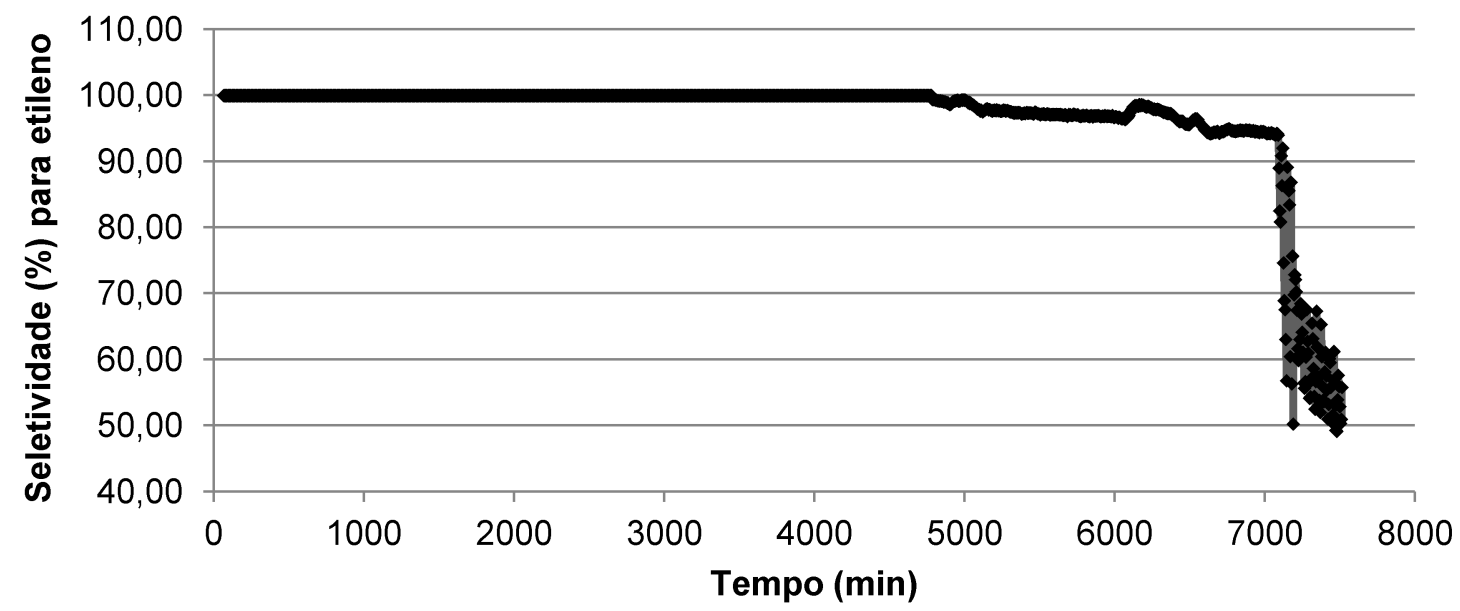

Figura 30: Gráfico de seletividade em função do tempo para a reação de desidratação do etanol PA, utilizando como catalisador $0,1 \mathrm{~g}$ da zeólita $\mathrm{Y}(80) 5 \mathrm{C}$.

As Figuras 31, 32 e 33 ilustram os gráficos obtidos pelo software do CG (intensidade $\mathrm{x}$ tempo) para os pontos 100, 520 e 1487, correspondente a $9 \mathrm{~h}$ de reação (100\% seletivo, 95\% conversão), 44 h de reação (100\% seletivo, 90\% conversão) e $124 \mathrm{~h}$ de reação (49\% seletivo, $75 \%$ conversão), respectivamente, com uso da $\mathrm{Y}(80) 5 \mathrm{C}$. A partir do ponto 520, traços do subproduto dietil éter começaram a ser observados, mas sua intensidade é da ordem de $10^{-10}$.

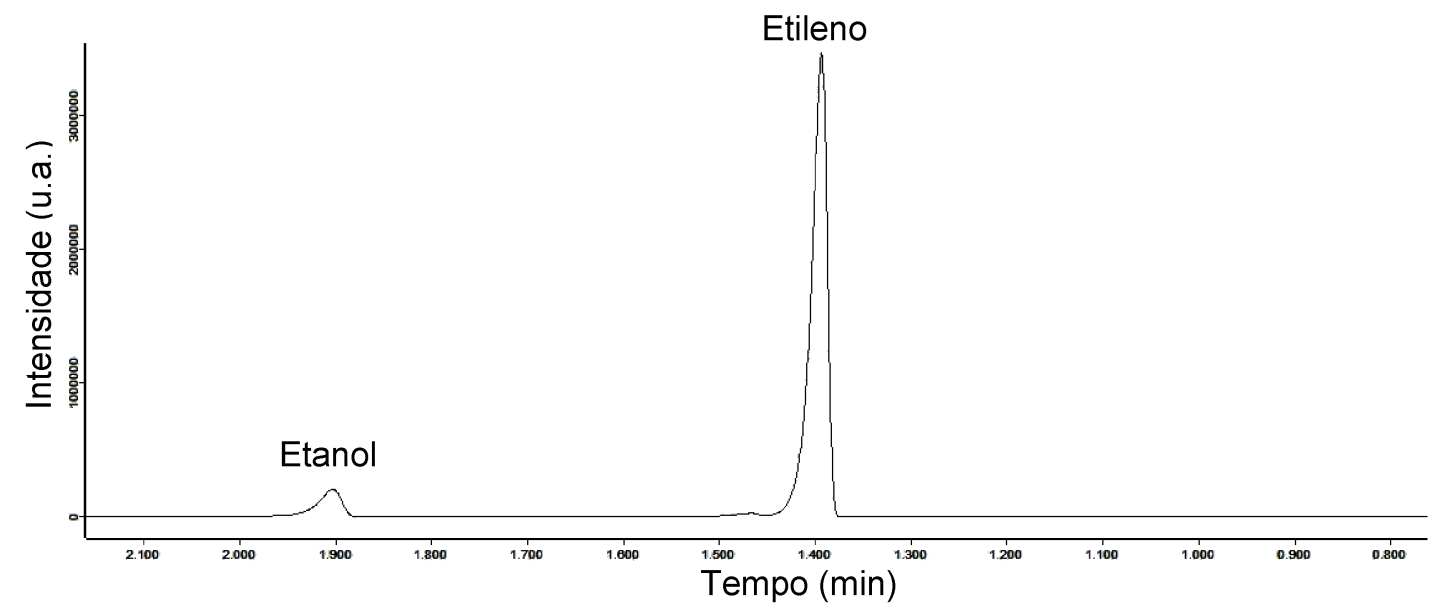

Figura 31: Picos obtidos por CG (ponto 100) mostrando o excesso de etanol não reagido (em 1,87 $\mathrm{min}$ ) e do produto etileno (em $1,38 \mathrm{~min}$ ) para a reação de desidratação do etanol PA, utilizando como catalisador $0,1 \mathrm{~g}$ da zeólita Y(80)5C. 


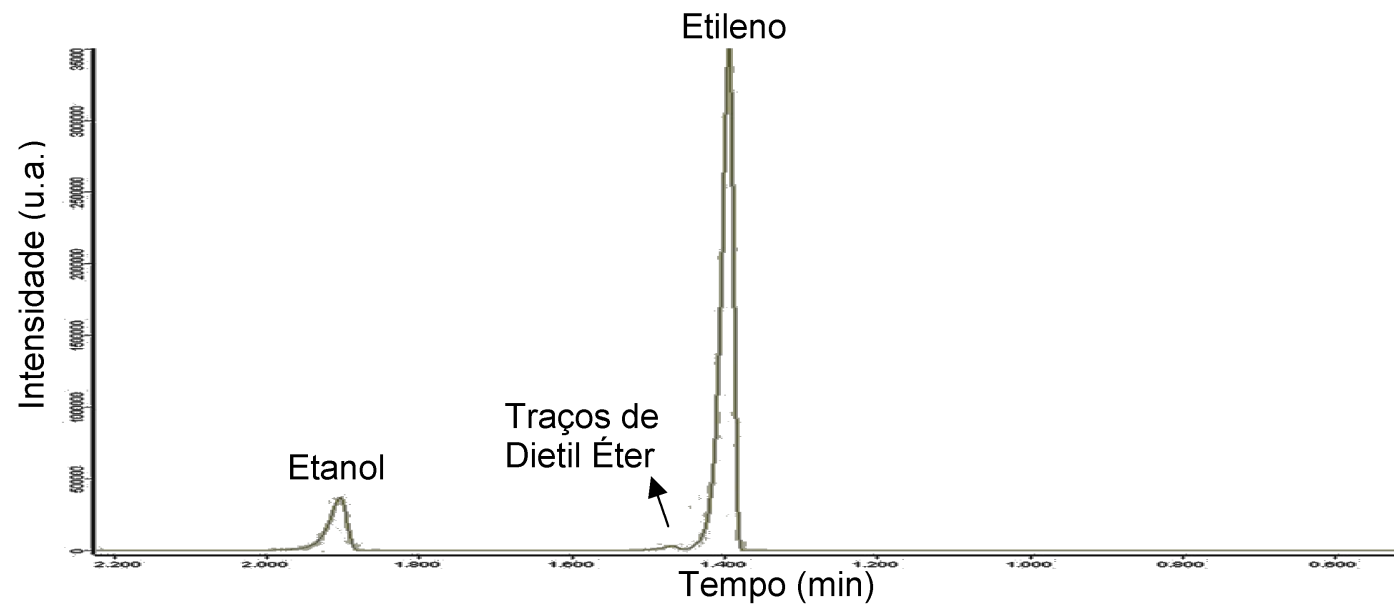

Figura 32: Picos obtidos por CG (ponto 520) mostrando o excesso de etanol não reagido (em 1,87 $\mathrm{min}$ ) e do produto etileno (em 1,38 min) para a reação de desidratação do etanol PA, utilizando como catalisador $0,1 \mathrm{~g}$ da zeólita $\mathrm{Y}(80) 5 \mathrm{C}$. Traços do subproduto dietil éter começaram a ser observados.

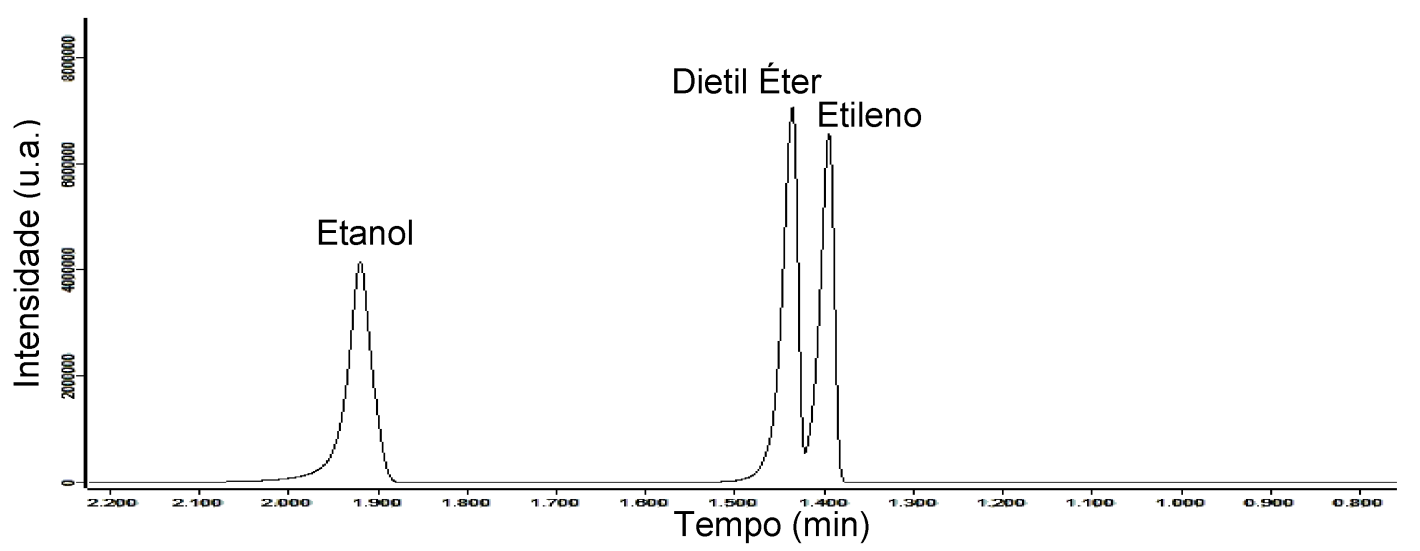

Figura 33: Picos obtidos por CG (ponto 1487) mostrando o excesso de etanol não reagido (em 1,87 $\mathrm{min}$ ), do produto etileno (em 1,38 $\mathrm{min}$ ) e do subproduto dietil éter (em $1,41 \mathrm{~min}$ ) para a reação de desidratação do etanol PA, utilizando como catalisador $0,1 \mathrm{~g}$ da zeólita $\mathrm{Y}(80) 5 \mathrm{C}$.

Comparativamente, o cromatograma obtido para um mesmo ponto reacional (ponto 100, 60\% conversão e 98\% seletividade), utilizando como catalisador a zeólita Y comercial (Figura 34), apresentou um excesso de etanol significativamente superior à da zeólita modificada, além de exibir um pico referente ao subproduto dietil éter. 


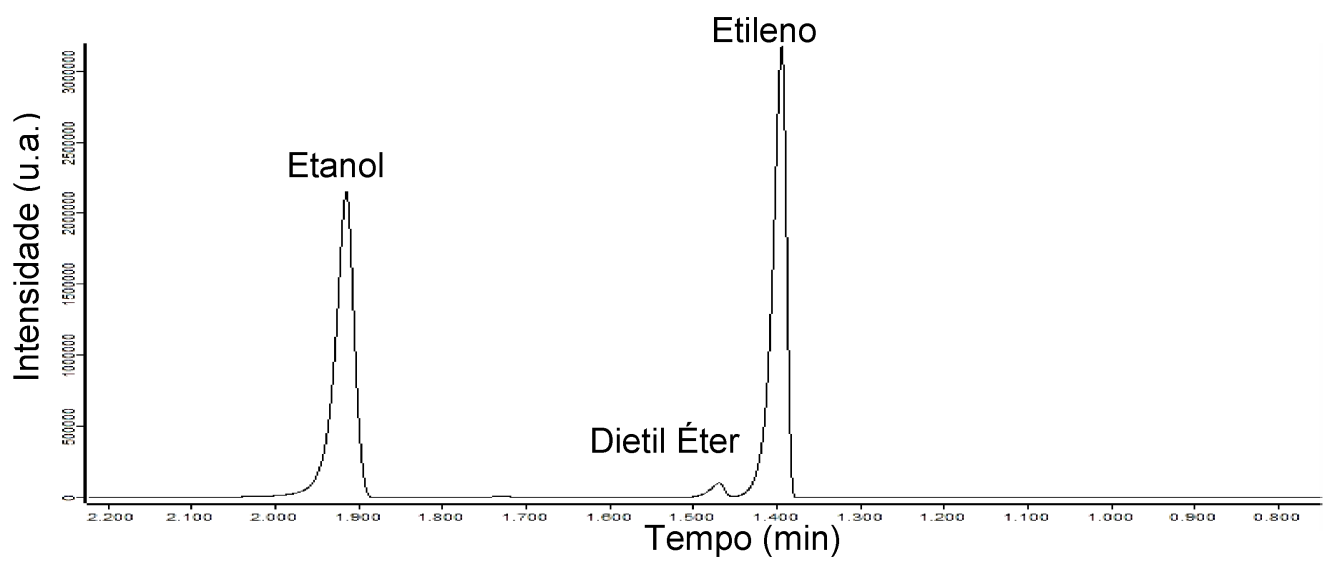

Figura 34: Picos obtidos por CG (ponto 100) do excesso de etanol não reagido (em $1,87 \mathrm{~min}$ ), do produto etileno (em 1,38 $\mathrm{min}$ ) e do subproduto dietil éter (em 1,41 $\mathrm{min}$ ) para a reação de desidratação do etanol PA, utilizando como catalisador $0,1 \mathrm{~g}$ da Y(pura)C.

Observando os dados de conversão e seletividade para as duas amostras, fica perceptível o maior poder de conversão e maior resistência da zeólita modificada pelo processo de desaluminização. Assim como reportado

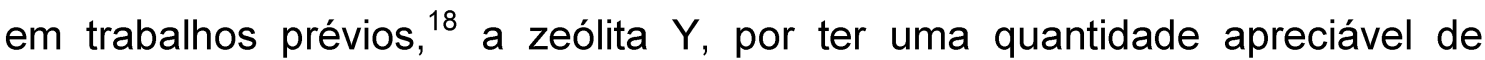
alumínios em sua rede, e, portanto, uma alta concentração de cátions, possui também uma superfície bastante heterogênea, o que gera uma hidrofilicidade alta. No caso de reações como a desidratação de alcoóis, em que a água é gerada nas mesmas proporções de formação da olefina, o caráter mais hidrofilico ou mais hidrofóbico da superfície zeolítica influenciará diretamente na atividade do catalisador. ${ }^{18,143}$

A amostra $Y(80) 5 C$ já havia se mostrado um catalisador resistente em reações de esterificação, ${ }^{18}$ que também geram água, sendo presumível sua maior hidrofobicidade. Entretanto, na desidratação do etanol, sua atividade se destacou, levando em consideração que apenas $0,1 \mathrm{~g}$ da zeólita apresentou alta conversão e seletividade durante 5 dias de reação com uma WHSV maior que aquelas reportadas na literatura. A eficiência do sólido desaluminizado em relação à zeólita padrão é mostrada na Tabela 5, em Turnover Frequency (TOF, velocidade de reação em unidades de mol de produto formado, por hora, por mol de catalisador utilizado). 
Tabela 5: Dados de conversão média, seletividade média e eficiência catalítica para $42 \mathrm{~h}$ de reação de desidratação de etanol PA, utilizando a zeólita Y padrão e a zeólita desaluminizada como catalisadores.

\begin{tabular}{|c|c|c|c|c|}
\hline Amostra & $\begin{array}{c}R_{\text {média }}{ }^{\mathrm{a}} \\
(\% \mathrm{~m} / \mathrm{m})\end{array}$ & $\begin{array}{c}S_{\text {Média }}^{\mathrm{b}} \\
(\% \mathrm{~m} / \mathrm{m})\end{array}$ & $\begin{array}{l}n_{\text {Sitios Ácidos }} \\
\left(\mathrm{mmol} \mathrm{g}^{-1}\right)^{\mathrm{C}}\end{array}$ & $\begin{array}{c}\mathrm{TOF}^{\mathrm{d}} \\
\left(\mathrm{mol}_{\text {etileno }} \mathrm{h}^{-1} \mathrm{~mol}^{-1}{ }_{\text {cat }}\right)\end{array}$ \\
\hline $\mathrm{Y}$ (pura)C & 65,0 & 97,2 & 1,0911 & 183,9 \\
\hline $\mathrm{Y}(80) 5 \mathrm{C}$ & 91,1 & 98,2 & 1,1088 & 244,6 \\
\hline
\end{tabular}

${ }^{a}$ Conversão média; ${ }^{b}$ Seletividade média para etileno; ${ }^{c}$ Número de sítios ácidos calculados por meio da adsorção de piridina gasosa nos sólidos e posterior análise por TG/DTG; ${ }^{\mathrm{d}}$ Turnover frequency.

Como pode ser observado na Tabela 5 , a zeólita desaluminizada apresentou uma eficiência catalítica superior à da zeólita $Y$ de partida. Assim, mesmo com quantidades semelhantes de sítios ácidos, o catalisador $\mathrm{Y}(80) 5 \mathrm{C}$ se mostrou mais ativo e com poder de conversão superior à amostra $\mathrm{Y}(\mathrm{pura}) \mathrm{C}$ durante um mesmo período reacional. Dessa forma, o processo de desaluminização foi efetivo para tornar o sólido mais ácido, corroborando com o fato de que os sítios remanescentes ao processo de desaluminização são incrementados em sua acidez e são capazes de converter os reagentes com eficiência superior à zeólita de partida.

\section{- Recuperação e Reutilização do Catalisador}

A desativação do catalisador ocorre em um dado momento reacional, mesmo quando este é bastante resistente, devido ao bloqueio de seus sítios ácidos. Dentre outros motivos, essa inibição acontece pela formação de coque, advindo de grupos orgânicos carbônicos adsorvidos. A Figura 22-b (Capítulo Experimental) mostra a imagem da zeólita $Y$ após a reação, a qual apresentou uma coloração preta, típica do coque formado, mas ainda, aparentemente, com o formato e as dimensões de pellets. Tanto o catalisador modificado como a zeólita de partida apresentaram formação de coque, advindo dos grupos orgânicos adsorvidos. De acordo com os dados de análise elementar por $\mathrm{CHN}$, a amostra $\mathrm{Y}($ pura)C $\mathrm{C}$, após a desidratação do etanol PA, apresentou $2,60 \%$ de carbono. A Y $(80) 5 \mathrm{C}$, por ter permanecido ativa durante 5 dias de reação, apresentou um maior teor de carbono: 8,37\%.

Portanto, para que fosse possivel reutilizar os materiais, estes foram submetidos a uma reativação via tratamento térmico a $550{ }^{\circ} \mathrm{C}$ durante $8 \mathrm{~h}$ em 
mufla, sendo recuperados $0,09 \mathrm{~g}$ das amostras $\mathrm{Y}$ (pura)C e $\mathrm{Y}(80) 5 \mathrm{C}$. Os gráficos das Figuras 35 e 36 mostram os resultados de conversão e seletividade, respectivamente, da zeólita $\mathrm{Y}$ (pura)C padrão no segundo ciclo catalítico de produção de etileno. Da mesma forma, os gráficos das Figuras 37 e 38 exibem a conversão e seletividade, respectivamente, da zeólita desaluminizada $Y(80) 5 \mathrm{C}$ também em seu segundo ciclo catalítico.

Após reutilização, a zeólita desaluminizada converteu, em média, 86,6\% do etanol PA em $46 \mathrm{~h}$ de reação. Nesse mesmo período, sua seletividade para o etileno, que, na média, foi de $86,8 \%$, decaiu bastante depois de $8 \mathrm{~h}$ de reação, tornando-se variável ao longo do tempo. O catalisador voltou a apresentar seletividade superior a $90 \%$ após $40 \mathrm{~h}$ reacionais. Já a zeólita Y(pura)C padrão manteve sua conversão média em torno de $69,5 \%$, com seletividade média de $95,7 \%$ durante $25 \mathrm{~h}$ de reação.

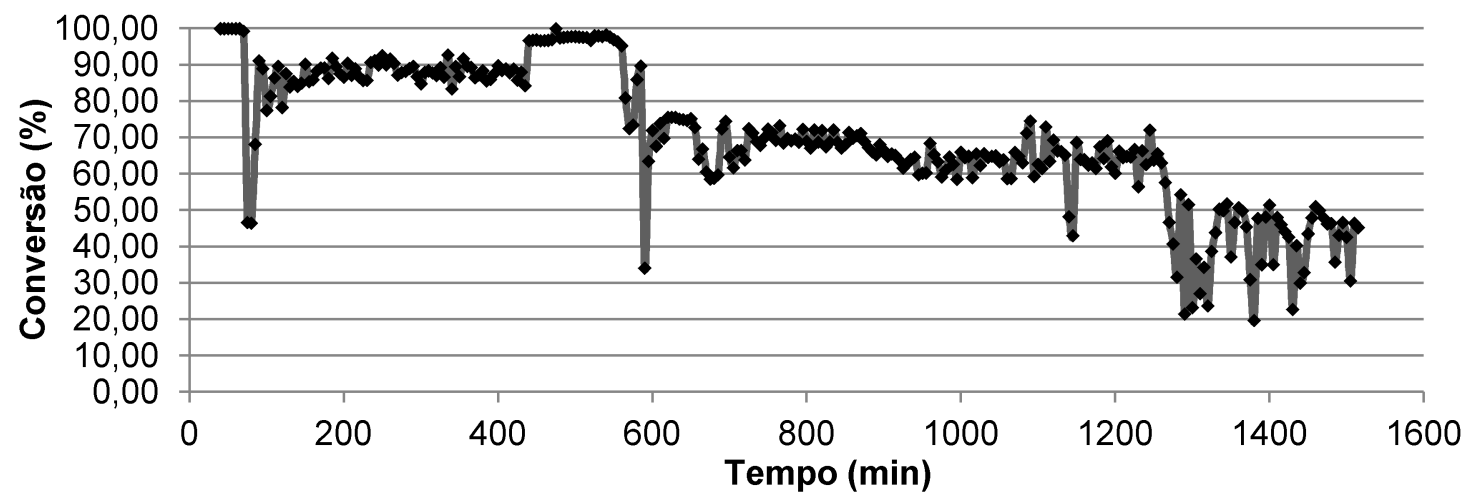

Figura 35: Gráfico de conversão em função do tempo para o segundo ciclo catalítico da reação de desidratação do etanol PA, reutilizando $0,09 \mathrm{~g}$ da zeólita Y(pura)C.

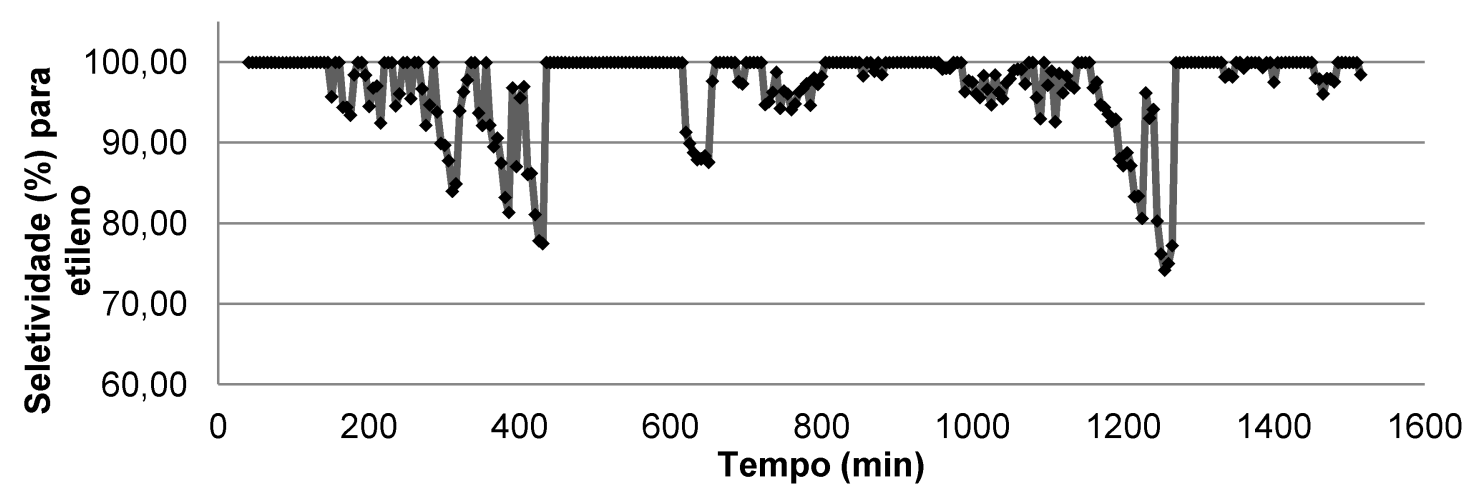

Figura 36: Gráfico de seletividade em função do tempo para o segundo ciclo catalítico da reação de desidratação do etanol PA, reutilizando $0,09 \mathrm{~g}$ da zeólita $\mathrm{Y}$ (pura)C. 


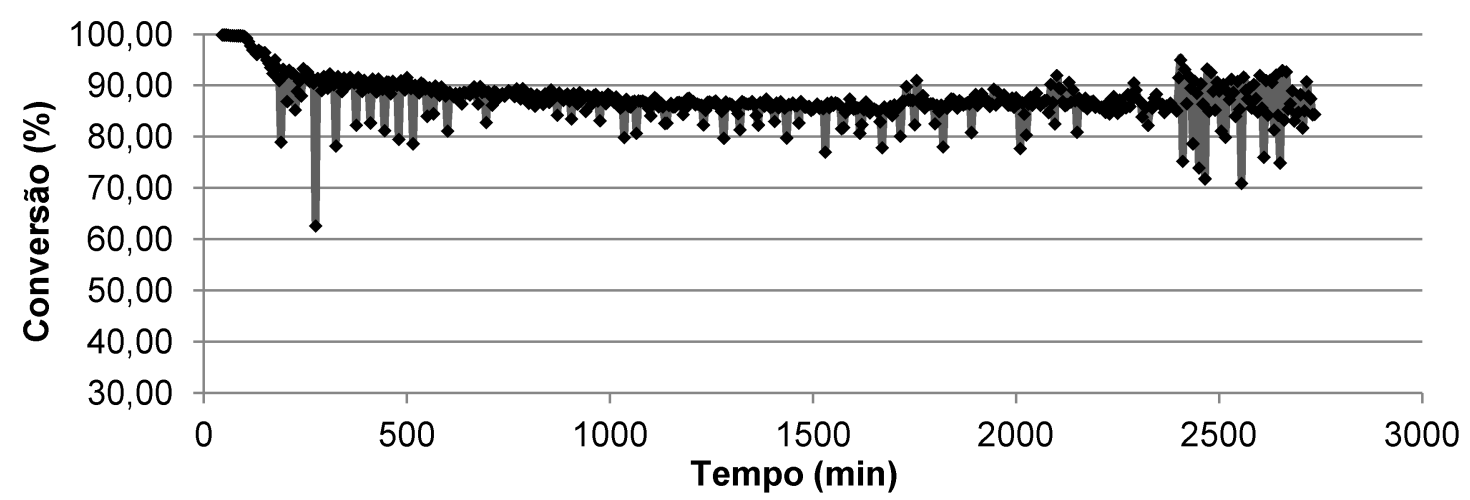

Figura 37: Gráfico de conversão em função do tempo para o segundo ciclo catalítico da reação de desidratação do etanol PA, reutilizando $0,09 \mathrm{~g}$ da zeólita $\mathrm{Y}(80) 5 \mathrm{C}$.

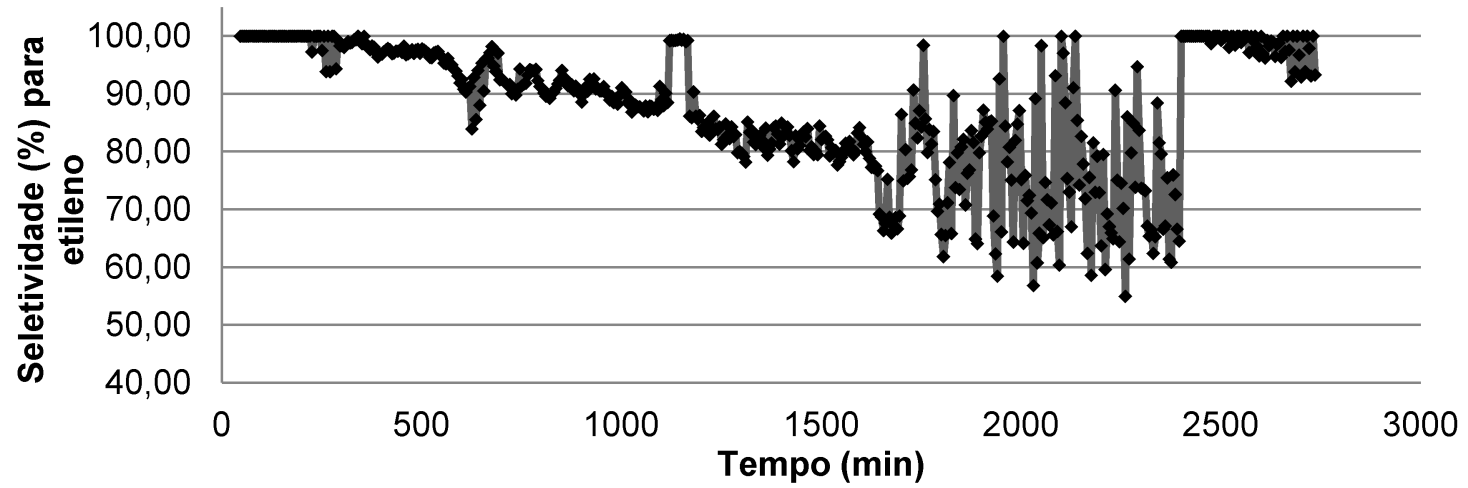

Figura 38: Gráfico de seletividade em função do tempo para o segundo ciclo catalítico da reação de desidratação do etanol PA, reutilizando $0,09 \mathrm{~g}$ da zeólita $\mathrm{Y}(80) 5 \mathrm{C}$.

Mesmo apresentando conversões inferiores à zeólita desaluminizada, a Y padrão parece ter conservado melhor suas propriedades após o processo de reativação, apresentando valores muito próximos de conversão e seletividade para etileno em relação àqueles do primeiro ciclo $(67,6 \%$ conversão e $99,2 \%$ de seletividade nas primeiras $25 \mathrm{~h}$ reacionais). A $\mathrm{Y}(80) 5 \mathrm{C}$ teve sua capacidade de coversão/seletividade mais afetada, principalmente porque a amostra foi submetida a um longo tempo reacional. Entretanto, sua integridade estrutural foi mantida, como pode ser observado no difratograma da Figura 39, apresentando apenas um leve alargamento de banda na faixa entre $10^{\circ}$ e $20^{\circ}$, um indicativo sutil de heterogeneidade de espécies e/ou presença de fases amorfas. 


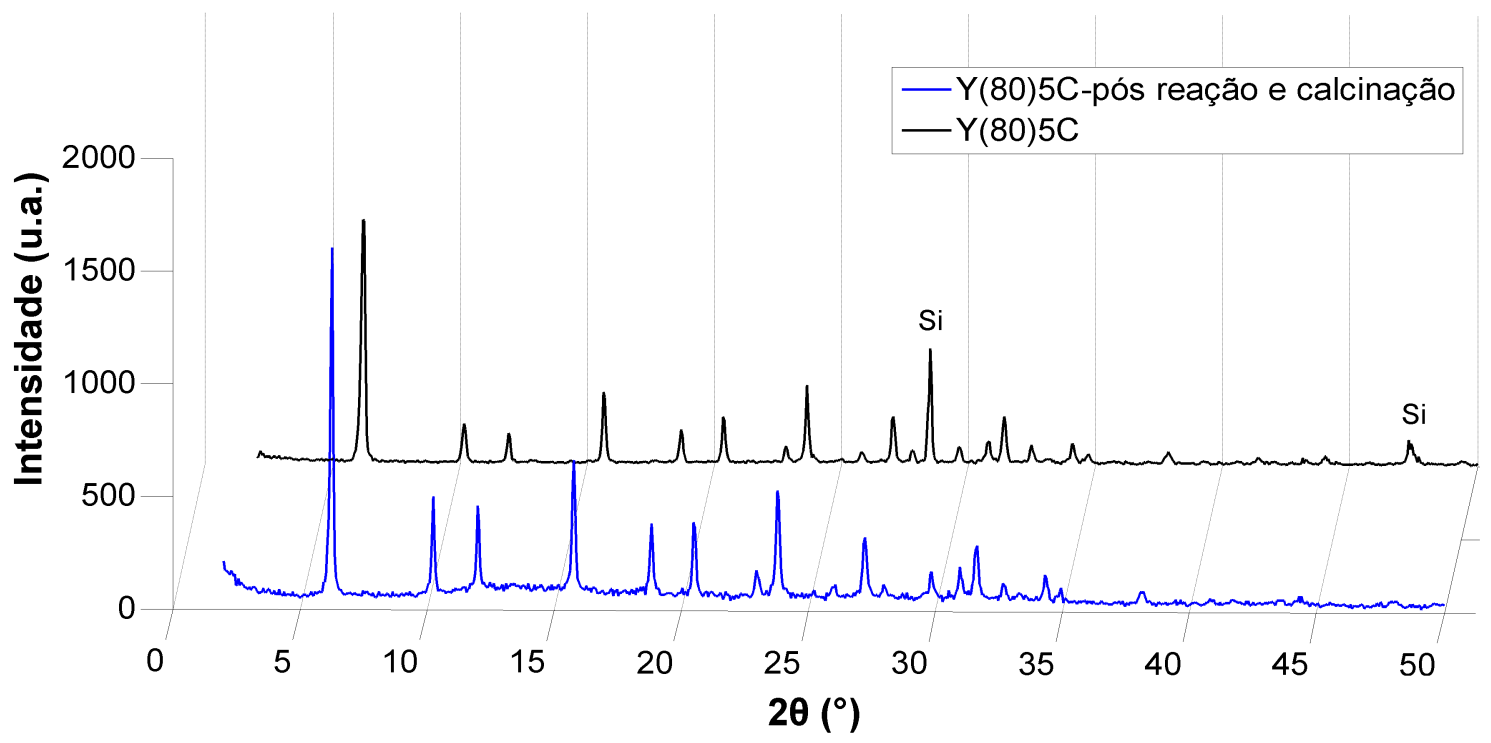

Figura 39: Difratograma da amostra $Y(80) 5 C$ (preto), antes da reação de desidratação de etanol PA e com padrão interno de Si elementar, ${ }^{18}$ e da mesma amostra após reação e calcinação (azul).

Os sólidos recuperados e calcinados mais uma vez a $550{ }^{\circ} \mathrm{C}$ por $8 \mathrm{~h}$ foram submetidos a novas adsorções de piridina e análises termogravimétricas (Figuras 40 e 41). Além da massa de água, física e química, perdida até $300^{\circ} \mathrm{C}$, essa mesma faixa de temperatura engloba ainda a massa perdida de Py fisicamente adsorvida. A partir de $300{ }^{\circ} \mathrm{C}$, ocorrem perdas de massas relativas à base quimicamente adsorvida: entre 300 e $500^{\circ} \mathrm{C}$, a dessorção de Py se dá naqueles sítios ácidos mais fracos, enquanto que, a partir de $600^{\circ} \mathrm{C}$, as perdas são referentes à dessorção da base nos sítios mais fortes da zeólita.

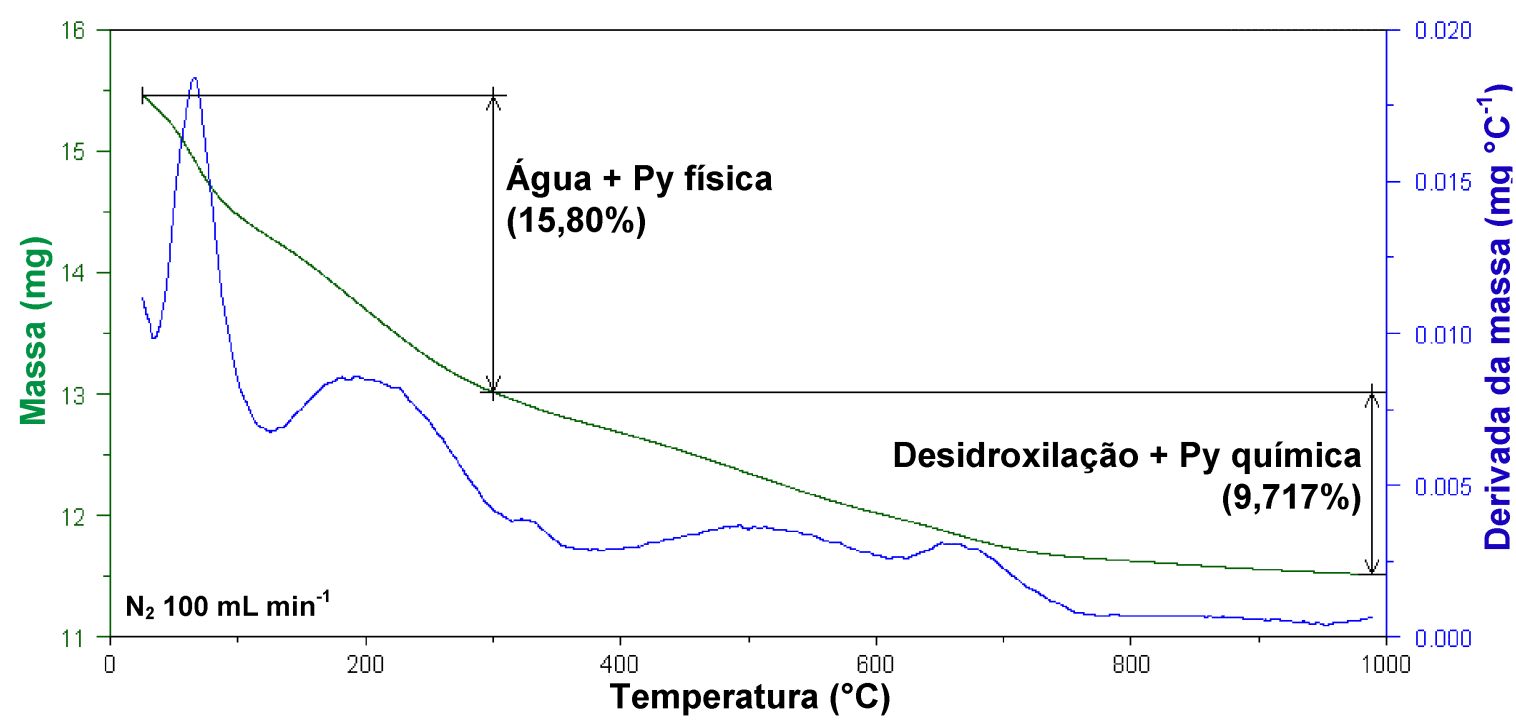

Figura 40: Curvas TG/DTG obtidas para a zeólita padrão $\mathrm{Y}(\mathrm{pura}) \mathrm{C}$ recuperada após reação de desidratação do etanol PA e adsorvida com Py. 


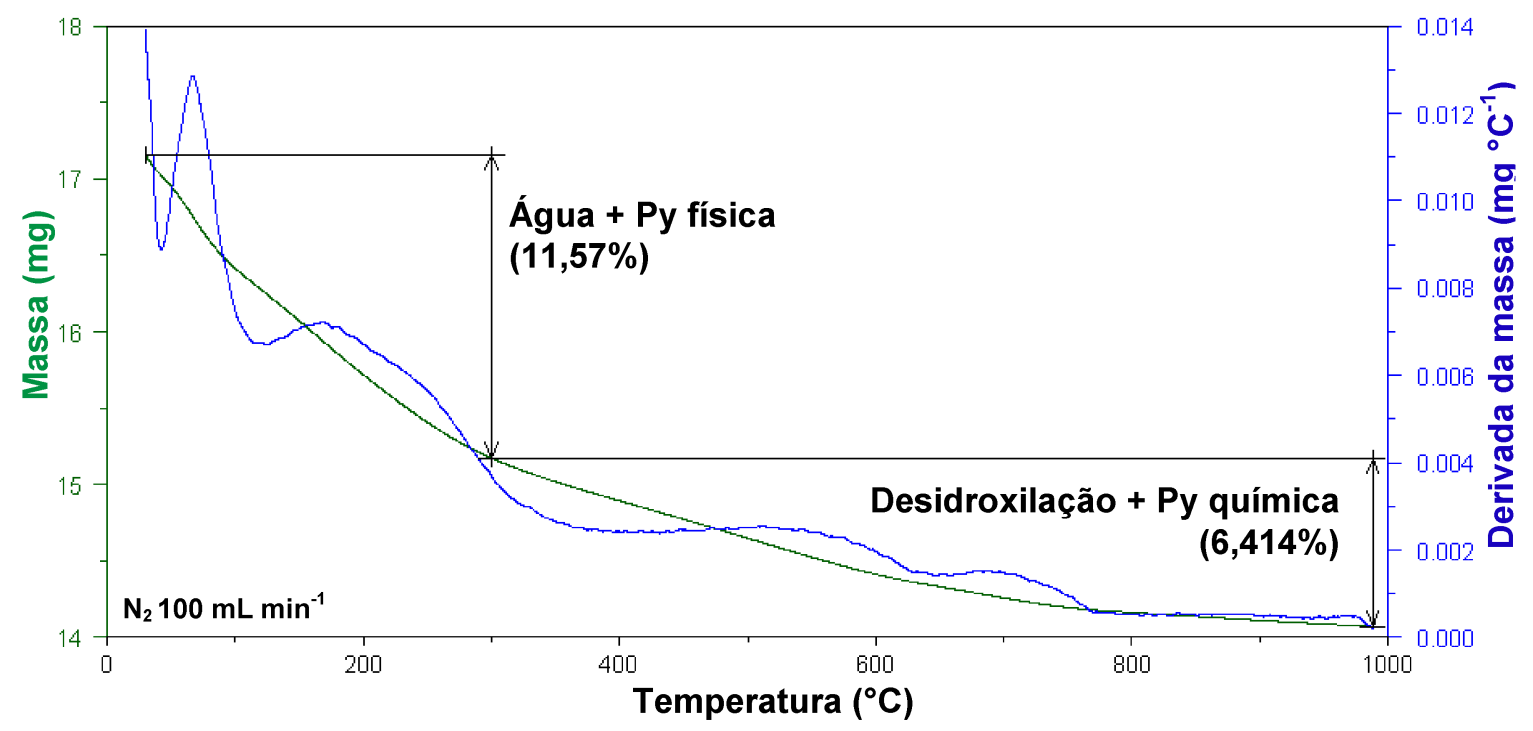

Figura 41: Curvas TG/DTG obtidas para a zeólita $Y(80) 5 \mathrm{C}$ recuperada após reação de desidratação do etanol PA e adsorvida com Py.

Como a quantidade de sítios adsorvidos é proporcional à área da curva DTG, foi possível calcular o número de sítios ácidos remanescentes após reação e tratamento térmico (Tabela 6). Embora tenha havido decréscimos significativos de conversão e seletividade, a zeólita $Y(80) 5 \mathrm{C}$ ainda apresentou altos valores de TOF, quase três vezes superior à Y(pura)C (Tabela 6). Assim, apesar do desgaste prévio dos $0,1 \mathrm{~g}$ da zeólita desaluminizada, depois de ser submetida a $125 \mathrm{~h}$ reacionais, seu reuso gerou bons resultados de conversão e de seletividade, confirmando também a alta resistência do sólido diante da redução de mais da metade de seus sítios ácidos.

Tabela 6: Dados de conversão média, seletividade média e eficiência catalítica para $25 \mathrm{~h}$ do segundo ciclo catalítico da reação de desidratação de etanol PA, com reutilização dos catalisadores zeólita Y padrão e zeólita desaluminizada.

\begin{tabular}{|c|c|c|c|c|}
\hline Amostra & $\begin{array}{c}R_{\text {média }}{ }^{a} \\
(\% \mathrm{~m} / \mathrm{m})\end{array}$ & $\begin{array}{c}S_{\text {Média }}^{b} \\
(\% \mathrm{~m} / \mathrm{m})\end{array}$ & $\begin{array}{c}n_{\text {Sitios Ácidos }} \\
\left(\mathrm{mmol} \mathrm{g}^{-1}\right)^{\mathrm{c}}\end{array}$ & $\begin{array}{c}\mathrm{TOF}^{\mathrm{d}} \\
\left(\mathrm{mol}_{\text {etileno }} \mathrm{h}^{-1} \mathrm{~mol}^{-1} \text { cat }\right)\end{array}$ \\
\hline$Y($ pura $) C$ & 69,5 & 95,7 & 1,0230 & 209,4 \\
\hline$Y(80) 5 C$ & 86,9 & 90,5 & 0,4850 & 552,3 \\
\hline
\end{tabular}

${ }^{a}$ Conversão média; ${ }^{b}$ Seletividade média para etileno; ${ }^{c}$ Número de sítios ácidos calculados por meio da adsorção de piridina gasosa nos sólidos e posterior análise por TG/DTG, sendo o tempo total de reação igual a $42 \mathrm{~h}$ para a $\mathrm{Y}($ pura $) \mathrm{C}$ e $125 \mathrm{~h}$ para a $\mathrm{Y}(80) 5 \mathrm{C}$; ${ }^{d}$ Turnover frequency. 


\section{- Teste da Variação do Fluxo de Etanol PA}

A alta atividade apresentada pelo catalisador $Y(80) 5 \mathrm{C}$ possibilitou a análise do fluxo de etanol PA sobre esse sólido ao longo da reação de desidratação desse álcool. Como se trata de uma zeólita resistente, objetivou-se encontrar um valor máximo de fluxo capaz de ainda gerar boa conversão e seletividade, aumentando, com isso, o valor de WHSV para o catalisador. Como o propósito do experimento era o de apenas verificar a resistência do catalisador, a variação do volume de etanol PA por minuto foi feita ininterruptamente, sem substituição da zeólita. Assim, iniciou-se a reação com um fluxo de $0,03 \mathrm{~mL} \mathrm{~min}^{-1}$ durante $1 \mathrm{~h}$ sobre $0,1 \mathrm{~g}$ da zeólita desaluminizada. Consecutivamente, a cada hora, a quantidade de álcool injetada foi aumentada para $0,05,0,10,0,15,0,18,0,20$ e $0,22 \mathrm{~mL} \mathrm{~min}^{-1}$. A Tabela 7 e os gráficos das Figuras 42 e 43 resumem os dados encontrados de conversão, seletividade e WHSV durante as $7 \mathrm{~h}$ reacionais.

Tabela 7: Dados obtidos de conversão, seletividade e WHSV para a variação do fluxo de etanol PA, a cada hora de reação, sobre $0,1 \mathrm{~g}$ da zeólita $\mathrm{Y}(80) 5 \mathrm{C}$.

\begin{tabular}{|c|c|c|c|c|}
\hline $\begin{array}{c}Q_{\text {etano }}{ }^{a} \\
\left(\mathrm{~mL} \mathrm{~min}^{-1}\right)\end{array}$ & $\begin{array}{c}V_{\text {etanol }}^{b} \\
(\mathrm{~mL})\end{array}$ & $\begin{array}{l}R_{m e ́ d i a}{ }^{c} \\
(\% \mathrm{~m} / \mathrm{m})\end{array}$ & $\begin{array}{c}S_{\text {média }}{ }^{d} \\
(\% \mathrm{~m} / \mathrm{m})\end{array}$ & $\begin{array}{c}\text { WHSV }^{\text {e }} \\
\left(h^{-1}\right)\end{array}$ \\
\hline 0,03 & 1,8 & 100,0 & 100,0 & 14,2 \\
\hline 0,05 & 5,0 & 99,9 & 100,0 & 23,7 \\
\hline 0,10 & 7,5 & 96,7 & 94,3 & 47,3 \\
\hline 0,15 & 11,3 & 77,0 & 60,4 & 71,0 \\
\hline 0,18 & 13,5 & 81,4 & 57,6 & 85,2 \\
\hline 0,20 & 15,0 & 78,3 & 52,7 & 94,7 \\
\hline 0,22 & 12,1 & 78,2 & 52,2 & 104,1 \\
\hline
\end{tabular}

${ }^{a}$ Fluxo de etanol; ${ }^{b}$ Volume de etanol injetado; ${ }^{\circ}$ Conversão média; ${ }^{d}$ Seletividade média para etileno; ${ }^{\mathrm{e}}$ Weight Hourly Space Velocity.

Como pode ser observado, uma conversão de $78,2 \%$ é obtida mesmo com um fluxo bastante alto de etanol em uma massa reduzida de catalisador. A zeólita comercial $\mathrm{Y}$ (pura) $\mathrm{C}$, nas mesmas $7 \mathrm{~h}$ de reação com fluxo único de $0,03 \mathrm{~mL} \mathrm{~min}{ }^{-1}$, apresentou conversão média de $74,6 \%$. Obviamente, utilizar um fluxo alto de reagente em apenas $0,1 \mathrm{~g}$ de sólido reduzirá o tempo de vida do catalisador, mas o experimento demonstra a robustez do material, que alcançou mais de $100 \mathrm{~h}^{-1}$ de velocidade espacial, mantendo pelo menos $50 \%$ de seletividade para o etileno. 


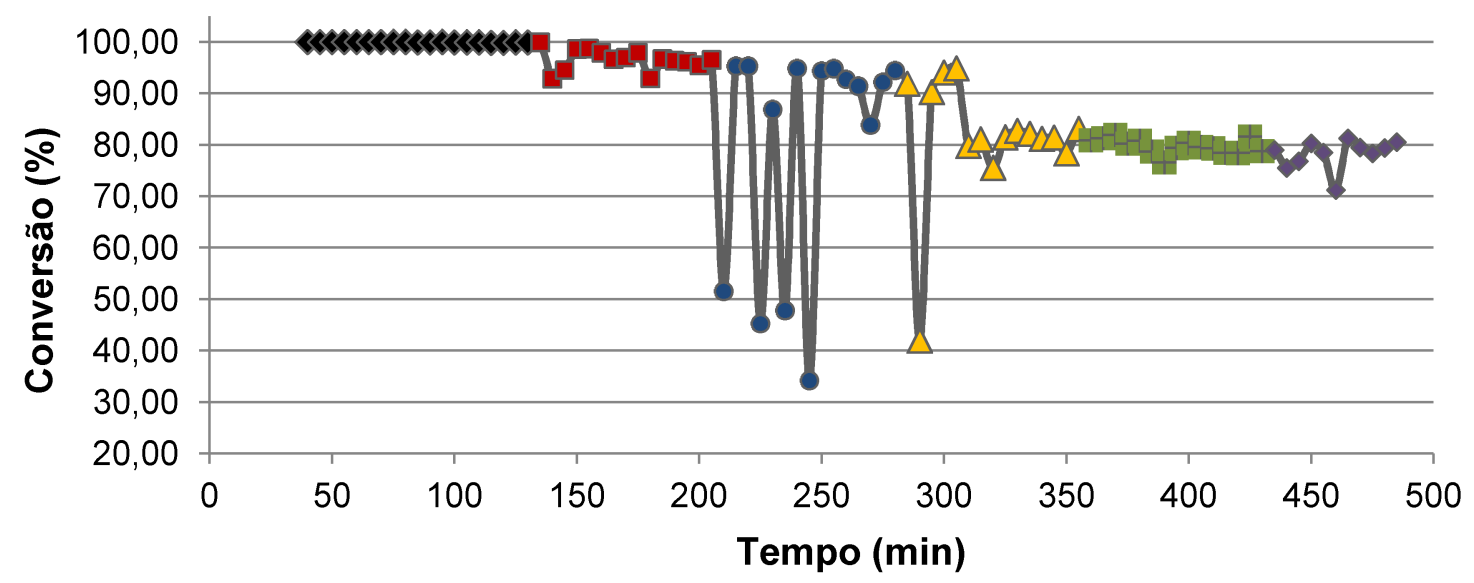

Figura 42: Gráfico de conversão em função do tempo obtido no teste de fluxo de etanol PA sobre o catalisador $\mathrm{Y}(80) 5 \mathrm{C}$. Os marcadores em preto representam um fluxo de 0,03 e $0,05 \mathrm{~mL} \mathrm{~min}^{-1}$; os vermelhos de $0,10 \mathrm{~mL} \mathrm{~min}^{-1}$; os azuis de $0,15 \mathrm{~mL} \mathrm{~min}^{-1}$; os amarelos de $0,18 \mathrm{~mL} \mathrm{~min}^{-1}$; os verdes de $0,20 \mathrm{~mL} \mathrm{~min}^{-1}$; e, os roxos de $0,22 \mathrm{~mL} \mathrm{~min}^{-1}$.

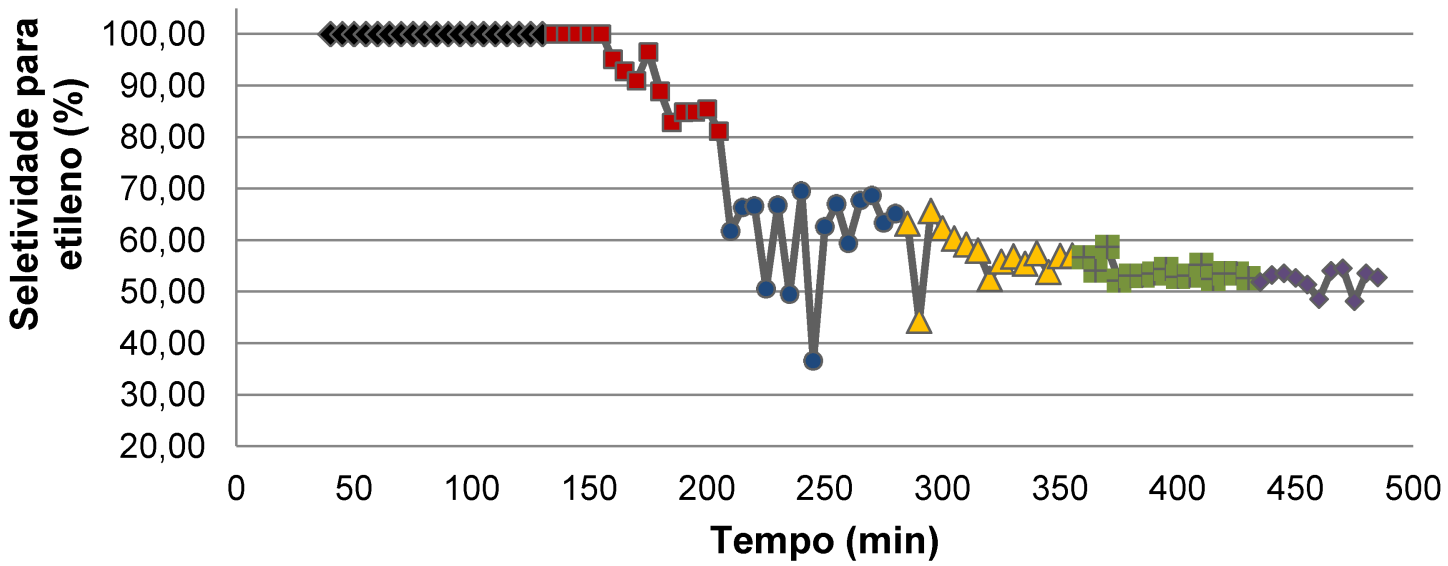

Figura 43: Gráfico de seletividade para etileno em função do tempo obtido no teste de fluxo de etanol PA sobre o catalisador $\mathrm{Y}(80) 5 \mathrm{C}$. Os marcadores em preto representam um fluxo de 0,03 e $0,05 \mathrm{~mL} \mathrm{~min}^{-1}$; os vermelhos de $0,10 \mathrm{~mL} \mathrm{~min}^{-1}$; os azuis de $0,15 \mathrm{~mL}$ $\mathrm{min}^{-1}$; os amarelos de $0,18 \mathrm{~mL} \mathrm{~min}^{-1}$; os verdes de $0,20 \mathrm{~mL} \mathrm{~min}^{-1}$; e, os roxos de 0,22 $\mathrm{mL} \min ^{-1}$.

\subsubsection{Desidratação do Bioetanol}

Uma amostra de bioetanol com 93,0\% de pureza, vendida em postos de gasolina do Distrito Federal, foi utilizada como reagente da reação de desidratação. No caso da zeólita $\mathrm{Y}(\mathrm{pura}) \mathrm{C}, 0,1 \mathrm{~g}$ do sólido foram testados na reação durante $48 \mathrm{~h}$, gerando os gráficos de conversão e seletividade das Figuras 44 e 45, respectivamente, que correspondem à conversão média de $81,5 \%$ e à seletividade média para etileno de $78,8 \%$. Após $24 \mathrm{~h}$ reacionais, é visível a queda na formação de produtos, principalmente na produção de etileno. 


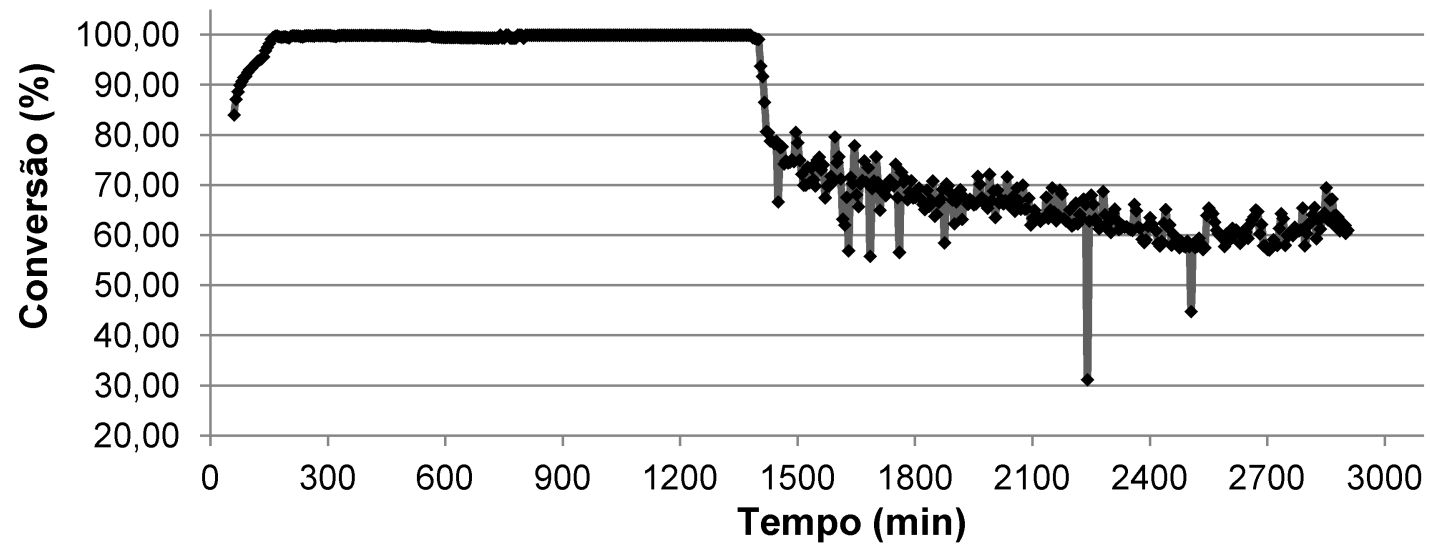

Figura 44: Gráfico de conversão em função do tempo para a reação de desidratação do bioetanol hidratado, utilizando como catalisador $0,1 \mathrm{~g}$ da zeólita Y(pura)C.

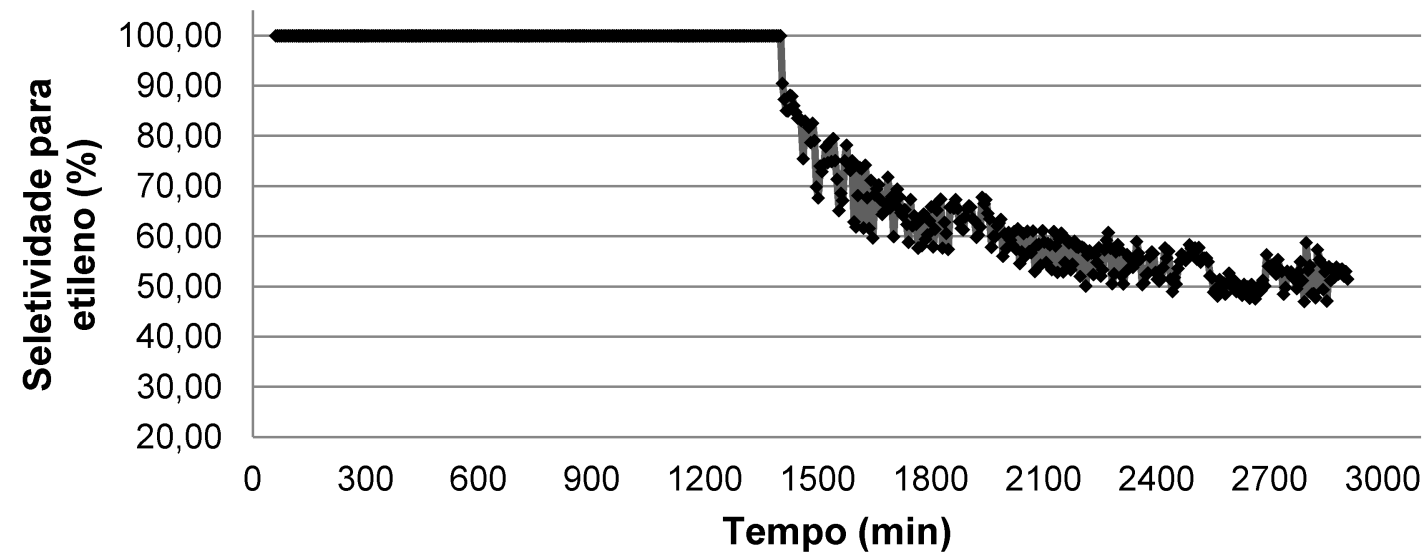

Figura 45: Gráfico de seletividade em função do tempo para a reação de desidratação do bioetanol hidratado, utilizando como catalisador $0,1 \mathrm{~g}$ da zeólita Y(pura)C.

Para a zeólita desaluminizada $\mathrm{Y}(80) 5 \mathrm{C}, 0,1 \mathrm{~g}$ do sólido foram testados na reação durante $75 \mathrm{~h}$, gerando os gráficos de conversão e seletividade ilustrados nas Figuras 46 e 47, respectivamente, correspondentes a uma conversão média de $98,0 \%$ e seletividade média para etileno de 94,2\%.

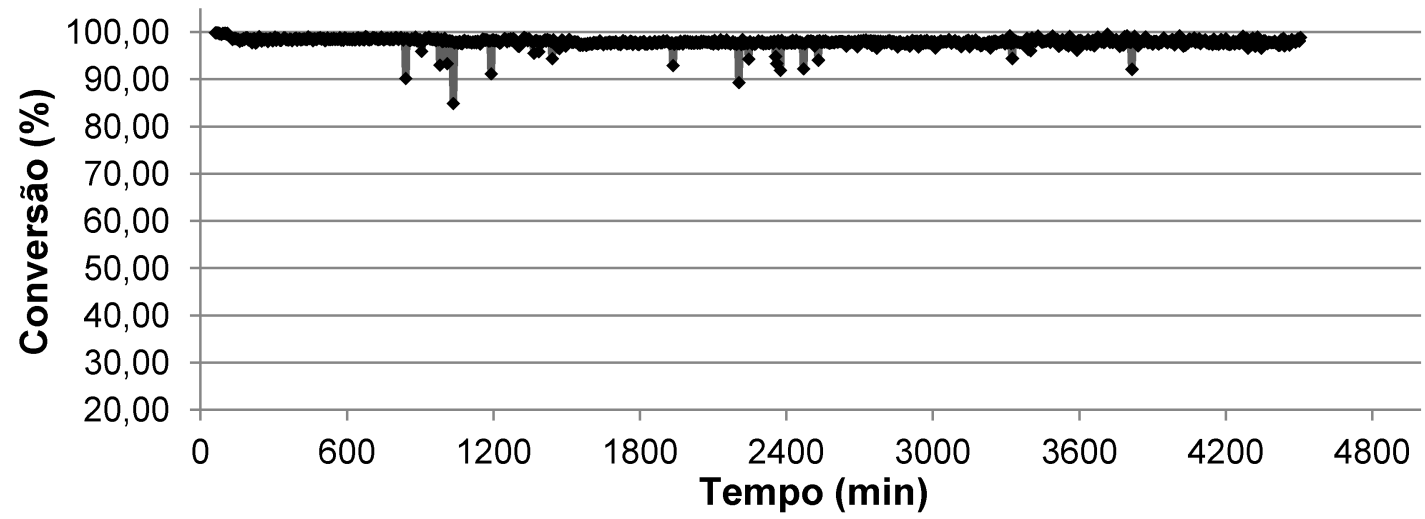

Figura 46: Gráfico de conversão em função do tempo para a reação de desidratação do bioetanol hidratado, utilizando como catalisador $0,1 \mathrm{~g}$ da zeólita $\mathrm{Y}(80) 5 \mathrm{C}$. 


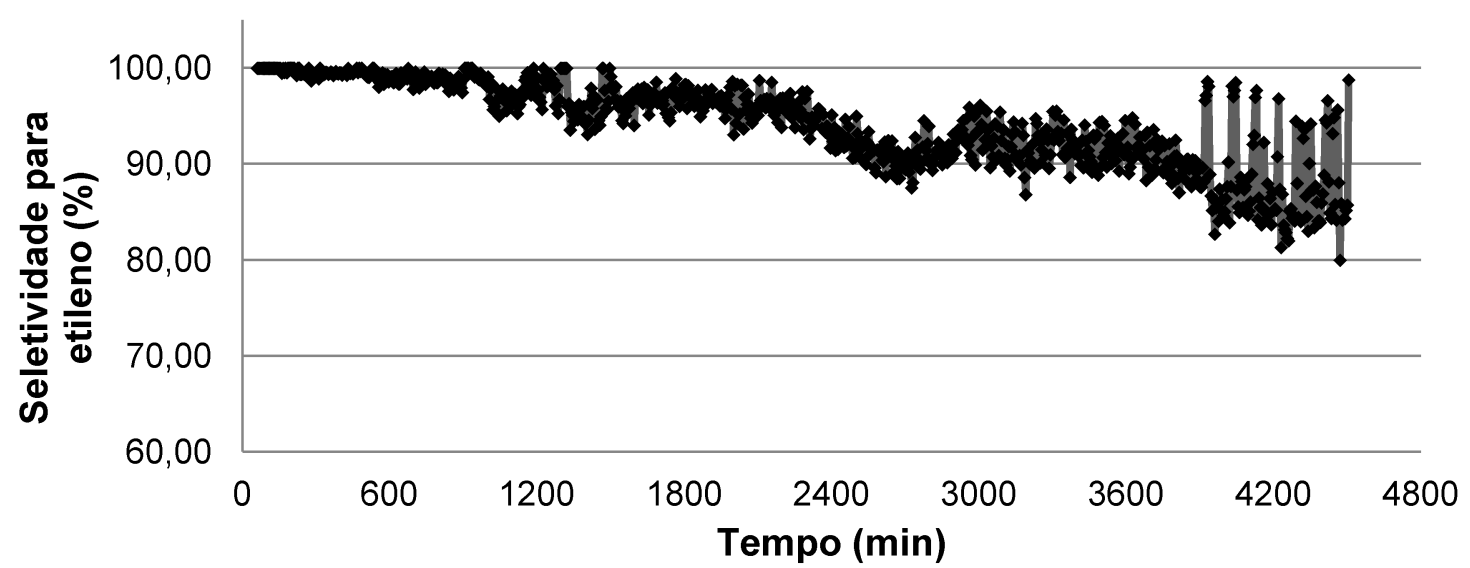

Figura 47: Gráfico de seletividade em função do tempo para a reação de desidratação do bioetanol hidratado, utilizando como catalisador $0,1 \mathrm{~g}$ da zeólita $\mathrm{Y}(80) 5 \mathrm{C}$.

Apesar de não apresentar $100 \%$ de conversão e ser $100 \%$ seletiva para etileno como a $\mathrm{Y}$ (pura)C nas primeiras $24 \mathrm{~h}$ reacionais, a amostra desaluminizada mostrou alta resistência no tempo total investigado, exibindo uma taxa de conversão praticamente constante. A Tabela 8 resume os dados encontrados para as desidratações feitas com etanol PA e bioetanol hidratado.

Tabela 8: Dados de conversão, seletividade para etileno e eficiência catalítica para $42 \mathrm{~h}$ de reação de desidratação do etanol PA e do bioetanol, utilizando a zeólita $Y$ padrão e a zeólita desaluminizada como catalisadores.

\begin{tabular}{|c|c|c|c|c|}
\hline Amostra & $\begin{array}{c}R_{\text {média }}{ }^{\mathrm{a}} \\
(\% \mathrm{~m} / \mathrm{m})\end{array}$ & $\begin{array}{c}S_{\text {média }}{ }^{\mathrm{b}} \\
(\% \mathrm{~m} / \mathrm{m})\end{array}$ & $\begin{array}{l}n_{\text {Sitios Ácidos }}{ }^{c} \\
\left(\mathrm{mmol} \mathrm{g}^{-1}\right)\end{array}$ & $\underset{\left(\text { mol }_{\text {etileno }} \mathrm{h}^{-1} \mathrm{~mol}^{-1}{ }_{\text {cat }}\right)}{\text { TOF }^{\mathrm{d}}}$ \\
\hline $\begin{array}{l}\text { Y(pura)C } \\
\text { Etanol PA }\end{array}$ & 65,0 & 97,2 & \multirow{2}{*}{1,0911} & 183,9 \\
\hline $\begin{array}{l}\text { Y(pura)C } \\
\text { Bioetanol }\end{array}$ & 84,7 & 83,1 & & 254,7 \\
\hline $\begin{array}{l}\mathrm{Y}(80) 5 \mathrm{C} \\
\text { Etanol PA }\end{array}$ & 91,1 & 98,2 & \multirow{2}{*}{1,1088} & 244,6 \\
\hline $\begin{array}{l}\mathrm{Y}(80) 5 \mathrm{C} \\
\text { Bioetanol }\end{array}$ & 98,0 & 97,4 & & 621,7 \\
\hline
\end{tabular}

${ }^{a}$ Conversão média; ${ }^{b}$ Seletividade média para etileno; ${ }^{c}$ Número de sítios ácidos calculados por meio da adsorção de piridina gasosa nos sólidos e posterior análise por TG/DTG; ${ }^{\mathrm{d}}$ Turnover frequency.

O tempo estabelecido para as comparações foi de $42 \mathrm{~h}$ reacionais, que corresponde ao menor período estudado nesse trabalho. Como pode ser visto, para ambos os catalisadores, houve um aumento de conversão em relação à reação feita com etanol PA, com queda acentuada nos valores de seletividade somente para a $\mathrm{Y}$ comercial. A elevação no grau de conversão está 
relacionada com a menor proporção de etanol que passa pelo sólido $(7 \%$ a menos em relação ao etanol PA), provocando uma menor saturação do material. Por outro lado, a maior concentração de água e/ou impurezas no reagente podem ter bloqueado parte dos centros ácidos fortes do catalisador Y(pura)C, favorecendo a reação menos energética: a de formação do subproduto dietil éter. A diminuição de seletividade constatada para a zeólita desaluminizada foi de apenas $0,8 \%$ e está dentro do erro experimental, ficando visível sua maior resistência frente a possíveis venenos/inibidores catalíticos.

Após a reação com bioetanol, as amostras foram recuperadas e calcinadas a $550{ }^{\circ} \mathrm{C}$, durante $8 \mathrm{~h}$, assim como feito após a desidratação do etanol PA. Entretanto, apenas a $\mathrm{Y}(80) 5 \mathrm{C}$ voltou a apresentar a coloração branca típica da zeólita, livre de coque, em praticamente toda a massa calcinada. A Y de partida exibiu coloração acinzentada (vide Figura 48), contendo ainda $3,08 \%$ de carbono, valor calculado por $\mathrm{CHN}$.

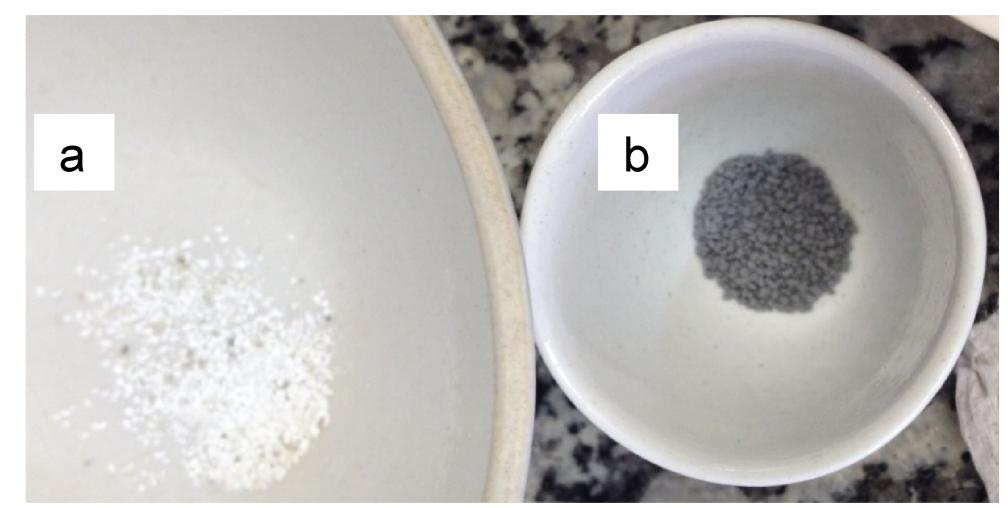

Figura 48: Catalisadores $\mathrm{Y}(80) 5 \mathrm{C}$ (a) e $\mathrm{Y}($ pura $) \mathrm{C}$ (b) submetidos à desidratação de bioetanol com posterior recuperação por calcinação a $550{ }^{\circ} \mathrm{C}$ durante $8 \mathrm{~h}$.

No difratograma da Figura 49, pode-se observar uma ausência total de cristalinidade da $Y$ (pura)C após esta ser submetida à reação com bioetanol $e$ ao tratamento térmico. A persistência de coque e a destruição estrutural comprovam que a zeólita foi fortemente afetada pela presença de água e impurezas contidas no álcool. No caso da zeólita $Y(80) 5 C$, a estrutura foi mantida (Figura 50). Entretanto, assim como na desidratação com etanol PA, a amostra apresentou um alargamento de banda na faixa entre 10 e $20^{\circ}$, mostrando que as três primeiras reflexões [220], [311] e [331], utilizadas para o cálculo de cristalinidade, ${ }^{18,144}$ são aquelas mais afetadas na estrutura zeolítica 
após o catalisador ser submetido às reações de desidratação e à posterior calcinação.

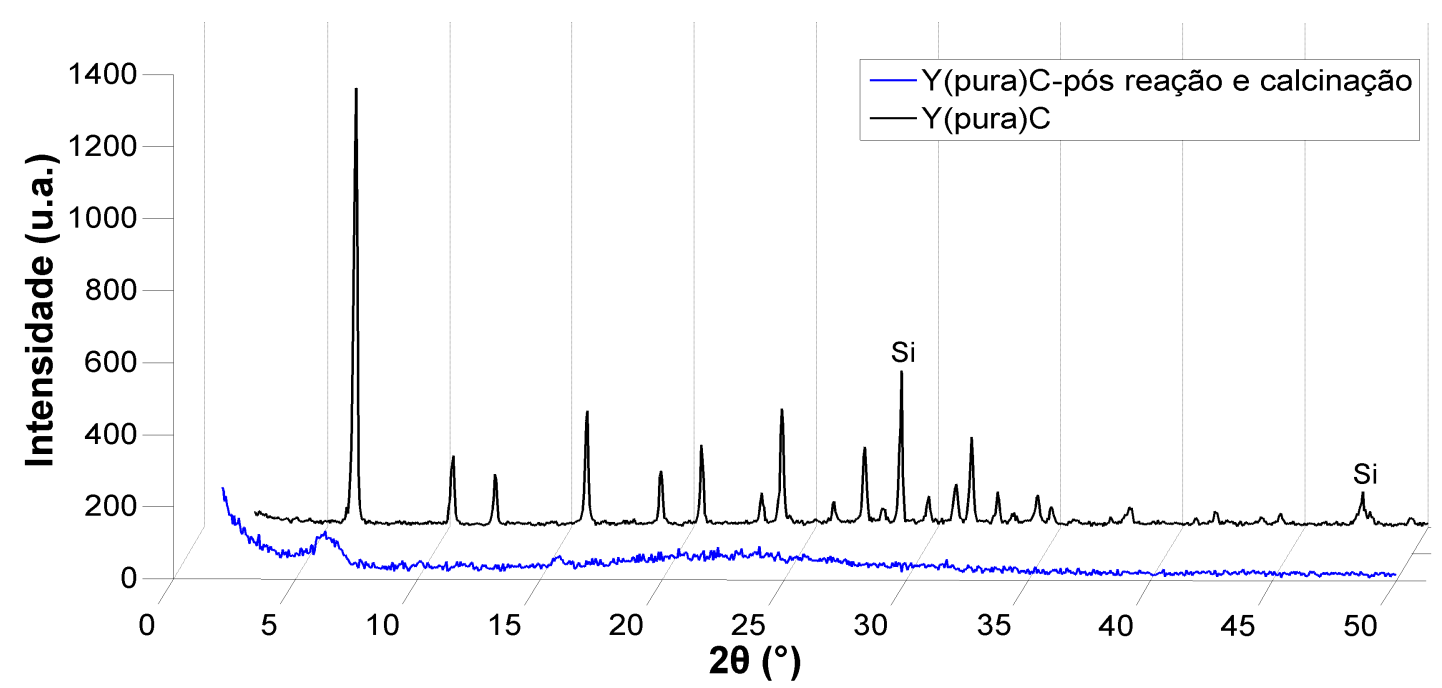

Figura 49: Difratograma da amostra $\mathrm{Y}$ (pura)C (preto), antes da reação de desidratação do bioetanol e com padrão interno de Si elementar, ${ }^{18}$ e da mesma amostra após reação e calcinação (azul).

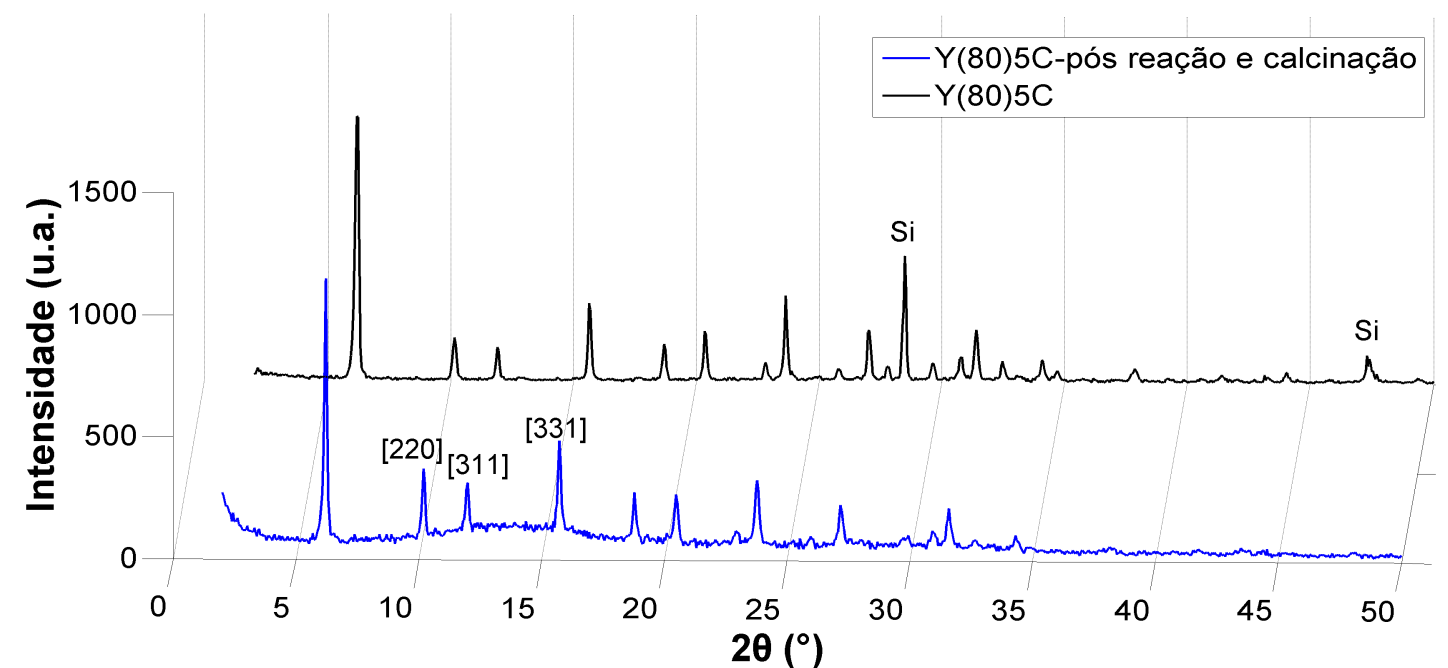

Figura 50: Difratograma da amostra $Y(80) 5 C$ (preto), antes da reação de desidratação do bioetanol e com padrão interno de Si elementar, ${ }^{18}$ e da mesma amostra após reação e calcinação (azul).

Para o cálculo do número de sítios ácidos dos catalisadores recuperados, foi feita uma nova adsorção de Py com análise via TG/DTG. As curvas TG/DTG podem ser observadas nas Figuras 51 e 52 com as mesmas transições encontradas nas Figuras 40 e 41, referentes à adsorção de Py nos catalisadores recuperados da reação de desidratação do etanol PA. Entretanto, 
após a reação com bioetanol hidratado, a Y(pura)C foi capaz de adsorver quimicamente menores quantidades da base, apresentando apenas $0,3887 \mathrm{mmol} \mathrm{g}^{-1}$ de centros ativos remanescentes, enquanto a $\mathrm{Y}(80) 5 \mathrm{C}$ mostrou $0,7631 \mathrm{mmol} \mathrm{g}^{-1}$ de sítios ácidos. Como visto, o dobro de sítios ácidos foram preservados na amostra desaluminizada em relação à $Y($ pura $) C$, mesmo com a primeira tendo sido submetida a um período reacional mais longo. Assim, o catalisador modificado demonstrou ter alto potencial em reações contendo água, mantendo sua atividade $30 \mathrm{~h}$ a mais que a zeólita de partida.

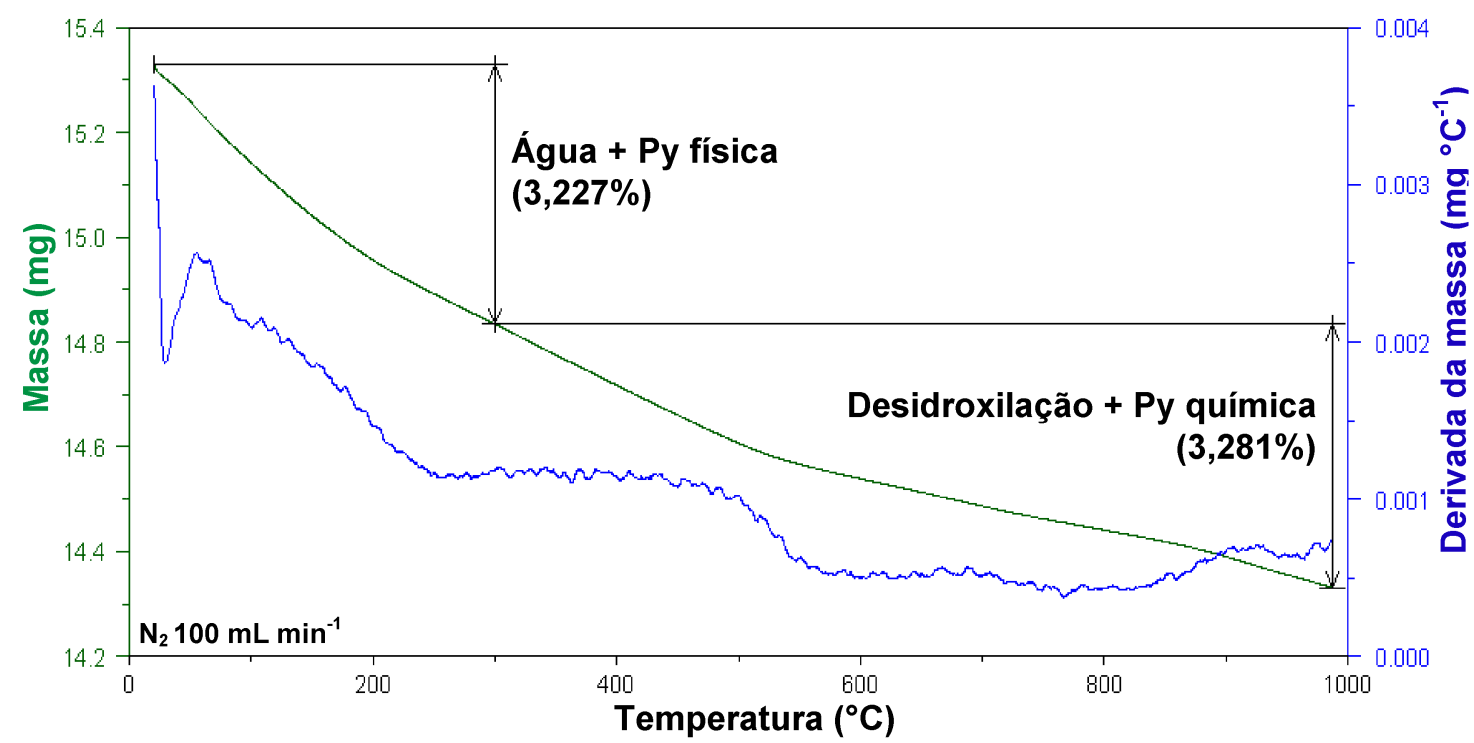

Figura 51: Curvas TG/DTG da amostra $Y($ pura)C recuperada e calcinada após reação de desidratação com bioetanol hidratado com posterior adsorção de Py gasosa.

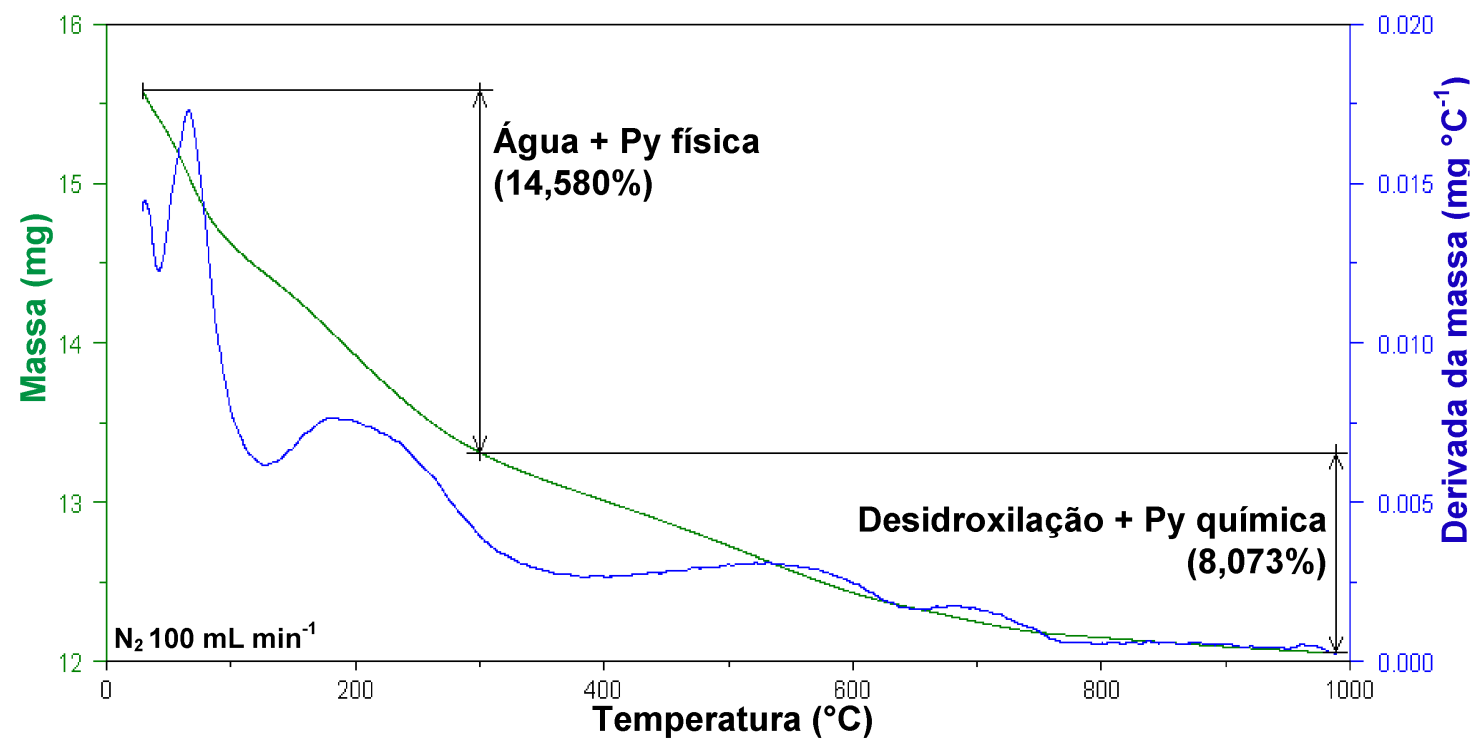

Figura 52: Curvas TG/DTG da amostra $Y(80) 5 \mathrm{C}$ recuperada e calcinada após reação de desidratação com bioetanol hidratado com posterior adsorção de Py gasosa. 


\section{- Teste da Modificação da Pressão do Reator}

A fim de testar a resistência da amostra $Y(80) 5 C$ frente a diferentes condições reacionais, a pressão do sistema foi elevada mais que quatro vezes em relação ao experimento anterior com o bioetanol, o que resultou no valor de $724,0 \mathrm{kPa}$ (ou, aproximadamente, 7,0 atm). Nesse caso, um volume total de $80,0 \mathrm{~mL}$ do bioálcool foi injetado no catalisador e os resultados de conversão e seletividade para etileno podem ser vistos nos gráficos das Figuras 53 e 54 e na Tabela 9.

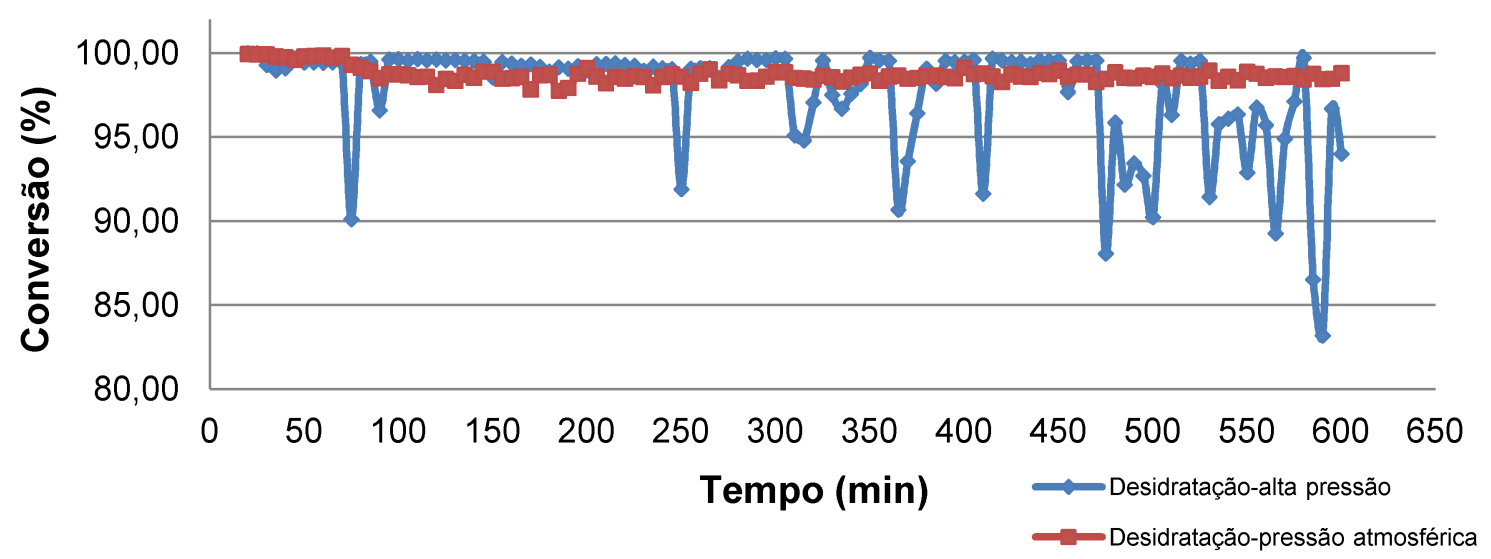

Figura 53: Gráfico de conversão em função do tempo para a reação de desidratação do bioetanol hidratado à pressão de $7,0 \mathrm{~atm}$ (azul), em comparação com a desidratação feita à pressão atmosférica (vermelho), utilizando como catalisador $0,1 \mathrm{~g}$ da zeólita $Y(80) 5 C$.

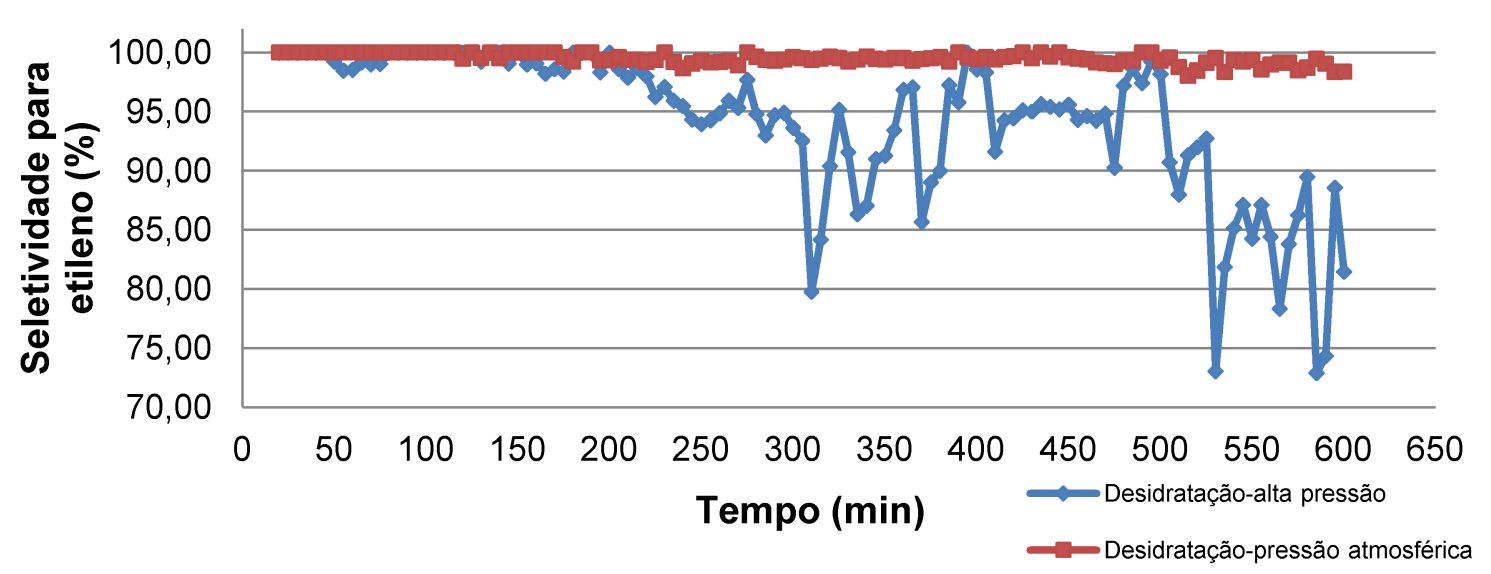

Figura 54: Gráfico de seletividade em função do tempo para a reação de desidratação do bioetanol hidratado à pressão de $7,0 \mathrm{~atm}$ (azul), em comparação com a desidratação feita à pressão atmosférica (vermelho), utilizando como catalisador $0,1 \mathrm{~g}$ da zeólita $Y(80) 5 \mathrm{C}$.

Altas pressões aumentam as chances de colisão entre as espécies químicas e, consequentemente, favorecem maiores valores de conversão, mas 
é possível perceber também um aumento da variação desses valores em comparação àqueles encontrados para a reação em pressão atmosférica. Mesmo assim, uma alta conversão média, de $97,7 \%$, foi obtida, com $94,3 \%$ de seletividade média para a olefina (Tabela 9). Com o passar do tempo, a pressurização do sistema provocou a rápida desativação do catalisador, aumentando a produção de dietil éter.

Tabela 9: Dados de conversão e seletividade para etileno, obtidos na desidratação de $80,0 \mathrm{~mL}$ de bioetanol em alta pressão e em pressão atmosférica.

\begin{tabular}{c|c|c}
\hline Amostra & $\begin{array}{c}\boldsymbol{R}_{\text {média }}{ }^{\mathbf{a}} \\
(\% \mathbf{~ m} / \mathbf{m})\end{array}$ & $\begin{array}{c}\boldsymbol{S}_{\text {média }}{ }^{\text {b }} \\
(\% \mathbf{~ m / m})\end{array}$ \\
\hline $\mathrm{Y}(80) 5 \mathrm{C}$ - Pressão atm & 98,4 & 98,9 \\
\hline $\mathrm{Y}(80) 5 \mathrm{C}$ - Alta pressão & 97,7 & 94,3 \\
\hline
\end{tabular}

${ }^{a}$ Conversão média; ${ }^{b}$ Seletividade média para etileno.

\subsubsection{Desidratação de Alcoóis via Microrreator de Pulso}

\subsubsection{Desenvolvimento e Montagem do Microrreator de Pulso}

O microrreator de pulso proposto nesse trabalho é uma modificação feita em equipamentos de CG. Nesses equipamentos, há uma câmara de injeção imediatamente abaixo do autoinjetor de amostras, na qual é possível optar pelos sistemas de injeção split ou splitless. Em ambos os casos, um pequeno tubo de borossilicato (ou de quartzo), chamado liner, contendo lã de vidro inativa, auxilia na vaporização das amostras e serve como passagem para os gases até a coluna cromatográfica. A Figura 55 mostra o tubo de vidro presente na câmara de injeção de um cromatógrafo gasoso.
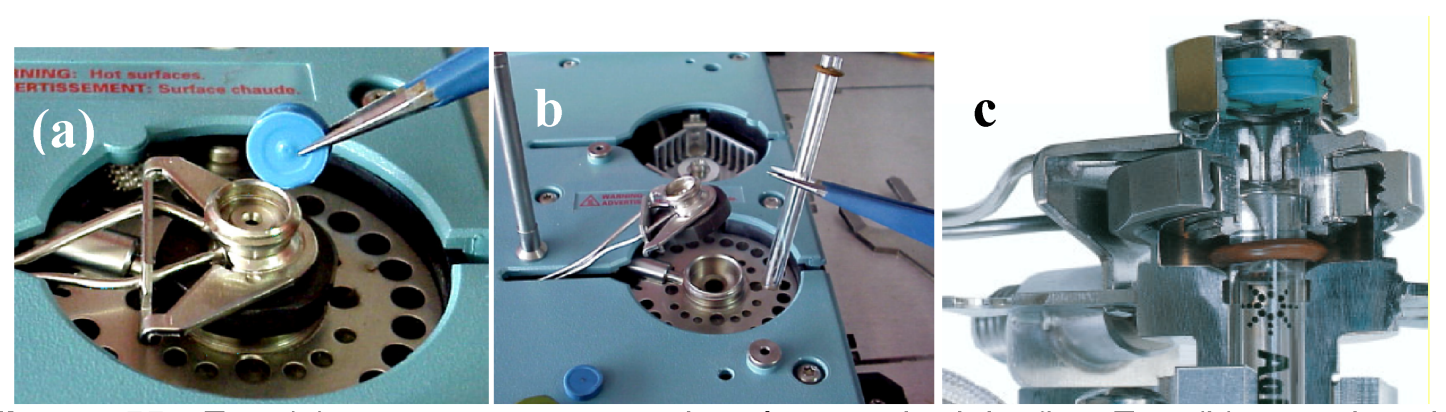

Figura 55: Em (a), a parte externa da câmara de injeção. Em (b), o tubo de borossilicato localizado dentro da câmara por onde passa a amostra injetada para a coluna cromatográfica. Em (c), a parte interna da câmara de injeção contendo o liner. 
O liner permite que uma quantidade maior (sistema splitless) ou menor (sistema split) de amostra seja inserida na coluna. O sistema utilizado depende do método de análise adotado pelo usuário, que está diretamente relacionado com a quantidade de analito presente na amostra. As Figuras 56 e 57 ilustram a montagem da câmara de injeção e o funcionamento do sistema split, respectivamente.

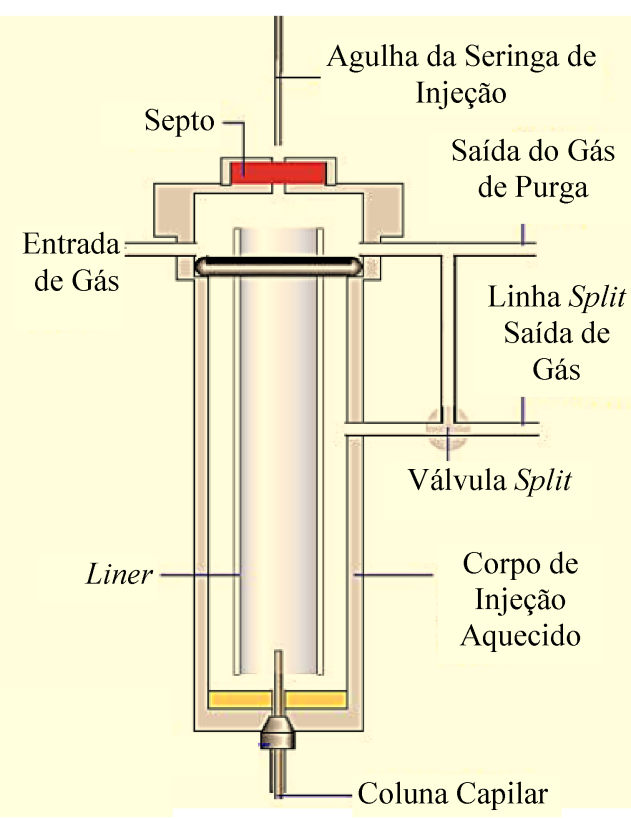

Figura 56: Ilustração da montagem interna da câmara de injeção de um cromatógrafo gasoso.

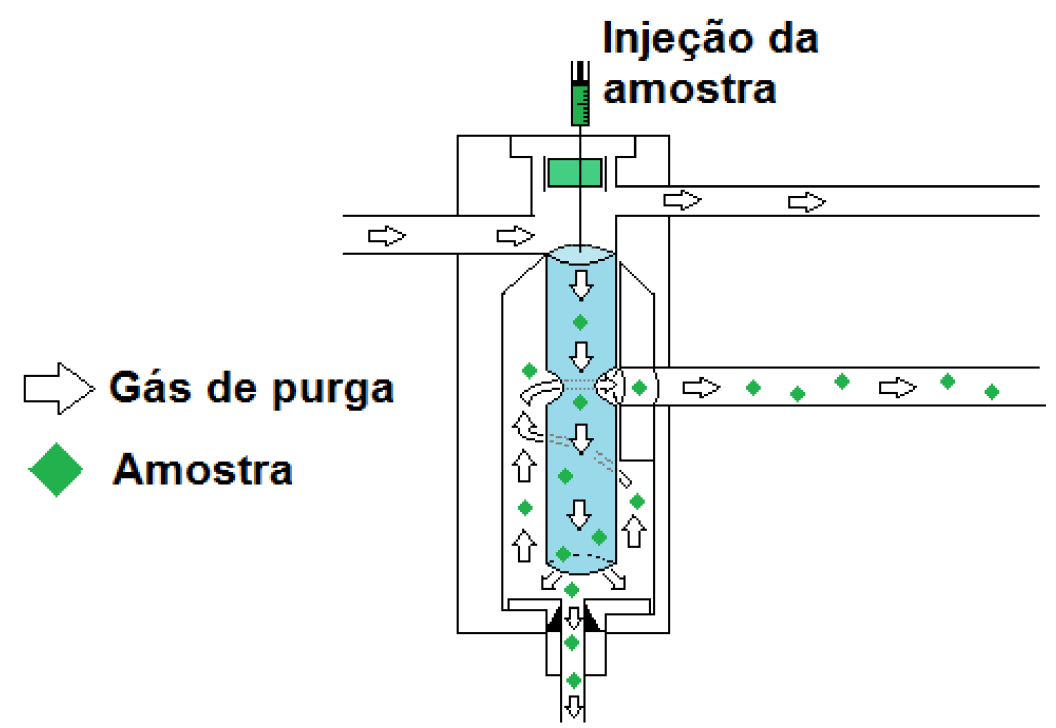

\section{Coluna}

Figura 57: Esquema simplificado do funcionamento do sistema split, em que somente uma parte do analito é injetada na coluna cromatográfica. 
$\mathrm{Na}$ adaptação realizada no cromatógrafo gasoso, o liner foi utilizado como um microrreator, onde uma massa previamente pesada de catalisador (em pellets ou em pó) foi colocada em seu interior, formando um leito fixo catalítico entre porções de lã de vidro (Figura 58). Assim, o reagente desejado em fase líquida é inserido na câmara de injeção, manualmente ou via autoinjetor, volatiliza-se com auxílio da lã de vidro na temperatura reacional escolhida, e, depois, passa pelo catalisador no interior do liner. Após interação com o catalisador, as moléculas reagentes são convertidas em produtos. Estes, caso sejam também voláteis na temperatura estudada, são transferidos para a coluna cromatográfica pelo gás de arraste e determinados pelo método de análise adotado pelo usuário. Se produtos não voláteis forem formados na temperatura reacional trabalhada, eles ficarão retidos no tubo, desativando o catalisador.

Assim como nas análises de CG, o método de análise do usuário deve ser previamente elaborado com parâmetros pré-definidos (por exemplo, pressão, temperatura, quantidade a ser injetada, etc.), de forma a evitar a coeluição de dois ou mais produtos. A injeção do reagente no catalisador pode ser feita diversas vezes e consecutivamente, podendo, então, gerar gráficos de conversão e seletividade do catalisador estudado.

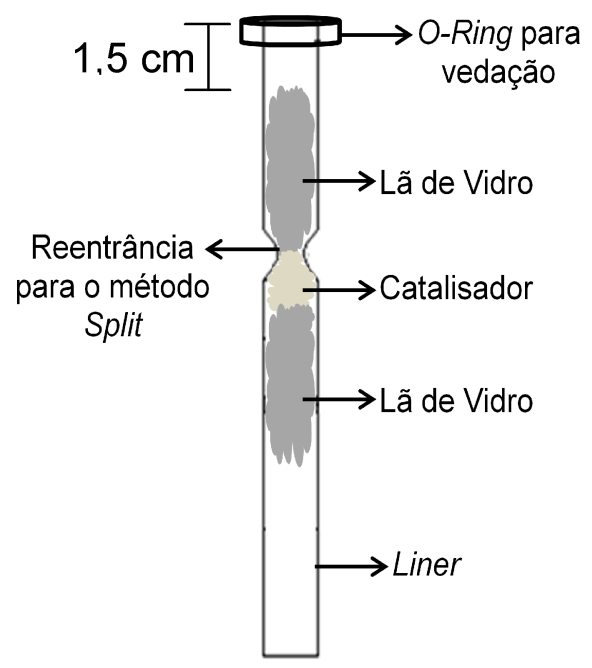

Figura 58: Esquema ilustrando o empacotamento do leito fixo no liner utilizado como microrreator.

Portanto, de acordo com a metodologia do microrreator de pulso proposto, torna-se possível fazer e analisar reações in situ, na temperatura 
escolhida (dentro da faixa permitida pelo equipamento de CG), quando um reagente a ser volatilizado é convertido em um ou vários produtos voláteis, como é o caso, por exemplo, de reações de desidratação de alcoóis, condensação da acetona, etc.

Como mostrado na Figura 58, a primeira camada da lã de vidro deve ser colocada a aproximadamente $1,5 \mathrm{~cm}$ da entrada do liner, de forma a garantir que a seringa de injeção (manual ou do autoinjetor) não entre em contato com a lã de vidro, mas fique o mais próximo possível dela para permitir que o reagente no estado líquido seja vaporizado rapidamente. A espessura do leito catalítico dependerá do tipo de catalisador e da sua massa a ser utilizada. Já a segunda porção de lã de vidro, além de servir para manter os reagentes no estado gasoso, auxilia na sustentação do leito catalítico, evitando que o catalisador saia do liner e contamine o equipamento. A quantidade de lã de vidro a ser colocada dentro do tubo pode ser escolhida pelo usuário, mas, em um liner padrão, com 9,5 cm de comprimento, há uma quantidade ótima estudada, em que $1,5 \mathrm{~cm}$ do comprimento do tubo são preenchidos sem compactar demasiadamente a lã. Para comparações entre catalisadores utilizando o microrreator de pulso, é recomendável que o tubo seja empacotado sempre com a mesma quantidade/comprimento de lã de vidro, de forma a garantir as mesmas condições para todas as amostras.

Sugere-se que o empacotamento do leito fixo no microrreator seja feito de acordo com os seguintes passos:

1- na abertura do topo do liner, aquela com menor comprimento até a reentrância para split, insere-se a primeira camada de lã de vidro até que a mesma se posicione a $1,5 \mathrm{~cm}$ do topo do tubo. Deve-se evitar o empacotamento compacto da lã, caso contrário, haverá maiores limitações de difusão do reagente para o catalisador. No caso de tubos sem reentrâncias (splitless), basta escolher uma das aberturas para posicionar a lã de vidro, observando a distância de $1,5 \mathrm{~cm}$ do bocal escolhido.

2- virando o tubo para que a parte com lã de vidro fique voltada para baixo, acrescenta-se a massa de catalisador desejada.

3- ainda com o tubo virado, insere-se a segunda camada de lã de vidro, de forma que a massa de catalisador adicionada fique retida entre as duas 
porções de lã. Assim como no item 2, deve-se evitar a compactação dos materiais, possibilitando que os reagentes gasosos passem sem grandes impedimentos pelo liner até a coluna cromatográfica.

É importante ressaltar que alguns catalisadores podem exercer forte pressão no interior do liner quando aquecidos devido à liberação de água fisicamente e/ou quimicamente adsorvida do sólido. Caso isso aconteça, a lã de vidro será deslocada dentro do tubo, podendo contaminar o equipamento e/ou não permitir que a análise seja realizada. Para evitar esse problema, sólidos muito finos e/ou muito hidrofílicos devem ser peletizados.

Raros são os artigos que utilizaram metodologia de microrreatores de pulso iguais à proposta nesse trabalho. Em uma vasta busca na literatura, apenas 3 pesquisas empregaram tecnologia análoga, ${ }^{120,121,145}$ mas, em nenhum desses casos, o reator foi utilizado na reação de desidratação de alcoóis. No primeiro caso, Choudhary, ${ }^{120}$ em 1977, descreveu um método de microrreator de pulso semelhante, porém o autor precisou fazer modificações em um equipamento de CG diferente dos comercializados atualmente, contendo duas seringas de injeção, assim como ilustram as Figuras 59 e 60. Segundo ele, pequenas variações de temperatura podem ocorrer no microrreator no caso de reações muito exotérmicas ou endotérmicas. Entretanto, essas mudanças são muito pequenas e podem ser negligenciadas.

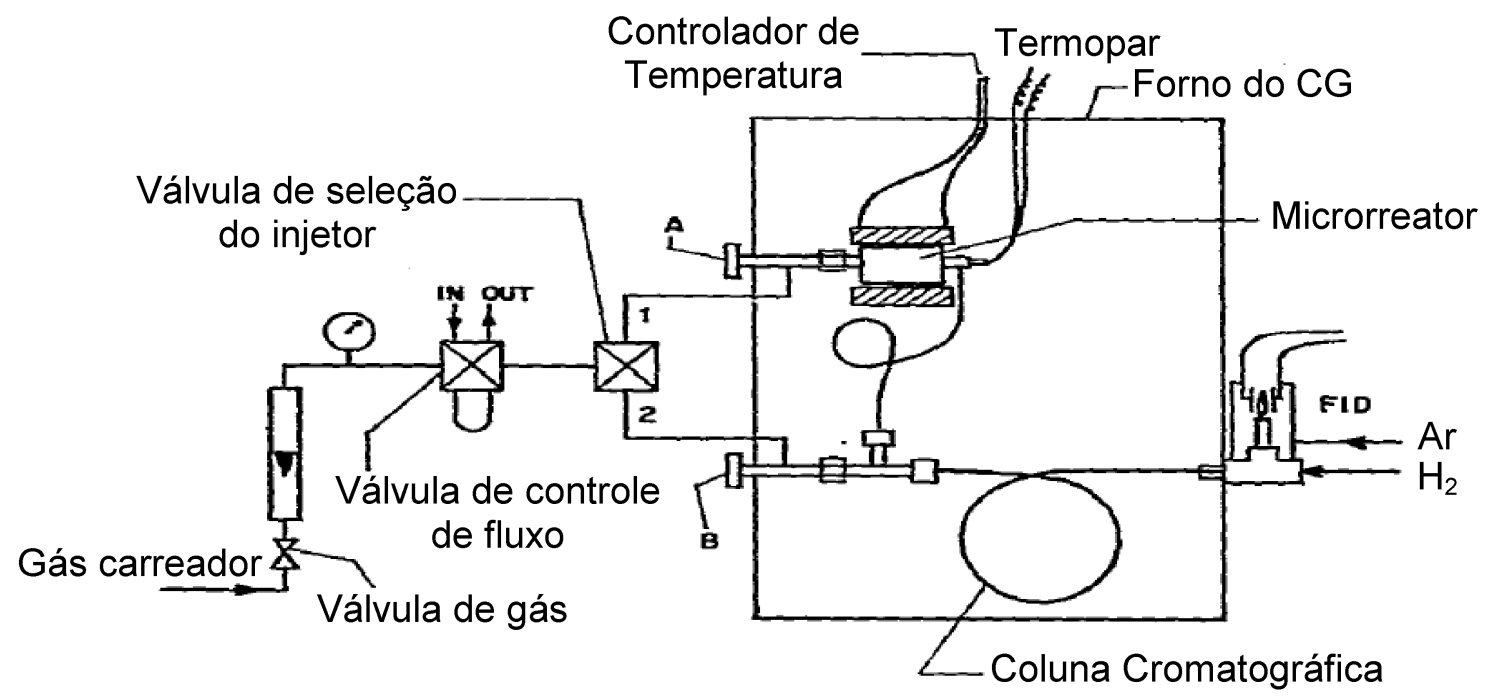

Figura 59: Diagrama esquemático do microrreator desenvolvido por Choudhary combinado com a cromatografia gasosa. ${ }^{120}$ Nesse caso, dois injetores (A e B) estão presentes no CG. 


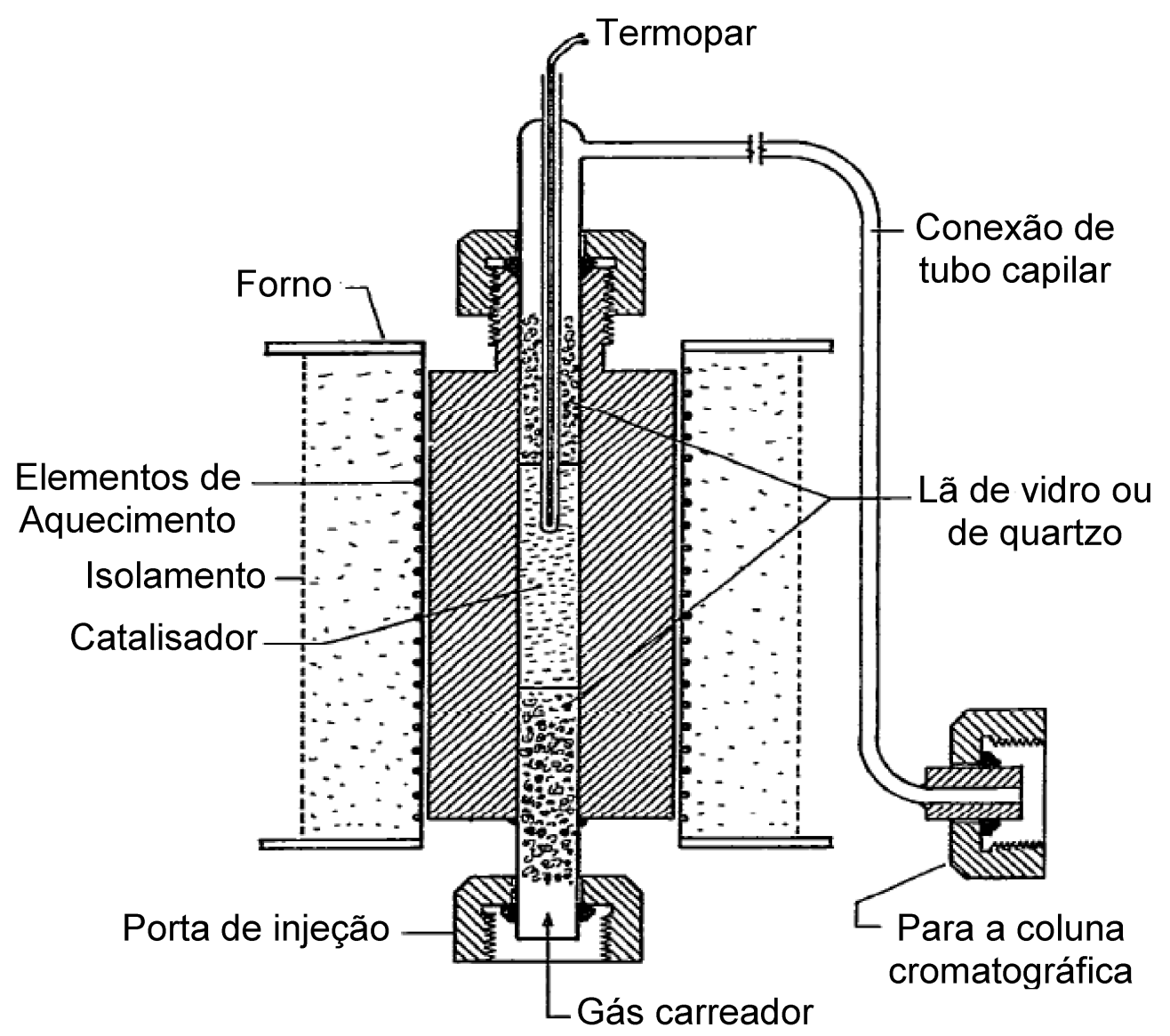

Figura 60: Detalhes do microrreator desenvolvido por Choudhary. ${ }^{120}$

No segundo trabalho encontrado, Reichle, ${ }^{121}$ em 1979, aplica essa técnica do microrreator de pulso acoplado internamente ao equipamento de CG para examinar a natureza do catalisador $\mathrm{MgO}$ suportado em alumina $(0,150 \mathrm{~g})$ por meio da reação da condensação da acetona. Todavia, o empacotamento do microrreator não foi detalhado. O último trabalho e mais recente (2006), de Ignatchenko e colaboradores, ${ }^{145}$ não utiliza o microrreator de pulso para uma reação de catálise heterogênea, mas estuda a interação de moléculas de água com a superfície de $0,04 \mathrm{~g}$ de zircônia e de titânia. A montagem do microrreator desenvolvida pelos autores é semelhante à proposta desse trabalho.

A partir desses três trabalhos supracitados, é possível notar que a aplicação da tecnologia do microrreator de pulso interno ao CG pode ser muito útil em diferentes casos, tanto para conduzir estudos de atividade catalítica de diversos materiais em catálise heterogênea, como para investigar a interação/adsorção de gases reagentes com a superfície de algum material. 


\subsubsection{Desidratação do Etanol em Diferentes Concentrações}

Utilizando o CG como microrreator de pulso, foram feitos estudos de conversão e seletividade do catalisador zeolítico desaluminizado Y(80)5C na desidratação do etanol, mas, agora, diluindo-se o etanol PA em água de forma a alcançar três diferentes concentrações: 25\%, 50\% e 75\% (v/v). Nesses casos, foram obtidos os resultados mostrados nos gráficos das Figuras A1 até A8 dos Apêndices desse trabalho. Para fins comparativos, a reação de desidratação com etanol a 99,8\% também foi testada no microrreator.

Inicialmente, antes do liner ser empacotado com catalisador, o padrão dos reagentes e produtos foi injetado no cromatógrafo nas condições préestabelecidas no CG. No método empregado, a coluna cromatográfica se manteve isotérmica a $60{ }^{\circ} \mathrm{C}$, e o detector teve sua temperatura elevada a 300 ${ }^{\circ} \mathrm{C}$. Com os valores de tempo de retenção determinados, os catalisadores foram previamente ativados durante $15 \mathrm{~min}$ a $300{ }^{\circ} \mathrm{C}$, mesma temperatura em que a reação se procedeu. Em seguida, foram realizadas 40 injeções (pulsos), de 0,2 $\mu \mathrm{L}$ cada uma, do etanol PA e das soluções em $20 \mathrm{mg}$ do catalisador. Essa massa correspondeu a uma espessura de $0,5 \mathrm{~cm}$ quando empacotada em um liner com 9,5 cm de altura e diâmetro de $3,4 \mathrm{~cm}$.

A massa escolhida de $20 \mathrm{mg}$ foi baseada em um estudo prévio, de maneira que diferentes catalisadores pudessem ser comparados entre si no que se refere a sua atividade catalítica ou potencial de adsorção. Todavia, outros valores de massa, inclusive menores, podem ser empregados. Müller, em um trabalho recente, ${ }^{32,146}$ utilizou apenas $1 \mathrm{mg}$ de catalisadores zeolíticos, como a Y, ZSM-5 e a mordenita, em reações de desidratação consecutivas de metanol, etanol, n-propanol e terc-butanol, gerando bons resultados de conversão e seletividade para posteriores comparações entre esses materiais.

Ficou constatado, entretanto, que pequenas variações na montagem do leito fixo do microrreator levam a tempos de retenção ligeiramente diferenciados de produtos e excesso de reagente no cromatograma, pois a pressão interna do leito pode variar, a depender do contato entre as moléculas gasosas e o catalisador sólido. Portanto, o empacotamento do microrreator deve ser rigorosamente efetuado de forma a evitar variações bruscas nas quantidades de massa (espessura do leito) e de lã de vidro inativa entre os 
testes catalíticos.

Como pode se observar na Tabela 10 e nos gráficos das Figuras A2, A4, A6 e A8, em todos os casos, foi possível alcançar conversões e seletividades médias acima de $78 \%$.

Tabela 10: Dados de intensidade, conversão e seletividade médios obtidos na produção de etileno a partir de diferentes concentrações de etanol.

\begin{tabular}{|c|c|c|c|}
\hline $\begin{array}{c}\mathrm{C}_{\text {etanol }}{ }^{\mathrm{a}} \\
(\%)\end{array}$ & $\begin{array}{l}I_{\text {média }}{ }^{\prime} \\
\text { (u.a.) }\end{array}$ & $\begin{array}{c}R_{\text {médio }}{ }^{\mathrm{c}} \\
(\%)\end{array}$ & $\begin{array}{c}S_{\text {médio }}{ }^{d} \\
(\%)\end{array}$ \\
\hline 25 & $4,4.10^{5}$ & 94,9 & 100,0 \\
\hline 50 & $9,1.10^{5}$ & 82,9 & 85,4 \\
\hline 75 & $1,0.10^{6}$ & 78,9 & 79,4 \\
\hline$\sim 100$ & $1,0.10^{6}$ & 93,5 & 78,1 \\
\hline
\end{tabular}

$\mathrm{Na}$ presença de mais água ( $25 \%$ de etanol), a reação, além de se manter com alta conversão, apresenta uma seletividade média superior para a produção de etileno. Isso ocorre porque a quantidade do etanol que passa pelo catalisador é reduzida, favorecendo a reação de produção de etileno e, consequentemente, gerando menos dietil éter. Portanto, nas 40 injeções feitas no microrreator, a água não se comportou como um veneno aos sítios ácidos da zeólita.

Em escala industrial, o uso de um sistema de reatores em paralelo, com menores injeções de álcool (em qualquer concentração disponível) em cada reator, otimizaria a produção de etileno, pois maiores seletividades para a olefina seriam alcançadas com uma desativação mais lenta do catalisador.

\subsubsection{Desidratação do 1-Propanol, do Isopropanol e do Terc-Butanol}

Utilizando ainda o microrreator de pulso desenvolvido nesse trabalho, os testes catalíticos com a zeólita desaluminizada foram expandidos por meio da desidratação de outros alcoóis, como o 1-propanol, o isopropanol e o terc-butanol, todos $\mathrm{PA}$, os quais geraram as bio-olefinas propileno e isobutileno. As condições de montagem do leito fixo foram as mesmas utilizadas na desidratação do etanol em solução. Entretanto, nesse caso, foram feitas 50 injeções do álcool, de 0,5 $\mathrm{LL}$ cada uma, na massa de $20 \mathrm{mg}$ das 
zeólitas padrão Y(pura)C e desaluminizada $\mathrm{Y}(80) 5 \mathrm{C}$. O aumento na quantidade de injeções foi feito na tentativa de melhorar a distinção entre as taxas de conversão e seletividade obtidas para esses catalisadores, uma vez que os alcoóis 1-propanol, o isopropanol e o terc-butanol são mais reativos que o etanol.

As Figuras B1 a B6 do Apêndice B mostram os gráficos obtidos de conversão e de seletividade para a zeólita desaluminizada $Y(80) 5 \mathrm{C}$. Já as Figuras B7 a B12, também no Apêndice B, mostram os gráficos obtidos para as reações de desidratação dos alcoóis com a zeólita Y padrão.

A Tabela 11 mostra que as reações de desidratação de 1-propanol, de isopropanol e de terc-butanol apresentaram conversões e seletividades médias de aproximadamente $100 \%$ para as injeções na zeólita $Y$ padrão e desaluminizada, mesmo com a reduzida quantidade de massa de catalisador utilizada (20 mg) e o maior número de injeções utilizado.

Tabela 11: Dados conversão e seletividade médios obtidos na produção das bio-olefinas propileno e isobutileno.

\begin{tabular}{|c|c|c|c|c|}
\hline 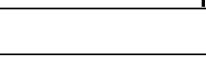 & \multicolumn{2}{|c|}{ Zeólita Y padrão } & \multicolumn{2}{|c|}{ Zeólita Desaluminizada } \\
\hline Álcool & $\begin{array}{c}R_{\text {médio }}{ }^{a} \\
(\%)\end{array}$ & $\begin{array}{c}S_{\text {médio }}^{b} \\
(\%)\end{array}$ & $\begin{array}{c}R_{\text {médio }}{ }^{a} \\
(\%)\end{array}$ & $\begin{array}{c}S_{\text {médio }}^{b} \\
(\%)\end{array}$ \\
\hline 1-propanol & 98,7 & 100,0 & 99,9 & 100,0 \\
\hline isopropanol & 100,0 & 100,0 & 100,0 & 100,0 \\
\hline terc-butanol & 99,9 & 100,0 & 100,0 & 100,0 \\
\hline
\end{tabular}

${ }^{\mathrm{a}}$ Conversão média; ${ }^{\mathrm{b}}$ Seletividade média para a olefina.

A zeólita desaluminizada se mostrou mais eficiente, pois, além de possuir uma quantidade menor de sítios ácidos em relação à $Y$ comercial, ela apresentou conversões iguais ou superiores à zeólita não modificada. No caso da desidratação do terc-butanol, não houve deteç̧ão de nenhum pico relacionado tanto a subprodutos quanto a excesso de álcool que não reagiu. Também, no caso da desidratação do 1-propanol, os picos de excesso do álcool foram detectados com intensidades muito mais baixas que aquelas encontradas para a zeólita $Y$ padrão, como pode ser comparado nos gráficos das Figuras B1 e B7. 


\subsubsection{Análise de Propostas de Mecanismos}

Apesar de existirem diversas pesquisas relacionadas à desidratação do álcool etílico para produção de etileno utilizando muitos tipos de catalisadores aluminossilicatos, o mecanismo envolvido nessa reação via catálise heterogênea não está totalmente estabelecido. Desde a metade do século XX, pesquisadores vêm tentando conduzir análises para descobrir as etapas do mecanismo por meio do estudo de diferentes catalisadores, como a alumina ativada, ${ }^{74,147-149}$ óxidos de magnésio, ${ }^{150}$ peneiras moleculares ${ }^{151} \mathrm{e}$ heteropoliácidos ${ }^{55,152}$. Entretanto, não existe ainda um consenso na literatura. ${ }^{153}$

Köhne e Knözinger publicaram, em 1966, possíveis etapas reacionais da desidratação de metanol e etanol utilizando $0,3 \mathrm{~g}$ de $\gamma$-alumina como catalisador. ${ }^{148} \mathrm{Em}$ temperaturas abaixo de $240{ }^{\circ} \mathrm{C}$, os autores constataram a formação preferencial do éter, enquanto que, em temperaturas entre $240 \mathrm{e}$ $250^{\circ} \mathrm{C}$, parte do éter foi consumido formando novamente etanol a partir de um deslocamento do equilíbrio químico da reação. Somente acima de $250{ }^{\circ} \mathrm{C}$ é que foi constatada a formação de etileno como produto principal. ${ }^{148} \mathrm{Em}$ temperaturas acima de $300{ }^{\circ} \mathrm{C}$, foi observada a desidrogenação do etanol, sendo detectados produtos como acetaldeído, hidrogênio e etano. ${ }^{148}$ Entretanto, a separação de hidrogênio, etano e etileno por CG ficou comprometida, pois, segundo os autores, os três produtos apareceram em um único pico, no qual a mistura desses gases provocou uma pequena deflexão, mostrando um pico menor que aquele de etileno puro. Portanto, ao longo da reação de desidratação de etanol, é possivel que perdas aparentes de etileno ocorram, as quais podem ser atribuídas a esse efeito. ${ }^{148}$ Além disso, condições reacionais como altas temperaturas (acima de $300{ }^{\circ} \mathrm{C}$ ) somadas a sítios fortemente ácidos do catalisador já foram reportadas por possibilitarem a polimerização do etileno, o que é um grande prejuízo para a reação de desidratação do etanol, em especial para a estabilidade da reação. ${ }^{153}$

Seis anos depois, em 1972, Knözinger e colaboradores ${ }^{147}$ verificaram que estruturas intermediárias poderiam ser formadas via transeliminações na alumina durante o processo de desidratação dos alcoóis. Shi e Davis ${ }^{149}$ e DeCanio e colaboradores, ${ }^{154}$ utilizando alcoóis deuterados, detectaram a 
formação de um produto intermediário do tipo alcóxido durante as reações de desidratação, isto é, um hidrogênio do grupo hidroxila da molécula do álcool foi substituído por um composto metálico, no caso, o alumínio.

Os trabalhos que propõem a formação do intermediário alcóxido $^{147,149,154,155}$ justificam sua formação por meio de duas rotas: (i) a primeira envolve uma reação direta pelo sítio de Lewis (Al), que resulta na desprotonação do complexo álcool com formação do alcóxido R-O-Al (Figura 61); e (ii) a segunda, envolve a reação do álcool com a superfície nucleofílica do sítio básico $\mathrm{Al}^{-} \mathrm{O}^{-}$, o qual ataca um hidrogênio do radical carbônico do álcool resultando em um rearranjo que gera o alcóxido e a água (Figura 62). ${ }^{149}$

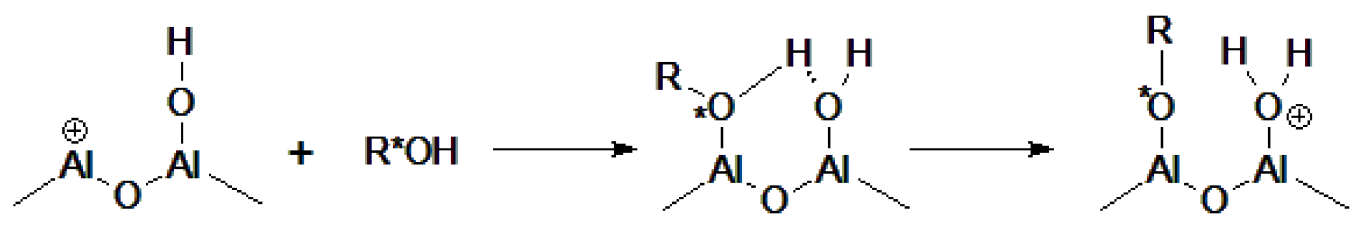

Figura 61: Mecanismo proposto, adaptado da referência [149], para a desidratação de alcoóis sobre alumina ativa via reação direta pelo sítio de Lewis (Al). O símbolo $\left(^{*}\right)$ mostra o oxigênio marcado.

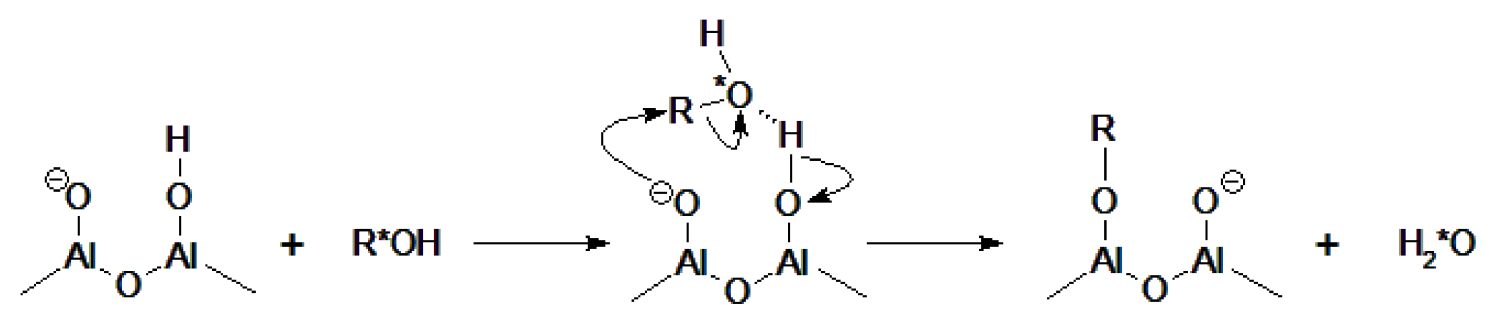

Figura 62: Mecanismo proposto, adaptado da referência [149], para a desidratação de alcoóis sobre alumina ativa via reação direta do álcool com um sítio básico do tipo Al$\mathrm{O}^{-}$. O símbolo $\left(^{*}\right)$ mostra o oxigênio marcado.

A Figura 63 mostra a formação do éter a partir da interação da molécula de álcool com um sítio de Lewis (1), um sítio de Brønsted (2) e um sítio básico (3). Assim, concomitantemente, uma das moléculas do álcool pode agir como um bom grupo eletrofílico, enquanto outra se desenvolve como um bom grupo de saída. A união das estruturas 1 e 2 forma a estrutura 3 , na qual a substituição nucleofilica e a expulsão de uma molécula de água gera o éter e recupera o catalisador. 
A estrutura 1 da Figura 63 corresponde à transferência do hidrogênio do grupo $-\mathrm{OH}$ do álcool para um ânion oxigenado. A partir dessa estrutura, 0 alceno poderá ser formado, regenerando o catalisador e formando uma molécula de água segundo o mecanismo da Figura 64.
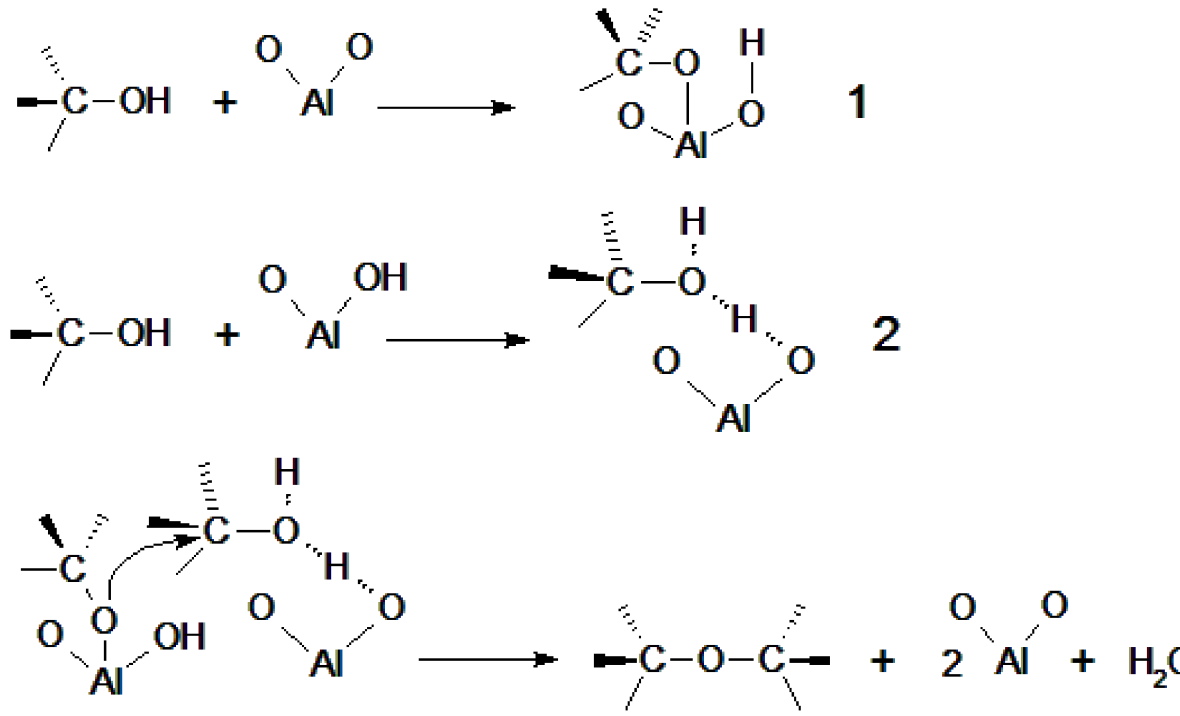

Figura 63: Mecanismo proposto, adaptado da referência [149], para a desidratação de alcoóis sobre alumina ativa a partir da utilização de um sítio de Lewis (1), um sítio de Brønsted (2) e um sítio básico (3).

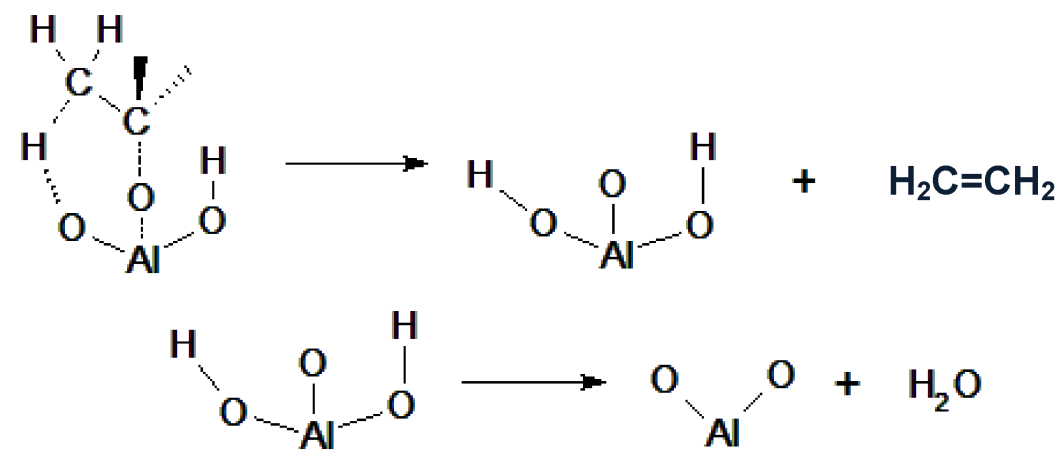

Figura 64: Mecanismo proposto, adaptado da referência [149], para a produção de olefinas a partir da desidratação de alcoóis.

Chiang e Bhan, em 2010, ${ }^{151}$ estudaram os mecanismos da reação de desidratação do etanol com hidrogênio deuterado sobre diferentes catalisadores zeolíticos em um reator de leito fixo. Os autores abordaram duas propostas de mecanismos (Figuras 65 e 66), explicando que ambas eram 
consistentes com os resultados obtidos experimentalmente, a depender do tipo de zeólita utilizada.

No primeiro caso (Figura 65), as moléculas de etanol são capazes de formar dímeros a partir de sua ativação sobre os sítios ácidos das zeólitas com tamanho de poro grande.

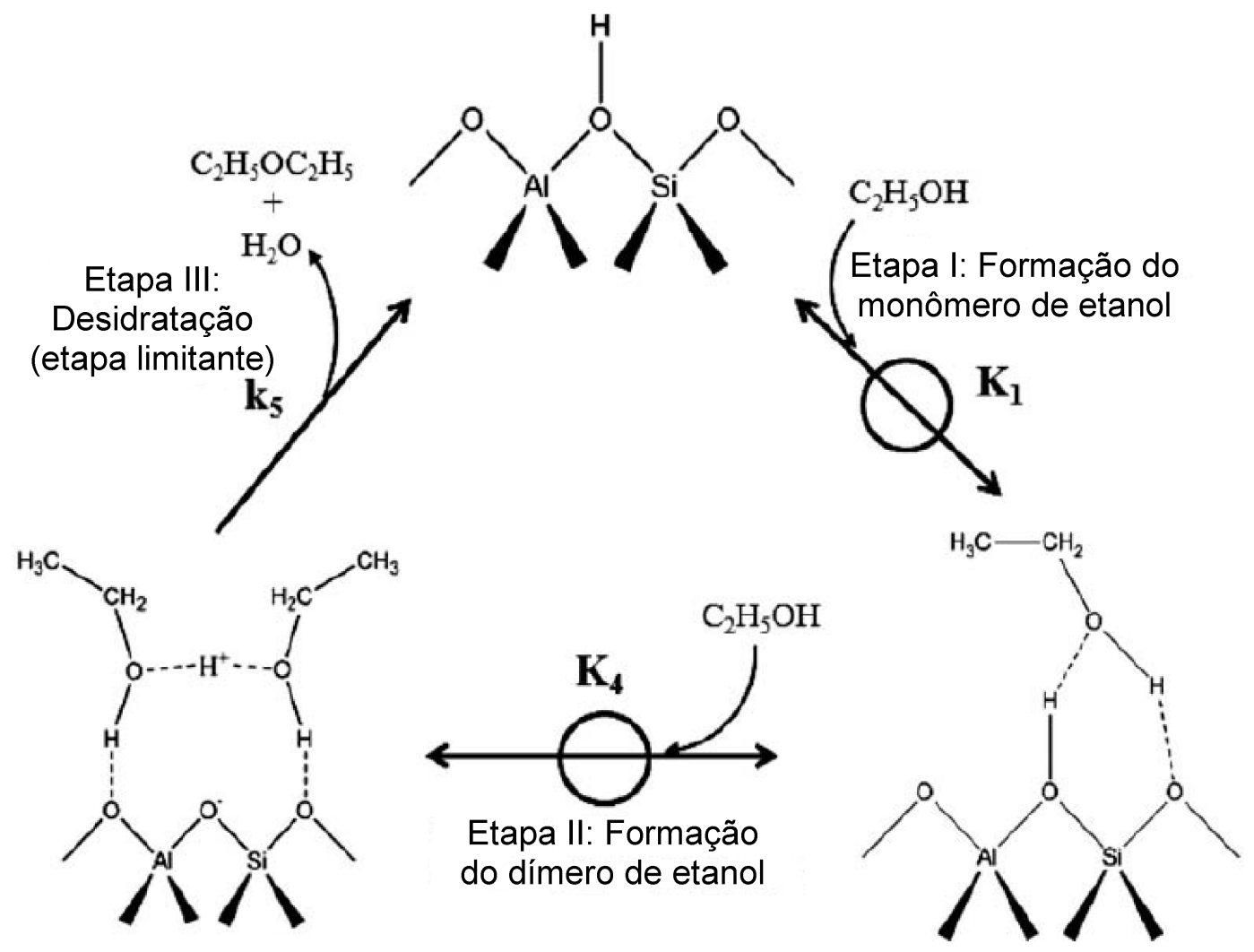

Figura 65: Etapas elementares propostas para a dimerização do etanol com formação do dietil éter, favorecido pela acessibilidade do álcool aos maiores canais do catalisador. $^{151}$

Entretanto, em se tratando de zeólitas com poros pequenos, a estrutura dimérica formada na etapa II é muito volumosa para ser formada nos poros zeolíticos. Assim, a reação acaba por encontrar um caminho, que é a formação do etóxido (mecanismo via alcóxido anteriormente mostrado), gerando uma espécie intermediária geometricamente favorável, a qual é dessorvida do catalisador gerando o alceno (Figura 66).

Portanto, segundo essas propostas de mecanismos, tanto etileno como dietil éter poderão ser produzidos a depender da acidez e, também, da estrutura cristalina dos catalisadores empregados. A existência de diferentes tamanhos de canais e cavidades nas zeólitas será responsável por uma maior 
ou menor quantidade de éter formado, a depender também da acessibilidade que o álcool terá aos sítios ácidos de Brønsted do catalisador. Müller e colaboradores também ressaltaram a dependência da estrutura dos catalisadores zeolíticos com o mecanismo de formação de éter e/ou de etileno. Em adição, segundo os autores, tanto a presença de sítios ácidos de Brønsted como de sítios de Lewis podem ser determinantes para a formação preferencial de etileno na desidratação do etanol, a depender da morfologia do material utilizado na catálise. ${ }^{146}$

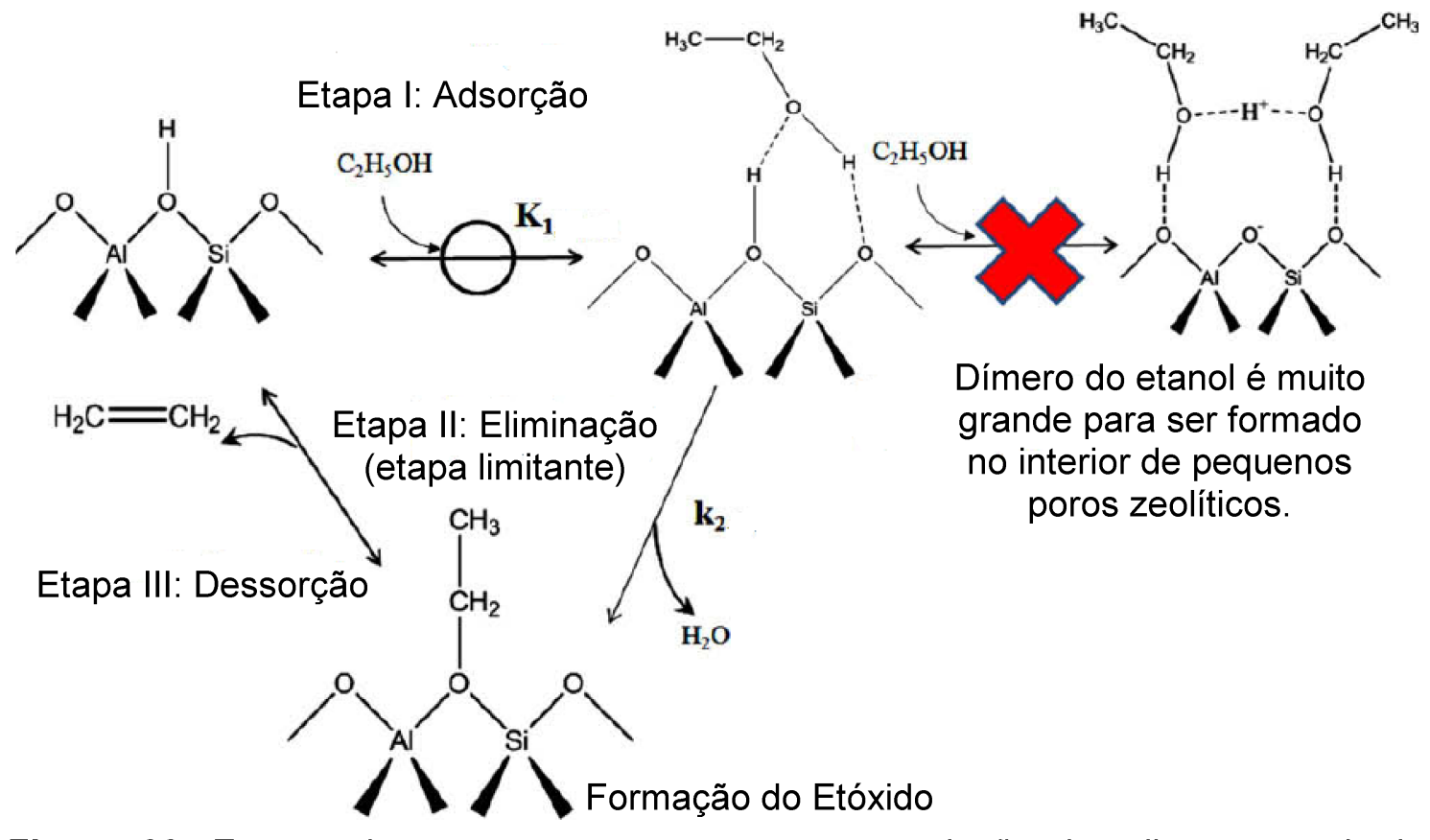

Figura 66: Etapas elementares propostas para a produção de etileno a partir da desidratação do etanol dentro dos poros da zeólita, que não permitem a formação de grandes estruturas diméricas. ${ }^{151}$ 


\subsection{Heteropoliácidos}

\subsubsection{ZrHPW}

\subsubsection{Caracterizações Estruturais - ZrHPW (papel filtro)}

A formação do heteropolissal ZrHPW via síntese dupla gerou dois diferentes materiais: um com estrutura micrométrica, assim como o precursor HPW, e, outro, nanoestruturado. A Figura 67 mostra fotos do papel filtro embebido com o ZrHPW, pronto para ser calcinado (Figura 67-a), e do material após calcinação (Figura 67-b). Como pode ser notado, a aparência do sólido final é bastante semelhante ao do próprio papel filtro, mantendo seu formato mesmo após ser submetido ao tratamento térmico de $400{ }^{\circ} \mathrm{C}$.

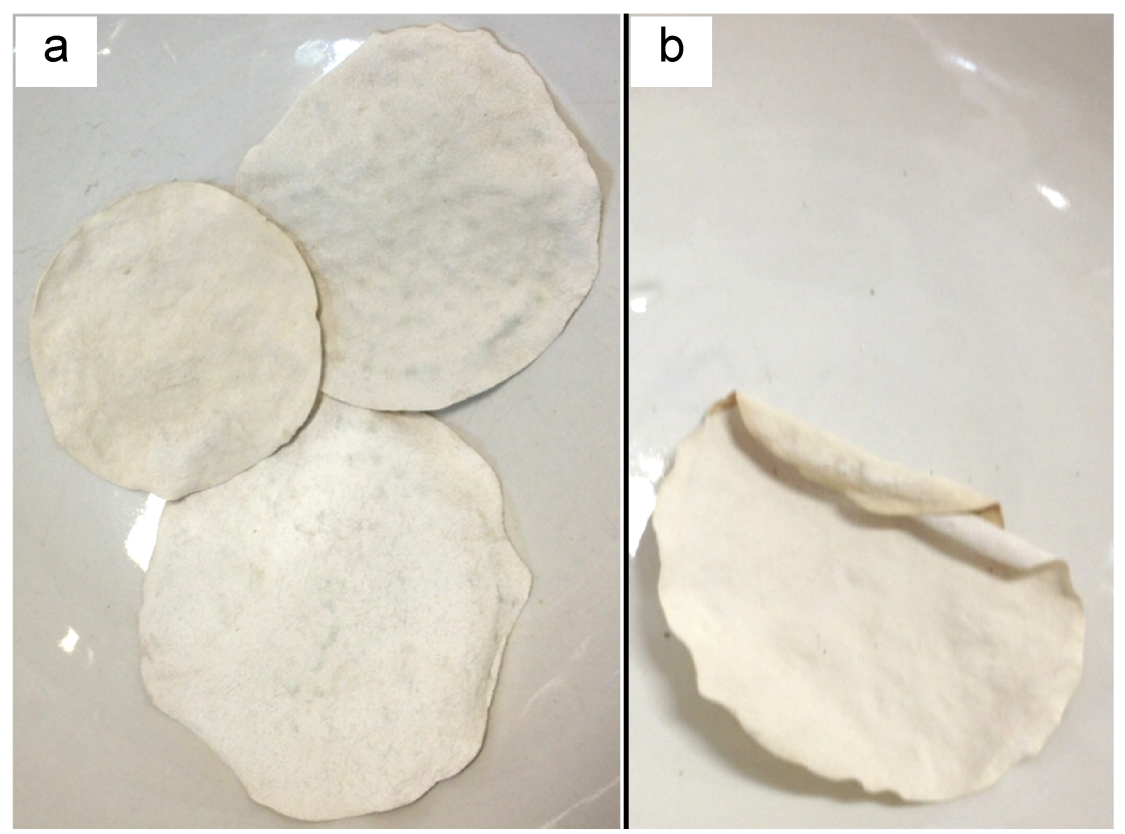

Figura 67: Em (a), imagem digital do molde papel filtro embebido com a mistura de ZrHPW e, em (b), o sólido nanoestruturado de ZrHPW no formato do papel após calcinação e eliminação da celulose.

Os sólidos micrométricos foram produzidos a partir da mistura residual da síntese (Figura 68). O material se apresentou cristalino, com um padrão hexagonal de cristalização. Após secagem total (Figura 68-b), o sal ZrHPW foi calcinado nas mesmas condições do material modelado com celulose. 

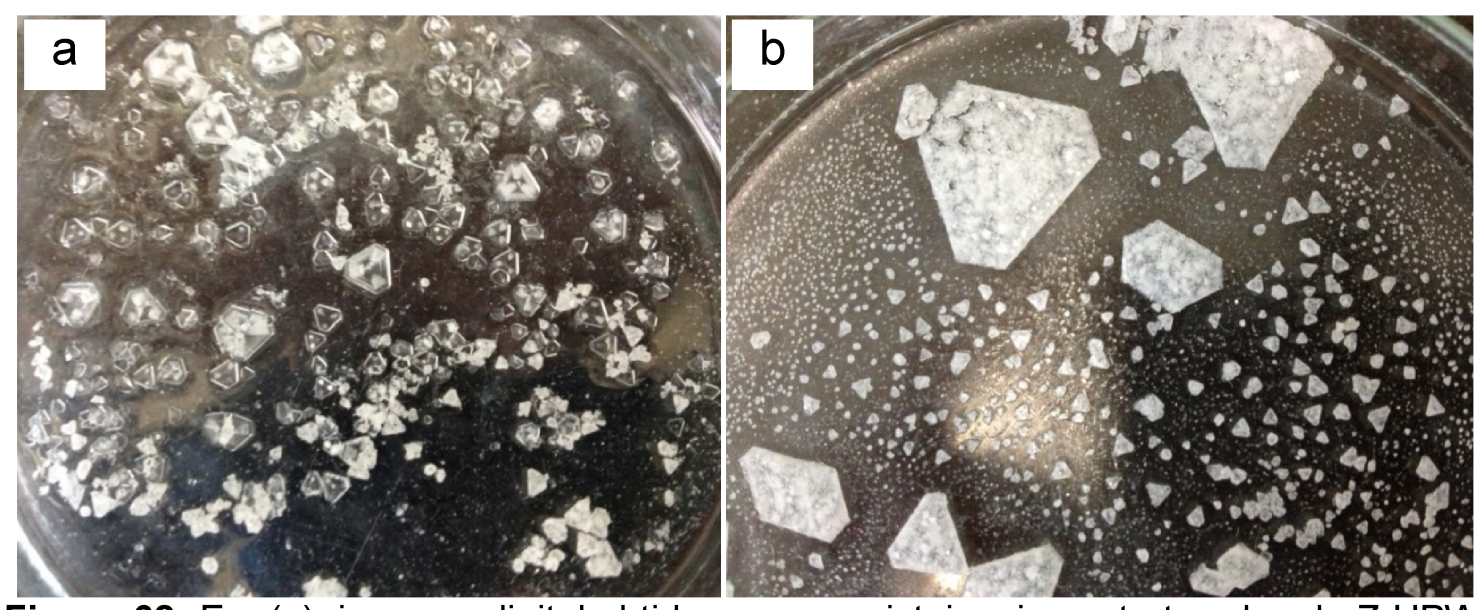

Figura 68: Em (a), imagem digital obtida para os cristais microestruturados de ZrHPW sendo formados após um dia de secagem ao ar e, em (b), o mesmo sólido já totalmente seco após 3 dias.

A calcinação gerou as amostras em pó ZrHPW-nano (Figura 69-a) e ZrHPW-micro (Figura 69-b), com aparências visivelmente distintas.

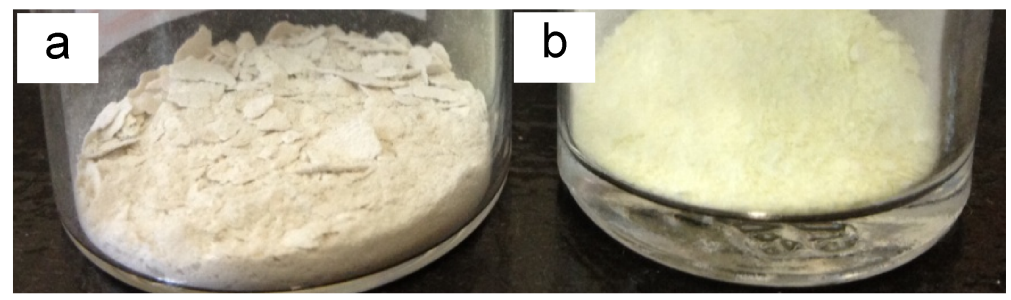

Figura 69: Em (a), imagem digital obtida para o pó ZrHPW-nano de coloração esbranquiçada e, em (b), o pó ZrHPW-micro de coloração levemente amarelada mais finamente disperso.

A fim de verificar se houve, de fato, a formação dos sólidos nano e microestruturados, bem como compreender melhor como o papel filtro interferiu na geometria desses materiais, micrografias em diferentes aproximações foram obtidas tanto para os reagentes $\mathrm{ZrOCl}_{2}$ (Figura 70) e HPW (Figura 71) como para os produtos ZrHPW-micro (Figuras 72 e 73) e ZrHPW-nano (Figura 74).
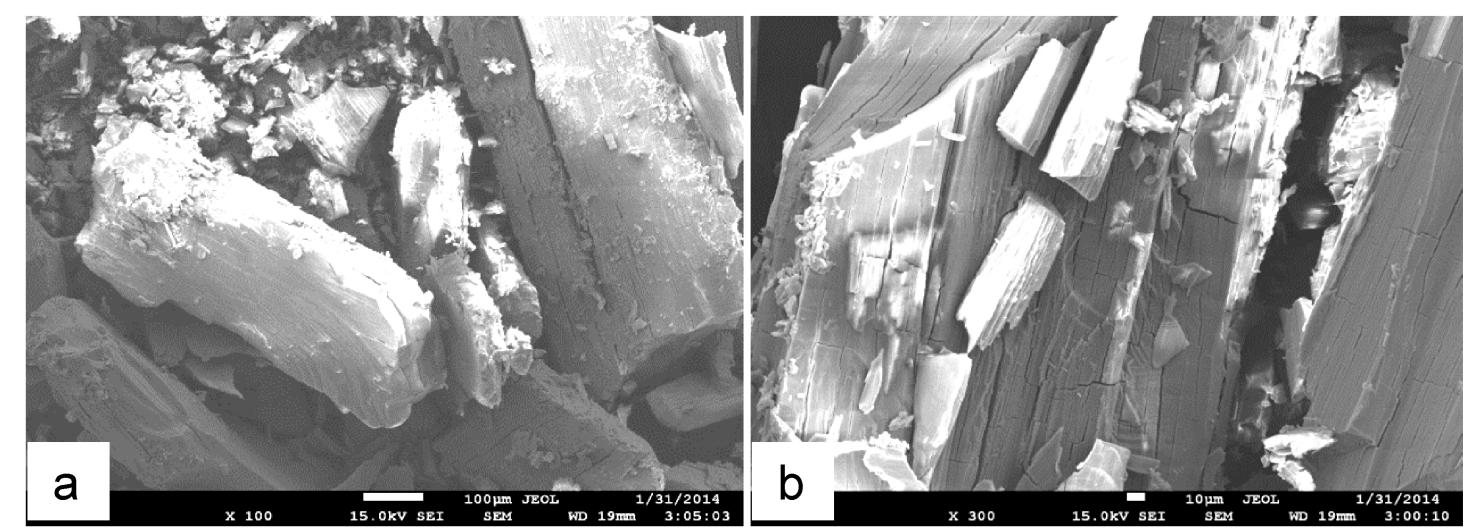

Figura 70: Micrografias do reagente $\mathrm{ZrOCl}_{2}$ com aproximações de $100 \times$ (a) e $300 \times(b)$. 


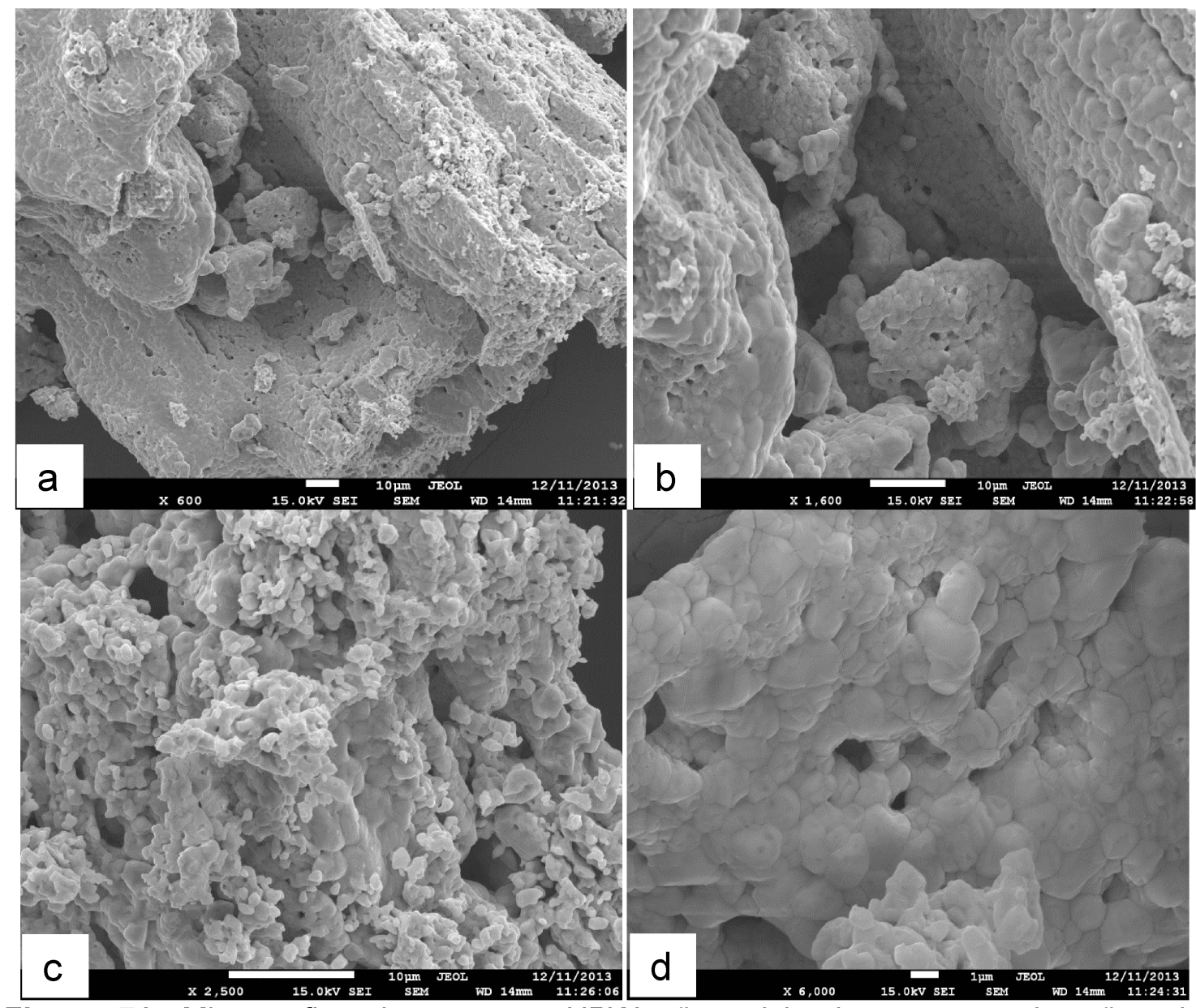

Figura 71: Micrografias do reagente HPW não calcinado com aproximações de $600 \times(a), 1.600 \times(b), 2.500 \times(c)$ e $6.000 \times(d)$.

As imagens de MEV para o HPW (Figura 71) mostram aglomerados submicrométricos com grânulos bastante unidos sem formato bem definido, ao contrário do reagente $\mathrm{ZrOCl}_{2}$ (Figura 70), que apresentou uma superfície mais compacta e com cristais maiores. Entretanto, diferentes formas podem ser observadas nas micrografias do HPW, a depender de seu grau de hidratação e de sua temperatura de calcinação, que pode gerar recristalizações e, portanto, alterações geométricas no sólido. ${ }^{156}$ As micrografias do sal ZrHPW-micro (Figura 72) também mostram aglomerados micrométricos, assim como no caso do HPW, mas exibem ainda partículas esféricas uniformes depositadas sobre eles com tamanho submicrométrico (entre 0,7 e $2 \mu \mathrm{m}$ de diâmetro). Ao serem analisadas por FRX/EDX no próprio equipamento de MEV (Figura 73), essas esferas mostraram ter a mesma composição do sólido como um todo, apresentando pouca variação nas proporções de oxigênio, zircônio e tungstênio. As micrografias dos precursores $\mathrm{HPW}$ e $\mathrm{ZrOCl}_{2}$ (Figuras 70 e 71) comprovam que esses grupamentos esféricos não condizem com um possível 
excesso de reagentes, mas podem estar relacionados com a formação de clusters entre o HPW e os íons zircônio, pois, para os outros íons estudados, $\mathrm{Zn}^{2+}$ e $\mathrm{Ag}^{+}$, não foram observados esses padrões, como será mostrado posteriormente.

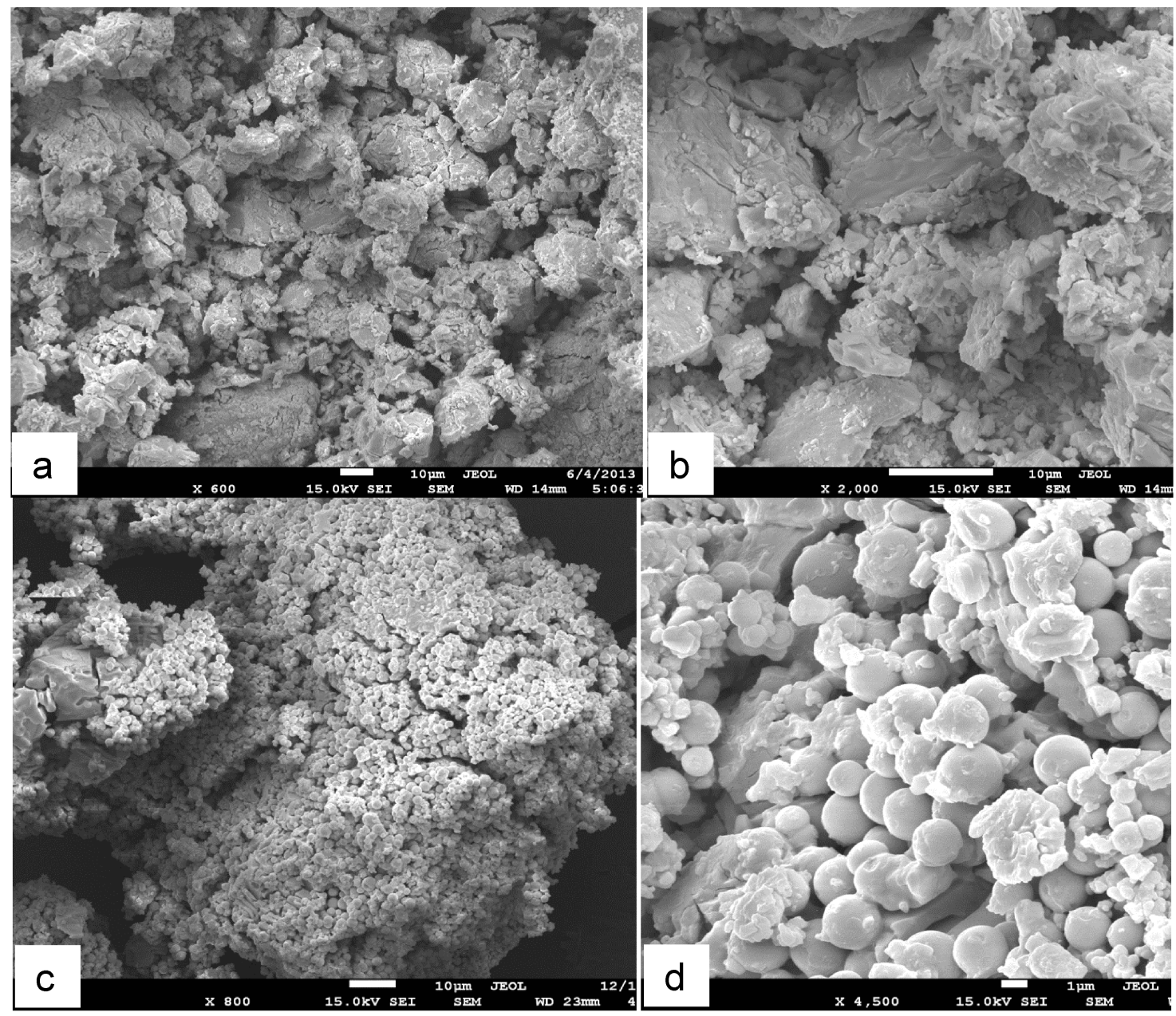

Figura 72: Micrografias do sólido sintetizado ZrHPW-micro com aproximações de $600 \times(a), 2.000 \times(b), 800 \times$ (c) e $4.500 \times(d)$.
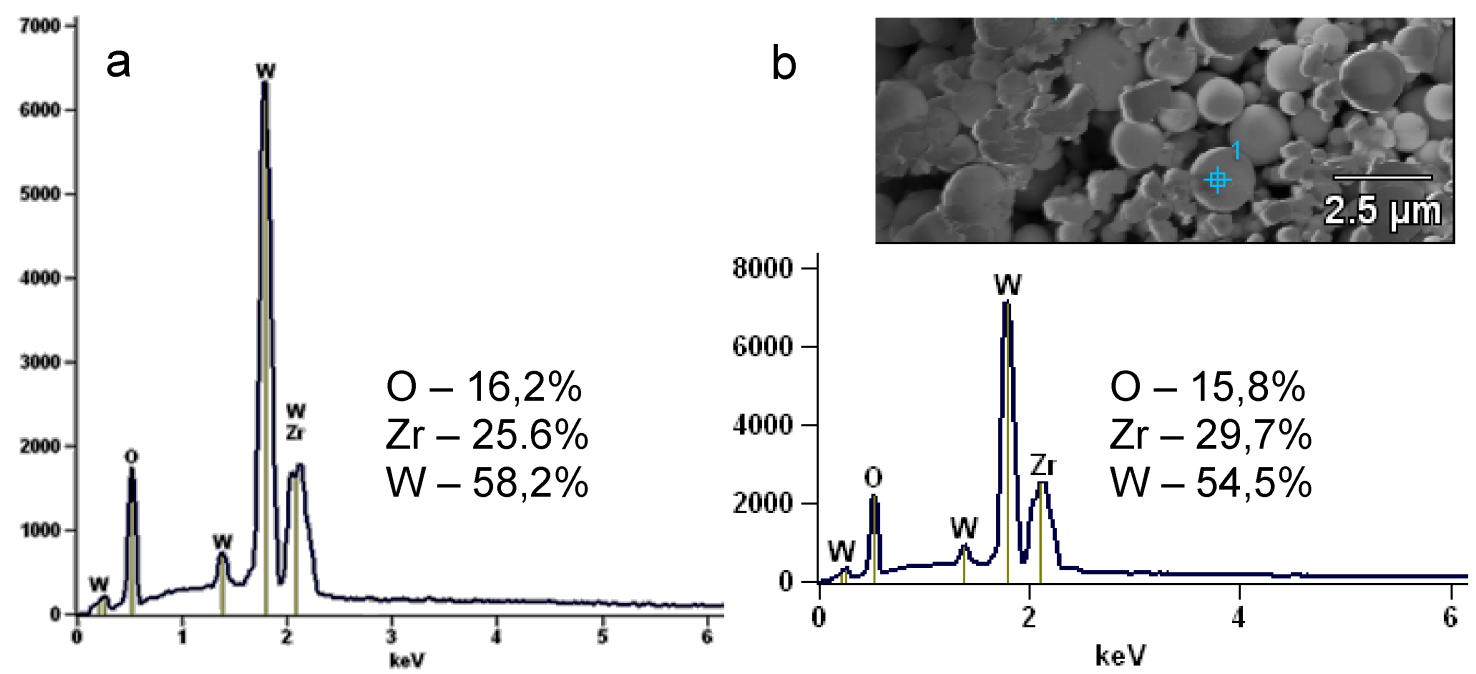

Figura 73: Análise de FRX/EDX pelo equipamento de MEV da amostra ZrHPW-micro em sua totalidade (a) e do ponto 1 , em azul, em (b). 


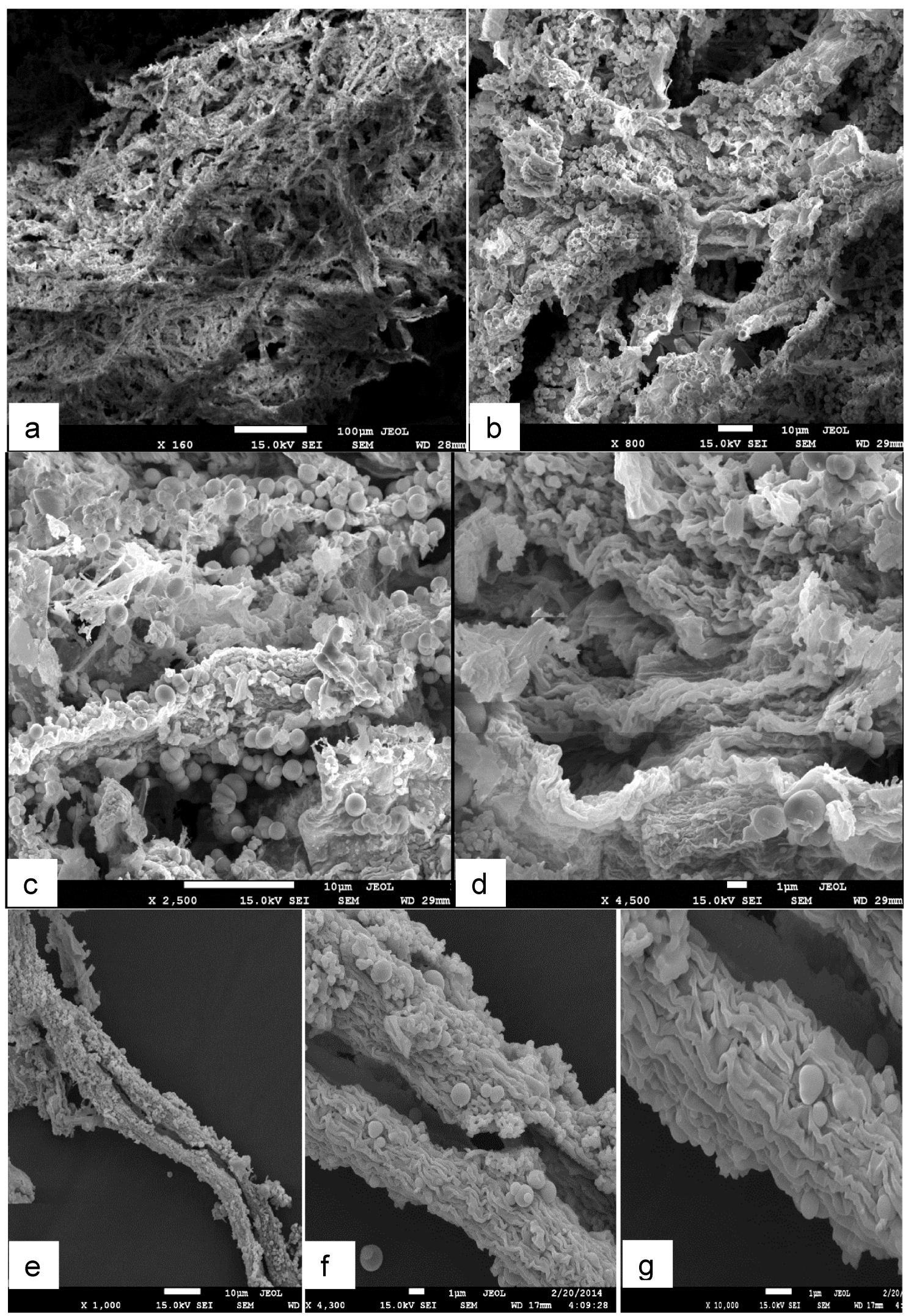

Figura 74: Microscopias do sólido ZrHPW moldado com papel filtro em aproximações de $160 \times(a), 800 \times$ (b), $2.500 \times$ (c) e $4.500 \times$ (d), na região de fibras entrelaçadas, e $1.000 \times(\mathrm{e}), 4.300 \times(\mathrm{f})$ e $10.000 \times(\mathrm{g})$, na região com fibras soltas. 
Já as micrografias da Figura 74 evidenciam que o complexo ZrHPW foi efetivamente moldado pela celulose, o qual exibiu uma estrutura de fibras entrelaçadas. Algumas regiões da amostra mostraram fibras soltas, destacando a rugosidade do material (Figura 74-e,f,g). Os aglomerados esféricos também estão presentes no sólido, depositados sobre a rede fibrosa. Na imagem de MET (Figura 75-a), é visto que as fibras possuem largura média entre 20 e $65 \mathrm{~nm}$, podendo ser consideradas um material nanométrico $(<100 \mathrm{~nm})$. O comprimento médio calculado foi de 200 a $300 \mathrm{~nm}$, o qual está diretamente ligado ao tamanho da superfície do papel filtro utilizado. Os aglomerados nanométricos também foram identificados nas imagens de MET, depositados sobre as fibras (Figura 75-b).
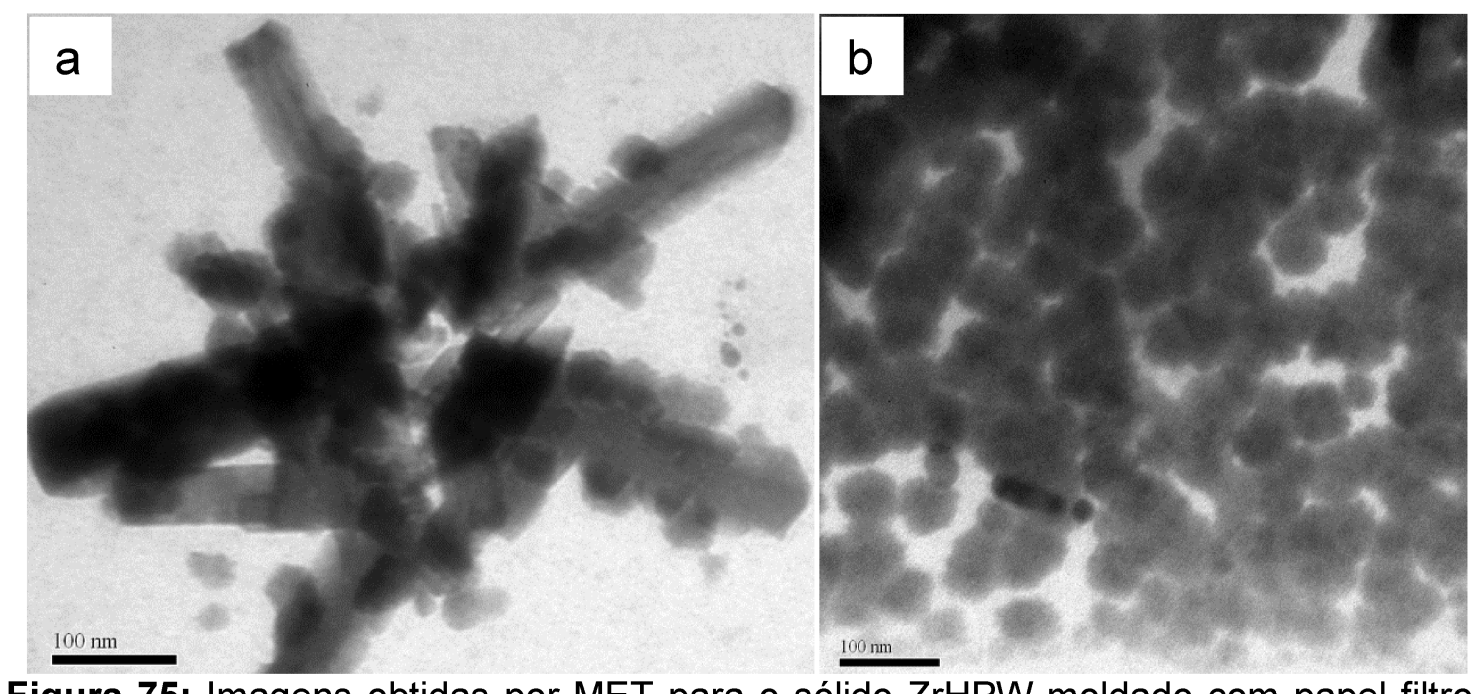

Figura 75: Imagens obtidas por MET para o sólido ZrHPW moldado com papel filtro. Em (a), a estrutura obtida de tamanho nanométrico e, em (b), os aglomerados depositados no material fibroso.

A imagem da Figura 75-a foi bastante semelhante àquela obtida por Zhang e colaboradores. ${ }^{8}$ Todavia, os autores reportaram que obtiveram um material em forma de tubos, com área interna cilíndrica. De fato, a observação apenas da imagem de MET leva a crer que a amostra é nanotubular, o que, em menores aproximações via MEV (Figura 74), mostrou se tratar de nanofibras.

No mapa de distribuição de elementos da Figura 76, feito por MEV-EDX, é possível observar a distribuição dos elementos $\mathrm{W}, \mathrm{Zr}$ e $\mathrm{O}$ nas nanofibras sintetizadas. O tungstênio (Figura 76-d) está distribuído regularmente na superfície do material, enquanto o oxigênio (Figura 76-b) e o zircônio (Figura 
76-c) possuem um padrão semelhante de distribuição, concentrados em locais mais específicos das fibras.

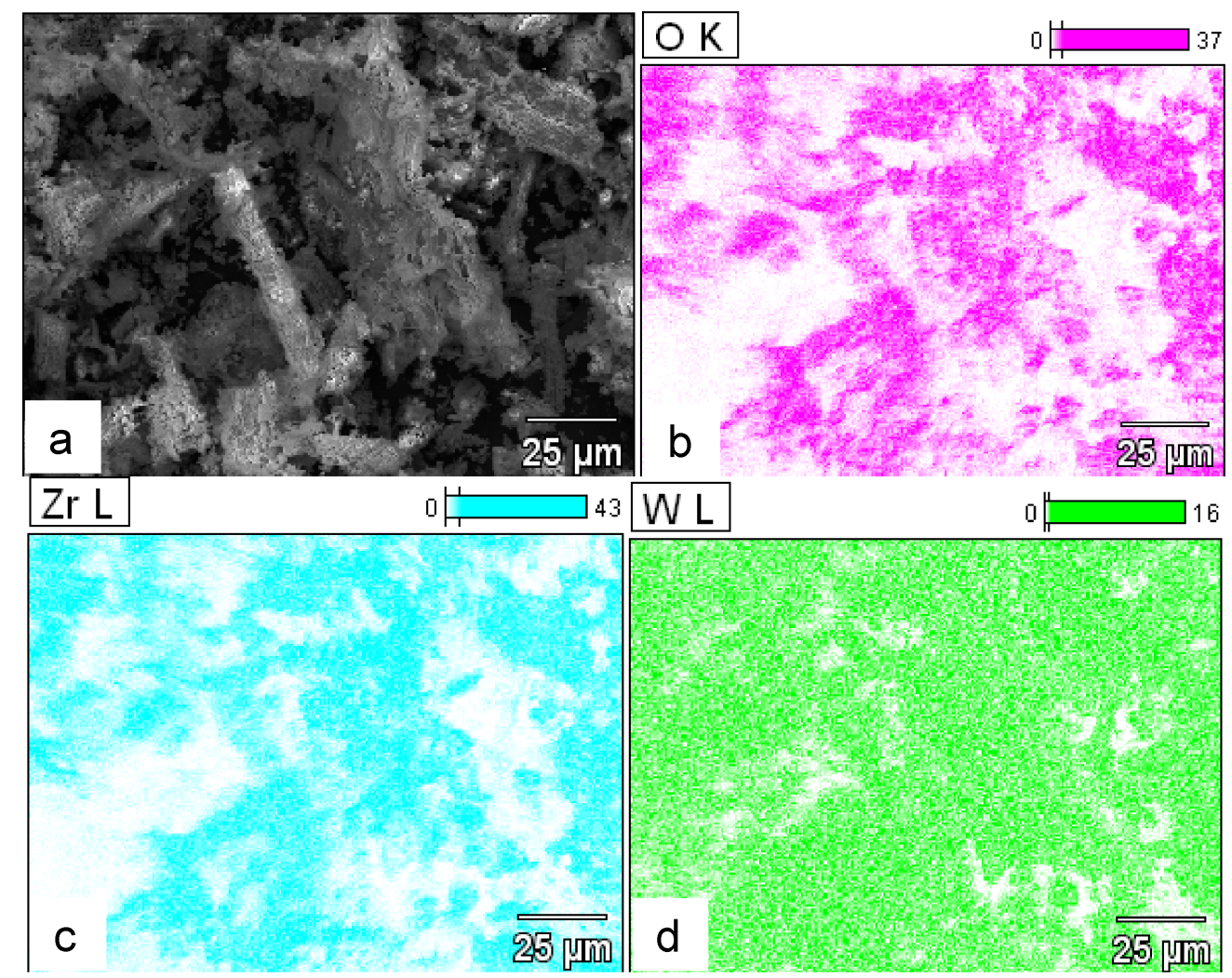

Figura 76: Micrografia (a) e mapas de distribuição dos elementos oxigênio (b), zircônio (c) e tungstênio (d) na superfície das nanofibras de ZrHPW.

Os difratogramas exibidos na Figura 77, juntamente com o espectro de FT-IR (Figura 78) comprovam a manutenção da estrutura primária e secundária de Keggin no sólido ZrHPW-micro. O HPW apresentou reflexões importantes em seu difratograma, correspondente ao padrão hexahidratado, em 10,50; 14,$79 ; 18,09 ; 20,89 ; 23,36 ; 25,60 ; 29,61 ; 31,40 ;$ e $34,82^{\circ}$ (referente aos planos [110], [200], [211], [220], [310], [222], [400], [411] e [332], respectivamente). ${ }^{157}$ Como todas as reflexões foram mantidas para a amostra microestruturada, fica comprovada a conservação da estrutura secundária do HPW. ${ }^{8,44}$ Pequenos deslocamentos foram observados no difratograma do ZrHPW-micro (10,27; 14,$57 ; 17,93 ; 20,78 ; 23,12 ; 25,40 ; 29,30 ; 31,20$; e $34,64^{\circ}$ ), que são esperados quando é feita a substituição do $\mathrm{H}^{+}$(raio iônico $=0,35 \AA$ ) por outros íons, como o $\mathrm{Zr}^{4+}$ (raio iônico $=0,72 \AA$ ), evidenciando uma modificação na estrutura secundária do HPW. ${ }^{8}$ 


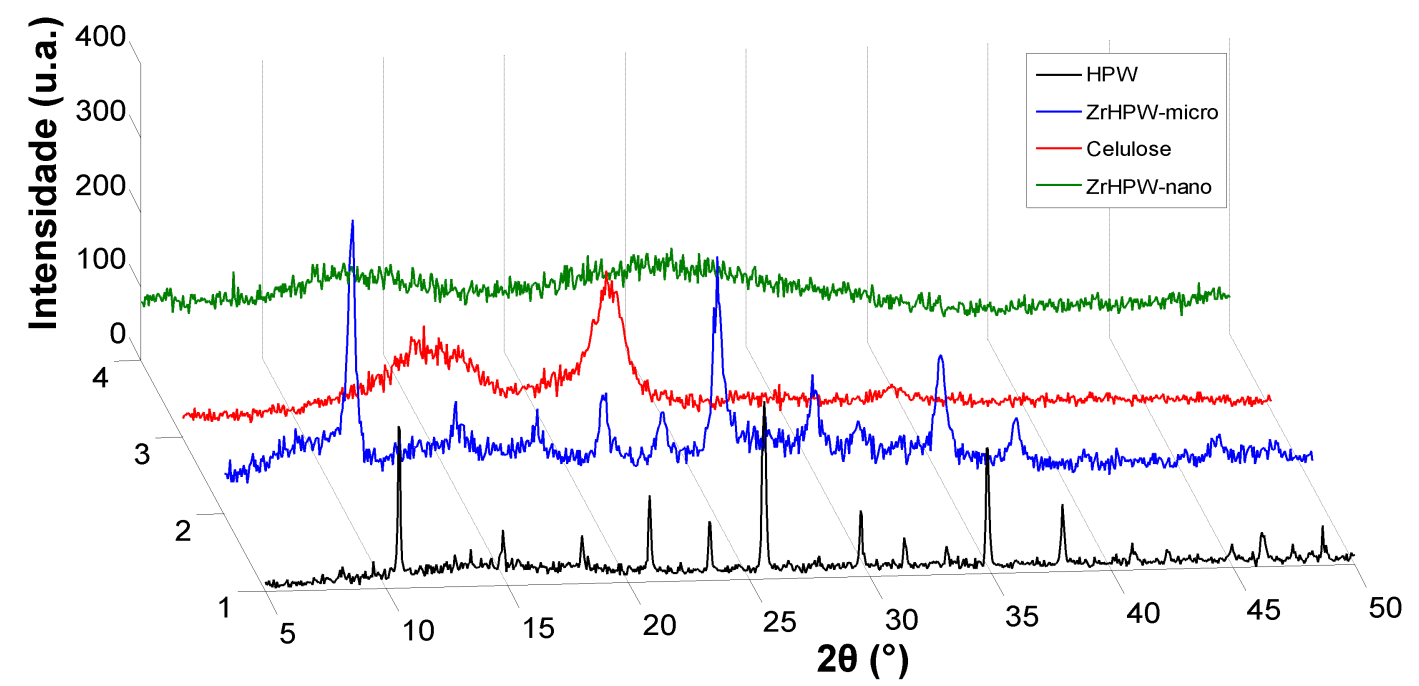

Figura 77: Difratogramas do HPW e da celulose em comparação com aqueles obtidos para as amostras ZrHPW-micro e ZrHPW-nano.

Os deslocamentos para ângulos menores, como é o caso da amostra ZrHPW-micro, estão relacionados a um aumento do parâmetro de cela. ${ }^{158}$ Considerando o sistema cúbico do HPW, em que o parâmetro de cela (a) pode ser calculado pela Equação 10 para um mesmo plano de reflexão, o aumento de $a$ é ocasionada pelo aumento da distância interplanar $\left(d_{h k l}\right)$, que, por sua vez, está relacionada com o aumento do raio iônico do cátion trocado.

$$
a=\sqrt[2]{\left(d_{h k l}\right)^{2} \cdot\left(h^{2}+k^{2}+l^{2}\right)}
$$

onde, $\mathrm{d}_{\mathrm{hkl}}=\frac{\lambda}{2 \sin \theta}$, com $\lambda=1,5406$ (radiação CuKa) e $\mathrm{h}, \mathrm{k}$ e I representando os índices de Miller do plano de reflexão escolhido.

Como as interações entre prótons e as unidades de Keggin não são as mesmas que aquelas entre os íns $\mathrm{Zr}^{4+}$ e esses ânions, uma desordem estrutural pode acontecer, ${ }^{44}$ a qual foi percebida pelo alargamento $e$ deslocamento dos picos. A depender do grau de hidratação do HPW, sua estrutura secundária, evidenciada pela técnica de DRX, é formada não somente por íons $\mathrm{H}^{+}$, mas pela união de espécies volumosas $\mathrm{H}_{5} \mathrm{O}_{2}^{+}$e os ânions de Keggin. ${ }^{156,157}$ Kremenovic e colaboradores ${ }^{157}$ reportaram que esses íons dioxônio $\left(\mathrm{H}_{5} \mathrm{O}_{2}{ }^{+}\right)$, que ligam os ânions de Keggin, produzem associações e dissociações em equilíbrio dinâmico, conforme a Equação 11, que podem ser induzidas por um aumento de temperatura.

$$
\mathrm{H}_{5} \mathrm{O}_{2}^{+} \rightleftharpoons \mathrm{H}_{3} \mathrm{O}^{+}+\mathrm{H}_{2} \mathrm{O} \rightleftharpoons \mathrm{H}^{+}+2 \mathrm{H}_{2} \mathrm{O}
$$


Dessa forma, como houve um aumento no parâmetro de cela nos materiais sintetizados, é necessário que esses cátions volumosos tenham sido substituídos por íons de maior raio iônico, que podem ser oriundos da polimerização e hidrólise das espécies de zircônio, como será melhor discutido posteriormente.

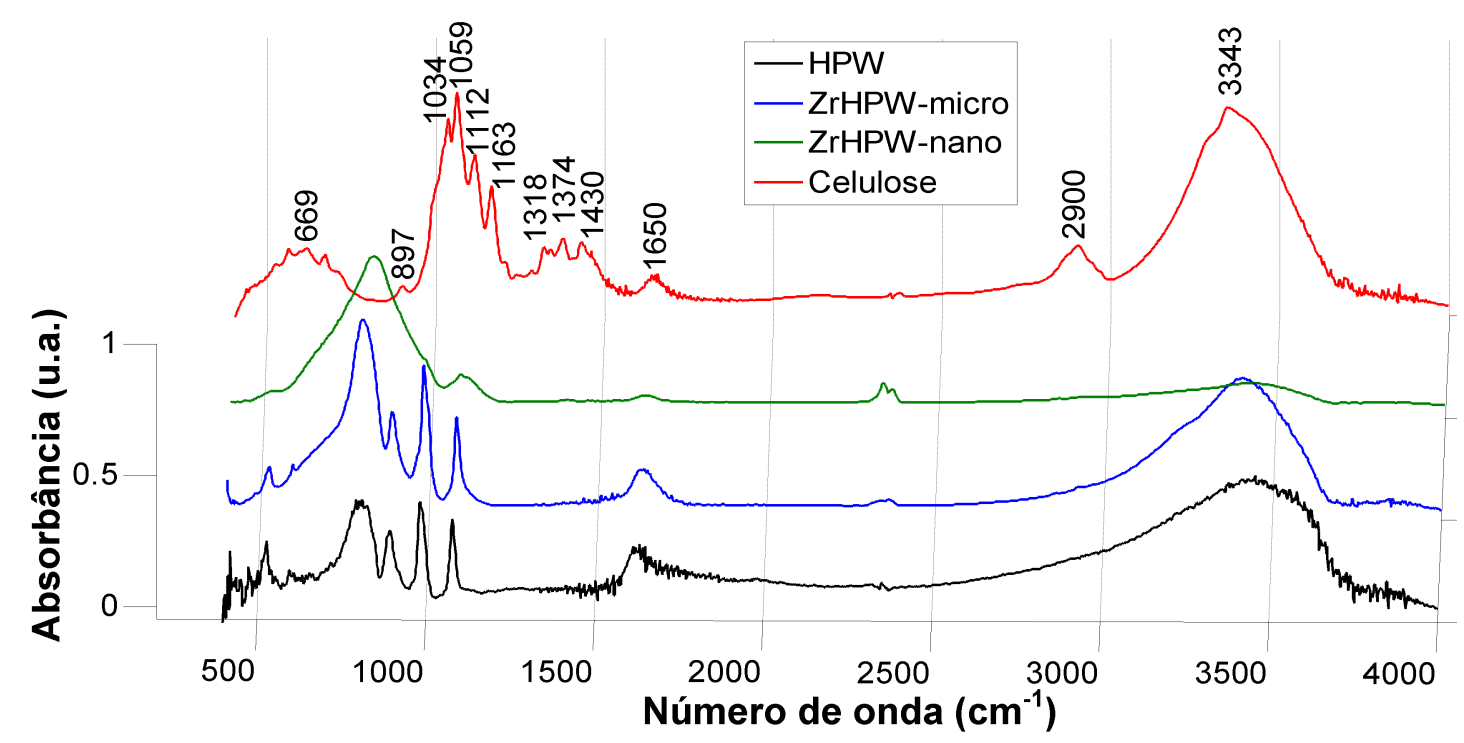

Figura 78: Espectros de FT-IR obtidos para o HPW, para a celulose e para as amostras ZrHPW-micro e ZrHPW-nano.

As bandas no infravermelho características da estrutura primária de Keggin também foram mantidas para o ZrHPW-micro (Figura 78), sendo detectados pequenos deslocamentos (Tabela 12) em relação ao HPW padrão, assim como observado nos difratogramas da Figura 77 , devido à troca de prótons por íons de espécies de zircônio. A posição das bandas na técnica de FT-IR depende da interação dos contraíons com os ânions $\left[\mathrm{PW}_{12} \mathrm{O}_{40}\right]^{3-}$ e do grau de hidratação das amostras. ${ }^{159}$ As vibrações em aproximadamente $3500 \mathrm{e}$ $1600 \mathrm{~cm}^{-1}$ são referentes ao estiramento assimétrico $\left(v_{\mathrm{as}}\right)$ e à deformação angular $(\delta)$ da água, respectivamente. A banda mais discreta em $550 \mathrm{~cm}^{-1} \mathrm{faz}$ referência à deformação angular do átomo de fósforo central com oxigênios ligados a ele $[\delta(O-P-O)]$ e, as mais importantes, estão especificadas na Tabela 12. Além disso, bandas mais intensas foram observadas na região de impressão digital do ânion de Keggin, o que pode estar relacionado com um maior distanciamento entre unidades $\left[\mathrm{PW}_{12} \mathrm{O}_{40}\right]^{3-}$ no novo material. $A$ substituição dos contraíons $\mathrm{H}^{+}$por cátions mais volumosos já foi reportada por aumentar a intensidade relativa das bandas das vibrações $v_{a s} W-O_{\text {aresta- }} \mathrm{W}$ a 
partir de uma diminuição nas interações ânion-ânion [Matias, A. E. B.; Macedo, J. L. de Inorganica Chimica Acta, a ser submetido, 2014].

No caso do ZrHPW-nano, entretanto, a estrutura secundária do HPW de partida não foi mantida, observando-se, no difratograma da Figura 77 , apenas duas largas bandas amorfas que remetem ao arranjo da celulose, o que corrobora com a geometria de fibras observada nas micrografias. Como houve a calcinação e eliminação do molde, a banda entre $20^{\circ}$ e $25^{\circ}$, correspondente ao único plano de reflexão da celulose, também foi eliminada.

Tabela 12: Valores de número de onda encontrados para as amostras de ZrHPW-micro e HPW padrão nos espectros de FT-IR.

\begin{tabular}{c|c|c}
\hline Ligação & $\begin{array}{c}\text { Número de Onda HPW } \\
\left(\mathbf{c m}^{-1}\right)\end{array}$ & $\begin{array}{c}\text { Número de Onda } \\
\text { ZrHPW-micro }\left(\mathbf{c m}^{-1}\right)\end{array}$ \\
\hline$v_{\mathrm{as}} \mathrm{P}-\mathrm{O}^{\mathrm{a}}$ & 1079,2 & 1080,9 \\
\hline$v_{\mathrm{as}} \mathrm{W}=\mathrm{O}^{\mathrm{b}}$ & 982,9 & 983,1 \\
\hline$v_{\mathrm{as}} \mathrm{W}-\mathrm{O}^{\mathrm{c}}-\mathrm{W}$ & 893,8 & 889,5 \\
\hline$v_{\mathrm{as}} \mathrm{W}-\mathrm{O}^{\mathrm{d}}-\mathrm{W}$ & 809,5 & 803,0 \\
\hline
\end{tabular}

a: oxigênio interno que conecta $\mathrm{P}$ e $\mathrm{W}$.

b: oxigênio terminal ligado a um átomo de $\mathrm{W}$.

c: oxigênio das arestas que conecta $W$.

$\mathrm{d}$ : oxigênio dos vértices que conecta as unidades $\mathrm{W}_{3} \mathrm{O}_{13}$.

O espectro de FT-IR (Figura 78) também comprova a variação estrutural das nanofibras, com a ausência dos principais estiramentos dos ânions de Keggin responsáveis pela formação da estrutura primária do HPW. Nas mesmas regiões, entretanto, foram identificadas duas bandas largas em $821 \mathrm{e}$ $1081 \mathrm{~cm}^{-1}$, as quais não fazem referência ao molde, como pode ser visto no espectro da celulose pura. Na celulose, estão presentes as bandas em $3343 \mathrm{e}$ $1650 \mathrm{~cm}^{-1}$, referentes a estiramentos e deformações angulares do grupo $\mathrm{OH}$ da água, respectivamente; em 2900 e $1374 \mathrm{~cm}^{-1}$, referentes a estiramentos e deformações no plano $\mathrm{C}-\mathrm{H}$, respectivamente; em $1430 \mathrm{~cm}^{-1}$, relativa a deformações angulares $\mathrm{H}-\mathrm{C}-\mathrm{H}$ e $\mathrm{O}-\mathrm{C}-\mathrm{H}$ no plano; em $1318 \mathrm{~cm}^{-1}$, relativa a vibrações $\mathrm{CH}_{2}$ no carbono $\mathrm{C} 6$; em $1163 \mathrm{~cm}^{-1}$, referente a estiramentos assimétricos C-O-C; na faixa de 1100 a $1034 \mathrm{~cm}^{-1}$, referente a vibrações C-C no anel e deformações de grupos laterais $\mathrm{C}-\mathrm{OH}$ e $\mathrm{CC}-\mathrm{H}$; em $897 \mathrm{~cm}^{-1}$, relativa a deformações e estiramentos $\mathrm{C}-\mathrm{O}-\mathrm{C}, \mathrm{C}-\mathrm{C}-\mathrm{O}$ e $\mathrm{C}-\mathrm{C}-\mathrm{H}$ de átomos de carbono C5 e C6; e, em $669 \mathrm{~cm}^{-1}$, relativa a deformações fora do plano $\mathrm{C}-\mathrm{OH}$. 
É possível que diferentes tipos de vibrações, semelhantes às do HPW, estejam ocorrendo em uma mesma região do espectro de FT-IR da amostra ZrHPW-nano, aumentando a largura das bandas. Lee e colaboradores, por exemplo, reportaram um alargarmento de banda da vibração $v_{\text {as }} \mathrm{W}-\mathrm{O}_{\text {aresta }} \mathrm{W}$ e atribuíram o fato à presença tanto de oxigênios de arestas compartilhadas protonados (menores números de onda) como daqueles não protonados (em números de onda mais elevados) vibrando nessa mesma região. Já Mioc e colaboradores, ${ }^{156}$ estudando as variações estruturais do $\mathrm{H}_{3}\left[\mathrm{PW}_{12} \mathrm{O}_{40}\right]$, apresentaram um espectro de FT-IR bastante semelhante ao da Figura 78, com vibrações nas mesmas regiões encontradas para $\circ$ material nanoestruturado. Os autores referenciaram as bandas à destruição da estrutura esférica dos íons de Keggin com formação da fase $\left[\mathrm{PW}_{8} \mathrm{O}_{26}\right]$ no material.

As análises de CHN confirmaram a eliminação praticamente total do papel filtro, como mostra a Tabela 13. A amostra ZrHPW-micro, que não foi submetida ao contato com celulose, foi utilizada para medir o erro do equipamento. Assim, seu valor de porcentagem de carbono foi subtraído daquele obtido para o ZrHPW-nano, restando apenas 0,08\% de carbono para o sólido nanoestruturado.

Tabela 13: Dados obtidos por CHN para as amostras sintetizadas de ZrHPW.

\begin{tabular}{c|c|c}
\hline Amostra & Carbono (\%) & Hidrogênio (\%) \\
\hline ZrHPW-nano & 0,17 & 0,01 \\
\hline ZrHPW-micro & 0,09 & 0,30 \\
\hline
\end{tabular}

Também é notável a inexistência de hidrogênios no ZrHPW-nano, o que não aconteceu para o ZrHPW-micro. Dessa forma, para o sólido nanoestruturado, a presença do papel filtro e da quantidade de íons $\mathrm{Zr}^{4+}$ utilizada proporcionou um rearranjo estrutural, diferente daquele de Keggin, gerando um material bastante hidrofóbico, praticamente livre de moléculas de água em sua estrutura e, ainda, com baixa acidez de Brønsted (como será visto posteriormente).

A curva DTG do HPW exibe dois picos relacionados a perdas de água, ambas com efeito endotérmico: (i) a primeira $(1,2 \%)$, até $150^{\circ} \mathrm{C}$, relacionada à perda de água fisicamente adsorvida (águas de cristalização); e (ii) a segunda $(3,5 \%)$, até $300{ }^{\circ} \mathrm{C}$, relacionada à perda de água quimicamente adsorvida 
(águas de hidratação dos prótons). As perdas de massa entre 300 e $550{ }^{\circ} \mathrm{C}$ $(0,6 \%)$ dizem respeito à remoção de água estrutural (efeito endotérmico pouco intenso), enquanto as bandas entre 550 e $1000^{\circ} \mathrm{C}(0,03 \%)$ fazem referência à decomposição do ânion de Keggin e cristalização de uma nova fase (efeito exotérmico). Haber e colaboradores reportaram que a perda observada por eles entre 432 e $582{ }^{\circ} \mathrm{C}$ na curva TG do HPW era resultado da remoção de 1,5 moléculas de água da estrutura por ânion de Keggin, enquanto a decomposição dos ânions de Keggin foi percebida em $595^{\circ} \mathrm{C} .{ }^{44} \mathrm{Na}$ Figura 79 , a degradação foi mais sutil, mostrando uma pequena perda de massa em $600{ }^{\circ} \mathrm{C}$.

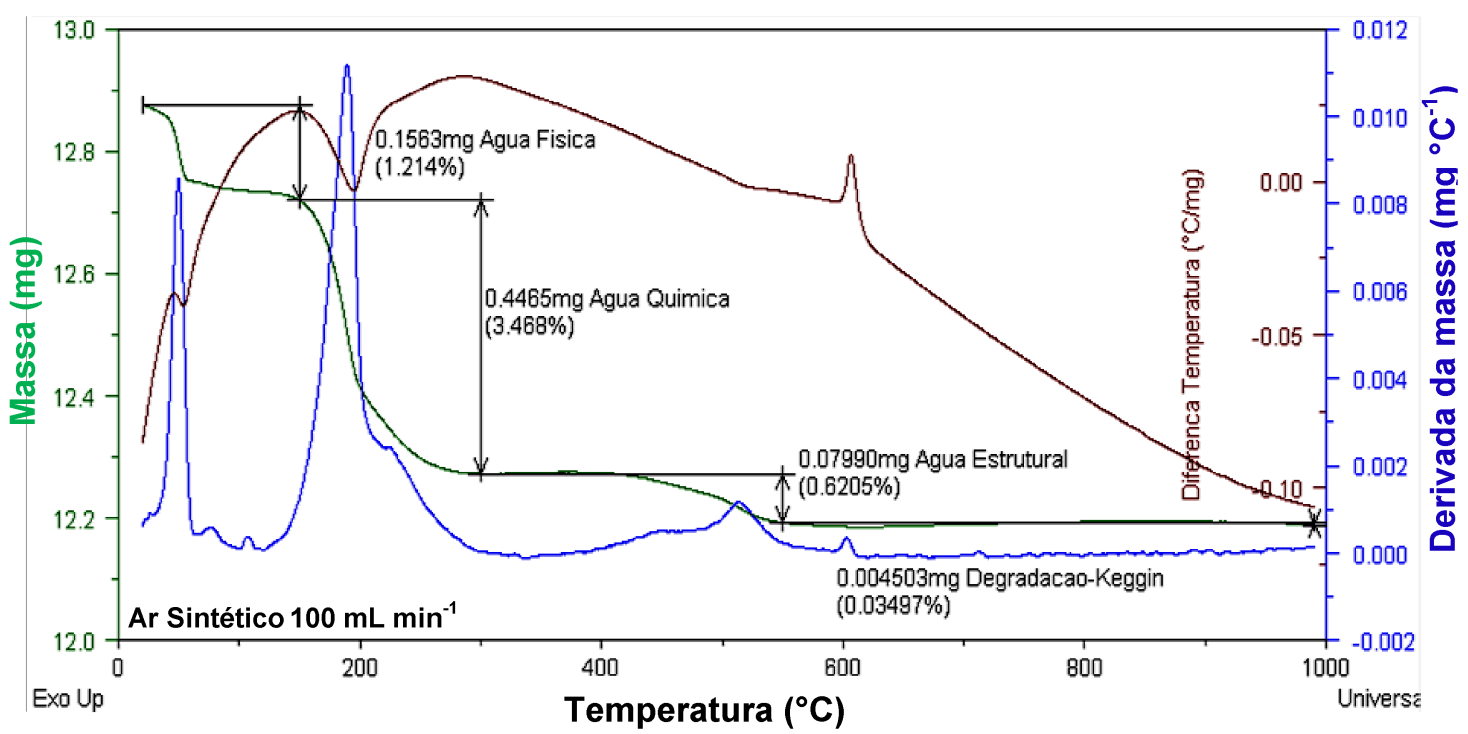

Figura 79: Curvas TG/DTG/DTA obtidas para o HPW puro.

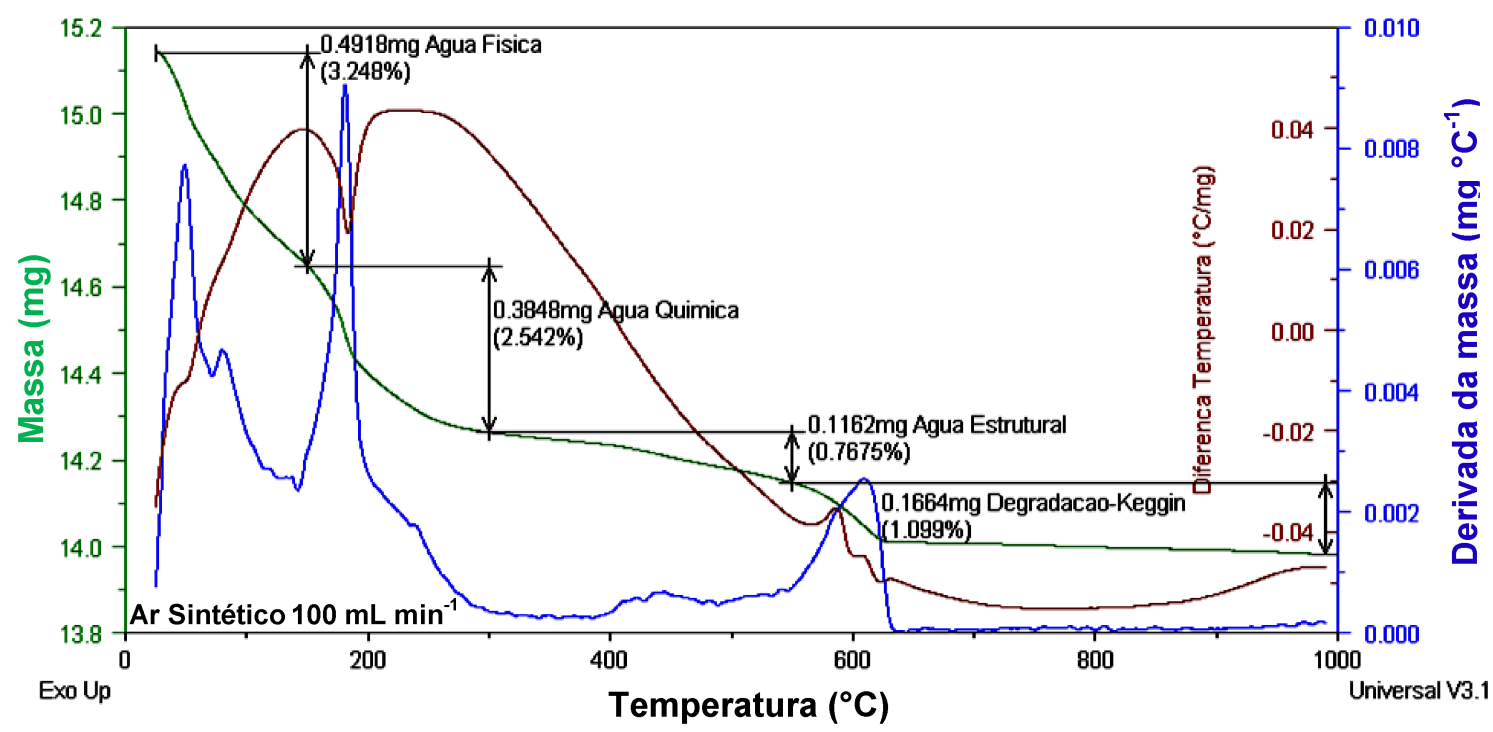

Figura 80: Curvas TG/DTG/DTA obtidas para a amostra ZrHPW-micro. 
As curvas TG/DTG/DTA do ZrHPW-micro (Figura 80) revelaram as mesmas perdas de massa encontradas para o HPW, mas com pequenas variações. Menos água de hidratação foi observada: $3,2 \%$ de água física e $2,5 \%$ de água química. Além disso, foi evidenciado o efeito reportado por Haber e colaboradores ${ }^{44} \mathrm{com}$ a distinção das perdas de massa referentes à água estrutural $\left(0,8 \%\right.$ entre 300 e $\left.550{ }^{\circ} \mathrm{C}\right)$ e à degradação dos ânions de Keggin e formação de óxidos simples $\left(1,1 \%\right.$ entre 550 e $\left.1000^{\circ} \mathrm{C}\right)$. Esta última, apresentou uma perda muito superior à do HPW, podendo estar relacionada, também, à desidroxilação das espécies de zircônio. ${ }^{160}$

Já as curvas TG/DTG/DTA da amostra ZrHPW-nano (Figura 81) se mostraram bastante diferentes das anteriores, apresentando uma perda muito pequena na região de eliminação de água, apenas $1,7 \%$, contra $4,7 \%$ para 0 HPW e 5,8\% para o ZrHPW-micro, o que corrobora com os dados anteriores de FT-IR e CHN. Baixos valores de degradação estrutural também foram encontrados $(0,9 \%)$, sendo que a perda de massa correspondente à decomposição dos ânions de Keggin foi de somente $0,3 \%$, com início da degradação ocorrendo acima de $700{ }^{\circ} \mathrm{C}$, temperatura mais alta que aquela obtida para a amostra microestruturada e para o HPW. Esses dados evidenciam que as nanofibras sintetizadas possuem maior resistência que o ZrHPW-micro e que o HPW, tratando-se ainda de um material bastante hidrofóbico.

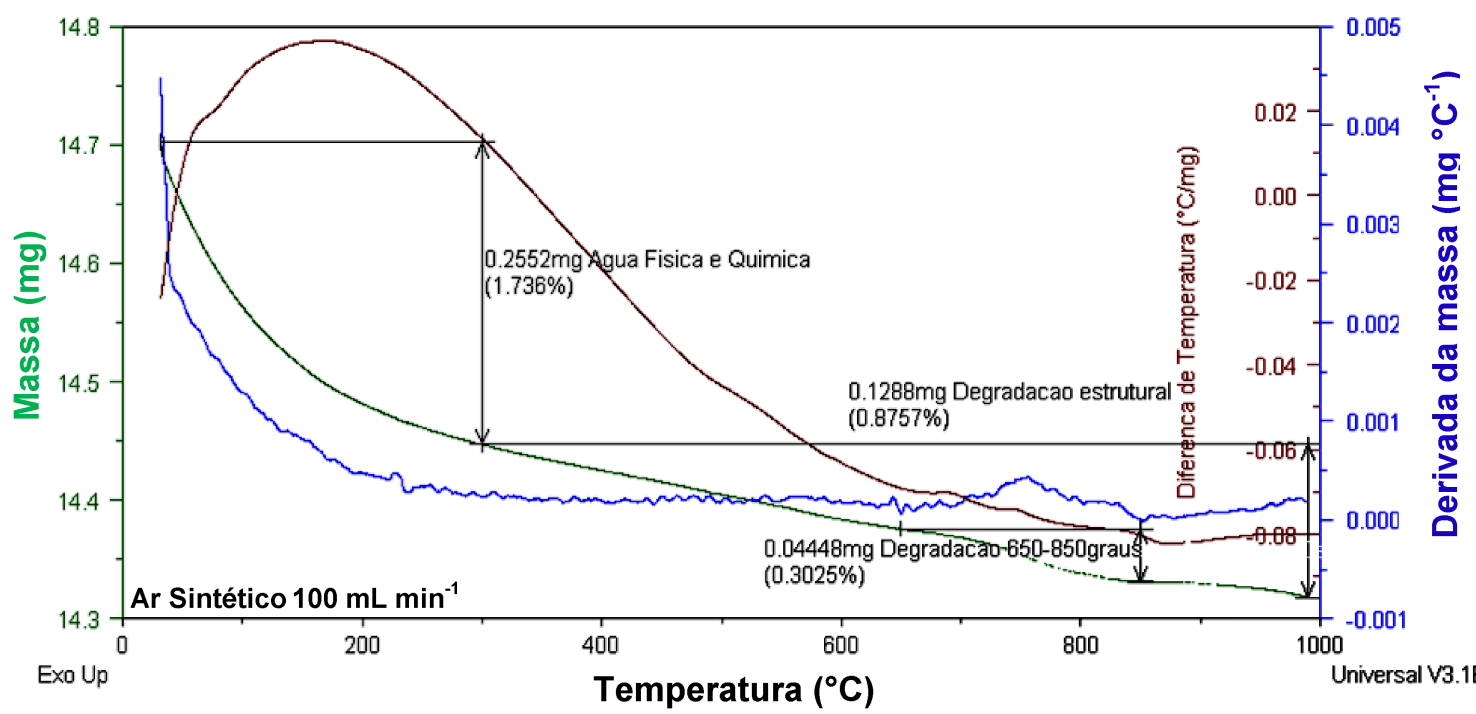

Figura 81: Curvas TG/DTG/DTA obtidas para a amostra ZrHPW-nano. 
De acordo com Zhang e colaboradores, ${ }^{8}$ no sal de zircônio do HPW, o ín $\mathrm{Zr}^{4+}$ é tetracoordenado, formando uma estrutura tetraédrica com acidez de Lewis. Esses sítios foram introduzidos no HPW por troca parcial do $\mathrm{H}^{+}$por $\mathrm{Zr}^{4+}$, de forma que a atuação combinada desses centros ácidos metálicos com os sítios $\mathrm{H}^{+}$remanescentes pode aumentar significativamente a acidez original de Brønsted. A relação estequiométrica proposta nesse trabalho, entretanto, leva em consideração que os cátions $\mathrm{Zr}^{4+}$ podem ter sido hidrolisados em solução durante o processo de síntese. De acordo com a literatura, ${ }^{161}$ as espécies de zircônio formadas em solução dependem da concentração do metal e do pH, podendo formar desde espécies monoméricas $\left(\mathrm{Zr}^{4+},[\mathrm{Zr}(\mathrm{OH})]^{3+},\left[\mathrm{Zr}(\mathrm{OH})_{2}\right]^{2+}\right.$, $\left.\left[\mathrm{Zr}(\mathrm{OH})_{3}\right]^{+}\right)$até espécies oligoméricas mais complexas $\left(\left[\mathrm{Zr}_{3}(\mathrm{OH})_{4}\right]^{8+}\right.$, $\left[\mathrm{Zr}_{4}(\mathrm{OH})_{8}\right]^{8+},\left[\mathrm{Zr}_{5}(\mathrm{OH})_{12}\right]^{8+},\left[\mathrm{Zr}_{8}(\mathrm{OH})_{19}\right]^{13+}$, etc.). Na síntese realizada, o $\mathrm{pH}$ da mistura permaneceu igual a zero ao longo de todo o procedimento, o que, de acordo com o trabalho de Walther e colaboradores, ${ }^{161}$ favorece a formação de espécies monoméricas, tendo sido detectadas menores quantidades de tetrâmeros, como $\circ\left[\mathrm{Zr}_{4}(\mathrm{OH})_{\mathrm{y}}\right]^{16-y}$, e pentâmeros, como $\circ\left[\mathrm{Zr}_{5}(\mathrm{OH})_{\mathrm{y}}\right]^{20-y}$, espécies altamente carregadas.

Desse modo, embora a combinação dos dados obtidos por FRX/EDX e TG/DTG/DTA (Tabela 14) forneçam parte da estequiometria do sólido sintetizado ZrHPW-micro (Equação 12), a determinação da espécie catiônica de zircônio ainda requer mais análises.

Tabela 14: Análise Elementar das amostras ZrHPW-micro e ZrHPW-nano por FRX/EDX e TG/DTG/DTA.

\begin{tabular}{c|c|c|c}
\hline Óxido & $\begin{array}{c}\text { \% Experimental } \\
\text { ZrHPW-micro }\end{array}$ & $\begin{array}{c}\text { \% Teórica } \\
\text { ZrHPW-micro }\end{array}$ & $\begin{array}{c}\text { \% Experimental } \\
\text { ZrHPW-nano }\end{array}$ \\
\hline $\mathrm{WO}_{3}{ }^{\mathrm{a}}$ & 87,71 & 88,05 & 54,64 \\
\hline $\mathrm{ZrO}_{2}{ }^{\mathrm{a}}$ & 4,07 & 4,06 & 23,88 \\
\hline $\mathrm{H}_{2} \mathrm{O}^{\mathrm{b}}$ & 5,97 & 5,98 & 1,88 \\
\hline
\end{tabular}

a: determinado por FRX/EDX.

b: determinado por TG/DTG/DTA (até $400^{\circ} \mathrm{C}$ ).

Além da oligomerização e hidrólise das espécies de zircônio, a não detecção da estrutura de Keggin e a ausência de cristalinidade e de hidrogênios no material ZrHPW-nano mostram que esse sólido apresenta um 
arranjo diferenciado, necessitando também mais estudos para entender como os átomos estão ligados entre si.

$$
\left[\mathrm{Zr}_{n}(\mathrm{OH})_{m}\right]_{(1,041 / n)} \mathrm{H}_{3-\mathrm{x}}\left[\mathrm{PW}_{12} \mathrm{O}_{40}\right] \cdot(10,5-\mathrm{m}) \mathrm{H}_{2} \mathrm{O}
$$

(Equação 12)

onde, $x=(1,041 / n) q \leq 3$ e a carga da unidade $\left[\mathrm{Zr}_{n}(\mathrm{OH})_{m}\right]^{q}$ é $q=4 n-m$.

Dentre as diversas espécies de zircônio, é provável que o cátion $\left[\mathrm{Zr}_{4}(\mathrm{OH})_{8}\left(\mathrm{H}_{2} \mathrm{O}\right)_{16}\right]^{+8}$ prevaleça em relação aos outros devido a ocorrência de polimerização de espécies envolvendo hidroxilas em ponte, em que cada $\mathrm{Zr}$ está ligado a outro por um oxigênio, como mostra a Figura 82. ${ }^{161,162}$

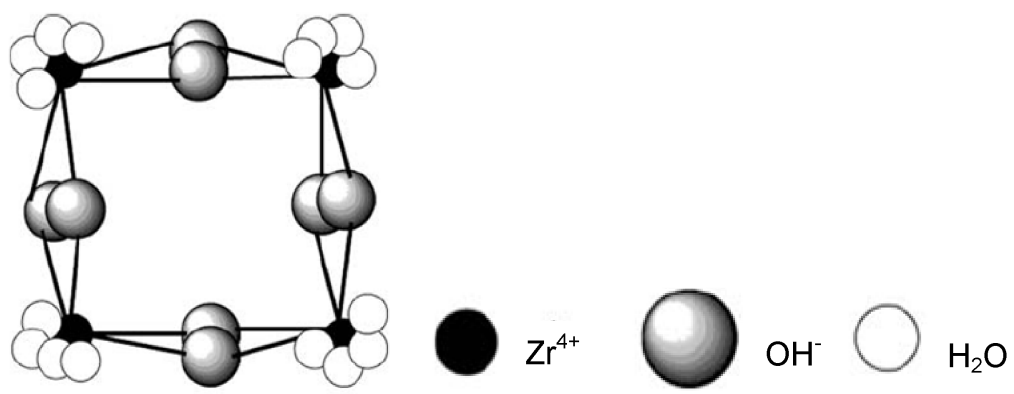

Figura 82: Esquema ilustrativo do cluster catiônico $\left[\mathrm{Zr}_{4}(\mathrm{OH})_{8}\left(\mathrm{H}_{2} \mathrm{O}\right)_{16}\right]^{+8}$. ${ }^{163}$

A estrutura hidratada do cloreto de zirconila, por exemplo, já é conhecida por ser um cluster iônico do tipo $\left[\mathrm{Zr}_{4}(\mathrm{OH})_{8}\left(\mathrm{H}_{2} \mathrm{O}\right)_{16}\right] \mathrm{Cl}_{8} \cdot 12 \mathrm{H}_{2} \mathrm{O}$. ${ }^{164}$ Assim, para constatar a hidrólise dos cátions $\mathrm{Zr}^{4+}$, mostrando que o sal $\mathrm{ZrOCl}_{2}$ é capaz de formar as nanofibras a partir de sua própria oligomerização, esse reagente foi novamente submetido às condições da síntese com papel filtro descrita no item 4.2.2.1. deste trabalho.
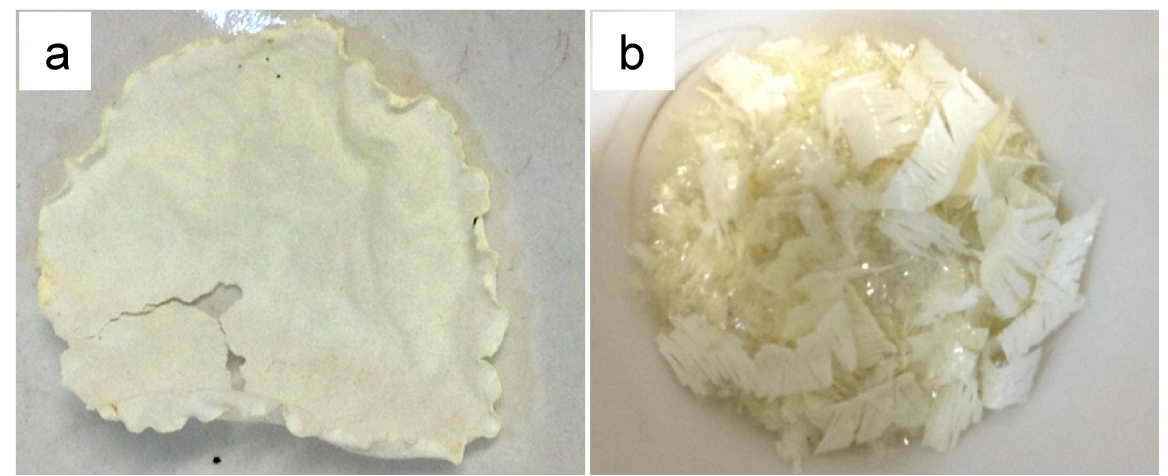

Figura 83: Materiais obtidos a partir da oligomerização do $\mathrm{ZrOCl}_{2}$ em água. A imagem (a) mostra as nanofibras após calcinação, que exibem o mesmo formato do molde papel filtro, e a foto (b) mostra o sólido recuperado após a síntese que não passou pelo molde. 
Os sólidos resultantes dessa síntese sem o HPW (Figura 83) apresentaram as mesmas características físicas daqueles preparados com HPW e suas micrografias podem ser vistas na Figura 84. Com a ausência do HPW, entretanto, não foi detectada a existência dos grupamentos esféricos mostrados nas Figuras 72, 73 e 74 . Isso comprova que essas partículas devem ser, de fato, clusters livres de Zr-HPW.

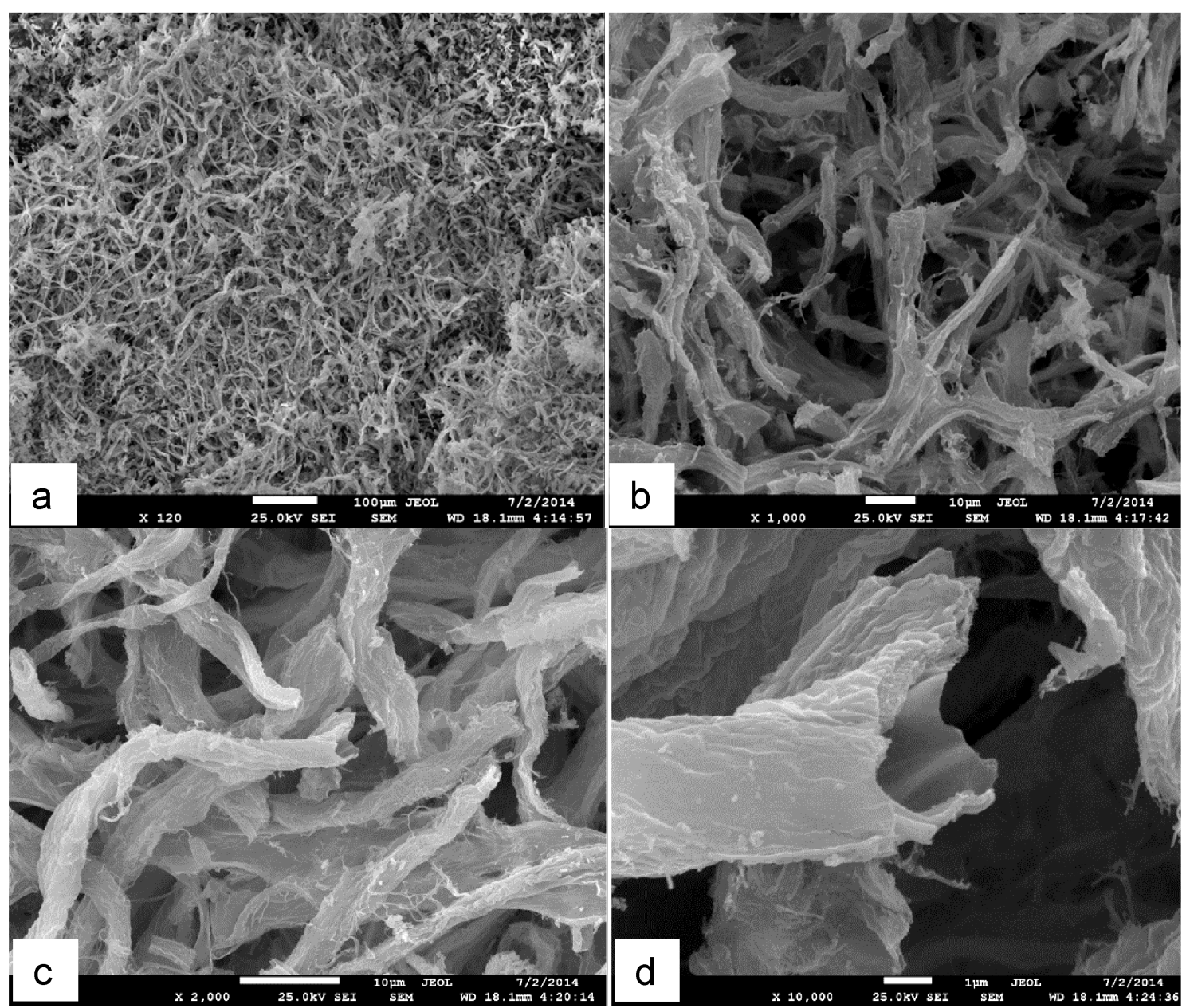

Figura 84: Microscopias do sólido $\mathrm{ZrOCl}_{2}$ hidrolisado e moldado com papel filtro em aproximações de $120 \times$ (a), $1.000 \times$ (b), $2.000 \times$ (c) e $10.000 \times$ (d).

As isotermas de adsorção de $\mathrm{N}_{2}$ das amostras de ZrHPW mostraram ser do tipo II, característica de materiais não porosos ou macroporosos. No entanto, o resultado obtido também pode ser uma indicação de que as moléculas de $\mathrm{N}_{2}$ não tiveram acesso aos poros dos materiais. De fato, a análise de área superficial (S) por BET (Tabela 15) gerou um valor de apenas $2,0 \mathrm{~m}^{2} \mathrm{~g}^{-1}$ para o sólido ZrHPW-micro, valor muito próximo do obtido para a área superficial externa $\left(1,8 \mathrm{~m}^{2} \mathrm{~g}^{-1}\right)$. No caso da amostra nanoestruturada, a 
área superficial foi superior, igual a $6,0 \mathrm{~m}^{2} \mathrm{~g}^{-1}$, mas a área superficial externa pouco variou $\left(2,0 \mathrm{~m}^{2} \mathrm{~g}^{-1}\right)$ em relação ao material micrométrico. $\mathrm{O}$ aumento na área superficial é esperado com a redução do tamanho das partículas em materiais nanométricos. ${ }^{8}$ Embora os resultados obtidos sejam típicos de heteropoliácidos, dados na literatura têm demonstrado que outras moléculasprova, como a água, podem ser utilizadas para uma determinação mais eficiente de área superficial e volume de poro. ${ }^{60}$ Já o valor de diâmetro de poro médio $(D)$ pode ser atribuído às cavidades geradas pela combinação de agregados no ZrHPW-micro (vide Figura 72-c) e pelo emaranhado existente no ZrHPW-nano (vide Figura 74-a).

Tabela 15: Resultados da análise textural para o ZrHPW-micro e ZrHPW-nano.

\begin{tabular}{c|c|c|c}
\hline Amostra & $\mathbf{S}^{\mathbf{a}}\left(\mathbf{m}^{2} \mathbf{g}^{-1}\right)$ & $\boldsymbol{S}_{\text {externa }}\left(\mathbf{m}^{\mathbf{2}} \mathbf{g}^{-1}\right)^{\mathbf{a}}$ & $\boldsymbol{D}(\mathbf{n m})^{\mathbf{b}}$ \\
\hline ZrHPW-micro & 2,0 & 1,8 & 24,0 \\
\hline ZrHPW-nano & 6,0 & 2,0 & 49,7 \\
\hline
\end{tabular}

${ }^{\mathrm{a}} \mathrm{S}=$ área superficial determinada por BET.

${ }^{\mathrm{b}} \mathrm{D}=$ diâmetro de poros médio determinado por BJH.

\subsubsection{Caracterizações Estruturais - ZrHPW (celulose em pó)}

Assim como na síntese com papel filtro, foi objetivo obter um sólido microestruturado (ZrHPW-micro-cp) e outro nanométrico (ZrHPW-nano-cp). Nesse caso, entretanto, o uso da celulose em pó como molde para o ZrHPW-nano-cp foi testado buscando simplificar o procedimento experimental pela substituição das 20 etapas da síntese com papel filtro pelo contato do pó da celulose com os reagentes durante $20 \mathrm{~h}$. Outra vantagem diz respeito à maior área superficial do molde em pó, o que, consequentemente, promove um maior contato entre as substâncias.

Em tese, o mesmo processo sol-gel anterior de interação dos grupos $-\mathrm{OH}$ do material orgânico com as espécies Zr-HPW aconteceria, moldando assim o material final de acordo com a porosidade da celulose em pó. Todavia, as micrografias da Figura 85 revelaram sólidos muito diferentes dos materiais sintetizados com papel filtro (Figuras 72 e 74). Em ambos os casos, as amostras não exibiram geometria definida, ficando constatada a presença de grandes aglomerados. No material ZrHPW-micro-cp, esses aglomerados se apresentaram com superfície bastante compactada, enquanto, para 0 
ZrHPW-nano-cp, as aglomerações se mostraram porosas, com tamanho médio de partícula menor que da celulose em pó, inferior a $1 \mu \mathrm{m}$.

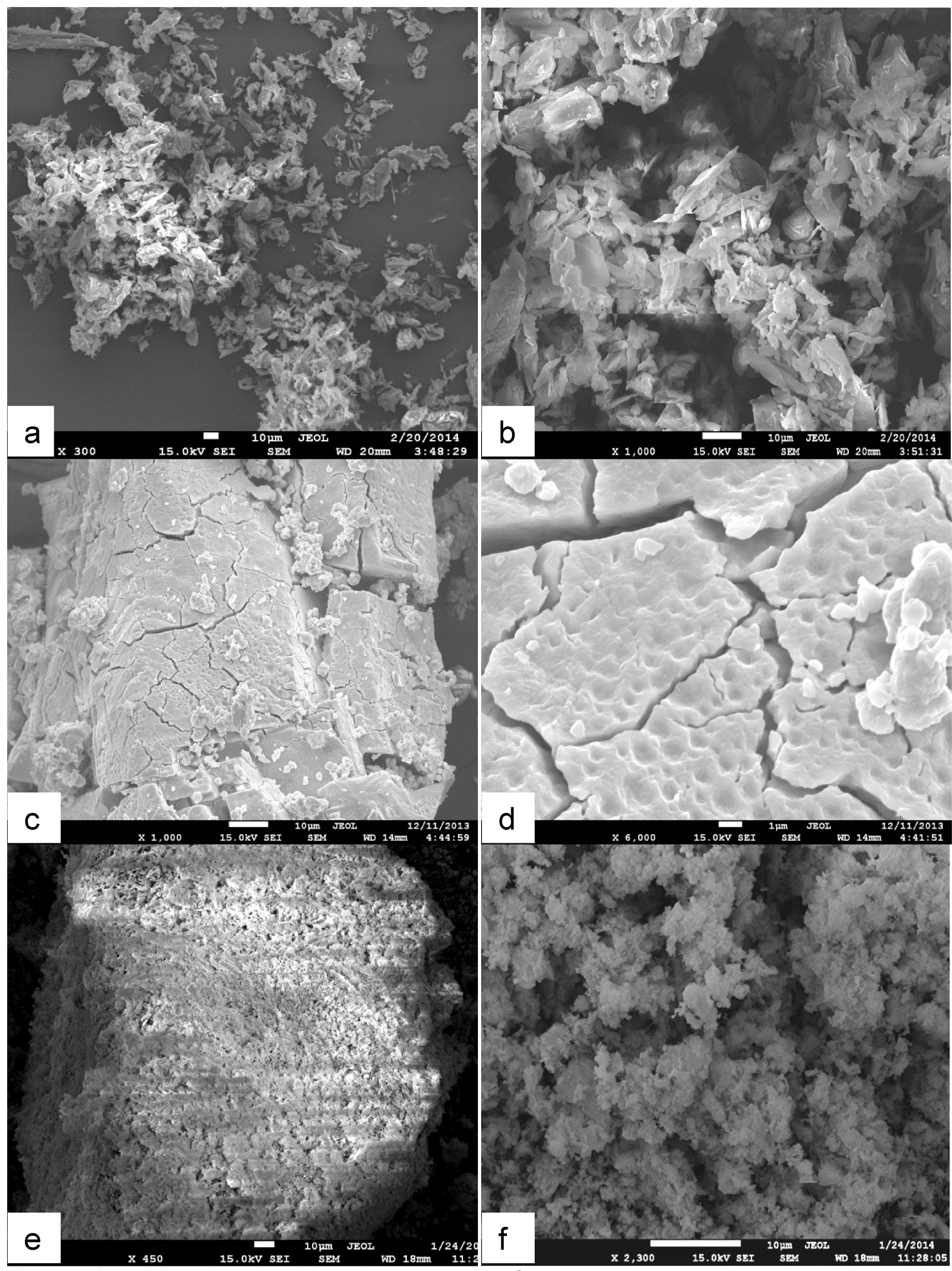

Figura 85: Microscopias da celulose em pó, com aproximações de $300 \times$ (a) e $1.000 \times$ (b); do material ZrHPW-micro-cp, com aproximações de $1.000 \times$ (c) e $6.000 \times$ (d); e da amostra ZrHPW-nano-cp, com aproximações de 450 x (e) e 2.300 x (f). 
Embora as nanofibras não tenham sido detectadas nessa metodologia de síntese pela técnica de MEV, também não houve formação dos clusters $\mathrm{Zr}$-HPW esféricos. Isso indica que as espécies $\mathrm{OH}^{-}$estão mais acessíveis na celulose em pó e conseguem se ligar mais efetivamente com o complexo Zr-HPW durante a síntese, não gerando os diferentes tipos de espécies identificados como depósitos nos sólidos moldados com papel filtro.

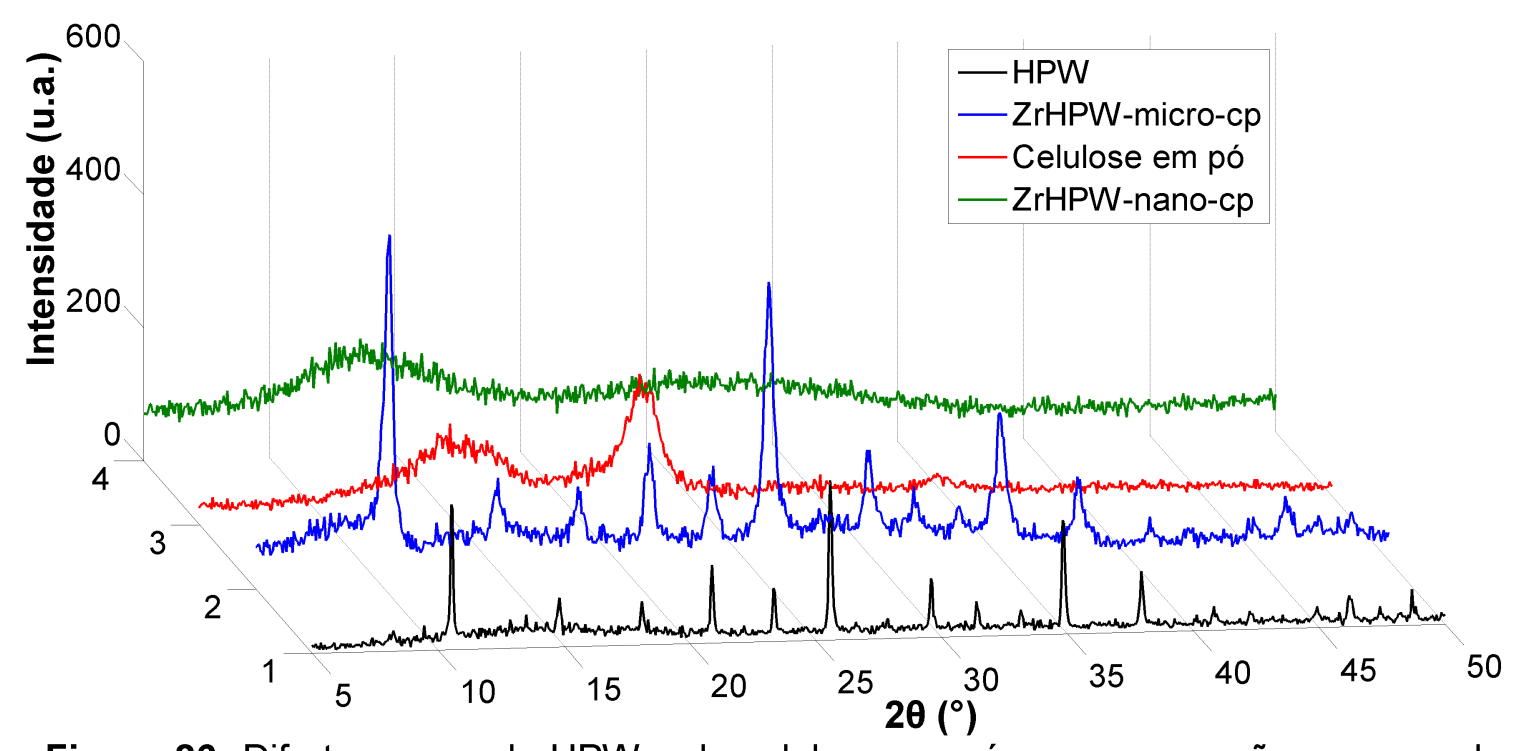

Figura 86: Difratogramas do HPW e da celulose em pó em comparação com aqueles obtidos para as amostras ZrHPW-micro-cp e ZrHPW-nano-cp.

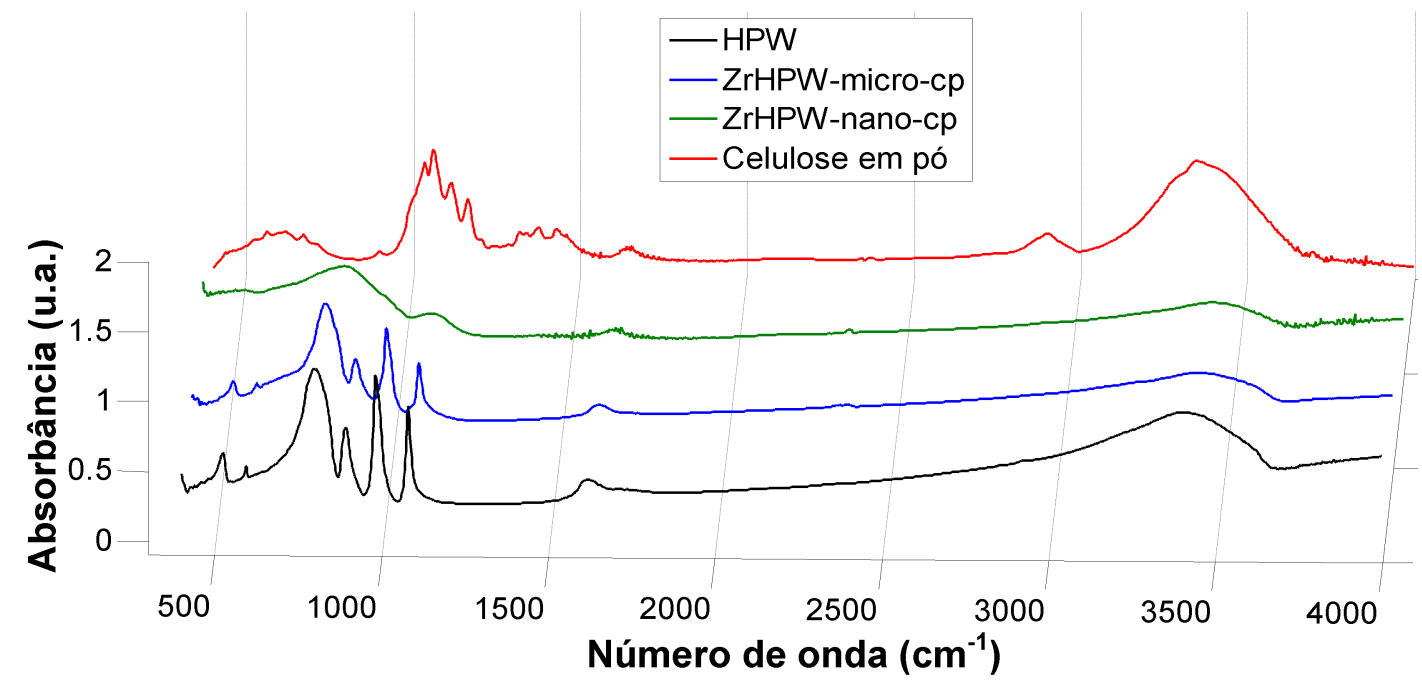

Figura 87: Espectros de FT-IR obtidos para o HPW, para a celulose em pó e para as amostras ZrHPW-micro-cp e ZrHPW-nano-cp.

Mesmo se tratando de materiais diferentes, os difratogramas (Figura 86) e os espectros de FT-IR (Figura 87) dessas amostras se assemelharam 
àqueles dos sólidos moldados com papel filtro (Figuras 77 e 78), apresentando os mesmos deslocamentos para ângulos mais baixos nas reflexões de DRX. Dessa forma, apesar de apresentarem uma estrutura diferenciada nas micrografias, o arranjo cristalográfico dos materiais sintetizados com molde de celulose em pó parece ser o mesmo.

A análise elementar por $\mathrm{CHN}$ (Tabela 16) corrobora com o fato de que a celulose em pó foi capaz de formar ligações mais efetivas com o ZrHPW durante a síntese, pois ainda foram detectados $0,18 \%$ de carbono no material ZrHPW-nano-cp mesmo após sua calcinação, $0,10 \%$ a mais que no sólido moldado com papel filtro. A maior quantidade de carbono foi responsável pelo aumento na proporção de hidrogênios no ZrHPW-nano-cp, o qual também se mostrou ser mais hidrofóbico que o padrão micrométrico. Assim como discutido anteriormente, a quantidade de hidrogênios no ZrHPW-micro-cp também está intimamente relacionada com as hidrólises da zircônia.

Tabela 16: Dados obtidos por CHN para as amostras sintetizadas de ZrHPW.

\begin{tabular}{c|c|c}
\hline Amostra & Carbono (\%) & Hidrogênio (\%) \\
\hline ZrHPW-nano-cp & 0,26 & 0,08 \\
\hline ZrHPW-micro-cp & 0,08 & 0,42 \\
\hline
\end{tabular}

As curvas TG/DTG/DTA (Figuras 88 e 89) mostram, respectivamente, as perdas de massa obtidas para os sólidos micrométrico e nanométrico na síntese com celulose em pó. A curva do material ZrHPW-micro-cp se assemelhou àquela do ZrHPW-micro (Figura 80). Entretanto, menores valores para a degradação estrutural foram observados, mas a temperatura em que a estrutura de Keggin começa a ser degradada é mais baixa $\left(400{ }^{\circ} \mathrm{C}\right)$ que no caso do sólido residual da síntese com papel filtro $\left(600{ }^{\circ} \mathrm{C}\right)$. Já o material nanoestruturado parece ser mais suscetível a degradações e formações de novas fases, pois maiores perdas de massa foram observadas. Assim, em termos estruturais, os sólidos sintetizados com celulose em pó apresentaram resistência inferior àqueles advindos da reação dupla com papel filtro. 


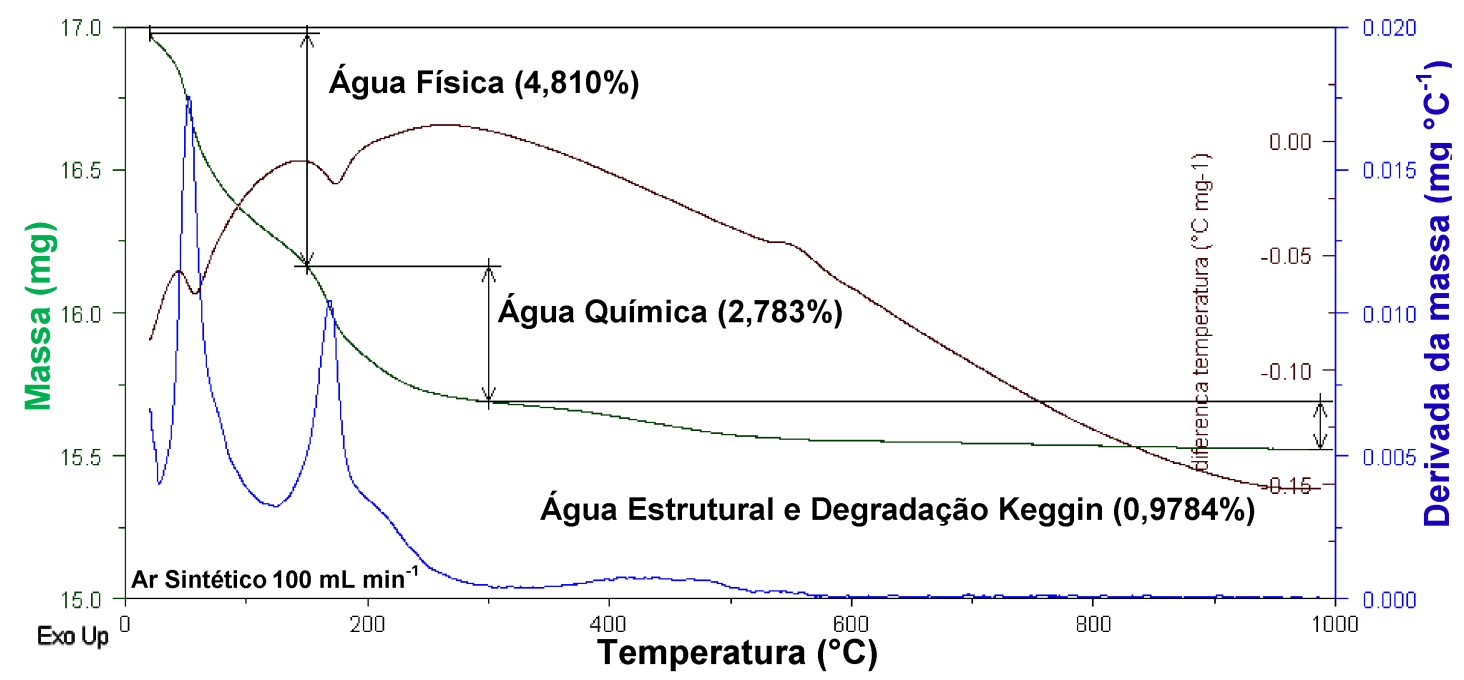

Figura 88: Curvas TG/DTG/DTA obtidas para a amostra ZrHPW-micro-cp.

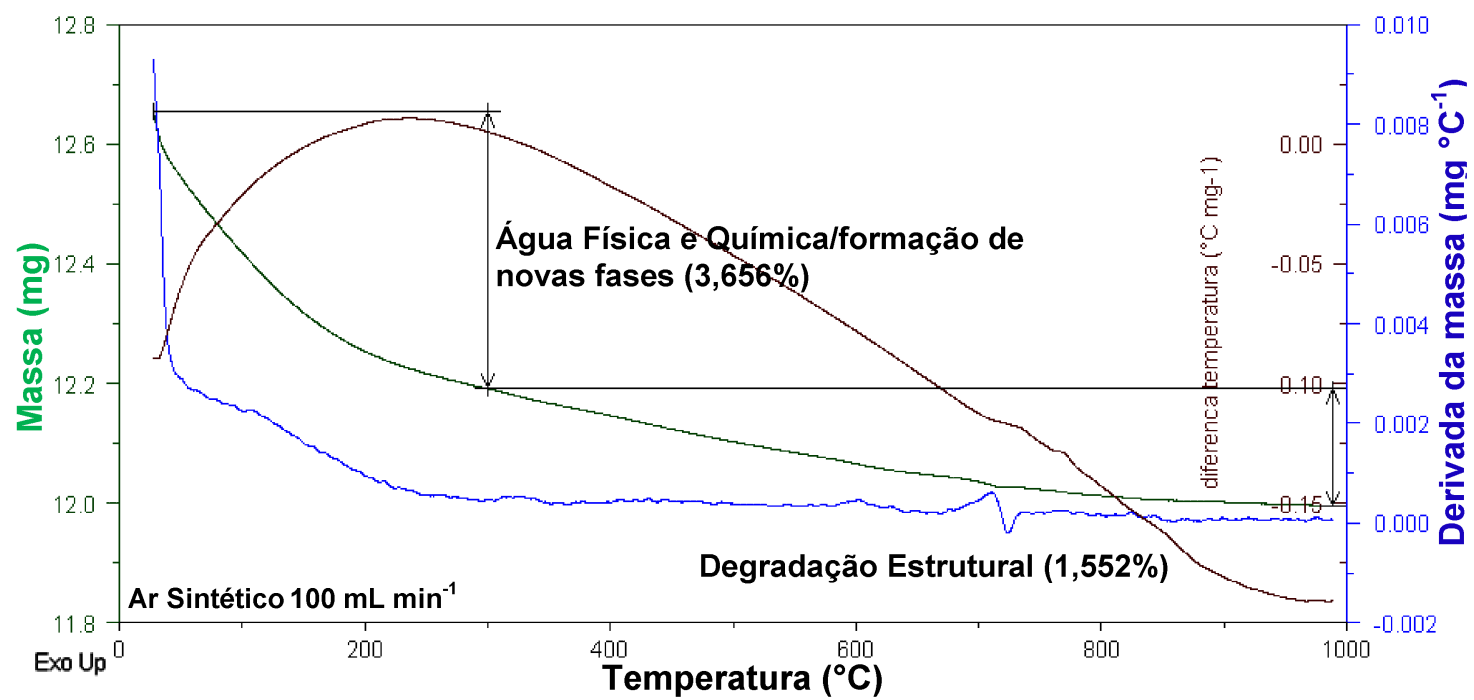

Figura 89: Curvas TG/DTG/DTA obtidas para a amostra ZrHPW-nano-cp.

\subsubsection{Caracterizações de Acidez}

O efeito de polarização do cátion $\mathrm{Zr}^{4+}$ facilita a hidrólise das moléculas de água coordenadas, levando a um incremento na acidez de Brønsted (Equação 13).

$$
\left[\mathrm{Zr}_{n}\left(\mathrm{H}_{2} \mathrm{O}\right)_{k}\right]^{4 n+} \rightarrow\left[\mathrm{Zr}_{\mathrm{n}}\left(\mathrm{H}_{2} \mathrm{O}\right)_{(\mathrm{k}-\mathrm{m})}(\mathrm{OH})_{m}\right]^{\mathrm{q}}+\mathrm{mH}^{+}
$$

onde, $\mathrm{k}=10,5 \mathrm{~mol}$ (medido experimentalmente por TG).

Para quantificar os sítios ácidos existentes nos materiais sintetizados, piridina gasosa foi adsorvida nas amostras ZrHPW-micro, ZrHPW-nano, 
ZrHPW-micro-cp e ZrHPW-nano-cp e, em seguida, os sólidos resultantes foram analisados por FT-IR e TG/DTG/DTA, conforme mostram as Figuras 90 a 95.

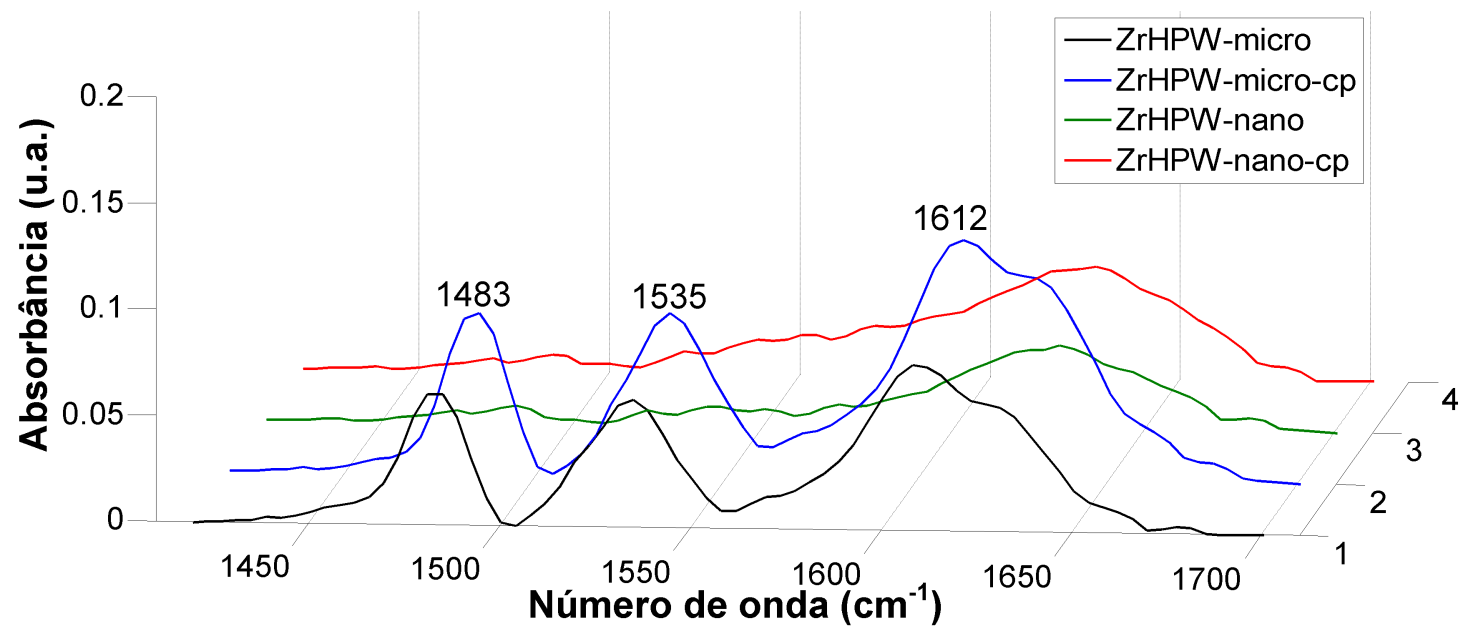

Figura 90: Espectros de FT-IR obtidos para as amostras ZrHPW-micro, ZrHPW-micro-cp, ZrHPW-nano e ZrHPW-nano-cp após adsorção de Py.

As possíveis interações da Py com os diferentes sítios ácidos dos catalisadores aparecem no espectro vibracional em uma faixa entre $1590 \mathrm{e}$ $1440 \mathrm{~cm}^{-1}$. As vibrações relacionadas especificamente a sítios de Lewis ocorrem na região de $1450 \mathrm{~cm}^{-1}$. Como pode ser visto na Figura 89, não há existência de bandas na frequência de Lewis para as amostras. No espectro dos sólidos micrométricos, apenas os estiramentos da piridina protonada por sítios de Brønsted aparecem em 1535 e $1483 \mathrm{~cm}^{-1}$, correspondente à vibração do grupo $\mathrm{N}-\mathrm{H}$ do íon piridínio. Zhang e colaboradores também atribuíram a banda em $1640 \mathrm{~cm}^{-1}$ a sítios de Brønsted, ${ }^{8}$ mas, no presente trabalho, esse sinal foi parcialmente encoberto pela vibração da água, em $1612 \mathrm{~cm}^{-1}$. Dessa forma, a acidez dos materiais ZrHPW-micro e ZrHPW-micro-cp está relacionada aos prótons residuais não substituídos e/ou aos prótons originados pela hidrólise das espécies de zircônio. Para as amostras nanoestruturadas, entretanto, o molde de celulose teve forte influência na polimerização do íon zircônio, e reduziu significativamente os hidrogênios dos materiais, como visto nas análises de $\mathrm{CHN}$. A adsorção de piridina comprovou a baixa acidez nesses materiais nanométricos e, portanto, a formação de sítios ácidos de Brønsted, gerados pela Equação 13, não foi favorecida na estrutura em fibras (Tabela 17). 
Nas curvas TG dos sólidos de HPW e ZrHPW microestruturados (Figuras 91 a 93), nota-se que não há uma perda de massa evidente de Py fisicamente adsorvida (dessorção até $400{ }^{\circ} \mathrm{C}$ ). Apenas dois ambientes relacionados à quimissorção dessa base estão presentes a partir de $400^{\circ} \mathrm{C}$. As duas perdas de massa observadas na Figura 91 para o HPW padrão estão relacionadas a sítios de força diferentes localizados em posições distintas na estrutura do HPW. ${ }^{165}$ Dessa maneira, é visível, nas amostras microestruturadas (Figuras 92 e 93), a perda dos sítios mais fortes, principalmente no sólido sintetizado com celulose em pó. Além disso, na primeira transição observada para o HPW puro, o largo pico mostra que há uma heterogeneidade dos sítios ácidos, caso contrário, eles se apresentariam em forma de um pico mais definido, assim como observado na segunda transição, acima de $550^{\circ} \mathrm{C}$.

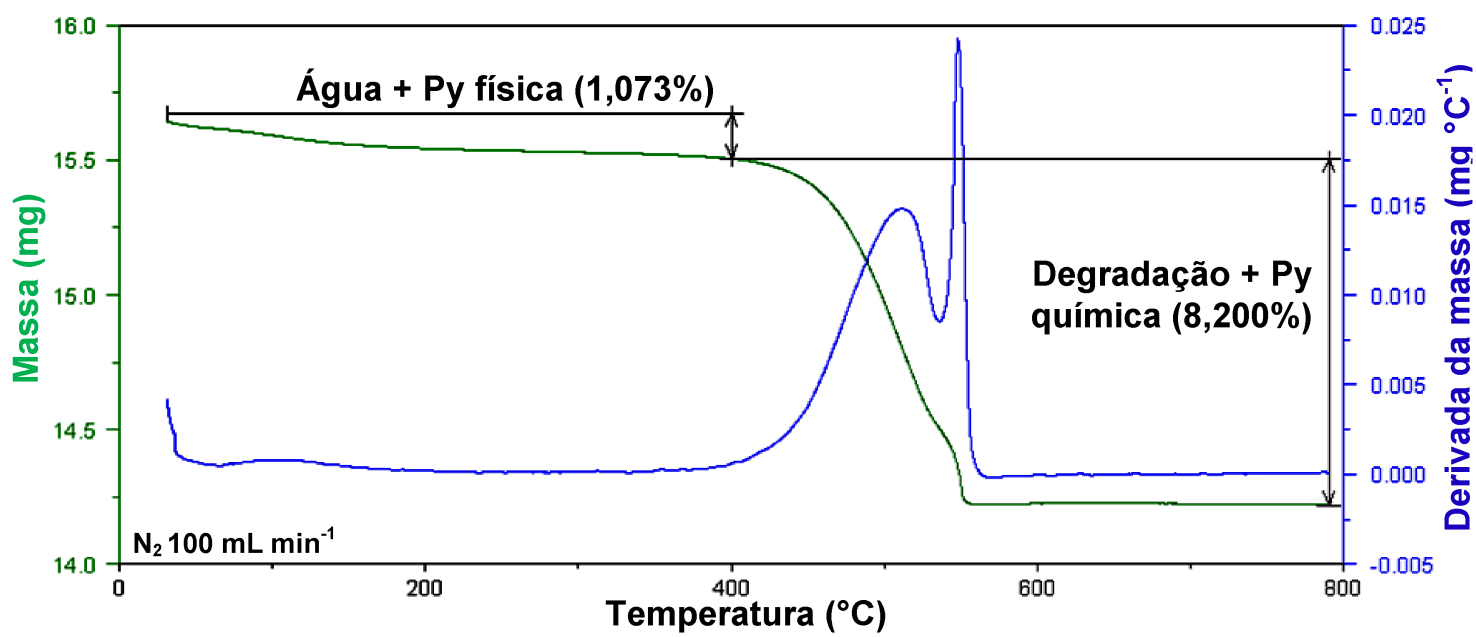

Figura 91: Curvas TG/DTG obtidas para o HPW após adsorção de Py.

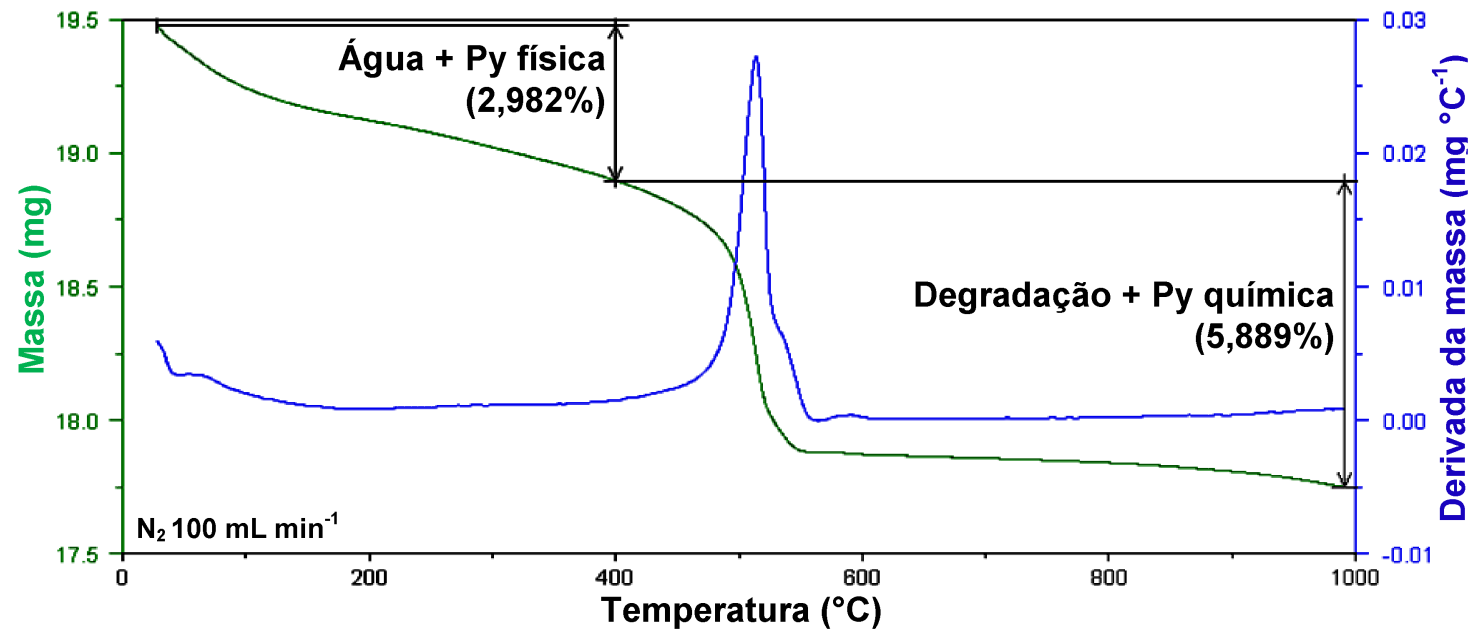

Figura 92: Curvas TG/DTG obtidas para a amostra ZrHPW-micro após adsorção de Py. 


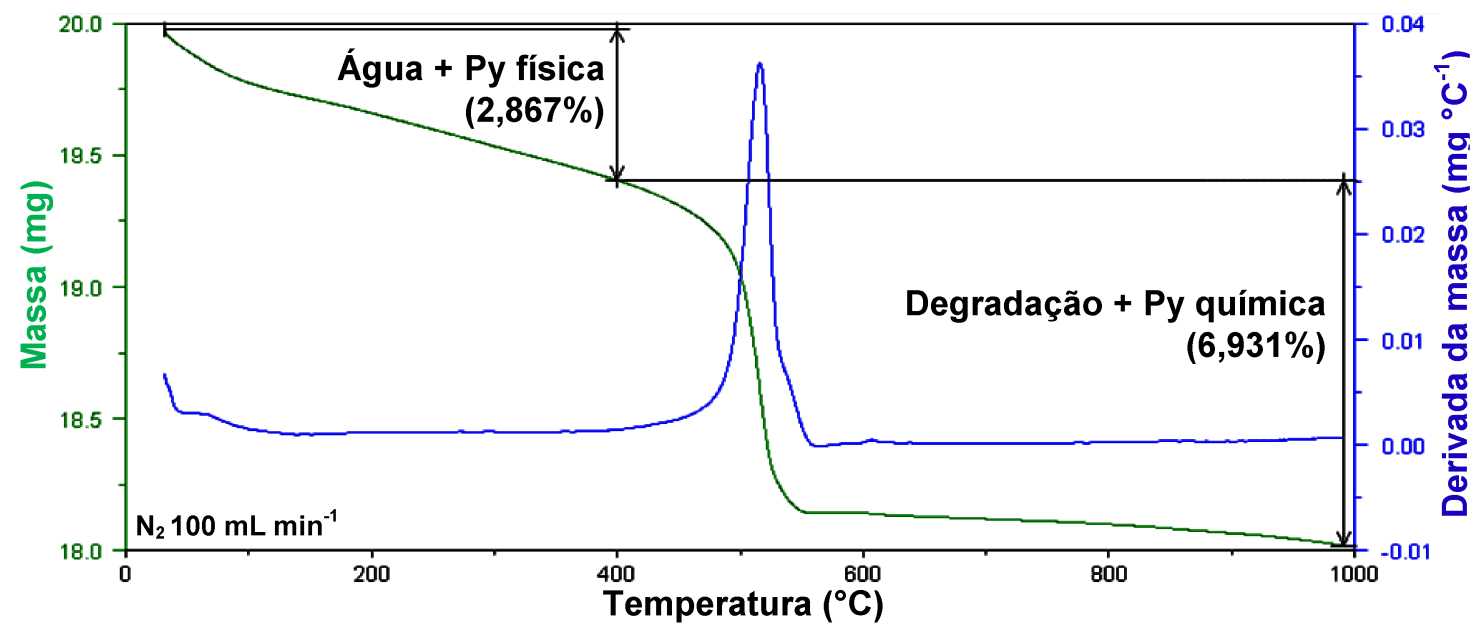

Figura 93: Curvas TG/DTG obtidas para a amostra ZrHPW-micro-cp após adsorção de Py.

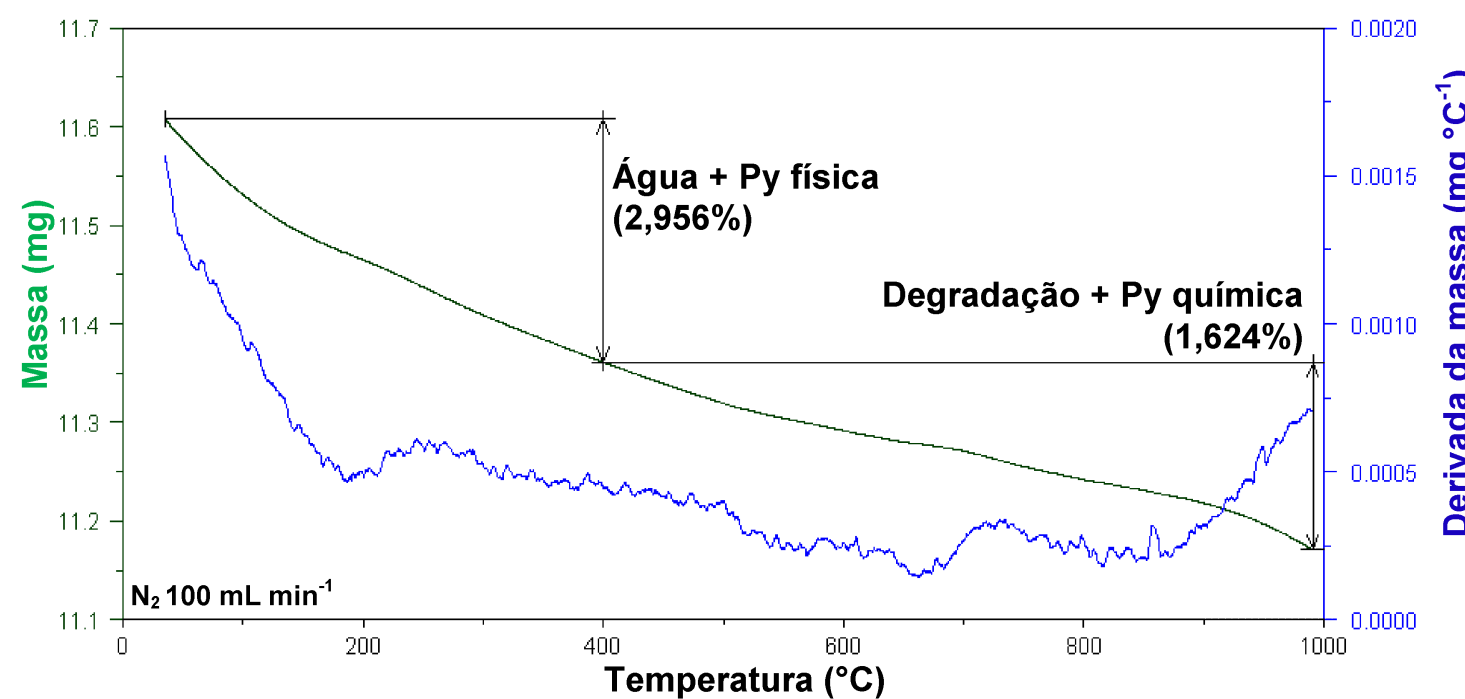

Figura 94: Curvas TG/DTG obtidas para a amostra ZrHPW-nano após adsorção de Py.

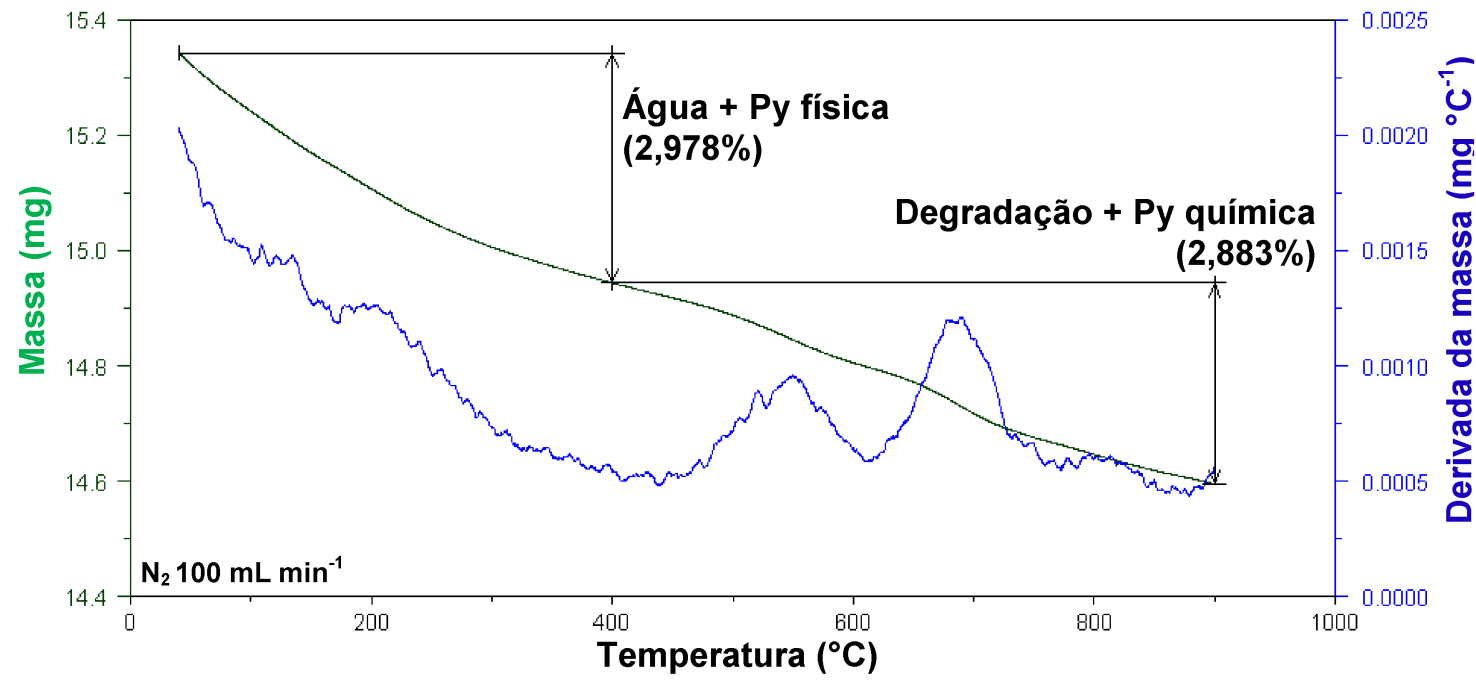

Figura 95: Curvas TG/DTG obtidas para a amostra ZrHPW-nano-cp após adsorção de Py. 
Assim como já evidenciado pelos espectros de FT-IR, os termogramas das amostras nanométricas (Figuras 94 e 95) comprovaram a baixa acidez desses materiais, não apresentando perdas de massa significativas referentes à dessorção de piridina física ou química.

Para proceder com o cálculo do número de sítios ácidos dos catalisadores, levou-se em consideração a massa perdida na região entre 400 e $1000{ }^{\circ} \mathrm{C}$. Os resultados encontrados podem ser vistos na Tabela 17 . Os dados mostram que quase o dobro dos sítios ácidos foi retirado do HPW por meio da substituição por espécies de $\mathrm{Zr}$ no material ZrHPW-micro. Já o sólido micrométrico sintetizado com celulose em pó apresentou maior acidez. No entanto, mais experimentos serão necessários para verificar se os sítios ácidos estão relacionados apenas aos prótons residuais não substituídos ou, se também, a prótons gerados pela hidrólise das espécies de zircônio. Na reação com celulose em pó, era esperado que o maior contato entre os reagentes com a agitação por $20 \mathrm{~h}$ favorecesse a substituição dos íons $\mathrm{H}^{+}$, mas, ao mesmo tempo, a maior liberdade dos íons em solução pode ter beneficiado a hidrólise das espécies de zircônio, aumentando a quantidade de sítios ácidos nesse material em relação ao sólido moldado com papel filtro.

Tabela 17: Número de sítios ácidos calculados via TG a partir da adsorção gasosa de piridina para o HPW e para as amostras sintetizadas com zircônia.

\begin{tabular}{c|c}
\hline Amostra & Número de Sítios Ácidos $\left(\mathbf{m m o l ~} \mathbf{~}^{-1}\right)$ \\
\hline HPW & 0,9593 \\
\hline ZrHPW-micro & 0,5421 \\
\hline ZrHPW-nano & 0,1179 \\
\hline ZrHPW-micro-cp & 0,8069 \\
\hline ZrHPW-nano-cp & 0,2181 \\
\hline
\end{tabular}

A pequena quantidade de sítios ativos encontrada para os materiais nanométricos está relacionada com a alta substituição dos prótons do HPW e corrobora com os baixos valores de hidrogênios detectados por CHN. Portanto, nesses casos, a modelagem em fibras gerou sólidos pouco ácidos com estruturas de longo alcance formadas pela polimerização das espécies de zircônio. 


\subsection{2. $\mathrm{ZnHPW}$}

\subsubsection{Caracterizações Estruturais - ZnHPW (papel filtro)}

Na literatura, é possível encontrar trabalhos que reportam a interação dos cátions $\mathrm{Zn}^{2+}$ com os ânions de HPAs para formação de nanotubos ${ }^{125,166,167}$ e microtubos. ${ }^{168}$ Não raro, essas pesquisas sintetizam os sólidos nanoestruturados e microestruturados a partir da substituição total das espécies $\mathrm{H}^{+}$por íons zinco. Pensando nisso, nesse trabalho, foram estudadas três diferentes proporções do sal $\mathrm{Zn}\left(\mathrm{NO}_{3}\right)_{2}$ para a síntese dupla com HPW na presença do molde papel filtro, buscando investigar as alterações causadas pela substituição total ou parcial dos íons $\mathrm{H}^{+}$na estrutura de Keggin.

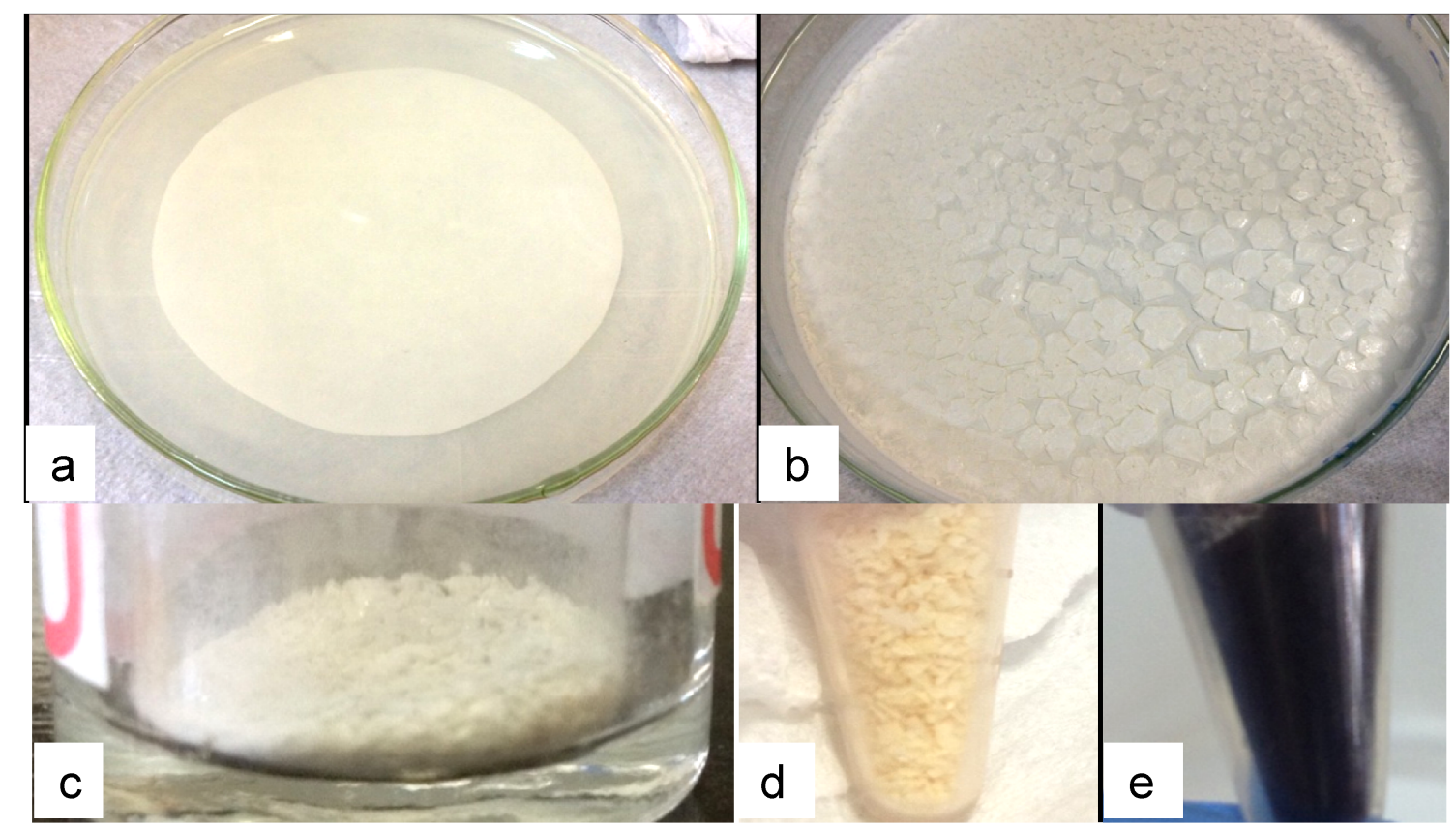

Figura 96: Imagens digitais dos sólidos Zn-HPW obtidos na síntese dupla com papel filtro. Em (a), o papel filtro mergulhado na solução de ZnHPW; em (b), o sólido branco residual ZnHPW-micro-1,33 após 3 dias de secagem ao ar; em (c), o mesmo sólido da foto (b) após calcinação; em (d), o sólido amarelado ZnHPW-micro-2,66, de mesma aparência do ZnHPW-micro-3,98; e, em (e), o sólido preto obtido para todas as amostras moldadas com o papel filtro após calcinação.

A Figura 96 mostra as fotos dos sólidos obtidos. Para a amostra microestruturada sintetizada com $1,33 \mathrm{~g}$ de $\mathrm{Zn}\left(\mathrm{NO}_{3}\right)_{2}$ (ZnHPW-micro-1,33), a menor proporção de íons $\mathrm{Zn}^{2+}$, foi observada uma coloração branca, enquanto os sólidos com massa intermediária (ZnHPW-micro-2,66), 2,66 g de $\mathrm{Zn}\left(\mathrm{NO}_{3}\right)_{2}$, e maior massa ( $\mathrm{ZnHPW}$-micro-3,98), 3,98 g de $\mathrm{Zn}\left(\mathrm{NO}_{3}\right)_{2}$, apresentaram 
coloração mais amarelada. Todos os materiais moldados com papel filtro, entretanto, exibiram cor preta, indicando a persistência de carbono advindo da celulose após calcinação. As análises de CHN (Tabela 18) confirmaram a presença desse carbono residual.

Tabela 18: Dados obtidos por CHN para as amostras sintetizadas ZnHPW.

\begin{tabular}{c|c|c|c}
\hline Amostra & Carbono (\%) & Hidrogênio (\%) & Nitrogênio (\%) \\
\hline ZnHPW-nano-1,33 & 3,35 & 0,42 & 0,07 \\
\hline ZnHPW-micro-1,33 & 0,09 & 0,05 & 0,13 \\
\hline ZnHPW-nano-2,66 & 2,67 & 0,58 & 0,11 \\
\hline ZnHPW-micro-2,66 & 0,08 & 0,06 & 0,26 \\
\hline ZnHPW-nano-3,98 & 4,81 & 0,77 & 0,14 \\
\hline ZnHPW-micro-3,98 & 0,08 & 0,05 & 0,35 \\
\hline
\end{tabular}

É provável que a maior quantidade de carbono retido esteja relacionada com interações fortes entre o zinco e o molde de papel filtro. Como visto anteriormente, o tamanho dos cátions é fator determinante na estrutura secundária do sal de $\operatorname{HPA}^{44,45}$ e, no caso desse trabalho, foi notada sua influência na formação das fibras. Como o íon $\mathrm{Zn}^{2+}$ possui raio iônico pequeno $(0,74 \AA)$, o carbono da celulose pode ter sido necessário para modelar o material em fibras em temperatura ambiente, sendo incorporado nesse processo. Dessa maneira, para remover totalmente o carbono da nova estrutura formada, aumentou-se a temperatura de calcinação. Todavia, um aumento de 400 para $450^{\circ} \mathrm{C}$ implicou na degradação da estrutura primária de Keggin. $\mathrm{O}$ cátion $\mathrm{Zr}^{4+}$ possui raio iônico $(0,72 \AA)$ semelhante ao do $\mathrm{Zn}^{2+}$, porém, é capaz de se hidrolisar e de formar polímeros, o que auxiliou na formação das nanofibras, não sendo detectadas quantidades apreciáveis de carbono.

Com o aumento na quantidade de carbonos, os materiais nanométricos de ZnHPW também aumentaram a porcentagem de hidrogênio. Já os materiais Zn-HPW-micro exibiram redução drástica da quantidade desse elemento. Portanto, o novo arranjo formado com os ânions de Keggin não favoreceu a hidrólise do íon $\mathrm{Zn}^{2+}$, o que está de acordo com a química do zinco, que não se hidrolisa facilmente como a zircônia. Por isso, era esperado que os sólidos micrométricos possuíssem baixa acidez de Brønsted e um comportamento mais hidrofóbico. Também foram detectadas quantidades residuais de 
nitrogênio nas amostras, o que reflete a presença do ânion $\mathrm{NO}_{3}{ }^{-}$nesses sólidos mesmo após calcinação.
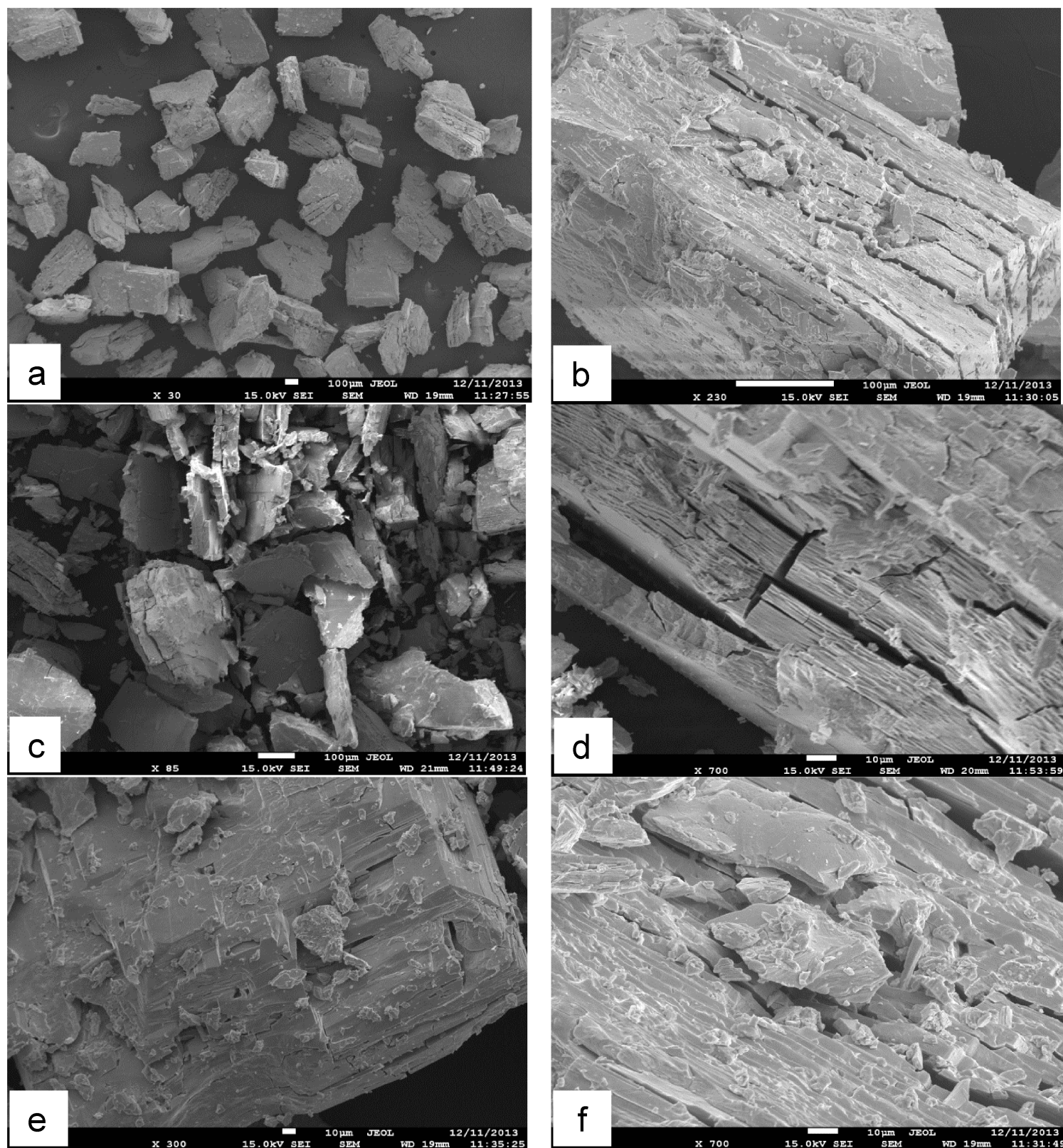

Figura 97: Micrografias dos sólidos sintetizados ZnHPW-micro-1,33, em aproximações de 30 x (a) e 230 x (b); ZnHPW-micro-2,66, em aproximações de 85 x (c) e 700 x (d); e ZnHPW-micro-3,98, em aproximações de $300 \times$ (e) e $700 \times$ (f).

As imagens de MEV obtidas para as amostras microestruturadas podem ser observadas na Figura 97. Como é visto, a morfologia do sal ZnHPW-micro não apresenta variações perceptíveis com o aumento da quantidade de massa de $\mathrm{Zr}\left(\mathrm{NO}_{3}\right)_{2}$ utilizada, exibindo um padrão de aglomerados poliédricos de 
comprimento médio entre 500 e $600 \mu \mathrm{m}$ e com fissuras. Já as micrografias da Figura 98 comprovam a síntese de nanofibras para as amostras ZnHPW-nano-1,33, mostrando fibras mais bem definidas que aquelas obtidas para as amostras de ZrHPW-nano (Figura 74).

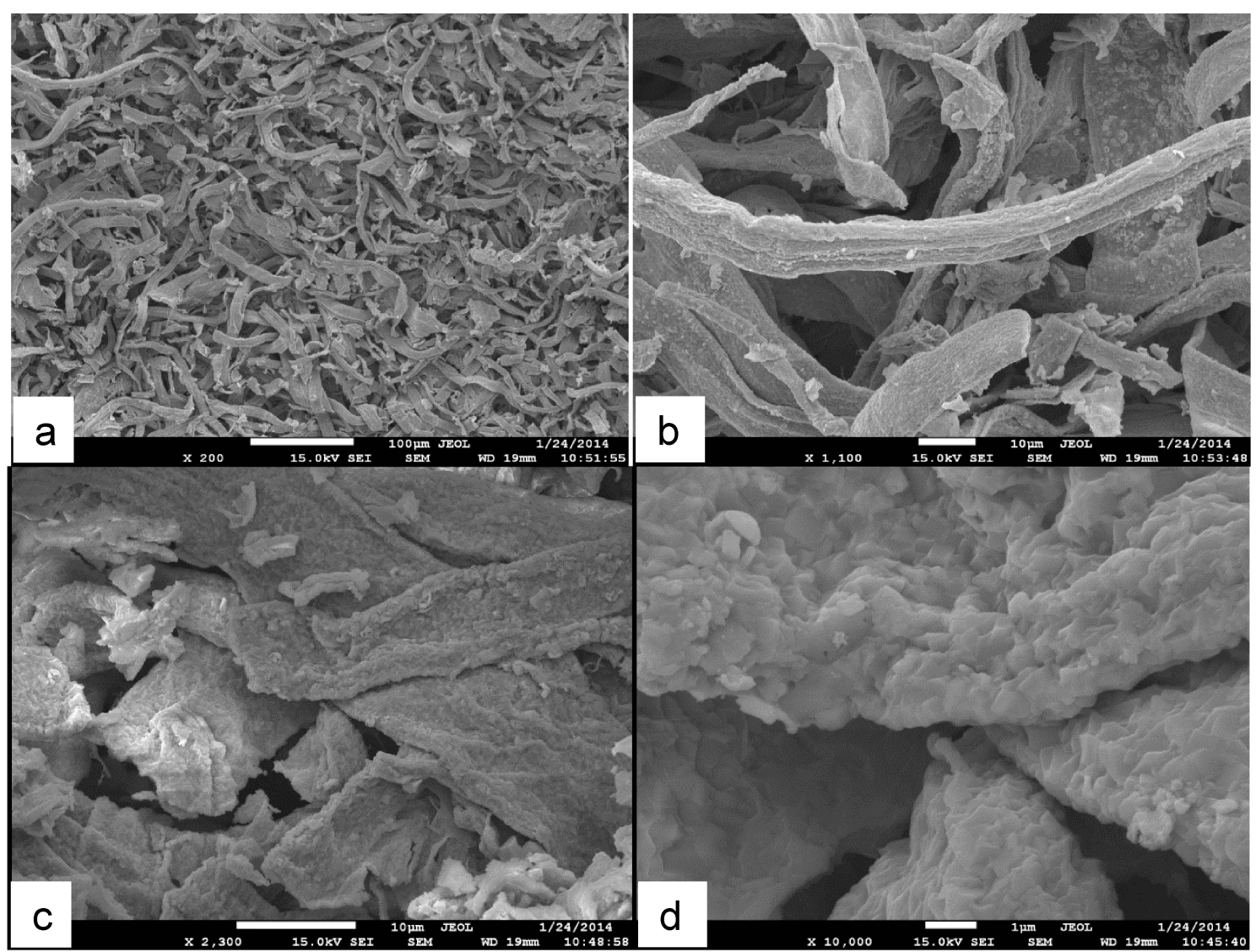

Figura 98: Micrografias do sólidos moldado com papel filtro ZnHPW-nano-1,33 em aproximações de $200 \times$ (a), $1.100 \times$ (b), $2.300 \times$ (c) e $10.000 \times$ (d).

O aumento da quantidade de zinco, no entanto, parece dificultar a formação e a separação das fibras. Nas micrografias da amostra ZnHPW-nano-2,66 (Figura 99), é possível observar fibras mais entrelaçadas, menos definidas e com depósitos, enquanto as imagens obtidas para o sólido com maior quantidade de zinco (ZnHPW-nano-3,98) (Figura 100) exibem uma grande massa, mais compacta, com apenas alguns padrões de fibras incrustadas. Como a amostra ZnHPW-nano-3,98 não apresentou a formação do material desejado e reteve grande quantidade de carbono, ela e seu padrão microestruturado foram descartados das futuras análises. 


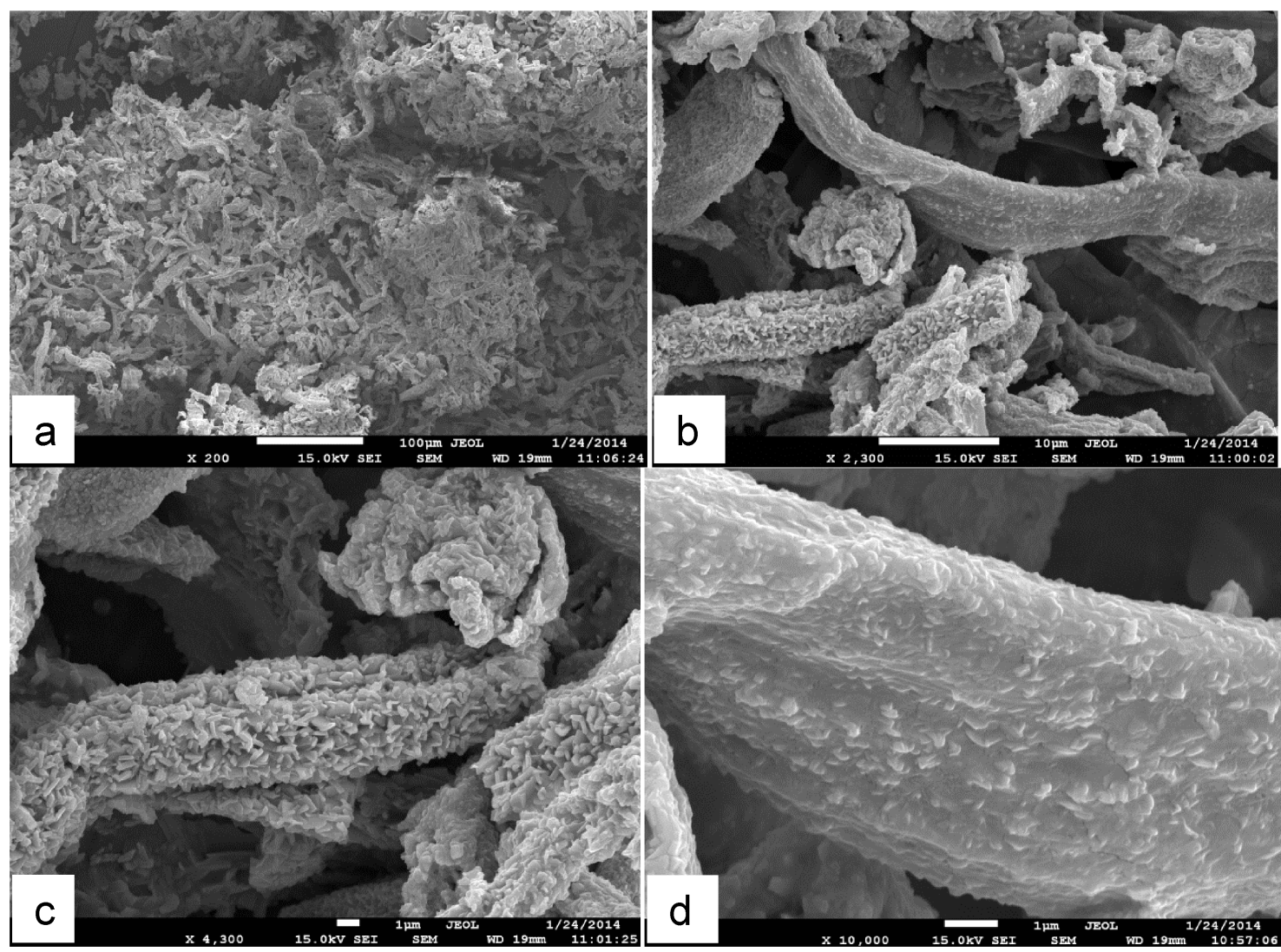

Figura 99: Micrografias do sólido moldado com papel filtro ZnHPW-nano-2,66 em aproximações de 200 x (a), 2.300 x (b), 4.300 x (c) e 10.000 x (d).

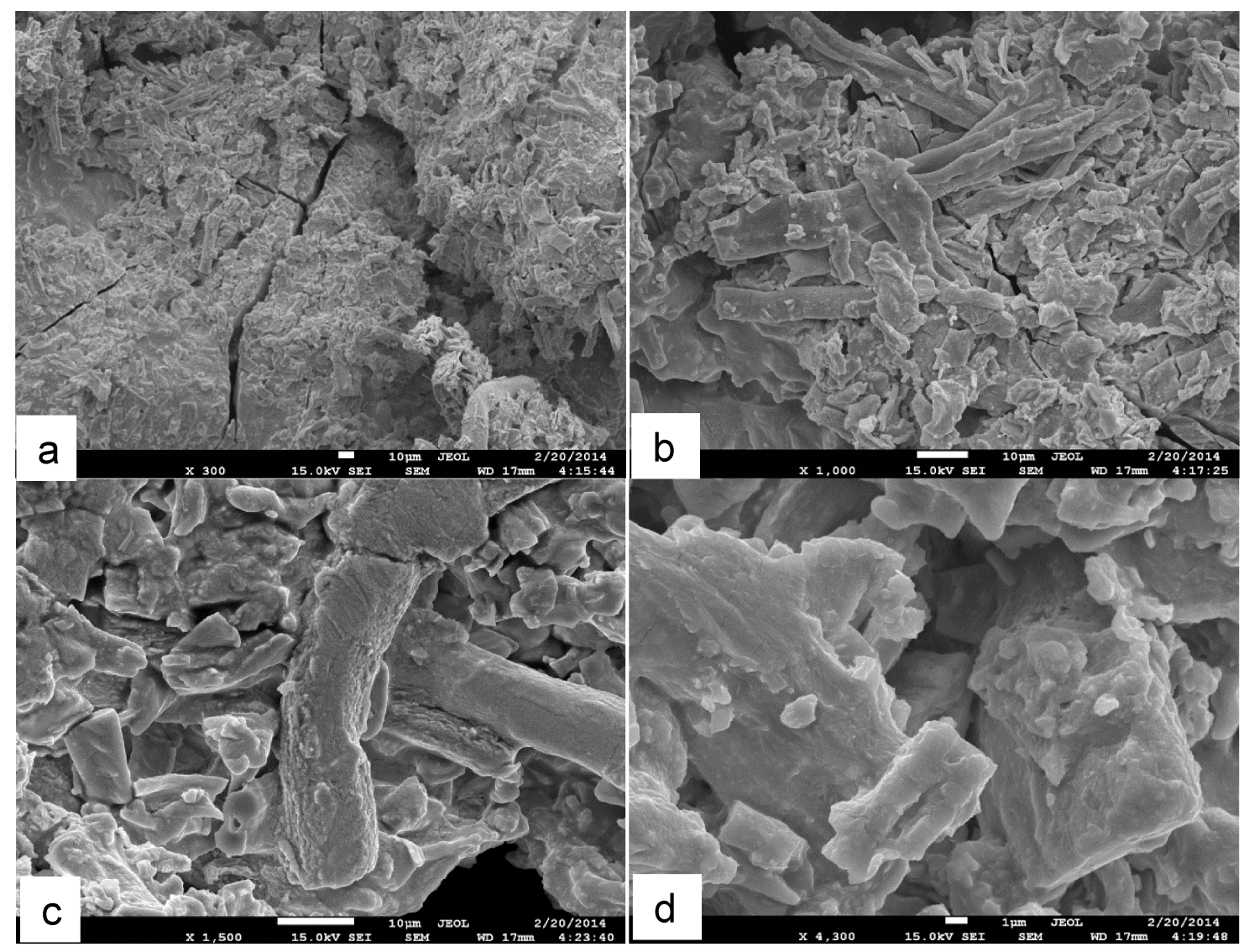

Figura 100: Micrografias do sólido moldado com papel filtro ZnHPW-nano-3,98 em aproximações de $300 \times$ (a), 1.000 x (b), $1.500 \times$ (c) e 4.300 x (d). 
Os espectros de FT-IR (Figura 101) confirmaram a manutenção da estrutura primária do HPW, exibindo a conservação das bandas relacionadas ao ânion Keggin tanto para as amostras nanoestruturadas como para aquelas sintetizadas com massa reduzida e massa intermediária de reagente $\mathrm{Zn}\left(\mathrm{NO}_{3}\right)_{2}$. Nos padrões ZnHPW-micro, principalmente na amostra ZnHPW-micro-2,66, foi possível observar bandas extras, em 1355 e $1388 \mathrm{~cm}^{-1}$, as quais estão relacionadas com estiramentos assimétricos do ânion $\mathrm{NO}_{3}{ }_{3}^{-169}$ Portanto, assim como visto nas análises de $\mathrm{CHN}$, a calcinação a $400{ }^{\circ} \mathrm{C}$ não foi capaz de eliminar totalmente o reagente de partida. As amostras ZnHPW-nano, apesar de exibirem as bandas de Keggin, apresentaram intensidades menores em relação ao HPW padrão e às amostras micrométricas, ressaltando as variações morfológicas que ocorreram nesses materiais.

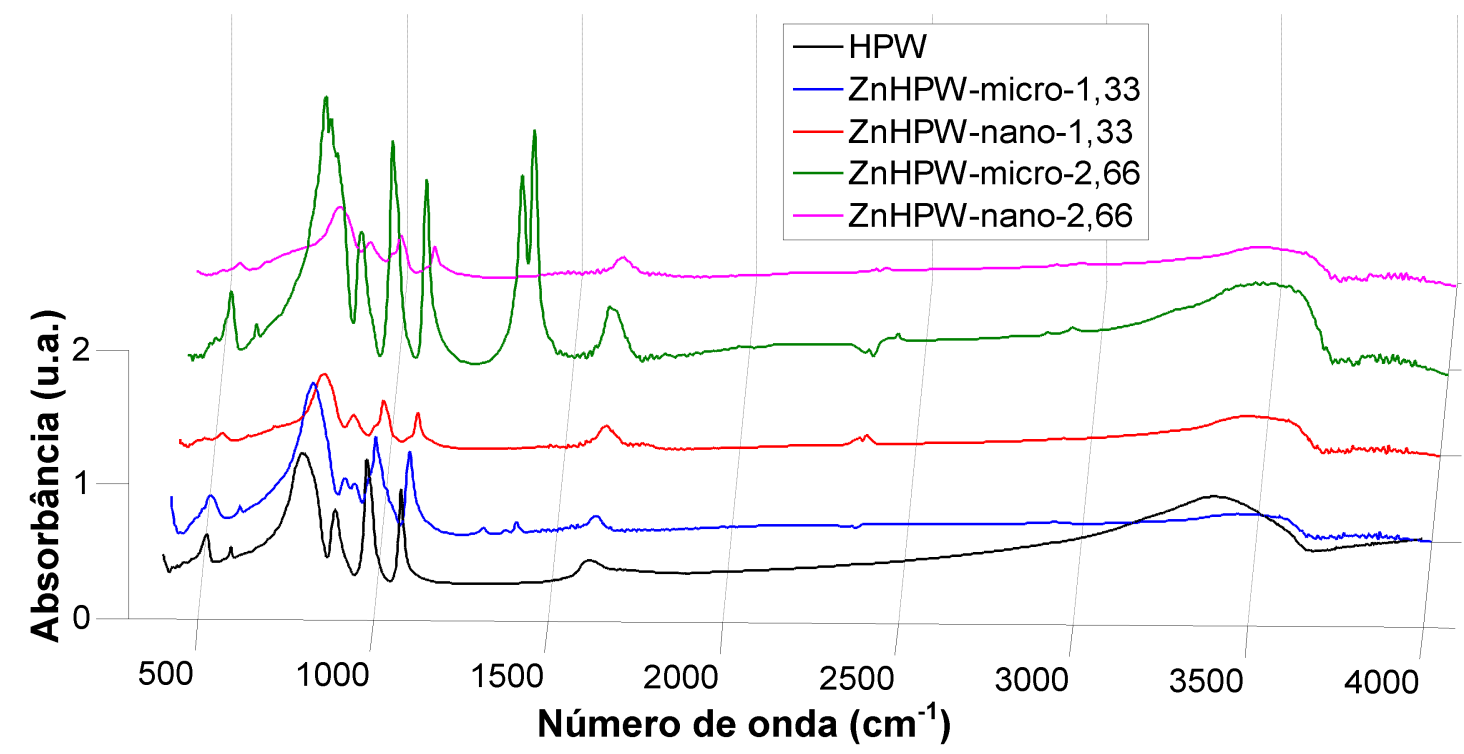

Figura 101: Espectros de FT-IR obtidos para $\circ$ HPW e para as amostras ZnHPW-micro-1,33, ZnHPW-nano-1,33, ZnHPW-micro-2,66 e ZnHPW-nano-2,66.

Era esperado que, após interagir com os ânions de Keggin, o nitrato de zinco não reagido, bem como os contraíons $\mathrm{NO}_{3}{ }^{-}$fossem decompostos em temperaturas de calcinação acima de $350{ }^{\circ} \mathrm{C}$ (Figura 102), ${ }^{170,171}$ restando apenas o complexo ZnO-HPW.

Matecka e colaboradores ${ }^{171}$ estudaram a decomposição do $\mathrm{Zn}\left(\mathrm{NO}_{3}\right)_{2}$ e perceberam a formação de intermediários, como o $\mathrm{Zn}\left(\mathrm{NO}_{3}\right)_{2} \cdot \mathrm{Zn}(\mathrm{OH})_{2}$, e de gases, como $\mathrm{H}_{2} \mathrm{O}, \mathrm{O}_{2}, \mathrm{NO}$ e $\mathrm{NO}_{2}$, além de pequenas quantidades de $\mathrm{N}_{2} \mathrm{O}$, ao longo da degradação desse sal. Pouco antes de $50{ }^{\circ} \mathrm{C}$, um pico endotérmico é 
evidenciado por DTA, temperatura em que o sal começa a se fundir e a gerar os intermediários, formando simultaneamente $\mathrm{HNO}_{3}$. As águas de cristalização são removidas entre 200 e $300{ }^{\circ} \mathrm{C}$, correspondendo aos efeitos endotérmicos na curva DTA. Nessas temperaturas, os complexos hidroxilados também entram em decomposição.

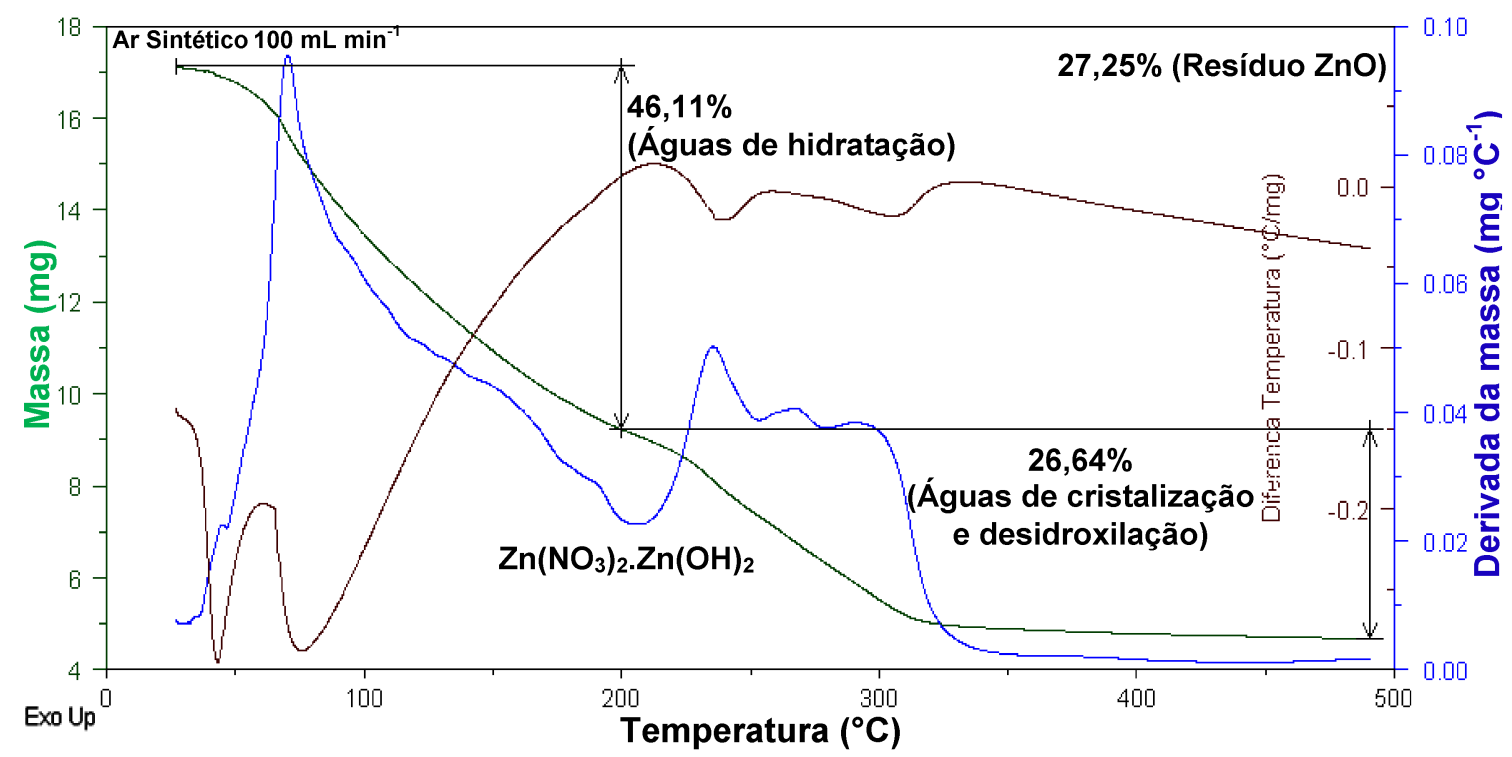

Figura 102: Curvas TG/DTG/DTA obtidas para o reagente $\mathrm{Zn}\left(\mathrm{NO}_{3}\right)_{2}$. A partir de $170{ }^{\circ} \mathrm{C}$, complexos hidroxilados são observados, decompondo-se acima de $250^{\circ} \mathrm{C}$.

A degradação dos grupos $\mathrm{NO}_{3}{ }^{-}$foi observada por Matecka e colaboradores apenas após total degradação da substância, com remoção de todas as águas do sistema, de acordo com a Equação $14 .{ }^{171}$ Assim, é provável que, com a presença do HPW, a temperatura de decomposição dos ânions $\mathrm{NO}_{3}{ }^{-}$tenha sido elevada ou, ainda, que complexos hidroxilados $\left(\mathrm{Zn}\left(\mathrm{NO}_{3}\right)_{2} \cdot \mathrm{Zn}(\mathrm{OH})_{2}\right)$ tenham permanecido no novo material por meio de interações com ânions de Keggin, o que explicaria a existência das vibrações do íon $\mathrm{NO}_{3}{ }^{-}$no espectro de FT-IR.

$$
2 \mathrm{NO}_{3}^{-} \rightarrow \mathrm{xNO}+(2-\mathrm{x}) \mathrm{NO}_{2}+1 / 2(\mathrm{x}+1) \mathrm{O}_{2}+\mathrm{O}^{2-}
$$

As curvas TG/DTG/DTA das amostras microestruturadas podem ser observados nas Figuras 103 e 104, respectivamente. As perdas na região entre 150 e $300^{\circ} \mathrm{C}$ condizem com as curvas DTG de formação de espécies poliméricas a partir do $\mathrm{Zn}\left(\mathrm{NO}_{3}\right)_{2}$ e sua desidroxilação (Figura 102). Após a calcinação do sólido, é possível então que espécies remanescentes contendo 
$\mathrm{NO}_{3}^{-}$tenham permanecido no material, sendo eliminadas somente em temperaturas acima de $400^{\circ} \mathrm{C}$, juntamente com a degradação da estrutura de Keggin.

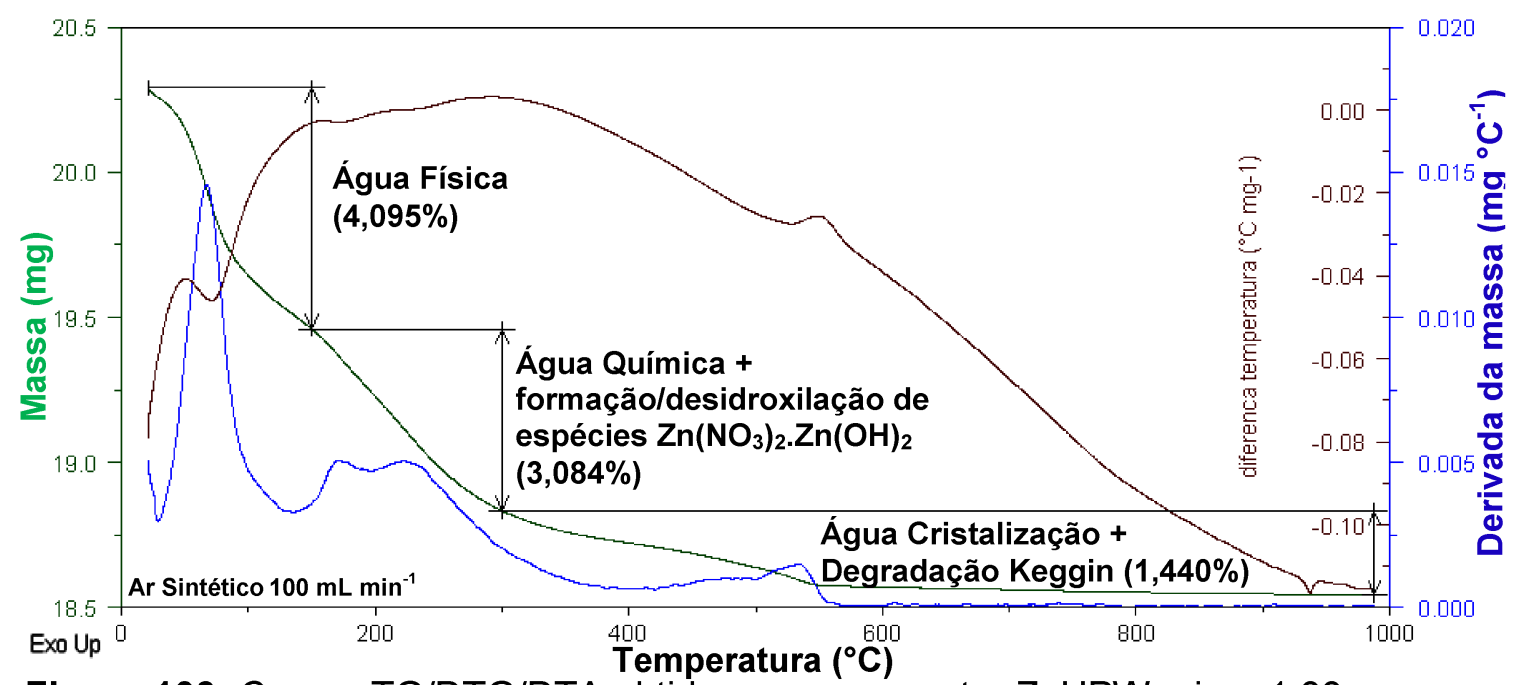

Figura 103: Curvas TG/DTG/DTA obtidas para a amostra ZnHPW-micro-1,33.

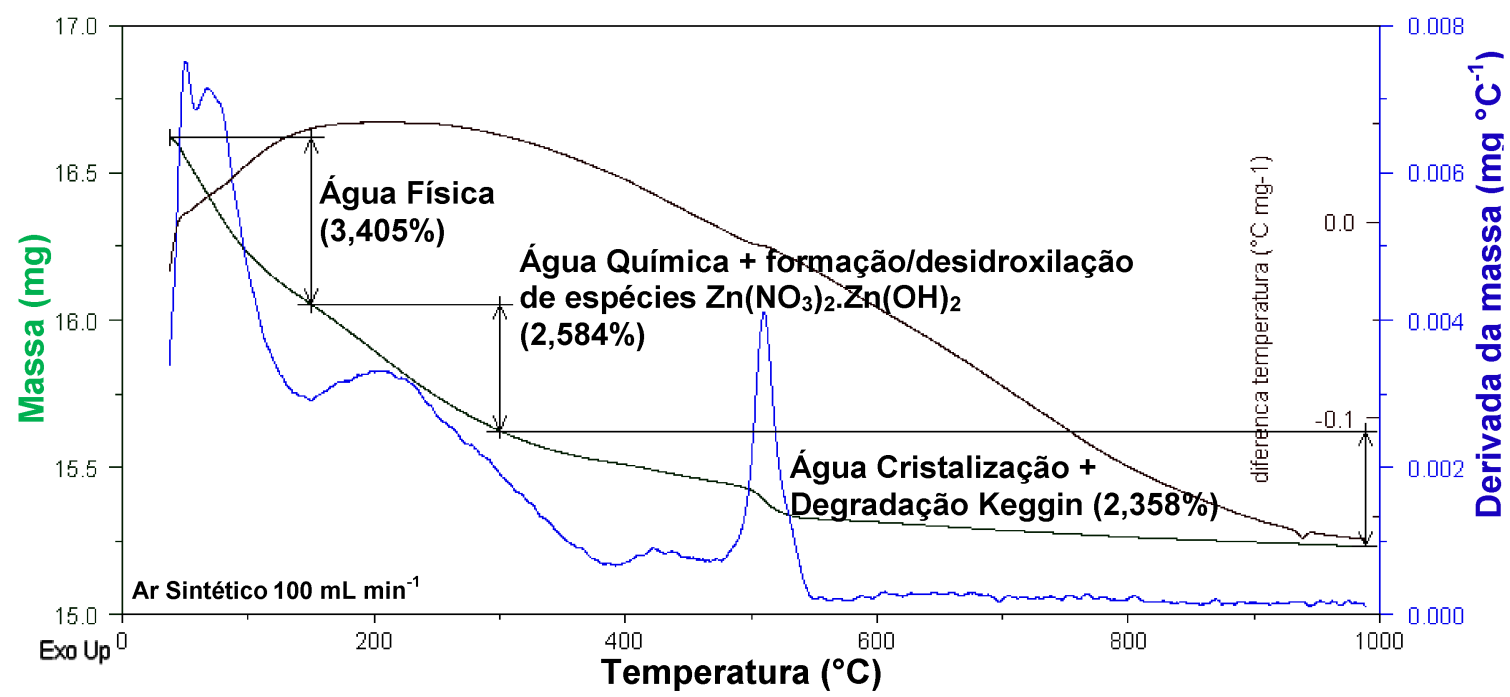

Figura 104: Curvas TG/DTG/DTA obtidas para a amostra ZnHPW-micro-2,66.

No material ZnHPW-micro-2,66, com o dobro da quantidade de zinco que o ZnHPW-micro-1,33, a técnica de CHN detectou, proporcionalmente, duas vezes mais nitrogênios remanescentes, sendo observado, também, quase o dobro de perda de massa de degradação estrutural. As curvas DTG/DTA (Figura 104) indicam que se trata de um sólido mais heterogêneo, com efeitos endo e exotérmicos menos evidentes. 


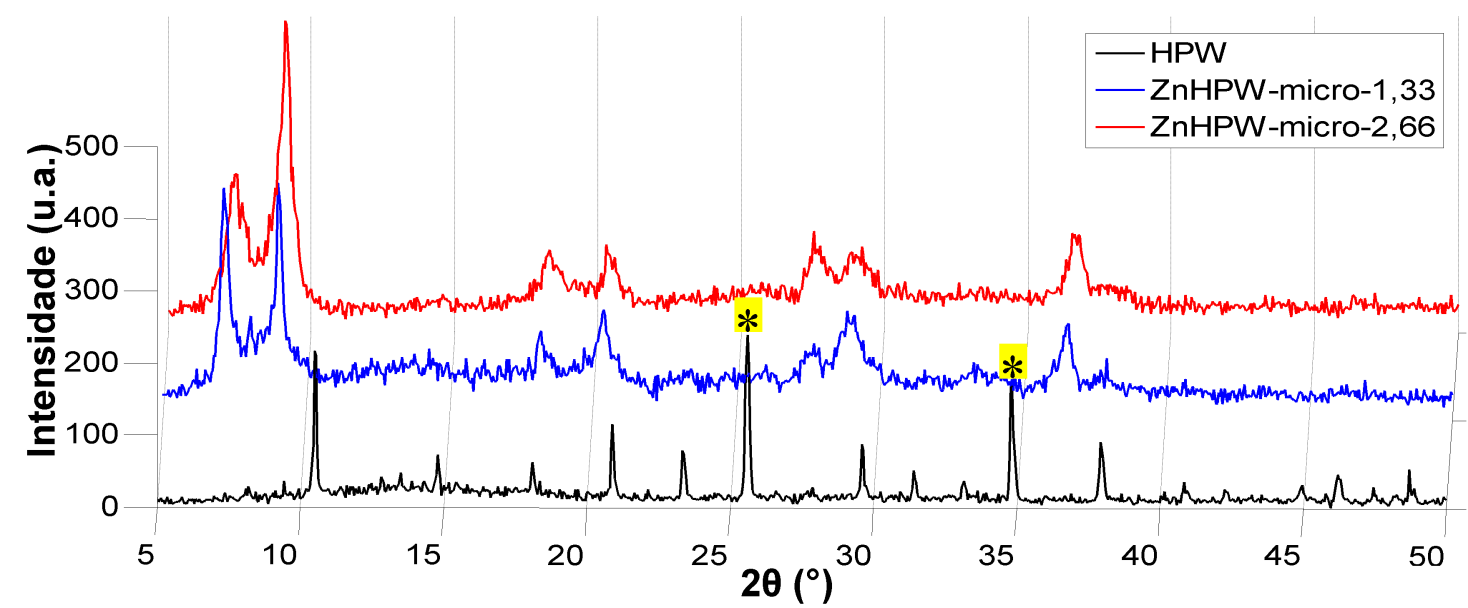

Figura 105: Difratogramas do HPW em comparação com aqueles obtidos para as amostras ZnHPW-micro-1,33 e ZnHPW-micro-2,66. O símbolo $\left(^{*}\right)$ destaca as reflexões não encontradas nos sólidos sintetizados.

Embora os materiais ZnHPW-micro tenham apresentado as bandas do HPW nos espectros de FT-IR, sua estrutura secundária se mostrou diferente, com desaparecimento das reflexões em $25,60^{\circ}$ (plano [222]) e em $34,82^{\circ}$ (plano [332]) da estrutura de Keggin (Figura 105). Uma nova reflexão em $7,18^{\circ}$ também foi observada, evidenciando a formação de uma fase cristalina desconhecida. Além disso, todos os demais picos foram deslocados para ângulos mais baixos, ratificando a forte variação estrutural dos novos materiais.

Assim como discutido para os sólidos sintetizados com zircônia, o deslocamento de picos para a esquerda do difratograma é indício de um aumento no parâmetro de cela, consequência do aumento da distância interplanar ocorrida na estrutura do cristal. Nos materiais microestruturados com zircônia, entretanto, a fácil polimerização dos íons zircônio favoreceu a formação de espécies mais volumosas que 0 cátion $\mathrm{H}_{5} \mathrm{O}_{2}{ }^{+}$, aumentando 0 parâmetro de cela do cristal e mantendo praticamente inalterada a estrutura secundária de Keggin. Apesar dos íons zinco possuírem raio iônico $(0,74 \AA)$ muito próximo daquele do íon $\mathrm{Zr}^{4+}(0,72 \AA)$, eles não formam facilmente espécies poliméricas e, portanto, a simples substituição do íon volumoso $\mathrm{H}_{5} \mathrm{O}_{2}{ }^{+}$ pelo $\mathrm{Zn}^{2+}$ não explica o aumento da distância interplanar observada.

Nesse caso, então, o aumento da distância interplanar, o desaparecimento de reflexões do HPW e o surgimento de um novo pico devem estar relacionados a um conjunto de diferentes modificações estruturais ocorridas nos novos sólidos ZnHPW-micro: (i) a presença dos ânions $\mathrm{NO}_{3}{ }^{-}$ podem alterar as interações entre as espécies no cristal; (ii) a bivalência do 
$\mathrm{Zn}^{2+}$, que, para contrabalancear sua carga, pode ocupar posições mais centrais, agindo como um cátion mais volumoso e afastando os ânions $\left[\mathrm{PW}_{12} \mathrm{O}_{40}\right]^{3-}$; (iii) a total substituição dos íons $\mathrm{H}^{+}$, comprovada pelos cálculos estequiométricos discutidos adiante e pela pouca água estrutural observada por TG/DTG (Figuras 103 e 104), corroborando com a formação de um novo arranjo estrutural, gerando um sólido com baixo teor de hidrogênio (Tabela 18); e (iv) a possível existência de duas fases mescladas no material, uma de $\mathrm{ZnPW}$ e outra do óxido simples $\mathrm{ZnO}$, detectada nas proporções estequiométricas calculadas (Tabela 19 e Equação 15).

Kremenovic e colaboradores ${ }^{157}$ estudaram a influência da temperatura no plano de reflexão [400] do HPW, verificando maiores distâncias interplanares com o aquecimento do heteropoliácido. Mioc e colaboradores ${ }^{156}$ também analisaram as variações estruturais existentes no HPW conforme seu grau de hidratação e sua temperatura de calcinação. Os autores encontraram um difratograma (vide Figura 106) semelhante aos das amostras ZnHPW-micro da Figura 105 quando calcinaram o HPW a $400^{\circ} \mathrm{C}$, reportando que o padrão cristalográfico fazia referência ao HPW anidro.

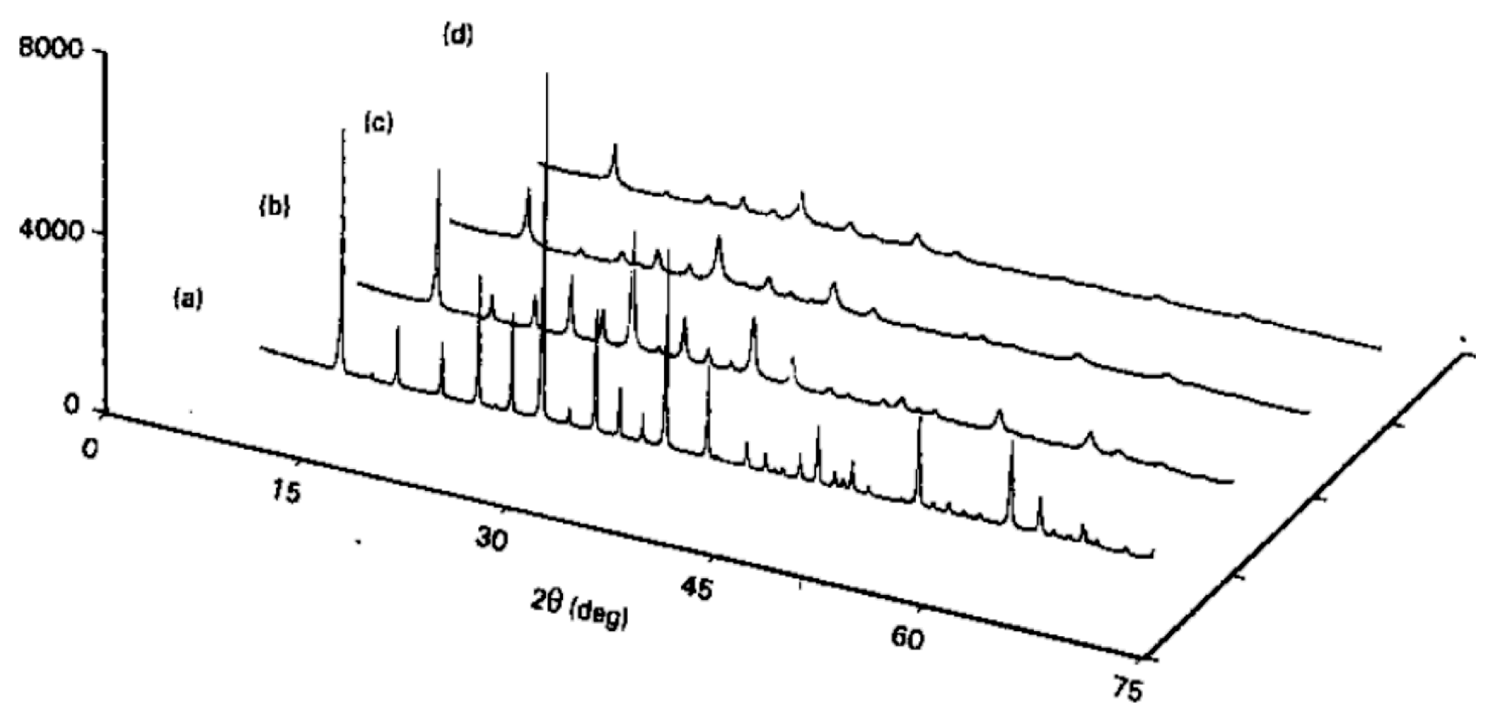

Figura 106: Difratogramas do HPW calcinado em diferentes temperaturas: (a) HPW hexahidratado a $170{ }^{\circ} \mathrm{C}$; (b) HPW anidro a $250{ }^{\circ} \mathrm{C}$; (c) HPW anidro a $350{ }^{\circ} \mathrm{C}$; e (d) HPW anidro a $400^{\circ} \mathrm{C} .^{156}$

De fato, como as amostras micrométricas de zinco apresentaram baixa hidratação, é provável que a calcinação tenha gerado um material semelhante ao do HPW anidro. Segundo esses mesmos autores, alterações na dimensão 
do parâmetro de cela podem implicar em uma repulsão mútua entre os ânions de Keggin, alongando as ligações hidrogênio entre eles. ${ }^{156} \mathrm{O}$ aumento do ruído (background), também percebido nos difratogramas dos sólidos ZnHPW-micro, é um indicativo de uma desordem posicional dos átomos de oxigênio. ${ }^{156}$ Já os sólidos nanométricos mostraram o mesmo comportamento daqueles obtidos com zircônia: apresentaram bandas amorfas semelhantes às da celulose, comprovando sua alteração estrutural a partir da modelagem em fibras.

Diferentemente dos sólidos sintetizados com zircônia, que pode sofrer hidrólise e formar espécies com diferentes cargas, compostos de zinco apresentam grande estabilidade com nox 2+, o que facilitou a determinação estequiométrica do material micrométrico formado com esse metal. Assim, com os dados obtidos por FRX/EDX e TG/DTG/DTA (Tabela 19), foi calculada a estequiometria do sólido ZnHPW-micro-2,66 (Equação 15), sendo observada a substituição total dos hidrogênios do HPW.

$$
\mathrm{Zn}_{1,83}\left(\mathrm{NO}_{3}\right)_{0,66}\left[\mathrm{PW}_{12} \mathrm{O}_{40}\right] \cdot 10,96 \mathrm{H}_{2} \mathrm{O}+4,25 \mathrm{ZnO}
$$

(Equação 15)

Uma alta proporção de íons zinco também foi determinada por FRX (razão $\mathrm{Zn} / \mathrm{W}(\mathrm{mol} / \mathrm{mol})=0,51)$, não havendo um balanço de cargas apropriado para neutralizar um ânion de Keggin e o grupo nitrato. Assim, espécies de óxidos simples $\mathrm{ZnO}$ devem coexistir com as de $\mathrm{ZnPW}$, o que resulta no balanceamento total desses ânions.

Tabela 19: Análise Elementar da amostra ZnHPW-micro-2,66 por FRX/EDX e TG/DTG/DTA.

\begin{tabular}{c|c|c}
\hline Óxido & $\begin{array}{c}\text { \% Experimental } \\
\text { ZnHPW-micro }\end{array}$ & $\begin{array}{c}\text { \% Teórica } \\
\text { ZnHPW-micro }\end{array}$ \\
\hline $\mathrm{WO}_{3}{ }^{\mathrm{a}}$ & 77,54 & 77,88 \\
\hline $\mathrm{ZnO}^{\mathrm{a}}$ & 13,80 & 13,86 \\
\hline $\mathrm{NO}_{3}{ }^{-\mathrm{b}}$ & 1,14 & 1,14 \\
\hline $\mathrm{H}_{2} \mathrm{O}^{\mathrm{b}}$ & 5,53 & 5,53
\end{tabular}

${ }^{a}$ Determinado por FRX/EDX.

${ }^{\mathrm{b}}$ Determinado por TG/DTG/DTA (até $400^{\circ} \mathrm{C}$ ).

Além de seu arranjo diferenciado, o ZnHPW-nano-2,66 não teve sua estequiometria determinada devido à alta porcentagem de carbono detectada, que passou a fazer parte da estrutura do material durante seu processo de 
moldagem em fibras, mas os dados experimentais obtidos por FRX/EDX exibiram $78,52 \%$ de $\mathrm{WO}_{3}$ e $16,70 \%$ de $\mathrm{ZnO}$ para esse sólido.

\subsubsection{Caracterizações Estruturais - ZnHPW(acetato)}

A forma não definida do acetato de zinco (Figura 107) também foi observada para os sólidos micrométricos, mas as micrografias da Figura 108 mostram um material mais compactado que o HPW e sem a rugosidade existente em seu precursor $\mathrm{Zn}\left(\mathrm{CH}_{3} \mathrm{COO}\right)_{2}$. As nanofibras foram formadas (Figura 109) e exibiram tanto padrões de fibras ocas, importantes para permear a entrada e saída de reagentes e produtos nas reações, como fibras totalmente fechadas, sem acesso para moléculas em um meio reacional (vide Figura 109-c). Portanto, a atividade catalítica/oxidativa desses materiais nanoestruturados poderá ser variável, podendo apresentar maiores valores de conversão/seletividade com a maior disponibilidade de área de sítios ativos, o que está intrinsecamente ligado à quantidade de fibras tridimensionais disponíveis.

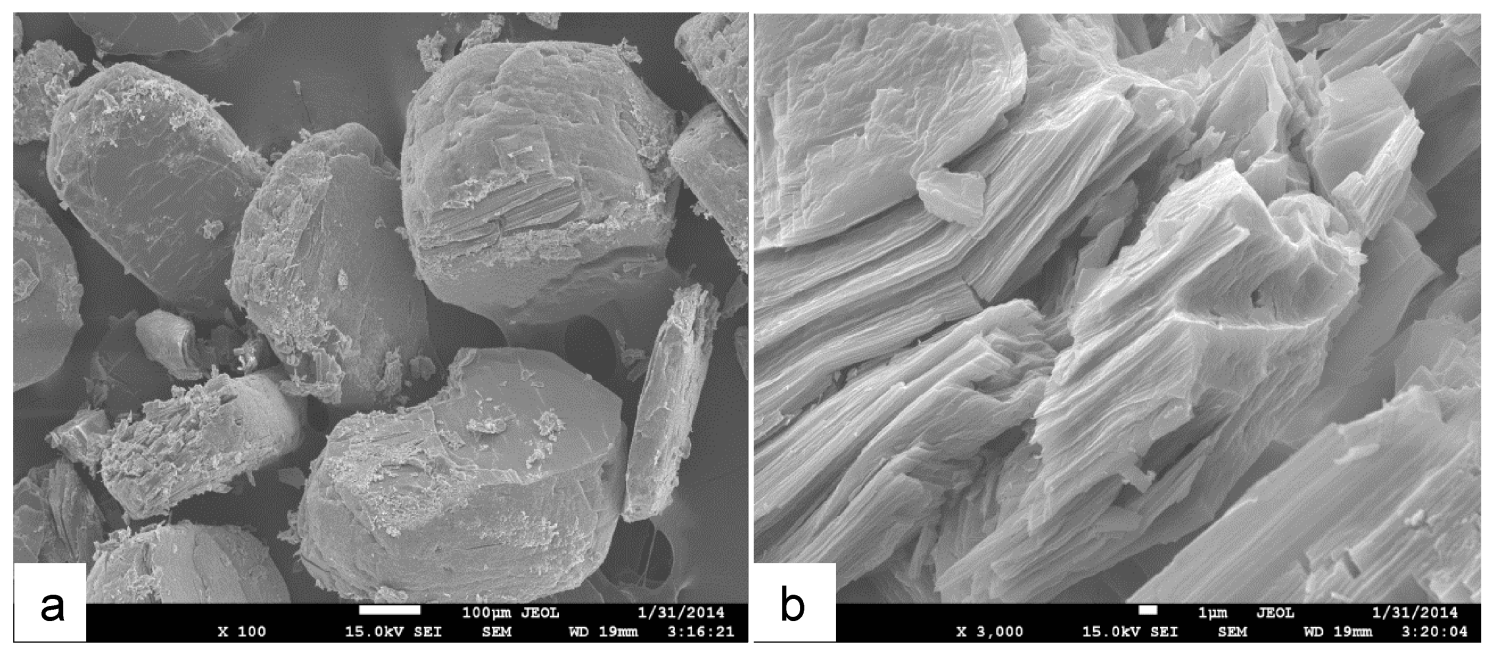

Figura 107: Micrografias obtidas para o reagente $\mathrm{Zn}\left(\mathrm{CH}_{3} \mathrm{COO}\right)_{2}$ em aproximações de $100 \times(a)$ e $3.000 \times(b)$. 


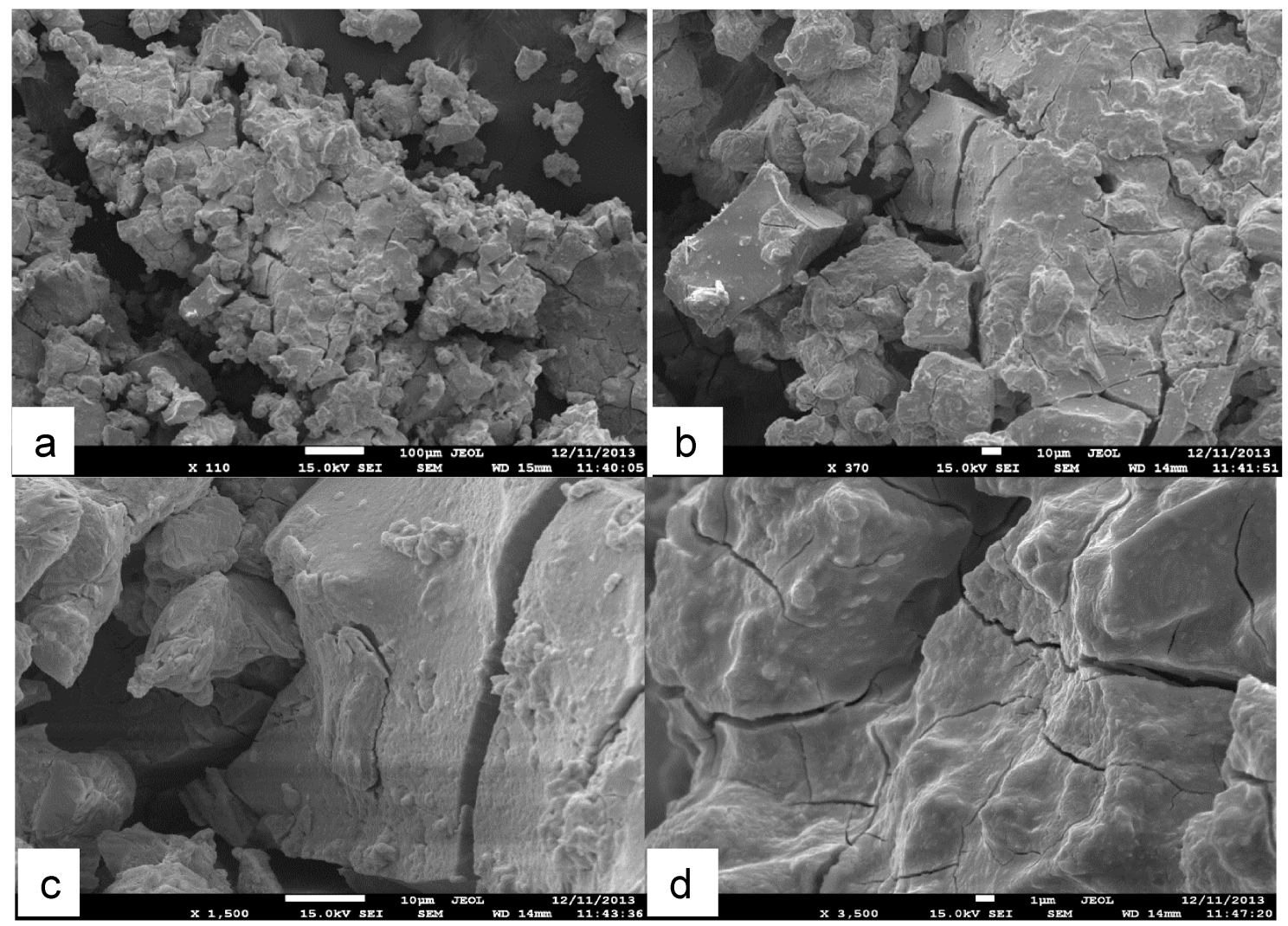

Figura 108: Micrografias do sólido ZnHPW-micro-acetato em aproximações de $110 \mathrm{x}$ (a), $370 \times(b), 1.500 \times(c)$ e $3.500 \times(d)$.

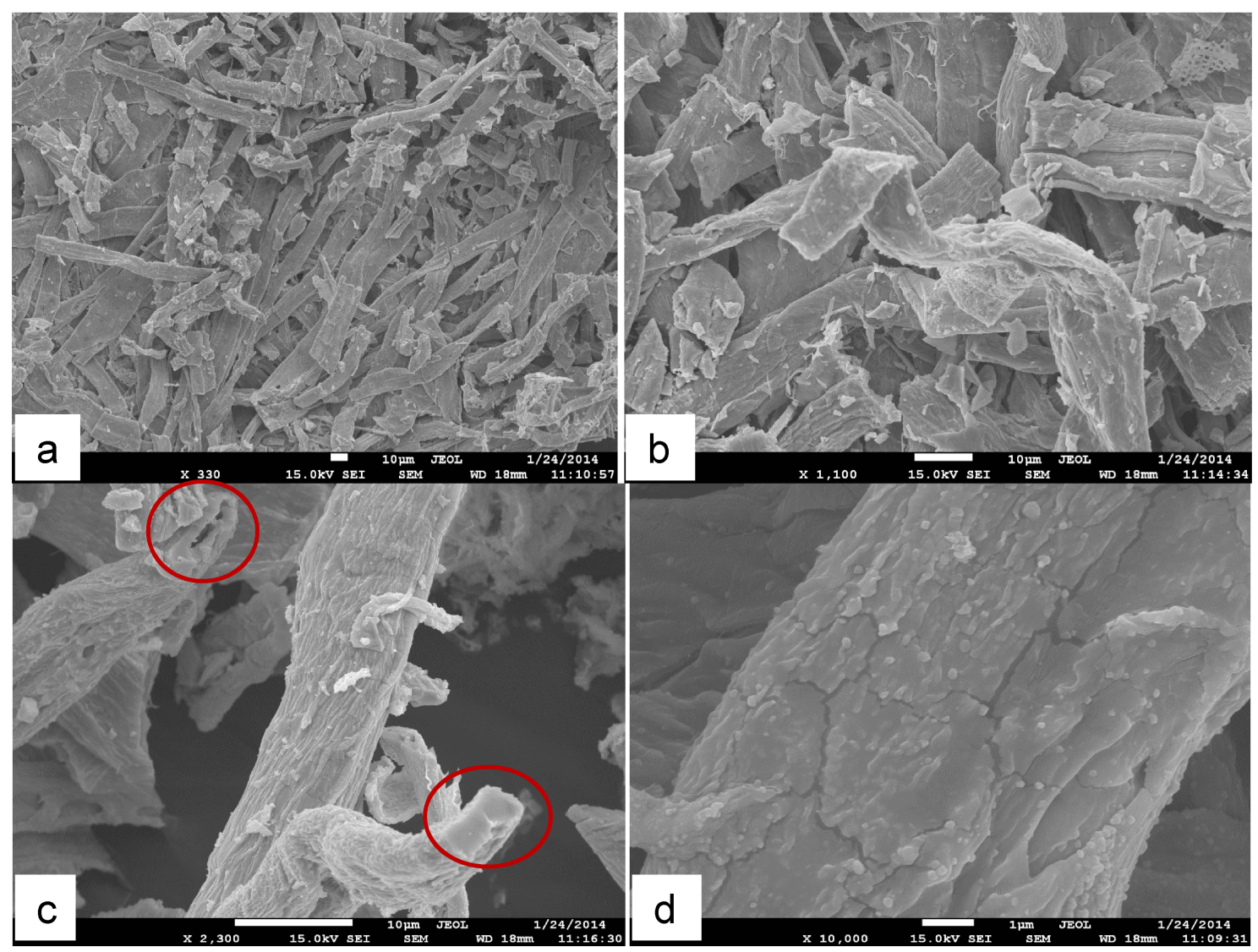

Figura 109: Micrografias do sólido ZnHPW-nano-acetato em aproximações de $330 \mathrm{x}$ (a), $1.100 \times$ (b), $2.300 \times$ (c) e $10.000 \times$ (d). O detalhe em (c) mostra dois padrões de fibras encontrados: um com abertura em sua extremidade e outro totalmente fechado. 
Como esperado, a síntese com o ânion acetato apresentou um pH mais brando $(\mathrm{pH}=2)$ que aquela com nitrato $(\mathrm{pH}=0)$ tendo em vista a formação do ácido conjugado mais fraco (ácido acético). A análise elementar de $\mathrm{CHN}$ (Tabela 20) mostrou que praticamente todo o acetato foi removido no padrão ZnHPW-micro-acetato. Considerando o erro de 0,08\% apresentado na detecção de carbono pelo equipamento na maioria dos materiais, há apenas $0,03 \%$ de carbono residual no sólido micrométrico. Esse fato é um indício de que o contraíon $\mathrm{CH}_{3} \mathrm{COO}^{-}$foi removido do meio mais facilmente que o nitrato após calcinação a $400{ }^{\circ} \mathrm{C}$.

Tabela 20: Dados obtidos por CHN para as amostras sintetizadas ZnHPW-acetato.

\begin{tabular}{c|c|c}
\hline Amostra & Carbono (\%) & Hidrogênio (\%) \\
\hline ZnHPW-nano-acetato & 6,08 & 0,37 \\
\hline ZnHPW-micro-acetato & 0,11 & 0,03 \\
\hline
\end{tabular}

De fato, Ghule e colaboradores estudaram a decomposição do acetato de zinco, reportando que o ânion acetato vem sendo preferido como precursor devido a sua baixa temperatura de decomposição, alta solubilidade e mínima contaminação. ${ }^{172} \mathrm{Na}$ presença de oxigênio, até $160^{\circ} \mathrm{C}$, a curva de DTG desse sal (Figura 110) mostrou uma perda de massa relacionada à moléculas de águas de hidratação (efeito endotérmico), com formação do acetato de zinco anidro. Em aproximadamente $252^{\circ} \mathrm{C}$, um pequeno ombro pode ser observado, referente ao complexo $\mathrm{Zn}_{4} \mathrm{O}\left(\mathrm{CH}_{3} \mathrm{CO}_{2}\right)_{6}$. O pico endotérmico na curva DTA nessa região é indicativo da fusão do sal e é reportado por ser independente da perda de massa. ${ }^{172,173}$ A partir de $255^{\circ} \mathrm{C}$, o oligômero $\mathrm{Zn}_{4} \mathrm{O}\left(\mathrm{CH}_{3} \mathrm{CO}_{2}\right)_{6}$ se decompõe completamente e uma mistura de ácido acético, acetona e $\mathrm{CO}_{2}$ é eliminada na presença de vapor de água (efeito endotérmico). Após $310{ }^{\circ} \mathrm{C}$, não são mais detectadas perdas de massa. ${ }^{172,173}$

Para as nanofibras, os $6,08 \%$ de carbono detectados estão relacionados, principalmente, à persistência de carbonos advindos da celulose. O material apresentou coloração preta, assim como as nanofibras sintetizadas com nitrato de zinco, e, novamente, com o aumento da quantidade de carbono, a porcentagem de hidrogênio nesse sólido nanométrico também foi elevada. 


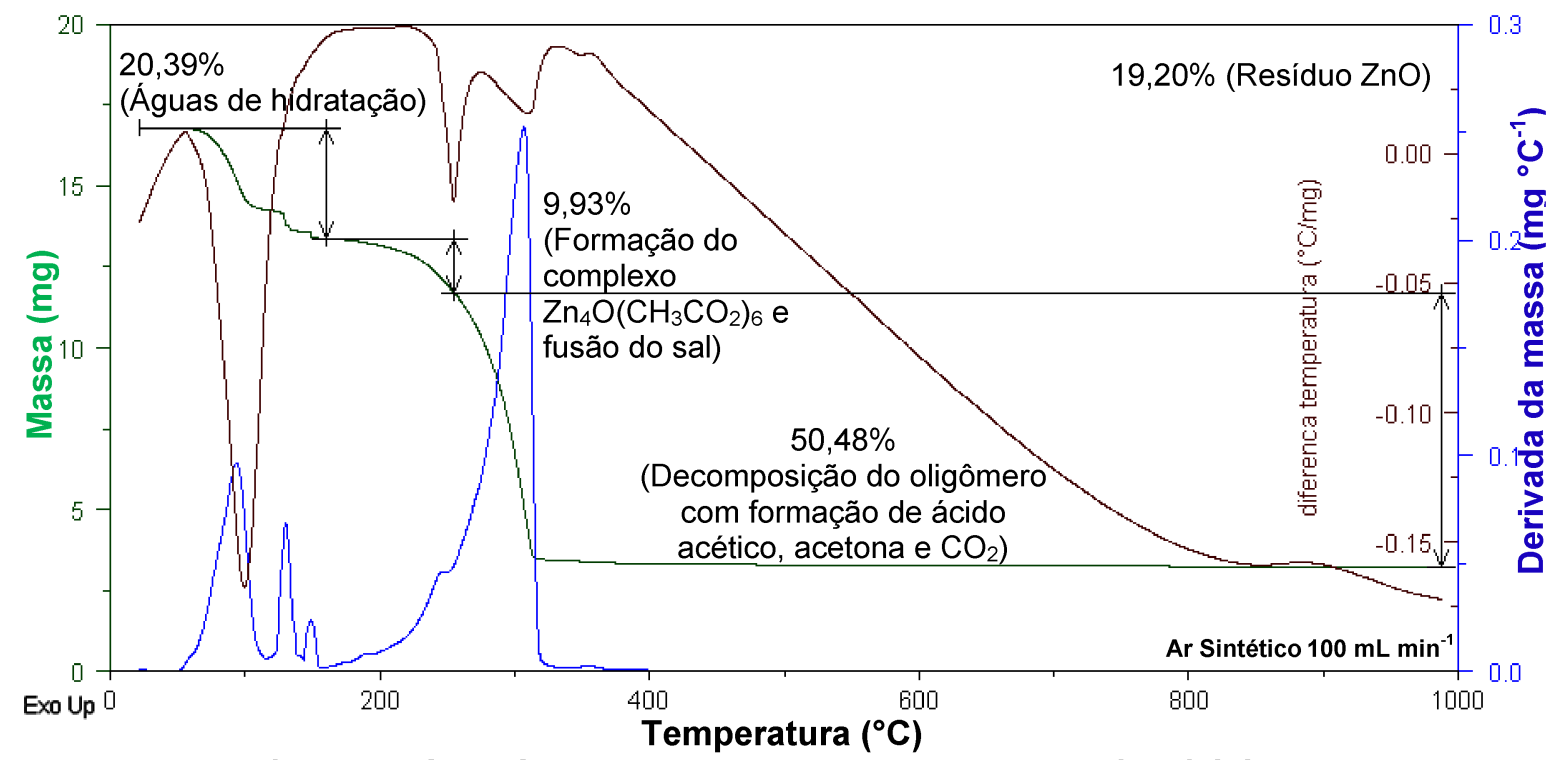

Figura 110: Curvas TG/DTG/DTA obtidas para o reagente $\mathrm{Zn}\left(\mathrm{CH}_{3} \mathrm{COO}\right)_{2}$.

A amostra ZnHPW-micro-acetato apresentou manutenção da estrutura primária do HPW, comprovada pela conservação das vibrações do ânion de Keggin nos espectros de FT-IR (Figura 111). Para o sólido nanométrico, entretanto, as bandas exibiram alterações de largura e intensidade, indicando variações nos tipos de ligações que formam o material. Além disso, foram identificadas bandas referentes a ligações $\mathrm{CH}_{2}$, em $1455 \mathrm{~cm}^{-1}$, existentes na celulose (Figura 78), comprovando a persistência do carbono nas nanofibras. Para ambos os materiais, a região dos estiramentos assimétricos da ligação $\mathrm{W}=\mathrm{O}_{\text {terminal }}$, em aproximadamente $983 \mathrm{~cm}^{-1}$, foi a mais afetada.

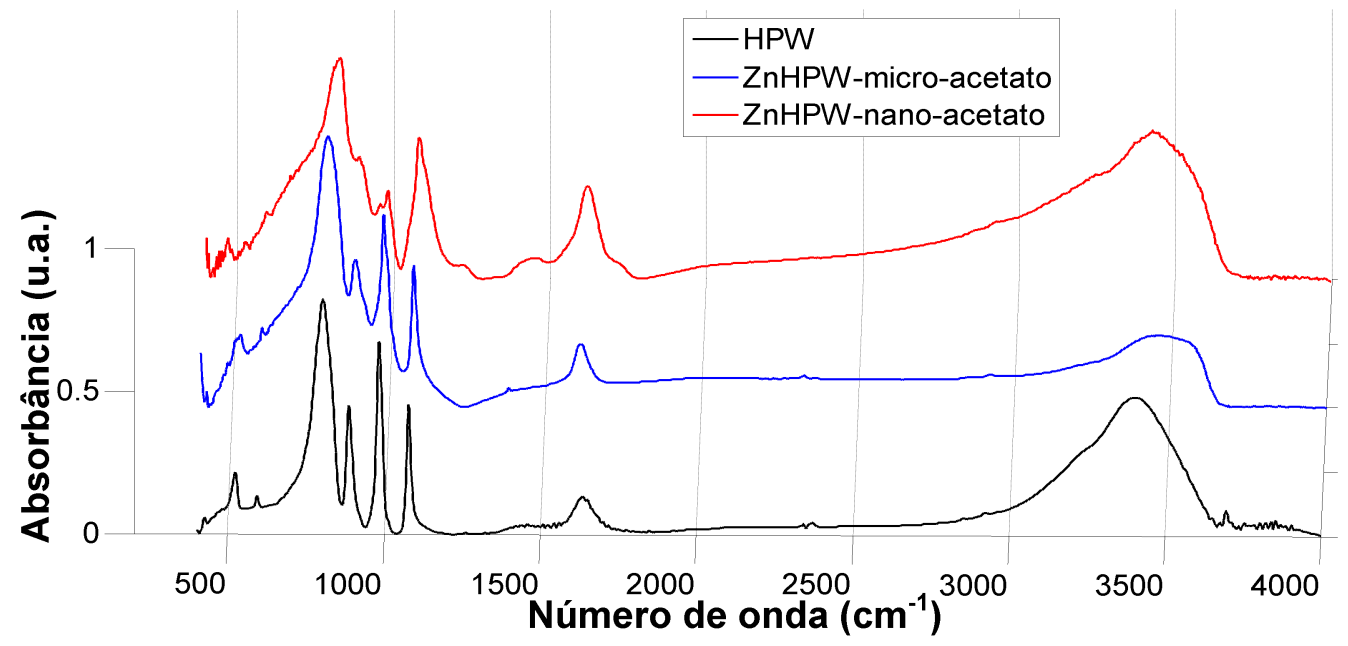

Figura 111: Espectros de FT-IR obtidos para o HPW e para as amostras ZnHPW-micro-acetato e ZnHPW-nano-acetato. 
Assim como apresentando pelos sólidos ZnHPW sintetizados com nitrato de zinco, os materiais preparados com o precursor acetato exibiram padrões cristalográficos diferentes do HPW. Mesmo com a manutenção da estrutura primária, constatada pelos espectros de FT-IR, o difratograma da amostra ZnHPW-micro-acetato (Figura 112) não apresentou alguns dos principais picos da estrutura secundária. As reflexões foram deslocadas para ângulos mais baixos, demonstrando um aumento no parâmetro de cela, assim como observado para a zircônia e para os sólidos ZnHPW sintetizados com nitrato. Novas reflexões foram identificadas na região entre 20 e $25^{\circ}$, que podem ser referentes ou a fases do óxido simples $\mathrm{WO}_{3},{ }^{174,175}$ ou ao polimorfo $\mathrm{PW}_{8} \mathrm{O}_{26}$ (vide Figura 113), ${ }^{156}$ ambos com padrões cristalográficos muito semelhantes.

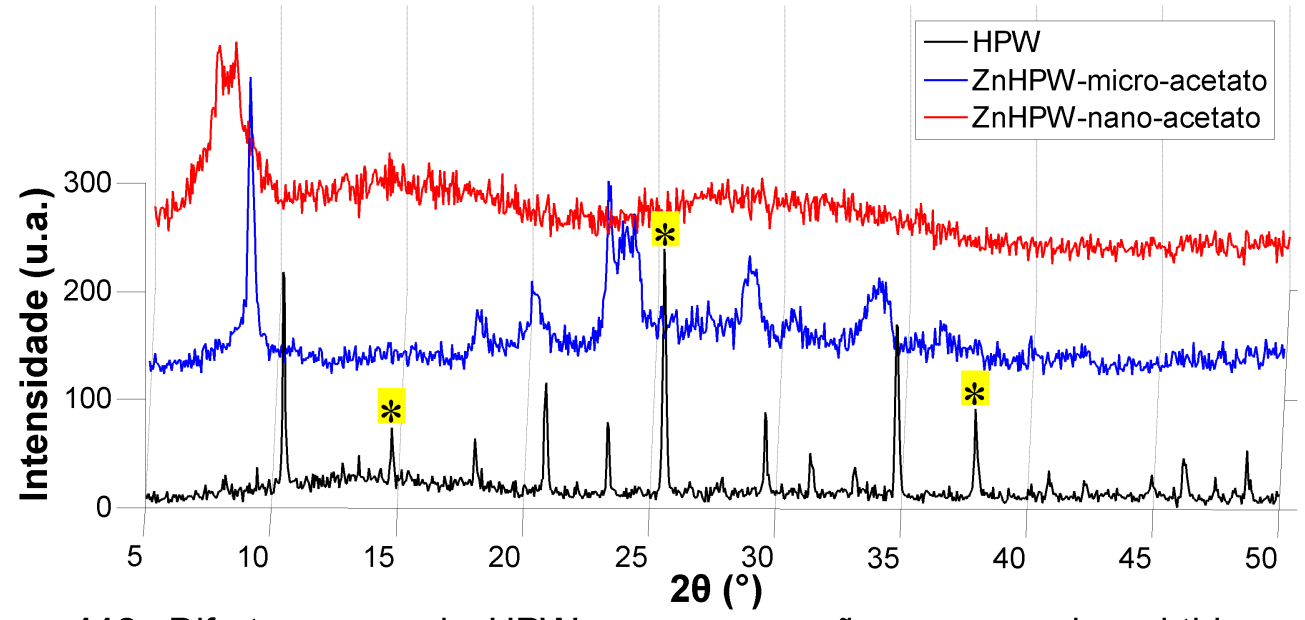

Figura 112: Difratogramas do HPW em comparação com aqueles obtidos para as amostras ZnHPW-micro-acetato e ZnHPW-nano-acetato. O símbolo $\left(^{*}\right)$ destaca as reflexões não encontradas no sólido ZnHPW-micro-acetato.

A coloração esverdeada do sólido formado, no entanto, remete à cor do $\mathrm{WO}_{3}$ hidratado (vide Figuras 114 e 115). ${ }^{176} \mathrm{Na}$ literatura, ${ }^{176}$ é possível encontrar diferentes micrografias do $\mathrm{WO}_{3}$, a depender de seu grau de hidratação (vide Figura 115), com geometria bem definida e distinta daquela observada nas micrografias da Figura 108, referente ao sólido ZnHPW-micro-acetato sintetizado. Dessa forma, o sólido ZnHPW-micro-acetato deve ser composto, na verdade, por um agregado de fases, não havendo distinção de cada uma por MEV. 


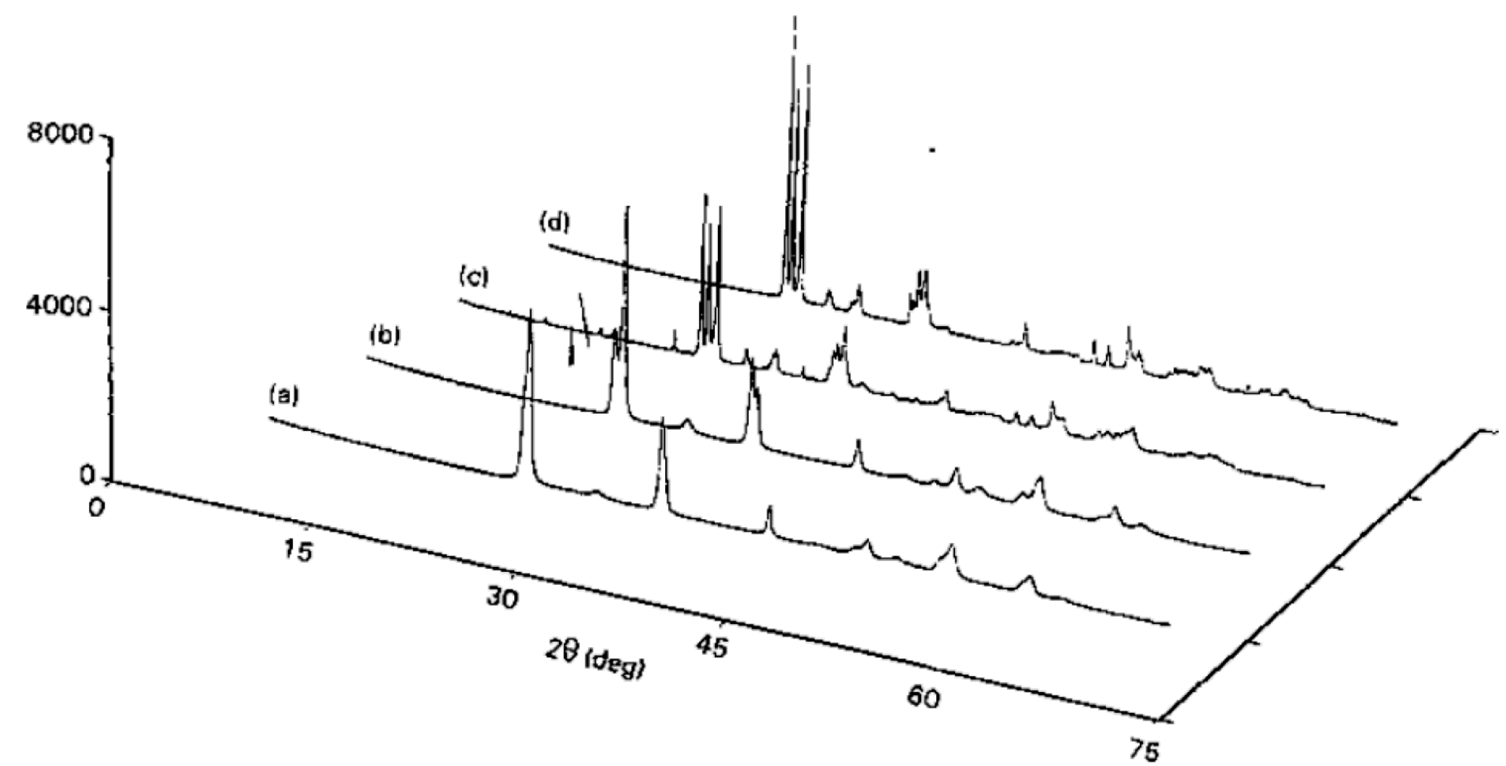

Figura 113: Difratogramas do polimorfo $\mathrm{PW}_{8} \mathrm{O}_{26}$ na faixa de temperatura de 650 $1150{ }^{\circ} \mathrm{C}$ : (a) cúbico, $650^{\circ} \mathrm{C}$; (b) monoclínico, $750{ }^{\circ} \mathrm{C}$; (c) ortorrômbico, $1050^{\circ} \mathrm{C}$; e (d) triclínico, $1150{ }^{\circ} \mathrm{C} .{ }^{156}$

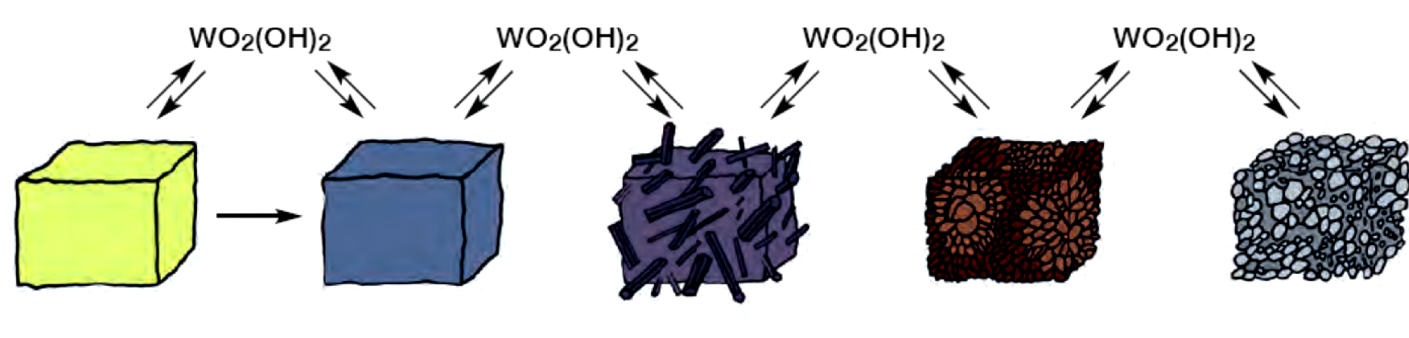

$\mathrm{WO}_{3}$

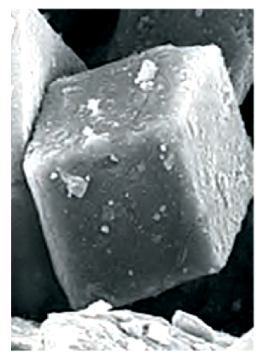

$\mathrm{WO}_{2.9}$

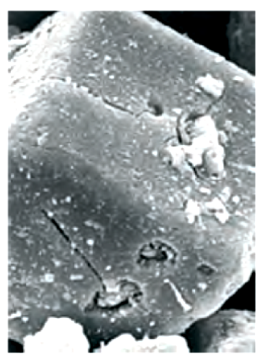

WO2.72

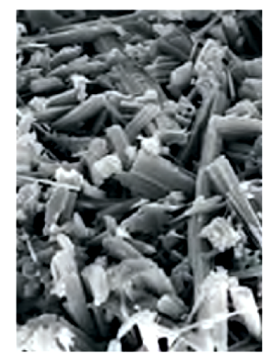

$\mathrm{WO}_{2}$

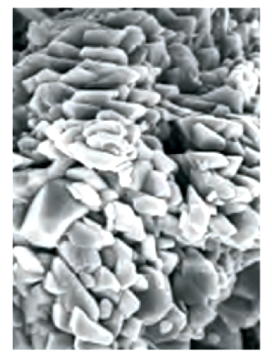

W

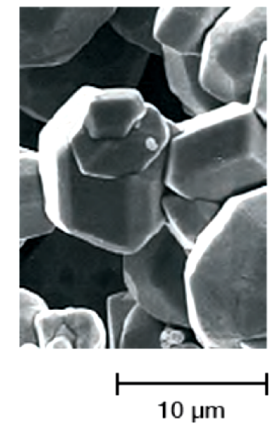

Figura 114: Micrografias dos óxidos de tungstênio e do metal $W$ formado pela redução do $\mathrm{WO}_{3}$ com hidrogênio. De acordo com Weil e Schubert, a razão para a mudança significativa na forma dos padrões das partículas é um transporte químico de vapor (CVT, do inglês Chemical Vapour Transport) de tungstênio via hidróxido de tungstênio volátil $\left(\mathrm{WO}_{2}(\mathrm{OH})_{2}\right)^{176,177}$ 


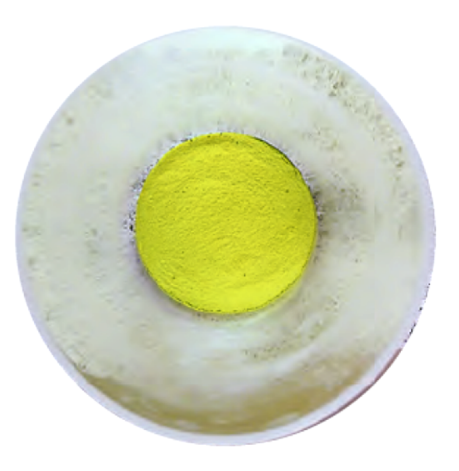

$\mathrm{wO}_{3} 25^{\circ} \mathrm{C}$

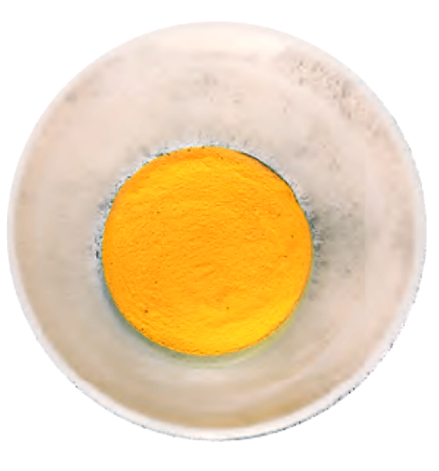

$\mathrm{WO}_{3} 200-300^{\circ} \mathrm{C}$

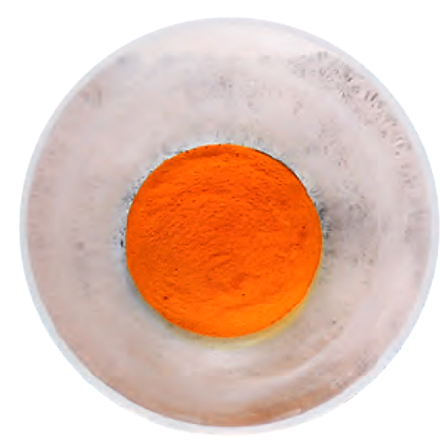

$\mathrm{WO}_{3} 400-500^{\circ} \mathrm{C}$

Figura 115: Com a elevação da temperatura, a cor do $\mathrm{WO}_{3}$ muda de amarelo esverdeado para amarelo escuro e, finalmente, laranja. ${ }^{176}$

Já o difratograma do sólido ZnHPW-nano-acetato (Figura 112) comprovou a alteração morfológica das nanofibras, mostrando o mesmo padrão de difração da celulose. Os dois picos na faixa de 7,6 a $8,3^{\circ}$ já foi evidenciado nos difratogramas de materiais híbridos de HPW com surfactantes [Matias, A. E. B.; Macedo, J. L. de Inorganica Chimica Acta, a ser submetido, 2014]. Esse padrão é típico de estruturas de longo alcance, como é o caso, também, de materiais multifuncionalizados de HPAs suportados em peneiras moleculares do tipo MCM. ${ }^{178}$

As curvas TG/DTG/DTA dos materiais ZnHPW-micro-acetato e ZnHPW-nano-acetato podem ser vistas nas Figuras 116 e 117, respectivamente. Até $100{ }^{\circ} \mathrm{C}$, em ambos os casos, as curvas DTA exibem o efeito endotérmico ocasionado pela eliminação de águas de hidratação. Para o material microestruturado, a perda de água física corresponde a $3,54 \%$ do sólido como um todo, enquanto, para o nanométrico, essa região apresenta uma perda mais alta, de $8,35 \%$. Não foram observadas perdas de massa associadas a moléculas de água quimicamente adsorvidas em ambas as amostras. A partir de $400{ }^{\circ} \mathrm{C}, \quad$ o ZnHPW-nano-acetato mostra curvas exotérmicas com perdas acentuadas de massa, bastante superior ao sólido micrométrico, que envolvem não só a degradação dos ânions de Keggin (detectados por FT-IR), mas, também, a eliminação de carbonos mais fortemente ligados ao material. 


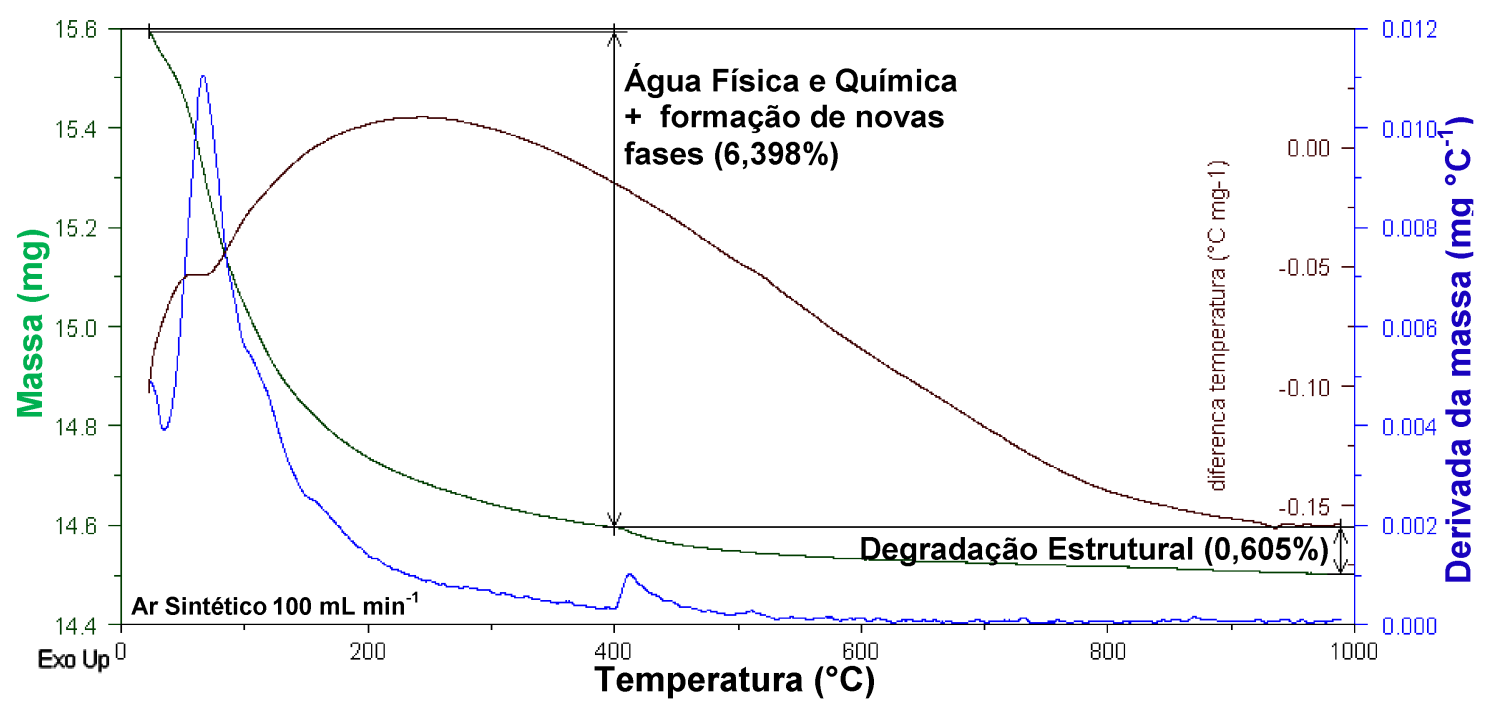

Figura 116: Curvas TG/DTG/DTA obtidas para o sólido ZnHPW-micro-acetato.

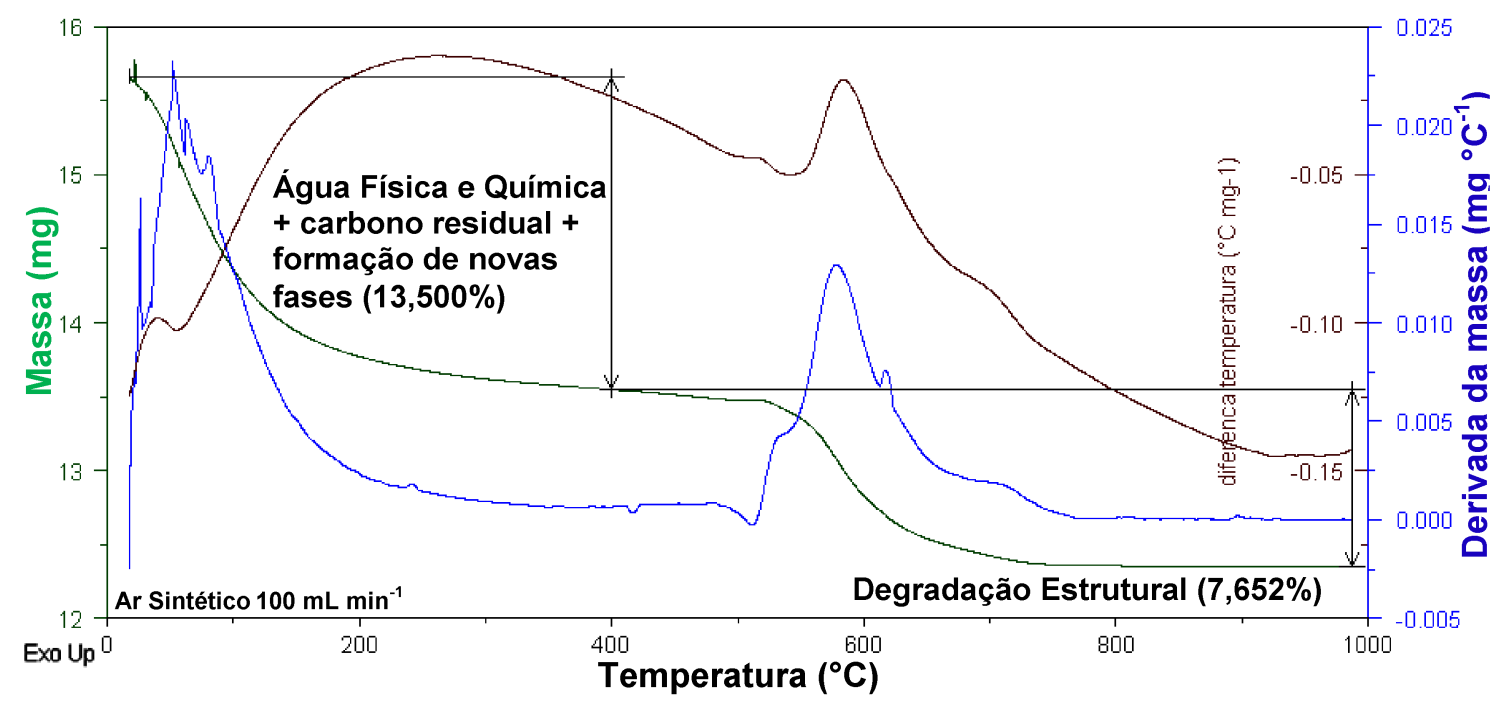

Figura 117: Curvas TG/DTG/DTA obtidas para o sólido ZnHPW-nano-acetato.

\subsubsection{Caracterizações de Acidez}

Para a caracterização de acidez, os sólidos de zinco foram submetidos à adsorção gasosa de piridina, sendo analisados por FT-IR (Figura 118) e TG/DTG/DTA (Figuras 119 a 122). Nos espectros de FT-IR da Figura 118, foi possível observar que apenas o sólido ZnHPW-micro-acetato apresentou as bandas referentes a vibrações de piridina protonada $\left(\mathrm{PyH}^{+}\right)$em $1486 \mathrm{e}$ $1537 \mathrm{~cm}^{-1}$, as mesmas bandas encontradas para os materiais com zircônia. Nesse caso, entretanto, essas bandas apresentaram baixa intensidade, 
evidenciando uma pequena acidez. Os outros materiais com zinco, portanto, não possuem acidez relevante.

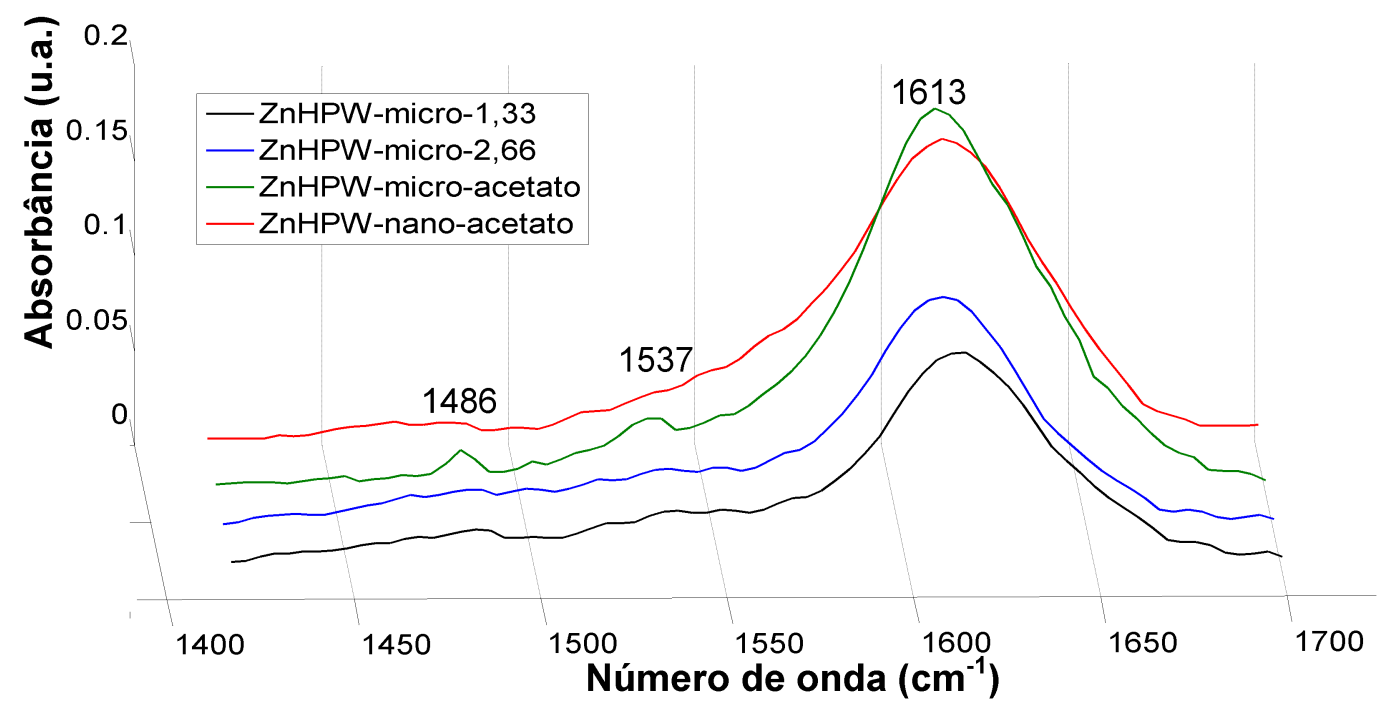

Figura 118: Espectros de FT-IR obtidos para as amostras ZnHPW, sintetizadas com nitrato e acetato, após adsorção de Py.

Os dados de TG comprovaram a ausência de acidez nos materiais micrométricos sintetizados (Figuras 119 e 121). A alta substituição por íons $\mathrm{Zn}^{2+}$ implicou na formação de sólidos sem hidrogênios ácidos, como visto nos cálculos estequiométricos desenvolvidos. A presença de ânions $\mathrm{NO}_{3}{ }^{-}$também pode ter influenciado no balanceamento de cargas do arranjo cristalográfico, 0 que impediria a interação de moléculas básicas com sítios de Lewis.

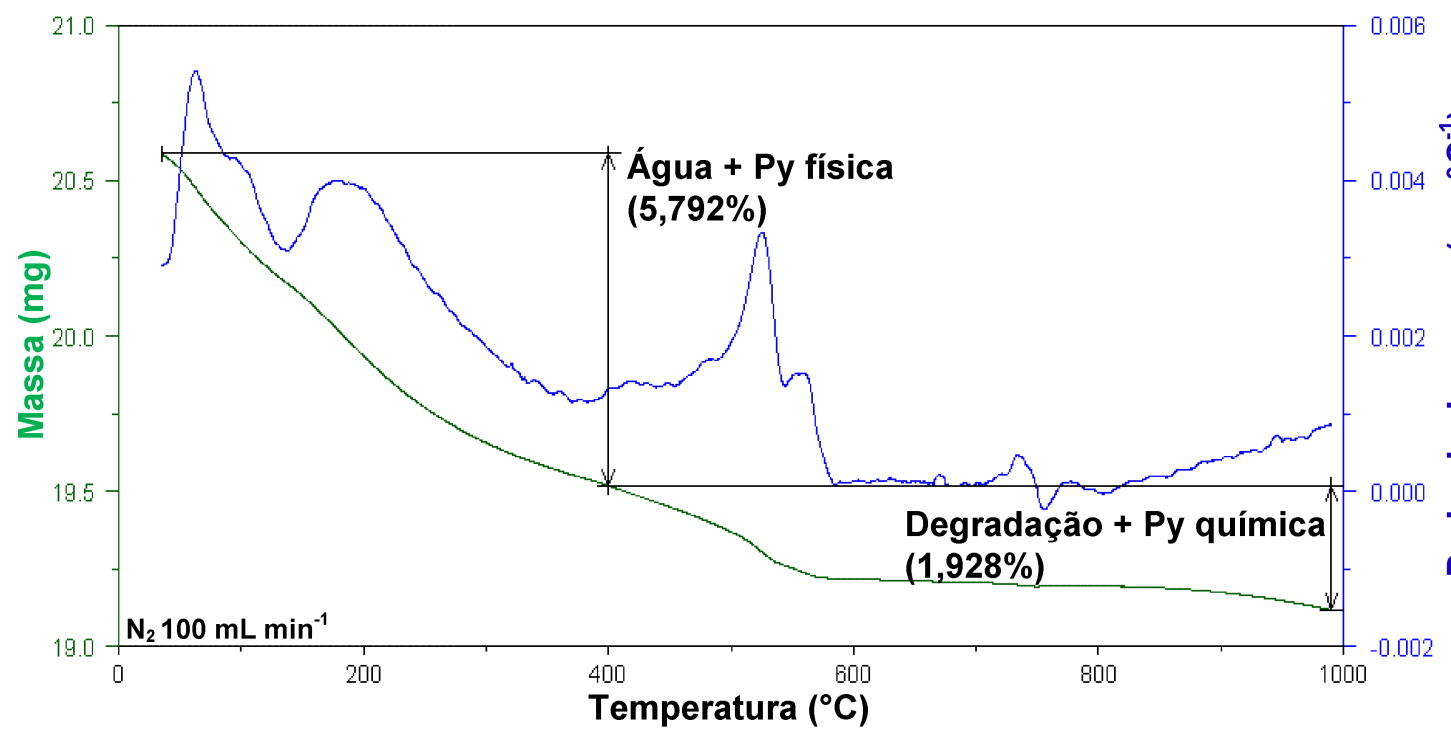

Figura 119: Curvas TG/DTG obtidas para a amostra ZnHPW-micro-1,33 após adsorção de Py. 


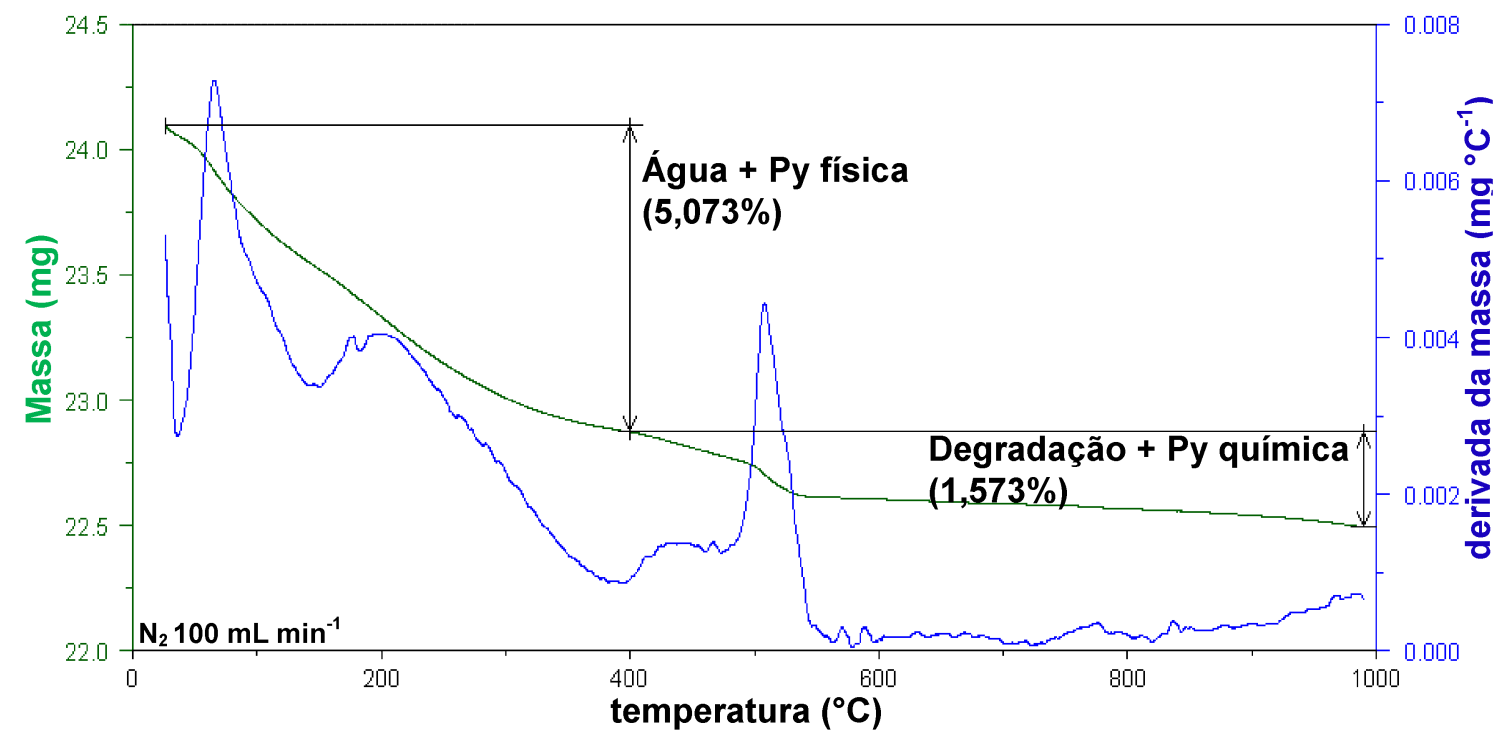

Figura 120: Curvas TG/DTG obtidas para a amostra ZnHPW-micro-2,66 após adsorção de Py.

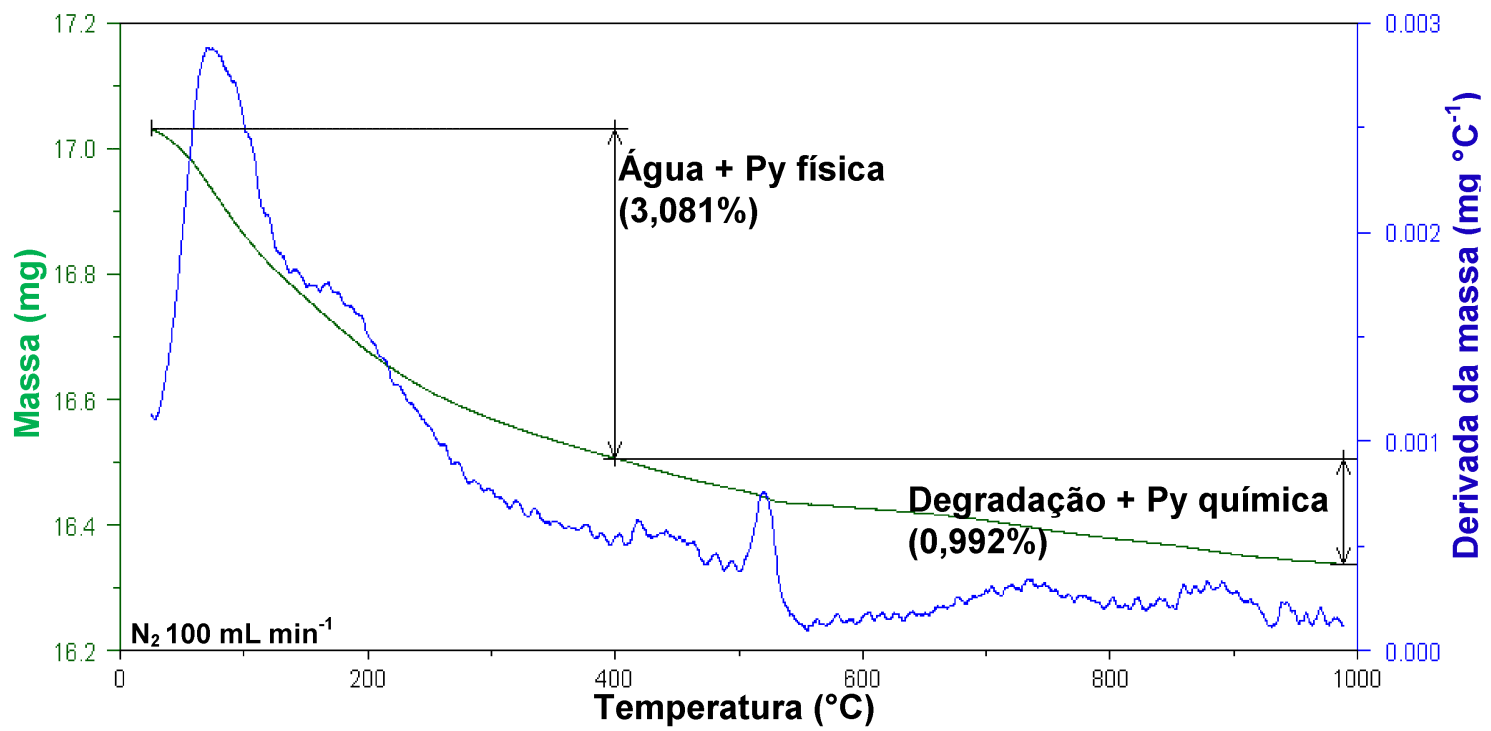

Figura 121: Curvas TG/DTG obtidas obtida para a amostra ZnHPW-micro-acetato após adsorção de Py.

Já o material ZnHPW-nano-acetato, apesar de não ter exibido nenhuma banda referente a vibrações da piridina no espectro de FT-IR (Figura 118), apresentou número de sítios ácidos a partir do cálculos feitos com dados de TG (Tabela 21). Todavia, esse valor não deve estar relacionado a uma acidez mais pronunciada do sólido, mas, sim, a interações entre a piridina e o carbono existente no material, detectado com alta porcentagem no ZnHPW-nano-acetato por CHN (Tabela 20). Cohen e colaboradores ${ }^{179}$ reportaram evidências de interações do tipo $\pi$ entre a piridina e nanotubos de 
carbono. Segundo os autores, um conjunto de dados de espectroscopias de fluorescência, de ultravioleta-visível (UV-vis) e fotoeletrônica de raios X (XPS) comprovaram a existência de interações entre orbitais $\pi$ advindos de ligações do tipo $\mathrm{sp}^{2}$ nos nanotubos de carbono e os elétrons $\pi$ da piridina, uma molécula orgânica conjugada. $O$ material piridina-nanotubo de carbono sintetizado pelos autores apresentou uma banda no espectro de UV-vis relativa à absorção da piridina, ao longo da superfície do nanotubo de carbono, estabilizada a partir da ressonância eletrônica existente nessas fortes interações do tipo doador-receptor. ${ }^{179}$ Não é certa a existência de ligações $\mathrm{sp}^{2}$ no sólido ZnHPW-nano-acetato, mas sua interação com a piridina também pode ter ocorrido por meio de interações com os hidrogênios (detectados por CHN) advindos dos grupos carbônicos.

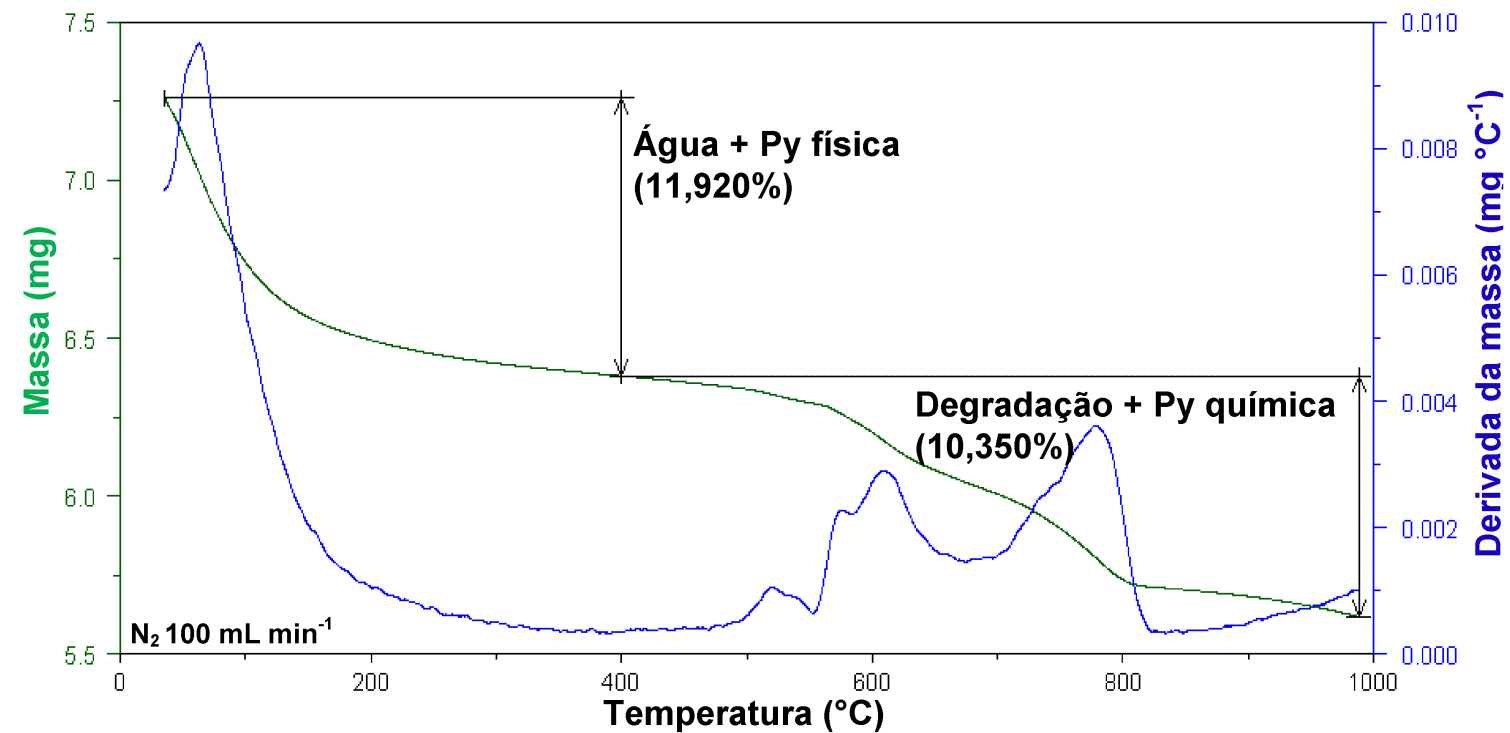

Figura 122: Curvas TG/DTG obtidas para a amostra ZnHPW-nano-acetato após adsorção de Py.

Os dados obtidos por TG/DTG das Figuras 119 a 122 foram utilizados para o cálculo do número de sítios ácidos dos sólidos e estão resumidos na Tabela 21. O sólido ZnHPW-micro-acetato mostrou uma baixa quantidade de sítios ácidos, enquanto aqueles sintetizados com nitrato não apresentaram nenhuma acidez, assim como evidenciado nos espectros de FT-IR (Figura 118). 
Tabela 21: Número de sítios ácidos calculados via TG a partir da adsorção gasosa de piridina para o HPW e para as amostras sintetizadas com zinco.

\begin{tabular}{c|c}
\hline Amostra & Número de Sítios Ácidos $\left(\mathbf{m m o l} \mathbf{~ g}^{-1}\right)$ \\
\hline HPW & 0,9593 \\
\hline ZnHPW-micro-1,33 & 0,0 \\
\hline ZnHPW-micro-2,66 & 0,0 \\
\hline ZnHPW-micro-acetato & 0,0477 \\
\hline ZnHPW-nano-acetato & 0,3925 \\
\hline
\end{tabular}

\subsubsection{AgHPW}

\subsubsection{Caracterizações Estruturais - AgHPW (papel filtro)}

A síntese dupla com papel filtro gerou os sais de AgHPW apresentados na Figura 123.

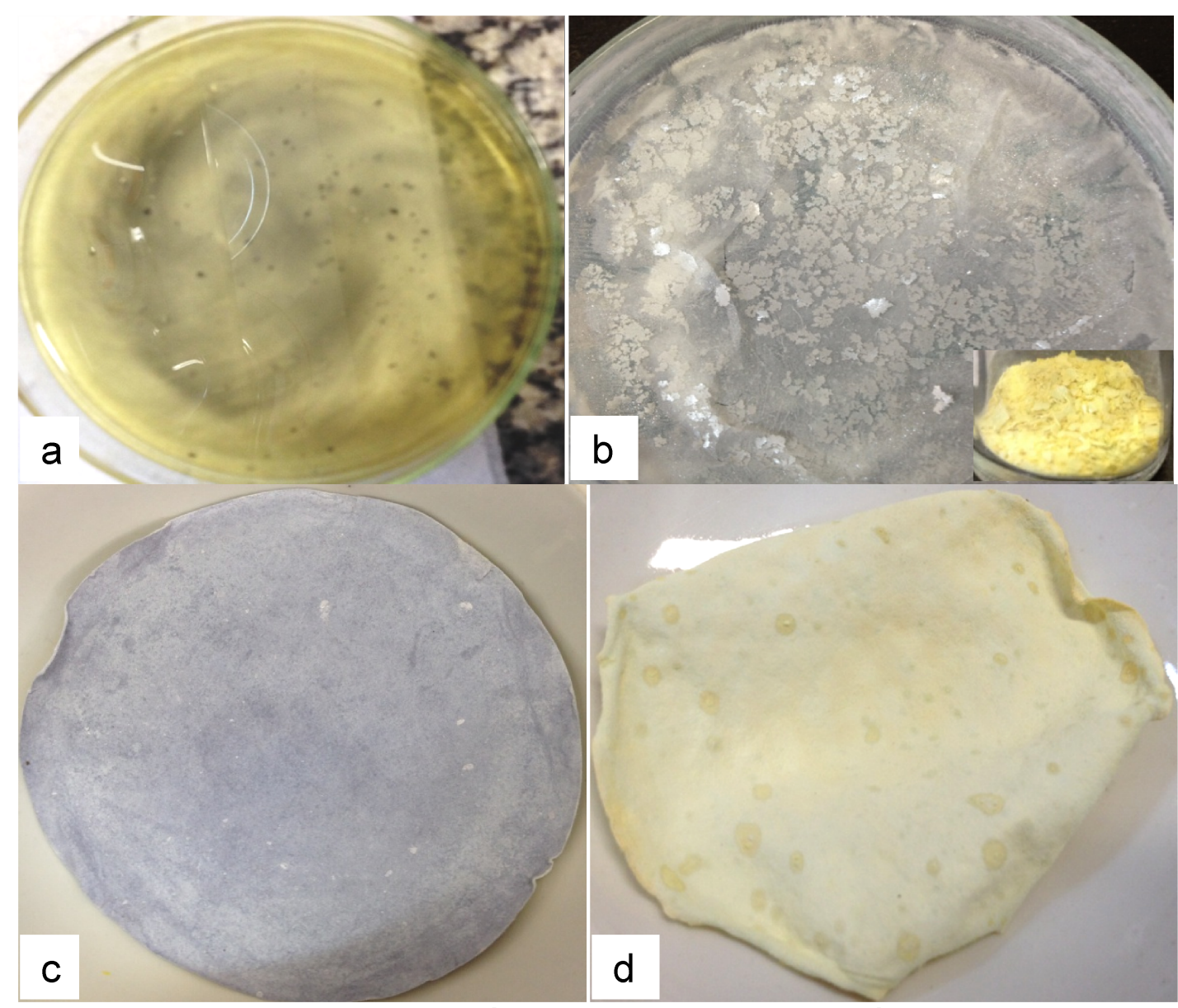

Figura 123: Imagens digitais dos sólidos AgHPW obtidos na síntese dupla com papel filtro. Em (a), a solução de AgHPW; em (b), o sólido residual AgHPW-micro após 3 dias de secagem ao ar - no detalhe, o mesmo sólido após calcinação; em (c), o papel filtro após ser embebido na solução de AgHPW; e, em (d), o sólido moldado AgHPW-nano de cor amarelada, após calcinação, com o mesmo formato do papel filtro. 
Dados de CHN (Tabela 22) comprovaram a eliminação do carbono advindo da celulose dos materiais nanoestruturados. Baixas proporções de hidrogênio foram detectadas para ambos os materiais, principalmente no sólido micrométrico, assim como observado para a síntese com zinco. Mas, diferentemente dos sais de $\mathrm{ZnHPW}$ sintetizados com $\mathrm{Zn}\left(\mathrm{NO}_{3}\right)_{2}$, os sólidos de AgHPW, também advindos do precursor nitrato, não apresentaram quantidades detectáveis de nitrogênio. Portanto, os ânions $\mathrm{NO}_{3}{ }^{-}$foram eficazmente eliminados após calcinação. O maior raio iônico do cátion $\mathrm{Ag}^{+}(1,26 \AA ̊)$, superior ao do íon $\mathrm{Zn}^{2+}(0,74 \AA)$, pode ter facilitado a moldagem do sólido em fibras, eliminando a necessidade da presença do carbono.

Tabela 22: Dados obtidos por CHN para as amostras sintetizadas AgHPW.

\begin{tabular}{c|c|c|c}
\hline Amostra & Carbono (\%) & Hidrogênio (\%) & Nitrogênio (\%) \\
\hline AgHPW-nano & 0,08 & 0,13 & 0,00 \\
\hline AgHPW-micro & 0,08 & 0,03 & 0,00 \\
\hline
\end{tabular}

As micrografias do $\mathrm{AgNO}_{3}$ mostraram que o reagente possui geometria não poliédrica e superfície lisa com depósitos nanométricos (Figura 124), enquanto o AgHPW-micro (Figura 125) apresentou aglomerados micrométricos com proeminências em sua superfície de morfologia tipo flor em todas as regiões investigadas. O tipo morfológico em flor também foi reportado por Rahman e colaboradores ${ }^{180}$ ao estudarem nanoestruturas de $\mathrm{Ag}_{2} \mathrm{O}$. Dessa forma, é provável que, no material AgHPW-micro deste trabalho, coexistam as fases agregadas de Ag-HPW e do óxido simples $\mathrm{Ag}_{2} \mathrm{O}$.

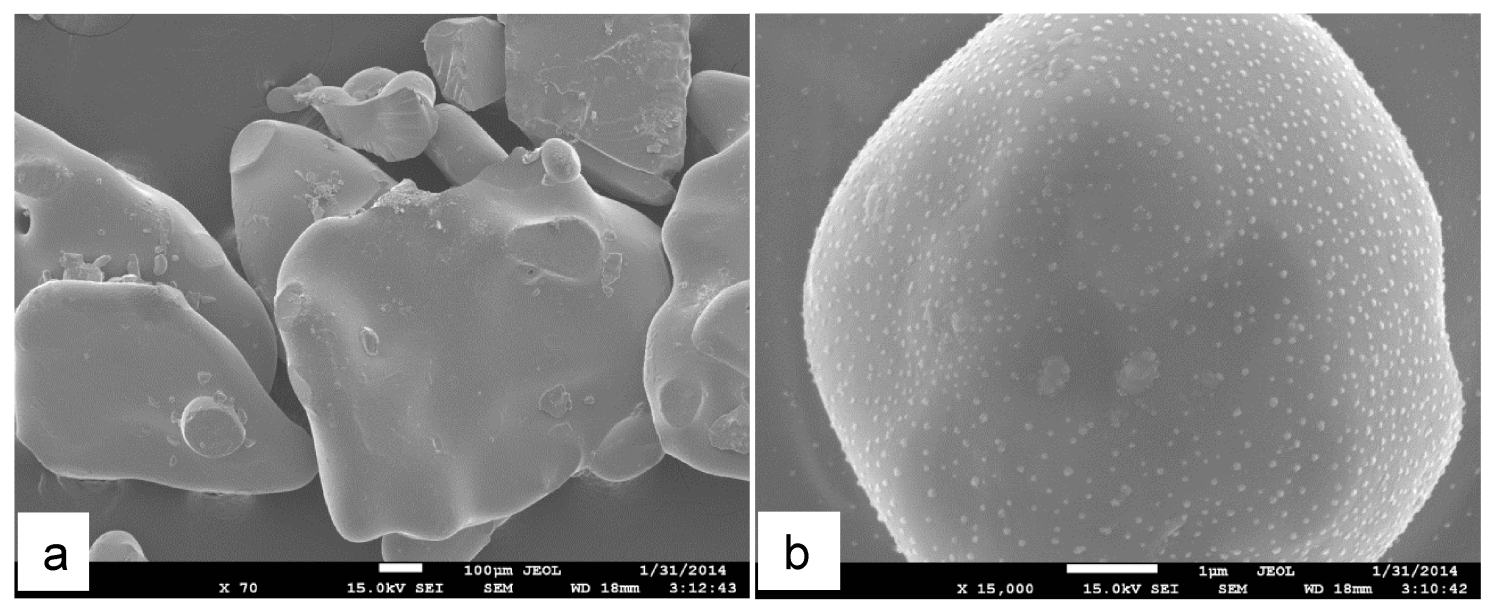

Figura 124: Micrografias do reagente $\mathrm{AgNO}_{3}$ em aproximações de 70 x (a) e $15.000 \times(b)$. 


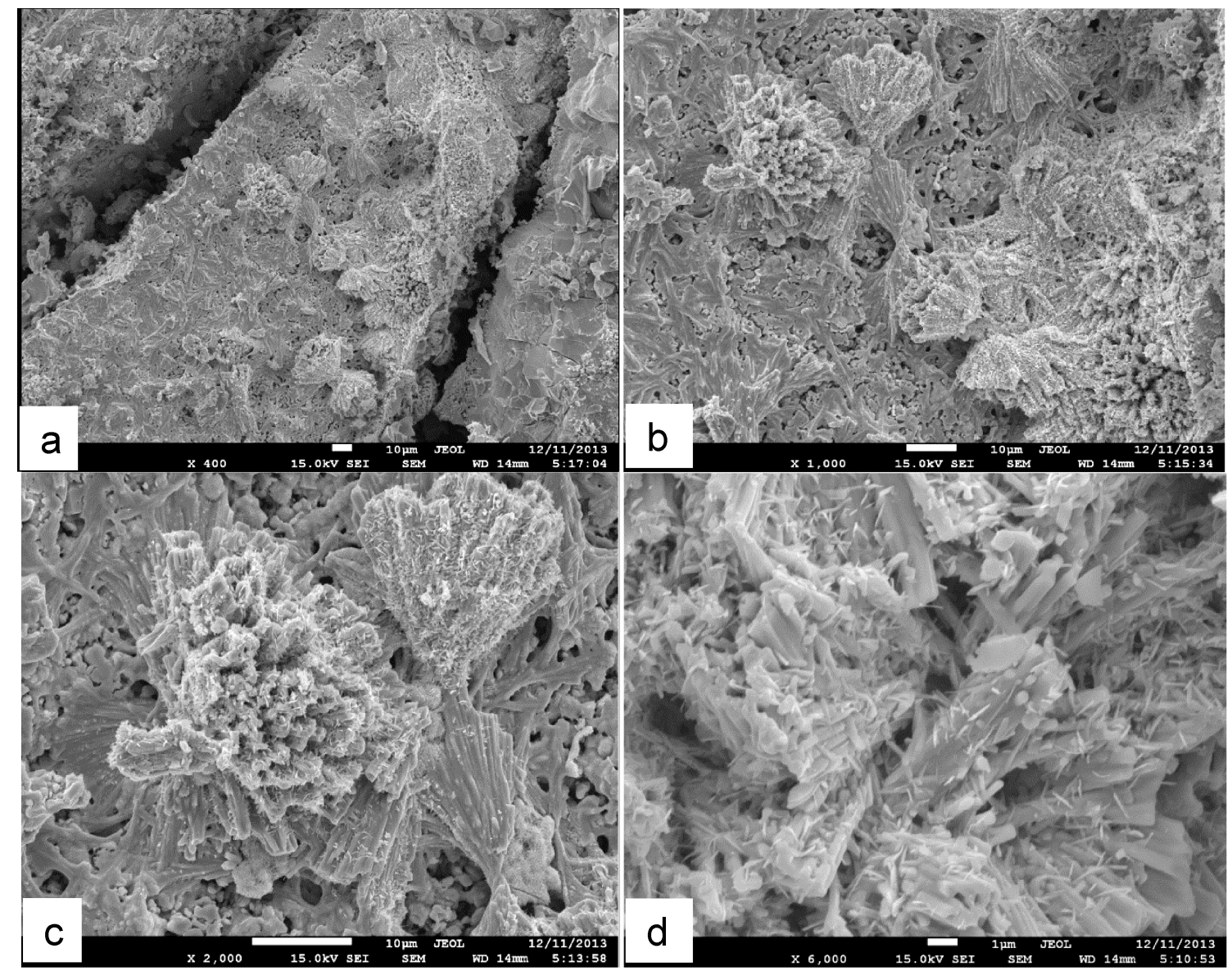

Figura 125: Micrografias da amostra AgHPW-micro em aproximações de $400 \times$ (a), $1.000 \times(b), 2.000 \times(c)$ e $6.000 \times(d)$.

O cátion $\mathrm{Ag}^{+}$não se polimeriza como o íon zircônio, mas, na presença de água, é capaz de se hidrolisar de acordo com a Equação 16. Biedermann e Hietanen ${ }^{181}$ estudaram a hidrólise do ín $\mathrm{Ag}^{+}$a partir de experimentos de potenciometria e reportaram que a faixa de acidez em que a hidrólise ocorre sem formação do precipitado $\mathrm{Ag}_{2} \mathrm{O}$ é pequena quando se trabalha com soluções mais concentradas de $\mathrm{Ag}^{+}$. Nesse caso, a espécie $\mathrm{AgOH}$ é rapidamente convertida à forma de óxido, segundo a Equação 17, liberando mais água para a hidrólise ao longo da síntese. Os autores ainda mostraram que o equilíbrio da Equação 18 existe em soluções saturadas, formando espécies do tipo $\mathrm{Ag}_{2} \mathrm{OH}^{+}$. Portanto, a existência de espécies de óxidos e hidróxidos de prata podem estar presentes no material, substituindo, inclusive, os cátions $\mathrm{H}_{5} \mathrm{O}_{2}{ }^{+}$da estrutura tridimensional do HPW. 


$$
\begin{aligned}
& \mathrm{Ag}^{+}(\mathrm{aq})+\mathrm{H}_{2} \mathrm{O}(\mathrm{I}) \rightleftharpoons \mathrm{AgOH}(\mathrm{aq})+\mathrm{H}^{+}(\mathrm{aq}) \\
& 2 \mathrm{AgOH}(\mathrm{aq}) \rightleftharpoons \mathrm{Ag}_{2} \mathrm{O}(\mathrm{s})+\mathrm{H}_{2} \mathrm{O}(\mathrm{I}) \\
& 1 / 2 \mathrm{Ag}_{2} \mathrm{O}(\mathrm{s})+1 / 2 \mathrm{H}_{2} \mathrm{O}(\mathrm{I})+\mathrm{Ag}^{+} \rightleftharpoons \mathrm{Ag}_{2} \mathrm{OH}^{+}(\mathrm{aq})
\end{aligned}
$$

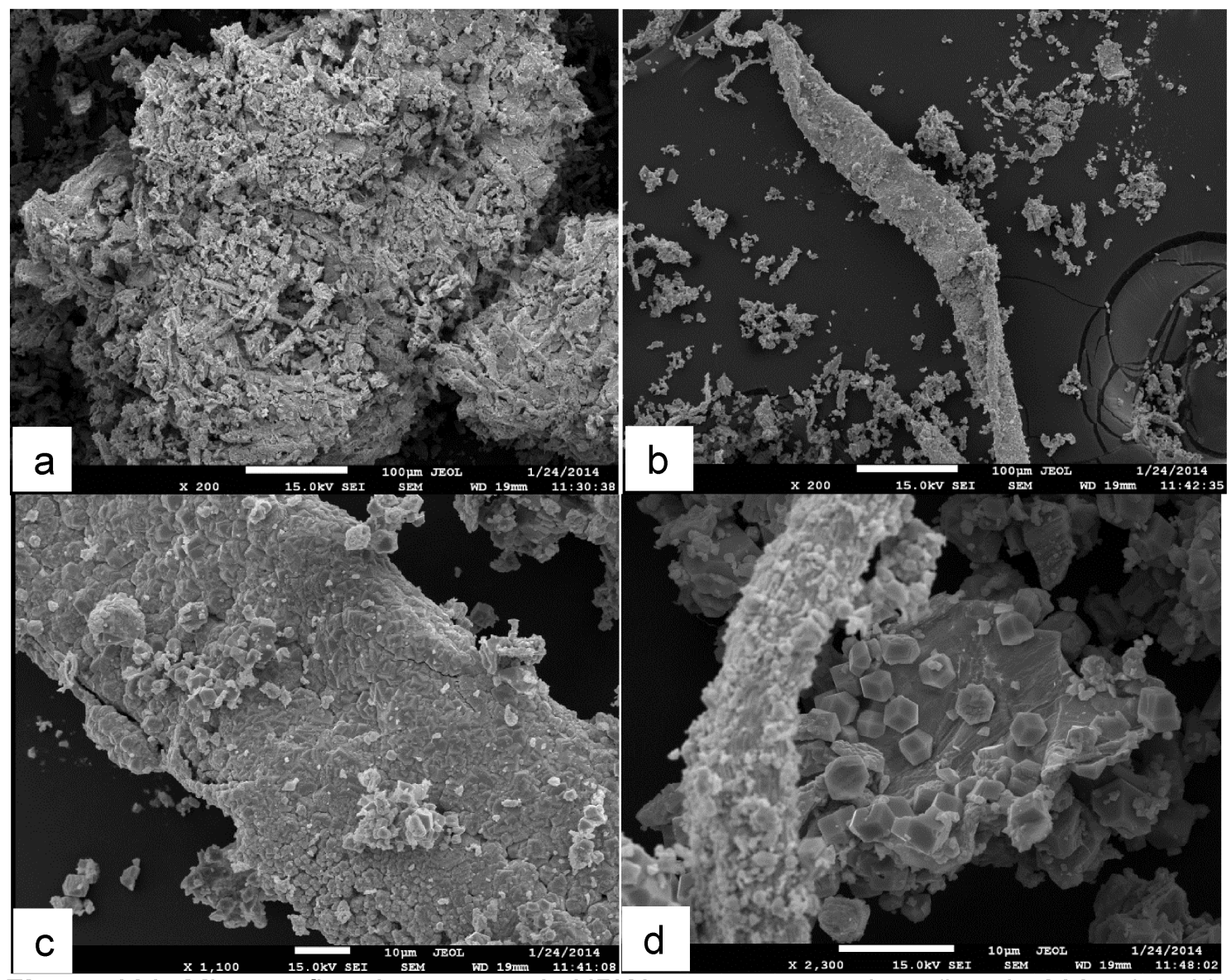

Figura 126: Micrografias da amostra AgHPW-nano em aproximações de $200 \times$ (a e b), $1.100 \times(c)$ e $2.300 \times(d)$.

A Figura 126 exibe as micrografias do sólido AgHPW-nano. Em muitas regiões analisadas, as fibras sintetizadas se mostraram menos livres (Figura 126-a) e envolvidas por aglomerados mássicos semelhantes às imagens da Figura 100, em que se utilizou uma alta porcentagem do precursor $\mathrm{Zn}\left(\mathrm{NO}_{3}\right)_{2}$. Assim como nas nanofibras de zircônia, nesse caso também foram observados clusters livres, na forma de depósitos poliédricos. A geometria desses depósitos já foi reportada tanto como sendo clusters de AgPW como de óxidos livres $\mathrm{Ag}_{2} \mathrm{O}$. Mucha e colaboradores ${ }^{182}$, ao estudarem o sal $\mathrm{Ag}_{3}\left[\mathrm{PW}_{12} \mathrm{O}_{40}\right]$, em que os íons $\mathrm{H}^{+}$do HPW foram totalmente substituídos, encontraram em suas 
micrografias esses clusters submicrométricos, que, segundo os autores, são dodecaedros fracamente ligados entre si. Wang e colaboradores $^{183}$ evidenciaram diferentes morfologias para microcristais de $\mathrm{Ag}_{2} \mathrm{O}$, a depender da metodologia de síntese adotada, e, dentre as geometrias identificadas, estão os dodecaedros rômbicos.

Mesmo com a menor definição das fibras identificada por MEV, o difratograma (Figura 127) comprovou que o arranjo estrutural do material nanoestruturado se assemelhou ao da celulose, inexistindo os picos cristalinos da estrutura secundária de Keggin. A amostra AgHPW-micro também apresentou baixa cristalinidade, exibindo um padrão cristalográfico semelhante ao dos sólidos de ZnHPW-nitrato, porém, com picos menos intensos.

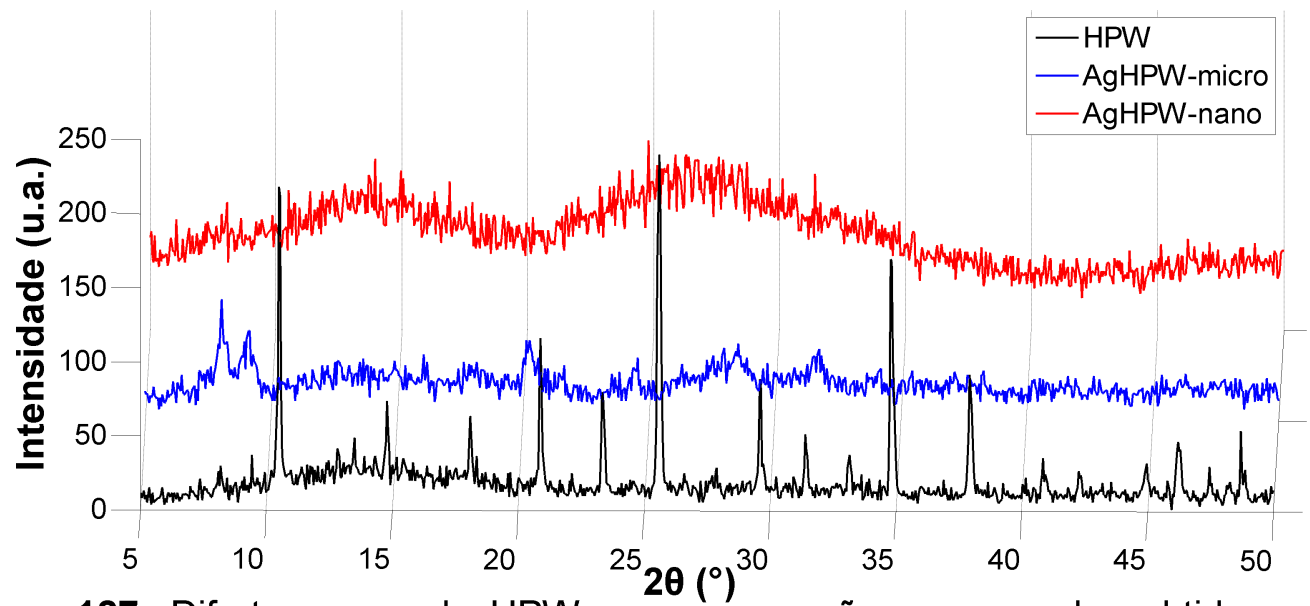

Figura 127: Difratogramas do HPW em comparação com aqueles obtidos para as amostras AgHPW-micro e AgHPW-nano.

Trabalhos da literatura que caracterizam materiais de AgHPW reportaram a manutenção da estrutura secundária de Keggin com deslocamentos para ângulos maiores, ou seja, com contração do parâmetro de cela do cristal devido ao menor raio iônico do íon prata em relação ao cátion $\mathrm{H}_{5} \mathrm{O}_{2}{ }^{+58,60,182,184,185}$ Além disso, nesses artigos, o sal AgHPW apresenta geometria dodecaédrica, igual àquela encontrada nas micrografias das nanofibras (Figura 126), com manutenção da estrutura tridimensional do HPW. Assim, ao contrário do que é observado na literatura, o sólido sintetizado no presente trabalho, AgHPW-micro, apresentou morfologia não poliédrica, exibindo baixa cristalinidade. Esse fato corrobora com a ideia de que duas fases (de $\mathrm{Ag}_{2} \mathrm{O}$ e $\mathrm{AgHPW}$ ) coexistem no material, não de maneira segregada, 
mas combinadas e interagindo entre si, já que o difratograma da amostra micrométrica não exibiu fases separadas de óxidos simples e, tampouco, da estrutura tridimensional de Keggin. Portanto, as espécies de prata (Equações 16 a 18), ao substituírem os prótons do HPW, alteraram a estrutura secundária do precursor, formando um novo material combinado, sem um padrão de repetição de celas unitárias.

Já a estrutura primária do HPW foi mantida integralmente para ambos os materiais sintetizados, sendo observadas todas as vibrações referentes ao ânion de Keggin nos espectros de FT-IR (Figura 128). As espécies de prata geradas pela hidrólise evitam a aglomeração dos grupos $\left[\mathrm{PW}_{12} \mathrm{O}_{40}\right]^{3-}$, alterando a estrutura secundária do HPW (vide DRX), mas preservam o arranjo primário de Keggin. Ao contrário dos sólidos sintetizados com nitrato de zinco, não foram identificadas bandas na região de vibração do íon $\mathrm{NO}_{3}{ }^{-}$, o que comprova sua eliminação, corroborando com os dados de $\mathrm{CHN}$.

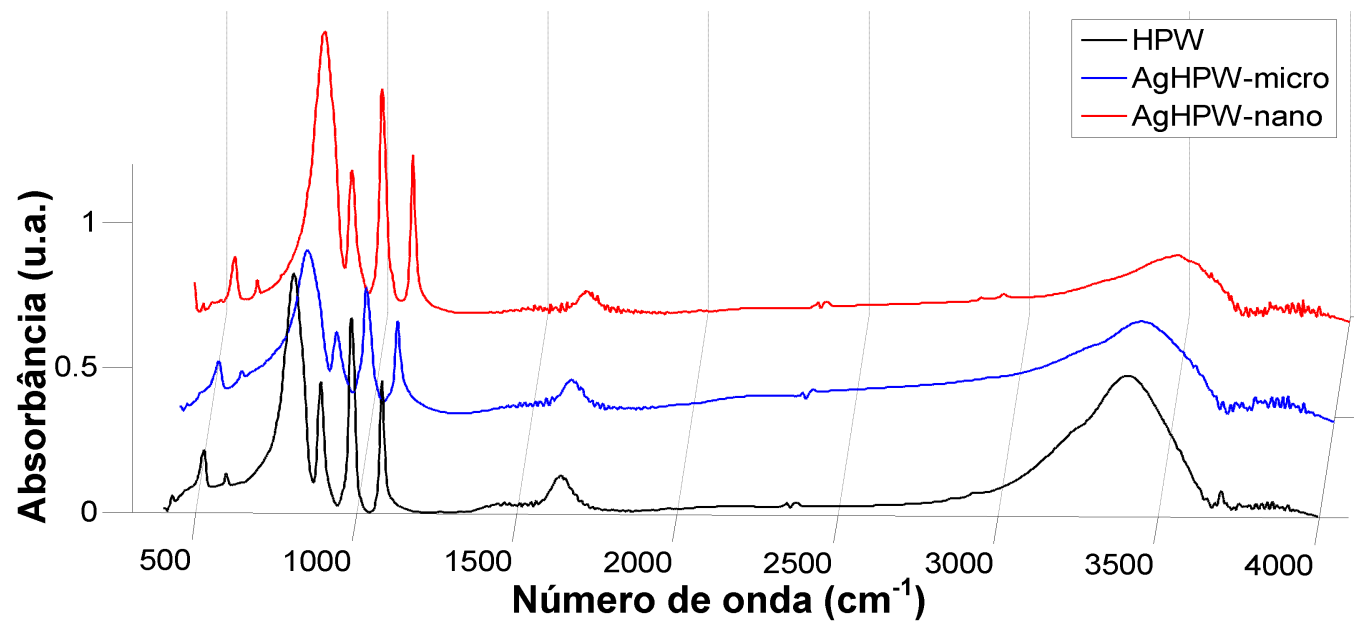

Figura 128: Espectros de FT-IR obtidos para 0 HPW e para as amostras AgHPW-micro e AgHPW-nano.

As curvas TG/DTG/DTA da amostra AgHPW-micro (Figura 129) demonstraram a alta resistência desse material, pois a degradação da estrutura de Keggin só foi evidenciada em maiores proporções a partir de $1100{ }^{\circ} \mathrm{C}$. A primeira perda de massa, até $100^{\circ} \mathrm{C}$, possui efeito endotérmico na curva DTA e diz respeito à água fisicamente adsorvida. Já a segunda perda de massa, próxima de $200{ }^{\circ} \mathrm{C}$, faz referência à água de cristalização do composto (água química), com efeito também endotérmico. 


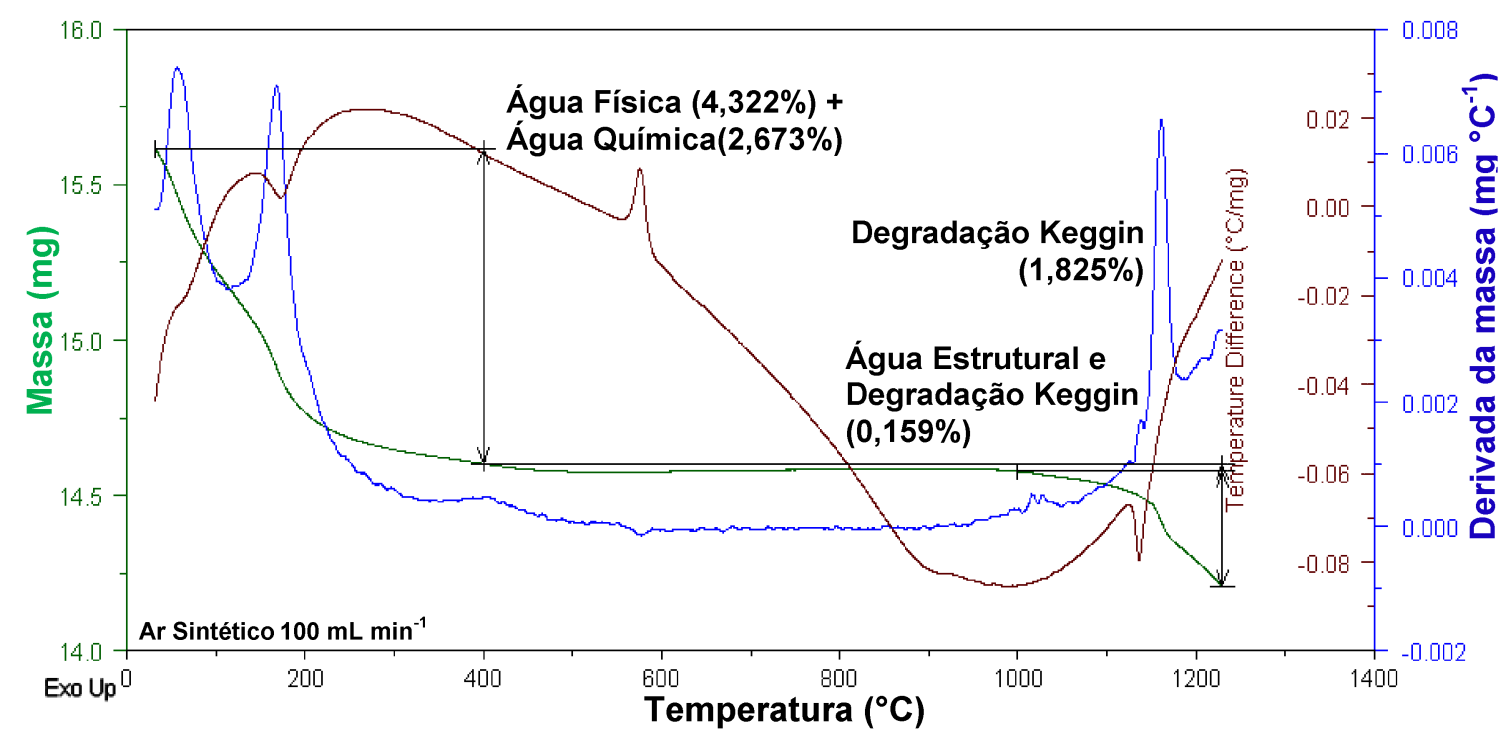

Figura 129: Curvas TG/DTG/DTA obtidas para a amostra AgHPW-micro.

Em adição, Matachowski e colaboradores ${ }^{60}$ reportaram uma outra perda de massa após $200^{\circ} \mathrm{C}$ e a relacionaram seu efeito endotérmico com uma perda de água da região sub-superficial do material $\mathrm{AgPW}$, correspondente à hidratação do cátion $\mathrm{Ag}^{+}$. Essa perda de massa é bastante sutil na curva DTG da Figura 129, o que indica que o sólido desse trabalho não possui muitas águas estruturais. Mucha e colaboradores estudaram a estrutura do $\mathrm{Ag}_{3}\left[\mathrm{PW}_{12} \mathrm{O}_{40}\right]$ anidro, após tratamento térmico a $400{ }^{\circ} \mathrm{C}$, e também verificaram essa ausência de moléculas de água de hidratação. ${ }^{182}$

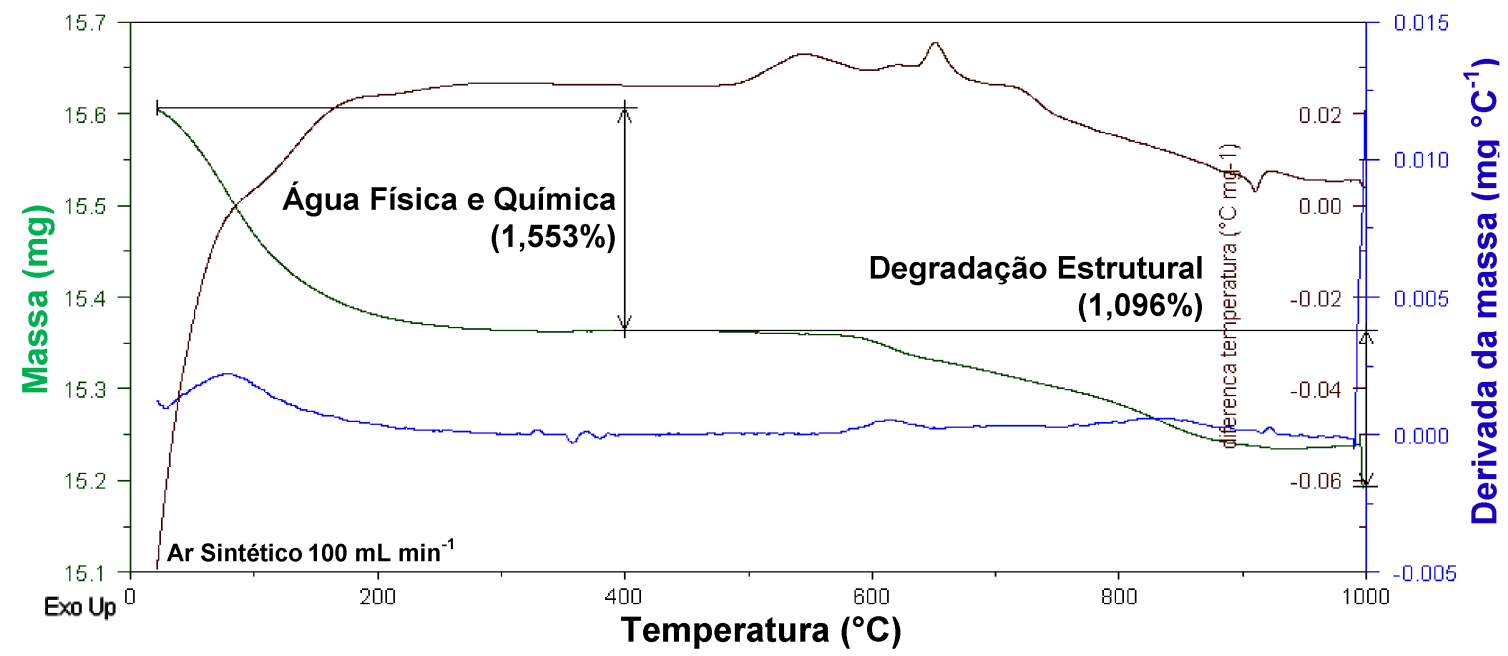

Figura 130: Curvas TG/DTG/DTA obtidas para a amostra AgHPW-nano.

O sólido nanoestruturado mostrou resistência térmica até $600{ }^{\circ} \mathrm{C}$ (Figura 130), com leves perdas de massa de degradação estrutural a partir dessa 
temperatura. Seu termograma apresentou apenas uma perda de massa mais ressaltada de água fisicamente adsorvida e pouca água química sendo eliminada, comprovando a maior hidrofobicidade desse material.

A partir da combinação dos dados de FRX e de TG (Tabela 23), foi possível calcular a estequiometria dos sólidos AgHPW-micro (Equação 19) e AgHPW-nano (Equação 20).

$$
\begin{aligned}
& \mathrm{Ag}_{3}\left[\mathrm{PW}_{12} \mathrm{O}_{40}\right] \cdot 13,3 \mathrm{H}_{2} \mathrm{O}+1,86 \mathrm{Ag}_{2} \mathrm{O} \\
& \mathrm{Ag}_{2,35} \mathrm{H}_{0,65}\left[\mathrm{PW}_{12} \mathrm{O}_{40}\right] \cdot 2,95 \mathrm{H}_{2} \mathrm{O}
\end{aligned}
$$$$
\text { (Equação 19) }
$$$$
\text { (Equação 20) }
$$

Como ambos os materiais evidenciaram a estrutura primária do HPW no espectro de FT-IR, os ânions de Keggin, $\left[\mathrm{PW}_{12} \mathrm{O}_{40}\right]^{3-}$, foram preservados. Como pode ser visto, os dados teóricos estão bem próximos daqueles experimentais.

Tabela 23: Análise Elementar das amostras AgHPW-micro e AgHPW-nano por FRX/EDX e TG/DTG/DTA.

\begin{tabular}{c|c|c|c|c}
\hline Óxido & $\begin{array}{c}\text { \% Experimental } \\
\text { AgHPW-micro }\end{array}$ & $\begin{array}{c}\text { \% Teórica } \\
\text { AgHPW-micro }\end{array}$ & $\begin{array}{c}\text { \% Experimental } \\
\text { AgHPW-nano }\end{array}$ & $\begin{array}{c}\text { \% Teórica } \\
\text { AgHPW-nano }\end{array}$ \\
\hline $\mathrm{WO}_{3}{ }^{\mathrm{a}}$ & 71,81 & 71,86 & 89,24 & 87,37 \\
\hline $\mathrm{Ag}_{2} \mathrm{O}^{\mathrm{a}}$ & 20,10 & 20,11 & 8,71 & 8,55 \\
\hline $\mathrm{H}_{2} \mathrm{O}^{\mathrm{b}}$ & 7,00 & 6,19 & 1,55 & 1,67 \\
\hline
\end{tabular}

${ }^{a}$ Determinado por FRX/EDX.

${ }^{\mathrm{b}}$ Determinado por TG/DTG/DTA (até $400^{\circ} \mathrm{C}$ ).

Para o AgHPW-micro, os cálculos estequiométricos realizados indicaram uma proporção $\mathrm{Ag} / \mathrm{W}$ igual a 0,56 , o que corresponderia a $6,72 \mathrm{~mol}$ de átomos de Ag para cada $12 \mathrm{~mol}$ de átomos de W. Como esse valor fere o balanço de cargas do composto, ele acaba por comprovar a existência de espécies $\mathrm{Ag}_{2} \mathrm{O}$ e do sal $\mathrm{Ag}_{3}\left[\mathrm{PW}_{12} \mathrm{O}_{40}\right]$, em que os átomos de $\mathrm{H}^{+}$foram totalmente substituídos, para que exista uma completa neutralização das cargas do sólido. No caso do AgHPW-nano, os cálculos mostraram uma razão Ag/W igual a 0,20, bastante inferior ao do sal micrométrico, devendo existir espécies $\mathrm{H}^{+}$para balancear a carga -3 do ânion de Keggin, o que está em conformidade com a maior proporção de hidrogênio detectada pela análise elementar de CHN. Portanto, nesse material, a substituição dos prótons não foi total. 


\subsubsection{Caracterizações de Acidez}

Da mesma maneira como feito para os sólidos com zircônia e com zinco, os materiais AgHPW foram testados no experimento de adsorção gasosa de Py com o objetivo de mensurar a acidez do composto micrométrico e daquele nanoestruturado. As bandas relativas a vibrações da piridina nesses sólidos podem ser observadas na Figura 131.

Apenas o material AgHPW-micro apresentou acidez ressaltada, exibindo bandas nas mesmas regiões identificadas nos sólidos ZrHPW-micro, referentes a sítios de Brønsted $\left(\mathrm{PyH}^{+}: 1534\right.$ e $\left.1482 \mathrm{~cm}^{-1}\right)$. Não foram identificadas bandas na região de $1450 \mathrm{~cm}^{-1}$, frequência exclusiva das vibrações de Lewis. Como visto anteriormente, os cálculos estequiométricos mostraram que todos os prótons foram substituídos nesse sólido, mas a acidez do material não fica comprometida com essa total substituição tendo em vista a capacidade da prata de se hidrolisar e gerar sítios $\mathrm{H}^{+}$(Equação 16). Assim, as águas de hidratação possibilitaram, juntamente com o aquecimento durante a adsorção de piridina, que as espécies de prata formassem novos sítios fortes.

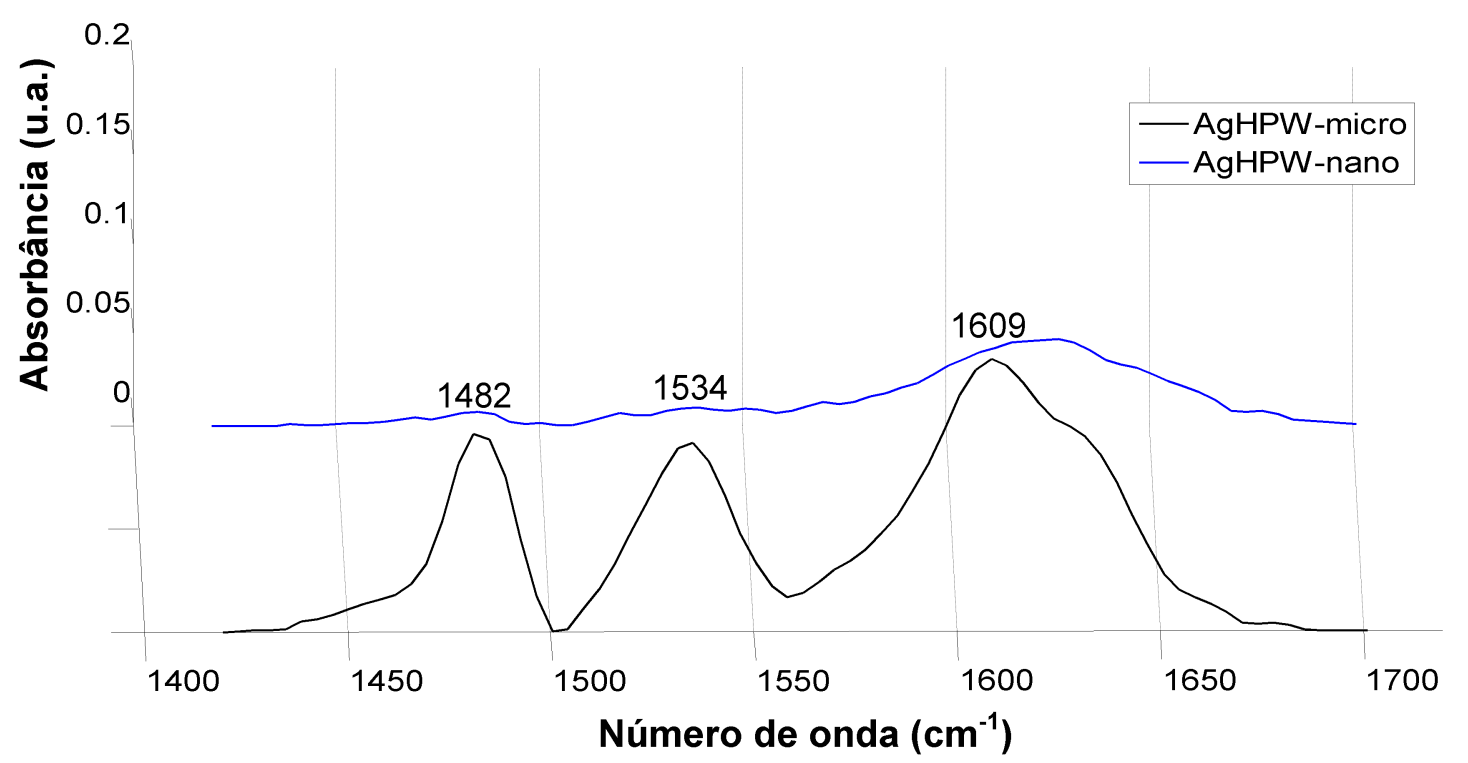

Figura 131: Espectros de FT-IR obtidos para as amostras AgHPW após adsorção de Py.

As Figuras 132 e 133 mostram as curvas TG/DTG para os sólidos AgHPW-micro e AgHPW-nano após o experimento de adsorção de Py. A 
Tabela 24 resume os dados calculados de número de sítios ácidos para ambos os materiais em comparação com o HPW de partida.

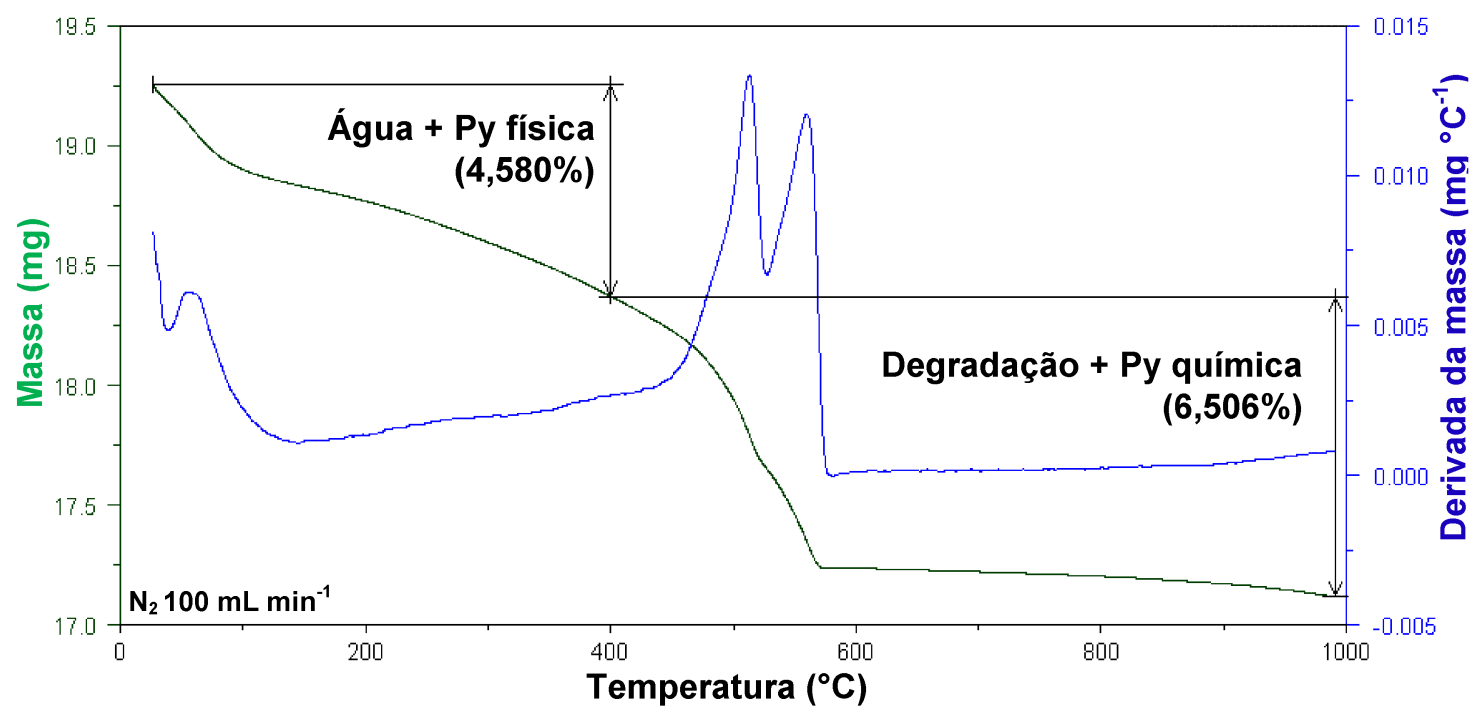

Figura 132: Curvas TG/DTG obtidas para a amostra AgHPW-micro após adsorção de Py.

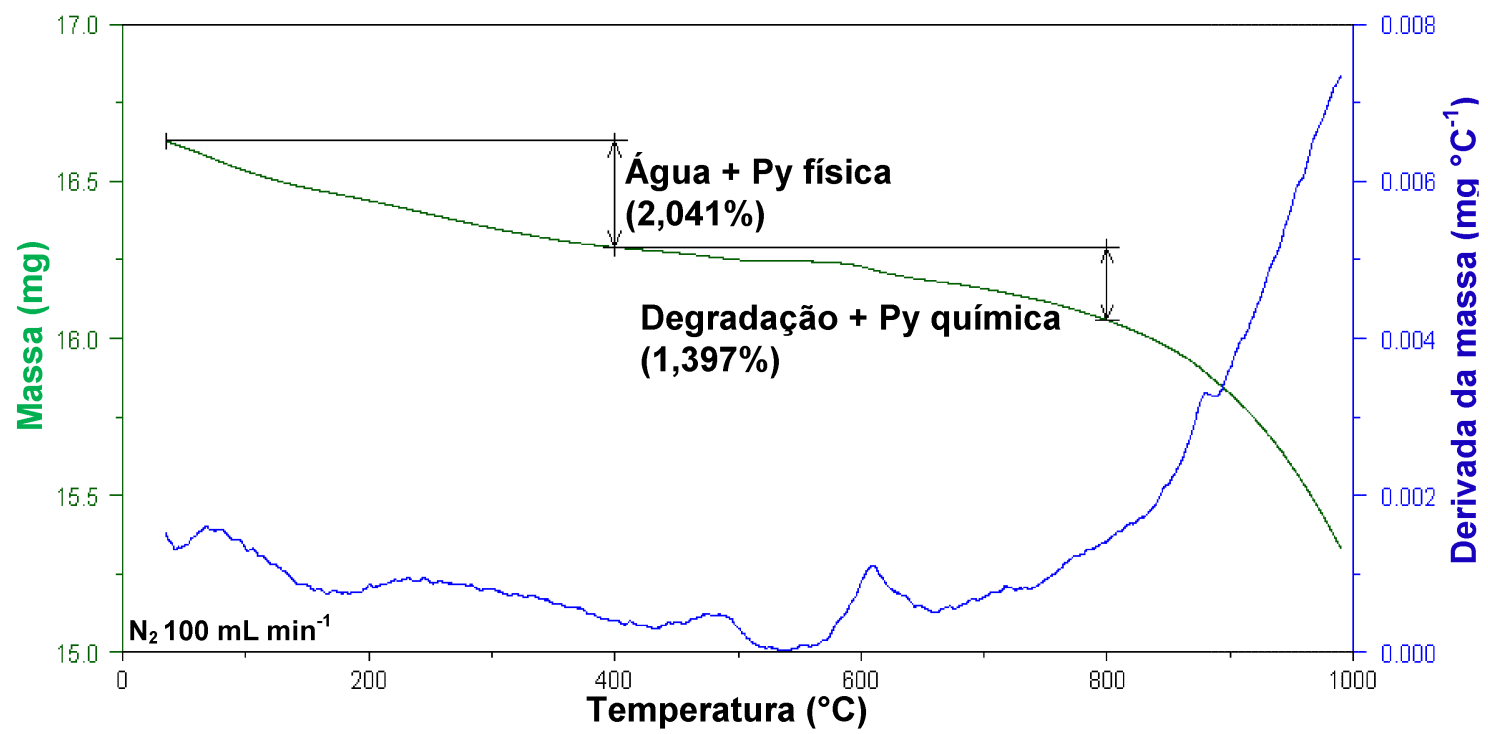

Figura 133: Curvas TG/DTG obtidas para a amostra AgHPW-nano após adsorção de Py.

Como parte dos hidrogênios do HPW foi preservada no material nanométrico (Equação 20), era de se esperar uma acidez maior que aquela calculada para esse sólido $\left(0,04 \mathrm{mmol} \mathrm{g}^{-1}\right)$. Entretanto, a curva DTG do AgHPW-nano (Figura 133) exibe uma baixa porcentagem de massa de água perdida, mais que duas vezes menor que a determinada para o AgHPW-micro, o que implica também em menores quantidades de $\mathrm{H}^{+}$advindos da hidrólise 
das espécies de prata. Dessa maneira, é possível que, durante a síntese do material nanométrico, os hidrogênios residuais tenham sido utilizados para moldar o sólido em fibras, tendo sua valência completada e gerando, com isso, um arranjo estrutural de baixa acidez.

Tabela 24: Número de sítios ácidos calculados via TG a partir da adsorção gasosa de piridina para o HPW e para as amostras sintetizadas com prata.

\begin{tabular}{c|c}
\hline Amostra & Número de Sítios Ácidos $\left(\mathbf{m m o l ~}^{-1}\right)$ \\
\hline HPW & 0,9593 \\
\hline AgHPW-micro & 0,8406 \\
\hline AgHPW-nano & 0,0393 \\
\hline
\end{tabular}

\subsubsection{Reações-modelo}

Apesar de já terem sido reportados como catalisadores solúveis, devido ao pequeno tamanho de seus cátions, ${ }^{45}$ os sais de HPW com zinco, zircônia e prata preparados nesse trabalho formaram precipitados em água durante sua síntese, de modo que se comportaram como catalisadores heterogêneos nas reações-modelo descritas a seguir.

\subsubsection{Desidratação do Etanol PA}

Os sólidos ZrHPW-micro e ZrHPW-nano foram testados na reação de desidratação de etanol PA, utilizando o microrreator de pulso desenvolvido nesse trabalho. Assim, de acordo com as integrações calculadas, pode-se perceber que, apesar de o ZrHPW-micro converter menos o etanol em etileno, apresentando conversões mais baixas que o HPW (Figura 134), sua resistência à desativação e sua seletividade para a formação do etileno é maior que a do HPW, sendo mantida por mais tempo acima de 80\% (Figura 135).

$\mathrm{Na}$ Tabela 25 estão descritos os valores obtidos de conversão e seletividade do etanol em etileno. A partir do número de sítios ácidos dos catalisadores HPW, ZrHPW-micro e ZrHPW-nano, obtido previamente, foi possível calcular o Turnover Number (TON) desses materiais, isto é, o quociente entre a quantidade de matéria de produto (moletieno), calculada a 
partir do volume de injeções de etanol e sua conversão média no produto desejado, e a quantidade de sítios ácidos do catalisador ( $\left.m o l_{c a t}\right)$.

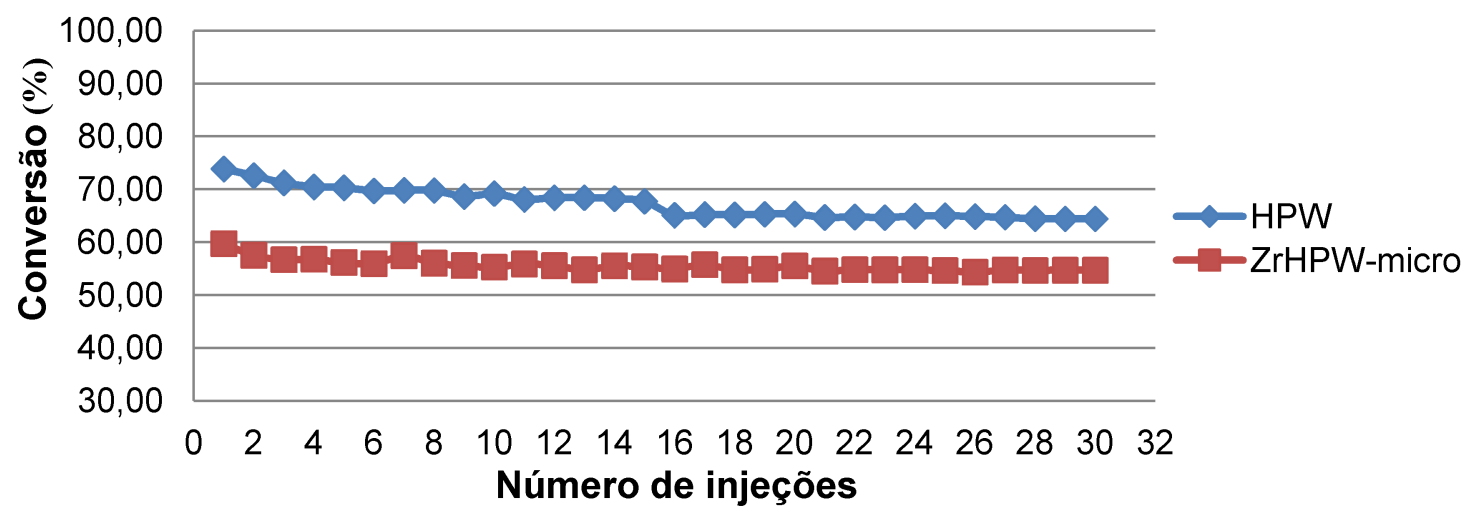

Figura 134: Gráfico da conversão versus o número de injeções para a reação de desidratação do etanol PA utilizando os catalisadores HPW e ZrHPW-micro.

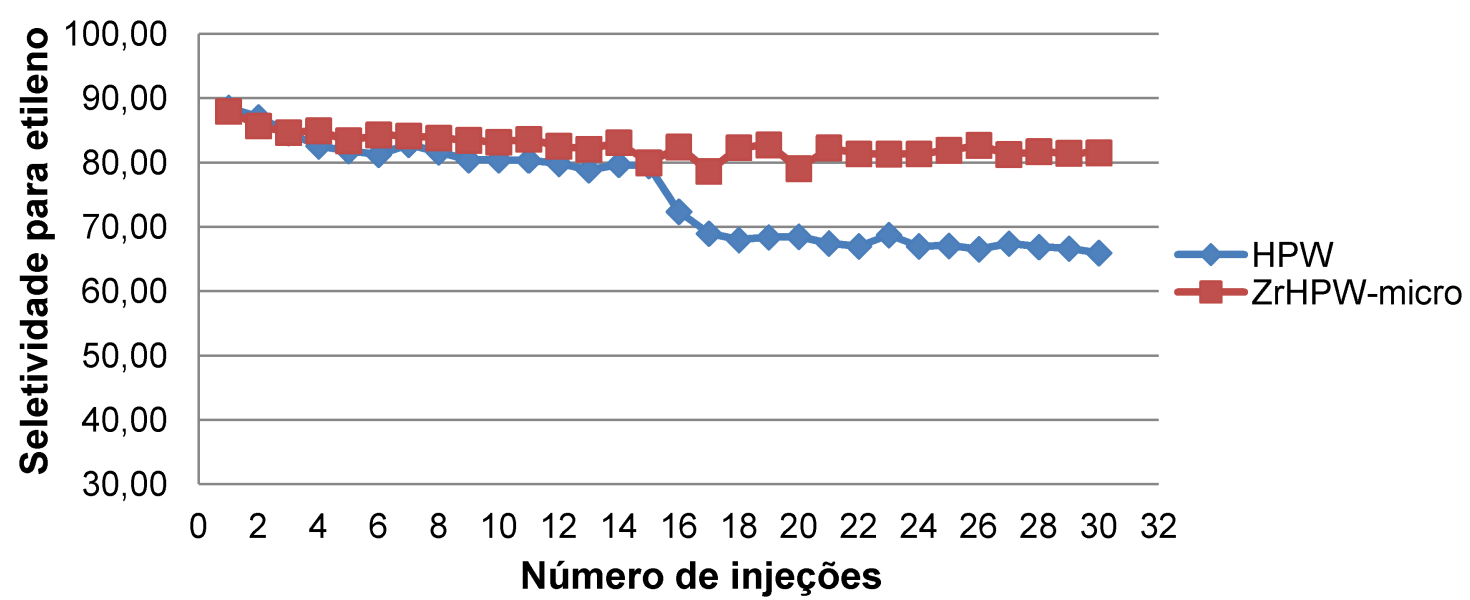

Figura 135: Gráfico de seletividade versus o número de injeções para a reação de desidratação do etanol PA utilizando os catalisadores HPW e ZrHPW-micro.

Mesmo com a remoção parcial dos sítios fortes de Brønsted do HPW no sólido micrométrico, a substituição por espécies de zircônio parece ter tornado os sítios remanescentes mais ativos para a reação de desidratação do etanol em etileno. Dessa forma, apesar de exibir uma conversão quase $12 \%$ mais baixa que o HPW, o ZrHPW-micro apresentou maior capacidade de conversão por sítio ácido existente no material. O material nanoestruturado apresentou conversão média bastante reduzida devido à alta substituição dos sítios $\mathrm{H}^{+} \mathrm{e}$ sua seletividade foi maior para a produção do dietil éter. No entanto, mesmo com baixas conversões, a quantidade de matéria de etileno produzida por mol de sítios ácidos do catalisador (TON) foi mais alta que a do HPW, o que ressalta a força desses sítios remanescentes. 
Tabela 25: Conversão média de etanol em etileno e Turnover Number (TON) calculados para os catalisadores HPW e ZrHPW.

\begin{tabular}{c|c|c|c}
\hline Amostra & $\begin{array}{c}\boldsymbol{R}^{\mathbf{a}} \\
\mathbf{( \% )}\end{array}$ & $\begin{array}{c}\boldsymbol{S}^{\mathbf{a}} \\
\mathbf{( \% )}\end{array}$ & $\begin{array}{c}\text { TON } \\
\text { (mol }_{\text {etileno }} \text { mol }^{-1} \text { cat) }\end{array}$ \\
\hline HPW & 67,35 & 74,91 & 0,12 \\
\hline ZrHPW-micro & 55,58 & 82,66 & 0,20 \\
\hline ZrHPW-nano & 11,75 & 46,05 & 0,17
\end{tabular}

${ }^{a}$ Conversão média; ${ }^{b}$ Seletividade média para etileno, sendo os valores calculados pela média aritmética das porcentagens de conversão em 30 injeções de $0,2 \mu \mathrm{L}$ de etanol $\mathrm{PA}$, a $300^{\circ} \mathrm{C}$, em $20 \mathrm{mg}$ dos catalisadores.

Os maiores resultados de seletividade, no caso do ZrHPW-micro, e de TON corroboram com a teoria de que a substituição dos sítios de Brønsted por sítios metálicos em heteropoliácidos incrementa a acidez e a resistência à água desses materiais. Como a desidratação de alcoóis gera água, o catalisador ZrHPW-micro, além de ser mais hidrofóbico que o HPW, pode gerar novos sítios ácidos de acordo com a Equação 13, de modo que a seletividade para o produto da reação intramolecular, o etileno, é mais elevada. Já o ZrHPW-nano, apesar de sua alta hidrofibicidade, apresentou uma morfologia diferenciada, que não propiciou a formação de novos sítios ácidos. No entanto, os sólidos de ZrHPW possuem a grande vantagem de serem catalisadores heterogêneos em solventes polares, de fácil recuperação, enquanto o HPW é um material altamente hidrofílico, solúvel em água e em alcoóis.

\subsubsection{Esterificação do Álcool Benzílico}

A esterificação de Fischer é a reação entre um ácido carboxílico e um álcool na presença de um catalisador ácido, sendo um dos principais métodos para se produzir ésteres, importantes na composição de flavorizantes e fragrâncias. ${ }^{186,187}$ Trata-se de uma reação que entra em equilíbrio em poucas horas sob refluxo, podendo-se, então, aumentar a formação do produto por meio da adição de diferentes proporções de ácido e/ou de álcool a depender da disponibilidade e custo dos reagentes. No presente trabalho, a proporção escolhida de álcool e ácido foi 1:1 (mol:mol), buscando verificar, com isso, a força ácida do catalisador testado sem favorecer o deslocamento do equilíbrio pelo excesso de um dos reagentes. 
O mecanismo, ilustrado na Figura 136, envolve uma protonação inicial do grupo carboxílico com posterior ataque pelo grupo hidroxila nucleofílico do álcool. Em seguida, ocorre uma transferência do próton desse grupo -OH com eliminação de uma molécula de água seguida de uma desprotonação para formar o éster. Como todas as etapas são reversíveis, o processo inverso é o mecanismo para a hidrólise do éster.

Então, além da desidratação de etanol em fase gasosa, alguns dos materiais de HPW também foram testados na esterificação do álcool benzílico $(\mathrm{BzOH})$, procurando observar a atividade catalítica desses sólidos na formação do acetato de benzila (BzAc) e sua resistência em uma reação no estado líquido (Figura 137). Os resultados de conversão, TON e TOF estão descritos na Tabela 26.

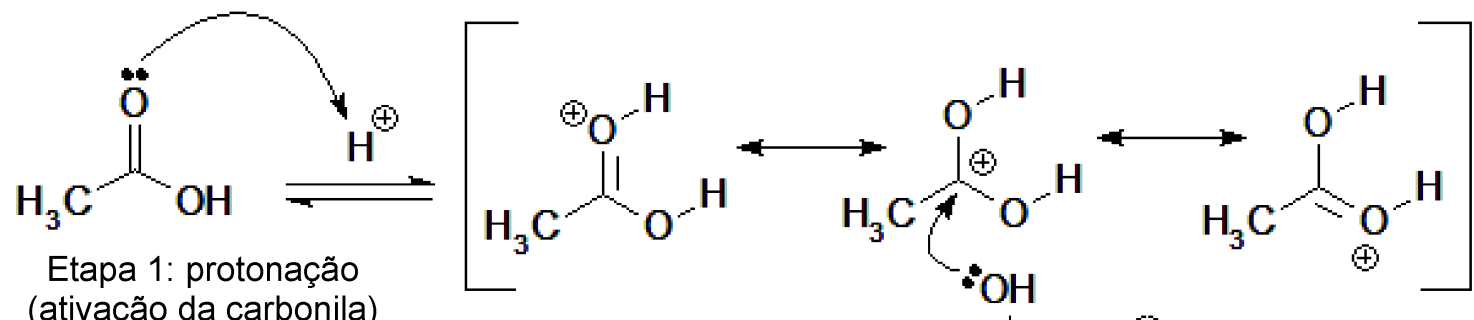
(ativação da carbonila)

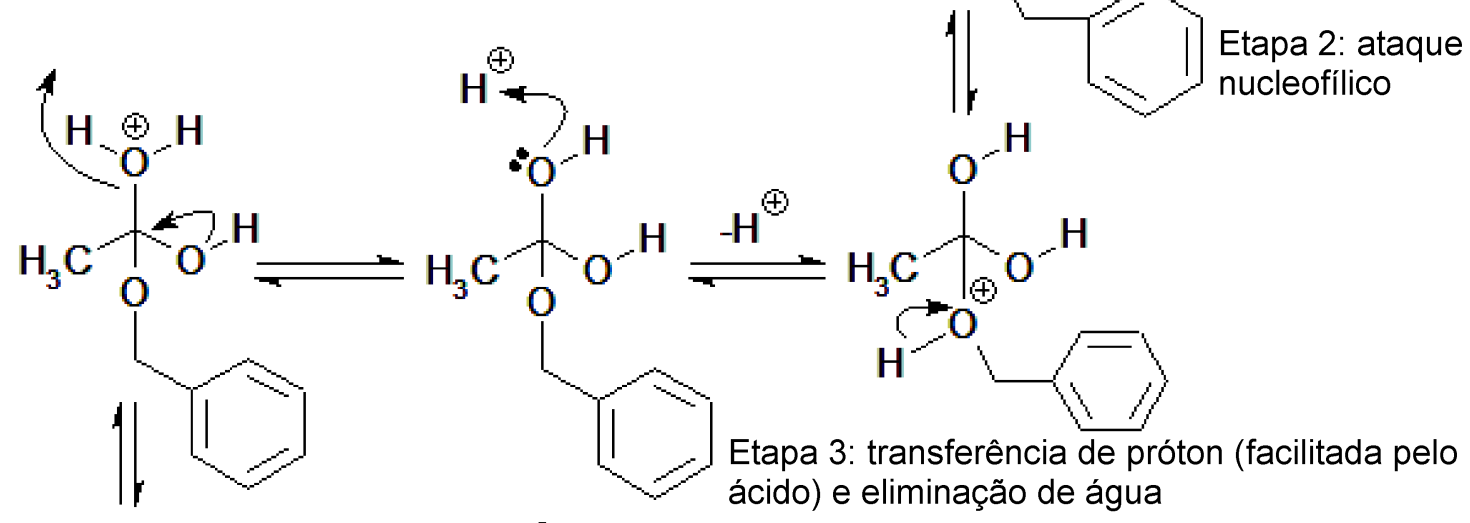

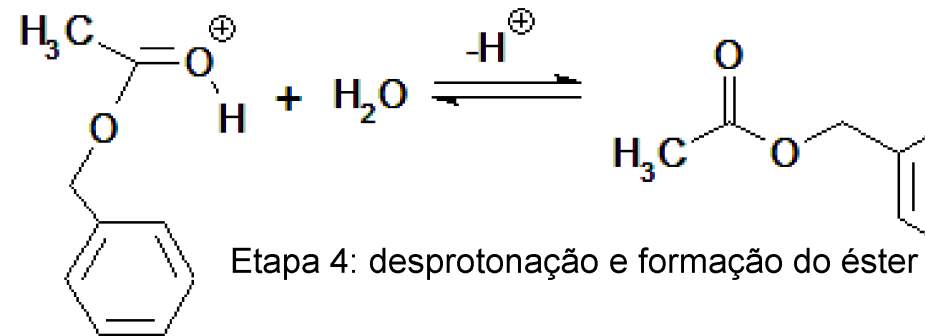

Figura 136: llustração do mecanismo da reação de esterificação do álcool benzílico com ácido acético na presença de um catalisador ácido. 
Tabela 26: Conversão do álcool benzílico em acetato de benzila, Turnover Number (TON) e Turnover Frequency (TOF) calculados para os catalisadores de HPW.

\begin{tabular}{c|c|c|c}
\hline $\begin{array}{c}\text { Amostra } \\
(\mathbf{1 0 \%} \text { catalisador })\end{array}$ & $\begin{array}{c}\boldsymbol{R}^{\mathbf{a}} \\
\mathbf{( \% )}\end{array}$ & $\begin{array}{c}\mathbf{T O N}^{\mathbf{b}} \\
\left(\mathbf{m o l}_{\mathbf{B z A c}} \mathbf{~ m o l}^{-1}{ }_{\text {cat }}\right)\end{array}$ & $\begin{array}{c}\mathbf{T O F}^{\mathbf{c}} \\
\left(\mathbf{m o l}_{\mathbf{B z A c}} \mathbf{~ m o l}^{-1}{ }_{\text {cat }} \mathbf{h}^{-1}\right)\end{array}$ \\
\hline $\begin{array}{c}\text { Branco } \\
\text { (sem catalisador) }\end{array}$ & 4,99 & - & - \\
\hline HPW & 80,53 & 119,3 & 91,3 \\
\hline ZrHPW-micro & 68,57 & 195,4 & 151,1 \\
\hline ZrHPW-micro-cp & 63,42 & 120,8 & 92,0 \\
\hline ZnHPW-micro-2,66 & 42,90 & - & - \\
\hline ZnHPW-micro-acetato & 29,79 & 878,7 & 514,3 \\
\hline AgHPW-micro & 7,75 & 5,0 & - \\
\hline AgHPW-nano & 1,65 & - & -
\end{tabular}

${ }^{a}$ Conversão de álcool benzílico após $2 \mathrm{~h}$ de reação a $60{ }^{\circ} \mathrm{C},{ }^{b}$ Turnover number após $2 \mathrm{~h}$ de reação a $60{ }^{\circ} \mathrm{C},{ }^{\circ}$ Turnover frequency após $1 \mathrm{~h}$ de reação a $60{ }^{\circ} \mathrm{C}$.

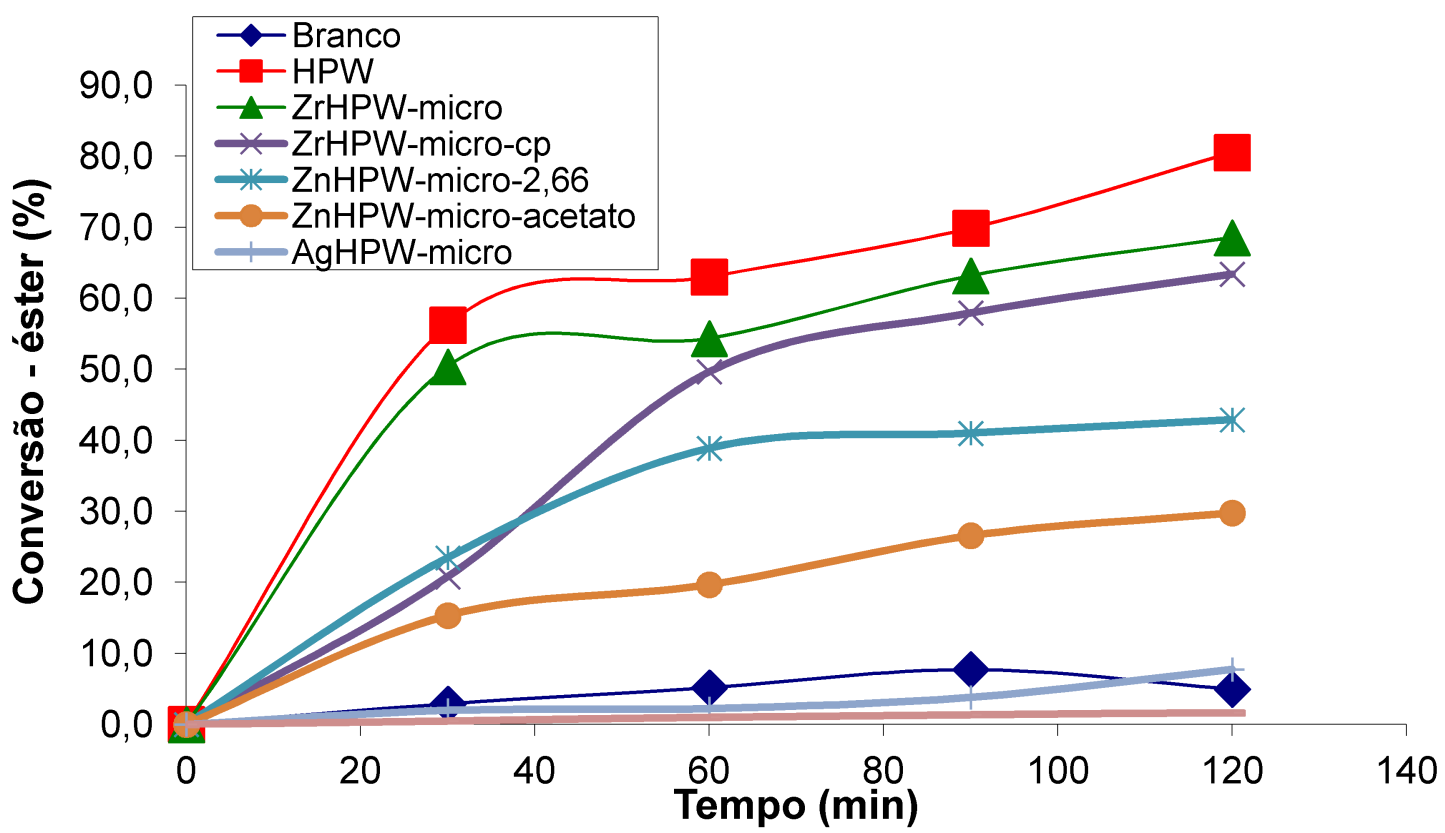

Figura 137: Gráfico de conversão (éster) versus o tempo de reação obtido na reação de esterificação do álcool benzílico sem catalisador (branco) e utilizando o HPW e os materiais de HPAs sintetizados.

Como o próprio ácido acético pode agir como um catalisador ácido na esterificação, o mesmo experimento foi feito sem a utilização dos sólidos de HPAs, obtendo-se o "branco" da reação. No gráfico da Figura 137, pode-se notar que o "branco" passa a diminuir sua conversão ao final de $2 \mathrm{~h}$ de reação 
e esse efeito é esperado, pois a quantidade de sítios ácidos advindos do ácido acético diminuem com o tempo já que são consumidos para formação do éster.

Os valores de TOF e TON da Tabela 26 foram calculados apenas para os sólidos que evidenciaram acidez no experimento de adsorção de piridina e que mostraram conversões superiores ao branco. Como pode ser observado, todos os materiais apresentaram conversão inferiores ao HPW, que atuou como catalisador homogêneo, mas os sólidos ZrHPW-micro e ZnHPW-microacetato, por possuírem menores quantidades de sítios ácidos, geraram conversões por mol de centro ativo bastante superiores àquelas do precursor HPW. O mesmo não ocorreu para o catalisador AgHPW-micro, que não foi ativo na reação, exibindo baixos valores de conversão e TON, apesar de ter apresentado o mais alto valor de sítios ácidos dentre os sólidos sintetizados no experimento de adsorção de piridina. O catalisador com prata, inclusive, foi aquele mais resistente à degradação segundo os dados de TG/DTG. Contrariamente, o sólido ZnHPW-micro-acetato, com praticamente ausência de sítios ácidos $\left(0,048 \mathrm{mmol} \mathrm{g}^{-1}\right)$, e o ZnHPW-micro-2,66, com total ausência de acidez, foram capazes de converter mais que o AgHPW-micro. Como é sabido, a atividade de catalisadores heterogêneos ácidos é fortemente dependente não apenas da quantidade de seus sítios, mas de sua forma, tamanho e distribuição de seus centros ativos ao longo de sua área superficial. Assim, a não linearidade da conversão do álcool em relação à quantidade de sítios ativos dos sólidos estudados deve estar relacionada a esses outros fatores.

D'Souza e Nagaraju, ${ }^{188}$ ao estudarem a atividade catalítica de sólidos com zircônia, alumina e sílica, também verificaram que as conversões obtidas na esterificação do álcool benzílico não foram dependentes do número de sítios ácidos dos catalisadores. Pelo fato de todas as etapas da reação serem um equilíbrio, o catalisador operará tanto no sentido de formação dos produtos como na direção dos reagentes, resultando em pouco aumento de conversão com o aumento da quantidade de sítio ácidos ou com aumento da quantidade de gramas de catalisador utilizada. Além disso, como a esterificação é uma reação reversível, o estado de equilíbrio é atingido quando certa porcentagem de éster é formada na mistura reacional. Assim, os autores somente perceberam variações na conversão ao utilizarem maiores quantidades do catalisador conjuntamente com um aumento no tempo reacional. Outro dado 
obtido no trabalho de D'Souza e Nagaraju diz respeito aos tipos de sítios realmente utilizados na esterificação. Segundo os pesquisadores, nem todos os sítios ácidos da superfície dos catalisadores investigados atuaram na formação do éster. Experimentos de Dessorção Térmica Programada (TPD, do inglês Temperature-Programmed Desorption) de amônia, mostraram que as maiores conversões foram encontradas em sólidos com sítios de força fraca a moderada, mas, nesses casos, a área superficial do catalisador e o volume das moléculas reagentes também tiveram que ser levados em consideração. Quando o número total de sítios ácidos por unidade de área do catalisador é alto, a probabilidade de todos os centros ativos serem bloqueados pela adsorção da molécula volumosa do álcool benzílico é menor, já que um efeito estérico passa a existir com a adsorção de duas ou mais moléculas volumosas em sítios adjacentes. Então, os sítios residuais mais fracos, que não adsorveram o álcool, ainda são capazes de adsorver as pequenas moléculas do ácido acético, favorecendo a formação do acetato de benzila. Caso a situação seja a oposta, em que há poucos sítios por unidade de área superficial, a probabilidade de cada sítio estar interagindo com o álcool é alta, pois os efeitos estéricos são reduzidos com o distanciamento de cada centro ativo. Assim, a disponibilidade de sítios para adsorção do ácido acético é menor, o que dificulta o progresso da esterificação. Portanto, os autores concluíram que, para essa reação, a quantidade de número de sítios ácidos totais de força fraca a intermediária por unidade de área superficial do catalisador é o fator determinante para a produção de acetato de benzila. ${ }^{188}$

No presente trabalho, as áreas superficiais de todos os materiais não foram mensuradas, mas foi possível constatar a teoria supracitada a partir das conversões alcançadas com uso de catalisadores em que há ausência de sítios fortes de Brønsted, como é o caso dos sais de HPW com zinco. Além disso, as maiores conversões foram obtidas para os catalisadores de zircônia, já que um aumento na quantidade de sítios $\mathrm{H}^{+}$por unidade de área superficial pode ter ocorrido devido à hidrólise das espécies de zircônio frente a uma reação que gera água. Nos materiais com prata, é possível que a estrutura de longo alcance do AgHPW-nano tenha distanciado os poucos sítios ativos existentes no sólido $\left(0,039 \mathrm{mmol} \mathrm{g}^{-1}\right)$, favorecendo a adsorção das moléculas volumosas do álcool benzílico, que bloqueiam os sítios e impedem a adsorção do reagente 
ácido acético. Já o AgHPW-micro possui a maior quantidade de sítios fortes $\left(0,841 \mathrm{mmol} \mathrm{g}^{-1}\right)$ dentre os materiais investigados, mas a quantidade de sítios de força fraca a intermediária nesse sólido é incerta. Portanto, o entendimento de sua baixa conversão necessitará dos estudos de sua área superficial e de mais investigações sobre a acidez desse catalisador.

\subsubsection{Oxidação do Álcool Benzílico}

Como alguns dos materiais sintetizados não apresentaram sítios ácidos e/ou foram pouco reativos nas reações de desidratação do etanol e de esterificação, uma nova reação modelo foi pensada procurando verificar, então, a capacidade oxidativa dos sólidos. Dessa maneira, os materiais foram utilizados como catalisadores na reação de oxidação do álcool benzílico.

A oxidação seletiva de alcoóis vem sendo estudada no sentido de prevenir a oxidação total do álcool, isto é, de forma a interromper a reação em seu estágio intermediário, o de produção do aldeído, impedindo que este se oxide e forme ácido carboxílico. Isso porque os aldeídos são importantes intermediários na síntese de diversos produtos farmacêuticos, agroquímicos e perfumes/flavorizantes. Assim, o principal objetivo das pesquisas vem sendo desenvolver um catalisador capaz de aumentar a seletividade desse produto intermediário, mesmo que isso signifique menores proporções de conversão ou perdas na atividade do catalisador. ${ }^{138}$

O benzaldeído é extensamente utilizado na indústria como aromatizante e flavorizante em alimentos, já que é um dos componentes existente nas amêndoas, além de ser usado também em perfumes, corantes e remédios. ${ }^{137}$ Sua produção industrial é feita principalmente via reação catalítica de oxidação do tolueno na presença de ar em estado líquido ou gasoso. Os catalisadores mais usados são óxidos de urânio ou molibdênio, muitas vezes misturados a pequenas quantidades de óxido de cobre buscando reduzir a formação de subprodutos. $^{189}$

A rota sintética que produz o benzaldeído a partir da oxidação parcial do álcool benzílico possui diversas metodologias reportadas na literatura e, dentre elas, a mais utilizada é aquela que emprega o peróxido de hidrogênio como agente oxidante. ${ }^{137,138,164}$ Como se trata de uma reação em fase líquida que 
contém tanto uma fase orgânica (a do benzaldeído) como uma aquosa, uma agitação vigorosa e um catalisador capaz de promover a transferência eletrônica entre essas fases são requeridos. ${ }^{137}$

A Tabela 27 e a Figura 138 resumem os valores de conversão alcançados em $2 \mathrm{~h}$ de reação a $60{ }^{\circ} \mathrm{C}$, utilizando a proporção 1:1 (mol:mol) de álcool benzílico e $\mathrm{H}_{2} \mathrm{O}_{2}$ e apenas $5 \%$ de catalisador. Como o próprio peróxido de hidrogênio pode transformar parte do álcool benzílico em benzaldeído, a oxidação sem a presença de catalisador ("branco" da reação) também foi feita. Nesse caso, a conversão do álcool foi muito pequena, demonstrando que o catalisador desempenha um papel bastante importante na reação.

Tabela 27: Conversão e seletividade obtidos na oxidação do álcool benzílico em benzaldeído calculada para os catalisadores de HPW após $2 \mathrm{~h}$ de reação a $60^{\circ} \mathrm{C}$.

\begin{tabular}{c|c|c}
\hline $\begin{array}{c}\text { Amostra } \\
\text { (5\% catalisador) }\end{array}$ & $\begin{array}{c}\boldsymbol{R}^{\mathbf{a}} \\
\mathbf{( \% )}\end{array}$ & $\begin{array}{c}\mathbf{S}^{b} \\
\mathbf{( \% )}\end{array}$ \\
\hline $\begin{array}{c}\text { Branco com } \mathrm{H}_{2} \mathrm{O}_{2} \\
\text { (sem catalisador) }\end{array}$ & 7,67 & 80,89 \\
\hline $\mathrm{HPW}$ & 12,24 & 38,27 \\
\hline ZrHPW-micro & 24,76 & 34,27 \\
\hline ZrHPW-micro-cp & 16,48 & 46,76 \\
\hline ZrHPW-nano & 25,74 & 65,13 \\
\hline ZnHPW-micro-1,33 & 21,05 & 44,02 \\
\hline ZnHPW-micro-2,66 & 21,38 & 55,18 \\
\hline ZnHPW-micro-acetato & 38,50 & 62,12 \\
\hline AgHPW-micro & 18,53 & 98,70 \\
\hline AgHPW-nano & 21,70 & 97,77
\end{tabular}

${ }^{a}$ Conversão de álcool benzílico, ${ }^{b}$ Seletividade para benzaldeído.

Todos os materiais sintetizados apresentaram conversões superiores ao HPW na oxidação do álcool benzílico, sendo as maiores seletividades para a formação de benzaldeído encontradas para os catalisadores de prata. Em todos os casos, subprodutos de identidade desconhecida foram detectados nos tempos de retenção de 4,9 e 6,2 min em maiores ou menores quantidades, a depender do catalisador utilizado, após $2 \mathrm{~h}$ reacionais. Todavia, em nenhuma dessas reações o pico referente ao ácido benzoico (tempo de retenção $=$ 1,6 min), produto da oxidação total do álcool benzílico, foi evidenciado. $\mathrm{Na}$ presença de ar e em temperatura ambiente, o benzaldeído pode se auto-oxidar 
espontaneamente, formando ácido benzoico. Entretanto, Sankar e colaboradores ${ }^{138}$ mostraram que a existência de uma pequena quantidade de álcool benzílico no meio reacional já é suficiente para inibir a oxidação do benzaldeído, mesmo em condições extremas de altas temperaturas e grandes quantidades de agente oxidante. Esse fato pôde ser observado no presente trabalho, já que, em nenhum dos casos, houve consumo total do álcool benzílico.

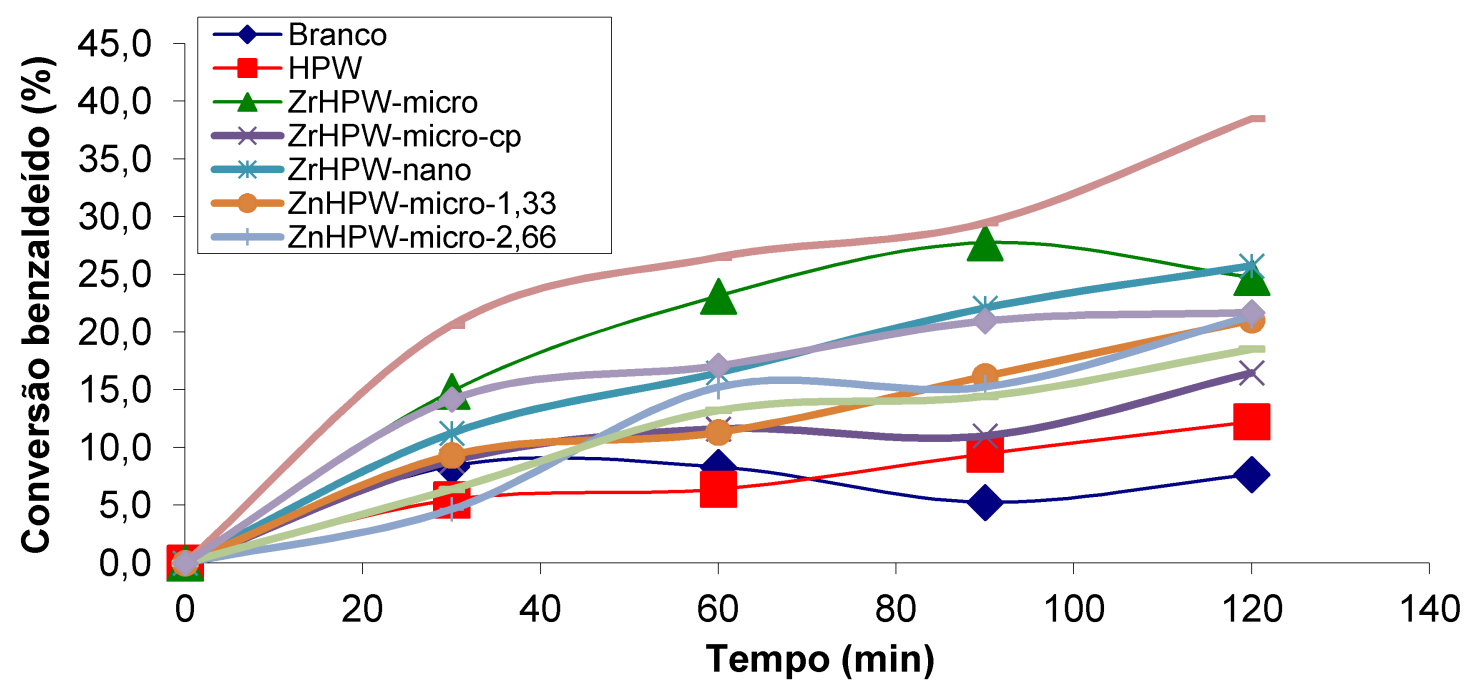

Figura 138: Gráfico de conversão (benzaldeído) versus o tempo de reação obtido na reação de oxidação do álcool benzílico sem catalisador (branco) e utilizando o HPW e os materiais de HPAs sintetizados.

Os valores de conversão dos materiais nanoestruturados foram muito próximos daqueles encontrados para os sais micrométricos, o que ressalta a importância da disponibilidade do metal de transição no mecanismo da oxidação catalítica, ${ }^{190}$ de forma que a maior acidez de Brønsted do sólido não possui grande influência nos valores de conversão. Ao contrário, a substituição dos prótons do HPW por metais já foi reportada por aumentar a conversão na oxidação do álcool benzílico, mediante diminuição da acidez do catalisador, mas com incremento de sua capacidade REDOX pela presença do metal. ${ }^{137,191}$

O mecanismo dessa reação bifásica utilizando catalisadores de HPAs já foi citado e envolve a catálise por transferência de fase, com perda da estrutura dos poliânions (Equação 21), principalmente quando se utiliza o HPW em conjunto com um excesso de peróxido. ${ }^{137} \mathrm{~A}$ degradação do ânion de Keggin ocorre devido a sua alta labilidade, formando rapidamente espécies ativas oxidadas, solúveis em água, do tipo $\left\{\mathrm{PO}_{4}\left[\mathrm{WO}\left(\mathrm{O}_{2}\right)_{2}\right]_{4}\right\}^{3-}$ e $\left[\mathrm{W}_{2} \mathrm{O}_{3}\left(\mathrm{O}_{2}\right)_{4}\left(\mathrm{H}_{2} \mathrm{O}\right)_{2}\right]^{2-}$, 
as quais oxidam o álcool e retomam sua forma original $\left\{\mathrm{PO}_{4}\left[\mathrm{WO}_{3}\right]_{12}\right\}^{3-}$ ao final da reação. ${ }^{134,135,137,190}$ Portanto, como o álcool benzílico é bastante solúvel em água, sua oxidação a benzaldeído ocorre em fase aquosa. Observando a Equação 20 , nota-se que, durante a reação com o peróxido, há a liberação de íons $\mathrm{H}^{+}$na mistura reacional, fato também constatado no presente trabalho pela diminuição do $\mathrm{pH}$ do meio, de 4 para 2 a $26^{\circ} \mathrm{C}$.

$$
\left\{\mathrm{PO}_{4}\left[\mathrm{WO}_{3}\right]_{12}\right\}^{3-}+24 \mathrm{H}_{2} \mathrm{O}_{2} \rightarrow\left\{\mathrm{PO}_{4}\left[\mathrm{WO}\left(\mathrm{O}_{2}\right)_{2}\right]_{4}\right\}^{3-}+4\left[\mathrm{~W}_{2} \mathrm{O}_{3}\left(\mathrm{O}_{2}\right)_{4}\left(\mathrm{H}_{2} \mathrm{O}\right)_{2}\right]^{2-}+8 \mathrm{H}^{+}+12 \mathrm{H}_{2} \mathrm{O}
$$

(Equação 21)

Todos os sólidos sintetizados se mostraram insolúveis no estágio inicial da reação, mas, com o decorrer do tempo, parte do catalisador parece ter sido dissolvido na fase aquosa, corroborando com a Equação 21, devido à interação da estrutura de Keggin com a água oxigenada. Assim como observado neste trabalho, sais de HPW com prata, por exemplo, já foram reportados por formarem suspensões coloidais em solventes como água e álcool e, por possuírem cristalitos muito finos $(10-20 \mathrm{~nm})$, são difíceis de serem recuperados por uma simples filtração e/ou centrifugação. ${ }^{192} A$ existência de duas fases na mistura reacional dificultou ainda mais a recuperação do catalisador e, dentre os materiais investigados, o sólido ZrHPW-nano foi aquele mais facilmente recuperado. Por isso, foi o catalisador utilizado em um segundo ciclo reacional, a fim de estudar sua resistência. O material foi recolhido a partir da decantação da mistura e lavado sucessivas vezes com acetonitrila (10 porções de $10 \mathrm{~mL}$ ) com posterior secagem ao ar durante um dia. Os resultados de conversão podem ser observados nos gráficos da Figura 139.

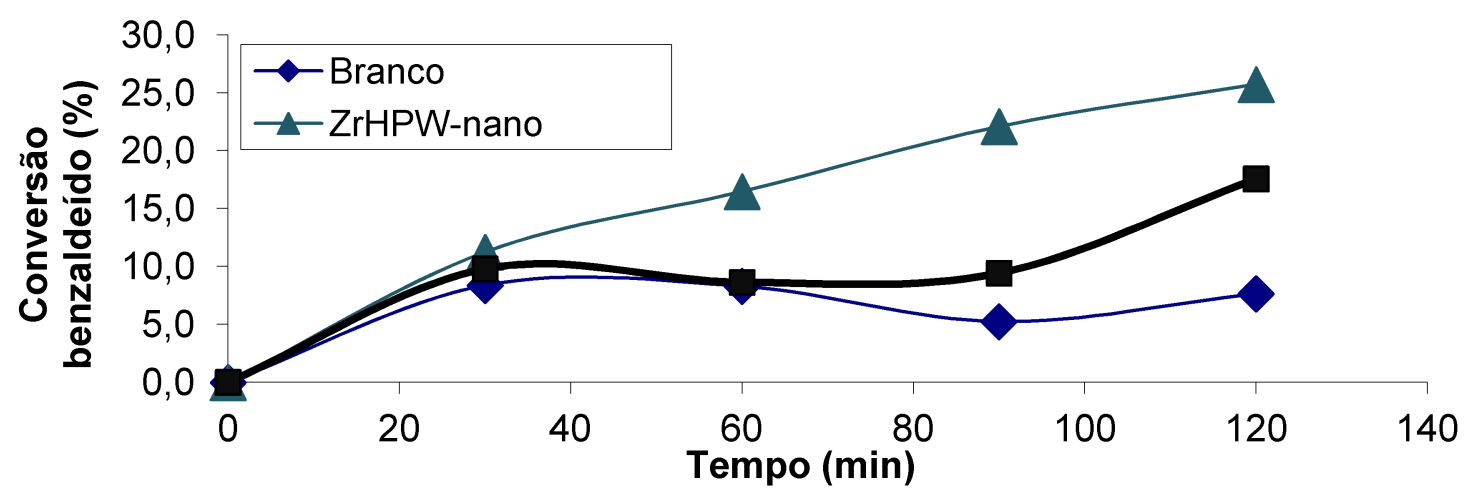

Figura 139: Gráfico de conversão (benzaldeído) versus o tempo de reação obtido em 2 h de reação de oxidação do álcool benzílico sem catalisador e utilizando o sólido ZrHPW-nano em dois ciclos reacionais. 
Mesmo com uma morfologia diferenciada e sem a detecção da estrutura de Keggin, os valores de conversão do ZrHPW-nano foram muito semelhantes ao do sólido ZrHPW-micro, que manteve inalterado o arranjo tridimensional do HPW. Portanto, é provável que a oxidação do álcool benzílico na presença do material ZrHPW-nano tenha se dado principalmente pelos centros metálicos polimerizados de zircônia em conjunto com ligações $\mathrm{W}-\mathrm{O}$, de forma semelhante ao mecanismo ilustrado por Chaudhari e colaboradores ${ }^{193}$ (Figura 140) para o tungstênio e, da mesma forma, por Neumann e colaboradores ${ }^{194}$ para o vanádio.

Etapa 1:

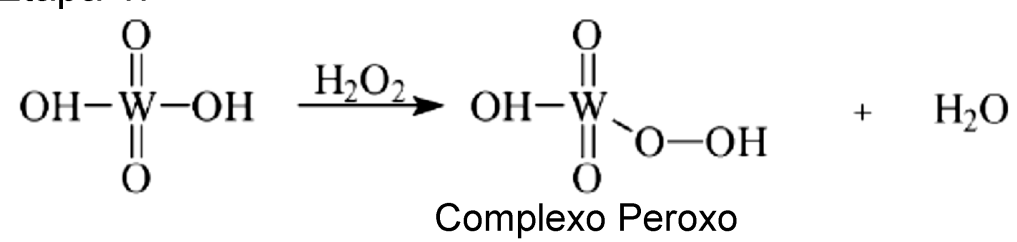

Etapa 2:

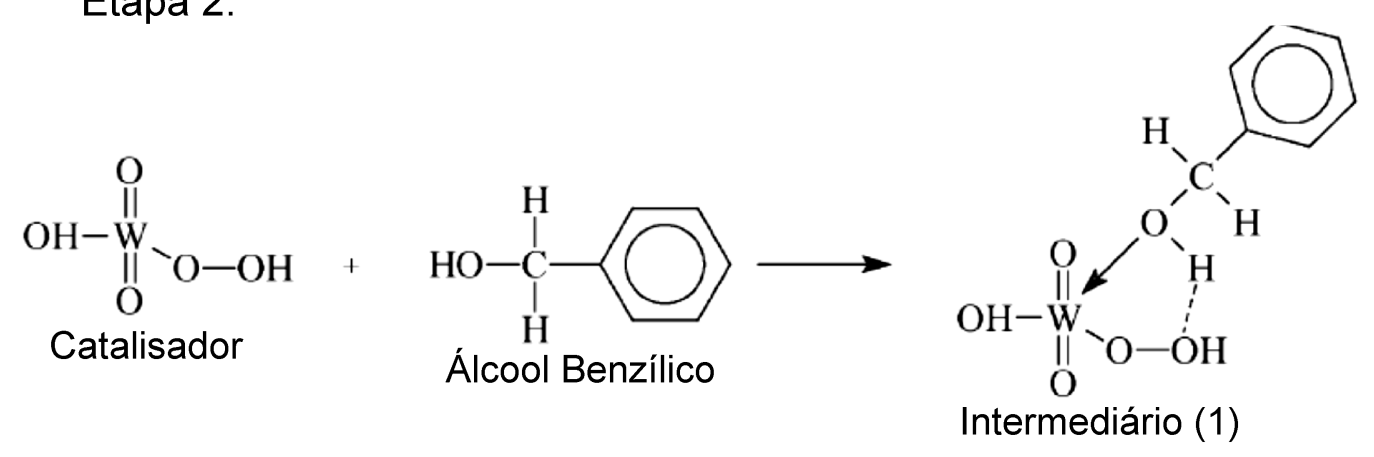

Etapa 3:

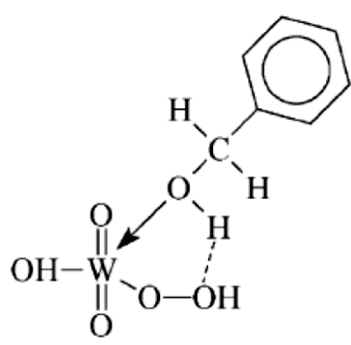

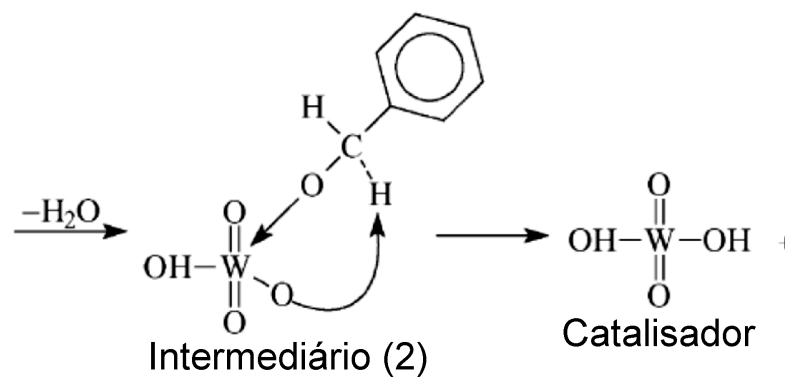<smiles>O=Cc1ccccc1</smiles>

Figura 140: Esquema representativo do mecanismo da oxidação do álcool benzílico utilizando um catalisador com grupos metálicos em alto estado de oxidação. ${ }^{193}$

Nesse caso, a espécie peroxo, contendo a ligação metal-oxigênio, é originada a partir da oxidação pela água oxigenada (Etapa 1). A presença de um metal em alto estado de oxidação na estrutura do catalisador labiliza o 
hidrogênio do grupo $-\mathrm{OH}$ do álcool benzílico, tornando esse hidrogênio mais ácido, capaz de interagir com o oxigênio do catalisador e formar o intermediário (1) (Etapa 2). Com a remoção de uma molécula de água, um novo intermediário (2) é gerado, que regenera o catalisador e libera o benzaldeído (Etapa 3).

Já no segundo ciclo catalítico, a seletividade foi aumentada de 65 para praticamente $100 \%$, sendo observadas apenas quantidades traço de subprodutos. Entretanto, a conversão no reciclo foi aproximadamente 8\% inferior àquele obtido na primeira reação, o que representa uma boa resistência do catalisador considerando que não foram feitos tratamentos térmicos em sua recuperação. Portanto, a diminuição da conversão pode ter ocorrido porque parte dos centros ativos foram desativados pela permanência de produtos residuais no catalisador, ou, ainda, devido à lixiviação das espécies metálicas. A presença de resíduos de benzaldeído no ZrHPW-nano deve ter sido responsável pelo acréscimo de seletividade, mas esse aumento também depende de como as espécies metálicas se arranjaram após a reação e a recuperação do material. Por isso, mais análises serão necessárias para se investigar as alterações estruturais, a formação ou a lixiviação de espécies ocorridas ao longo da reação e a recuperação desses catalisadores preparados com HPW em uma mistura bifásica.

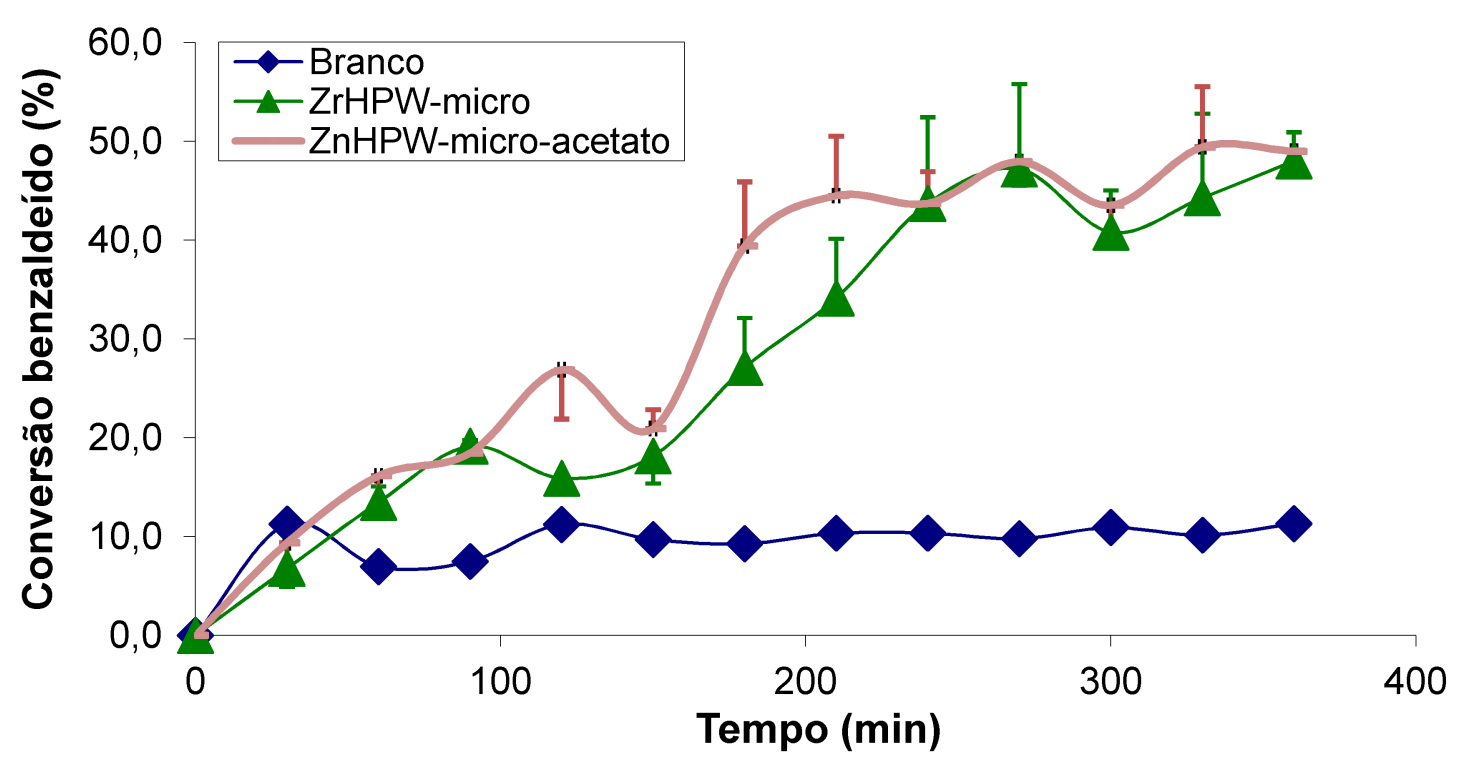

Figura 141: Gráfico de conversão (benzaldeído) versus o tempo de reação obtido nas $6 \mathrm{~h}$ da reação de oxidação do álcool benzílico sem catalisador e utilizando os materiais ZrHPW-micro e ZnHPW-micro-acetato. As barras representam o erro mensurado a partir da duplicata da reação. 
Os catalisadores ZrHPW-micro e ZnHPW-micro-acetato, por terem apresentado os valores de conversão mais altos na reação por $2 \mathrm{~h}$, foram testados durante um período mais longo, de $6 \mathrm{~h}$. Considerando os erros, representados pelas barras nos gráficos da Figura 141, ambos os sólidos apresentaram atividade catalítica semelhante, exibindo praticamente o mesmo valor de conversão após $6 \mathrm{~h}$ : 48\%, para o ZrHPW-micro, e 49\%, para o ZnHPW-micro-acetato. Quanto à seletividade, no entanto, o ZrHPW-micro foi $100 \%$ seletivo para a formação do benzaldeído, enquanto o catalisador com zinco formou $87,2 \%$ do produto desejado. Dessa maneira, um tempo reacional mais longo favoreceu a produção do benzaldeído, principalmente no catalisador com zircônia, e diminui a quantidade dos subprodutos evidenciados nas reações por $2 \mathrm{~h}$.

Assim, como discutido anteriormente, a oxidação do álcool benzílico gera uma mistura bifásica com a formação do benzaldeído. Pensando nisso, alguns trabalhos na literatura reportam o uso de um solvente nessa reação, como o tetracloreto de carbono $\left(\mathrm{CCl}_{4}\right)^{137}$ ou a acetonitrila $\left(\mathrm{CH}_{3} \mathrm{CN}\right)^{193}$, capaz de homogeneizar as fases orgânica e aquosa e propiciar maior acessibilidade do catalisador aos reagentes, alcançando, com isso, melhores conversões. Todavia, a literatura mostra que a oxidação de alcoóis no estado líquido é sensível ao tipo de solvente utilizado, ${ }^{194-197}$ já tendo sido constatada, por exemplo, uma alteração no tempo de decomposição do peróxido de hidrogênio com a variação do solvente. ${ }^{197}$

Nesse trabalho, o solvente acetonitrila foi testado na oxidação do álcool benzílico durante $2 \mathrm{~h}$, utilizando os catalisadores de zircônia nano e microestruturados. Os valores de conversão foram apresentados nos gráficos da Figura 142. Como pode ser visto, em nenhum dos dois casos a presença do solvente promoveu um aumento da conversão do álcool. Os valores de seletividade para produção do benzaldeído não variaram muito na presença da acetonitrila. No entanto, a recuperação do catalisador foi facilitada com a formação da mistura homogênea. As moléculas solventes, apesar de promoverem o melhor contato dos reagentes pela homogeneização das fases, influenciam significativamente nas taxas de transferência de massa e de difusão das moléculas nos catalisadores heterogêneos e podem ainda alterar a atividade catalítica do sólido por meio da solvatação dos centros metálicos. ${ }^{195}$ 
Ambili ressaltou a importância das propriedades hidrofilicas/hidrofóbicas do catalisador nessas reações com uso de solvente. De fato, o catalisador nanométrico, mais hidrofóbico, foi menos influenciado pela presença da acetonitrila que o ZrHPW-micro, mais hidrofílico.

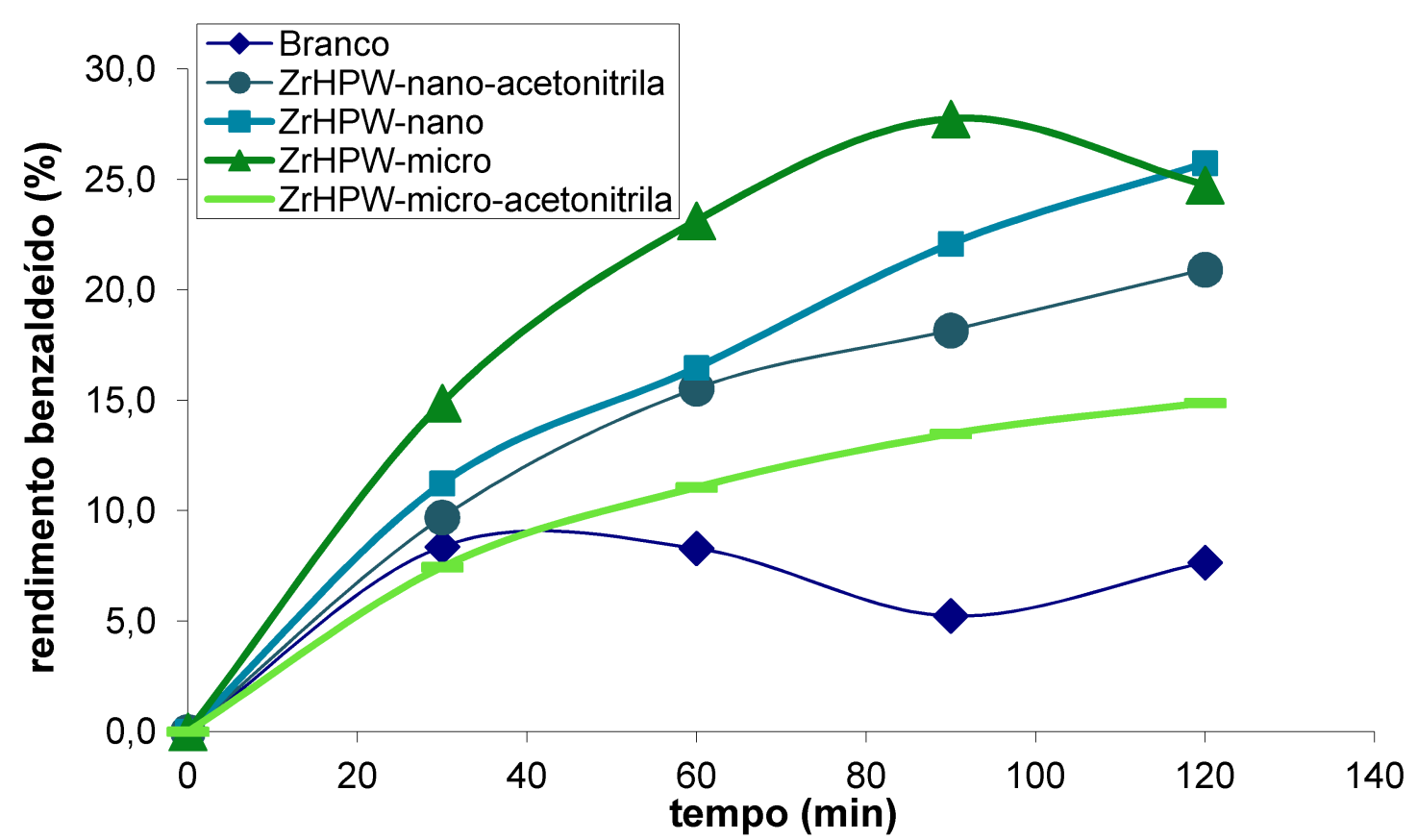

Figura 142: Gráfico de conversão (benzaldeído) versus o tempo de reação obtido nas $2 \mathrm{~h}$ da reação de oxidação do álcool benzílico sem catalisador e utilizando os materiais ZrHPW-micro e ZrHPW-nano na presença e ausência do solvente acetonitrila. 
Conclusões e Perspectivas 


\section{CONCLUSÕES}

A desidratação de alcoóis proposta nesse trabalho aumentou 0 desempenho de produção de bio-olefinas, como etileno, propileno e butileno, gerando-as com maior pureza, com menor custo financeiro e, no caso do etanol, a partir de uma fonte renovável que vem da biomassa. A metodologia proposta é pouco complexa, utiliza temperaturas reacionais mais baixas, pressão atmosférica e velocidade espacial bastante elevada. Além disso, o catalisador pôde ser reutilizado na reação e a tecnologia também foi aplicada com sucesso a soluções aquosas de etanol.

Apesar de haver uma pré-modificação do catalisador zeolítico, isso não desfavoreceu o procedimento, pois não são usados nem solventes, nem altas temperaturas. Essa é uma grande vantagem da metodologia, pois, enquanto outros trabalhos utilizam ácidos fortes, solventes, metais e/ou altas temperaturas para proceder com a modificação dos catalisadores, a desaluminização aqui utilizada foi feita no estado sólido, necessitando apenas do agente desaluminizante $\left(\mathrm{NH}_{4}\right)_{2} \mathrm{SiF}_{6}$ (hexa(fluoro)silicato(IV) de amônio).

O microrreator de pulso desenvolvido no Laboratório de Catálise é bastante útil por reduzir gastos de tempo, de recursos materiais e de recursos humanos em reações em que o reagente, passível de ser volatilizado na temperatura desejada de análise, gera, in situ, dentro do próprio CG, um ou mais produtos também voláteis nessa mesma temperatura de estudo, os quais são rapidamente analisados pela técnica de cromatografia gasosa. Assim, foi possível gerar resultados de conversão e seletividade de diferentes catalisadores para uma mesma reação. Uma massa de $20 \mathrm{mg}$ foi suficiente para gerar boas análises e fazer comparações de atividade catalítica entre diversos sólidos no microrreator de pulso. Além disso, reatores de pulso permitem um tempo de vida maior ao catalisador, de forma que a comparação da atividade catalítica de diferentes catalisadores se tornou mais efetiva.

$\mathrm{Na}$ busca por novos materiais, diferentes catalisadores foram sintetizados a partir do HPW, com grande destaque para o sólido ZrHPW-micro, que apresentou bons resultados de conversão e seletividade nas três reações-modelo testadas nesse trabalho. Dentre os materiais híbridos produzidos, foi aquele de maior força ácida, incrementada pela grande 
capacidade de hidrólise das espécies de zircônia. As nanofibras produzidas via molde biológico são promissoras como materiais de morfologia diferenciada, com alta resistência e hidrofobicidade, mas não se mostraram propícias para uso em catálise ácida. Seu emprego em catálise oxidativa, no entanto, gerou resultados semelhantes ou melhores com os sólidos micrométricos. Os sólidos com prata AgHPW-micro e AgHPW-nano, por exemplo, exibiram alta seletividade na produção de benzaldeído no estado líquido e em baixa temperatura.

\section{PERSPECTIVAS}

Mais estudos de reciclo devem ser feitos no intuito de entender a menor seletividade encontrada para o etileno quando se emprega a zeólita desaluminizada $\mathrm{Y}(80) 5 \mathrm{C}$ recuperada. É possível que menores temperaturas de reativação da zeólita possam ser utilizadas, comprometendo menos sua integridade estrutural, ou ainda que o sólido não seja utilizado até seu desgaste total, facilitando a recuperação de seus sítios ácidos fortes.

Testes catalíticos podem ser desenvolvidos buscando recuperar o excesso de etanol liberado após a reação, reconduzindo-o ao sistema reacional para servir como insumo de uma nova desidratação. Além disso, é possível incrementar ainda mais esse processo ambientalmente sustentável a partir do uso de um segundo catalisador para polimerização do bioetileno in situ. Para tanto, o gás etileno produzido deverá ser separado da mistura água:etanol e ser direcionado para que entre em contato com o segundo catalisador.

No que diz respeito aos materiais híbridos de HPW, uma vasta área de pesquisas nesse campo ainda é necessária, tendo em vista que, neste trabalho, apenas os passos iniciais foram dados na caracterização e na aplicação das nanofibras e dos sólidos microestruturados. Por causa da grande diversidade estrutural desses materiais, mais investigações precisam ser feitas no que diz respeito à área superficial, à estequiometria/composição e à acidez dos sólidos, buscando entender melhor a arquitetura molecular desses compostos, principalmente daqueles em que o metal é capaz de se hidrolisar. Novas aplicações, inclusive fora do escopo da catálise, podem ser pensadas para as nanofibras, a partir de uma caracterização mais profunda de sua morfologia e de como as ligações estão sendo estabelecidas entre os ânions de Keggin e o metal. 


\section{REFERÊNCIAS}

(1) FAPESP. Brasil líder mundial em conhecimento e tecnologia de cana e etanol; Fundação de amparo à pesquisa do estado de São Paulo: São Paulo, 2007.

(2) Kohlhepp, G. Estud. Avançados 2010, 24, 223.

(3) Braskem. Disponível em:

http://www.braskem.com.br/site.aspx/plasticoverde. Acessado em novembro de 2014.

(4) Nomura, K.; Takamatsu, Y. Br PI 0615895-1, 2012.

(5) Pinho, A. de R.; Cabral, J. A. R.; Leite, L. F. Br PI 0605675-0, 2008.

(6) Long, D.-L.; Tsunashima, R.; Cronin, L. Angew. Chemie 2010, 49, 1736.

(7) Luna, F. J.; Schuchardt, U. Quim. Nov. 2001, 24, 885.

(8) Zhang, X.; Li, J.; Chen, Y.; Wang, J.; Feng, L.; Wang, X.; Cao, F. Energy \& Fuels 2009, 23, 4640.

(9) Yamase, T. Chem. Rev. 1998, 98, 307.

(10) He, T.; Yao, J. Prog. Mater. Sci. 2006, 51, 810.

(11) Zhang, T.; Liu, S.; Kurth, D. G.; Faul, C. F. J. Adv. Funct. Mater. 2009, 19, 642.

(12) Clemente-Juan, J. M.; Coronado, E.; Galán-Mascarós, J. R.; GómezGarcía, C. J. Inorg. Chem. 1999, 38, 55.

(13) Hasenknopf, B.; Micoine, K.; Lacôte, E.; Thorimbert, S.; Malacria, M.; Thouvenot, R. Eur. J. Inorg. Chem. 2008, 5001.

(14) He, P.; Xu, B.; Liu, H.; He, S.; Saleem, F.; Wang, X. Sci. Rep. 2013, 3, 1833.

(15) Guisnet, M.; Ribeiro, F. R. Zeólitos: um nanomundo ao serviço da catálise; Fundação Calouste Gulbenkian: Lisboa, 2004.

(16) Borges, L. D.; Müller, J. M.; Macedo, J. L. de. Ciência Hoje 2013, 52, 34.

(17) Araújo, A. S. In Síntese e Caracterização de Peneiras Moleculares; Araújo, A. S.; Ramos, A. L. D.; Pontes, L. A. M., Eds.; Rede de Catalise Norte/Nordeste/Centro Oeste: Aracajú, 2006; pp. 87-115.

(18) Borges, L. D. Dissertação de Mestrado, Universidade de Brasília, Brasil, 2011. 
(19) IZA Online. Disponível em: http://www.iza-structure.org. Acessado em novembro de 2014.

(20) Baerlocher, C.; McCusker, L. B.; Olson, D. H. Atlas of Zeolite Framework Types; Elsevier: Amsterdan, 2007.

(21) Yue, M. B.; Xue, T.; Jiao, W. Q.; Wang, Y. M.; He, M.-Y. Microporous Mesoporous Mater. 2012, 159, 50.

(22) Boréave, A.; Auroux, A.; Guimon, C. Microporous Mater. 1997, 11, 275.

(23) McDaniel, C. V; Maher, P. K. Mol. Sieves 1968, 186.

(24) Beyer, H. K.; Borbély-Pálné, G.; Wu, J. Zeolites Relat. Microporous Mater. 1994, 84, 933.

(25) Kubelková, L.; Beran, S.; Malecka, A.; Mastikhin, V. M. Zeolites 1989, 9, 12.

(26) Martens, J. A.; Grobet, P. J.; Jacobs, P. A. Prep. Catal. 1991, 355.

(27) Qin, Z.; Shen, B.; Yu, Z.; Deng, F.; Zhao, L.; Zhou, S.; Yuan, D.; Gao, X.; Wang, B.; Zhao, H.; Liu, H. J. Catal. 2013, 298, 102.

(28) López-Fonseca, R.; Rivas, B. de; Gutiérrez-Ortiz, J. I.; Aranzabal, A.; González-Velasco, J. R. Appl. Catal. B 2003, 41, 31.

(29) Sohn, J. R.; Park, J. H. Appl. Catal. A Gen. 2001, 218, 229.

(30) Gortsema, F. P.; Brent, B. M. T. Modification of Molecular Sieves by Treatment with a Silicon Tetrafluoride Gas Mixture. US 4569833, 1984.

(31) Abramova, A. V; Slivinsky, E. V; Kubasov, A. A.; Kitaev, L. E.; Nefedov, B. K.; Shahnovskya, O. L. Stud. Surf. Sci. Catal. 2000, 128, 515.

(32) Müller, J. M. Dissertação de Mestrado, Universidade de Brasília, Brasil, 2013.

(33) Altwasser, S.; Jiao, J.; Steuernagel, S.; Weitkamp, J.; Hunger, M. Stud. Surf. Sci. Catal. 2004, 154, 3098.

(34) Long, D.-L.; Burkholder, E.; Cronin, L. Chem. Soc. Rev. 2007, 36, 105.

(35) Zurowski, A. Tese de Doutorado, Università di Camerino, Scholl of Advanced Studies, 2008.

(36) Müller, A.; Peters, F.; Pope, M. T.; Gatteschi, D. Chem. Rev. 1998, 98, 239.

(37) Macedo, J. L. de. Tese de Doutorado, Universidade de Brasilia, Brasil, 2007. 
(38) Castagno, K. R. L. Tese de Doutorado, Universidade Federal do Rio Grande do Sul, Brasil, 2007.

(39) Vieira, I. C. M. da S. S. Tese de Doutorado, Universidade de Aveiro, 2005.

(40) Pope, M. T. Heteropoly and Isopoly oxometalates; Springer Verlag Ed.: Berlin, 1983.

(41) Zhang, F.-Q.; Wu, H.-S.; Cao, D.-B.; Zhang, X.-M.; Li, Y.-W.; Jiao, H. J. Mol. Struct. 2005, 755, 119.

(42) Santos, J. S. dos. Dissertação de Mestrado, Universidade de Brasília, Brasil, 2008.

(43) Keggin, J. F. Proc. R. Soc. Lond. A 1934, 144.

(44) Haber, J.; Matachowski, L.; Mucha, D.; Stoch, J.; Sarv, P. Inorg. Chem. 2005, 44, 6695.

(45) Kozhevnikov, I. V. Chem. Rev. 1998, 98, 171.

(46) Heravi, M. M.; Sadjadi, S. J. Iran. Chem. Soc. 2009, 6, 1.

(47) Sheng, X.; Kong, J.; Zhou, Y.; Zhang, Y.; Zhang, Z.; Zhou, S. Microporous Mesoporous Mater. 2014, 187, 7.

(48) Micek-Ilnicka, A. J. Mol. Catal. A Chem. 2009, 308, 1.

(49) Zhao, Q.; Wang, L.; Zhao, S.; Wang, X.; Wang, S. Fuel 2011, 90, 2289.

(50) Pozniczek, J.; Lubanska, A.; Micek-IInicka, A.; Mucha, D.; Lalik, E.; Bielanski, A. Appl. Catal. A Gen. 2006, 298, 217.

(51) Marme, F.; Coudurier, G.; Védrine, J. C. Microporous Mesoporous Mater. 1998, 22, 151.

(52) Gulbinska, M.; Wojtowski, M.; Laniecki, M. Stud. Surf. Sci. Catal. 2002, 142, 1221.

(53) Micek-Ilnicka, A.; Bielańska, E.; Lityńska-Dobrzyńska, L.; Bielański, A. Appl. Catal. A Gen. 2012, 421-422, 91.

(54) Neudachina, L. K.; Barkovskii, V. F. Russ. Chem. 1981, 50, 1521.

(55) Saito, Y.; Cook, P. N.; Niiyama, H.; Echigoya, E. J. Catal. 1985, 95, 49.

(56) Baba, T.; Watanabe, H.; Ono, Y. J. Phys. Chem. 1983, 87, 2406.

(57) Matachowski, L.; Drelinkiewicz, a.; Lalik, E.; Mucha, D.; Gil, B.; BrożekMucha, Z.; Olejniczak, Z. Microporous Mesoporous Mater. 2011, 144, 46. 
(58) Gurgul, J.; Zimowska, M.; Mucha, D.; Socha, R. P.; Matachowski, L. J. Mol. Catal. A Chem. 2011, 351, 1.

(59) Varisli, D.; Dogu, T.; Dogu, G. Chem. Eng. Sci. 2007, 62, 5349.

(60) Matachowski, L.; Zimowska, M.; Mucha, D.; Machej, T. Appl. Catal. B Environmental 2012, 123-124, 448.

(61) Pozniczek, J.; Lubanska, A.; Mucha, D.; Bielanski, A. J. Mol. Catal. A Chem. 2006, 257, 99.

(62) Moreira, F. de S. Projeto Final de Curso de Engenharia Química, Universidade Federal do Rio de Janeiro - Escola de Quimica/Agência Nacional do Petróleo, Brasil, 2006.

(63) Pereira, R. A. Dissertação de Mestrado, Universidade Federal do Rio de Janeiro - Escola de Quimica/Agência Nacional do Petróleo, Brasil, 2010.

(64) Júnior, G. Processamento Primário de Petróleo e Noções de Processo de Refino. Disponível em:

http://www.tecnicodepetroleo.ufpr.br/apostilas/engenheiro_do_petroleo/pr ocessamento_primario.pdf. Acessado em janeiro de 2014.

(65) Andrade, J. E. P. de; Pan, S. S. K.; Zaporski, J.; Melo, K. C. de A. A Indústria Petroquimica; Gerência Setorial de Quimica do BNDES: Rio de Janeiro, 1995.

(66) Gomes, G.; Dvorsak, P.; Heil, T. Indústria petroquímica brasileira: situação atual e perspectivas; Departamento de Industrias Quimicas do BNDES: Rio de Janeiro, 2005.

(67) Zhang, M.; Yu, Y. Ind. Eng. Chem. Res. 2013, 52, 9505.

(68) Clayden, J.; Warren, S.; Greeves, N.; Wothers, P. Organic Chemistry; Oxford University Press: United States, 2001.

(69) Martins, L.; Cardoso, D.; Hammer, P.; Garetto, T.; Pulcinelli, S. H.; Santilli, C. V. Appl. Catal. A Gen. 2011, 398, 59.

(70) Butler, J. D. J. Chem. Soc. B 1968, 905.

(71) Arai, H.; Take, J.-I.; Saito, Y.; Yoneda, Y. J. Catal. 1967, 9, 146.

(72) Solomon, H. J.; Bliss, H.; Butt, J. B. Ind. Eng. Chem. Fundam. 1967, 6, 325.

(73) Banerjee, A. K.; Sarma, A. R. K.; Mukherjee, P. K.; Nath, D.; Singh, N.; Mahapatra, H.; Majumdar, D. S. Recent Adv. Basic Appl. Asp. Ind. Catal. 1998, 113, 241.

(74) Padmanabhan, V. R.; Eastburn, F. J. J. Catal. 1972, 24, 88. 
(75) Golay, S.; Doepper, R.; Renken, A. Appl. Catal. A Gen. 1998, 172, 97.

(76) Bi, J.; Guo, X.; Liu, M.; Wang, X. Catal. Today 2010, 149, 143.

(77) Tsunoda, T.; Sekiguchi, M.; Asahi. Br PI 0513338-6, 2008.

(78) Nomura, K.; Takamatsu, Y. Br PI 0615893-5, 2012.

(79) Yurchak, S.; Lee, W. European pat. 96996, 1988.

(80) Le Van Mao, R. US pat. 4873392, 1989.

(81) Ramesh, K.; Borgna, A.; Zheng, J. WO pat. 162717, 2011.

(82) Liu, Y.; Malek, A.; Stears, B. WO pat. 005864, 2012.

(83) Kakodkar, S. B.; Naik, S. P.; Narasimhan, K.; Fernandes, J. B. Recent Adv. Basic Appl. Asp. Ind. Catal. 1998, 113, 729.

(84) Arenamnart, S.; Trakarnpruk, W. Int. J. Appl. Sci. Eng. 2006, 4, 21.

(85) Instituto Brasileiro de Geografia e Estatística, Indicadores IBGE: Estatistica da Produção Agrícola. Disponível em: http://www.ibge.gov.br/home/estatistica/indicadores/agropecuaria/lspa/est ProdAgr_201203.pdf. Acessado em janeiro de 2014.

(86) Guillon, E.; Oliver-Bourbigou, H.; Bournay, L. B.; Magna, L.; Touchais, N.; Cadran, N. Br PI 1101818-6, 2012.

(87) Portal Brasil. Disponível em: http://www.brasil.gov.br/infraestrutura/2011/12/brasil-revoluciona-o-uso-ea-producao-de-biocombustivel. Acessado em janeiro de 2014.

(88) União da Indústria de Cana-de-Açúcar (UNICA), Relatório Final da Safra 2012/2013 - Região Centro-Sul. Disponível em:

http://www.unicadata.com.br/listagem.php?idMn=83. Acessado em janeiro de 2014.

(89) Instituto Brasileiro de Geografia e Estatística, Indicadores IBGE: Estatistica da Produção Agrícola. Disponível em: ftp://ftp.ibge.gov.br/Producao_Agricola/Levantamento_Sistematico_da_Pr oducao_Agricola_\%5Bmensal\%5D/Publicacao_Indicadores/estProdAgr_ 201311.pdf. Acessado em janeiro de 2014.

(90) União da Indústria de Cana-de-Açúcar (UNICA), Relatório de Acompanhamento da Safra 2013/2014 - Região Centro-Sul. Disponível em: http://www.unicadata.com.br/listagem.php?idMn=85. Acessado em janeiro de 2014.

(91) Fan, D.; Dai, D.-J.; Wu, H.-S. Materials (Basel). 2013, 6, 101. 
(92) Kagyrmanova, A. P.; Chumachenko, V. A.; Korotkikh, V. N.; Kashkin, V. N.; Noskov, A. S. Chem. Eng. J. 2011, 176-177, 188.

(93) Chen, G.; Li, S.; Jiao, F.; Yuan, Q. Catal. Today 2007, 125, 111.

(94) Leonardi, P. L. Projeto Final de Curso, Escola de Quimica/Agência Nacional de Petróleo, Gás Natural e Biocombustíveis - Processamento, Gestao e Meio Ambiente na Indústria do Petróleo e Gás Natural, Brasil, 2009.

(95) Díaz, I.; Kokkoli, E.; Terasaki, O.; Tsapatsis, M. Chem. Mater. 2004, 16, 5226.

(96) Heng, L. CN101138735, 2008.

(97) Qinghua, C.; Aizhu, H.; Baoquan, H.; Guiyang, Y.; Liren, X.; Kewei, L. No Title. CN101139241, 2008.

(98) Guo, X.; Bi, J.; Wang, X. CN101244971, 2008.

(99) Cheng, L. Y. CN1974007, 2007.

(100) Xie, Z.; Qi, G.; Zhang, H.; Zhong, S. Br PI 0806359, 2011.

(101) Minoux, D.; Nesterenko, N.; W., V.; Van, D. S. WO pat. 2009098268, 2009.

(102) Vermeiren, W. WO pat. 2010066830, 2010.

(103) Le, V. M. R.; Nguyen, T. M. European pat. 0340061, 1992.

(104) Chen, Y.; Wu, Y.; Tao, L.; Dai, B.; Yang, M.; Chen, Z.; Zhu, X. J. Ind. Eng. Chem. 2010, 16, 717.

(105) ANP: Agência Nacional do Petróleo, Gás Natural e Biocombustíveis Disponível em: http://www.anp.gov.br/?id=494. Acessado em novembro de 2014.

(106) Andrigo, P.; Bagatin, R.; Pagani, G. Catal. Today 1999, 52, 197.

(107) Henning, G. P.; Perez, G. A. Chem. Eng. Sci. 1986, 41, 83.

(108) Aris, R. Elementary Chemical Reactor Analysis; General Publishing Company: Canadá, 1999.

(109) Intec: Inovação Tecnologia. Disponível em: http://www.inovacaotecnologia.com.br/e04_trocador_calor.html.Acessado em janeiro de 2014.

(110) Portal de Laboratórios Virtuais de Processos Químicos. Disponível em: http://labvirtual.eq.uc.pt/siteJoomla/index.php?option=com_content\&task= view\&id=173\&ltemid=457. Acessado em janeiro de 2014. 
(111) TroCalor: catálogo técnico. Disponível em: http://www.trocalor.com.br/pdf/trocadores_de_calor.pdf. Acessado em janeiro de 2014.

(112) Assis, R. C. de; Silva, J. B. de C. M. da; Barrocas, H. V. V. US pat. 4232179, 1980.

(113) Wei, Z. Chinese J. Chem. Eng. 2009, 17, 688.

(114) Tannous, K. Tecnologia da Fluidização Disponível em: http://www.fluidizacao.com.br/pt/home.php?pgi=leito2.php. Acessado em janeiro de 2013.

(115) Tsao, U.; Zasloff, H. B. US pat. 4134926, 1979.

(116) Liu, Z.; Dadyburjor, D. B. J. Catal. 1992, 134, 583.

(117) Dumitriu, E.; Hulea, V.; Kaliaguine, S.; Huang, M. M. Appl. Catal. A Gen. 1996, 135, 57.

(118) Cobzaru, C.; Oprea, S.; Dumitriu, E.; Hulea, V. Appl. Catal. A Gen. 2008, $351,253$.

(119) Han, W.; Jia, Y.; Xiong, G.; Yang, W. Chinese J. Catal. 2011, 32, 418.

(120) Choudhary, V. R. J. Chromatogr. 1978, 152, 208.

(121) Reichle, W. T. J. Catal. 1980, 63, 295.

(122) Borges, L. D.; Macedo, J. L. Phys. Chem. Chem. Phys. Submetido para publicação.

(123) Caruso, R. A.; Antonietti, M. Chem. Mater. 2001, 13, 3272.

(124) Zhao, J.; Guan, H.; Shi, W.; Cheng, M.; Wang, X.; Li, S. Catal. Commun. 2012, 20, 103.

(125) Chai, F.; Wang, L.; Xu, L.; Wang, X.; Huang, J. Dye. Pigment. 2008, 76, 113.

(126) Inovação Tecnológica. Disponível em:

http://www.inovacaotecnologica.com.br/noticias/noticia.php?artigo=nanoc elulose-nanotecnologia-madeira\&id=010165120828. Acessado em novembro de 2014.

(127) Beer, M. Peneiramento de Catalisadores. Disponível em: http://www.h2so4.com.br/manuseio-de-catalisadores-e-recheios/.

Acessado em janeiro de 2014.

(128) Santos, H. M. M.; Veiga, F. J. B.; Pina, E. M. S. T. de; Sousa, J. J. M. S. de. Braz. J. Pharm. Sci. 2004, 40, 455. 
(129) Santos, H. M. M.; Veiga, F. J. B.; Pina, E. M. S. T. de; Sousa, J. J. M. S. de. Braz. J. Pharm. Sci. 2006, 42, 309.

(130) SPLabor: equipamentos para laboratórios. Disponível em: http://www.splabor.com.br/acessorio/peneiras-granulom-tricas/peneirasgranulometricas-em-aco-inox-diametro-8-203-2mm-x-altura-2-50mm.html. Acessado em janeiro de 2014.

(131) Padilha, A. F. Microscopia Eletrônica de Transmissão Disponível em: http://www.angelfire.com/crazy3/qfl2308/1_multipart_xF8FF_3_MET_PMI -2201.pdf. Acessado em janeiro de 2014.

(132) Maliska, A. M. Microscopia Eletrônica de Varredura. Disponível em: http://www.materiais.ufsc.br/lcm/web-MEV/MEV_Apostila.pdf. Acessado em janeiro de 2014.

(133) Smith, W. F.; Hashemi, J. Fundamentos de Engenharia e Ciência dos Materiais; 5a Edição.; McGraw-Hill Companies: Porto Alegre, 2010.

(134) Su, H.; Yang, C. Chinese J. Catal. 2014, 35, 1224.

(135) Ishikawa, E.; Yamase, T. J. Mol. Catal. A Chem. 1999, 142, 61.

(136) Norouzi, M.; Ashrafi, F.; Taharimehr, M.; Bagheri, F. Int. J. ChemTech Res. 2010, 2, 1666.

(137) Yadav, G. .; Mistry, C. . J. Mol. Catal. A Chem. 2001, 172, 135.

(138) Sankar, M.; Nowicka, E.; Carter, E.; Murphy, D. M.; Knight, D. W.; Bethell, D.; Hutchings, G. J. Nat. Commun. 2014, 5, 3332.

(139) Braga, A. A. C.; Morgon, N. H. Quim. Nov. 2007, 30, 178.

(140) Malicki, N.; Mali, G.; Quoineaud, A.-A.; Bourges, P.; Simon, L. J.; Thibault-Starzyk, F.; Fernandez, C. Microporous Mesoporous Mater. 2010, 129, 100.

(141) Triantafillidis, C. S.; Vlessidis, A. G.; Evmiridis, N. P. Ind. Eng. Chem. Res. 2000, 39, 307.

(142) Petushkov, A.; Merilis, G.; Larsen, S. C. Microporous Mesoporous Mater. 2011, 143, 97.

(143) Ribeiro, F. R.; Alvarez, F.; Henriques, C.; Lemos, F.; Lopes, J. M.; Ribeiro, M. F. J. Mol. Catal. A Chem. 1995, 96, 245.

(144) Giannetto, G. Zeolitas: características, propiedades y aplicaciones industriales; Editorial Innovación Tecnológica: Caracas, 1990.

(145) Ignatchenko, A.; Nealon, D. G.; Dushane, R.; Humphries, K. 2006, 256, 57. 
(146) Müller, J. M.; Mesquita, G. C.; Franco, S. M.; Borges, L. D.; de Macedo, J. L.; Dias, J. a.; Dias, S. C. L. Solid-state dealumination of zeolites for use as catalysts in alcohol dehydration; Elsevier Inc., 2014 (DOI: 10.1016/j.micromeso.2014.11.002).

(147) Knözinger, H.; Bühl, H.; Kochloefl, K. J. Catal. 1972, 24, 57.

(148) Knözinger, H.; Köhne, R. J. Catal. 1966, 5, 264.

(149) Shi, B.; Davis, B. H. J. Catal. 1995, 157, 359.

(150) Takezawa, N.; Hanamaki, C.; Kobayashi, H. J. Catal. 1975, 38, 101.

(151) Chiang, H.; Bhan, A. J. Catal. 2010, 271, 251.

(152) Okuhara, T.; Arai, T.; Ichiki, T.; Lee, K. Y.; Misono, M. J. Mol. Catal. 1989, 55, 293.

(153) Zhang, M.; Yu, Y. Ind. Eng. Chem. Res. 2013, 52, 9505.

(154) DeCanio, E. C.; Nero, V. P.; Bruno, J. W. J. Catal. 1992, 135, 444.

(155) Kondo, J. N.; Ito, K.; Yoda, E.; Wakabayashi, F.; Domen, K. J. Phys. Chem. B 2005, 109, 10969.

(156) Mioc, U.; Dimitrijevic, R.; Davidovic, M.; Nedic, Z.; Mitrovic, M.; Colomban, P. J. Mater. Sci. 1994, 29, 3705.

(157) Kremenovic, A.; Spasojevic-de-Bire, A.; Dimitrijevic, R.; Sciau, P.; Mioc, U. B.; Colomban, P. Solid State Ionics 2000, 132, 39.

(158) Guinebretière, R. X-ray Diffraction by Polycrystalline Materials; ISTE: Londres, 2007.

(159) Santos, J. S.; Dias, J. A.; Dias, S. C. L.; Macedo, J. L.; Garcia, F. A. C.; Almeida, L. S.; Carvalho, E. N. C. B. C. Appl. Catal. A Gen. 2012, 443444, 33.

(160) Yamanaka, S.; Brindley, G. W. Clays Clay Miner. 1979, 27, 119.

(161) Walther, C.; Rothe, J.; Fuss, M.; Büchner, S.; Koltsov, S.; Bergmann, T. Anal. Bioanal. Chem. 2007, 388, 409.

(162) Mak, T. C. W. Can. J. Chem. 1968, 46, 3491.

(163) Qin, D.; Chen, H. J. Mater. Sci. 2006, 41, 7059.

(164) Ishihara, K. Tetrahedron 2009, 65, 1085.

(165) Dias, J. A.; Osegovic, J. P.; Drago, R. S. J. Catal. 1990, 183, 83.

(166) Zhang, Y.; Li, D.; Chen, Y.; Wang, X.; Wang, S. Appl. Catal. BEnvironmental 2009, 86, 182. 
(167) Jiguo, H.; Yu, W.; Tingting, X.; Sen, L.; Baifeng, S. Int. Conf. Biol. Environ. Chem. 2011, 24, 62.

(168) Shen, Y.; Peng, J.; Chen, C.; Zhang, H.; Meng, C.; Li, X. Inorg. Chem. Commun. 2011, 14, 221.

(169) Suppl. Mater. J. Mater. Chem. 2010, 6.

(170) Andronescu, E.; Jinga, S.; Onose, C. IEEE 2001, 6.

(171) Małecka, B.; Gajerski, R.; Małecki, A.; Wierzbicka, M.; Olszewski, P. Thermochim. Acta 2003, 404, 125.

(172) Ghule, A. V.; Ghule, K.; Chen, C.-Y.; Chen, W.-Y.; Tzing, S.-H.; Chang, H.; Ling, Y.-C. J. Mass Spectrom. 2004, 39, 1202.

(173) Arii, T.; Kishi, A. Thermochim. Acta 2003, 400, 175.

(174) Kuzmin, A.; Purans, J.; Cazzanelli, E.; Vinegoni, C.; Mariotto, G. J. Appl. Phys. 1998, 84, 5515.

(175) Sun, Q.; Xiao, F.; Ren, S.; Dong, Z.; Wang, J.; Su, X. Ceram. Int. 2014, $40,11447$.

(176) Weil, M.; Schubert, W. The Beautiful Colours of Tungsten Oxides. Disponível em: www.itia.info. Acessado em novembro de 2014.

(177) Lassner, E.; Schubert, W.-D. Tungsten: Properties, Chemistry, Technology of the Elements, Alloys, and Chemical Compounds; Springer Science \& Business Media: Nova Yorque, 1999, p. 91.

(178) Wang, Z.; Navarrete, J. World J. Nano Sci. Eng. 2012, 2, 134.

(179) Cohen, E.; Dodiuk, H.; Ophir, A.; Kenig, S.; Barry, C.; Mead, J. Compos. Sci. Technol. 2013, 79, 133.

(180) Rahman, M. M.; Bahadar Khan, S.; Jamal, a.; Faisal, M.; Asiri, A. M. Chem. Eng. J. 2012, 192, 122.

(181) Biedermann, G.; Hietanen, S. Acta Chem. Scand. 1960, 14, 711.

(182) Mucha, D.; Matachowski, L.; Machej, T.; Gurgul, J.; Socha, R. P. Solid State Sci. 2011, 13, 1276.

(183) Wang, G.; Ma, X.; Huang, B.; Cheng, H.; Wang, Z.; Zhan, J.; Qin, X.; Zhang, X.; Dai, Y. J. Mater. Chem. 2012, 22, 21189.

(184) Ren, Y.; Liu, B.; Zhang, Z.; Lin, J. J. Ind. Eng. Chem. 2014, 40.

(185) Zhu, S.; Gao, X.; Dong, F.; Zhu, Y.; Zheng, H.; Li, Y. J. Catal. 2013, 306, 155. 
(186) Costa, T. S.; Ornelas, D. L.; Guimarães, P. I. C.; Merçon, F. Quim. Nov. na Esc. 2004, 19, 36.

(187) McMurry, J. Organic Chemistry; $5^{a}$ Edição.; Brooks/Cole: Pacific Gove, 2000; cap. 21.3 e 21.6.

(188) D’Souza, J.; Nagaraju, N. Indian J. Chem. Technol. 2006, 13, 605.

(189) Dutia, P. Chem. Wkly. 2008, 195.

(190) Neumann, R.; Khenkin, A. M. J. Org. Chem. 1994, 59, 7577.

(191) Kanjina, W.; Trakarnpruk, W. Silpakorn U Sci. Tech J. 2009, $16,7$.

(192) Zieba, a.; Matachowski, L.; Gurgul, J.; Bielańska, E.; Drelinkiewicz, a. J. Mol. Catal. A Chem. 2010, 316, 30.

(193) Chaudhari, M. P.; Sawant, S. B. Chem. Eng. J. 2005, 106, 111.

(194) Neumann, R.; Levin-Elad, M. Appl. Catal. A Gen. 1995, 122, 85.

(195) Ambili, V. K. Tese de Doutorado, Cochin University of Science and Technology, 2011.

(196) Tuel, A.; Moussa-Khouzami, S.; Taarit, Y. B.; Naccache, C. J. Mol. Catal. $1991,68,45$.

(197) Yu, R.; Xiao, F.-S.; Wang, D.; Sun, J.; Liu, Y.; Pang, G.; Feng, S.; Qiu, S.; Xu, R.; Fang, C. Catal. Today 1999, 51, 39. 
Apêndices 


\section{APÊNDICES}

A. Conversões e seletividades do catalisador zeolítico $Y(80) 5 \mathrm{C}$ nas reações de desidratação de etanol PA e em solução feitas no microrreator de pulso.

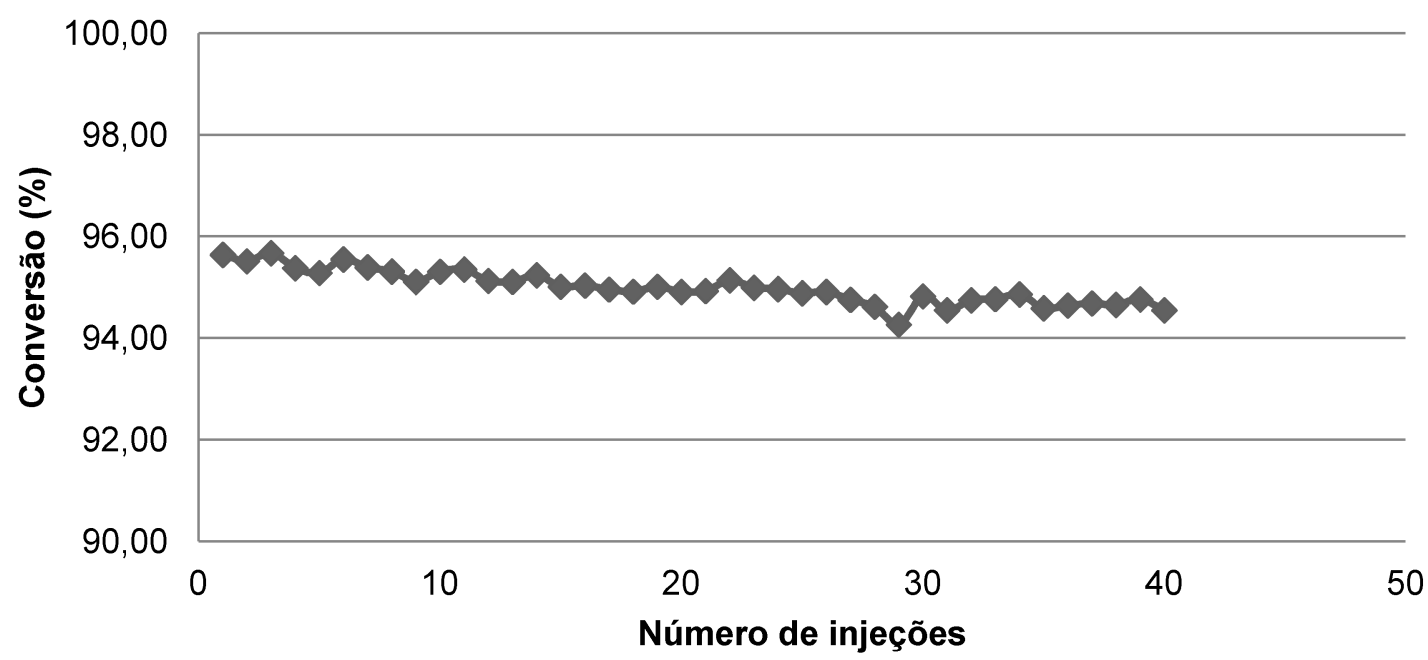

Figura A1: Gráfico de conversão (\%) versus número de injeções para a reação de desidratação do etanol a $25 \%$, feita em um microrreator de pulso, utilizando como catalisador $20 \mathrm{mg}$ da zeólita $\mathrm{Y}(80) 5 \mathrm{C}$.

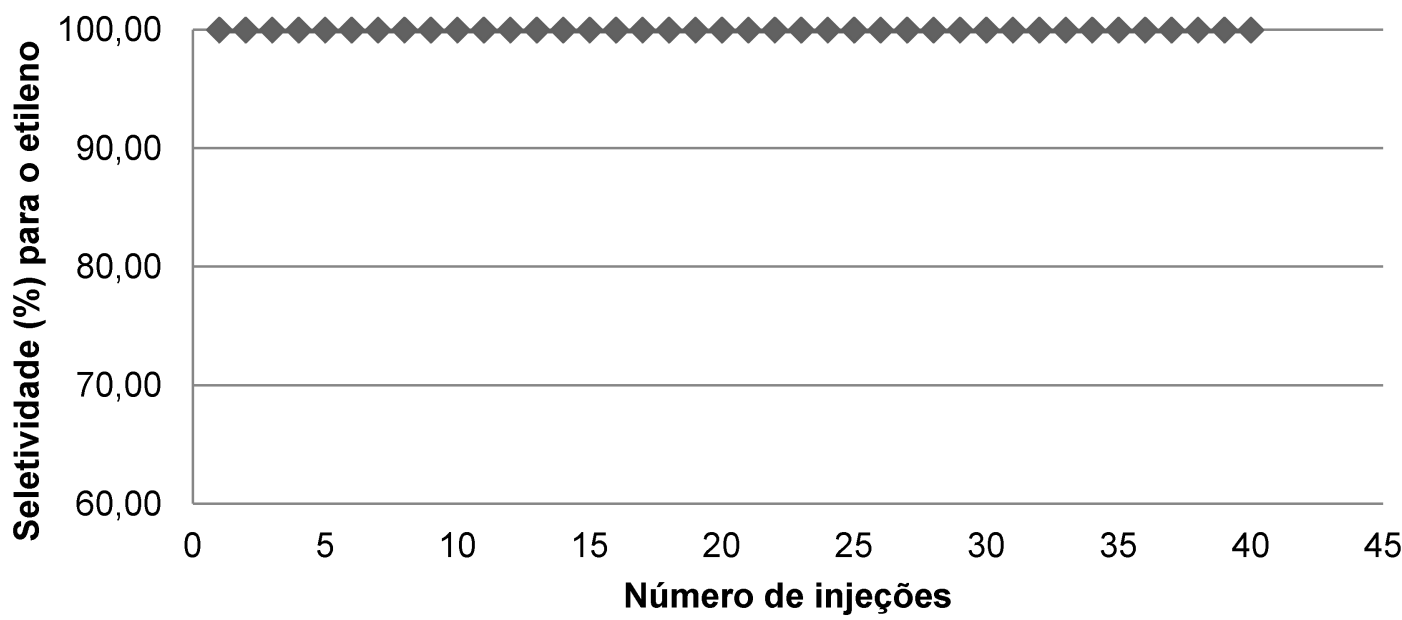

Figura A2: Gráfico de seletividade para etileno (\%) versus número de injeções para a reação de desidratação do etanol a $25 \%$, feita em um microrreator de pulso, utilizando como catalisador $20 \mathrm{mg}$ da zeólita $\mathrm{Y}(80) 5 \mathrm{C}$. 


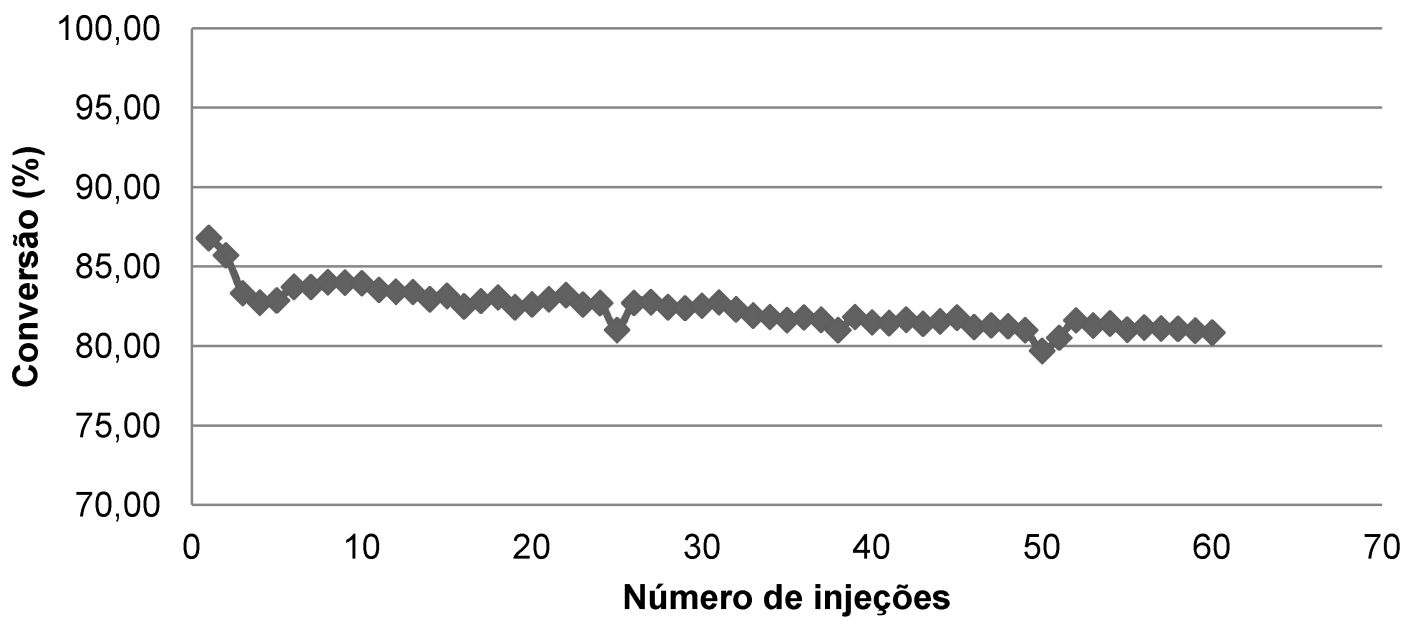

Figura A3: Gráfico de conversão (\%) versus número de injeções para a reação de desidratação do etanol a $50 \%$, feita em um microrreator de pulso, utilizando como catalisador $20 \mathrm{mg}$ da zeólita $\mathrm{Y}(80) 5 \mathrm{C}$.

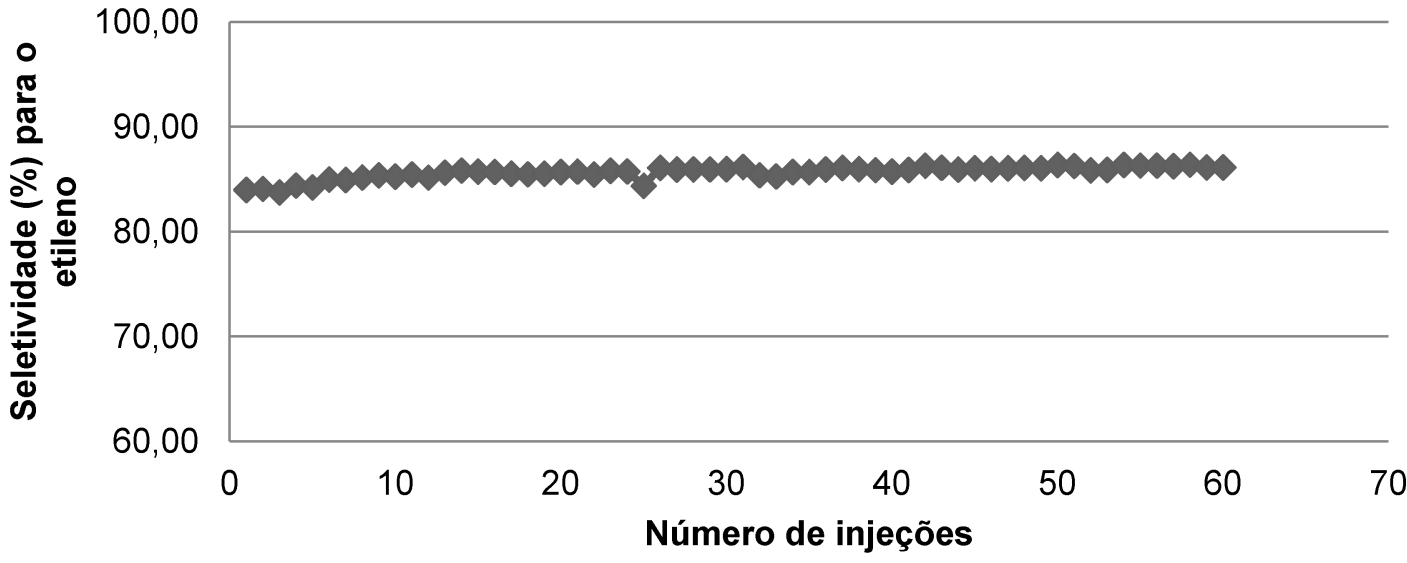

Figura A4: Gráfico de seletividade para etileno (\%) versus número de injeções para a reação de desidratação do etanol a $50 \%$, feita em um microrreator de pulso, utilizando como catalisador $20 \mathrm{mg}$ da zeólita $\mathrm{Y}(80) 5 \mathrm{C}$.

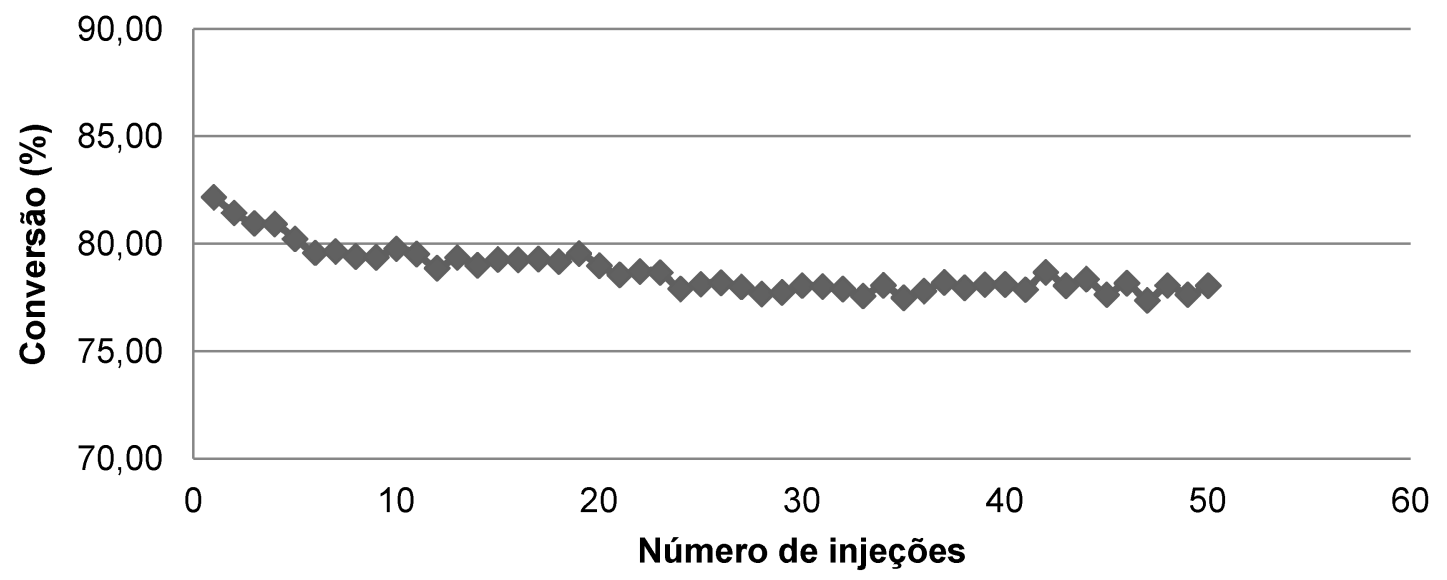

Figura A5: Gráfico de conversão (\%) versus número de injeções para a reação de desidratação do etanol a $75 \%$, feita em um microrreator de pulso, utilizando como catalisador $20 \mathrm{mg}$ da zeólita $\mathrm{Y}(80) 5 \mathrm{C}$. 


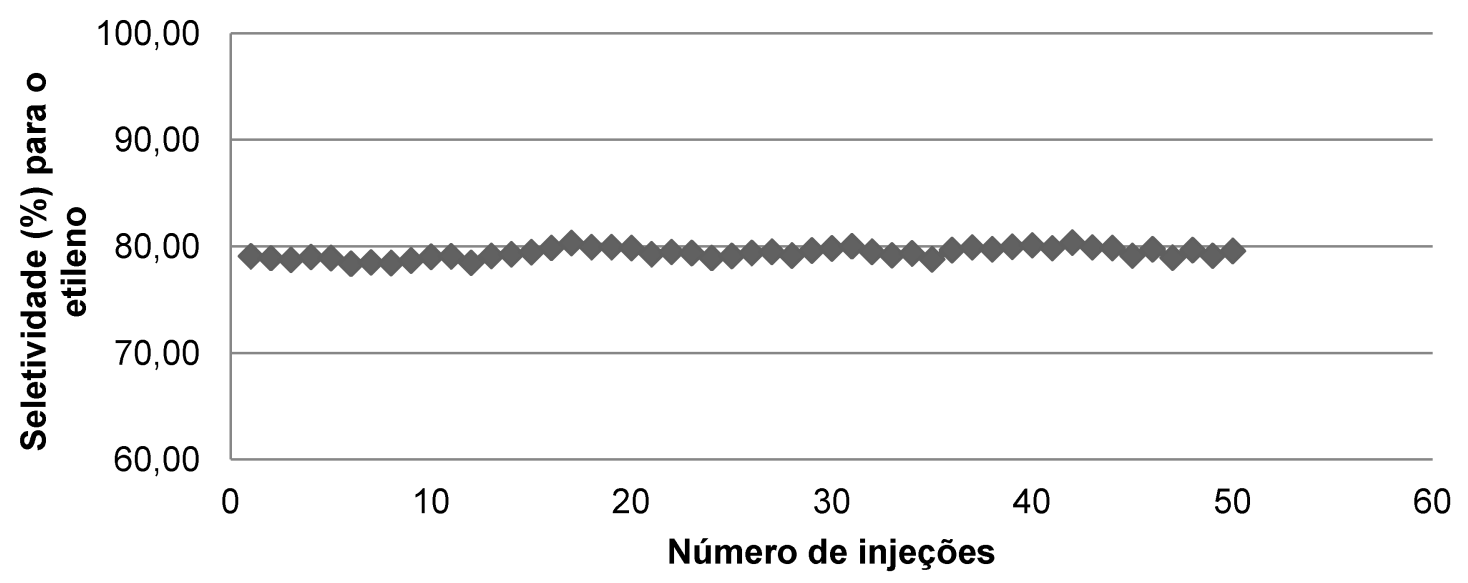

Figura A6: Gráfico de seletividade para etileno (\%) versus número de injeções para a reação de desidratação do etanol a $75 \%$, feita em um microrreator de pulso, utilizando como catalisador $20 \mathrm{mg}$ da zeólita $\mathrm{Y}(80) 5 \mathrm{C}$.

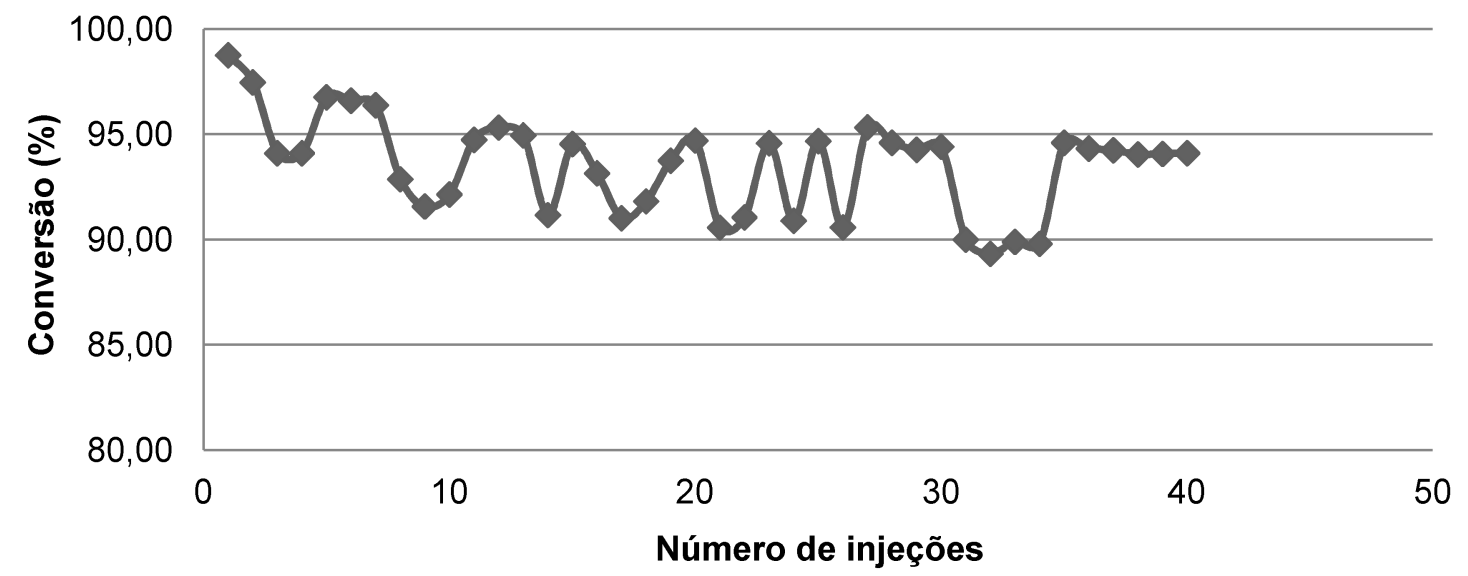

Figura A7: Gráfico de conversão (\%) versus número de injeções para a reação de desidratação do etanol PA $(99,8 \%)$, feita em um microrreator de pulso, utilizando como catalisador $20 \mathrm{mg}$ da zeólita $\mathrm{Y}(80) 5 \mathrm{C}$.

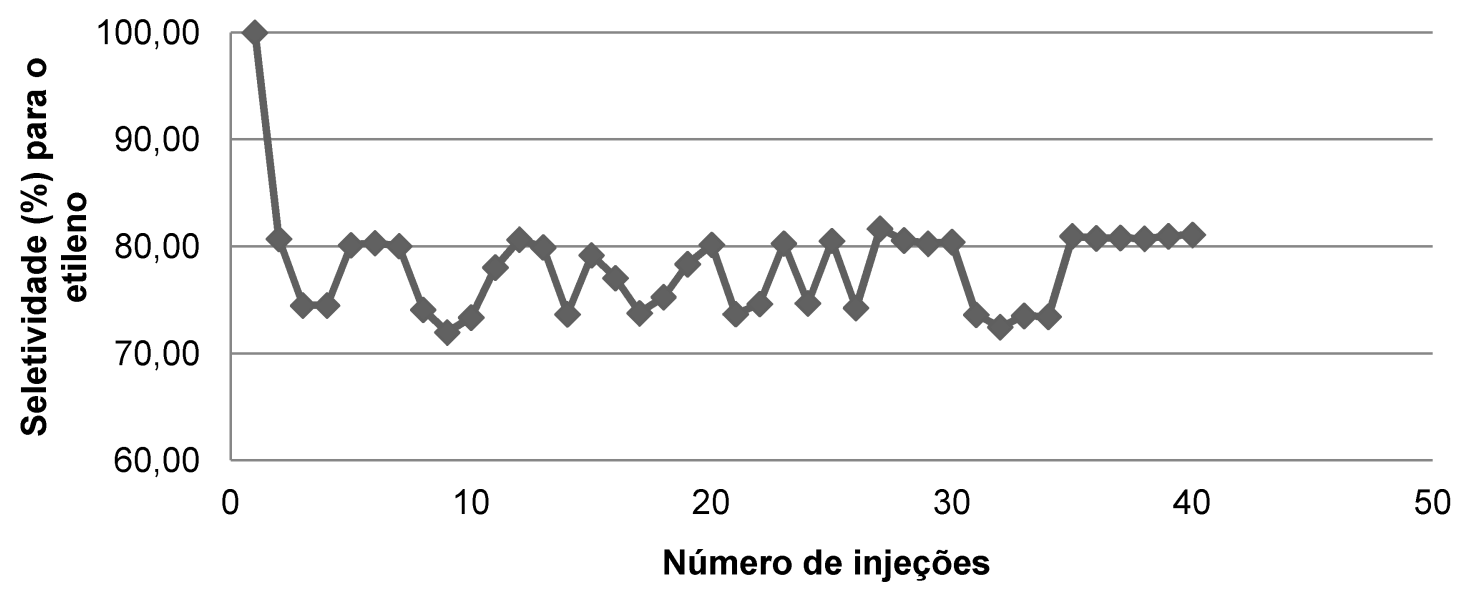

Figura A8: Gráfico de seletividade para etileno (\%) versus número de injeções para a reação de desidratação do etanol PA $(99,8 \%)$, feita em um microrreator de pulso, utilizando como catalisador $20 \mathrm{mg}$ da zeólita $\mathrm{Y}(80) 5 \mathrm{C}$. 
B. Conversões e seletividades do catalisador zeolítico HY e $\mathrm{Y}(80) 5 \mathrm{C}$ nas reações de desidratação de 1-propanol, isopropanol e terc-butanol PA feitas no microrreator de pulso.

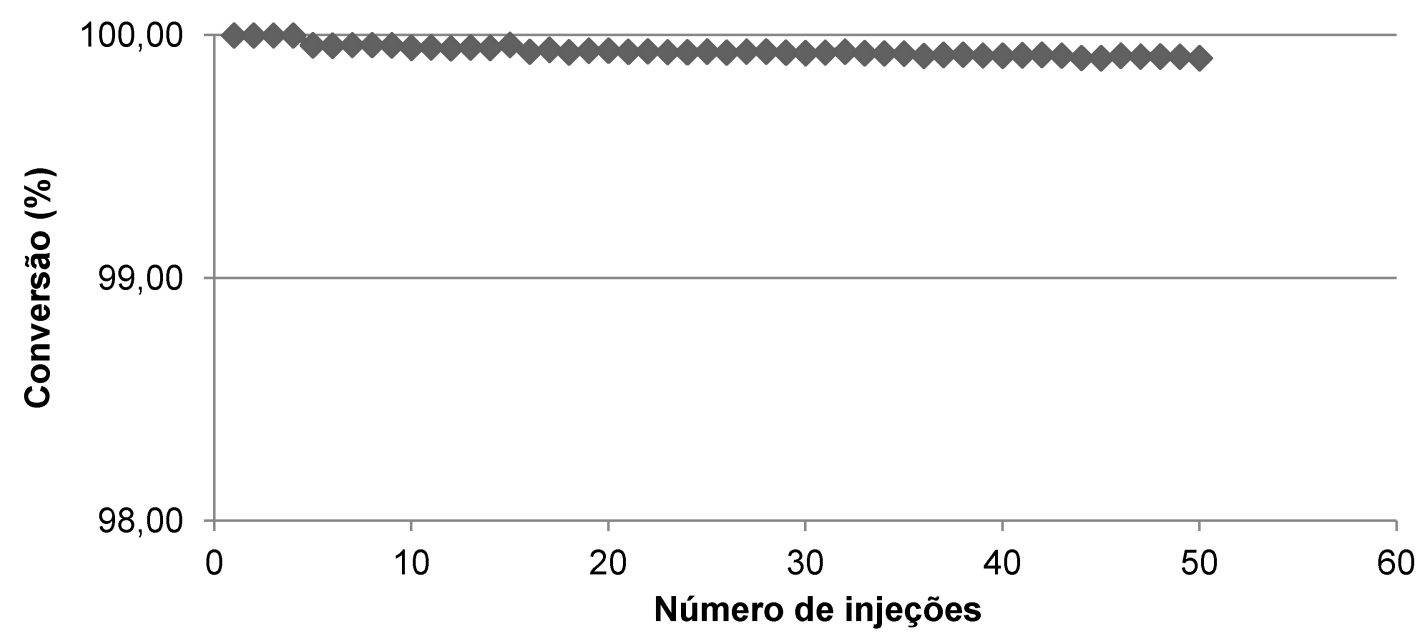

Figura B1: Gráfico de conversão (\%) versus número de injeções para a reação de desidratação do 1-propanol PA ( $\geq 99,8 \%$ ), feita em um microrreator de pulso, utilizando como catalisador $20 \mathrm{mg}$ da zeólita Y(80)5C.

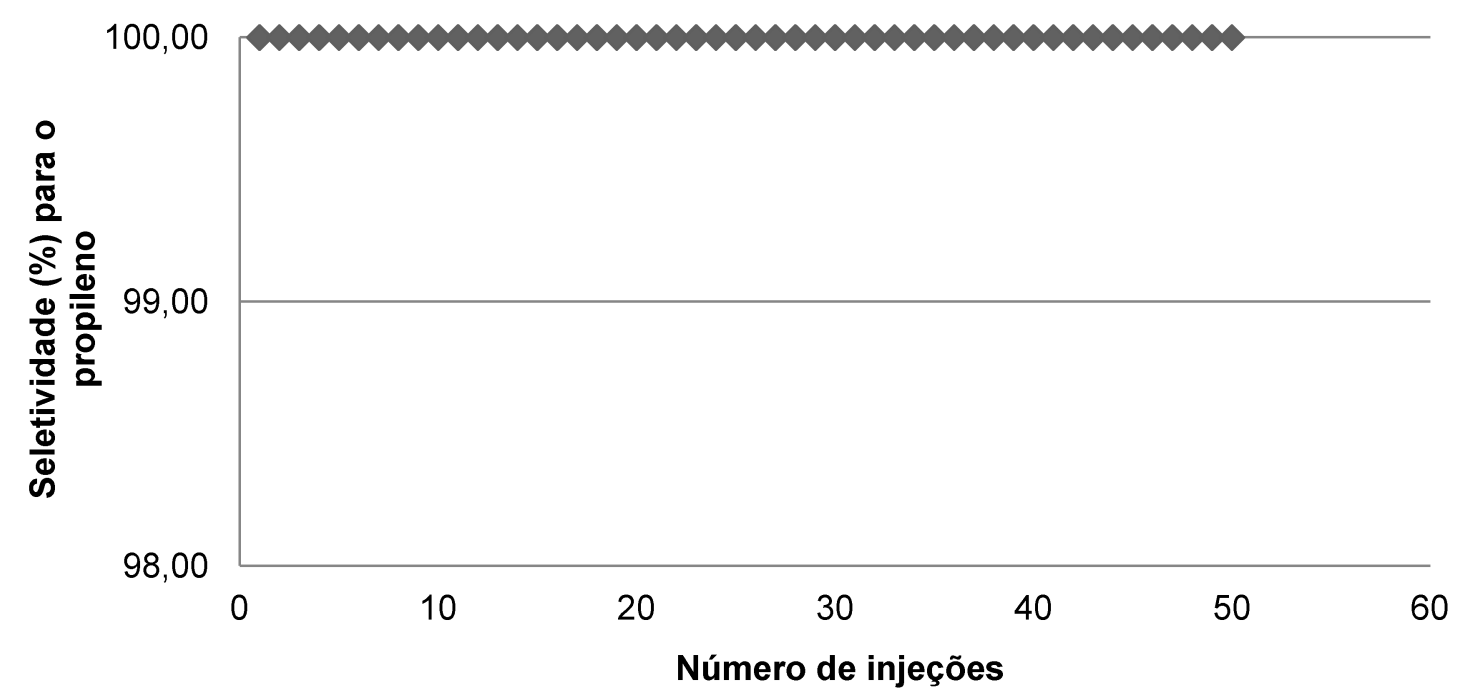

Figura B2: Gráfico de seletividade para propileno (\%) versus número de injeções para a reação de desidratação do 1-propanol PA ( $\geq 99,8 \%)$, feita em um microrreator de pulso, utilizando como catalisador $20 \mathrm{mg}$ da zeólita $\mathrm{Y}(80) 5 \mathrm{C}$. 


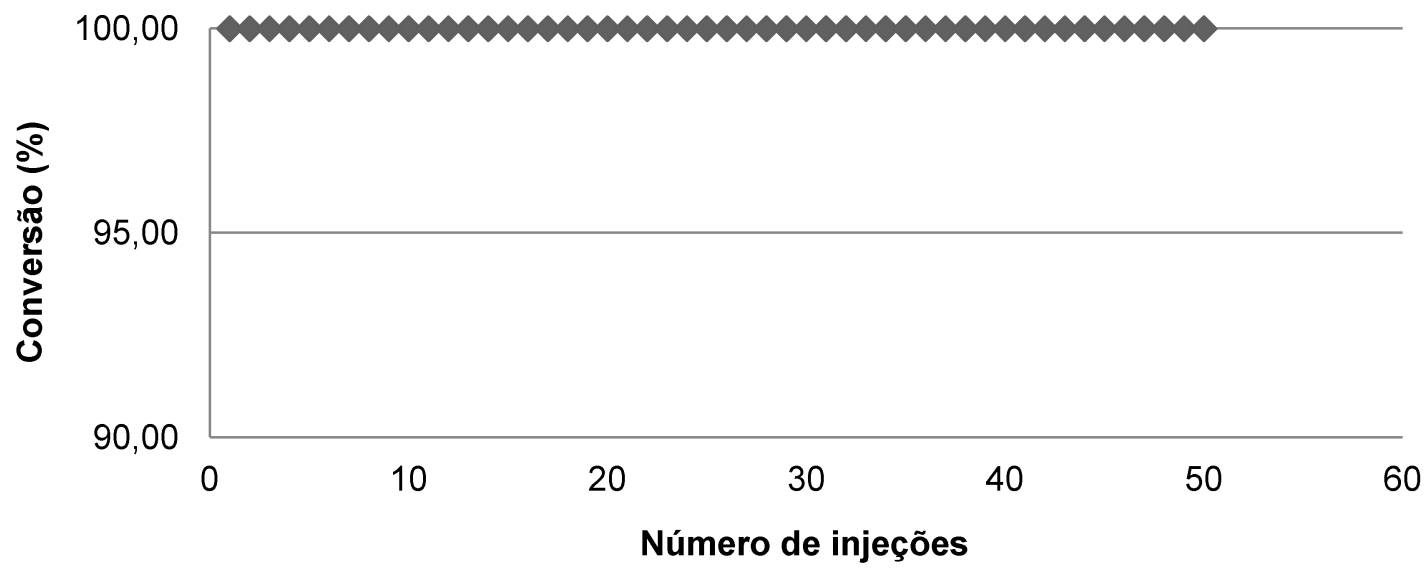

Figura B3: Gráfico de conversão (\%) versus número de injeções para a reação de desidratação do isopropanol PA $(99,5 \%)$, feita em um microrreator de pulso, utilizando como catalisador $20 \mathrm{mg}$ da zeólita $\mathrm{Y}(80) 5 \mathrm{C}$ como catalisador.

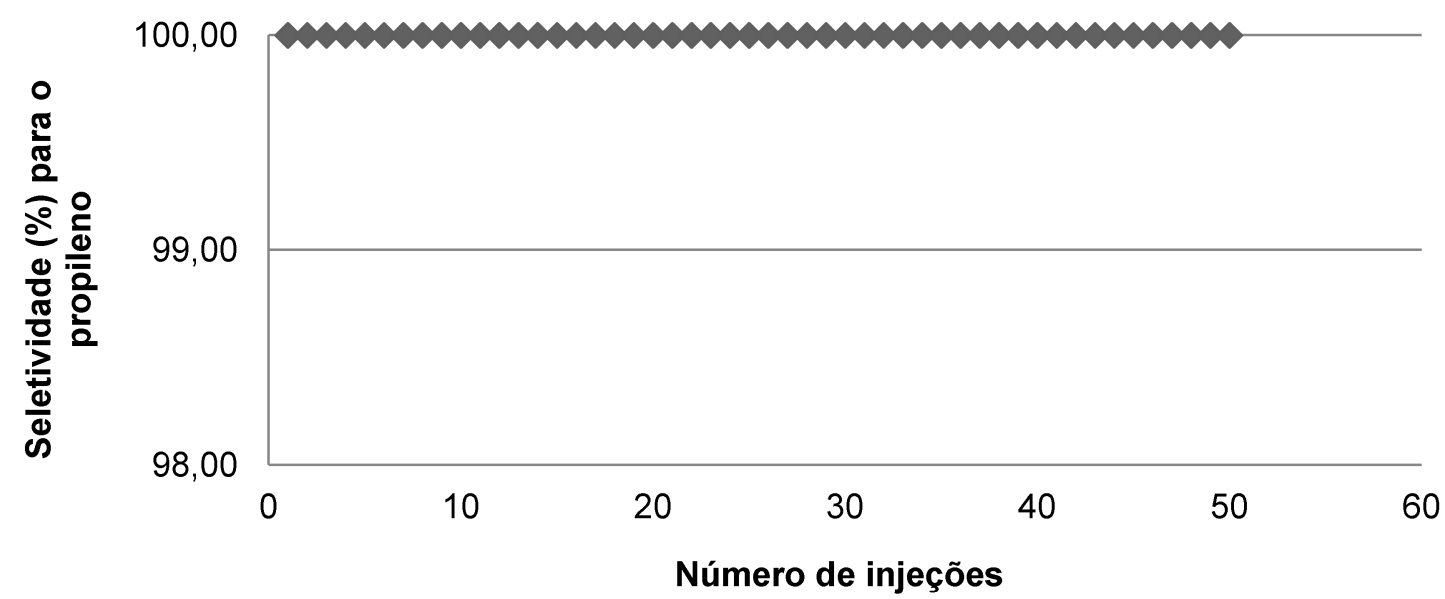

Figura B4: Gráfico de seletividade para propileno (\%) versus número de injeções para a reação de desidratação do isopropanol PA $(99,5 \%)$, feita em um microrreator de pulso, utilizando como catalisador $20 \mathrm{mg}$ da zeólita $\mathrm{Y}(80) 5 \mathrm{C}$ como catalisador.

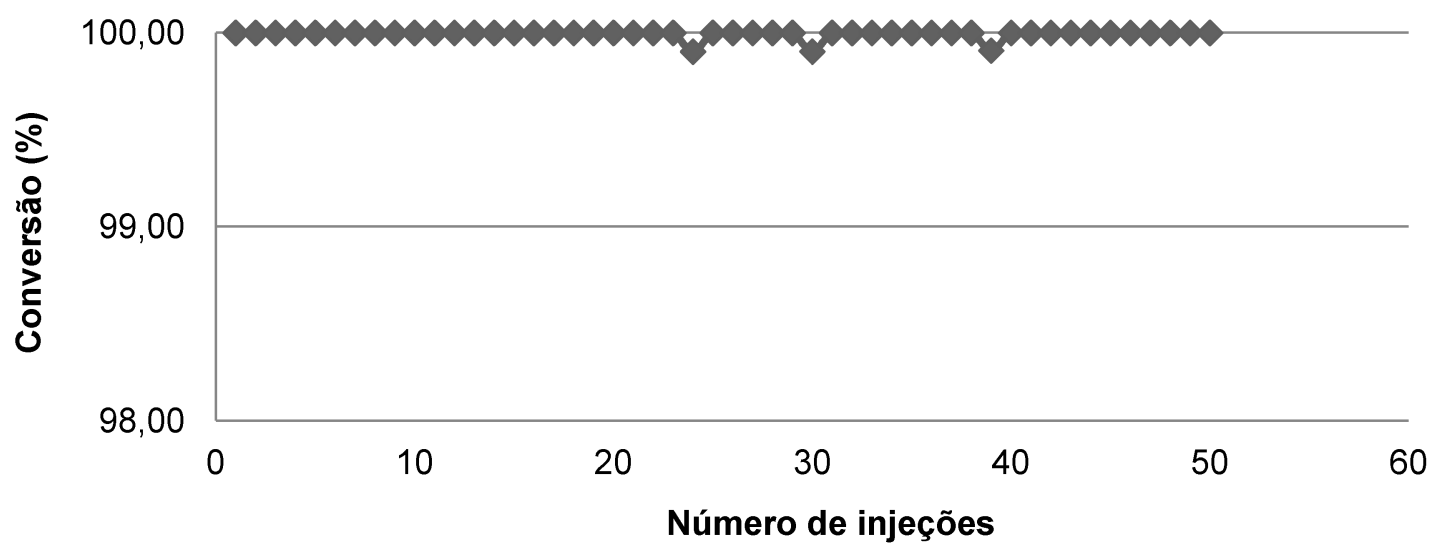

Figura B5: Gráfico de conversão (\%) versus número de injeções para a reação de desidratação do terc-butanol PA (99\%), feita em um microrreator de pulso, utilizando como catalisador $20 \mathrm{mg}$ da zeólita $\mathrm{Y}(80) 5 \mathrm{C}$. 


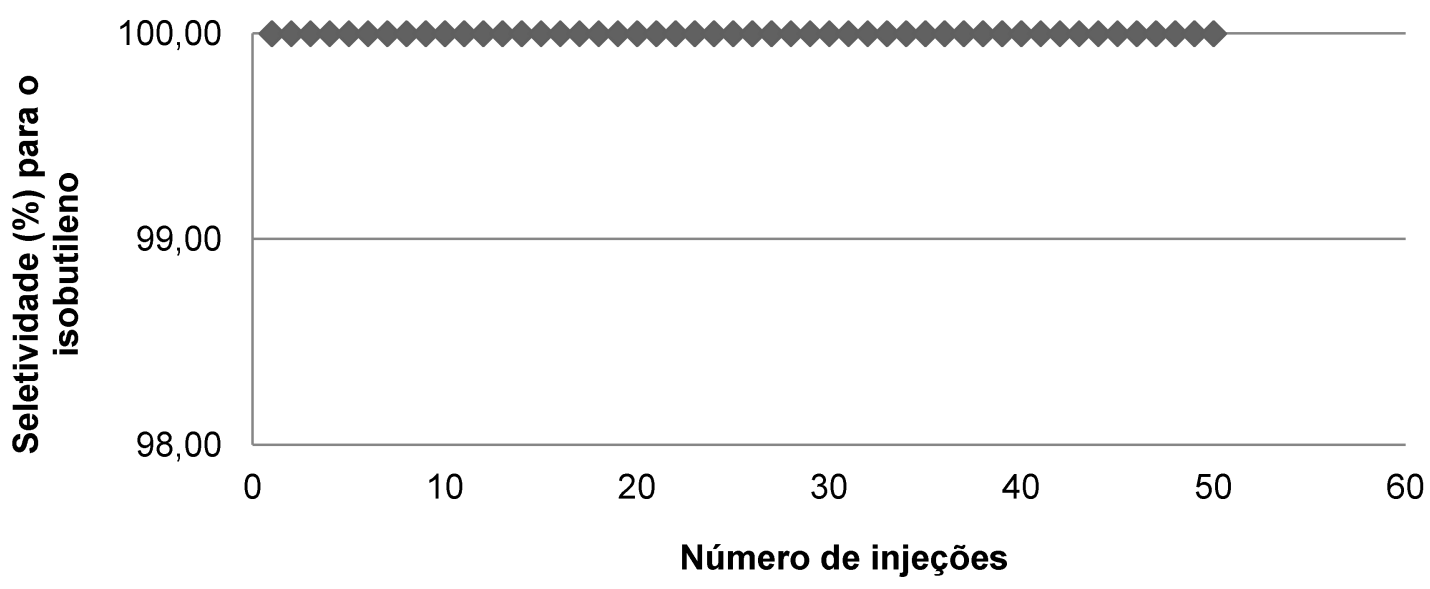

Figura B6: Gráfico de seletividade para isobutileno (\%) versus número de injeções para a reação de desidratação do terc-butanol PA (99\%), feita em um microrreator de pulso, utilizando como catalisador $20 \mathrm{mg}$ da zeólita $\mathrm{Y}(80) 5 \mathrm{C}$.

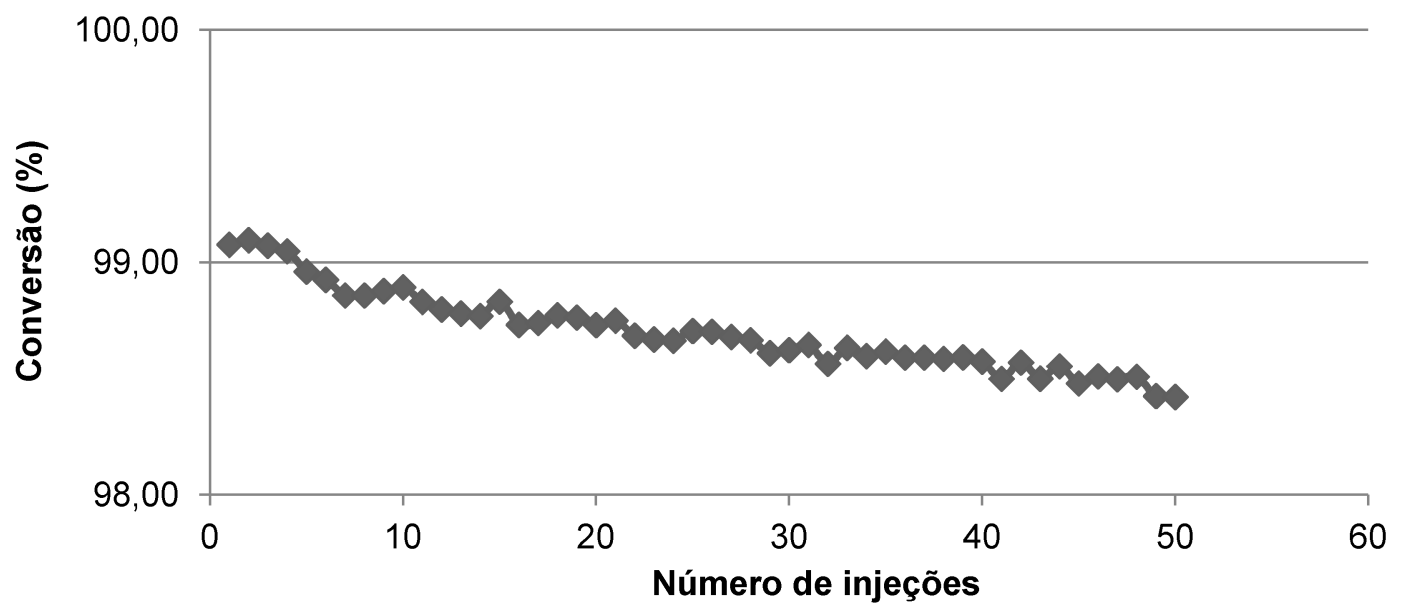

Figura B7: Gráfico de conversão (\%) versus número de injeções para a reação de desidratação do 1-propanol PA $(99,8 \%)$, feita em um microrreator de pulso, utilizando como catalisador $20 \mathrm{mg}$ da zeólita Y(pura)C.

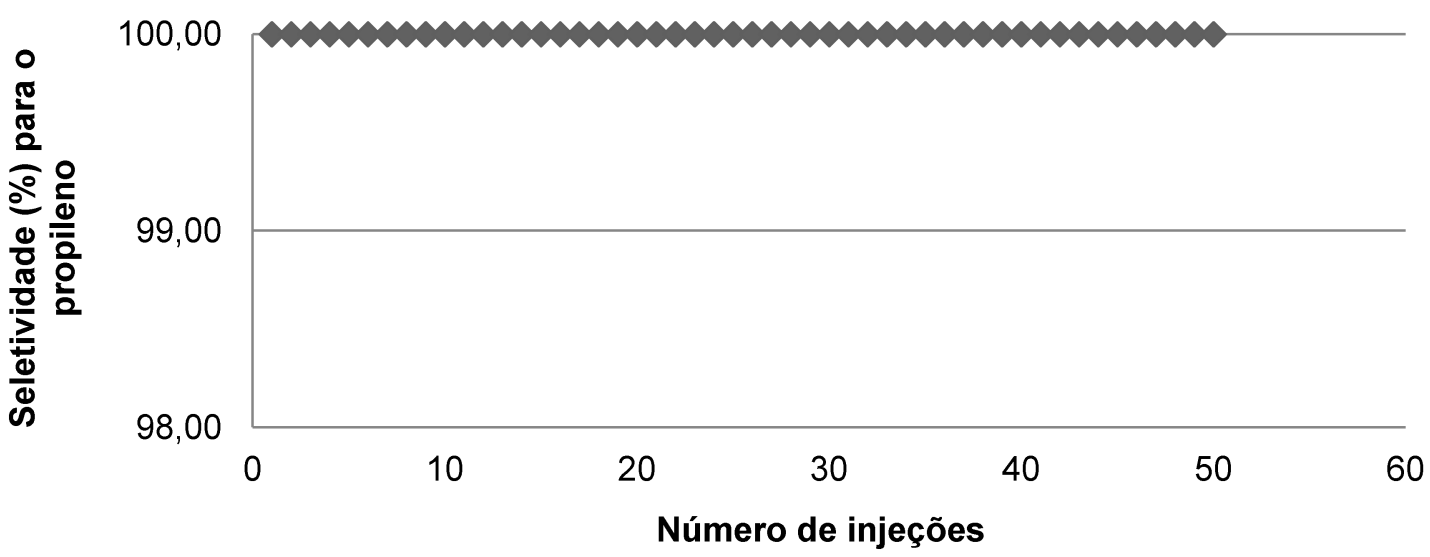

Figura B8: Gráfico de seletividade para propileno (\%) versus número de injeções para a reação de desidratação do 1-propanol PA $(99,8 \%)$, feita em um microrreator de pulso, utilizando como catalisador $20 \mathrm{mg}$ da zeólita $\mathrm{Y}$ (pura)C. 


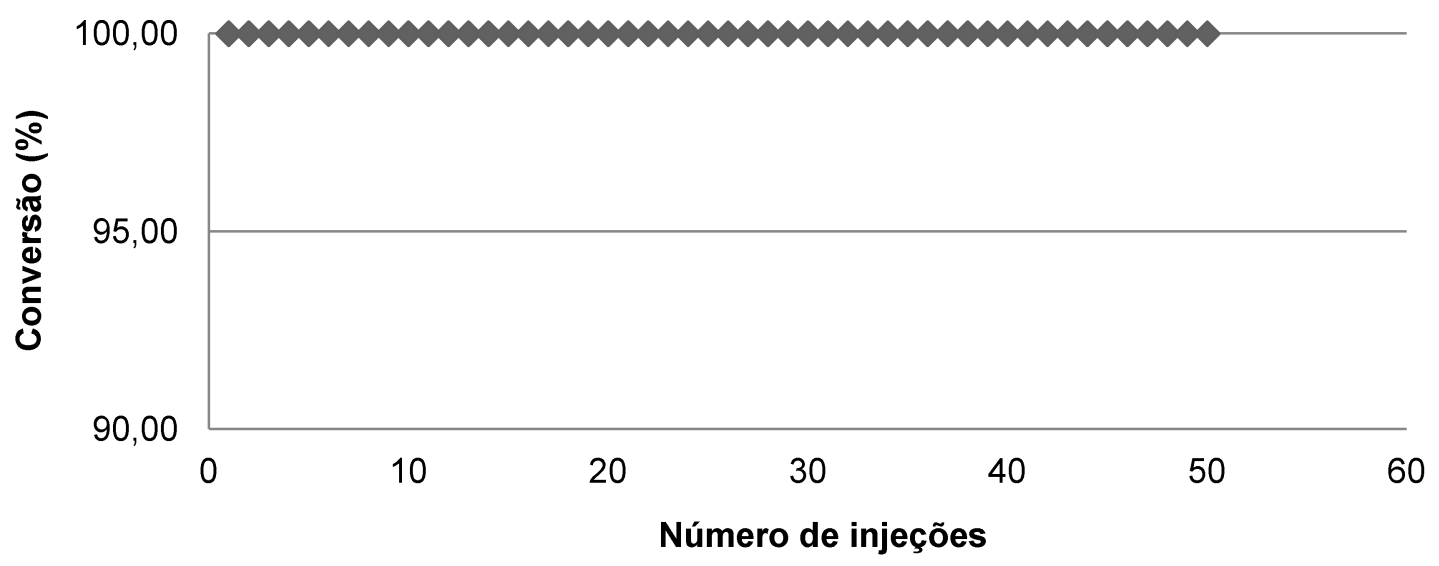

Figura B9: Gráfico de conversão (\%) versus número de injeções para a reação de desidratação do isopropanol PA $(99,5 \%)$, feita em um microrreator de pulso, utilizando como catalisador $20 \mathrm{mg}$ da zeólita Y(pura)C.

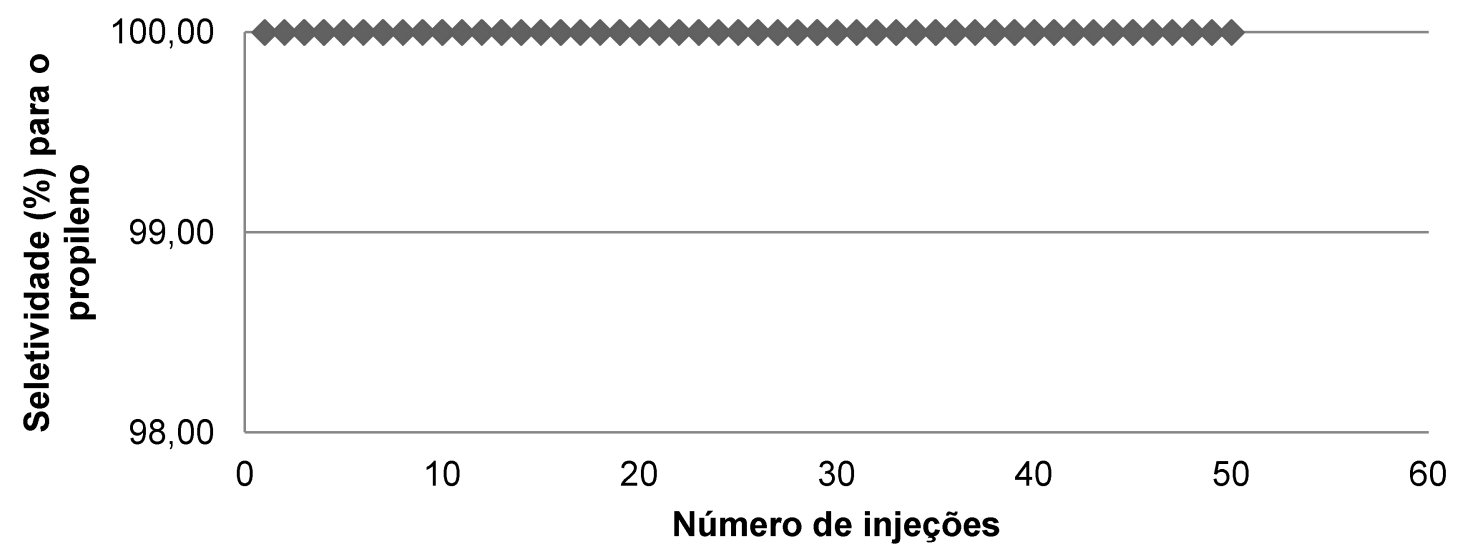

Figura B10: Gráfico de seletividade para propileno (\%) versus número de injeções para a reação de desidratação do isopropanol PA (99,5\%), feita em um microrreator de pulso, utilizando como catalisador $20 \mathrm{mg}$ da zeólita $\mathrm{Y}($ pura)C.

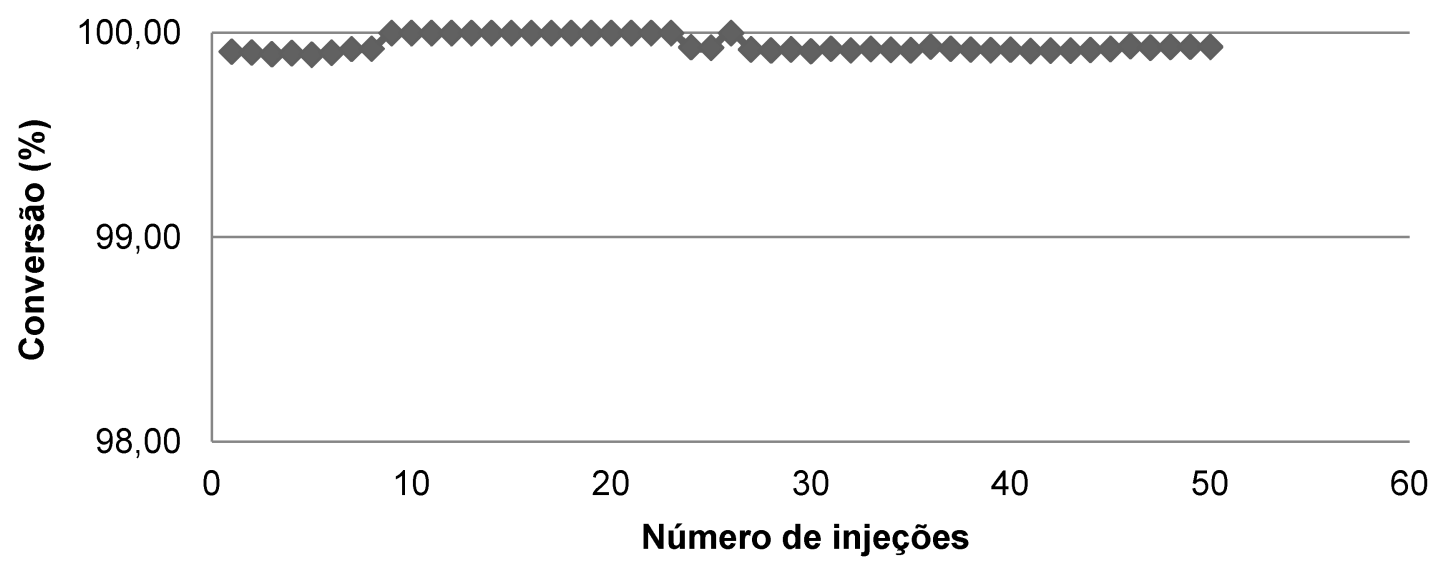

Figura B11: Gráfico de conversão (\%) versus número de injeções para a reação de desidratação do terc-butanol PA (99\%), feita em um microrreator de pulso, utilizando como catalisador $20 \mathrm{mg}$ da zeólita Y(pura)C. 


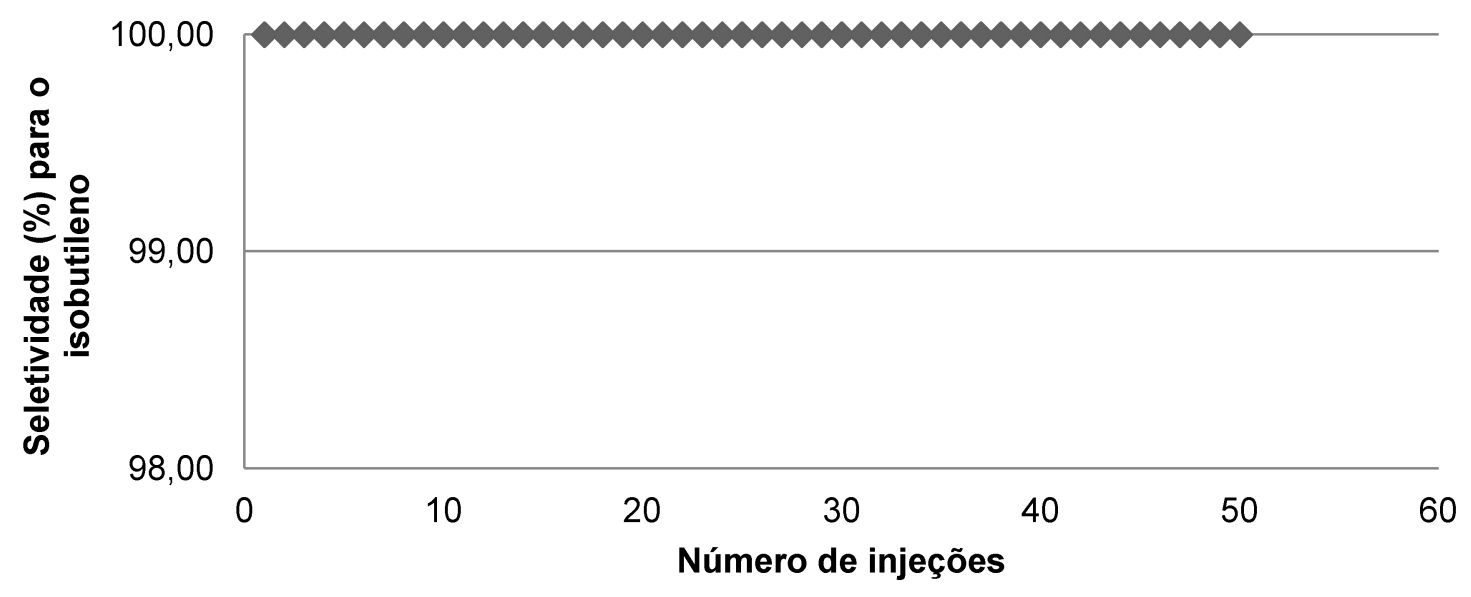

Figura B12: Gráfico de seletividade para isobutileno (\%) versus número de injeções para a reação de desidratação do terc-butanol PA (99\%), feita em um microrreator de pulso, utilizando como catalisador $20 \mathrm{mg}$ da zeólita Y(pura)C. 